National

Academy

\title{
NAS-NS
}

of

Sciences

National Research Council

NUCLEAR SCIENCE SERIES

\section{The Radiochemistry of Uranium}




\section{NATIONAL ACADEMY OF SCIENCES-NATIONAL RESEARCH COUNCIL}

\section{COMMITTEE ON CHEMICAL SCIENCES}

James L. Kinsey, Cochairman, Massachusetts Institute of Technology Alan Schriesheim, Cochairman, Exxon Research and Engineering Company William Spindel, Executive Secretary, National Academy of Sciences

Andreas Acrivos, Stanford University

Allen J. Bard, University of Texas, Austin

Fred Basolo. Northwestern University

Stephen J. Benkovic, Pennsylvania State University

R. Stephen Berry. University of Chicago

Alfred E. Brown, Washington, D. C.

David A. Evans, California Institute of Technology

Robert E. Naylor, Rohm and Haas Co.

George C. Pimentel, University of California

Norman Sutin, Brookhaven National Laboratory

Barry M. Trost, University of Wisconsin

Edel Wasserman, E. I. du Pont de Nemours \& Co., Inc.

\section{Liaison Members}

Richard S. Nicholson, National Science Foundation

Elliot S. Pierce, U. S. Department of Energy

\section{SUBCOMMITTEE ON NUCLEAR AND RADIOCHEMISTRY}

Darleane C. Hoffman, Chairman, Los Alamos National Laboratory

Eugene T. Chulick, Babcock \& Wilcox Co.

Christopher Gatrousis, Lawrence Livermore National Laboratory

Peter E. Haustein, Brookhaven National Laboratory

Rolfe H. Herber, Rutgers University

Paul J. Karol, Carnegie-Mellon University

Edward S. Macias, Washington University

Michael J. Welch, Washington University School of Medicine

Raymond G. Wymer, Oak Ridge National Laboratory

\section{Liaison Member}

John L. Burnett, U. S. Department of Energy 


\section{DISCLAIMER}

This report was prepared as an account of work sponsored by an agency of the United States Government. Neither the United States Government nor any agency Thereof, nor any of their employees, makes any warranty, express or implied, or assumes any legal liability or responsibility for the accuracy, completeness, or usefulness of any information, apparatus, product, or process disclosed, or represents that its use would not infringe privately owned rights. Reference herein to any specific commercial product, process, or service by trade name, trademark, manufacturer, or otherwise does not necessarily constitute or imply its endorsement, recommendation, or favoring by the United States Government or any agency thereof. The views and opinions of authors expressed herein do not necessarily state or reflect those of the United States Government or any agency thereof. 


\section{DISCLAIMER}

Portions of this document may be illegible in electronic image products. Images are produced from the best available original document. 


\title{
The Radiochemistry of Uranium
}

\author{
JAMES E. GINDLER
}

Argonne National Laboratory

Argonne, Illinois

Issuance Date: March 1962

Reprinted by the Technical Information Center

U.S. Deportment of Energy

Subcommittee on Radiochemistry

National Academy of Sciences - National Research Council 
Available as NAS-NS.3050 for $\$ 17.00$ from

National Technical Information Service U. S. Department of Commerce Springfield, Virginia 22161

Printed in the United States of America USDOE Technical Information Center, Oak Rıdge. Tennessee March 1962, latest printıng November 1982 


\section{FOREWORD}

The subcommlttee on Radiochemistry is one of a number of subcommittees working under the Committee on Nuclear science within the National Academy of Sciences - National Research counc1l. Its members represent government, 1ndustrial, and university laboratories in the areas of nuclear chemistry and analytical chemlstry

The Subcomittee has concerned 1tself with those areas of nuclear science which involve the chemist, such as the collection and distribution of radiochemical procedures, the establishment of specifications for radiochemically pure reagents, avallablilty of cyclotron time for service 1rradiations, the place of radiochemistry in the undergraduate college program; etc.

This series of monographs has grown out of the need for up-to-date compliations of radiochemlcal Information and procedures. The subcomittee has endeavored to present a serles which will be of maximum use to the working scientist and which contalns the latest avaliable information. Each monograph collects in one volume the pertinent information required for radiochemical work with an individual element or a group of closely related elements.

An expert in the radiochemistry of the particular element has written the monograph, following a standard format developed by the Subcomittee. The Atomic Energy Commission has sponsored the printing of the series.

The Subcommittee is confldent these publications w1Il be useful not oniy to the radiochemist but also to the research worker in other fields such as physics, biochemistry or medicine who wishes to use radiochemlcal techniques to solve a specific problem. 


\section{INTRODUCTION}

This volume which deals with the radiochemistry of uranium is one of a series of monographs on radiochemistry of the elements. There is included a review of the nuclear and chemical features of particular interest to the radiochemist, a discussion of problems of dissolution of a sample and counting techniques, and finally, a collection of radiochemical procedures for the element as found in the literature.

The series of monographs w1ll cover all elements for which radlochemical procedures are pertinent. Plans include revision of the monograph periodically as new techniques and procedures warrant. The reader is therefore encouraged to call to the attention of the author any published or unpublished material on the radiochemistry of uranium which might be included in a revised version of the monograph. 


\section{CONTENTS}

I. General Reviews of the Inorganic and Analytical Chemistry of Uranium

II. General Reviews of the Radiochemistry of Uranium 3

III. Table of Isotopes of Uranium 3

IV. Review of Those Features of Uranium Chemistry of Chief Interest to the Radiochemist

A. Metall1c Uranium 5

1. Preparation

2. Physical properties

3. Chemical properties

B. Compounds of Uranium 7

C. The Chemistry of Uranium in Solution 14

1. Oxidation states 14

2. Complex ion formation 21

3. Non-aqueous solutions of uranium 30

D. Separation of Uranium 39

1. Precipitation 40

2. Solvent extraction, 60

Ethers, esters, ketones, and alcohols 63

Organophosphorus compounds 122

Amines and quaternary anmonium salts 169

Carboxylic acids 180

3. Ion exchange Chelating agents $\quad 182$

(2)

Cation exchange 222

4. Chromatography 227

5. Volatilization 231

6. Electrochemical methods 232

7. Pyrometallurgical processes 235

E. Determination of Uranium 236

1. Counting techniques 236

$\begin{array}{ll}\text { 2. Sample preparation } & 247\end{array}$ 
F. Dissolution of Uranium Samples

1. Metall1c uranium

2. Alloys of uranium

3. Compounds of uranium

4. Meteorites, minerals, and ores

5. Blological samples

5. Alr dust samples

V. Collection of Detalled Procedures 


\title{
The Radiochemistry of Uranium
}

\author{
JAMES E. GINDLER \\ Argonne National Laboratory \\ Argonne, Illinois
}

I. General Reviews of the Inorganic and Analytical Chemistry of Uran1um.

1. J. W. Melior, "Uranium" in "A Comprehens1ve Treatise on Inorganic and Theoretical Chemistry," Volume XII, Chapter IXIII, pp. 1-138, Longmans Green and Company, London, 1932.

2. R. J. Meyer and E. Pletsch, "Gmelins Handbuch der Anorgan1schen Chemle," 8th Edit1on, System No. 55, Verlag Chemie, G.m.b.H., Berlin, 1936.

3. N. V. Sidgwick, "Uranium" in "The Chemical Elements and The1r Compounds," pp. 1069-1086, Clarendon Press, Oxford, 1950.

4. C. J. Rodden and J. C. Warf, "Uranium" in "Analyt1cal Chemistry of the Manhattan Project," National Nuclear Energy Series, D1vision VIII, Volume 1, Chapter 1, pp. 3159, C. J. Rodden, Ed., McGraw-H1ll Book Co., Inc, New York, 1950.

5. J. J. Katz and E. Rab1now1tz, "The Chemistry of Uranium," National Nuclear Energy Series, Division VIII, Volume 5, McGraw-H11 Book'Co., Inc., New York, 1951.

6. G. T. Seaborg, "The Actinide Series" in "Comprehensive Inorganic Chemistry," Volume I, Chapter 3, pp. 161-223, 
M. C. Sneed, J. I. Maynard, and R. C. Brasted, Ed., D. van Nostrand Company, Inc., New York, 1953.

7. H. R. Hoekstra and J. J. Kátz, "The Chemistry of Uranium" in "The Actinide Elements," National Nuclear Energy Series, Division IV, Volume 14A, Chapter 6, pp. 130-188, G. T. Seaborg and J. J. Katz, Ed., McGraw-H1ll Book Co., Inc., New York, 1954.

8. J. J. Katz and G. T. Seaborg, "The Chemlstry of the Actinide Elements," Chapter V, pp. 94-203, John W1ley and Sons, Inc., New York, 1957.

9. "Urantum," R. Ca1llat and J. Elston, Directors, in "Nouveau Traite de Chemie M1nérale," Part I, Volume XV, P. Pascal, Director, Masson et C1e, Par1s, 1960. Part II, 1961.

10. G. Melster, "Uranium" in "Rare Metals Handbook," Chapter 26, pp. 501-571, C. A. Hampel, Ed., Relnhold Publishing Corp., New York, 1954.

11. L. Grainger, "Uranium and Thorlum," George Newnes IImited, London, 1958.

12. A. N. Holden, "Physical Metallurgy of Uranium," AddisonWesley Publishing Company, Inc., Reading, Mass., 1958.

13. "Urantum Ore Processing," J. W. Clegg and D. D. Foley, Ed., Addison-Wesley Publishing Company, Inc., Reading, Mass., 1958 .

14. "Uranium" in "Scott's Standard Methods of Chemlcal Analys1s, "Volume I, pp. 1017-1027, N. H. Furman, Ed., D. van Nostrand Co., Inc., New York, 1939.

15. TID-5223, Production and Separation of $U^{233}$, Collected Papers, Part 1 and Part 2, I. I. Katz1n, Ed., 1952.

16. TID-5290, Chemistry of Uranlum, Collected Papers, Book 1 and Book 2, J. J. Katz and E. Rabinow1tz, Ed., 1958.

17. G. H. Morrison and H. Freiser, "Solvent Extraction in Analyt1cal Chemistry," John W1ley and Sons, Inc., New York, 1957. 
II. General Reviews of the Radlochemistry of Urantum.

1. E. K. Hyde, "Radiochemical Separation of the Actinide Elements" in "The Actinide Elements," Nat1onal Nuclear Energy Series, Division IV, Volume 14A, Chapter 15, pp.

542-595, G. T. Seaborg and J. J. Katz, Ed., MCGraw-H1II Book Co., Inc., New York, 1954.

2. E. K. Hyde, Paper $P / 728$ "Radiochemlcal Separations Methods for the Actinide Elements," Volume 7, pp. 281-303, Proceedings of the International Conference in Geneva, August, 1955, on the Peaceful Uses of Atomic Energy, Untted Nat1ons, New York, 1956.

III. Table of Isotopes of Uraniuma .

\begin{tabular}{|c|c|c|c|}
\hline Isotope & Half-IIfe & $\begin{array}{l}\text { Type and Energy } \\
\text { of Radiation (Mev) }\end{array}$ & $\begin{array}{l}\text { Method of } \\
\text { Preparation }\end{array}$ \\
\hline$U^{227}$ & $1.3 \mathrm{~min}$ & a 6.8 & $T^{232}(a, 9 n)$ \\
\hline \multirow[t]{2}{*}{$U^{228}$} & $9.3 \mathrm{~min}$ & $\alpha(-80 \%) 6.67$ & $\operatorname{Th}^{232}(\alpha, 8 n) ;-2 \%$ \\
\hline & & $\operatorname{EC}(-20 \%)$ & daughter $36 \mathrm{~min} \mathrm{Pu}^{232}$ \\
\hline \multirow[t]{2}{*}{$U^{229}$} & $58 \mathrm{msn}$ & $\operatorname{EC}(\sim 80 \%)$ & $\operatorname{mn}^{232}(\alpha, 7 n) ;-0.2 \%$ \\
\hline & & $a(-20 x) 6.42$ & daughter $20 \mathrm{~min} \mathrm{Pu}^{233}$ \\
\hline \multirow[t]{3}{*}{$U^{230}$} & 20.8 day & $\alpha 5.884(67.2 \not 6)$ & $\operatorname{Tn}^{232}(\alpha, 6 n) ;-15 \%$ \\
\hline & & $5.813(32.1 \%)$ & $\begin{array}{l}\text { daughter } 17.7 \text { day } \\
\mathrm{Pa}^{230}\end{array}$ \\
\hline & & $5.658(0.7 \%)$ & $\begin{array}{l}\text {-6\% daughter } 9.0 \\
\text { hour Pu } 234\end{array}$ \\
\hline \multirow[t]{3}{*}{$U^{231}$} & 4.3 day & EC $(99+\not)$ & $\operatorname{Tn}^{232}(a, 5 n)$ \\
\hline & & $\alpha\left(5.5 \times 10^{-3} \not\right) \quad 5.45$ & $\mathrm{~Pa}^{23 I}(\mathrm{~d}, 2 \mathrm{n})$ \\
\hline & & & $\begin{array}{l}3 \times 10^{-3 \%} \text { daughter } \\
26 \mathrm{~min} \mathrm{Pu}^{235}\end{array}$ \\
\hline \multirow[t]{5}{*}{$\mathrm{U}^{232}$} & 74 year & $\alpha 5.318(68 \%)$ & $\operatorname{Th}^{232}(\alpha, 4 n)$ \\
\hline & & $5.261 \quad(32 \%)$ & daughter 1.31 day \\
\hline & & $5.134(0.32 \%)$ & $\mathrm{Pa}^{232}$; daughter \\
\hline & & & 2.85 year $\mathrm{Pu}^{236}$ \\
\hline & & & $U^{233}(n, 2 n)$ \\
\hline
\end{tabular}


Table of Isotopes of Uranlum (Continued)

\begin{tabular}{|c|c|c|c|}
\hline Isotope & Half-LIfe & $\begin{array}{l}\text { Type and Energy } \\
\text { of Radiation (Mev) }\end{array}$ & $\begin{array}{l}\text { Method of } \\
\text { Preparation }\end{array}$ \\
\hline$U^{233}$ & $\begin{array}{l}1.626 \times 10^{5} \\
\text { yearb }\end{array}$ & $\begin{array}{r}\alpha .816(83.5 \%) \\
4.773(14.9 \%) \\
4.717(1.6 \%) \\
4.655(0.07 \%) \\
4.582(0.04 \%)\end{array}$ & $\begin{array}{l}\text { daughter } 27.0 \text { day } \\
\mathrm{Pa}^{233}\end{array}$ \\
\hline$U^{234}\left(U_{I I}\right)$ & $2.48 \times 10^{5}$ year & $\begin{array}{rrr}\alpha 4.768 & (72 \%) \\
4.717 & (28 \%)\end{array}$ & $\begin{array}{l}\text { natural radioactivity } \\
0.0056 \% ; \\
\text { daughter } 1.175 \mathrm{~min} \\
\mathrm{~Pa}^{234 \mathrm{~m}}\left(\mathrm{Ux}_{2}\right) \text {; } \\
\text { daughter } 6.66 \text { hour } \\
\mathrm{Pa}^{234}(\mathrm{Uz}) ; \\
\text { daughter } 86.4 \text { year } \\
\mathrm{Pu}^{238} ; \mathrm{U}^{233}(\mathrm{n}, y)\end{array}$ \\
\hline $\mathrm{U}^{235 \mathrm{~m}}$ & $26.5 \mathrm{~min}$ & IT & $\begin{array}{l}\text { daughter } 24,360 \\
\text { year } \mathrm{Pu}^{239}\end{array}$ \\
\hline$U^{235}(A C U)$ & $7.1 \times 10^{8}$ year & $\begin{array}{ccc}a & 4.559 & (6.7 \%) \\
4.520 & (2.7 \%) \\
4.370 & (25 \%) \\
4.354 & (35 \%) \\
4.333 & (14 \%) \\
4.318 & (8 \%) \\
4.117 & (5.8 \%)\end{array}$ & $\begin{array}{l}\text { natural radioactivity } \\
0.720 \% \text {; } \\
\text { daughter } 26.5 \mathrm{~min} \\
\mathrm{U}^{235 \mathrm{~m}} \text {; daughter } \\
410 \text { day } \mathrm{Np}^{235} \text {; } \\
\text { daughter } 23.7 \mathrm{~min} \\
\mathrm{~Pa} 235\end{array}$ \\
\hline$U^{236}$ & $2.39 \times 10^{7}$ year & a 4.499 & $\begin{array}{l}51 \% \text { daughter } \\
\mathrm{Np}^{236} \mathrm{c} ; \\
\text { daughter } 6,580 \text { year } \\
\mathrm{Pu}^{240} ; \mathrm{U}^{235}(\mathrm{n}, y)\end{array}$ \\
\hline$U<21$ & 6.75 day & $\mathrm{B}^{-} 0.248$ & $\begin{array}{l}\text { daughter il min } \\
\mathrm{Pa}^{237} \mathrm{~d} ; \\
4 \times 10^{-3} \% \text { daughter } \\
\mathrm{Pu}^{241} ; \\
\mathrm{U}^{238}(\mathrm{n}, 2 \mathrm{n}) ; \\
\mathrm{U}^{236}(\mathrm{n}, y)\end{array}$ \\
\hline
\end{tabular}


Table of Isotopes of Uranium (Continued)

\begin{tabular}{|c|c|c|c|}
\hline Isotope & Half-ILfe & $\begin{array}{l}\text { Type and Energy } \\
\text { of Radiation (Mev) }\end{array}$ & $\begin{array}{l}\text { Method of } \\
\text { Preparation }\end{array}$ \\
\hline$U^{238}\left(U_{I}\right)$ & $4.51 \times 10^{9}$ year & $\alpha 4.195$ & $\begin{array}{l}\text { natural radio- } \\
\text { activity }\end{array}$ \\
\hline & & & $99.276 \%$ \\
\hline$U^{239}$ & $23.54 \mathrm{mIn}$ & $\mathrm{B}^{-} 2.21$ & $\begin{array}{l}U^{238}(n, y) \\
U^{238}(d, p)\end{array}$ \\
\hline$U^{240}$ & 14.1 hour & $B^{-0} 0.36$ & $\begin{array}{l}\text { daughter }-7.6 x \\
10^{7} \text { year } \\
\mathrm{Pu}^{244} \text {; 2nd order } \\
\text { neutron capture } \\
\text { on } U^{238}\end{array}$ \\
\hline
\end{tabular}

a Data concerning half-lives, radiations and branching ratios, unless otherwise noted has been obtalned from the "Table of Isotopes" by D. Strominger, J. M. Hollander and G. T. Seaborg, Reviews of Modern Physics, 30, No. 2, Part II, April, 1958. Th1s compilation may be consulted for more complete information on the 1sotopes and for references to the original literature.

E Ya. P. Dokuchayev and I. S. Osipov, Atomnaya Energiya, 6, 73 (1959).

C J. E. Gindler and R. K. Sjoblom, J. Inorg. Nuclear Chem., 12, 8 (1959).

d The half-life of $\mathrm{Pa}^{237}$ has been reported recently to be $39 \pm 3$ min, K. Takahashi and H. Morinaga, Nuclear Physics, 15, 664 $(1960)$.

IV. Review of Those Features of Uranium Chemistry of Chief Interest to the Radiochemist.

\section{A. Metal11c Uranium}

1. Preparation. Uranium metal may be prepared by several methods: I the reduction of uranium oxides with carbon in an arc-melting furnace; reduction of uranium oxides with magnesium, aluminum, calclum or calclum hydride; the reduction of uranium halldes with alkall or alkaline-earth metals; electrolytic reduction of uranium halides; and the thermal decomposition of uranium lodide. 
2. Physical properties. Metallic uranium exists in three allotroplc forms: 2,3 the orthorhombic alpha form, stable below $663^{\circ} \mathrm{C}$; the tetragonal beta form which exists between $663^{\circ} \mathrm{C}$ and $770^{\circ} \mathrm{C}$; and the body-centered cublc form which exists at higher temperatures $\left(>770^{\circ} \mathrm{C}\right)$. The physical properties of the metal as complled by Gralnger 4 are glven in Table $I$. Because of the method of preparation, impurities may be contalned in the metal which alter its properties. Also, a number of the physical characteristics depend upon anisotropic and structural effects, eg. thermal expansion. Therefore, if physical properties are pertinent to an experiment or design, it is best to determine them individually for the metal used.

The changes wrought in metallic uranium by radiation and thermal cycling may be considerable. The results of reactor radiation on the metal are: dimensional instability, surface roughening and plmpling, warping, high hardness, extreme brittleness, cracks and porosity, broadened $x$-ray diffraction lines, and decreased thermal and electrical conductivity. 3 Thermal cycling growth is similar in many respects to that caused by radiation damage. However, differences exist, the fundamental difference being in the mechanism of growth. (The reader is directed to reference 3 for more detalled discussion of this subject.)

3. Chemlcal properties. Uranlum is a highly reactive metal. A potential of +1.80 volts for the half-cell reaction, $U \rightarrow U^{+3}+3 e$, places it below berylifum and above hafnium and aluminum in the electromotive force series. 2 The metal forms intermetalic compounds w1th $\mathrm{Al}, \mathrm{Be}, \mathrm{Bl}, \mathrm{Co}, \mathrm{Cu}, \mathrm{Ga}, \mathrm{Au}, \mathrm{Fe}, \mathrm{Pb}, \mathrm{Mn}, \mathrm{Hg}, \mathrm{N} 1$, $\mathrm{Sn}, \mathrm{Ge}, \mathrm{In}, \mathrm{Ir}, \mathrm{Pd}, \mathrm{Pt}, \mathrm{Tl}$, and $\mathrm{Zn} ; \underline{2}$ solid solutions with Mo, T1, $\mathrm{Zr}$, and $\mathrm{Nb} . \underline{2}$ It reacts at varying temperatures with $\mathrm{H}_{2}, \mathrm{~B}, \mathrm{C}, \mathrm{S} 1$, $\mathrm{N}_{2}, \mathrm{P}, \mathrm{As}, \mathrm{O}_{2}, \mathrm{~S}$, Se, $\mathrm{F}_{2}, \mathrm{Cl}_{2}, \mathrm{Br}_{2}, \mathrm{I}_{2}, \mathrm{H}_{2} \mathrm{O}, \mathrm{HF}(\mathrm{g}), \mathrm{H}_{2} \mathrm{~S}, \mathrm{NH}_{3}, \mathrm{NO}, \mathrm{HCl}(\mathrm{g})$ $\mathrm{N}_{2} \mathrm{O}_{4}, \mathrm{CH}_{4}, \mathrm{CO}, \mathrm{CO}_{2} . \underline{1}, \underline{2}$ In a1r, at room temperature, massive uranium tarnishes to form a yellow and eventually a black oxide 
coating. Finely divided powder may burn spontaneously. In boiling water, massive uranium corrodes slowly with the formation of uranIum dioxide and hydrogen. The reaction products with steam are uranium oxide and hydride. The dissolution of uranium metal is discussed in section IV-F.

Table I. Physical Properties of Uranium Metala

\begin{tabular}{|c|c|}
\hline Density (high purity) & $19.05 \pm 0.02 \mathrm{gm} / \mathrm{cm}^{3}$ \\
\hline Density (1ndustrial uranium) & $18.85 \pm 0.20 \mathrm{gm} / \mathrm{cm}^{3}$ \\
\hline Melting point & $1.132 \pm 1^{\circ} \mathrm{C}$. \\
\hline Bo1ling point & $3,818^{\circ} \mathrm{C}$. \\
\hline Heat of fusion & $4.7 \mathrm{kcal} / \mathrm{mole}$ \\
\hline Vapor pressure $\left(\therefore, 600^{\circ} \mathrm{C}.\right)$ & $10^{-4} \mathrm{~mm}$ \\
\hline Thermal conductivity $\left(70^{\circ} \mathrm{C}.\right)$ & $0.071 \mathrm{cal} / \mathrm{cm}-\mathrm{sec}-{ }^{\circ} \mathrm{C}$. \\
\hline Electrical resistivity $\left(25^{\circ} \mathrm{C}.\right)$ & $35 \times 10^{6} \mathrm{onm} / \mathrm{cm}^{3}$ \\
\hline $\begin{array}{l}\text { Mean coefficient of linear } \\
\text { thermal expansion (random } \\
\text { orlentation } 25-100^{\circ} \mathrm{C} \text {.) }\end{array}$ & $16 \times 10^{-6} /{ }^{\circ} \mathrm{C}$. \\
\hline Specific heat $\left(25^{\circ} \mathrm{C}.\right)$ & 6.65 \\
\hline Enthalpy $\left(25^{\circ} \mathrm{C}.\right)$ & $1,520 \mathrm{cal} / \mathrm{mole}$ \\
\hline Entropy $\left(25^{\circ} \mathrm{C}.\right)$ & $12.0 \mathrm{cal} / \mathrm{mole} /{ }^{\circ} \mathrm{C}$ \\
\hline
\end{tabular}

\section{IV-B. Compounds of Uranium}

Uranium combines with most elements to form a large number and variety of compounds. "Gmelins Handbuch der Anorganischen Chemie, "6 which surveys the literature through the year 1935 , describes several hundred compounds. Katz and seaborg 2 describe some of the more recently prepared compounds, princlpally of organic character, such as chelates, alkoxides, amides, mercaptides, and $\pi$-cyclopentadienyl compounds. 
The oxidation states of uranium in the combined form vary from II to VI. D1valent uranlum compounds reported are UO and US. Trivalent uranium compounds are more numerous and include the hydride, nitride, sesquisulfide, halides and borohydride. Uranium (III) sulfate $\mathrm{UH}\left(\mathrm{SO}_{4}\right)_{2}$ has also been reported. I A large number of tetravalent compounds are known varying in complexity from the oxide and simple binary salts to more complicated organic structures. Complex salts such as $3\left(\mathrm{CN}_{3} \mathrm{H}_{6}\right)_{2} \mathrm{CO}_{3}$. $\mathrm{U}\left(\mathrm{CO}_{3}\right)_{2} \cdot 4 \mathrm{H}_{2} \mathrm{O}$ and $2\left(\mathrm{NH}_{4}\right)_{2} \mathrm{C}_{2} \mathrm{O}_{4} \cdot \mathrm{U}\left(\mathrm{C}_{2} \mathrm{O}_{4}\right)_{2} \cdot 6 \mathrm{H}_{2} \mathrm{O}$ form an important group of urantum (IV) compounds. Complex salts are formed also with hallde, sulfite, sulfate, and phosphate lons. Inorganic compounds of pentavalent uranium are $\mathrm{UF}_{5}, \mathrm{UCl}_{5}, \mathrm{UCl}_{5} \cdot \mathrm{SOCl}_{2}, \underline{8}$ $\mathrm{UCl}_{5} \cdot \mathrm{PCl}_{5}, \underline{6}$ and $\mathrm{UF}_{5} \cdot \mathrm{xHF}, \underline{6} \mathrm{UOCl}_{3}$ has been reported as an intermediate compound in the chlorination of uranium oxides with carbon tetrachloride. I Uranium (V) alkoxides have been prepared. $\cong$ Also, the compounds $\left(\mathrm{C}_{5} \mathrm{H}_{6} \mathrm{~N}\right)_{2} \mathrm{UOCl}_{5}$ and $\mathrm{UOCl}_{3}$. EtOH have been reported. 9 Hexavalent uranlum is represented by $\mathrm{UF}_{6}, \mathrm{UCl}_{6}, \mathrm{UO}_{3}$, uranates, and uranyl $\left(\mathrm{UO}_{2}^{2+}\right)$ compounds. Uranyl compounds are the most numerous uranium compounds and vary in type from simple salts to complex organic arrangements. Complex salts are formed with hal1de, lodate, nitrate, carbonate, cyanlde, acetate, oxalate, sulfate, phosphate, arsenate, chromate and vanadate 1ons. Triple acetate salts of the form

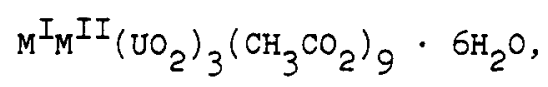

where $M^{I}$ is an alkall metal ( $L 1, \mathrm{Na}$, or $K$ ) and $M^{I I}$ is a divalent metal ( $\mathrm{Mg}, \mathrm{N}_{1}, \mathrm{Zn}$, etc.), are used in analytical separations of uranium. Addition compounds, such as $\mathrm{UO}_{2}\left(\mathrm{NO}_{3}\right)_{2} \cdot 2 \mathrm{CH}_{3} \mathrm{COC}_{4} \mathrm{H}_{9}$, represent a large number of uranyl compounds.

Uranates and peruranates are important in the analytical chemistry of uranium. Uranates have the general formula $x M_{2}^{I} O$. $\mathrm{yUO}_{3}$ or $\mathrm{xM}^{\mathrm{II}} \cdot \mathrm{yUO}_{3}$. They may be prepared by a1fferent methods. -10 However, in usual analytical procedures, they are precipitated 
from a uranyl solution by the addition of a soluable metal hydrox1de, $\mathrm{NH}_{4} \mathrm{OH}, \mathrm{NaOH}, \mathrm{Ca}(\mathrm{OH})_{2}$, etc. The uranates are insoluble in water but dissolve in acids.

Peruranates 6 are formed when uranyl solutions containing hydrogen peroxide are made alkaline. The composition of the peruranates depends upon the concentration of the alkali and peroxide. The following groups have been ldentifled:

$\mathrm{M}_{2} \mathrm{U}_{2} \mathrm{O}_{10} \cdot \mathrm{xH}_{2} \mathrm{O}, \mathrm{M}_{2} \mathrm{UO}_{6} \cdot \mathrm{xH}_{2} \mathrm{O}, \mathrm{M}_{6} \mathrm{U}_{2} \mathrm{O}_{13} \cdot \mathrm{xH}_{2} \mathrm{O}$, and $\mathrm{M}_{4} \mathrm{UO}_{8} \cdot \mathrm{xH}_{2} \mathrm{O}$. The pemaranates are generaliy soluble in water. The least soluble are those of the $\mathrm{M}_{2} \mathrm{U}_{2} \mathrm{O}_{10} \cdot \mathrm{xH}_{2} \mathrm{O}$ group. The peruranates are soluble in dilute mineral acias.

Table II lists a number of uranium compounds together with their behavior in different solvents. The compounds listed are primarily binary compounds or simple salts. The order in which they appear is the order in which they may be found in "Gmelins Handbuch der Anorganischen Chemie." $\underline{6}$

Table II. Uranium Compounds and Their Solvents.

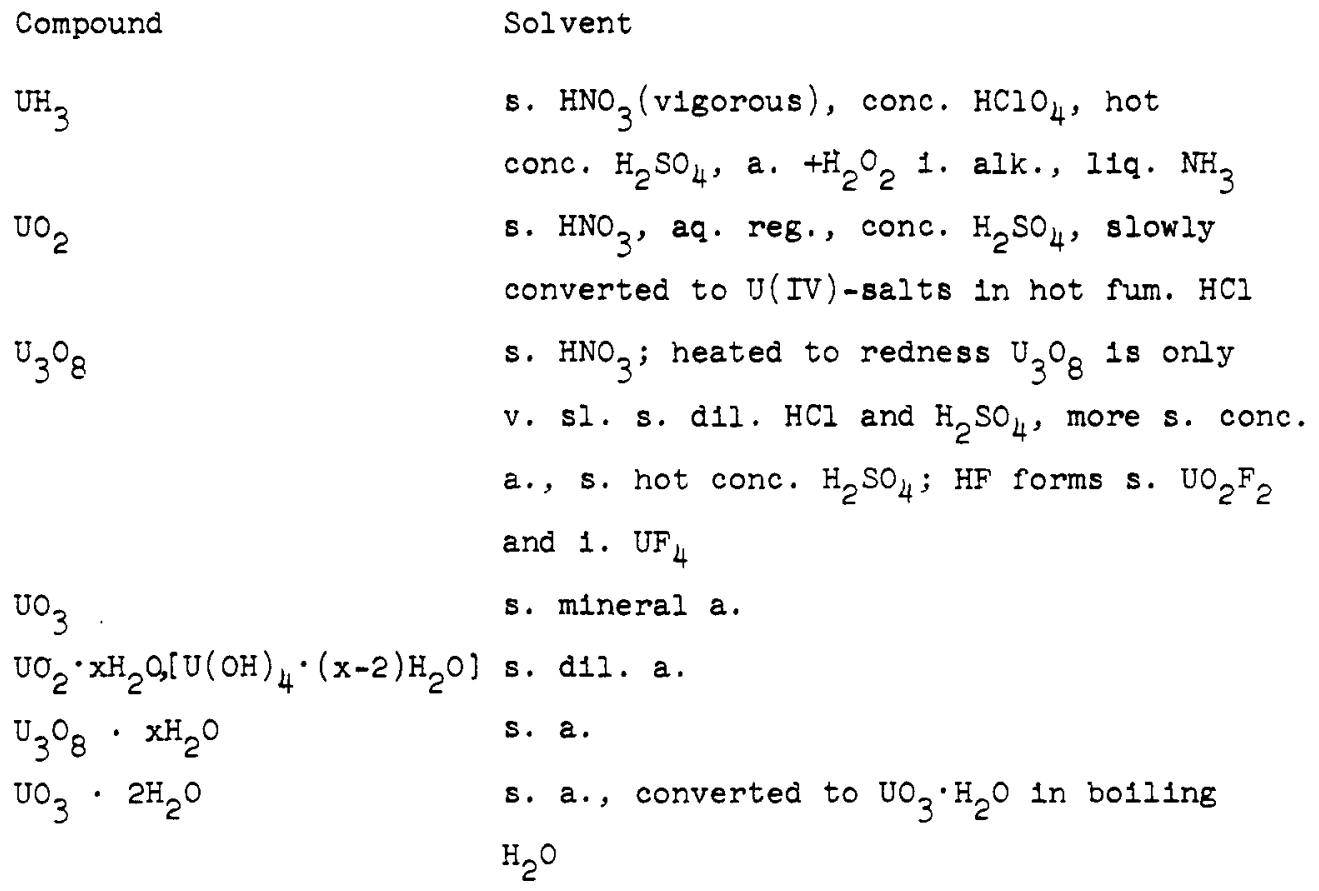


Table II. - Continued

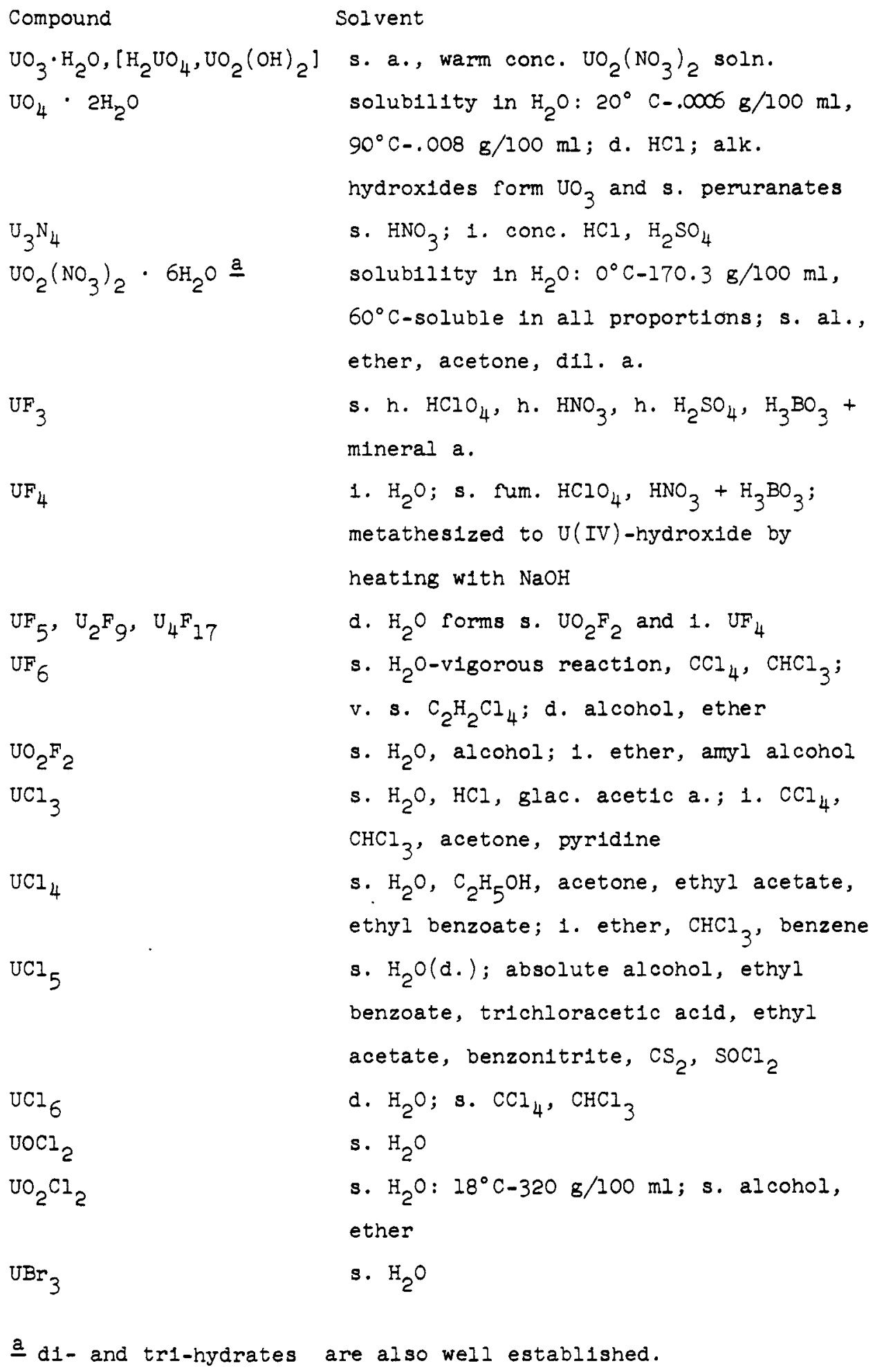


Table II. - Continued

Compound

$\mathrm{UBr}_{4}$

$$
\begin{aligned}
& \mathrm{WBr} r_{2} \\
& \mathrm{UO}_{2} \mathrm{Br}_{2} \\
& \mathrm{UI}_{3} \\
& \mathrm{UI}_{4} \\
& \mathrm{UO}_{2}\left(\mathrm{IO}_{3}\right)_{2} \cdot \mathrm{H}_{2} \mathrm{O}
\end{aligned}
$$

US

$$
\begin{aligned}
& \mathrm{U}_{2} \mathrm{~S}_{3} \\
& \mathrm{US}_{2} \\
& \mathrm{UO}_{2} \mathrm{~S} \\
& \mathrm{UO}_{2} \mathrm{SO}_{3} \cdot 4 \mathrm{H}_{2} \mathrm{O} \\
& \mathrm{U}\left(\mathrm{SO}_{4}\right)_{2} \cdot 9 \mathrm{H}_{2} \mathrm{O} \\
& \mathrm{U}\left(\mathrm{SO}_{4}\right)_{2} \cdot 8 \mathrm{H}_{2} \mathrm{O}
\end{aligned}
$$$$
\mathrm{U}\left(\mathrm{SO}_{4}\right)_{2} \cdot 4 \mathrm{H}_{2} \mathrm{O}
$$$$
\mathrm{UOSO}_{4} \cdot 2 \mathrm{H}_{2} \mathrm{O}
$$$$
\mathrm{UO}_{2} \mathrm{SO}_{4} \cdot 3 \mathrm{H}_{2} \mathrm{O}
$$$$
\mathrm{UO}_{2} \mathrm{SO}_{4} \cdot \mathrm{H}_{2} \mathrm{O}
$$$$
\mathrm{USe}_{2}
$$$$
\mathrm{UO}_{2} \mathrm{Se}
$$

\section{Solvent}

s. $\mathrm{H}_{2} \mathrm{O}$, acetone, methyl- and ethyl-acetate, pyridine; 1 . ether

s. $\mathrm{H}_{2} \mathrm{O}$

s. $\mathrm{H}_{2} \mathrm{O}$, alcohol, ether

s. $\mathrm{H}_{2} \mathrm{O}$

s. $\mathrm{H}_{2} \mathrm{O}$

v. sl. s. $\mathrm{H}_{2} \mathrm{O}: 18^{\circ} \mathrm{C}-\alpha$ form, 0.1049

$\mathrm{g} / 100 \mathrm{ml}, B$ form, $0.1214 \mathrm{~g} / 100 \mathrm{ml}$;

cold ppt. 8. $\mathrm{HNO}_{3}$ and $\mathrm{H}_{3} \mathrm{PO}_{4}$, 1. a.

after previously heating to bolling

temp. ; 8. alk. carbonates

v. difflcultig s. conc. $\mathrm{HCl}$, dil. $\mathrm{HNO}_{3}$

to aq. reg., conc. $\mathrm{HNO}_{3}$

d. steam, $\mathrm{HNO}_{3} ;$ s. hot conc. $\mathrm{HCl}$

sl. s. $\mathrm{H}_{2} \mathrm{O}$; s. dil. a., alcohol, $\left(\mathrm{NH}_{4}\right)_{2} \mathrm{CO}_{3}$;

1. absolute alcohol

1. $\mathrm{H}_{2} \mathrm{O}$; s. aq. or alcoholic $\mathrm{SO}_{2}$ solution

s. d11. $\mathrm{H}_{2} \mathrm{SO}_{4}$

hydrolyzes in $\mathrm{H}_{2} \mathrm{O}$ with separation of basic sulfate, $\mathrm{UOSO}_{4} \cdot 2 \mathrm{H}_{2} \mathrm{O}$; s. dil. mineral a., acetic a.

hydrolyzes in $\mathrm{H}_{2} \mathrm{O}\left(\right.$ d.); s. d1l. $\mathrm{H}_{2} \mathrm{SO}_{4}$, $\mathrm{HCl}$

s. a.

s. $\mathrm{H}_{2} \mathrm{O}: 15.5^{\circ} \mathrm{C}-20.5 \mathrm{~g} / 100 \mathrm{ml}, 100^{\circ} \mathrm{C}-$ $22.2 \mathrm{~g} / 100 \mathrm{ml}$; s. mineral a.

s. $\because 20$

ignites with $\mathrm{HNO}_{3}$; chemical properties similar to US?

d. $\mathrm{H}_{2} \mathrm{O} ; \mathrm{s}$. cold $\mathrm{HCl}$ - forms $\mathrm{UO}_{2} \mathrm{Cl}_{2}$ 
Table II. - Continued

Compound

Solvent

and $\mathrm{H}_{2} \mathrm{Se}$; reacts violently with $\mathrm{HNO}_{3}$ Se is first formed and is then oxidized

$\mathrm{UO}_{2} \mathrm{SeO}_{3} \cdot 2 \mathrm{H}_{2} \mathrm{O}$

1. $\mathrm{H}_{2} \mathrm{O} ; \mathrm{s}$. $\mathrm{HCl}$

$\mathrm{UB}_{2}$

s. aq. reg., $\mathrm{HNO}_{3}, \mathrm{HF}$

$\mathrm{UB}_{4}$

s. cold $\mathrm{HF}$, cold $\mathrm{HCl}, \mathrm{HNO}_{3}$, conc. $\mathrm{H}_{2} \mathrm{O}_{2}$, reduces conc. $\mathrm{H}_{2} \mathrm{SO}_{4}$

$\mathrm{UB}_{12}$

1. hot conc. $\mathrm{HCl}, \mathrm{HF}$; slowly s. hot conc. $\mathrm{H}_{2} \mathrm{SO}_{4}$

$\mathrm{U}\left(\mathrm{BH}_{4}\right)_{4}$

d. $\mathrm{H}_{2} \mathrm{O}$, alcohol

$\mathrm{UC}_{2}$

d. $\mathrm{H}_{2} \mathrm{O}, \mathrm{d} 1 \mathrm{l} . \mathrm{HCl}, \mathrm{d} 11 . \mathrm{HNO}_{3}, \mathrm{~d} 1 \mathrm{l}, \mathrm{H}_{2} \mathrm{SO}_{4}$;

reacts vigorously with heated conc. a.

$\mathrm{UO}_{2} \mathrm{CO}_{3}$
$\mathrm{UO}_{2}\left(\mathrm{HCO}_{2}\right)_{2} \cdot \mathrm{H}_{2} \mathrm{O}$

s. a.

s. $\mathrm{H}_{2} \mathrm{O}: 15^{\circ} \mathrm{C}-420 \mathrm{~g} / 100 \mathrm{ml}$; s. methyl

alcohol; sl. s. formic a.; 1. ethyl

alcohol, ether, acetone, $\mathrm{CS}_{2}, \mathrm{CCl}_{4}$,

$\mathrm{CHCl}_{3}$, benzene, petroleum ether

$\mathrm{UO}_{2}\left(\mathrm{HCO}_{2}\right)_{2} \cdot \mathrm{UO}_{3} \cdot 3 \mathrm{H}_{2} \mathrm{O}$ less $\mathrm{s} \cdot \mathrm{H}_{2} \mathrm{O}$ than neutral salt; more

s. formic a. than neutral salt

$\mathrm{UO}_{2}\left(\mathrm{CH}_{3} \mathrm{CO}_{2}\right)_{2} \cdot 2 \mathrm{H}_{2} \mathrm{O}$

s $\mathrm{H}_{2} \mathrm{O}: 15^{\circ} \mathrm{C}-7.694 \mathrm{~g} / 100 \mathrm{ml} ; \mathrm{v} . \mathrm{s}$.

alcohol; 1 . ether

$\mathrm{U}\left(\mathrm{C}_{2} \mathrm{O}_{4}\right)_{2} \cdot 6 \mathrm{H}_{2} \mathrm{O}$

1. $\mathrm{H}_{2} \mathrm{O}$, dll. a.; s. warm conc. $\mathrm{HCl}$, conc. $\mathrm{HNO}_{3}$

$\mathrm{UO}_{2} \mathrm{C}_{2} \mathrm{O}_{4} \cdot 3 \mathrm{H}_{2} \mathrm{O}$

sl. s. $\mathrm{H}_{2} \mathrm{O}: 14^{\circ} \mathrm{C}-0.8 \mathrm{~g} / 100 \mathrm{ml}, 100^{\circ} \mathrm{C}-$

$3.3 \mathrm{~g} / 100 \mathrm{ml}$ : s. mineral a., $\mathrm{H}_{2} \mathrm{C}_{2} \mathrm{O}_{4}$ and alk. oxalate solutions

$U\left(\mathrm{C}_{4} \mathrm{H}_{4} \mathrm{O}_{6}\right)_{2} \cdot 2 \mathrm{H}_{2} \mathrm{O}$

1. $\mathrm{H}_{2} \mathrm{O}$, organic solvents; $\mathrm{s}$. tartaric a., tartrates, conc. a.

$\mathrm{UO}_{2}\left(\mathrm{C}_{4} \mathrm{H}_{4} \mathrm{O}_{6}\right) \cdot 4 \mathrm{H}_{2} \mathrm{O}$

sl. s. $\mathrm{H}_{2} \mathrm{O}: 17^{\circ} \mathrm{C}-3.28 \mathrm{~g} / 100 \mathrm{cc}$ solution

$\mathrm{UO}_{2}(\mathrm{CNS})_{2} \cdot 8 \mathrm{H}_{2} \mathrm{O}$

s. $\mathrm{H}_{2} \mathrm{O}$, ethyl and amyl alcohol, acetone, ether 


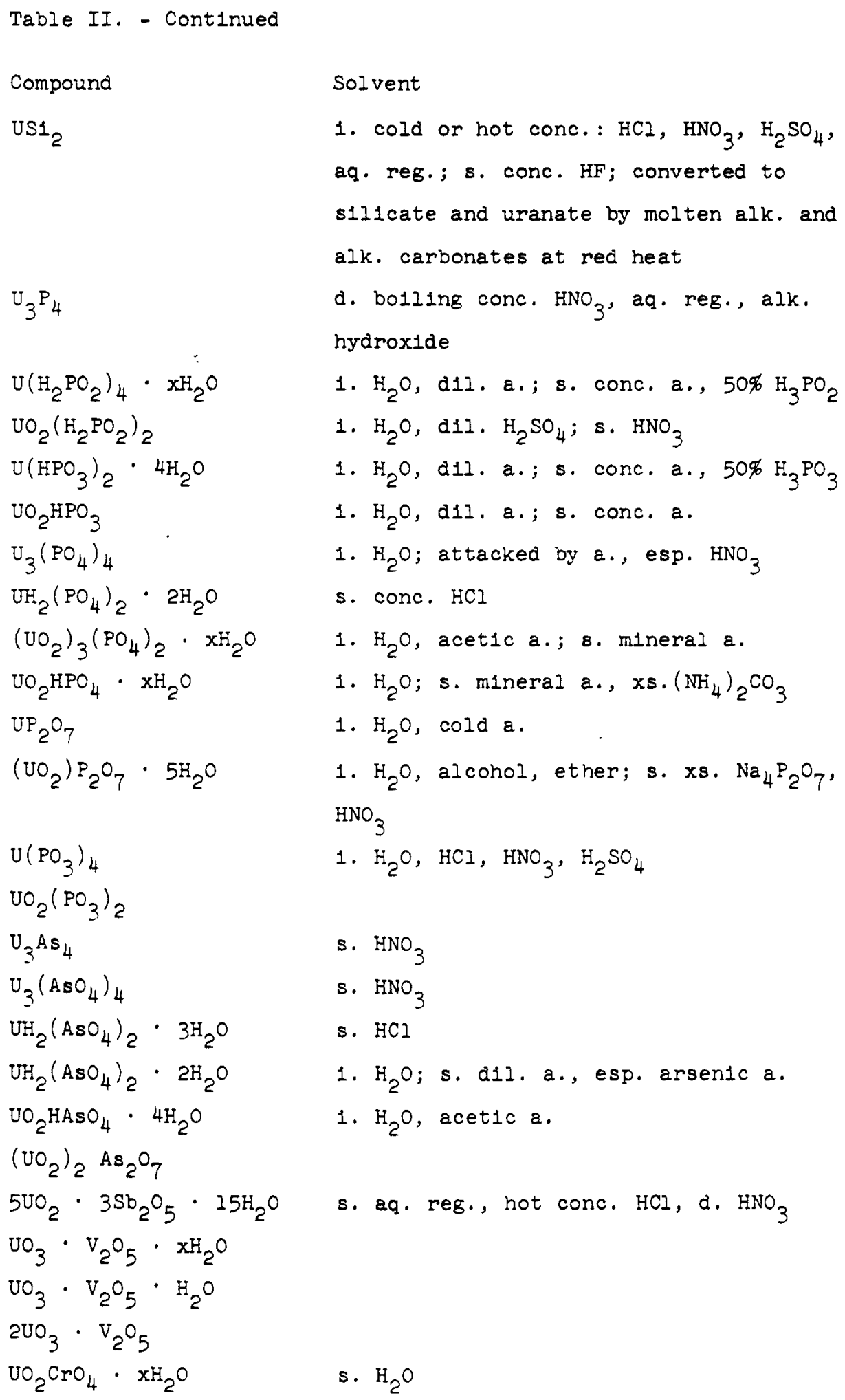


Table II. - Continued

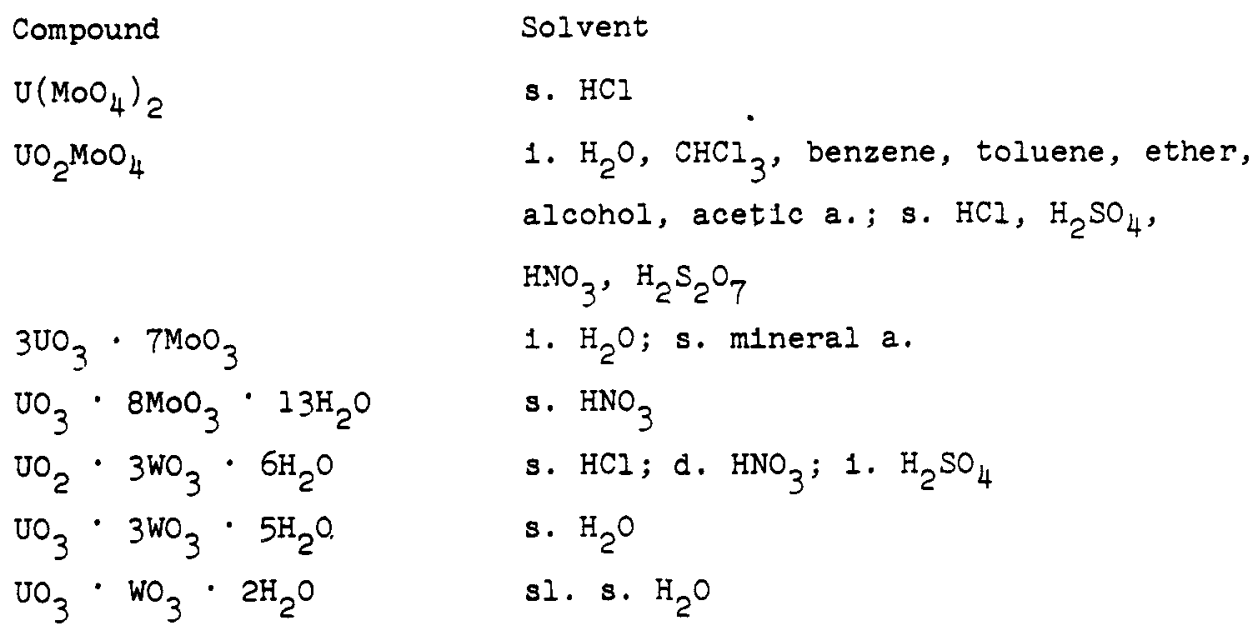

Abbreviations used:

\begin{tabular}{|c|c|c|c|c|}
\hline a. & - actd & fum. & - & fuming \\
\hline alk. & - alkal1 & h. & - & not \\
\hline aq. & - aqueous & 1. & - & Insoluble \\
\hline aq. reg. & aqua regia & 1. & - & IIquid \\
\hline conc. & concentrated & s. & - & solubie \\
\hline d. & - decomposes & sl. & - & slightly \\
\hline d11. & - dilute & $\mathrm{v}$. & - & very \\
\hline & - especially & xs. & - & excess \\
\hline
\end{tabular}

IV-C. The Chemistry of Uranium in Solution

1. Oxidation states. Four oxidation states are known for uranium Ions in aqueous solution: the tr1-, tetra-, penta-, and hexapositive states. Ions in these states are usually represented as $\mathrm{U}^{+3}, \mathrm{U}^{+4}, \mathrm{UO}_{2}^{+}$and $\mathrm{UO}_{2}^{+2}$, respectively. The potentials between the various oxidation states are given below for acldic and basic solutions. 2

Acldic solution: $1 \mathrm{M} \mathrm{HClO}_{4}$ at $25^{\circ} \mathrm{C}$

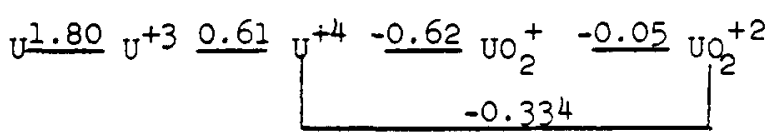


Basic solution:

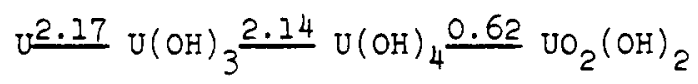

Tripositive uranium, $\mathrm{U}^{+3}$. Evidence for the existence of $U^{+3}$ comes from the reversibility of the $U(I I I) / U(I V)$ couple. Solutions may be prepared by the dissolution of a uranium trihalide or by the electrolytic reduction of a uranium (IV) or (VI) solution. Chloride, bromide, lodide, perchlorate and sulfate solutions of uranium(III) have been reported. II They are deep red in color and unstable, with oxidation of $\mathrm{U}^{+3}$ to $U^{+4}$ occurring and hydrogen being evolved. Strongly acidified solutions 12 or those kept at low temperatures 10 appear to be more stable.

Tetrapositive uranium, $\mathrm{U}^{+4}$. The existence of the $\mathrm{U}^{+4}$ Ion in solution has been confirmed by measurement of the acid liberated on dissolving $\mathrm{UCl}_{4} \stackrel{13}{3}$ and by solvent extraction studies of $U(I V)$ with thenoyltrifluoroacetone $14 a$ and acetylacetone. $14 \mathrm{~b}$ Uranous solutions may be prepared by dissolution of a water-soluble salt: the chloride, bromide, lodide, or sulfate; by dissolution of uranium or a uranium compound in an approprlate solvent, e.g., uranium metal in sulfuric or phosphoric acid; or by reduction of a uranyl solution by chemical, electrochemical or photochemical means. The solutions are green in color. They are stable in the absence of a1r but are oxidized by oxygen. Uranium(IV) undergoes hydrolysis with evidence in the flrst stages for the formation of the mononuclear species, $\mathrm{UOH}^{+3}$. 13,15-18 $\mathrm{Poly}-$ meric species also are formed which apparently are not in equilibrium with the monomer. $13,15,19$ Hietanen 17 found that In addition to the monomeric species, a polymer of the type $\mathrm{U}\left[(\mathrm{OH})_{3} \mathrm{U}\right]_{n}^{4+n}$ could account for the hydrolysis of uranium(IV) to good approximation. Table III, based primarily upon the data complied by Bjermum, Schwarzenbach, and S1lién, $\underline{20}$ 
Table III. Hydrolya1s of $\mathrm{v}^{4+}$ and $\mathrm{VO}_{2}^{2+}$ Ions:

\begin{tabular}{|c|c|c|c|c|c|}
\hline Ion & Method & $\mathbf{T}$ & Medium & Log or equilibrium constant, remarks & Reference \\
\hline \multirow[t]{9}{*}{$u^{4+}$} & magnet & 20 & var & ${ }^{*} \beta_{2}-2.30$ & 21 \\
\hline & sp & 25 & $\mathrm{C}\left(\mathrm{NaClO}_{4}\right)$ & ${ }^{*} \mathrm{~K}_{1}-1.63(\mathrm{C}=2),-1.56(\mathrm{C}=1),-1.50(\mathrm{C}=0.5)$ & 13 \\
\hline & $s p$ & $10-43$ & $0.5\left(\mathrm{NaClO}_{4}\right)$ & ${ }^{*} \mathrm{~K}_{1}-1.90\left(10^{\circ}\right),-1.47\left(25^{\circ}\right),-1.00\left(43^{\circ}\right)$ & 22 \\
\hline & sp & $10-43$ & $\rightarrow 0$ & $\begin{array}{l}{ }^{*} K_{1}=1.12\left(10^{\circ}\right),-0.68\left(25^{\circ}\right),-0.18\left(43^{\circ}\right) \\
\Delta^{*} H_{1}=11.7, \Delta^{*} s_{1}=36\left(25^{\circ}\right)\end{array}$ & 13,21 \\
\hline & sp & $15-25$ & $0.19\left(\mathrm{HClO}_{4}\right)$ & ${ }^{*} k_{1}-1.38\left(15.2^{\circ}\right),-1.12\left(24.7^{\circ}\right)$ & 16 \\
\hline & & 25 & $0 \operatorname{corr}$ & $\Delta^{*} H_{1}=10.7, \Delta^{*} S_{1}=33, \Delta S_{1}=52$ & 16 \\
\hline & 81, red & 25 & $3(\mathrm{Na}) \mathrm{ClO}_{4}$ & ${ }^{*} K_{1}-2.0, B_{3 n, n+1}-1.2--3.4 n$ & 17 \\
\hline & sol & 25 & 0 corr & $\mathrm{K}_{\mathrm{S}_{5}}-3.77\left[\mathrm{NO}(\mathrm{OH})_{4}(\mathrm{~S}) "\right]$ & 23 \\
\hline & sp & 25 & $2\left(\mathrm{ClO}_{4}^{-}\right)$ & 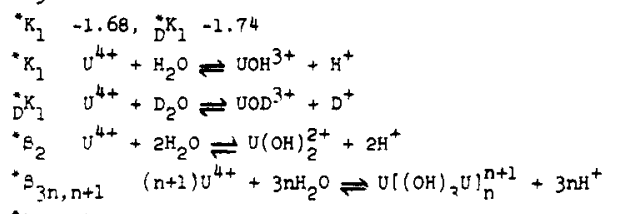 & 18 \\
\hline \multirow[t]{3}{*}{$\mathrm{vo}_{2}^{2+}$} & $a h$ & $25-26$ & 0 corr & $\cdot \mathrm{K}_{1} \quad-4 \cdot 3$ & 49 \\
\hline & s1 & $20-25$ & var & ${ }^{*} B_{22}-5.87$ & 37 \\
\hline & $c 01$ & ? & var & $\begin{array}{l}{ }^{*} \mathrm{~K}_{1}-4.50,{ }^{*} \mathrm{~B}_{22}-4.95 \\
\text { ev } \mathrm{UO}_{2} \mathrm{NO}_{3} \mathrm{OH}, \mathrm{NO}_{2}\left(\mathrm{NO}_{3}\right)_{3} \mathrm{OH}^{2-}\end{array}$ & 38 \\
\hline \multirow[t]{13}{*}{$\mathrm{wo}_{2}^{2+}$} & ah, & 25 & $0 \operatorname{sorr}$ & ${ }^{\prime} K_{1}-4.09$ & $25 \mathrm{c}$ \\
\hline & gl & 15 & $\mathrm{C}\left[\mathrm{Ba}\left(\mathrm{NO}_{3}\right)_{2}\right]$ & ${ }^{*} e_{22}-5.97(c=0.6), \quad-5.72(c=0.06)$ & $39,52,53$ \\
\hline & Qh, 81 & 20 & $1(\mathrm{Na}) \mathrm{ClO}_{4}$ & ${ }^{*} \mathrm{~K}_{1}-4.70(\%$, see rer. 43), ev polyn epx & 42 \\
\hline & & $\begin{array}{l}20 \\
20\end{array}$ & $\begin{array}{l}2(\mathrm{Na}) \mathrm{ClO}_{4} \\
2(\mathrm{Na}) \mathrm{ClO}_{4}\end{array}$ & $\begin{array}{l}\beta_{2 n, n+1} 0.30 \cdots 6.35 n \\
B_{2 n, n+1} 0.30 \cdots 6.40 n\end{array}$ & $\begin{array}{l}\text { 42, } \operatorname{cr} 43 \\
\text { 42, } \operatorname{crs} 4\end{array}$ \\
\hline & $\mathrm{gl}, \mathrm{rp}, \mathrm{sp}$ & $25^{\circ}$ & $0.15\left(\mathrm{NaClO}_{4}\right)$ & $\begin{array}{l}{ }^{2} B_{22}-5.94,{ }^{*} B_{43}-14.29 \\
K_{8}\left[U_{3} O_{8}(O H)_{n}^{2-n}\right) \cdot-3.55(n-0),-6.5(n=1), \\
-7.4(n-2),-11.0(n=3),-11.4(n=4)\end{array}$ & 40 \\
\hline & gl, fp, sp & $25^{\circ}$ & $0.2 \mathrm{ClO}_{4}$ & ${ }^{*} B_{22}-5.94, \quad B_{43}-12.90$ & 40 \\
\hline & $\mathrm{p}\left(\mathrm{H}_{2} \mathrm{O}\right)$ & 25 & $\begin{array}{l}2 \mathrm{NO}_{2}\left(\mathrm{ClO}_{4}\right) \\
+\mathrm{NO}_{3}\end{array}$ & ev $\left(\mathrm{UO}_{2} \mathrm{OH}\right)_{2}^{2+}$, not $\mathrm{VO}_{2} \mathrm{OH}^{+}$ & 44 \\
\hline & .001 & 25 & 0 corr & $\begin{array}{l}{ }^{*} \mathrm{~K}_{\mathrm{S}_{0}} 6.04,{ }^{*} \mathrm{~K}_{\mathrm{S}_{1}} 2.90, \mathrm{~K}_{\mathrm{S}_{3}}{ }^{-2.60,} \mathrm{~K}_{\mathrm{S}_{4}}-2.77 \\
{ }^{*} \mathrm{~K}_{1}-4.14 \text {, ev polym cps }\end{array}$ & 48 \\
\hline & sp & ? & var & " $\mathrm{K}_{1}-4.19$ & 50 \\
\hline & dist & 25 & $0.1(\mathrm{Na}) \mathrm{ClO}_{4}$ & ${ }^{*} K_{1}-4.2, " k_{2}-5.20$ & 51 \\
\hline & 81 & 25 & $0 \cos r$ & ${ }^{*} B_{22}-5.06,{ }^{*} B_{24}-1.26$ & 45 \\
\hline & gl & 25 & $0.347\left(\mathrm{Ba}\left(\mathrm{ClO}_{4}\right)_{2}\right)$ & ${ }^{*} x_{1}-5.40, B_{22}-5.82$ & 46 \\
\hline & 81 & $25-40$ & $0.0347\left[\mathrm{Be}\left(\mathrm{CLO}_{4}\right)_{2}\right]$ & $\begin{array}{l}X_{1}-5.82\left(25^{\circ}\right),-5.10\left(40^{\circ}\right), \Delta \Delta^{*} H_{1}=20.8 \\
B_{22}-6.25\left(25^{\circ}\right),-5.92\left(40^{\circ}\right), \Delta \Delta^{*} H_{B 2}=6.7\end{array}$ & 46 \\
\hline \multirow[t]{3}{*}{$\mathrm{vo}_{2}^{2+}$} & & 25 & $0.0347\left(\mathrm{Ba}\left(\mathrm{ClO}_{4}\right)_{2}\right)$ & $\Delta s_{1}=4 \cdot 3, \Delta^{*} s_{B_{22}}=-6$ & 46 \\
\hline & ah, Bi & 25 & $\begin{array}{l}1\left(\mathrm{Na}_{\mathrm{a}} \mathrm{ClO}_{4}\right. \\
0.4 \mathrm{UO}_{2}^{2+}\end{array}$ & $-3.66,{ }^{B_{22}}-6.02$ & 47 \\
\hline & qh, 81 & 25 & $\begin{array}{l}3(\mathrm{Ne}) \mathrm{ClO}_{4} \\
1.400_{2}^{2+}\end{array}$ & 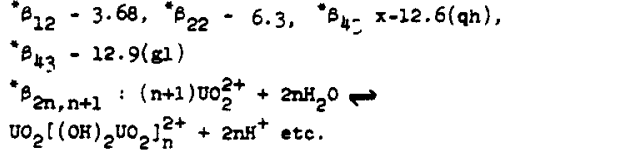 & 47 \\
\hline
\end{tabular}

a After J. Bjemrum, G. Schwarzenbach, and L. G. S1llén, reference 20. 


\section{Table III (Continued)}

TAELE NOTATIO

The notation uaed in this and in the tables on complex for formation 18 petterned arcer that used by Bjerrux, Sabwarzengach, and silién, reference 20 The explanetion of the table which rollows is taicen primarily from part II of reforence 20 and this anould be consulted for further detells concerning notation Part I of reference 20 may be consulted for a description of the verious methods by when equilibrium constants are detemined

Colums one, "Ion,' refers to the centraj Ion $M$ about whter the complex 18 rormed

Colung two, "Method,' refers to the mothot which the constunts were messured The sbrevietions used are

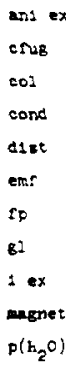

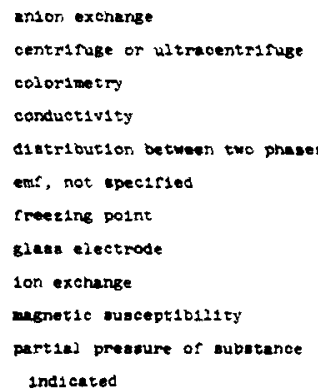

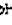

po?

prep

ath

rece

.01

8

$x-2 \cos$

$\Delta C$

Pt

$\mathrm{AC}_{2} \mathrm{C}_{2} \mathrm{O}_{4}$ ph methoo, not upeciried

polarography

preperative work

ouinhyarone electroot

ens with rodox electrode

olutility

epectrophotometry

$x$-ray diffrectior

combination of therwodynaric date

emf menturwent with Pt esectrode

onf masurament with $\mathrm{AB}_{2} \mathrm{C}_{2} \mathrm{C}_{4}$ electrode

method not kram to conpisters

Colum three, " $I$, ' gives the temperature in ' $C$, "RT' Ind1cates room tomperature, and " $"$ is uned if the tomperature is uriknown to the compilers

Column sour, "Madium,' denotes the mature of the metiur to whict the equlibrium constants refer the concentrations giver in terms of moles per liter or moles per kilogran are not distingulated water is the olvent unles: otherwise stated Syavols unec are

$2\left(\mathrm{NaClO}_{4}\right)$

$\mathrm{I}\left(\mathrm{NaClO}_{4}\right)$

$2(\mathrm{Na}) \mathrm{C}_{2} \mathrm{O}_{4}$ contents extrepolated to zero lonsc strengt constast corrected to zero lonic atrengtr applicetior of some theoretica, or emplrict sormila

ar lonle strengtr of 0 a mole per lices constent concentration of the absiance atated (a mose per liter Nacio lonic atrength held constant at value statec (2 mole per liter) by additior of the inert velt indicated

meaturements made at berles of lon 1 atrengths (I) with $\mathrm{NaClO}_{4}$ as the inert ant concentration of the anion $\left(\mathrm{ClO}_{4}^{-}\right)$nelo constart at the value atated (1 mole per 11 ter with the ion how in parentheses as the iner: cestor.

$\mathrm{ClCiO}_{4}{ }^{-1}$ meacurements made at aeriet of perchiorate concentretions

aij dilute solution, concentration usually not more that 0.0 . wole per ilter

ver lontc medium varled, and ir one cases no apec1el at tempt was made to control the lonic strengs-

KC2 var the mediur was malniy equeous $\mathrm{KC}$ at var1ous concert rations

Etor ethanol as aoj ven:

ore varioss orgaric boiverts

$505 \mathrm{MeC}-\quad 505$ methano, -wate- as solver:

Columr five, 'Log of equilibriur constart, remarks. The following corvertions are used $" K_{2} E^{\prime}$ means ' ${ }^{\prime} E_{2} K_{2}=E$,

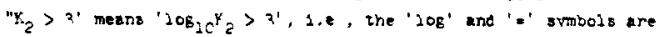
onitiee Concentrations : l are umaily expresued as moles per 2iter, but is not diatingulabed from moles per kilogram Preasures of are 1: atmospheres

The equilidriur conscants refer te various types of reactions 1rdickted on the next page 
Coneecutive or step-wise constant K

- Addition of ilgand (L)

$$
M L_{n-1}+L-M L_{n} \quad x_{n}=\frac{\left(M L_{r}\right.}{\left[M L_{n-1}\right](L)}
$$

b Addition of protonated ligand (Hi) with ellmination of proton

$$
M L_{n-1}+H L \rightleftharpoons M L_{n}+H^{+}+x_{n}=\frac{\left[M L_{n}\right)\left[H^{+}\right]}{\left(M L_{n-1}\right)[H L]}
$$

c Addition of protonated ligand $\left(H_{D} L\right)$

$$
M\left(H_{p} L\right)_{n-1}+H_{p} \mathcal{L} \rightleftharpoons M\left(H_{p} L\right)_{n} \quad H_{p} L K_{n}=\frac{\left[M \left(H_{p} L\right.\right.}{\left(M\left(H_{p} L\right)_{n-1}\left[H_{p} L\right]\right.}
$$

a Adasizon or central etom (M)

$$
M_{n-1} L+M \sim M_{n}{ }^{2} \quad x_{1 n} * \frac{\left|M_{r} L\right|}{\left[M_{n-1} I \mid[M]\right.}
$$

2 Cumusetive or grose constants B

In $B_{n m}$ and ${ }^{\circ} s_{n n}$ the subscripts $n$ and $m$ denote the composition of the complex $M_{m} L_{n}$ formad when $m=+$ the second oubeript 1. omsted

- Addition or eentral stome (M) and l1gands (L)

$$
m+n L=M_{m} L_{n} \quad B_{n+m}=\frac{\mid M_{T} I_{n}}{\left[M{ }^{m}[L]^{n}\right.}
$$

b addition of contral atoms (M) and protonated 21gands

(HI) with elinination of protons

$$
m M+n H E \rightleftharpoons M_{m} L_{n}+n H^{+} \quad B_{n d}=\frac{\left(M_{m} L_{n}\right]\left[H^{+}\right]^{n}}{(M)^{m}[H L]^{n}}
$$

3 Solubility constant $K_{s}$

- Sol1d $M_{a} I_{b}$ in equilibriure witn rree lone in solution

$$
\left.M_{a} L_{v}(s)=a M+b L \quad K_{a_{0}}=\{M\}^{2} I_{L}\right\}^{D}
$$

- Sol1e $M_{2} L_{0}$ in equ111brium $w_{1 \text { th }}$ complex $M_{m} L_{n}$ and 1 gand I in solution

$$
\begin{aligned}
& \frac{m}{a} M_{a} L_{b}(s)=M_{m} L_{n}+\left(\frac{m b}{s}-n\right) L \\
& \qquad K_{s=1}=\left[M_{m} L_{n}\right][s)^{\left(\frac{m b}{a}-n\right)}
\end{aligned}
$$

In $k_{a_{n m}}$ the subscripts $n$ and in denote the composition or the complex $M_{\pi} L_{n}$ formed $1 n$ solution when w $=1$ the ecoond subserpt is omitted

c Protonated ligand reaces with the elimination of proton

$$
\begin{aligned}
& \frac{m}{a} m_{a} L_{b}(s)+\left(\frac{m b}{a}-n\right) H^{+} \rightarrow M_{m} L_{n}+\left(\frac{m b}{2}-n\right) h L \\
&{ }^{*} k_{s m}=\frac{\left(M_{n} L_{n}\right)(H L)\left(\frac{m b}{a}-n\right)}{\left(H^{+}\right)\left(\frac{m b}{a}-n\right)}
\end{aligned}
$$

4 Acidic and besic constant:

- when I is nydroxide $\left(\mathrm{OH}^{-}\right)$, thL is water and ${ }^{*} \mathrm{~K}_{\mathrm{n}}$ 1s the nth ac1d dissociation conutant for the mydrolysis of a metalic ion b The use of $\mathrm{H}^{+}$as the centrel atom to repreaent protolytic constants 13 liluotrated by 1 of above

$c$ other acidic constants are denoted by $\mathrm{K}_{\mathrm{a}}$ followed by parertheses encloaing the formule of the speciel doneting the proton

d Bestc constants are denoted by $k_{0}$ rollow if neceseery, by parenthases enclosing the formule of the specles accepting the proton

5 Special constants

$$
\begin{aligned}
& \text { * K (equation) } \\
& \text { The equation detarea the reaction to mich } x \text { refers } \\
& b{ }^{\top} \mathrm{K} \quad{ }^{+} \mathrm{K}_{\mathrm{s}_{\mathrm{nm}}}
\end{aligned}
$$

The corresponding rection is given in perentheses after the constant when the latter is flrat uaed for a particular ligand or central atom or the resction 19 given 1mediately below the equilibrium constanta for a partlcular ilgand or central atom

$$
\text { c (rormula) }
$$

The formula gives the composition of the complex in terms of the apecies from which it is forwed Species with negative subacript are aliminated in the formation of the complex

d $\mathrm{Ka}$ (rotmule)

The formule given the composition of the sol1d phese in terws of the opecies with which it is in equ111briun in colution speciel with negative subecripte are eliminated in the formetion of the solld

Hont content and entropy changes ere included in colum five $\Delta H$ is uausly witten in kilocalories and $\Delta S$ in caloriea per degree They are related to the corresponding curmulative equilibriun constants as rollow $B_{n}, \Delta H_{B} B_{n m} \Delta H_{B_{n m}}$ " $e_{n m}$ " $\Delta{ }^{*} B_{n}$ where the symbol $K$ is uaed for the equilibrium conatant $H$ or $S 18$ given the ane muperacript or mubeript at the corresponding $K \in B \quad K_{n} \Delta H_{n} K_{0} \Delta H_{0}{ }^{+} K_{n m} \Delta^{+} H_{n m}$ etc

Othar abbreviation used in column five are

ev $M_{m}{ }^{2}$ evidence for the exietence of the complex $M_{m} L_{n}$ epx complex

cet gationic

ani anionse

unch uncharged

polsn polymuclear

- authors coubt axpreceed in refarence given

(?) compilers doubt

Colums s2x, Rererences list the referenced as they are tound at the end of this work A reference such as 6 ef 25 indicates that calculation have been made in reforence 25 based upon data in reference 6 
summarizes the results of several studies on the hydrolysis of the uranium(IV) 1on.

Pentapositive uranium, UOt. The existence of $\operatorname{urantum}(\mathrm{V})$ ion in solution has been confirmed by polarographic measurements. $24-26$ support for the $\mathrm{UO}_{2}{ }^{+}$ion comes from the reversibility of the $U(V) / U(V I)$ couple $\frac{27}{}$ and from infrered $\frac{28}{}$ and crystallographic $\frac{29,30}{}$ studies of uranium and transuranic elements. Solutions of $\mathrm{UO}_{2}{ }^{+}$may be prepared by dissolution of $\mathrm{UCI}_{5} 31$ or by reduction of a uranyl solution, electrolytically or with $U(I V)$ ions, hyarogen, or zinc amalgam. 15 The formation of $U(V)$ is an intermediate process in the photochemical reduction of $U(V I)$ in a sucrose solution. 32 The solutions are unstable and disproportionate to $U(V I)$ and $U(I V)$. The rate of disproportionation is second order in uranium( $V)$ concentration and first order in acid concentration. $\frac{33,15}{2}$ The $\mathrm{UO}_{2}{ }^{+}$ion is most stable in the pH range of 2 to 4.15 It is oxidized to the uranyl ion by molecular oxygen, $\mathrm{Fe}$ (III) and $\mathrm{Ce}$ (IV). 15 Hexapositive uranium, $\mathrm{UO}_{2}^{+2}$. A number of physical-chemical measurements as well as crystallographic, infrared and Raman spectra studies support the existence of $U(V I)$ ion as $\mathrm{UO}_{2}^{+2}, \underline{2,10}$ Uranyl solutions are eas1ly prepared by dissolution of water-soluble salts: the nitrate, fluoride, chlorlde, bromide, lodide, sulfate, and acetate. Other watersoluble uranyl salts include those of other organic aclds: the formate, proplonate, butyrate, and valerate; and certain double salts such as potassium uranyl sulfate, sodium uranyl carbonate, sodium uranyl chromate, etc. Uranyl solutions may be prepared also by dissolution of a urantum(VI) compound in an appropriate solvent, by dissolution of a lower valence uranium compound in an oxidizing medium, or by oxidation of lower valence uranium lons already in solution. Uranyl solutions are yellow in color. They are the most stable of uranium solutions. As indicated in preceding paragraphs, the 
uranyl Ion may be reduced by reducing agents 34 or by electrochemical or photochemical means. The degree of dissociation of uranyl salts in aqueous solution varies. Uranyl perchlorate is apparently completely dissoclated; $\frac{10}{}$ whereas, uranyl fluorlde is undissociated and tends to form dimers (see section on complex ion formation - IV-C2),$\frac{35,36}{3}$ Hydrolysis of the uranyl ion has been the subject of extensive investigation. Considerable evidence has been adduced for the formation of polymer1c species of the type $\mathrm{UO}_{2}\left(\mathrm{UO}_{3}\right)_{n}^{2+} \cdot 37-47$ According

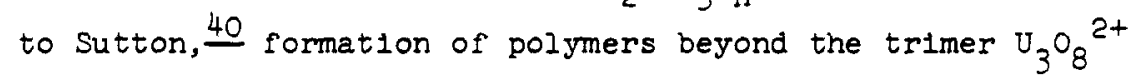
is negligible. However, the trimer itself may undergo further hydrolysis with the formation of $\mathrm{U}_{3} \mathrm{O}_{8}(\mathrm{OH})^{+}, \mathrm{U}_{3} \mathrm{O}_{8}(\mathrm{OH})_{2}$, and eventually anionic species. 40,41 Ahrland, 42 in his original paper, proposed the formation of the monomer $\mathrm{UO}_{2}(\mathrm{OH})^{+}$ as well as polynuclear species. In a reappralsal of the work, Arhland, Hletanen, and Sillén $\frac{43}{3}$ stated that there was no certain indication of mononuclear complexes being formed. Rather, the experimental data was explained on the basis that complex ions of the type $\mathrm{UO}_{2}\left[(\mathrm{OH})_{2} \mathrm{UO}_{2}\right]_{n}^{2+}$ were formed. From the data 1 was not possible to distingulsh between a limited mechanism in which $n$ varled from 1 to 3 or 4 or an unilmited mechanism in which $n$ assumed all integral values. The authors were 1nclined to prefer the latter. Kraus 19 suggested that reactions leading to the formation of polymers may have a less positive value of $\Delta H$ than the reaction leading to the formation of the monomer. Consequentiy, the latter process $\mathrm{might}$ be ldentified more readily at high temperatures than at room temperature. This is apparently the case as was shown by Hearne and White 46 who determined the enthalpy change to be $20.8 \mathrm{kcal} / \mathrm{mole}$ for the monomerlc reaction ( $\mathrm{UO}_{2} \mathrm{OH}^{+}$formed) and $6.7 \mathrm{kcal} / \mathrm{mole}$ for the dimeric reaction $\left(\mathrm{U}_{2} \mathrm{O}_{5}{ }^{2+}\right.$ formed). Table III summarizes much of the 
data avaliable on the hydrolysis of the uranyl ion. Included In the table are values of the equilibrium constant ${ }^{*} \mathrm{~K}_{1}$, the constant for the formation of the monomeric species. This constant has been evaluated by at least seven groups of

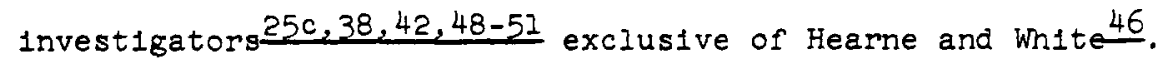
The values obtained agree very well ( $108{ }^{*} \mathrm{~K}_{I}=-4.09$ to -4.70 ). However, the experimental conditions $\underline{25 c, 38,50}$ and assumptions $\frac{25 c, 38}{1}$ used in some of the evaluations have been questioned. 46 Also, the re-evaluation of Ahrland ' 42 work already has been mentioned, and Rydberg 51 has proposed an explanation for not detecting polynuclear species in his experiments. None-the-less, one must concur with Rydberg 51 who wrote, "--1t seems remarkable that the same constants should be obtalned for a fictive mononuclear hydrolysis product with different $U(V I)$ concentrations and so different methods of investigation-..."

Complex ion formation. The ability of uranium to form complex. ions in solutions is of considerable importance in its analytical separation and determination. Hydrolysis, mentioned in the previous section, is but a special case of complex ion formation. Numerous complexes have been reported. 34 However, the amount of quantitative data for the various ligands is rather limited and often contradictory.

Tripositive uranium. Evidence has been reported for uranium(III) cupferrate 55 and uranium(III) chloro 56 complexes. Tetrapositive uranium. Inorganic complexes of uranium(IV) which have been recognized through the formation of complex salts include the fluoride, chloride, sulfate, sulfite, and phosphate. 34 Table IV lists the equilibrium constants and thermodynamic data avaliable for some of the uranium(IV) complexes in aqueous solution. In addition, a carbonate complex, possibly $U\left(\mathrm{CO}_{3}\right)_{5}^{6-}$, has been found to be stable in solutions of excess carbonate or bicarbonate 1ons. 63 


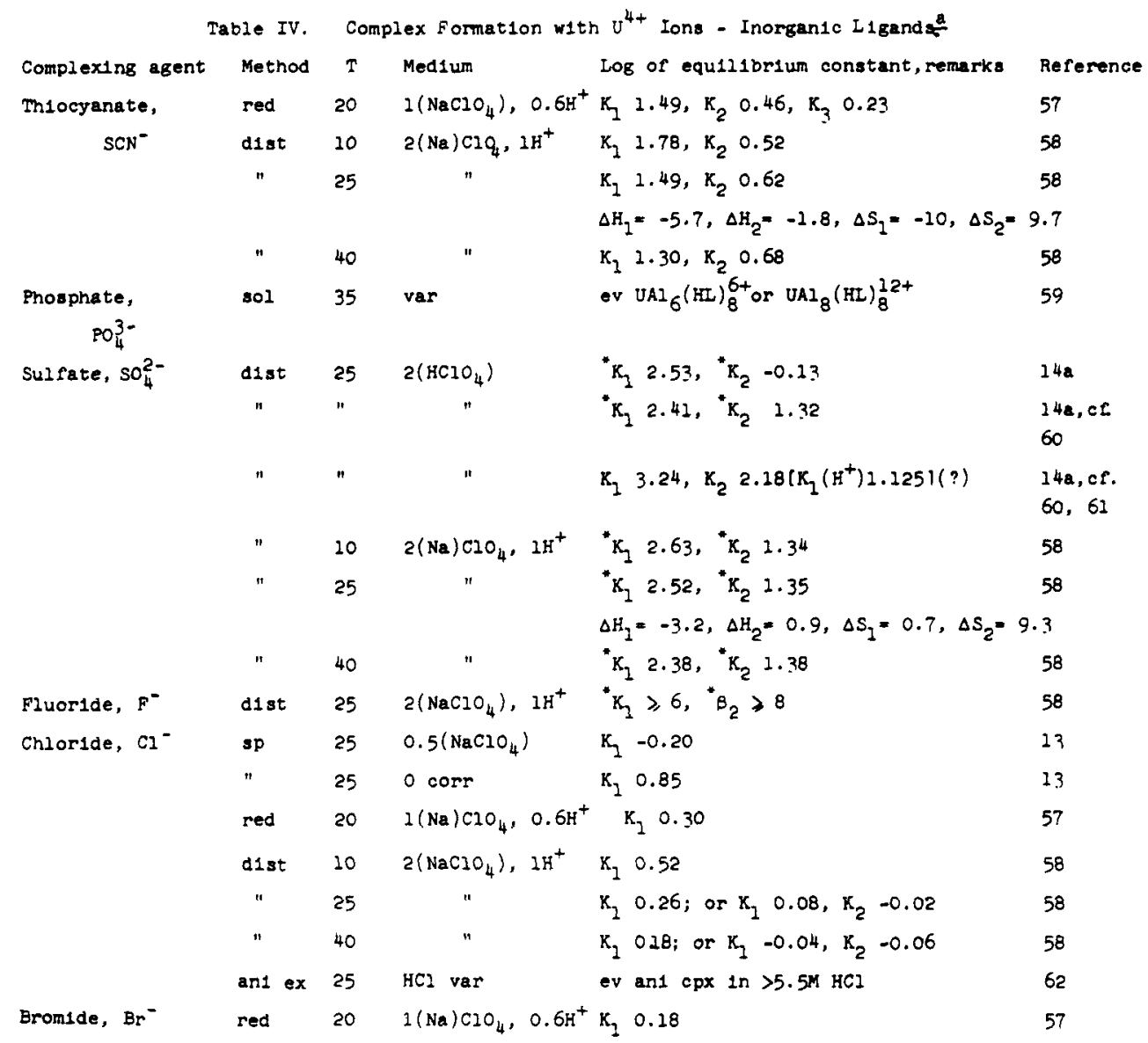

After J. Bjerrum, G. Schwarzenbach, and L. G. S1lien, reference 20 .

Column one denotes the complexing ligand (L). The notation 1s explained following Table III.

Numerous organ1c complexes are formed with the uranium(IV) ion: the acetate, oxalate, tartrate, malate, citrate, lactate, glycolate, etc. 34 However, the amount of quantitative data avaliable on their formation is very meager. Tishkoff 64 has calculated dissoclation constants for acetate complexes on the basis of the oxygenated uranium(IV) ion $U O^{2+}$ being formed. The formation constants measured for acetylacetone, thenoyltrifluoroacetone and ethylenediamine tetraacetic acid complexes are given in Table V.

Pentapositive uranium. Although it appears that uranium(V) complexes should be formed in the reduction of uranium(VI) ions 
In complexing media, 63 little data is avallable.

Hexapositive uranium. Inorgantc uranium(VI) complexes whlch have been identifled through the formation of crystalline salts include the fluorldes, chlorides, nitrates, sulfates, carbonates, cyanides, and phosphates. 34 Uranyl solutions with these anions present have been studied. The results are 11sted in Table VI. A number of discrepancies appear in the data. For example, evidence for some complexing of the uranyl ion with nitrate $\frac{74,76,77}{\text { and chloride } 67,76,77,105-107}$ ions has been reported by some investigators; but a complete lack of evidence has been reported by others. $2^{\circ}$ Day and Powers $\frac{77}{1}$ have pointed out that the constants calculated by them are concentration constants rather than activity constants. Consequentiy, the small complexing effect may be caused by the variation of activity coefficlents with a change in medium. Other investigators, however, who have corrected their results to apply to pure aqueous solutions have found some complexing to occur with the chloride 1on.67, $105-107$

The type of complex formed between uranyl and fluoride ions also is subject to some question. Ahrland and co-workers 102,104 heve determined equilibrium constants for the formation of complexes $\mathrm{UO}_{2} \mathrm{~F}^{+}$, $\mathrm{UO}_{2} \mathrm{~F}_{2}, \mathrm{UO}_{2} \mathrm{~F}_{3}{ }^{-}$, and $\mathrm{UO}_{2} \mathrm{~F}_{4}{ }^{2-}$ and found no evidence for the dimerization of $\mathrm{UO}_{2} \mathrm{~F}_{2}$ for uranyl ion concentrations less then 0.1M. Day and Powers, $\frac{77}{}$ however, found no evidence for the formation of complexes beyond $\mathrm{UO}_{2} \mathrm{~F}^{+}$; and Johnson, Kraus and Young $\frac{36}{6}$ have reported the dimerization of $\mathrm{UO}_{2} \mathrm{~F}_{2}$ in solutions not very different from those investigated by Ahrland, et al. 104 Numerous organic complexes have been reported. 34 Much of the quantitative data is summarized in Table VII.

There is often disagreement between different investigators concerning the nature of the complexing 11gand. Uranyl-oxalate complexes serve as an example. The oxalate lon, $\mathrm{C}_{2} \mathrm{O}_{4}{ }^{2-}$, has been proposed by some investigators $\underline{146,49}$ as the complexing ligand; the bloxalate 1on, $\mathrm{HC}_{2} \mathrm{O}_{4}^{-}$, by others 147,116 ; and Heidt 49 has 
Table v. Compiex Formation with $U^{4+}$ Ions - Urganic Liganda

\begin{tabular}{|c|c|c|c|c|c|c|c|}
\hline Complexing agent & Method & $T$ & Mecium & pK of & ${ }_{p}{ }^{L}$ & Log of equilibrium conatant, & Reference \\
\hline \multirow[t]{2}{*}{$\begin{array}{l}\mathrm{C}_{5} \mathrm{H}_{8} \mathrm{O}_{2} \\
\text { acetylace tone : } \mathrm{HL}\end{array}$} & $d 1 s t$ & 25 & $0.1\left(\mathrm{ClO}_{4}{ }^{-}\right)$ & 8.82 & & $\begin{array}{l}\mathrm{k}_{1} 8.6, \mathrm{~K}_{2} 8.4, \mathrm{~K}_{3} 6.4 \\
\mathrm{k}_{4} 6.1\end{array}$ & 140,211 \\
\hline & " & " & $"$ & 8.82 & & $\begin{array}{l}\mathrm{x}_{1} 9.02, \mathrm{x}_{2} 8.25, \mathrm{x}_{3} 6.52 \\
\mathrm{~K}_{4} 5.98, \mathrm{~B}_{2} 17.27, \mathrm{~B}_{3} 27.79 \\
\mathrm{~B}_{4} 29.77\end{array}$ & $\begin{array}{l}24 b, \text { ef. } 112 \text {, } \\
113\end{array}$ \\
\hline $\begin{array}{l}\mathrm{C}_{8} \mathrm{H}_{5} \mathrm{O}_{2} \mathrm{~F}_{3} \mathrm{~S} \\
\text { thenoyltrifluoro- } \\
\text { acetone } \mathrm{HL}\end{array}$ & $\mathbf{s p}$ & 25 & 0.1 & & & $\mathrm{x}_{2} 7.2$ & 214 \\
\hline $\begin{array}{l}\mathrm{C}_{10^{\mathrm{H}}} 16^{\mathrm{O}} 8^{\mathrm{N}} 2 \\
\text { ethylenediamine- } \\
\text { tetracet1c acid. } \\
\mathrm{H}_{4}{ }^{+}\end{array}$ & $\mathrm{col}$ & 25 & $\left(\mathrm{H}_{2} \mathrm{SO}_{4}\right)(0)$ & $\begin{array}{l}\mathrm{H}_{4} \mathrm{~L}^{-} \\
\mathrm{H}_{3} \mathrm{I}^{-} \\
\mathrm{H}_{2} \mathrm{~L}^{2-} \\
\mathrm{HL}^{3-}\end{array}$ & $\begin{array}{l}2.21 \\
2.77 \\
6.16 \\
10.26\end{array}$ & $\begin{array}{l}\mathrm{K}_{2} 25.6 \\
\mathrm{pK}\left(\mathrm{H}_{6} \mathrm{~L}^{2+} \rightleftharpoons \mathrm{H}_{4}{ }^{2}+2 \mathrm{H}^{+}\right) 1.9 \mathrm{I}\end{array}$ & 115 \\
\hline
\end{tabular}

\section{after Bferrin, Schwarzenbach, and S1lien, reference 20 .}

The cata, with the exception of reference 211 , has beer complied oy $\Sigma$. Slndier.

column one lists the empirlcal formula, the name of the ligand, and a formula of the type $H p L$ which defines the ertity $I$ in terms of which the equilibrium constants are expressed.

The $11 \mathrm{gands}$ are placed $1 \mathrm{r}$ order of their empirical formula according to Be1lstelr's system

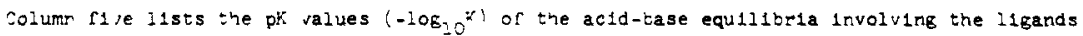

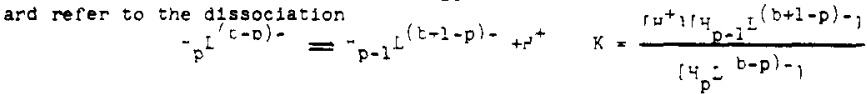

The notatior is explaired following ratle II:

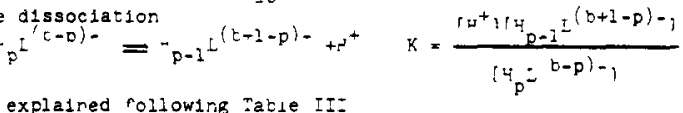

Tatle VI Complex i ormation with $\mathrm{LO}_{2}^{2+}$ Ions - Inorganle + 1gands

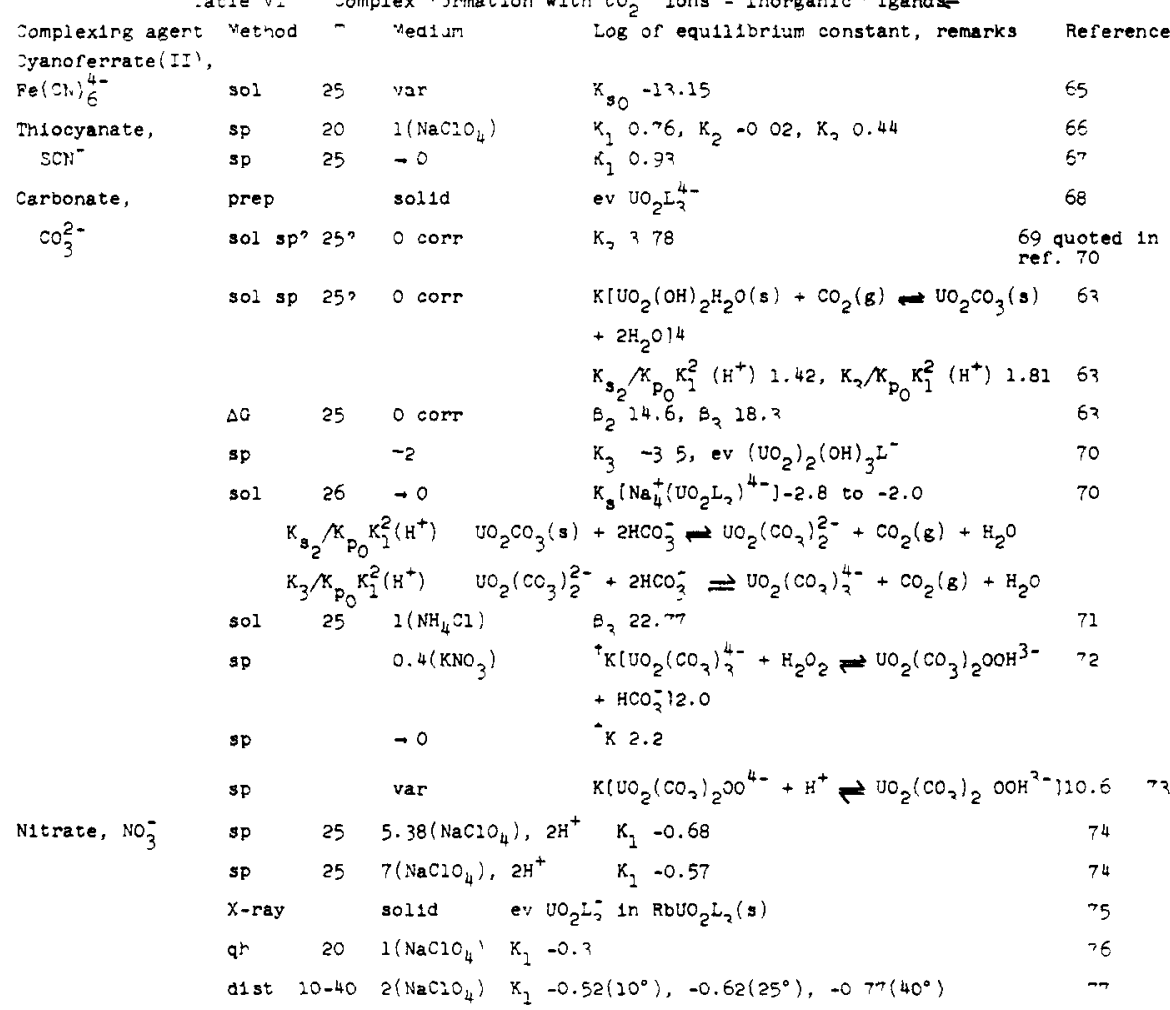


Tabje VI. - Cont Inued

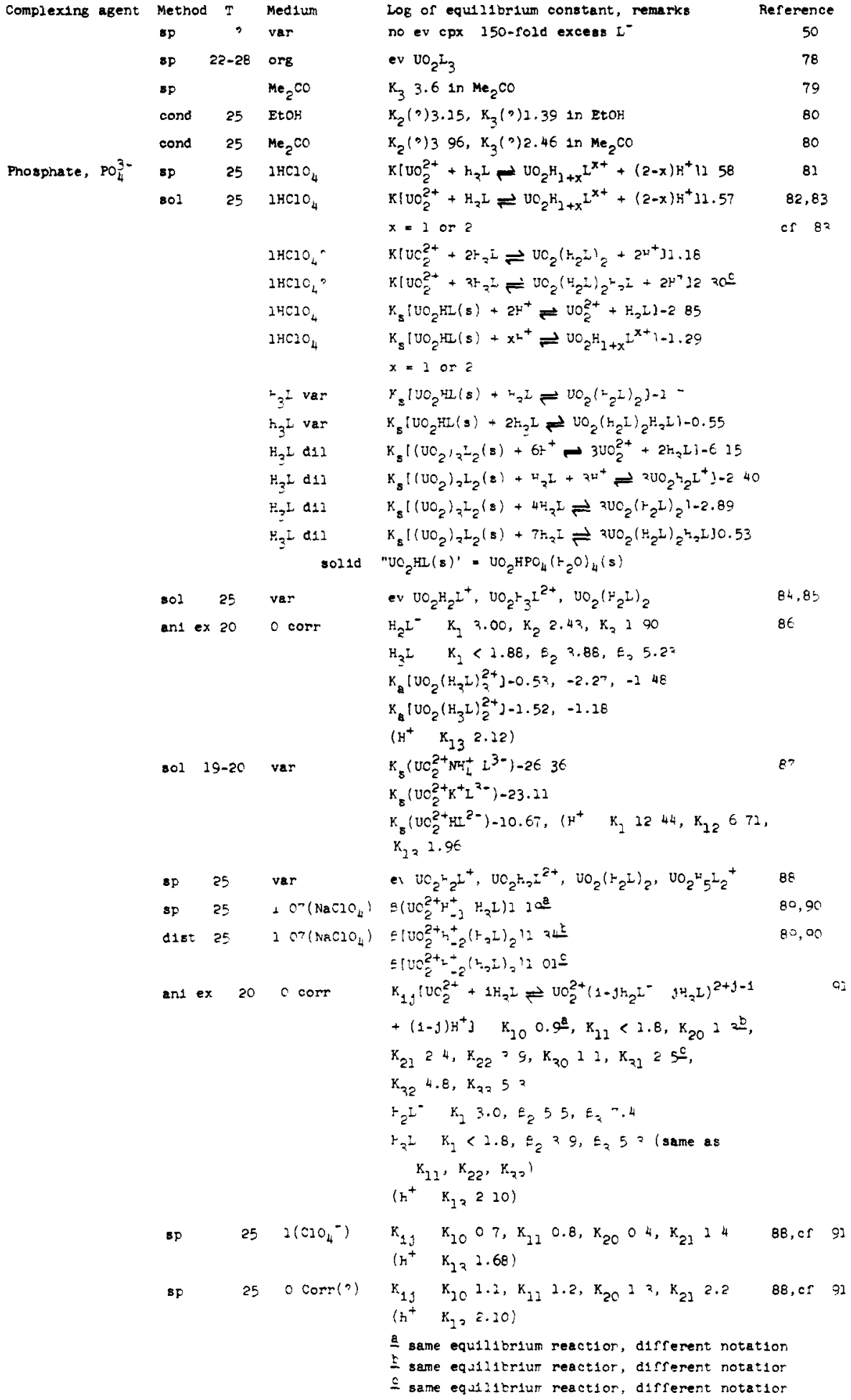




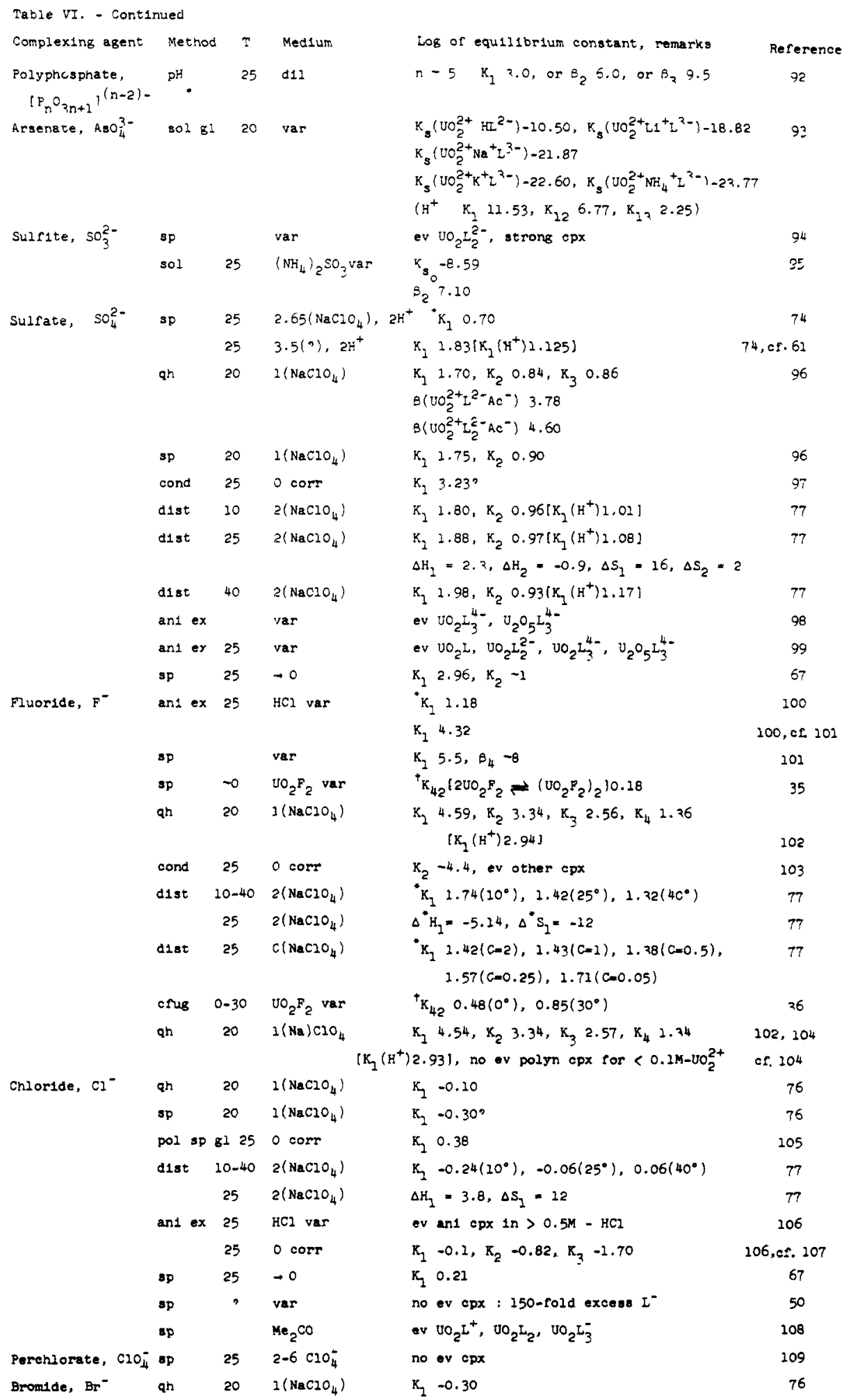




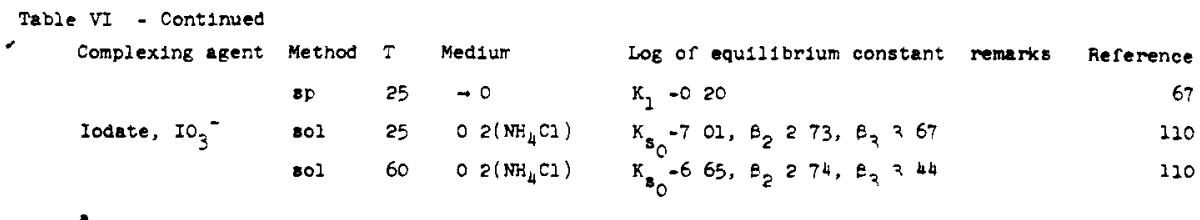

a After Bjermum, Schwarzenben and Silien, reference 20 Data which appeared in the literature prior to the middle of 1057 has been coaplied mostiy by the above authors subsequent data has been complled by $\mathrm{J}$ aindler

The notation 18 explained following Table III

Table VII Complex Formation with $\mathrm{VO}_{2}^{2+}$ I ons - Organic ilgandsa

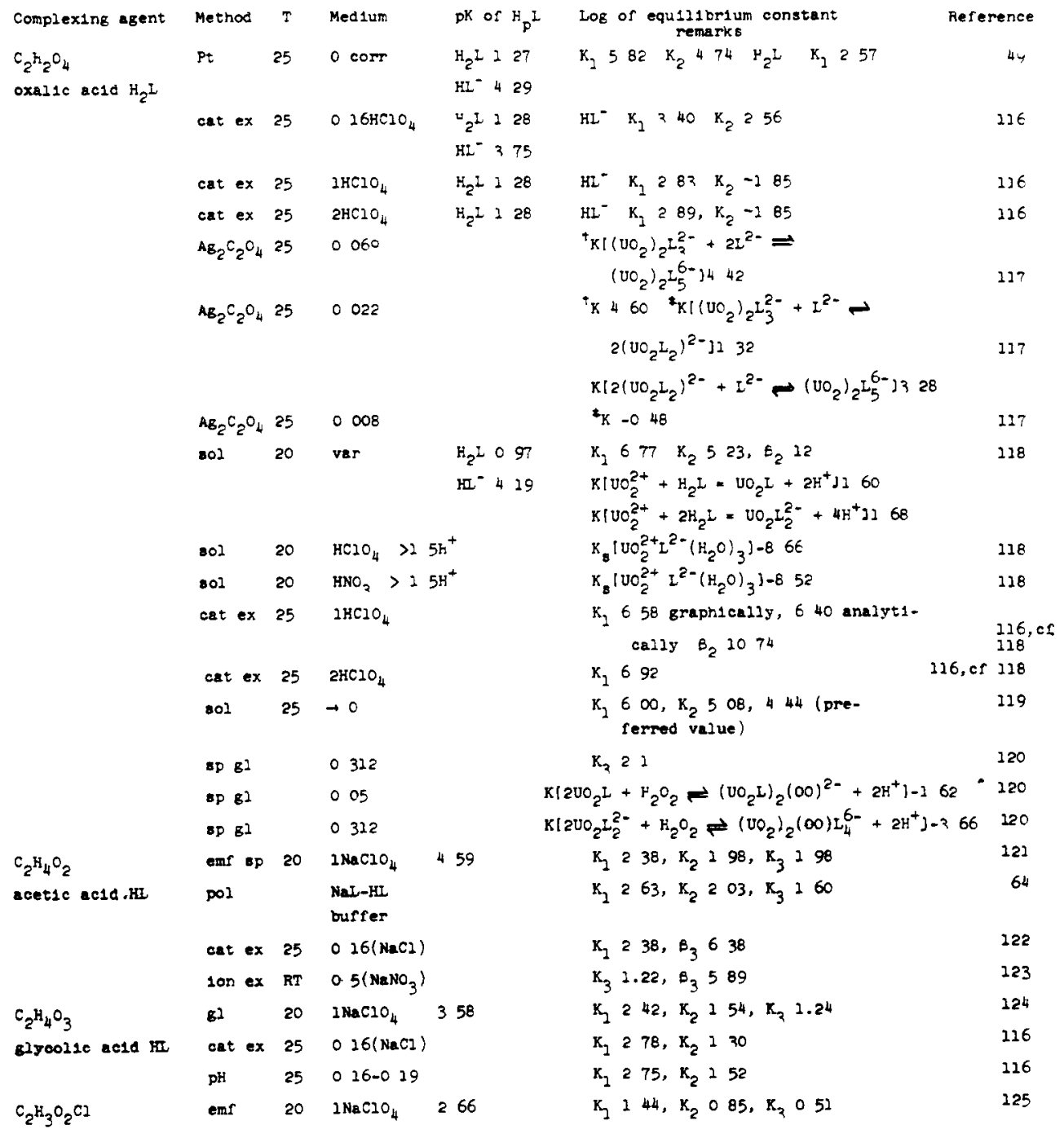




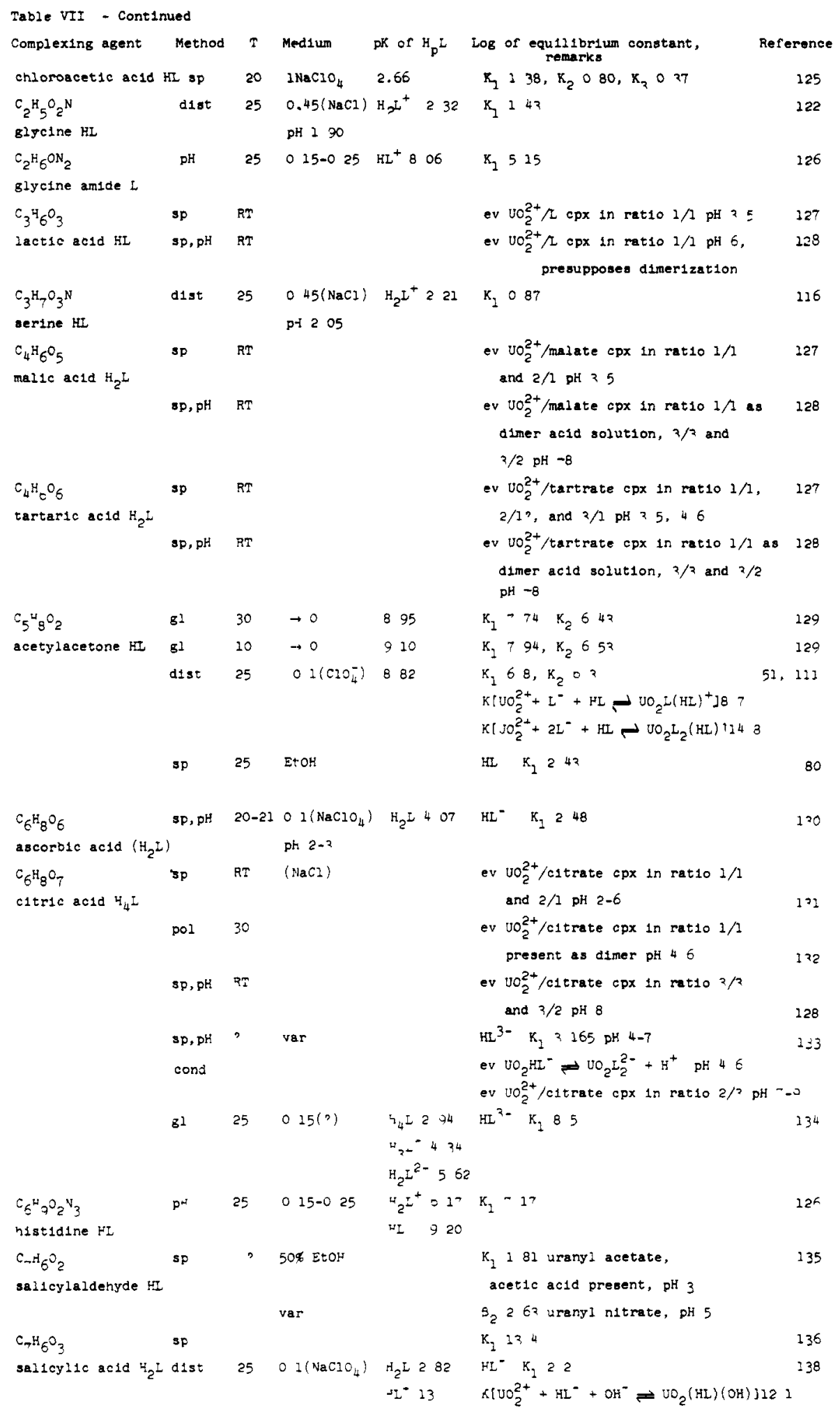


Table VII - Continued

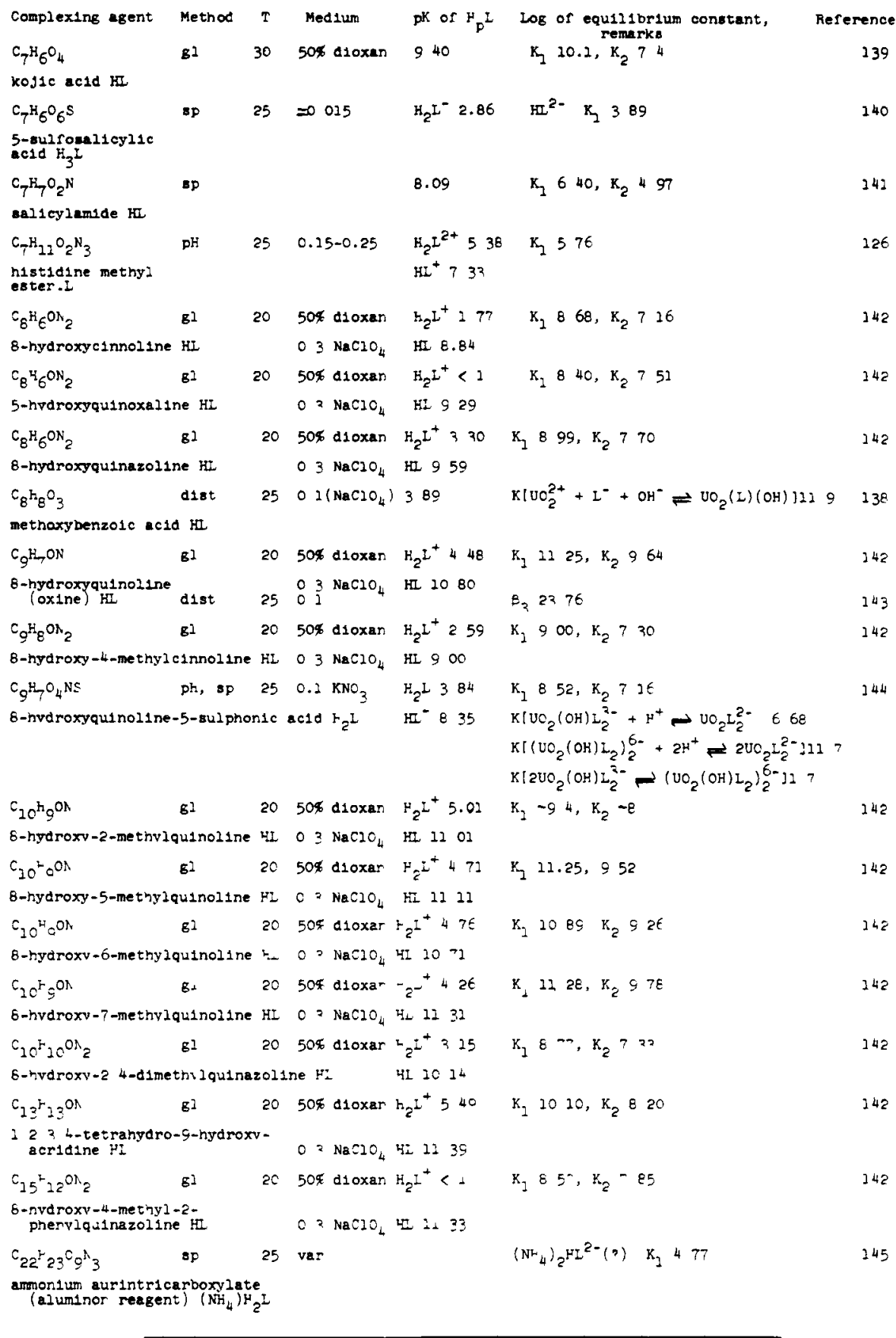

a After Ejermum, Schwarzenbach, and Sillén, reference 20

Data which appeared in the l1terature prior to l956 has been complled mostly by the above atrors Subsequent data has beer complled by I alndier

The notatior 18 explained following Taties IIZ and 
stated that a complex is formed with undissociated oxalic acid, $\mathrm{H}_{2} \mathrm{C}_{2} \mathrm{O}_{4}$. In more recent work, Moskvin and Zakharova 118 conclude that complexes may be formed w1th both $\mathrm{C}_{2} \mathrm{O}_{4}{ }^{2-}$ and $\mathrm{HC}_{2} \mathrm{O}_{4}^{-}$ions and that the amount of each formed will depend upon 1ts stability and the conditions of the experiment.

The composition of a complex is sometimes decided upon by comparison with complexes having similar ligands. For example, Holk-Bernstrom, $\underline{138}$ in her work with sal1cylic acid, $\mathrm{H}_{2} \mathrm{~A}$, and methoxybenzolc acid, $H B$, was able to show that complexes of the type $\mathrm{UO}_{2}\left(\mathrm{H}_{2} \mathrm{~A}\right)\left(\mathrm{H}^{+}\right)_{-1}$, $\mathrm{UO}_{2}\left(\mathrm{H}_{2} \mathrm{~A}\right)\left(\mathrm{H}^{+}\right){ }_{-2}$, and $\mathrm{UO}_{2}(\mathrm{HB})\left(\mathrm{H}^{+}\right){ }_{-2}$ were formed in the aqueous phase. (The negative subscripts indicate that $\mathrm{H}^{+}$was eliminated in.the formation of the complex.) The experimental data for methoxybenzolc ac1d was approximated by assuming only the complex $\mathrm{UO}_{2}(\mathrm{~B})(\mathrm{OH})$. For salicylic acld, the complexes $\mathrm{UO}_{2}(\mathrm{HA})^{+}$corresponding to $\mathrm{UO}_{2}\left(\mathrm{H}_{2} \mathrm{~A}\right)\left(\mathrm{H}^{+}\right)-1$ and $\mathrm{UO}_{2}(\mathrm{HA})(\mathrm{OH})$ or $\mathrm{UO}_{2} \mathrm{~A}$ corresponding to $\mathrm{UO}_{2}\left(\mathrm{H}_{2} \mathrm{~A}\right)\left(\mathrm{H}^{+}\right){ }_{-2}$ were postulated. It was not possible to distinguish between the latter two.

However, from the similarity of the distribution curves found for the two acids, it was suggested that the salicylate complexes are formed by $\mathrm{HA}^{-}$ligands.

A vast amount of work other than that listed in Table VII has been done on the preparation and identification of organic uranyl complexes. Some of the complexing agents studied recentiy Include dihydroxy-maleic acid, 148 triose-reductone 149,150 (enoltartronaldehyde), reductic acid 151 (cyclopentene-2-diol-2,3one-1), complexones 152,153 (iminodiacetic acid and 1 ts derivatives),

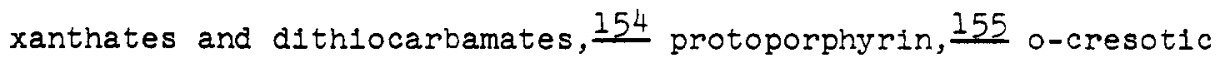
acid, $\frac{156}{m i r 1 c 1 t r i n e, ~} \frac{157}{}$ dialkyl phosphoric acids, $\underline{158,159}$ and pyrazolone derivatives. 160

\section{Non-aqueous solutions of u ranium.}

Solubility studies. A number of uranium salts are soluble in organic solvents. Uranyl nitrate is the notable example. As the hexahydrate, this salt is soluble in a 
varlety of ethers, esters, ketones, alcohols, aldehydes, and subst1tuted hydrocarbons. $\frac{161-165}{16}$ The following general1zations have been made $\frac{165}{}$ concerning 1ts solution in organic solvents :

(1) In a given homologous series, the solubility decreases as the molecular weight of the solvent increases. 161,165

(2) Solutions occur with: $: \frac{165}{}$

$\begin{array}{ll}\text { Ethers: } & \text { allphatic } \\ & \text { ethylene glycol } \\ & \text { diethylene glycol } \\ & \text { saturated cyclic }\end{array}$

Acetals

Ketones: aliphatic aromatic alicyclic mixed aliphatic-aromatic

Alcohols: aliphatic alicyclic

Var1ous esters

Nitrogen-containing solvents: nitriles aromatic bases.

(3) Solutions do not occur w1th:

$$
\begin{aligned}
& \text { Hydrocarbons } 161 \\
& \text { Ethers: } 165 \text { aromatic } \\
& \text { unsaturated cyclic } \\
& \text { Sulfur-containing solvents. } \underline{165}
\end{aligned}
$$

Glue ckaur 166 has made the phenomenological observation that a plot of the solubility of uranyl nitrate against the oxygen-to-carbon rat1o in the solvent molecule results in a single curve for alcohols and ethers; but in a double curve for ketones; one for symmetric and one for asymmetric ketones. Ionization. The quantity ( $\Lambda \eta /$ constant) ${ }^{*}$ has been used by McKay and co-workers $\frac{167-169}{10}$ est1mate the degree of ionlzation of uranyl salts in organlc solvents. By this criterion, uranyl nitrate in concentrations of 0.01 - $1 \mathrm{M}$ is

$\Lambda=$ molar conductivity. $T_{1}=$ viscosity. The constant 60 is used for $1: 1$ - electrolytes; 120 for $1: 2$ - electrolytes. 
substantially unionized in water-saturated solutions of ethers, ketones, alcohols and tributyl phosphate. Only in saturated dethyl cellosolve and in 1sobutyl alcohol is lonization in excess of 10\%. The large amount of water which dissolves in the latter solvent may account for this.

In tributyl phosphate, the dissociation of uranyl nitrate Increases as 1ts concentration in the organic phase is decreased. At $10^{-5} \underline{M}$ the salt is approximately 40 per cent dissoclated, $\frac{169}{1 . e ., ~} \Lambda \eta / 120=0.4$ Uranyl perchlorate at this concentration is almost completely Ionized. 169 Ion assoclation accurs at higher concentrations, but significantly less than for uranyl nitrate. At approximately $0.01 \mathrm{M}$, the association of uranyl perchlorate is maximum $(\Lambda \eta / 120$ has a minimum value of -0.1 ) in the concentration range $10^{-5}$ to $1 \mathrm{M}$. The Ionlzation of this salt may well be associated with the amount of water contained within the tributyl phosphate since the electrical conductivity is decreased by dehydration. 169 Jezowska - Trzeblatowska and co-workerg 80 have measured the molar conductivity of uranyl nitrate in organic solvents that contain only water from the hexahydrated uranyl salt.** The conductivity was found to be low and to decrease with a decrease of the dielectric constant of the solvent.

Conductivity measurements of $\mathrm{UCl}_{4}$ in methyl alcohol indicated the salt to be somewhat dissociated. $\frac{80}{\text { The }}$ dissociation was found to increase on addition of tributyl phosphate.

Kaplan, H1ldebrandt, and Ader $\stackrel{170}{ }$ have classified into

* Solvents tested other than tributyl phosphate: diethyl ether, diethyl cellosolve, dibutyl carbitol, methylisobutyl ketone, 1sobutyl alcohol, and isoamyl alcohol.

* Solverits tested: methyl alcohol, ethyl alcohol, acetone, ethyl-methyl ketone, methyl 1sobutyl ketone, acetylacetone, stannous chloride in acetone. 
types the absorption spectra of uranyl nitrate in a number of solvents and solvent mixtures. Differences between types were attributed to a series of hydrated and solvated nitrate complexes, $\mathrm{UO}_{2}^{2+}, \mathrm{UO}_{2} \mathrm{NO}_{3}{ }^{+}, \mathrm{UO}_{2}\left(\mathrm{NO}_{3}\right)_{2}$, and $\mathrm{UO}_{2}\left(\mathrm{NO}_{3}\right)_{3}{ }^{-}$. The relative concentrations of the complexes depend upon the nature of the solvent, 1ts water content, and the concentration of added nitrates. It is interesting to note that the absorption spectrum of uranyl nitrate in tributyl phosphate 10.016 $1.6 \mathrm{M})$ is characteristic of the complex $\mathrm{UO}_{2}\left(\mathrm{NO}_{3}\right)_{2}$ and indicates little ionization. $168 \mathrm{~A}$ similar spectmum is given by uranyl nitrate in methyl isobutyl ketone $(0.02 \mathrm{M})$. 78 Uranyl perchlorate in methyl isobutyl ketone $(0.02 \mathrm{M})$, however, exhibits a spectrum characteristic of the uranyl ion, $\mathrm{UO}_{2}^{\text {?+ }}$. These results appear to be in general agreement with those obtained through conduct1vity-viscosity measurements. $167-169$

The trinitratouranyl complex $\mathrm{UO}_{2}\left(\mathrm{NO}_{3}\right)_{3}{ }^{-}$has been studied by a number of workers $\frac{78,79,171-173}{1 t}$ is formed by the addition of a second soluble nitrate to a solution of uranyl nitrate in a non-aqueous solvent such as anhydrous nitric acid, $\underline{171}$ dinitrogen tetroxide, $\underline{172}$ acetone, $\underline{78,79}$ methyl

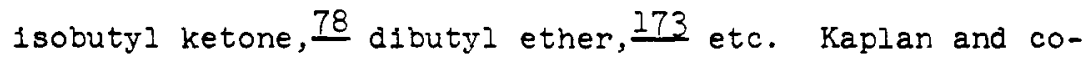
workers $\frac{78}{18}$ so report that the complex is formed in $16 \underline{M}$ nitric acid, but that its formation is far from complete. The negative character of the complex has been demonstrated by electrolytic transference experiments.78 Its composition has been deduced by the isolation of solid compounds from solutions of the type described above $79,171,172$ and by the similarity of the absorption spectrum of such solutions with that of crystalline cesium uranyl nitrate, $\mathrm{CsuO}_{2}\left(\mathrm{NO}_{3}\right)_{3} \frac{78,79}{4}$

\footnotetext{
* Spectra classified: uranyl nitrate in water, acetone-water, dioxane-water, n-propanol-water, ethanol, chloroform $+0.7 \%$ ethanol, pyridine, acetic acid, ethylacetate, tetraethylene glycol dibutyl ether, nitroethane, methyl isobutyl ketone, cyclohexanone; uranyl perchlorate in methyl 1sobutyl ketone.
} 
The stablilty of the complex depends upon the nature of the associated cation as well as the nature of the solvent and the presence of water in the solvent. The general order of the solvents with respect to stab1l1ty of the trinitrate complex 1s: ketone > ether > alcohol > water: $\frac{78}{}$

The formation of chlorouranyl complexes in non-aqueous solvents has been reported by Vdovenko, Iipovskil, and Nikitina 108 The complexes $\mathrm{NO}_{2} \mathrm{Cl}^{+}, \mathrm{UO}_{2} \mathrm{Cl}_{2}, \mathrm{UO}_{2} \mathrm{Cl}_{3}$ - were formed by the addition of pyridine hydrochloride or hydroxylamine hydrochloride to a solution of uranyl perchlorate or uranyl chloride in acetone. The stability of the trichlorouranyl complex was found to be dependent upon the amount of water present in the solvent. A compound was separated and 1dentifled as $\left(\mathrm{C}_{5} \mathrm{H}_{5} \mathrm{NH}_{2} \mathrm{UO}_{2} \mathrm{Cl}_{4}\right.$.

Hydration. In partition studies of uranyl nitrate between aqueous solution and organic solvent (alcohols, esters, ethers and ketones) it is generally found that the water content of the organic phase 1ncreases with uranyl nitrate concentration. $163,167^{*}$ For alcohols, the relation between the water content $M_{W}$ and uranyl nitrate concentration $M_{u}$ appears to be a complex function. ${ }^{* *}$ For esters, ethers, and ketones the relation is linear except possibly at high values of $M_{L}$. This relation may be expressed

$$
M_{w}=M_{w}^{0}+h M_{u} \text {. }
$$

The quantities are expressed in terms of molalities of the dry solvent. $M_{w}^{\circ}$ is the solubility of water in the pure solvent; $h$ is a constant. The slope of the line, $h$, repre-

\footnotetext{
* The water content of alcohols may decrease 1nitially as the uranyl nitrate concentration is increased from 0 to $0.1-0.2$ molai. 167

* Katzin and Sullivan $\frac{163}{16}$ report a linear relation between $M_{w}$ and $M_{u}$ for 1sobutyl alcohol. McKay and Mathieson 167 point out that if the data of Katzin and Sullivan at low $M_{u}$ are given significance, then a more complicated relationship between the two quantities exists.
} 
sents the degree of hydration. For many of the linear solvents $h$ is very nearly $4.0 . \underline{163,167}$ This has been interpreted by Katz1n $\frac{174}{}$ to mean that the species $\mathrm{UO}_{2}\left(\mathrm{H}_{2} \mathrm{O}\right)_{4}\left(\mathrm{NO}_{3}\right)_{2}$

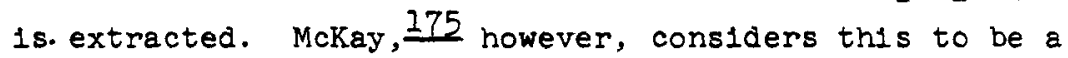
mean nydration number; that a series of hydrates are present ranging from the di- to the hexahydrate; that these hydrates are in equilibrium with each other and are of comparable stab111ty. The latter view is supported by 1sopiestic measurements. 176

Infrared measurements on ethereal and ketonic solutions* of uranyl nitrate, Indicate two molecules of water to be strongly bound to the uranyl nitrate and the remalning water molecules to be more weakly bound. 177,178

The extraction of uranyl nitrate from an aqueous system 1nto tributyl phosphate (TBP) causes the displacement of water from the organic phase. $\frac{168}{}$ The displacement is roughly Inear with $h$ being -2.168 Th1s is in agreement with the formulae $\mathrm{TBP} \cdot \mathrm{H}_{2} \mathrm{O}$ and $\mathrm{UO}_{2}\left(\mathrm{NO}_{3}\right)_{2} \cdot 2 \mathrm{TBP} .168$ Uranyl perchiorate, however, apparently does carry some water into tributyl phosphate. 169 Whether this water is associated with free uranyl lons or unionized $\mathrm{JO}_{2}\left(\mathrm{ClO}_{4}\right)_{2}$ is undetermined.

Solvation. The 1solation of solvated uranium salts, in particular uranyl nitrate, is reported in the ilterature. 6 , 163,180-182 In phase studies of ternary systems: uranyl nitrate, water, organic solvent, Katzin and Sullivan 163 have concluded that uranyl nitrate in aqueous solution is largely hexasolvated, subject to the activity. As organic molecules are dissolved, 2,3,4 and perhaps 6 water molecules may be displaced, depending upon the electron-donor capabilities of the organic molecules. The total solvation is a function of the activity levels of the water and organic molecules.

Solvents studied: dlethyl ether, acetone, methylethyl ketone. 
If a particular configuration is stable enough, it may survive as a crystalline solld. The particular stablilty of the final two water molecules is in agreement with the results of Ryskin and co-workers 177,178 obta1ned through infrared absorption measurements. The ab1lity of solvents to displace water is In the order: 2lcohols > ethers > ketones.163 Th1s general order of solvate stablilty is confirmed by heat of solution measurements. 183 It is in agreement also with the order of bese (electron-donor) strengths of the solvents determined by other means. 163,183 Methyl isobutyl ketone 18 anomalous in that it behaves s.tronger toward uranyl nitrate than 1ts base strength would indlcate. 163,183 Tributyl phosphate, according to heat measurements, competes w1th water almost as well as diethyl ether and 1sobutyl alcohol. 183

The order of solvents with respect to solvate stablilty 1s opposite to that with respect to the stab111ty of the trinltratouranyl complex. This suggests a competition between solvent molecule and nitrate ion for coordination with the uranyl ion. 171

Feder, Ross and Voge $1 \frac{184}{2}$ have studied the stab111ty of molecular addition compounds with uranyl nitrate. The compounds were prepared by shaking uranyl nitrate dehydrate with varlous addenda in an inert solvent: benzene and/or 1,2dichloroethane. $1: 1$ molecular addition compounds were found with uranyl nitrate and ethyl alcohol, n-dodecyl alcohol, tetrahydrofuran, propylene oxide, mesityl oxide, tributyl phosphate, and $N, N$-dibutylacetamide. $1: 2$ compounds were observed w1th uranyl nitrate and acetone, methyl 1sobutyl ketone, cyclohexanone, ethyl acetate, 2,4-dimethyltetrahydrothlopene 1,1-dloxide, B-chloroethylacetate, ethyl chloroacetate, ethyl cyanoacetate, diethyl ether, allyl alcohol, ethylene chlorohydrin, and acetonitrile. Formation constants were determined from changes in the solubility of uranyl nitrate. 
It was shown that the stability of the addition molecules, for those addenda having similar functional groups, was in agreement with the base strength of the addend; 1.e., the more stable the molecule, the greater the base strength of the addend.

The average number of solvate molecules $n$ associated with uranyl nitrate in its partition between water and various organic solvents ${ }^{*}$ has been studied by McKay 185,186 and co-workers. The value of $n$ was found to vary with the uranyl nitrate concentration of the organic phase. For most of the solvents studied, $n$ varied between $I$ and 4 . For cyclohexane, considerably larger values were found for low uranyl nitrate concentrations.

A saturated solution of uranyl nitrate hexahydrate In tributyl phosphate corresponds closely to the unhydrated disolvated compound $\mathrm{UO}_{2}\left(\mathrm{NO}_{3}\right)_{2} \cdot 2 \mathrm{TBP} .168,187$ Evidence for the existence of the single species is: 168,187

(1) The solubility is not appreciably temperature dependent over the range $0-50^{\circ} \mathrm{C}$.

(2) On freezing and rewarming a saturated solution, a sharp melting-point of $-6.0 \pm 0.5^{\circ} \mathrm{C}$ is observed.

(3) The mole ratio of uranyl nitrate to TBP approaches the value $1: 2$ asymptotically under a varlety of conditions.

(4) The effect of inert diluents for the TBP on uranyl nitrate partition coefficients supports a $1: 2$ formula, 1.e., the partition coefficlent of uranyl nitrate varies as the square of the TBP concentration.

The experimental conditions under which Feder, Ross and Vogel 184 reported the formation of $\mathrm{UO}_{2}\left(\mathrm{NO}_{3}\right)_{2} \cdot$ TBP were considerably different from those of Healy and McKay. 168

Organic solvents studied: diethyl ether, dilsopropyl ether, diethyl cellosolve, dibutyl cellosolve, dibutyl carbitol, penta-ether, isoamylacetate, methyl isobutyl ketone, cyclohexanone. 
Jezowska - Trzebiatowska, et al $\underline{80}$ report that the absorption spectrum of uranyl nitrate in tributyl phosphate gives no Indication of the formation of a stable complex. Attempts to ldentify a complex species in the concentration range 0.02-0.06 were unsuccessful.

Hesford and McKay 169 report evidence for the formation of $\mathrm{UO}_{2}\left(\mathrm{CO}_{4}\right)_{2}$.2TBP under certain conditions. From a $10.3 \mathrm{M}$ aqueous perchloric acid solution, the partition coefficlent of uranium varies as the square of the TBP concentration in benzene. Under other conditions, other solvates may be formed. Jezowska - Trzebiatowska, et al $\frac{80}{}$ report the formation of a $1: 1$ complex between $\mathrm{UCl}_{4}$ and TBP in methyl alcohol.

Tributyl phosphine oxide, like tributyl phosphate, forms an anhydrous disolvate with uranyl nitrate. 187 Healy and Kennedy 188 report a number of other neutral organophosphorus solvents wich form solvates with uranyl nitrate. Most, but not all, of the solvates reported are anhydrous. All of the solvents extract uranium from aqueous solution In proportion to the square of the solvent concentration (In benzene). However, not all solutions of the solvent in benzene and saturated in uranyl nitrate glve mole ratios of solvent to uranium of $2: 1$. For the two diphosphanates and one pyrophosphate studied the mole ratios were $1: 1$. Th1s may be indicative of chelation or polymer formation. The mole rat10 in triphenyl phosphate was $-22: 1$. This is probably the result of the solvent being unable to displace water from the coordination sphere of the uranyl 1on. 188 Solvate formation between uranyl salts and acld organophosphorus compounds, eg. mono- and di-alkyl phosphoric acids has been the subject of some investigation. $80,158,159,188$ $1: 1$ complexes between uranyl nitrate and mono- and d1-buty 1 phosphate and mono- and d1-amyl phosphate in ethyl alcohol

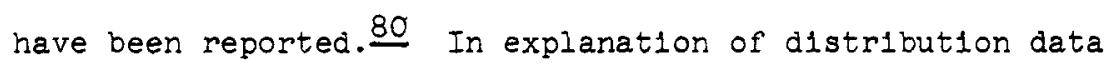


In conjunction with isopiestic and viscosity measurements, Baes, Zingaro and Coleman 158 have hypothesized that uranium (VI) is extracted from aqueous perchlorate solutions into n-hexane solutions of di-(2-ethylhexyl)-phosphate, HI, as the species $\mathrm{UO}_{2}(\mathrm{HL})_{2} \mathrm{~L}_{2}$. As the uranium concentration of the organic phase is increased, there is strong evidence that polymerization occurs. 158 Similar conclusions have been made by Dyrssen 159 on the basis of the distribution of uranium (VI) between aqueous perchlorate solution and albutyl phosphate, $\mathrm{HK}$, in chloroform. In hexone, the species $\mathrm{UO}_{2}(\mathrm{HK})_{2} \mathrm{~K}_{2}$ and $\mathrm{UO}_{2} \mathrm{~K}_{2}$ have been 1dentified. 159 The extraction of uranium (VI) by dibutyl phosphate from aqueous nitrate solutions 1nto benzene has been studied by Healy and Kennedy. 188 In addition to the species $\mathrm{UO}_{2}(\mathrm{HK})_{2} \mathrm{~K}_{2}$, the polyuranyl species $\left(\mathrm{UO}_{2} \mathrm{~K}_{2}\right) \mathrm{x}^{2 \mathrm{HKK}}$ and the nitrated species $\mathrm{UO}_{2}\left(\mathrm{NO}_{3}\right)_{2}$. 2HK have been postulated to explain the shape of the extraction curve as a function of nitric acid concentration.

It has been postulated thet the formation of mixed solvates or solvated chelates enhances the extraction of uranium into certain solvent mixtures. These systems are discussed In a later section on solvent extraction.

\section{IV-D Separation of Uranium}

A number of review articles have been written on the analytical chemistry of urantum. $6,34,189-200$ These, together w1th many texts on chemical analysis (see, for example, references 201-209), serve well as guldes to the separation and purification of the element. More specialized surveys have been made by Hecht $\frac{210}{1}$ on the quantitative micro-analysis of urantum-bearing minerals, and by Lawrowski 21 f on separation processes for the recovery of nuclear fuels.

Two general techniques are avallable for the separation of urantum. (1) Uranium is removed from solution in the presence 
of contaminants by precipitation, solvent extraction or some alternative method. (2) Uranium is kept in solution and contamInants are removed. These techniques are fac1litated by the fact that uranium is reasonably stable in two oxidation states, (IV) and (VI), and that complex formation may be effected to prevent the removal of either uranium or contaminant from solution.

In the following paragraphs, the separation of uranium by precipitation, solvent extraction, and ion exchange are described In some detall. Reference is made also to other methods of separation: chromatography, electrodeposition, volatilization and pyrometaliurgy .

1. Precipitation. In classical, systems of analysis, uranium is a member of the third group of elements." That is, It is not precip1tated by hydrochlorlc ac1d or by hydrogen sulfide in an acidic solution, but it is precipltated by ammonium hydroxide or ammonlum sulfide (see references 204 , 206, 208, 213). Unfortunately, for the separation of uranium, many other elements also are precipitated by the same reagents. However, there exists a large number of reagents capable of precipitating uranium over a wide range of. $\mathrm{pH}$. These, comblned with judicious use of the two oxidation states and/or the complexing ability of uranium, may be used to provide reasonably pure uranium deposits.

Precipitants. With the advent of nuclear energy as a source of power, numerous precipitants have been invest1gated in an effort to find one specific for the separation and/or determination of uranium. None have been found to date. Ware 214 has summar1zed early work using organic rea-

In the system outlined by Noyes and Bray, 202 uranium is precipitated in the sixth group with ammoniun hydroxide and is converted to the sulfide with hydrogen sulfide. In the system of West and Parks, 212 uranium is precipitated in the fifth (baslc benzoate) group. 
gents as precipltants. She 215 and Balley $\frac{216}{2}$ have invest1gated some of the more promising ones. Rodden and Warf 34 have discussed the use of many reagents, both Inorganlc and organic, and have described procedures for the use of many of them. The latter precipitants, 1.e., those for which procedures have been given by Rodden and Warf, 34 are denoted by a dagger ( + ) in the following discussion.

Inorganic precipitants. The reagents are listed alphabetically according to anion.

Arsenates. ${ }^{\dagger}$ Arsenic acid and ammonium, sodium and potassium arsenate precipitate uranium as uranyl metal arsenate. Silver, titanium, zirconium, thorium and lead interfere. Separation is made from the alkall metals, alkaline earths, aluminum, 1ron (II), and rare earths, including trivalent cerium. 34

Carbonates. $6,63,201,204,206,217-224$ Prec1pitation of urantum with amonium, sodium, or potassium carbonates is not very satisfactory. Highly soluble carbonate-uranyl complexes are formed. Under proper conditions, the metal uranyl tricarbonate salts $\mathrm{M}_{4} \mathrm{UO}_{2}\left(\mathrm{CO}_{3}\right.$ ) are formed. The solubilities of the respective ammonium, sodium, and potassium salts in water are $50\left(15^{\circ} \mathrm{C}\right), \underline{224} 150(\mathrm{RT}), \underline{225}$ and $71\left(18^{\circ} \mathrm{C}\right) \stackrel{218}{\underline{2 r a m s} \text { per }}$ 11ter. The solubility of the potassium salt in a $50 \%$ solution of potassium carbonate is 0.200 grams per liter. 221 The solubility of the sodium salt is decreased by increasing temperature and by increasing sodium salt concentration. $\underline{223}$ Tezak $\frac{217}{7}$ has studied the precipitation of uranium by ammonium and sodium carbonate. From a $0.043 \mathrm{~N}$ uranyl nitrate solution, precipitation was observed to be maximum in the region of $0.1 \mathrm{~N}$ precipitant concentration. Two maxima were ubserved for ammonium carbonate; one for sodium carbonate. Above and below these falrly narrow regions of precipltant concentration, uranium enters into solution. 
The uranium (IV) salt, $\mathrm{Na}_{6} \mathrm{U}\left(\mathrm{CO}_{3}\right)_{5} \cdot 11 \mathrm{H}_{2} \mathrm{O}$ is precipitated from reduced carbonate solutions at high uranium and carbonate concentrations. $\frac{63}{6}$

Barlum uranyl carbonate salts are reported to be very insoluble. $\frac{63}{}$ However, in the presence of carbonate solutions the alkaline earth salts are unstable according to the reaction, $\frac{63}{1}$

$$
\mathrm{M}_{2} \mathrm{UO}_{2}\left(\mathrm{CO}_{3}\right)_{3}(\mathrm{~s})+2 \mathrm{CO}_{3}^{2-}=\left[\mathrm{UO}_{2}\left(\mathrm{CO}_{3}\right)_{3}\right]^{4-}+\mathrm{MCO}_{3}(\mathrm{~s}) \cdot
$$

Tezak 217 has found the precipltation of uranium to be nearly complete when the barlumiuranium ratio is greater than 600 and the excess. carbonate is less than four times the barlum concentration.

A suspension of barlum carbonate may be used to prec1p1tate uranium. 34,226 Ammonium salts interfere. A suspension of basic zinc carbonate may be similarly used. 34,227 Iron, aluminum and thorlum also precipitate.

Cyanides. Alkali cyanides form a yellow precipitate when added to uranyl solutions. 34

Ferrocyanides. ${ }^{t}$ The addition of potassium ferrocyanide to a uranyl salt solution causes the formation of a deepred precipltate or suspension, depending upon the concentration of uranium. The reaction is used much in qualitative analysis for the 1dentification of uranium. However, it is little used for quantitative separation. The separation is poor and there are many interferences. 34 Separation can be made from beryllium in a weakly acla1c sulfate solution. $\frac{228}{2}$ Fluorides. 'Hydrogen fluoride precipltates uranium (IV) as the tetrafluoride. The precipitate is gelatinous and difficult to filter. $\frac{34}{4}$ Separation is made from metals complexed by fluoride 1ons, eg., tantalum and z1rconium. UranIum may be reduced to the (IV)-state with zinc in a solution mace slightly acidic. 196 
The double fluorides, eg., $\mathrm{NaUF}_{5}$, are sparingly soluble - even in the presence of strong acids. 196 separation can be made under tnese conditions from Mo, $\mathrm{T} 1, \mathrm{N1}$, Co, $\mathrm{Mn}$, $\mathrm{Cu}$, Fe (II), and $I$ (III). Aluminum precipitates as the double salt, $\mathrm{Na}_{2} \mathrm{AlF}_{6}$. Iron (III) precipitates in part. Reduction to uranium (IV) may be done in the presence of fluorides with ircn (II). 197,229 Rongalite $\left(\mathrm{Na}_{2} \mathrm{H}_{2} \mathrm{~S}_{2} \mathrm{O}_{4} \cdot 2 \mathrm{CH}_{2} \mathrm{O} \cdot 4 \mathrm{H}_{2} \mathrm{O}\right)$ also has been used to effect reduction. $\underline{230}$

Hydroxides. The addition of a metal hydroxide to a solution of uranyl salts results in the formation of the metal uranate. It has commonly been assumed that the metal diurante, $\mathrm{M}_{2} \mathrm{U}_{2} \mathrm{O}_{7}$, is precipitated by ammonium, sodium, or potassium hydroxide. However, experimental evidence ind1cates that the composition of the precipitate depends upon the conditions which exist during precipitation and upon the subsequent treatment, such as washing, which it receives. $\underline{231-237}$

Ammonium hydroxide ${ }^{\dagger}$ precipitates uranium quantitatively at $\mathrm{pH} 4$ or greater. 34 The presence of ammonium salts and macerated filter paper facliltate precipitation. Separation is made from alkall metals, alkaline earths, and cations forming ammonia complexes. Repeated precipitations may be necessary to give sufficient separation. Phosphorus, vanadium, silicon, boron, aluminum, iron and other elements of the ammonium hydroxide analytical group also are precipitated. 212 Complexing agents: carbonate, oxalate, cltrate, tartrate, fluoride, etc., interfere.

Precipltation with alkali metal hydroxides is similar to that with ammonlum hydroxide. Uranium may be precipitated in the presence of carbonate with sodium ur potassium hydroxide of sufficient concentration. Carbonate ion interference may be removed by heating. 
Pale green gelatinous $\mathrm{UO}_{2} \cdot \mathrm{H}_{2} \mathrm{O}$ is precipltated from uranium (IV) solutions by ammonium and alkali metal hydroxides. 190

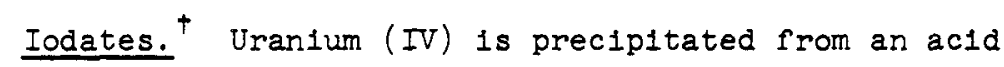
solution by potassium lodate. 34 separation can be made from copper, molybdenum, and reduced vanadium. $\frac{238}{\text { Aluminum in }}$ amounts up to fifty times that of uranium does not interfere. Larger amounts of aluminum and divalent iron in any concentration cause incomplete precipitation. Titanium, zirconium, cerium (IV), and thorium precipitate with lodate. 34

Mercuric oxide. Uranium is precipitated when a suspension of mercuric oxide is bolled in an aqueous solution containing ammonium chloride. $\frac{34}{4}$ separation is made from alkali metals and alkaline earths. Hydroxy aclds interfere. Peroxides. ${ }^{+}$Hydrogen peroxide precipitates uranium peroxide, $\mathrm{UO}_{4} \cdot \mathrm{xH}_{2} \mathrm{O}$, from slightly acidic solutions. The reaction occurs in the $\mathrm{pH}$ range $0.5-3.5$. The optimum range 1s 2.0-2.5. Hydrogen Ions released with the formation of uranlum peroxide are neutralized with ammonia or ammonium acetate. Complete precipitation requires an excess of hydrogen peroxide. Quantitative separation may be effected by freezing the solution, allowing it to stand, and filtering at $2{ }^{\circ} \mathrm{C}$. The separation from most elements is good since it

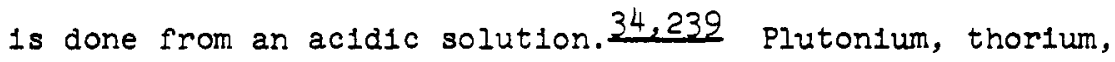
hafnium, zirconium, and vanadium also preclpitate. Iron interferes by catalytically decomposing hydrogen peroxide. Small quantities of Iron may be complexed with acetic, lactic, or malonic acid. Low ylelds may result from the use of malonic acid. Ammonium, potassium, and alkaline earths retard the rate of precipitation. Complexing lons such as oxalate, tartrate, sulfate, and fluoride in large quantities, also interfere. Fluoride ion may be complexed with aluminum. $\frac{239 a}{}$ 
Phosphates. Phosphoric ac1d and sodium monohydrogen phosphate prec1p1tate $\mathrm{UO}_{2} \mathrm{HPO}_{4}$ from uranyl solutions. Uranyl ammonium phosphate, $\mathrm{UO}_{2} \mathrm{NH}_{4} \mathrm{PO}_{4}$, is prec1pitated by $\left(\mathrm{NH}_{4}\right)_{2} \mathrm{HPO}_{4}$ or $\mathrm{Na}_{2} \mathrm{HPO}_{4}$ in the presence of ammonium acetate. "Precipitation is made in the $\mathrm{pH}$ range $1.2-2.3,1.7$ being optimum. It is not very selective. Z1rconlum, bismath, and thorlum precipitate under similar conditions. Alkall metals are retalned. Separation is made from vanadium. Both $\mathrm{UO}_{2} \mathrm{HPO}_{4}$ and $\mathrm{UO}_{2} \mathrm{NH}_{4} \mathrm{PO}_{4}$ are soluble in mineral acias. 34

Phosphate prec1p1tation of uranium (IV) is more select1ve. It is made from dilute hydrochloric or perchloric ac1d solutions. Separation is made from manganese, 1ron, vanadium and most other elements. Zirconium, thorium, and, to a smaller extent, titanium and tin precipitate. 196-198 Aluminum interferes by the formation of soluble complexes with uranium and phosphate ions. 29 with sulfate and aluminum present, uranium is preclpitated in a narrow pH-range around one. At higher $\mathrm{ph}$, the soluble aluminum-uranium-phosphate complex 18 formed; at lower $\mathrm{pH}$, the soluble uranium-sulfate complex. Chromium in excess of 0.2 gram per 100 mililters causes incomplete precipitation. 196 Large amounts of fluoride Ion prevent precipitation. 196

Sod1um hexametaphosphate $\left[\left(\mathrm{NaPO}_{3}\right)_{6}\right]$ also precipltates uranlum (IV) from ac1d solutions. $\frac{240}{}$ Adherence to falrly stringent conditions allows for complete precipitation. A $3 \mathrm{~N} \mathrm{FlO}_{4}$ solution of uranium (IV) is heated to $60-70^{\circ} \mathrm{C}$. If more than $2 \mathrm{mg}$. of uranium are to be precipltated, a freshly prepared 2\% hexametaphosphate solution is added unt1l its concentration in the precipitating medium is $0.30-0.35$ per cent. To precipltate smalier amounts of uranium, a 0.5 per cent solution of thorlum chloride is added as carrler and the hexametaphosphate added until it is in excess 25 per cent with respect to the thorlum, 1.e., molar ratio of Th: $\mathrm{PO}_{3}{ }^{-}$ 
is $1: 5$. Coagulation 1s improved by heating in a water-batn for ten to fifteer minutes after precipitation. Under these conditions separation is made from $V$ (III) and (IV), $\mathrm{Fe}$, Cu, and other di- and tri-valent metals. Incomplete preclpitation occurs with increased or decreased acidity -- probably because of enhanced solubility of the compound and complex formation, respectively. Precipitation from sulfuric acid is incomplete because of uranium-sulfate complex formation. Under certain conditions both uranium (IV) and (VI) form complexes with hexametaphosphate.

Hypophosphorlc acid $\left(\mathrm{H}_{4} \mathrm{P}_{2} \mathrm{O}_{6}\right)$, sodium dihydrogen hypophosphate $\left(\mathrm{Na}_{2} \mathrm{H}_{2} \mathrm{P}_{2} \mathrm{O}_{6}\right)$, and sodium pyrophosphate $\left(\mathrm{Na}_{2} \mathrm{P}_{2} \mathrm{O}_{7}\right)$ precipitate uranium (IV) from acid solutions. ${ }^{\dagger}$ Other tetravalent metals, $T 1, \mathrm{Zr}$, and $\mathrm{Th}$, also precipitate. Separation is made from uranium (VI) and trivalent metals in general. 34

Phosphites. Sodium hypophosphite $\left(\mathrm{NaH}_{2} \mathrm{PO}_{2}\right)$ and ammonium thiosulfate or sulfurous ac1d precipltate uranium from a

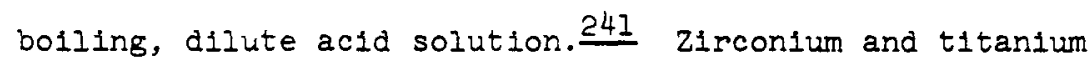
precipitate under similar conditions. These elements may be separated prior to uranium by bolling with sodium hyposulfite alone. Elements forming acid-insoluble sulfides are removed with hydrogen sulfide before adding sodium hypophosphite and ammonium thiosulfate.

Sulfates. Uranium (IV) sulfate is practically insoluble in 47 per cent perchloric ac1d. Precipitation is made in a sulfuric acid medium. Uranium is reduced on a mercury cathode and concentrated perchloric acid is then added.

Sulfides. Ammonium sulfide ${ }^{\dagger}$ or polysulfide precipltates brown, amorphous uranyl sulfide. Numerous other elements are precipitated under similar conditions. 213 Complexing agents such as carbonate, pyrophosphate, and c1trate interfere. 34 Uranium (IV) salts are precipitated as $\mathrm{UO}_{2} \cdot \mathrm{H}_{2} \mathrm{O}$ by ammonium sulfide. 190 
Hydrogen sulflde bubbled through a nearly neutral solution of uranyl salts containing hexamethylene tetramine precipitates uranium in a readily filterable, crystalifne form of "urantum red." Separation is made from alkal1 metals and alkaline earths. 34,197

Vanadates. Anmonium metavanadate precipitates ammonium uranyl vanadate from uranyl solutions buffered with ammonium acetate. 34 Uranovanadic ac1ds are precipitated at $\mathrm{pH} 2.2-$ 6.5.느 Within these limits, the composition does not depend upon the hydrogen ion concentration. It does depend upon the vanadium : uranium rat1o present in solution. Compounds corresponaing to the formulae $\mathrm{H}\left[\mathrm{UO}_{2}(\mathrm{OH})_{2} \mathrm{VO}_{3}\right] \cdot \mathrm{H}_{2} \mathrm{O}, \mathrm{H}\left[\mathrm{UO}_{2}(\mathrm{OH})\left(\mathrm{VO}_{3}\right)_{2}\right] \cdot 2 \mathrm{H}_{2} \mathrm{O}$, and $\mathrm{H}\left[\mathrm{UO}_{2}\left(\mathrm{VO}_{3}\right)_{3}\right] \cdot 4 \mathrm{H}_{2} \mathrm{O}$

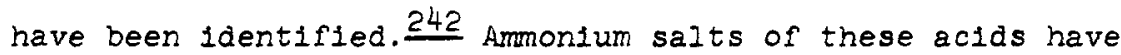
been synthesized in the presence of ammonium chloride. $\frac{242}{2}$ Ammonium uranyltrimetavanadate is the least soluble. However, its formation is a long process at room temperature. Heating greatly accelerates its rate of formation.

\section{Organic precipitants. Organic precipitating reagents} are listed al phabetically.

3-Acety $1-4$-hydroxycoumarin (3-acetyl benzotetronic acid). An alcoholic solution of the reagent added to a uranyl salt solution forms a pale yeliow precipitate insoluble in ethanol. Precipltation occurs between $\mathrm{pH} 1.5$ and 7 . Below $\mathrm{pH} 1.5$ the reagent precipitates. The thorium complex is soluble in alcohol, but precipitates from an aqueous solution at $\mathrm{pH} 2-4$. Lanthanum and cerium (III) do not interfere wher present in amounts ten times that of uranium. Cerium (IV) interferes even in small amounts.

Acradine. Uranium (IV) and (VI) are precipitated by the reagent with the addition of ammonium thiocyanate. 215 Iron (III), cobalt, copper, zinc, cadmium, mercury, and bismuth precipitate. $\frac{214,216}{}$ 
Aldehyde ammonia precipitates $\mathrm{UO}_{3} \cdot \frac{216}{}$

Alizarin and Alizarin Red S (sodium allzarin sulfonate).

Uranlum is precipltated slowly by the reagents when the uranyl ion concentration is less than 20 micrograms per m111111ter. 215

Aluminon (ammonium salt of aurintricarboxylic ac1a). The reagent precipitates both uranium (IV) and (VI) from sulfate solutions at $\mathrm{pH} 3 \cdot 5 . \underline{216}$

Amines. Ammine salts, generally of the form UO ${ }_{2}$ (Amine) $2 x_{2}$, where $X$ is an acid radical such as acetate, chloride, nitrate, etc. have been prepared from acetan1l1de, ant1pyrene, bromoantipyrine, diethylaniline, exalgin, nitrosoantipyrine, p-nitrosodimethylaniline, phenacetin, pyramidon, pyridine, quinaldine, and quinoline. Mono-, tri- and tetraammine salts also have been formed. The salts are generally prepared in anhydrous chloroform or amyl alcohol solutions. However, some of the more stable salts may be precipltated from aqueous or alcohol1c solutions. 214,244

2-Amino pyridine precipitates $\mathrm{UO}_{3} \cdot \frac{216}{}$

Amonium benzoate. Uranyl ion is precipitated by the reagent from slightly acldic solutions heated to bolling. A 0.05 N solution of the reagent contalning about $2.5 \%$ $\mathrm{NH}_{4} \mathrm{OH}$ is bolled separately and added in an excess of three to four times the uranium present. Carbonate ion prevents quant1tat1ve precipitation. $\underline{189,245}$

Ammonlum dith1ocarbonate precipltates uranium (VI). Derlvatives also are formed with $A I, M n(I I), F e(I I), C o$, $\mathrm{N1}, \mathrm{Cu}(I I), \mathrm{Zn}, \mathrm{Ag}, \mathrm{Sn}(\mathrm{IV}), \mathrm{Pb}$, and $\mathrm{B} 1 . \underline{246}$

Anthragallol forms brown precipltates or solutions w1th $\mathrm{U}^{4+}, \mathrm{UO}_{2}^{2+}, \mathrm{Fe}^{3+}, \mathrm{Cu}^{2+}$, and $\mathrm{MoO}_{4}^{2-} \cdot \frac{215}{2}$

Anthran1l1c ac1d. Uranlum (IV) is prec1pitated from a solution of the reagent buffered with ammonium acetate. The reagent added to a $0.1 \mathrm{MCO}_{2}\left(\mathrm{NO}_{3}\right)_{2}$ solution forms a heavy 
yellow precipitate. The amount of prec1pitate is increased by the addition of IM acetic acid; decreased by the addition of IM sodium acetate. Fifty micrograms of uranyl ion per drop of solution gives no observable precipitate. In acetic acid-sodium acetate buffered solutions, slightly soluble salts are formed with the reagent and $\mathrm{Mn}, \mathrm{CO}_{0}, \mathrm{~N} 1, \mathrm{Cu}, \mathrm{Zn}$, $\mathrm{Cd}, \mathrm{Hg}(\mathrm{II})$, and $\mathrm{Pb} . \underline{215}$

Arsonic acids. Benzenearsonic acid precipitates uranium (IV) in a weakly acldic solution, $\mathrm{pH}$ 1-3. Titanium and cerium (IV) are partially precipltated. Thorlum, zirconfum, hafnium, tin (IV), niobium, and tantalum are quantitatively precipitated. 34

Arsonilic acid (p-aminobenzenearsonic acid) precipitates uranium (VI) in a weakly acidic solution, $\mathrm{pH} 1-4$ or greater. At $\mathrm{pH} 2.1$ or greater the precipitation is quantitative as evidenced by negative ferrocyanide tests of the filtrate. Other lons which precipltate from neutral or slightly acidic solutions include $\mathrm{Cu}^{2+}, \mathrm{zn}^{2+}, \mathrm{Cd}^{2+}$, and $\mathrm{U}^{4+}$. With the addition of sodium acetate, aluminum and ferric lons also precipltate. $\frac{215}{}$

Other substituted arsonic aclds which give difficulty soluble uranyl salts are 3-nitro-4-hydroxybenzene- and methane-arsonic acics. $\frac{34}{4}$

B1s-benzenephosphon 1c ac1d. Tests on $50-150 \mathrm{mg} / \mathrm{l}$ uranium (VI) in sulfuric acid solutions in the presence of approximately 100- to 1000-fold excess ferrous, sulfate, aluminum, magnesium, and phosphate lons gave nearly $99 \%$ precipitation with the reagent. Optimum conditions for precipitation are $\mathrm{pH} \rightarrow 25^{\circ} \mathrm{C}$, and $10 / 1$ molar ratio of reagent to uranium. $\frac{248}{2}$

Benzenesulfinic acio precipitates uranium (IV) in acidic solutions. Iron (III) and the tetravaleni ions $\mathrm{TI}$, Sn, Ce, and Th also precipltate. 214 
Benzopurpin prec1p1tates uran1um (IV) and (VI). 216

Benzoylacetone precipitates urantum (VI). 216

5-Bromo-7-carboxy-8-hydroxyquinoline precipltates

uranium (VI), copper, zinc, cadmium, mercury, and lead. $\frac{249}{2}$

5-Carboxy-8-hyaroxyquinoline prec1p1tates uranium (VI)

in solutions buffered with acetic acid and sodium acetate. Iron, copper, zinc, cadmium, mercury, and lead precipitate. $\frac{249}{}$

7-Carboxy-8-hydroxyquinoline precip1tates uranium (VI)

in ammoniacal tartrate solutions.

Catechol forms compounds with tetravalent uranium, silicon, titanium, zirconium, and thorium. 214 Catechol combined with pyridine precipitates hexavaient uranium. $\frac{214}{4}$

Cresotinic ac1d in the presence of sodium acetate precipitates uranium (IV) from solution. Aluminum and iron (III) also precipitate. Separation is made from $\mathrm{Cr}, \mathrm{Fe}$ (II), $\mathrm{Co}, \mathrm{N} 1, \mathrm{Cu}, \mathrm{Zn}, \mathrm{Cd}$, and Mo. 215,216

Cupferron (ammonlum nitrosophenylhydroxylamine). ${ }^{\dagger}$ Uranium (IV) is precipitated from acidic solutions by the reagent. Good separation is made from other elements if this preclpitation follows one in which urantum was kept in the hexavalent state. Ions which are preclpitated by cupferron from acldic solutions include $\mathrm{Tl}, \mathrm{V}, \mathrm{Fe}, \mathrm{Ga}, \mathrm{Zr}, \mathrm{Nb}, \mathrm{Sn}, \mathrm{Sb}$, $\mathrm{Hf}$, and $\mathrm{Ta}$. Ions which are not precipltated under such conditions include the alkal1 metals, alkaline earths, Be, $B$ as borate or fluoborate, $\mathrm{Al}, \mathrm{P}, \mathrm{Cr}, \mathrm{Mn}, \mathrm{N} 1, \mathrm{Zn}$, and $\mathrm{U}(\mathrm{VI})$. Preclpltation is usually made in a sulfurlc acid medium but hydrochloric or organic acids may be used. Nitric acid should be avolded; also perchloric acid if the precipitate is to be 1gnited. The presence of a reducing agent, hydrcxylamine or sodium hydrosulfite, facilitates complete precipitation of uranium (IV). The cupferrate may be filtered or extracted with an organic solvent such as chloroform. $\frac{34,250}{2}$ 
Hexavalent uranium is precipltated by cupferron from neutral solutions. $\underline{250}$

Dibenzoyl methane forms a yellow preclpitate with uranium (VI). 216

3,5-D1bromosalicylaldoxime prec1p1tates $\mathrm{U}(\mathrm{VI})$, Co, $\mathrm{N} 1$, $\mathrm{Hg}$ (II), and $\mathrm{Pb} .25 \mathrm{I}$

$4,4^{\prime}$-Dihydroxy $-3,5,3^{\prime}, 5^{\prime}$-tetra (hydroxymethyl) -diphenylmethane precip1tates $U(V I), M n, F \in(I I I), C u(I I)$, and $\mathrm{Hg}(I I) . \underline{2 l 6}$

Dimethylammonium dimethyla1thiocarbomate forms a red precipitate with uranium (VI). 216

Diphenyl thlocarbazide precipitates uranium (VI) from neutral solutions. Copper (II), silver, lead, and bismuth also preclpitate with the reagent. $\frac{216}{6}$

Dipropylamine forms a yellow precipltate w1th uranium. 216 Disalicylalethylene dilmine precipitates uranium (IV) and (VI). Most heavy metals are precipitated by the reagent. 34 Ethanolamine precipitates $\mathrm{UO}_{3} .216$

Ethylenediamine and uranyl nitrate form an insoluble double salt, $\mathrm{UO}_{2} \mathrm{SO}_{4}\left(\mathrm{H}_{2} \mathrm{SO}_{4}\right) \mathrm{NH}_{2} \mathrm{CH}_{2} \mathrm{CH}_{2} \mathrm{NH}_{2}$, in elcoholic-sulfurlc acid solution. 252 Double salts of the same type are formed with plperazine and dimethylp1perazine. Siemssen $\frac{253}{\text { observed }}$ that a solution of ethylenediamine added to a uranium solution gives a bright yellow crystalline preclpitate that is soluble in excess reagent.

Ethylenediamine tetracetic ac10. Uranium is prec1pitated when a uranyl acetate solution is bolled with solid reagent. 254 Gal11c ac1d precipitates U(IV), U(VI), Fe(III), Cu(II), and $\mathrm{Zn} .215$

Gualacol. A brown preclpitate results from the reaction of the potassium salt of gualacol and uranyl acetate in an aqueous solution. $\underline{255}$

Hexamethylene tetramine (urotropine) ${ }^{\dagger}$ is a weaker base than ammonium hydroxide and does not absorb carbon dioxide. 
This reduces the likelihood of carbonate interference and of alkaline earth carbonate precipitation. Uranium is precipitated when the reagent is boiled in a uranyl solution that contains ammonium ion and no excess ac1d. 34 Ions that form stable complexes with uranium interfere. Separation can be made from alkali metals, alkaline earths, $\mathrm{Mn}, \mathrm{Co}, \mathrm{Ni}$, and $\mathrm{Zn}$. $\mathrm{Zr}, \mathrm{T} 1, \mathrm{Fe}, \mathrm{Al}, \mathrm{Ce}(\mathrm{IV}), \mathrm{Th}$, and some other elements precipitate.

A double salt, $\mathrm{UO}_{2} \mathrm{SO}_{4} \cdot \mathrm{H}_{2} \mathrm{SO}_{4} \cdot\left(\mathrm{CH}_{2}\right)_{6} \mathrm{~N}_{4}$, is formed with the reagent and an excess of sulfurlc acid and uranyl salt. $\frac{256}{}$

a-Hydroxyacetophenone forms a white precipitate with hexavalent uranium. $\frac{216}{}$

1-Hydroxyacridine (1-acridol or benzoxine) preclpitates uranium (VI) in neutral solutions. Calcium precipitates from neutral solutions; $\mathrm{Mg}, \mathrm{Ca}$, and $\mathrm{Ba}$ from alkaline solutions; $\mathrm{Cr}$ (III), $\mathrm{Mn}(I I), \mathrm{Fe}$ (II and III), $\mathrm{Cu}(I I), \mathrm{Zn}, \mathrm{Cd}, \mathrm{Hg}$ (I and II), $\mathrm{Te}$ (II), and $\mathrm{Pb}$ from solutions containing acetic acid and sodium acetate. $A I, S n(I I)$, and $B 1$ do not precipitate. $\frac{257}{2}$

l-Hydroxyanthraquinone forms slightly soluble complexes w1th uranyl, cobalt, cupric, nickel, magnesium, and manganese tons. $\underline{215}$

1-Hydroxy-3-methoxyxanthone may be used to separate uranium, thorlum, ceric salts and cerite earths. 258 The ceric salts and cerite earths are not precipitated by the reagent. Thorium is precipitated at pH 2.6-4.0. Uranium (uranyl 1on) precipitates at higher $\mathrm{pH}$.

8-Hydroxyquinaldine. Tetravalent uranium is precipitated by the reagent with the addition of ammonium acetate. The preclpitation of hexavalent uranium is almost quantitative In the $\mathrm{pH}$ range 7-9 from carbonate-free ammonium acetate buffer. 259 Iron, cobalt, nickel, copper, cadmlum, and chromium are precipitated by the reagent. $\frac{215}{}$

8-Hydroxyquinoline (oxine). ${ }^{\dagger}$ Hexavalent uranium is 
precipitated as $\mathrm{UO}_{2}\left(\mathrm{C}_{9} \mathrm{H}_{6} \mathrm{NO}\right)_{2} \cdot \mathrm{C}_{9} \mathrm{H}_{7} \mathrm{NO}$ from weakly acidic or basic solutions. $\frac{34}{4}$ Quantitative recovery has been reported over the $\mathrm{pH}$ range 4.1-13.5. A large number of other elements are precipitated by oxine inclualing $\mathrm{Mg}, \mathrm{Al}, \mathrm{Cr}, \mathrm{Fe}, \mathrm{Co}, \mathrm{N} 1$, Cu, $\mathrm{Zn}, \mathrm{Cd}, \mathrm{Mo}, \mathrm{BI}$, and $\operatorname{Tr} .215,260-263$ Uranium can be precipltated in the presence of small amounts of complexing agents: fluoride, hydroxylamine, oxalate,lactate, and tartrate. 34 separation from small amounts of phosphate also can be made at pH 10-12 using an excess of oxine. Ammonium carbonate interferes. Tetravalent uranium and oxine form a brownish-yellow deposit. 215

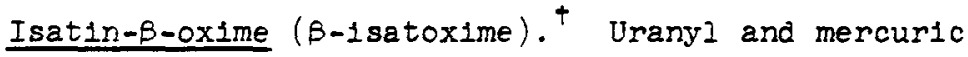
ions are precipitated by the reagent from weakly acidic solution. Precipitation is incomplete but can be made quantitative by increasing the $\mathrm{pH}$ with sodium acetate. A number of other elements precipitate under these conditions including $\mathrm{Fe}(\mathrm{II}), \mathrm{Co}, \mathrm{N} 1, \mathrm{Ag}, \mathrm{Hg}(\mathrm{I})$, and $\mathrm{Pb} . \underline{264}$ separation can be made from $\mathrm{Mn}(I I), \mathrm{Zn}$, and alkaline earth ions. $\underline{265}$ In alkali tartrate solutions, uranium can be separated from cobalt and nickel. $\frac{266}{}$

Isojuglone. The sodium salt of this reagent and uranyl acetate form a carmine-red preclpitate after washing with ethanol. Iron, cobalt, nickel, zinc, cadmium, mercury, and lead are precipitated by the reagent. $\underline{267}$

Isonitroso-N-phenyl-3-methylpyrazolone. Uranyl nitrate or acetate forms a redalsh-orange precipitate with a $1 \%$ solution of the reagent in a 50\% alcoholic solution. Precipitation is quantitative with the addition of sodium acetate. Mercury (I) and (II), copper (I) and (II) and uranyl lons precipitate in acidic media (nitrate or sulfate). In acetate solutions, $\mathrm{Ag}, \mathrm{Cd}, \mathrm{N} 1, \mathrm{Co}, \mathrm{Zn}, \mathrm{Cu}(\mathrm{II})$, and $\mathrm{UO}_{2}^{2+}$ lons precipitate. By reducing the acidity with sodium acetate, salts of $\mathrm{Ag}, \mathrm{Pb}, \mathrm{B1}$, $\mathrm{Cd}, \mathrm{Mn}, \mathrm{N} 1, \mathrm{Co}, \mathrm{Fe}(\mathrm{II})$, and $\mathrm{Fe}$ (III) can be precipitated from 
nitrate solutions. Salts of $T I(I), S b$ (III), $S n$ (II), AI, $\operatorname{Cr}$ (III), and the alkaline earths do not precipitate. $\frac{268}{4}$

Lauramidine hydrochloride. Th1s reagent has been

tested for the separation of uranium from phosphate solutions. $\frac{248}{2}$ At $\mathrm{pH} 2.45,75 \%$ of the uranium was precipitated.

N-Lauryl-lauramidine. This reagent also has been tested for the separation of uranium from phosphate solutions. At $\mathrm{pH} 2.45,85 \%$ of the uranium was precipitated.

Mercapto-acet1c ac1d forms a green1sh-white prec1p1tate w1th tetravalent uraniuu. 215,216

Methylamine precipltates uranium (VI). .214

Methyl red causes urantum (VI) and aluminum to precipitate. 215

Morpholine prec1pitates uranium (IV) and (VI) as well as a number of other metal 1ons. $\frac{215}{}$ A I $\mathrm{mg}$ per $\mathrm{ml}$ solution of uranyl nitrate shows only a yellow color with the reagent. No precipitate is formed. 215

B-Naphthoguinoline in the presence of thlocyanate ion prec1pitates uranium (VI), mercury, b1smuth, copper, cadmium, nlckel, cobalt, zinc, and iron (III) from sulfuric or nitric acid solutions. $\frac{269}{}$

Neo-cupferron (ammonium $a$-nitrosonaphthyl hydroxylamine) is similar to cupferron in 1ts application. Uranium (IV) is precipitated by the reagent. $\frac{214}{4}$

Nitrilotrlacet1c ac1d forms derlvatives with uranium (VI), Iron (III), nickel, and copper (II). $\underline{270}$

m-N1trobenzolc ac1d precipitates uranium (IV). 34

o-N1trosohydroxylaminophenyl p-toluenesulfonate forms a yellow precipitate with hexavalent uranium. Many other metallic lons are precipitated by the reagent including $\mathrm{Al}, \mathrm{Cr}$, $\mathrm{Fe}(I I I), \mathrm{Co}, \mathrm{N1}, \mathrm{Cu}(\mathrm{II}), \mathrm{Cd}, \mathrm{La}, \mathrm{Ce}, \mathrm{Hg}(I I), \mathrm{B} 1, \mathrm{~Pb}$, and $\mathrm{Th} . \frac{27 I}{}$ a-Nitroso-B-naphthol ${ }^{+}$deposits uranium $(V I)$ as a very fine, yellow-orange 34 to brown 215 precipltate. Precipitation 
is made in the pH range 4.0-9.4.272 Metals such as 1ron, cobalt, nickel, and copper are precipltated from slightly ac1d solitions. Molybdenim as molybdate ion, zinc, and uranium (IV) form colored solutions. $\frac{215}{15}$ Aluminum, chromium, and cadmium give no visible reaction. 215 The uranium compound can be extracted with amyl alcohol. 34

B-Nitroso-a-naphthol precipltates uranyl ion from slightly acidic solution. Iron, cobalt, nickel, copper, zinc, and molybdate lons also are precipitated by the reagent. Aluminum, chromium, cadmium, and uranium (IV) give no visible reactions. The precipitation of uranium (VI) is most nearly complete in an acetate buffered solution. $\underline{215}$

Oleic acid is a precipitant of uranium (VI). 216 Oxalic acid ${ }^{\dagger}$ precipitates uranium (IV) from acidic solution. 34 Strongly complexing organic compounds and fluoride, sulfate, and large amounts of phosphate lons interfere. Uranium is precipitated from 2-3N hydrochlorlc ac1d media. At lower aciaities other metal oxalates precipitate, eg., $\mathrm{Fe}(\mathrm{II}), \mathrm{Zn}$, Cu. At higher ac1d1ties the solubility of uranium (IV) oxalate increases. Immediate filtration of the precipitate may result in losses up to $1 \%$ of the uranium to the filtrate. Recovery of urantum may be made more quant1tative by chilling the solution and allowing 1 to stand.

Small amounts of manganese, iron, and nickel may be carried with the precipitate. N1oblum, the rare earths, and thorium precipitate under similar conditions. If uranium is reduced on a mercury cathode prior to precipitation, no cations in moderate amounts interfere except rare earths and thorium.

Precipitation of uranium can be made in cold IN nitric acid solutions. $\frac{230}{0}$ The uranium content should be less than 70 grams per liter. Enough oxalic acid is added to give a $10 \%$ excess of the amount theoretically required to precipitate $\mathrm{U}\left(\mathrm{C}_{2} \mathrm{O}_{4}\right)_{2}$. The uranium then is reduced to the (IV)-state by 
adding sufficient rongalite $\left(\mathrm{Na}_{2} \mathrm{H}_{2} \mathrm{~S}_{2} \mathrm{O}_{4} \cdot 2 \mathrm{CH}_{2} \mathrm{O} \cdot 4 \mathrm{H}_{2} \mathrm{O}\right)$ to give a 7-10\% excess of 1 mole of rongalite per mole of uranium.

Phenanthrene quinone monoxime prec1p1tates uranium (IV) and (VI), aluminum, iron, cobalt, nickel, copper, and zinc. 215

Phenoxarsinicac1d precipitates hexavalent uranium. $\frac{248}{2}$

Phthiocol precipitates $\mathrm{U}^{4+}, \mathrm{UO}_{2}^{2+}, \mathrm{Zn}^{2+}$, and $\mathrm{MOO}_{4}^{2-}$ Ions. $\frac{215}{2}$

Picrolonic acid precipltates tetra- and hexa-valent uranium and most other metallic 1ons. 215

Plperazine. (See ethylenediamine).

Pyridine $^{\dagger}$ does not absorb carbon dioxide like ammonium hydroxide does. This reduces the possiblilty of carbonate interference or of alkaline earth precipitation in a uranium separation. Ammonium nitrate facilitates uranium precipitation. Sulfate ion hinders 1t. Separation can be made from alkal1 metals, alkal1ne earths, $\mathrm{Mn}, \mathrm{Co}, \mathrm{N} 1, \mathrm{Cu}$, and $\mathrm{Zn} . \mathrm{Zr}, \mathrm{Ti}, \mathrm{Fe}$, $\mathrm{Cr}, \mathrm{Al}$, and others are prec1pitated by the reagent. 34

Pyrogallol and pyridine combine to form a derlvative with hexavalent urantum. $\frac{214}{4}$

Quinaldic ac1d ${ }^{\dagger}$ forms a yellow, amorphous preclpitate with uranyl 1on. 216 Prec1pitation is made from a neutral or weakly aclalc (pH 2-3) solution in the presence of ammonium chloride. The reagent precipitates a number of metals including copper, zinc, cadmium $\underline{273}$ and uranium (IV). $\underline{215}$ Uranyl ion is not precipitated in the presence of alkall tartrate 274 or a high concentration of acetate ion. 215

Quinlzarin (1,4-dihydroxy-anthraquinone) prec1p1tates uran1um (IV) and (VI), 1ron and copper. 215

Rhodizonic acld forms a blue-black precipltate with tetravalent uranium. In neutral solutions, $\mathrm{Ag}, \mathrm{Hg}$ (I and II), $\mathrm{Tl}, \mathrm{Pb}, \mathrm{Cu}(I I), \mathrm{Cd}, \mathrm{B} 1, \mathrm{Zn}, \mathrm{Sr}, \mathrm{Ba}, \mathrm{Fe}(I I)$, and $\mathrm{JO}_{2}(I I)$ lons are precip1tated. At $\mathrm{pH} 2.8, \mathrm{Ag}, \mathrm{Hg}(\mathrm{I}), \mathrm{Tl}, \mathrm{Pb}, \mathrm{Cd}, \mathrm{Ba}$, and $\mathrm{Sn}$ (II) are precipitated. $\underline{275}$ 
Salicyclic acid. The sodium salt of the reagent forms a greenish-white preclpitate with uranium (IV). Under conditions tested, $\mathrm{Al}, \mathrm{Cr}, \mathrm{Fe}, \mathrm{CO}, \mathrm{N} 1, \mathrm{Zn}, \mathrm{Cd}, \mathrm{MoO}_{4}^{2-}$, and $\mathrm{Ud}_{2}^{2+}$ lons were not precipitated. $\underline{215}$

Sebacic ac1d precipitates uranium (IV). 34

Sodium acetate prec1pltates sodium uranyl acetate from neutral or weakly acidic solutions of uranyl salts. 189 The method is not very useful for the precipitation of traces of urantum. The solublilty of sodium uranyl acetate in a solution $5 \mathrm{M}$ in sodium nitrate, $1 \mathrm{M}$ in acetic acid, and $0.5 \mathrm{M}$ In sodium acetate is about $100 \mathrm{mg}$ per 11 ter. $\underline{276}$ Neptunium (VI) and plutonium (VI) also precipltate under these cond1tions. The addition of sodium acetate and zinc acetate to a neutral or weakly acialc uranyl salt solution precipitates the triple salt, sodium zinc uranyl acetate. $\underline{189}$

Sodium diethyldithiocarbemate precipitates tetravalent uranium, aluminum, 1ron, cobalt, nickel, copper, and cadmium. 215 Hexavalent uranium may be precipitated when both uranyl and reagent concentrations are sufficlently large. $\frac{246,277}{2}$

Sodium ethyl xanthate forms an orange precipitate with uranium (VI). $\underline{216}$

Strychnine in the presence of fluoride ion precipltates hexavalent uranium as $7\left(\mathrm{C}_{21} \mathrm{H}_{22} \mathrm{O}_{2} \mathrm{~N}_{2} \mathrm{HF}\right) \cdot 6\left(\mathrm{UO}_{2} \mathrm{~F}_{2}\right) \cdot 2 \mathrm{HF}$. The solubility of the preclpitate in water at $25^{\circ} \mathrm{C}$ is $47.5 \mathrm{mg} / 100$ $\mathrm{mi}$; In $60 \%$ alcohol1c solution at $25^{\circ} \mathrm{C}, 30 \mathrm{mg} / 100 \mathrm{ml} . \frac{278}{}$

Tannic ac1d (digallic acld) ${ }^{\dagger}$ and tannin (a glucose ester of tannic ac10 ${ }^{\dagger}$ react with uranium (VI) to give a deep-browr precipltate. 34 Elements arranged according to decreasing ease of precipitation by tannin are $\mathrm{Ta}, \mathrm{Tl}, \mathrm{Nb}, \mathrm{V}, \mathrm{Fe}, \mathrm{Zr}$, Hf,

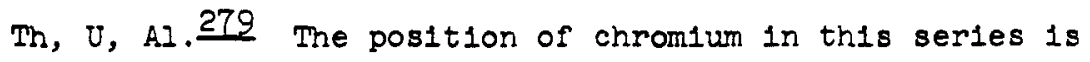
uncerta1n. Tantalum, titanlum, and nlobium may be separated by tannin in a slightly acidic oxalate solution. Uranium and others are precipitated by adding more tannin and by making 
the solution ammoniacal. Uranium may be precipltated from such solutions in the presence of arbonate, acetate, or tartrate 1ons. $\frac{209}{2}$

Th1osinamine. Urantum and cadmium are preclpitated when an alkaline solution contalning these elements is bolled with the reagent. $\frac{280}{}$

Carriers. Trace amounts of uranlum mas be removed from solution by the use of gathering agents or carriers. The cholce of a part1cular agent depends upon the conditions under which precipltation is to be made and upon subsequent chemistry to which the precipitate is to be subjected. Rodden and Warf $\frac{34}{4}$ have described the application of several carriers: ferric, aluminum, and calclum hydroxide. The use of barium carbonate and thorlum hexametaphosphate has been mentioned in the section on 1norganic precipitants. Magnesium oxide and thorlum peroxide have been used. 34 The oxide and salts of antimony, 281,282 calclum fluoride, and the phosphates of z1rcontum, 197 b1smuth, $\underline{283}$ and thor1um 197 , 240 have been used to carry uranium from reduced solutions. Uranium (IV), in general, should behave simllarly as neptunium (IV) and plutonfum (IV). These are carried by lanthanum fluoride, ceric and zirconlum lodates, ceric and tnorium oxalates, barium sulfate, zirconium phosphate, and bismuth arsonate. $\frac{276}{}$ Uranium (VI) does not carry with these agents providing the concentration of elther carrier or uranium is not too large.

Complexes. The precipltation of uranium in normally precipitating media is inhibited by the formation of soluble complexes.34 Carbonate ion is a very efficient complexing agent of uranyl 1on. In ammonium hydroxide solution, uranium can be separated from 1ron, titanium, zirconium, and aluminum with carbonate ion present. In ammontum sulfide solutions, carbonate ion makes possible the separation 
of uranium from manganese, 1ron, cobalt, zinc, and titanium. Ammonium carbonate prevents the precipitation of uranium with phosphate. Precipitation with sodium carbonate makes possible the separation of uranium from beryllium, manganese, 1ron, cobalt, nlckel, zinc, titanium, zirconium, and the alkaline earths.

Sodium peroxide facilitates the separation of uranium and other metals with sodium carbonate. The addition of the peroxide alone to acld solutions of Iron, cobalt, rare eartins, titanium, zirconium, hafnium, and thorium causes their prec1pitation while uranium, if present, remains in solution.

Uranium does not precipitate with tannic acid in slightly acidic solution with oxalate ion present. Titanium, nioblum, iln, tantalum, and tungsten are precipitated under such conditions. Oxalate ion also interferes in the precipitation of uranium by ammonia.

Tartrate, citrate, and malate lons prevent the precipitation of uranium by ammonium hydroxide or sulfide. 34

Salicylic acid and hydroxylamine have both been used to complex uranium in separatiors from rare earth elements. 34 Hydroxylamine has been used in separations between uranium and berylitum, aluminum, iron, and thorium. 34

Complexing agencs that form weak complexes with uranium and relatively strong complexes with other metallic lons make separation possible between the two: uranium is preclpitated by a suitable reagent; the other ions remain in solution. Ethylenedlaminetetracet1c ac1o (complexone II) and 1ts disodium salt (complexone III) have been used successfully in this respect. Uranium has been preclpitated with ammonia in the presence of complexones without interference from $\mathrm{Al}, \mathrm{Cr}, \mathrm{Mn}, \mathrm{Fe}, \mathrm{Co}, \mathrm{N} 1, \mathrm{Cu}, \mathrm{Zn}, \mathrm{Cd}, \mathrm{Ia}, \mathrm{Ce}, \mathrm{Hg}, \mathrm{Pb}, \mathrm{B} 1$, and the alkaline earths. 284 The recovery of uranium is not entirely quantitative since the complexing agent increases the solubility of the ammonlum uranate., 196,285 The absorp- 
tion of 1mpurities in the precipitate may necessitate dissolution and reprecipitation of the uranium. 196 Beryllium and titanium follow the uranium chemistry. $\frac{286}{6}$

Quantitative recovery of uranium from the aforementioned cations: $\mathrm{Al}, \mathrm{Cr}, \mathrm{Mn}, \mathrm{Fe}$, etc., can be made with ammonium monohydrogen phosphate, $\left(\mathrm{NH}_{4}\right)_{2} \mathrm{HPO}_{4}$, in the presence of ethyle nediaminetetracetic acid. $\underline{285,287}$ Beryllium and titanium again interfere. Small amounts of titanium may be complexed with hydrogen peroxide before the addition of other reagents. $\frac{287}{}$

Sen Sarma and Mall1k $\frac{288}{2}$ have studied the separation of uranium from other elements using 8-hydroxyquinoline (oxine) as precipitant and complexone III as complexing or masking agent. It was found that complexone had no masking action on uranium in the $\mathrm{pH}$ range 5-9. In a solution buffered with acetic acid and ammonium acetate at $\mathrm{pH} \sim 5.3$ quantitative separation was reported between uranium and $A I, M n, F e(I I I)$, $\mathrm{Co}, \mathrm{N} 1, \mathrm{Cu}, \mathrm{Zn}, \mathrm{Zr}, \mathrm{Cd}$, rare earths, $\mathrm{Pb}, \mathrm{B1}$, Th, and $\mathrm{P}_{2} \mathrm{O}_{5}$. In ammoniacal medium at $\mathrm{pH}-8.4$, a similar separation was made from $\mathrm{V}_{2} \mathrm{O}_{5}, \mathrm{MoO}_{3}$, and $\mathrm{WO}_{3}$. Steele and Taverner, $\underline{198}$ however, were unable to duplicate the above results.

2. Solvent extraction. The solubility of uranyl nitrate in organic solvents has long been recognized. 185 The ab1l1ty of diethyl ether to extract this salt has been used in systems of analysis for many years. However, it is only within recent years (starting in the 1940's) that widespread use has been made of solvent techniques as a means of separating and purifying 1norganic substances in general 289-299 and uran1um in part1cular. 191,192,194,197-199,300-305

The conditions under which uranium may be extracted are many and varled. In the present paper, extraction from aqueous solution is considered. However, extraction from

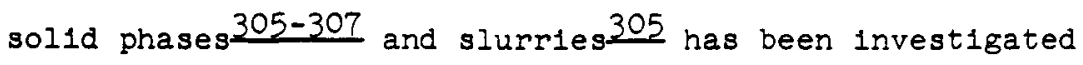


and a favorable uranium partition has been found. Conditions which affect the extraction of uranium from aqueous solution by organic solvent are the composition of the aqueous phase, the nature of the organic phase, the temperature, and the time of equilibration. In the aqueous phase, such factors as uranium, acid, common anion, foreign anion, and foreign cation concentration must be considered. The nature of the organic phase depends upon the type and concentration of solvent and diluent. If the organic phase is not initially barren, its concentration of uranium, acid, etc., affects partition.

Because of the number of variables and the large number of uranium solvents, one cannot consider, in a volume of this size, each solvent in the light of each variable. Indeed, the behavioral relation between solvent and the afore-mentioned variables is known for only a few well-studied solvents. The purpose of the present paper is to provide information on the conditions best-sulted for the quantitative extraction of uranium or for the separation of uranium from interfering elements. This is done as much as possible in graphic or tabular form.

The solvents are divided into five general classifications: 1) ethers, esters, ketones, and alcohols; 2) organo-phosphorous compounds; 3) amines and quaternary ammonium salts; 4) carboxyl1c acids; 5) chelating agents. Dialkylphosphoric acids, eg., dibutyl phosphate, are classified as organophosphoms compounds rather than chelating agents. Carboxylic acids are classifled as such, although some may also be considered chelating agents, eg., salicylic acid. A number of extractants may serve also as diluents or secondary solvents for other extractants. Such systems are described under the primary extractant. For example, a cupferron-hexone system is described under "cupferron" rather than under "hexone." 
In the discussion, the terms "extractant" and "solvent" are often used interchangeably. "D1luent" is used to describe a secondary solvent rather than the term "Inert solvent." The cholce of diluent may appreclably affect the partition of uranium. A number of terms that are frequently used are defined below.

Partition or extraction coefficient:

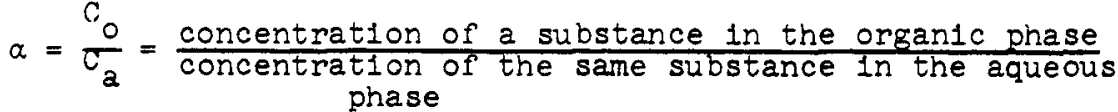

Percentage extracted:

$P=\frac{\alpha}{I+\alpha} \times 100$, when equal volumes of both phases are present after shaking.

$$
\begin{aligned}
& \text { Mass ratio: } \\
& \mu=\frac{M_{0}}{M_{a}}=\frac{\text { amount of a substance in the organic phase }}{\text { amount of the same substance in the aqueous }}=a \frac{V_{0}}{\text { phase }} \\
& \text { Separation factor: }
\end{aligned}
$$$$
B=\frac{\frac{\text { concentration of substance } A \text { in the organic phase }}{\text { concentration of substance } B \text { in the organic phase }}}{\text { concentration of substance } A \text { in the aqueous phase }}
$$

Equilibrium laws. The physical chemical principles Involved in the solvent extraction of uranyl nitrate have been summarized in references 308-312. Detalled methods of treating the various equilibria involved have been devised.111,313-315 A more s1mple approach, adapted from a paper by Carleson $\frac{31}{1}$ is herewith presented.

It may be assumed that within a certain concentration range an average urantum complex is extracted. The complex is representative of a whole set of complexes and may be written $\mathrm{H}_{y} \mathrm{M}^{(+x)} L_{(x+y)}\left(\mathrm{H}_{2} \mathrm{O}\right)_{h} \cdot(\mathrm{S})_{n} \cdot \mathrm{M}^{+x}$, in this case, may be $\mathrm{U}^{+4}$ or $\mathrm{UO}_{2}^{+2}$. I, as written, is a singly, negatively charged l1gand. It may be more highly charged. S represents a solvent molecule. The subscripts $y, h$, and $n$ need not be 1ntegers. The reaction for the extraction mechanism may be written 


$$
\begin{aligned}
\mathrm{M}^{+\mathrm{x}} \mathrm{aq}+\mathrm{yH}^{+} \mathrm{aq}+(\mathrm{x}+\mathrm{y}) \mathrm{L}^{-} \mathrm{aq}+\mathrm{nS} \text { org } \longrightarrow \\
\mathrm{H}_{\mathrm{y}} \mathrm{ML}(\mathrm{x}+\mathrm{y}) \mathrm{S}_{\mathrm{n}}\left(\mathrm{H}_{2} \mathrm{O}\right)_{h} \text { Org }+\mathrm{mH}_{2} \mathrm{O} .
\end{aligned}
$$

The thermodynamic equilibrium constant for the reaction is

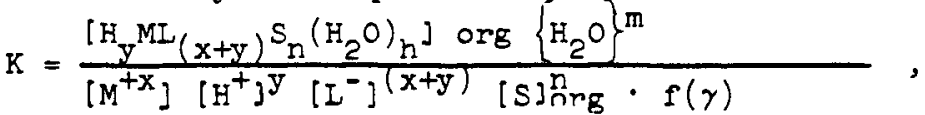

where \{\} and [ ], respectively, represent the activity and concentration of a quant1ty in the aqueous phase unless otherw1se 1dentified by the symbol "org." $f(\gamma)$ represents the product of the activity coefficlents. The partition coefficient is approximated by

$$
\alpha=\frac{\left[H_{y}{ }^{M L}(x+y) S_{n}\left(H_{2} O\right)_{h}\right] \text { org }}{\left[M^{+x}\right]} .
$$

The relation between the partition coefficient and equilibrium constant is

$$
\begin{gathered}
\log \alpha=y \log \left[\mathrm{H}^{+}\right] \mathrm{aq}+(\mathrm{x}+\mathrm{y}) \log \left[\mathrm{L}^{-}\right] \mathrm{aq}+\mathrm{n} \log [\mathrm{S}] \text { org } \\
-\mathrm{m} \log \left\{\mathrm{H}_{2} \mathrm{O}\right\}+\log \mathrm{f}(\gamma)+\log \mathrm{K} .
\end{gathered}
$$

Information concerning the extracted species may be obtained by measuring the partition coefficlent wh1le varying the concentration of only one of the quantities. A knowledge of the activity coefficients is then required or the product of the activity coefficients in both phases must be kepr constant. As stated previously, the above approach to solvent extraction is a simplified version. It represents only an average extracted species. Among other things, it does not consider the effect of water activity in the organic phase, solvent activity in the aqueous phase, complex formation between the var1ous components in elther phase, or the formation of polynuclear specles. These effects may be large or small depending upon the solvent, aqueous medium, and uranium concentration involved.

ETHERS, ESTERS, KETONES, AND AICOHOLS, Urany I nitrate 18 extracted by meny polar solvents which contain donor oxygen atoms such as ethers, esters, ketones, and alcohols. $316-320$ 
Extraction from water solutions is small unless the uranium concentration is appreciable. Th1s is shown in flgures $1-5$ In whlch the data of McKay and co-workers, 176,185 Wamer, $\frac{321,322}{2}$ and Veselý, et al $\frac{323}{2}$ are plotted. In general, 1t has been observed 301 that:

1) the extraction coefficient of uranium decreases when the number of carbon atoms increases for a given homologous series of organic solvents,

2) for a molecule with a given number of carbon atoms and a given chemical functional group, solvents with straight chains are more efficlent extractants than those with branched chains,

3) one or more double bonds in a molecule increases the efficlency,

4) primary alcohols are more efflclent than secondary ones,

5) the coefficient of extraction increases with the solub1lity; but there is no well-defined relation between the two.

Evidence considered in the section on non-aqueous solutions indicates that uranium is extracted from aqueous nitrate solutions as hydrated, solvated uranyl nitrate, $\mathrm{UO}_{2}\left(\mathrm{NO}_{3}\right)_{2}\left(\mathrm{H}_{2} \mathrm{O}\right)_{h} \mathrm{~s}_{\mathrm{r}_{1}}$. Under appropriate conditions, the hydrated, solvated trinitrate-uranyl complex may be extracted. The relationship between partition coefficlent and equilibrium constant for the extraction mechanism shows the extraction of the former species to be favored by large free nitrate and free solvent concentrations and by small water activity. Effect of nitric acid. The addition of nitric acid to the aqueous phase favors the extraction of uranium by preventing or decreasing the hydrolysis of uranyl ion and by increasing the nitrate ion concentration. 324 N1tric ac1d is extracted also by the organic solvents. Th1s requires 


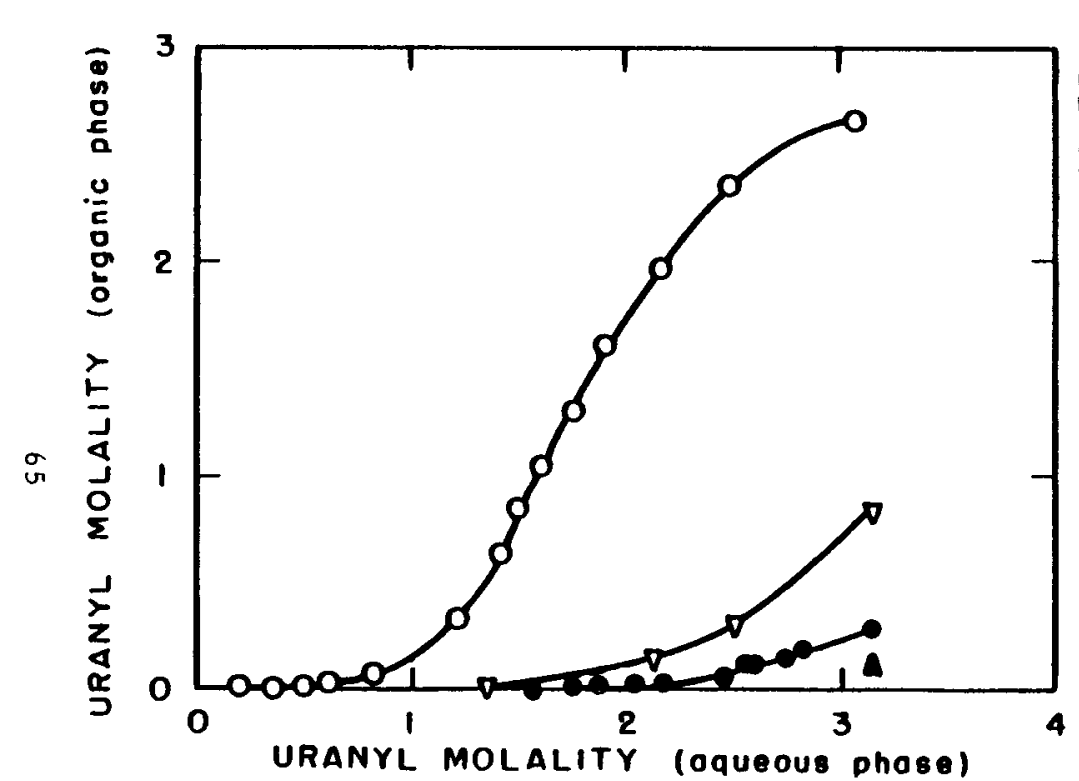

(A)

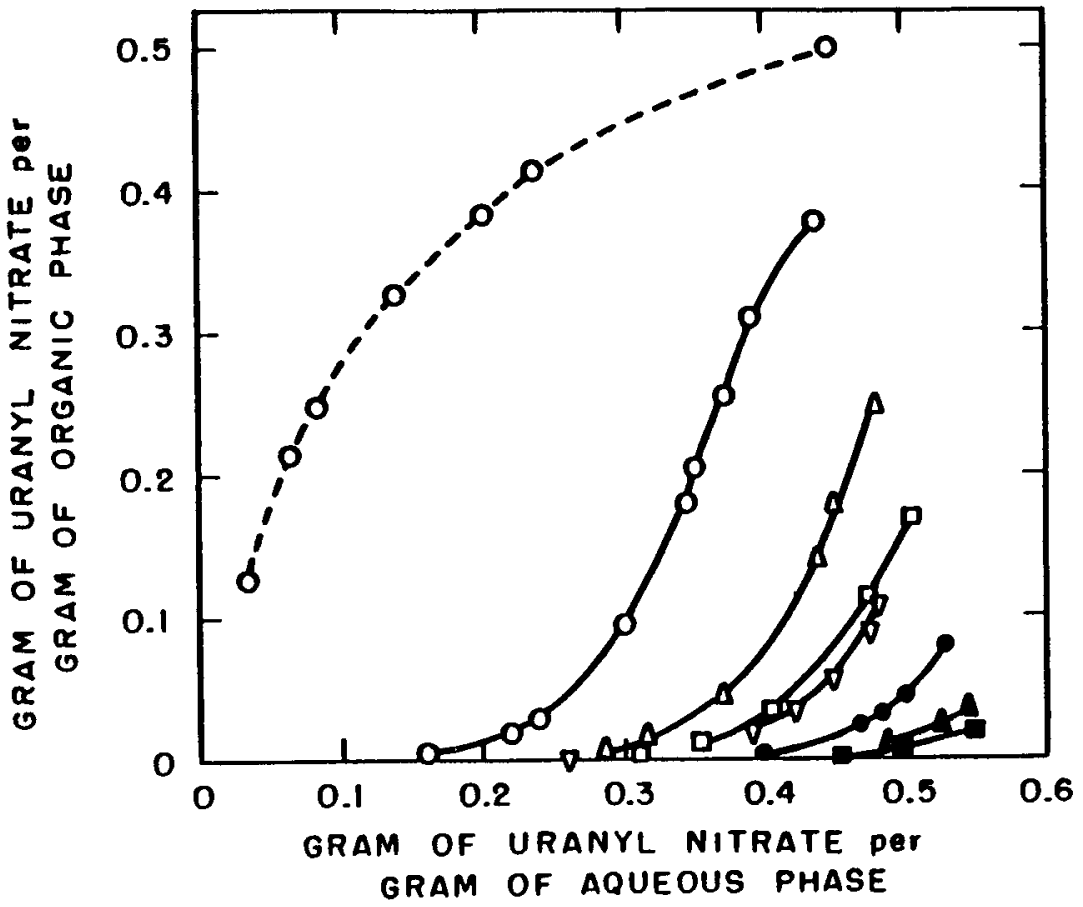

(B)

Figure 1. Partition of uranyl nitrate between water and simple ethers. ethyl-n-propyl ether. $\quad 0$, ethyl-n-butyl ether. $\nabla$, d1-1sopropyl ether.

O, diethyl ether. $\triangle$, d1-n-hexyl ether. $\quad$, $2,2^{\prime}$-dichlorethyl ether.

1-A. After E. Glueckauf, H. McKay, and A. Mathieson, reference 185 . Temperature, $25^{\circ} \mathrm{C}$ except for diethyl ether: first three points at $25^{\circ} \mathrm{C}$, last point at $20^{\circ} \mathrm{C}$, remainder at $18^{\circ} \mathrm{C}$.

$1-B$. After R. K. Warner, reference 321 . Dashed curve represents the partition of uranyl nitrate between diethyl ether and a saturated ammonium nitrate solution. Temperature, $20^{\circ} \mathrm{C}$. 


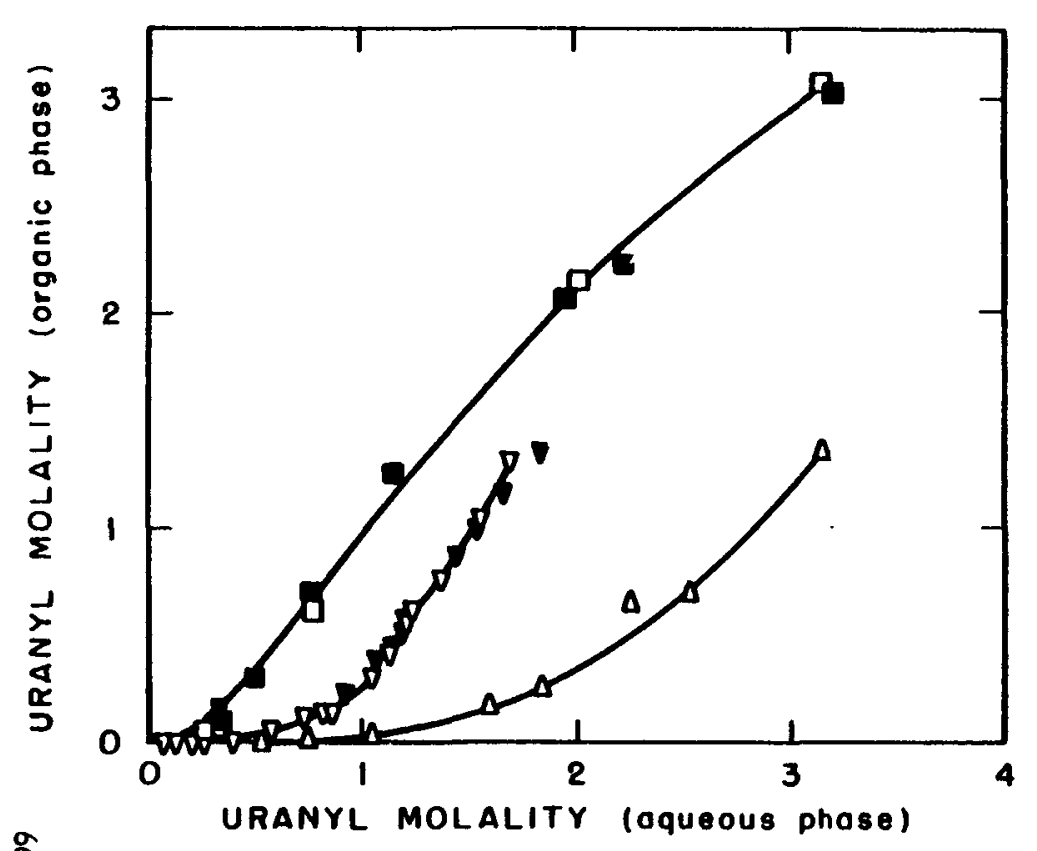

(A)

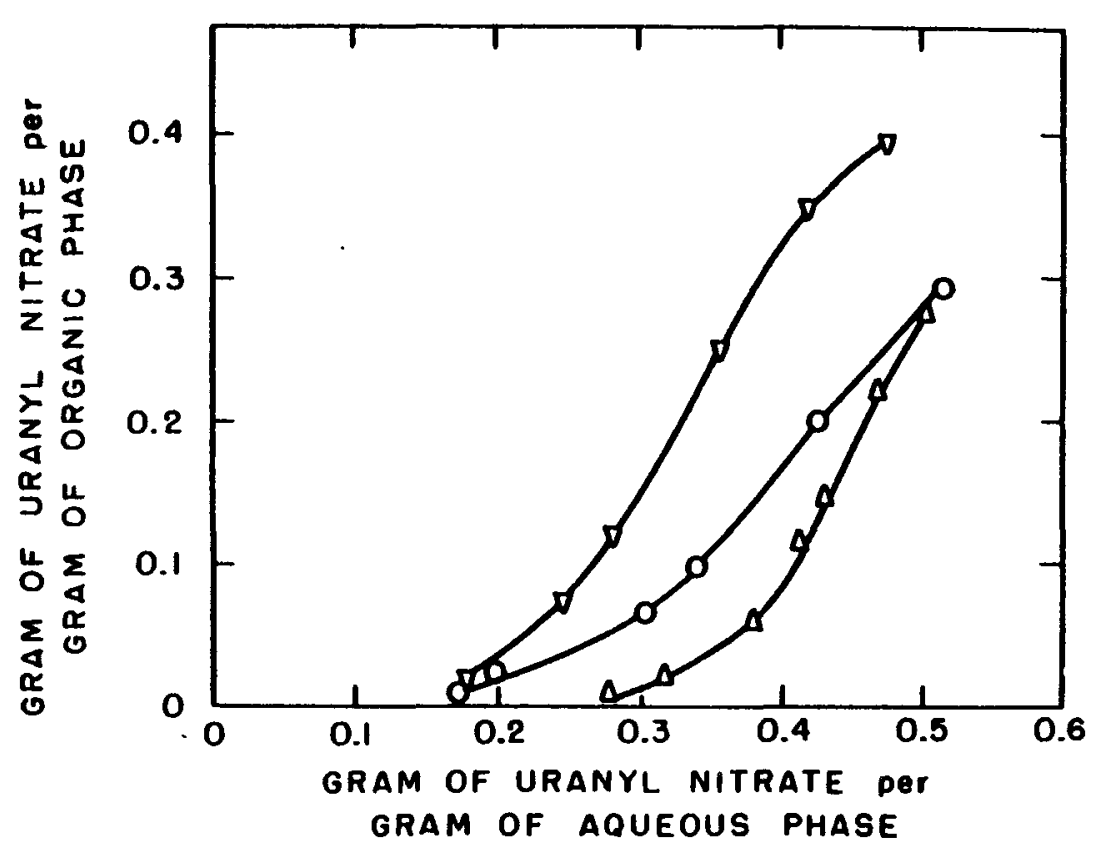

(B)

Flgure 2. Partition of uranyl nitrate between water and complex ethers. O, phenyl cellosolve. $\triangle$, dibutyl cellosolve. $\nabla, \nabla$, dibutyl carbitol. $a, 0$, pentaether.

2-A. Open symbols, after E. Gleuckauf, H. McKay, and A. Mathleson, reference 185 . Sol1d symbols, after A. Gardner, H. McKay, and D. Warren, reference 176 . Temperature, $25^{\circ} \mathrm{C}$.

2-B. After R. K. Warner, reference 321 . Temperature $20^{\circ} \mathrm{C}$. 


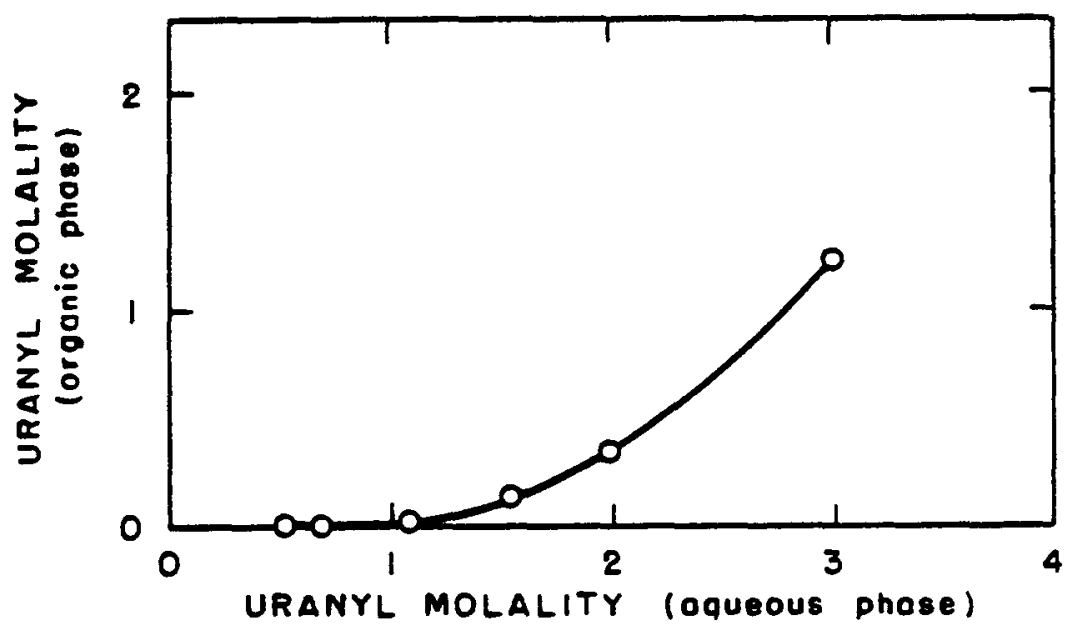

Figure 3-A. Partition of uranyl nitrate between water and isoamyi acetate. After E. Glueckauf, H. McKay, and A. Mathieson, reference i85. Temperature, $25^{\circ} \mathrm{C}$.

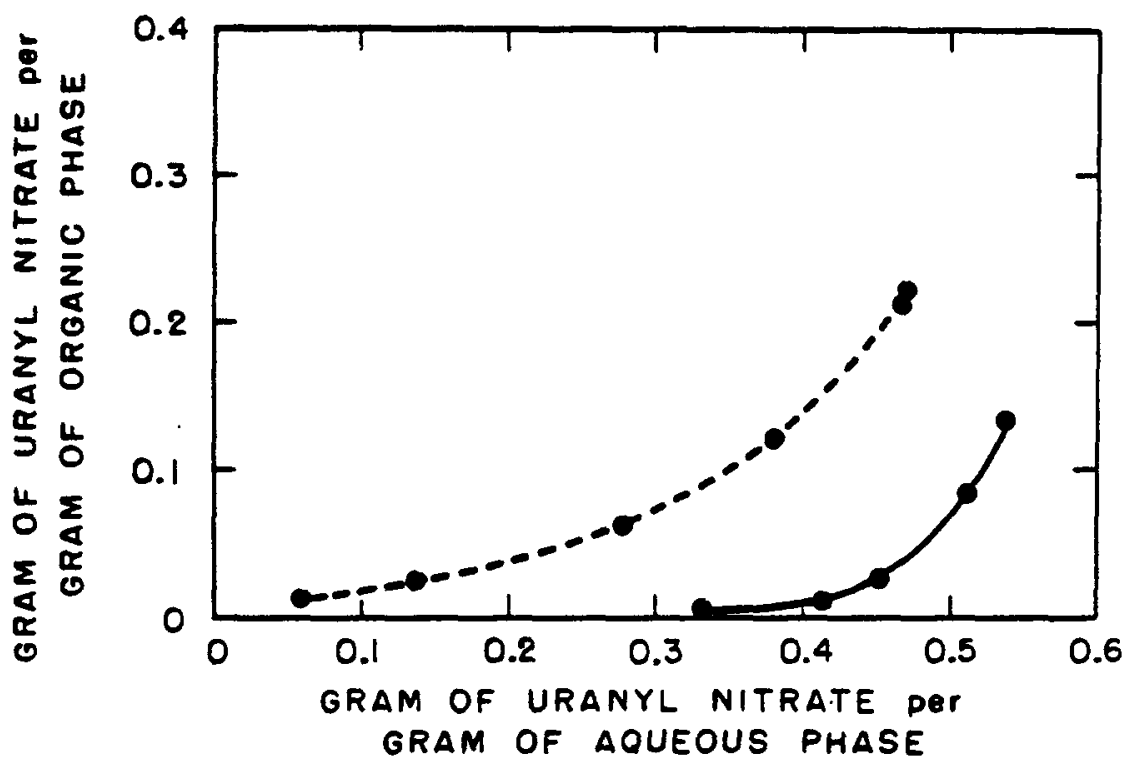

F1gure 3-B. Partition of uranyl nitrate between water and nitromethane and saturated ammonium nitrate (dashed curve) and n1tromethane. After R. K. Warner, reference 322. Temperature, $20^{\circ} \mathrm{C}$. 


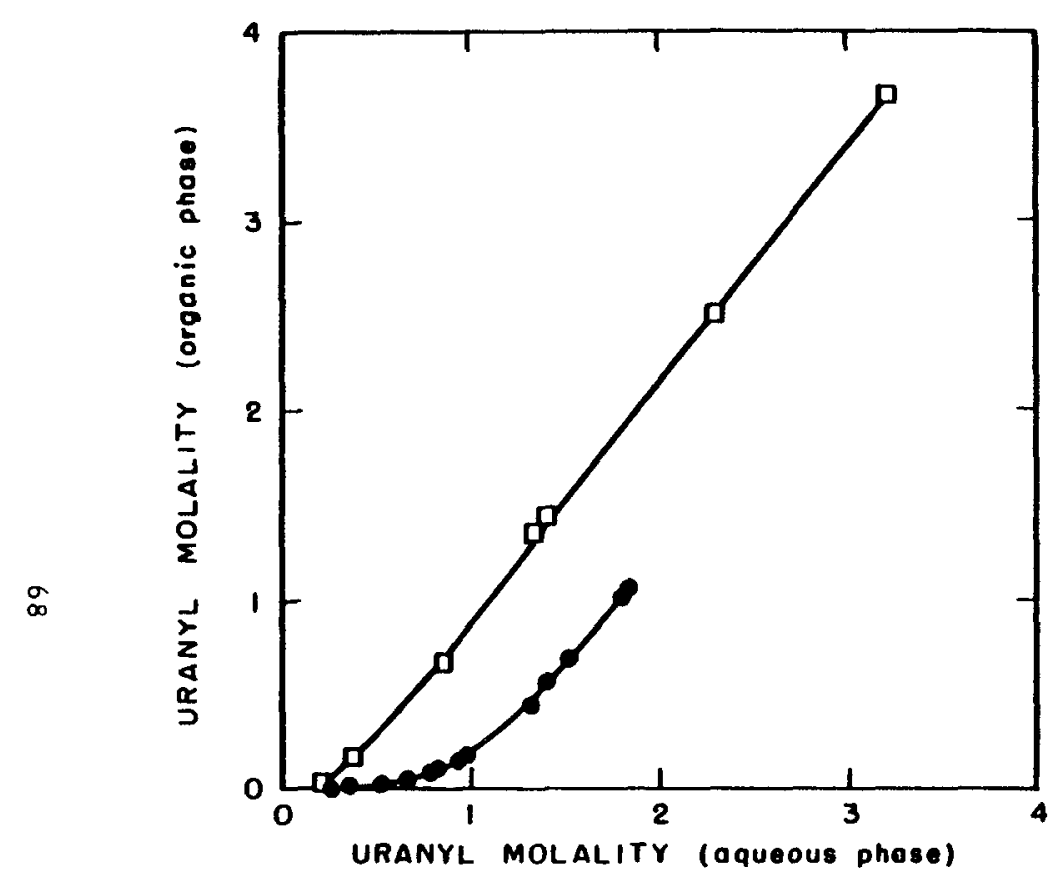

(A)

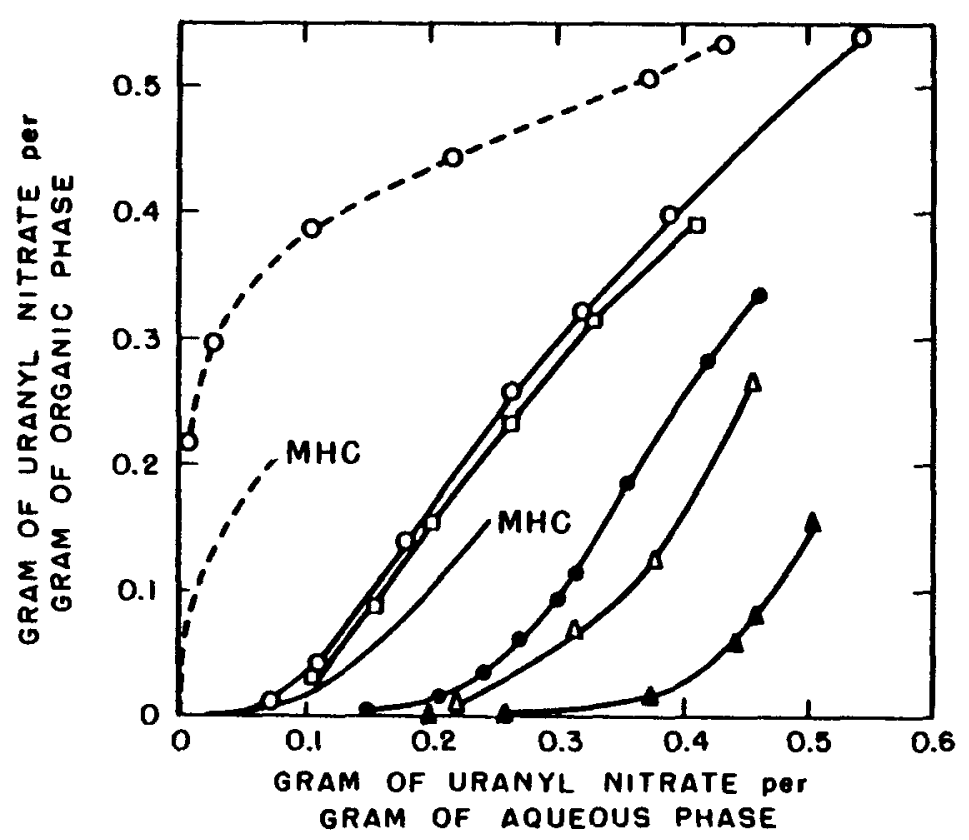

(B)

Figure 4. Partition of uranyl nitrate between water and ketones. O, methyl ethyl ketone. methyl isobutyl ketone. $\triangle$, methyl n-amyl ketone. $\Delta$, di-1sobutyl ketone. $\square$, cyclohexanone. MHC, methyl cyclohexanone.

4-A. After E. Glueckauf, H. McKay, and A. Mathleson, reference 185 . Temperature, $25^{\circ} \mathrm{C}$.

4-B. MHC curves, after V. Veselý, H. Beranová, J. Malý, reference 323 . Dashed curve--aqueous solution, $6 \mathrm{M}$ NH $4 \mathrm{NO}_{3}$. Remaining curves, after $\mathrm{R}$. K. Warner, reference 321 . Temperature, $20^{\circ} \mathrm{C}$. Dashed curvé--aqueous solution, saturated ammonium nitrate. 


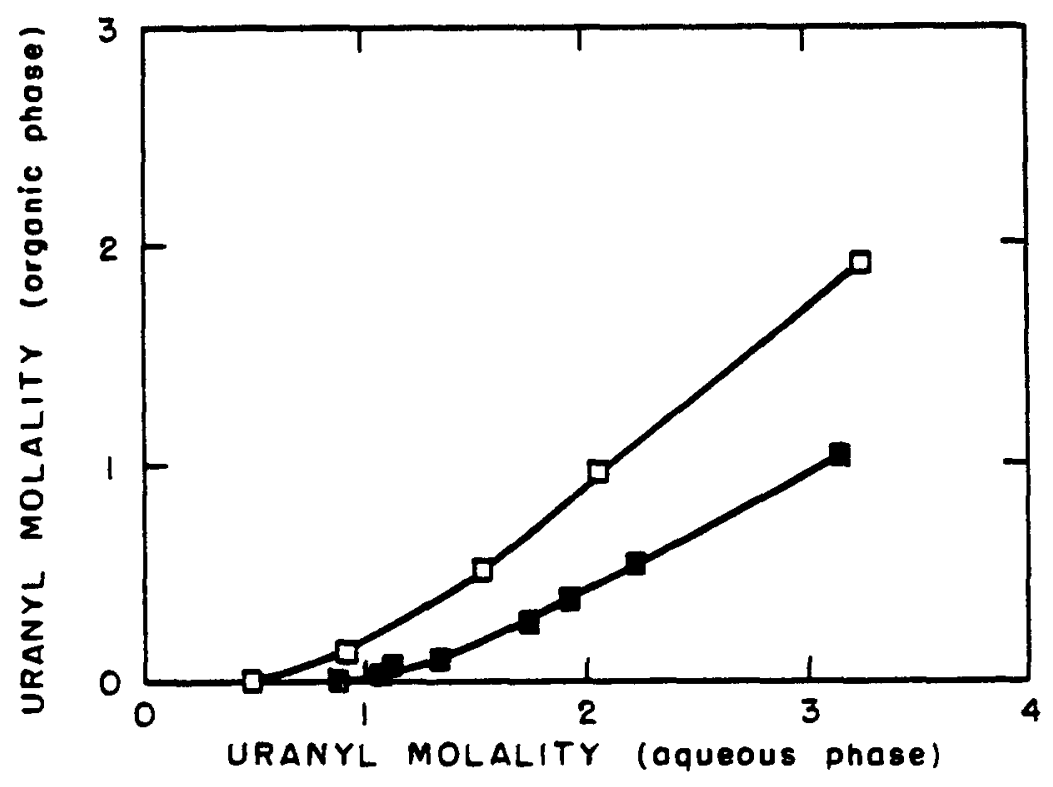

(A)

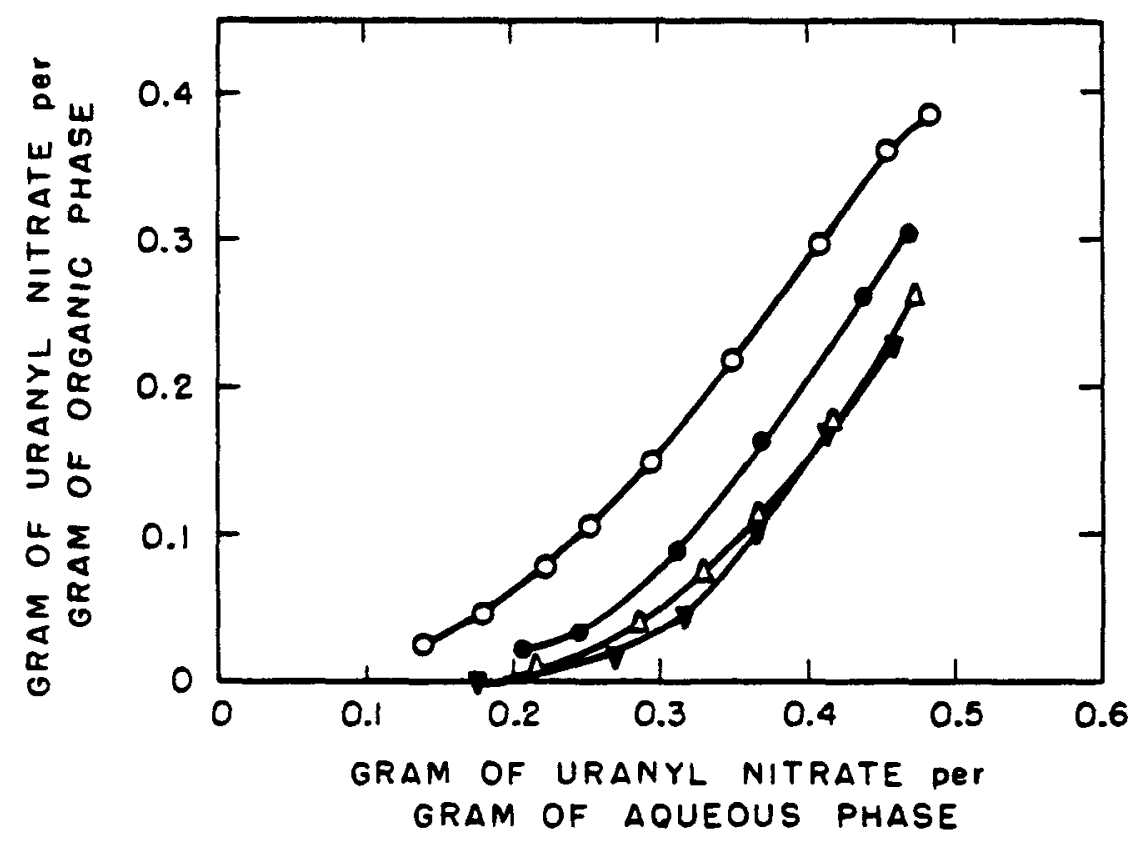

(B)

Figure 5. Partition of uranyl nitrate between water and alcohols. 0 , n-butanol. $\bullet$, n-pentanol. $\Delta$, n-hexanol. $\nabla$, methyl isobutyl carbinol. a, isoamyl alcohol. sec-octyl alcohol

5-A. After E. Glueckauf, H. McKay, and A. Mathieson, reference 185. Temperature, $25^{\circ} \mathrm{C}$.

5-B. After R. K. Warner, reference 321. Temperature, $20^{\circ} \mathrm{C}$. 
that it be replaced in continuous or multicontact extraction process. Large concentrations of nitric ac1d are generally not desirable. The formation of $\mathrm{HNO}_{3} \cdot \mathrm{S}_{n}$ complexes reduces the amount of free solvent, the extraction of other elements is enhanced, and the danger of an explosive reaction between solvent and ac1d is increased. The formation of $\mathrm{HM}\left(\mathrm{NO}_{3}\right) \mathrm{x}+1$ specles, which may be more easily extracted than $\mathrm{M}\left(\mathrm{NO}_{3}\right) \mathrm{x}$, is promoted by the addition of nitric acid. For uranium, however, the formation of the trinitrate-uranyl complex is far from complete, even in $16 \mathrm{M} \mathrm{HNO}_{3} .78$

Effect of nitrate salts. The nitrate ion concentration may be increased by the addition of metal nitrates of significant solubility to the aqueous phase. This not only promotes the extraction of uranium but also the extraction of other elements whose nitrates are soluble in the organic solvent. In some cases, nitrates which serve as salting-out agents, eg. thorium may also be extracted in signiflcant amounts. The extraction of other salting-out agents, eg., ceslum, may be enhanced by the rormation of uranyl trinitrate complexes, $\mathrm{MUO}_{2}\left(\mathrm{NO}_{3}\right)_{3} \cdot \frac{325}{2}$ The ability of various nitrates to salt-out uranium has been related to the hydration of the cation, $\frac{326}{6}$ the activity coefficient of the pure nitrate salt, $\underline{327}$ and the radius and charge of the cation. $\frac{328}{A}$ salting-out agent which is highly hydrated fac1litates extraction of uranium by reducing the water act1vity. In flgure 6 , the partition coefficient of uranium is plotted as a function of aluminum nitrate for several solvents. The partition of uranium between saturated ammonium nitrate solutions and diethyl ether, nitromethane, and methyl ethyl ketone is shown by the dashed curves in figures $1 \mathrm{~B}, 3 \mathrm{~B}$, and $4 \mathrm{~B}$, respectively. $\underline{321,322}$ Ammonium nitrate is widely used as a salting agent in spite of 1ts relatively poor salting-out ability. The ease with which it is removed from solution or from heated samples 


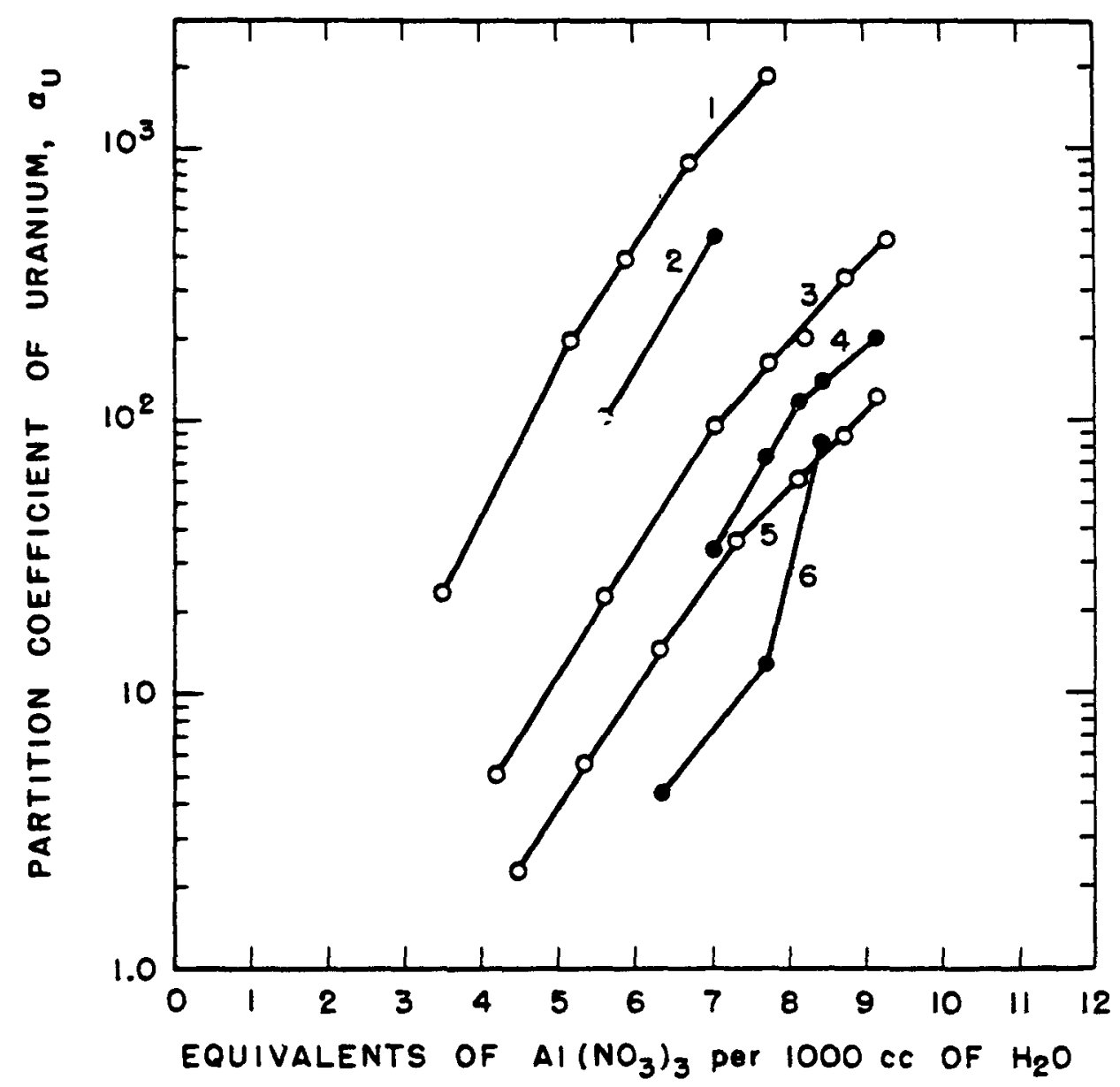

F1gure 6. Effect of aiuminum nitrate as salting-out agent on the extraction of uranium by various solvents.

Curve l, dibutoxytetraethylene glycol (pentaether); Curve 2 , dibutoxytrlethylene glycol; Curve 3, dibutoxydiethylene glycol (dibutyl carb1tol); Curve 4, methyl 1sobutyl ketone (hexone); Curve 5, diethyl ether; and curve 6, dibutylmonoethylene glycol (dibutyl cellosoive).

Data adapted from $E$. Evers and $C$. Kraus, reference 332.

Conditions: Aqueous phase -2.0 to 6.0 grams of $U$ per $100 \mathrm{cc}$ of solution containing aluminum nitrate. Organic phase - solvent represented by curve. Equal phase volumes* equilibrated at $27^{\circ} \mathrm{C}$.

*Equal or approximately equal phase volumes were employed in alstribution experiments w1th dibutyl carb1tol (C. A. Kraus, A-2322(1945)) and with hexone (C. A. Kraus, A-2324(1945)). It is assumed that the same volume rat10 was used for other experiments. 
makes 1ts use advantageous.

The presence of nitrate salts which are suffictently soluble in the organic solvent facilitates the extraction of uranium by formation of the trinitratouranyl complex, $\mathrm{RUO}_{2}\left(\mathrm{NO}_{3}\right)_{3} \cdot \frac{78}{}$ Th1s 1 is discussed further under "Hexone." Effect of other salts. Anlons that complex uranium In the aqueous phase may seriously interfere with the extraction of the latter. Chlorlde, fluoride, sulfate, phosphate, and several organic anions have been studied for the1r interference. The adverse effects of these 1ons may be minimized by removing them from solution prior to uranium extraction, by complexing the anions with cations of saltingout agents, or by using an excess of an efflclent saltingout agent to over-ride the anion interference. The 1norganic anfons may be precipltated as silver chloride, lanthanum fluoride, barlum sulfate, zircontum phosphate, or ammonium phosphomolybdate. Fluoride ion is complexed by aluminum and calclum. Sulfate ion 1 s complexed by ferric lon. Large amounts of sulfate ion are also preclpitated by calclum nitrate. Phosphate ion is complexed by ferric and aluminum 1ons. Calclum nitrate has been used to counteract the effect of acetate and oxalate. The effect of chloride on the partition of uranium may be reduced in the presence of a strong salting-out agent. Chloride ion is more objectionable from the fact that 1 promotes the extraction of other eiements, notably iron. In the presence of large amounts of interfering Ions, particularly sulfate and phosphate, it is advisable to separate the uranium from solution prior to extraction. This may be done by precipitation with carbonate-free ammonium hydroxide. The precipltate is dissolved in nitric acid and the extraction 1s inltiated. Ferric hydroxide may be used to carry trace amounts of uranium.

Uranium may be extracted from aqueous media other than 
nitrate. Thiocyanate solutions have been found satisfactory. The extraction, nowever, is less selective from thiocyanate than from nitrate solutions.

Solvent action. The partition of uranyl nitrate is dependent upon the free solvent concentration. This is reflected in the coefficients of extraction of micro and macro amounts of uranium from highly salted aqueous solutions. The partition coefficient of trace amounts is larger than that of large amounts as a result of more avallable solvent. As mentioned previously, macro amounts of uranium extract more readily from water solutions or less highly salted aqueous solutions than do micro amounts. Thls effect may be attributed to the salting-out ablifty of uranyl nitrate 1tself.

The extraction of other elements is affected also by the uranium concentration. High loading of the solvent by uranium reduces the extraction of less preferred complex specles. High uranium loading may be achieved by diluting the solvent with a secondary solvent in which uranyl nitrate is insoluble or significantly less soluble than in the primary extractant. Solvent dilution, in general, causes a decrease In the partition coefficient. $319,321,329,330$ wohlhuter and Sauteron 331 nave listed a number of aromatic and chlorinesubstituted diluents in order of increasing harmfulness to uranlum extraction: benzene, toluene, xylene, carbon tetrachloride and dichloroethylene, chloroform. Solvent dilution may be used also to Improve upon the physical properties of the organic phase, eg., density, viscosity, etc.

The sultability of mixtures of oxygen-containing solvents as extractants for uranyl nitrate has been studied. $318-320,329,330$ stover and co-workers 320 reported that none of the mixtures they investigated were better than the pure solvent. Recently, however, Fomin and Morgunov $\frac{329}{2}$ 
and Vdovenko and Krivokhatsk11 $\frac{330}{2}$ have reported enhanced uranyl nitrate partition coefficients from solvent mixtures. Vdovenko and Krivokhatsk11 report that over ten such mixtures have been found. Among them are: di-1sopropyl ether and $B, B^{\prime}-$ dichlorodiethyl ether, dibutyl ether and $\beta, \beta^{\prime}$-dichlorodiethyl ether, diethyl ether and acetophenone, isoamyl alcohol and methyl isobutyl ketone. The enhanced extraction by solvent mixtures has been attributed to the formation of mixed solvates of uranyl nitrate. $\frac{329,330}{2}$

Effect of temperature. The extraction of uranyl nitrate is decreased by a temperature increase. The partition coefficlent of uranium is plotted as a function of temperature for several solvents in flgure $7 . \underline{32}$

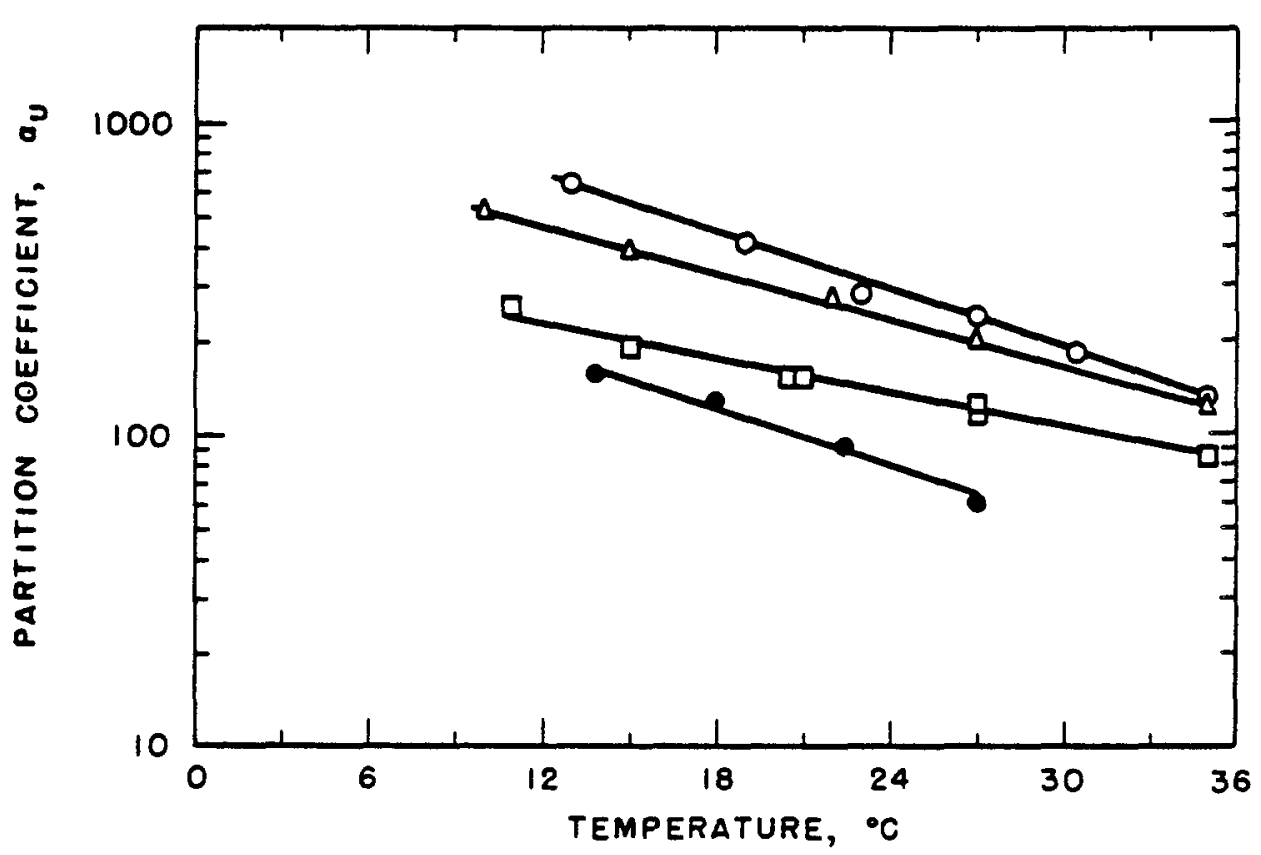

F1gure 7. The effect of temperature on the extraction of uranium by organic solvents. 0 , dibutyl carb1tol. $\square$, hexone. $\bullet$, diethyl ether. $\triangle$, pentaether.

After E. C. Evers and C. A. Kraus, reference 332 .

The triangles represent aqueous solutions salted with 36.6 grams of $\mathrm{Al}\left(\mathrm{NO}_{3}\right)_{3}$ per $100 \mathrm{cc}$ of water. $\mathrm{All}$ other symbols represent solutions salted with 58 grams of $\mathrm{Ai}\left(\mathrm{NO}_{3}\right)_{3}$ per $100 \mathrm{cc}$ of water. 2 to 6 grams of uranium per $100 \mathrm{cc}$ of solution were extracted. 
Re-extraction. Uranium is re-extracted from the organic solvents considered in this section by contact with water. Several water contacts may be required if large amounts of uranium or nitric acid have been extracted. Watersoluble salts whose anions complex uranyl ion, eg., ammonlum sulfate, facilitate re-extraction.

\section{Extraction of other elements. A number of elements} other than uranium are extracted by oxygen-containing solvents. Those commonly found with Irradiated uranium are hexavalent Np and $\mathrm{Pu}^{*}$; pentavalent $\mathrm{Pa}$; tetravalent $\mathrm{Th}, \mathrm{Np}$, $\mathrm{Pu}, \mathrm{Zr}(+\mathrm{Nb})$, and $\mathrm{Ce}$; and ruthentum complexes. Neptunium, plutonium, and cerlum are made less extractable by reduction to lower oxidation states. Favorable separation of uranium from the other elements may be achleved by control of the nitric acid and salting-out agent concentrations. Free halogens are extracted. These elements may be eliminated from solution prior to uranium extraction. The halogens also combine chemically with a number of solvents; eg," lodine and hexone. The comblned halogen is not re-extracted by water contacts.

General survey. The extraction of uranyl nitrate by polar oxygen-contalning solvents has been investigated under a varlety of conditions. The results of three surveys $\frac{318-320}{3}$ In which the experimental conditions were ali different, are given in Table VIII.

\footnotetext{
* Am(VI) forms an extractable nitrate. Strong oxidizing conditions are necessary, however, for americlum to be . present in the (VI)-state. It is geneially found in solution as Am(III).
} 


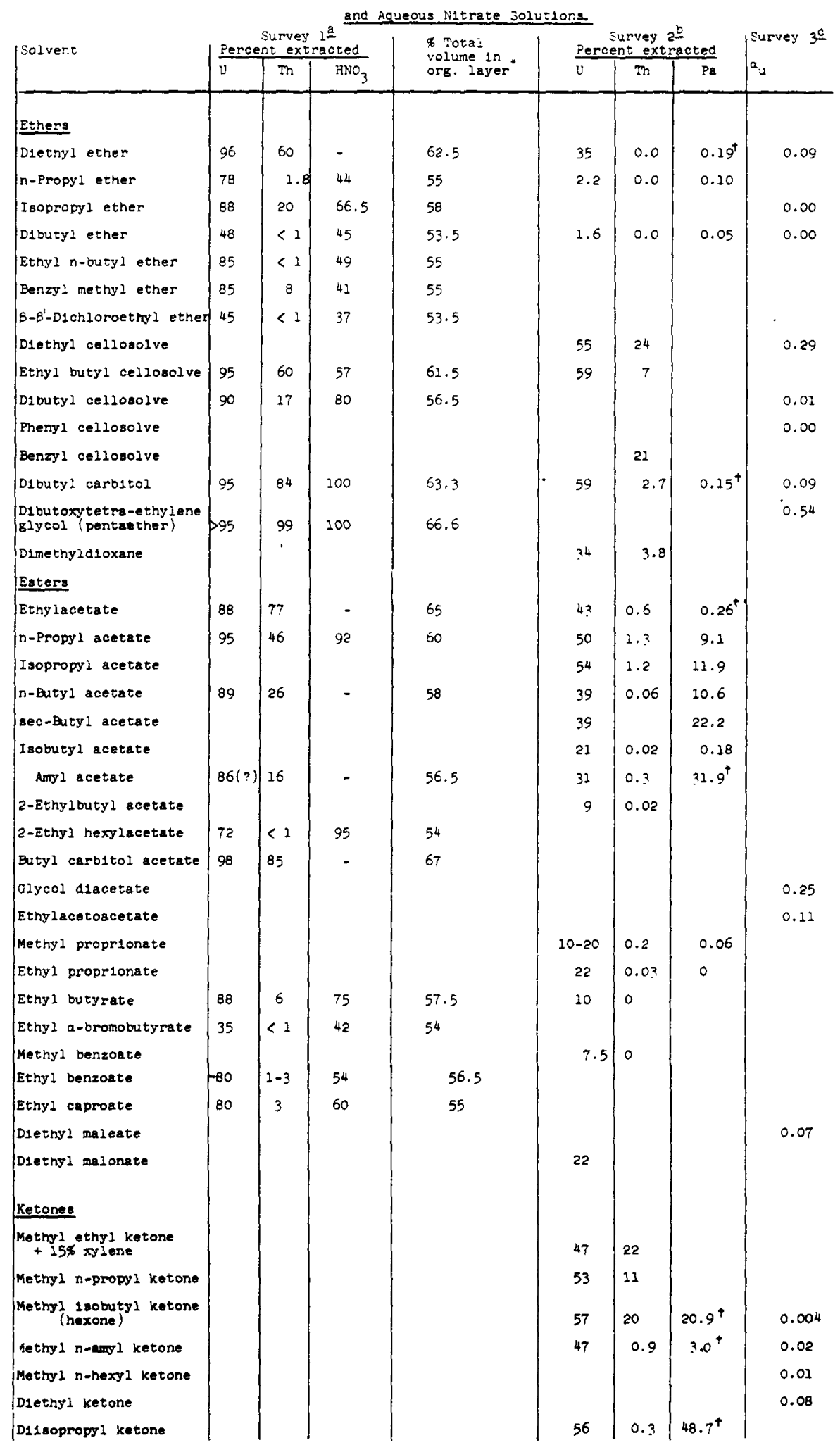




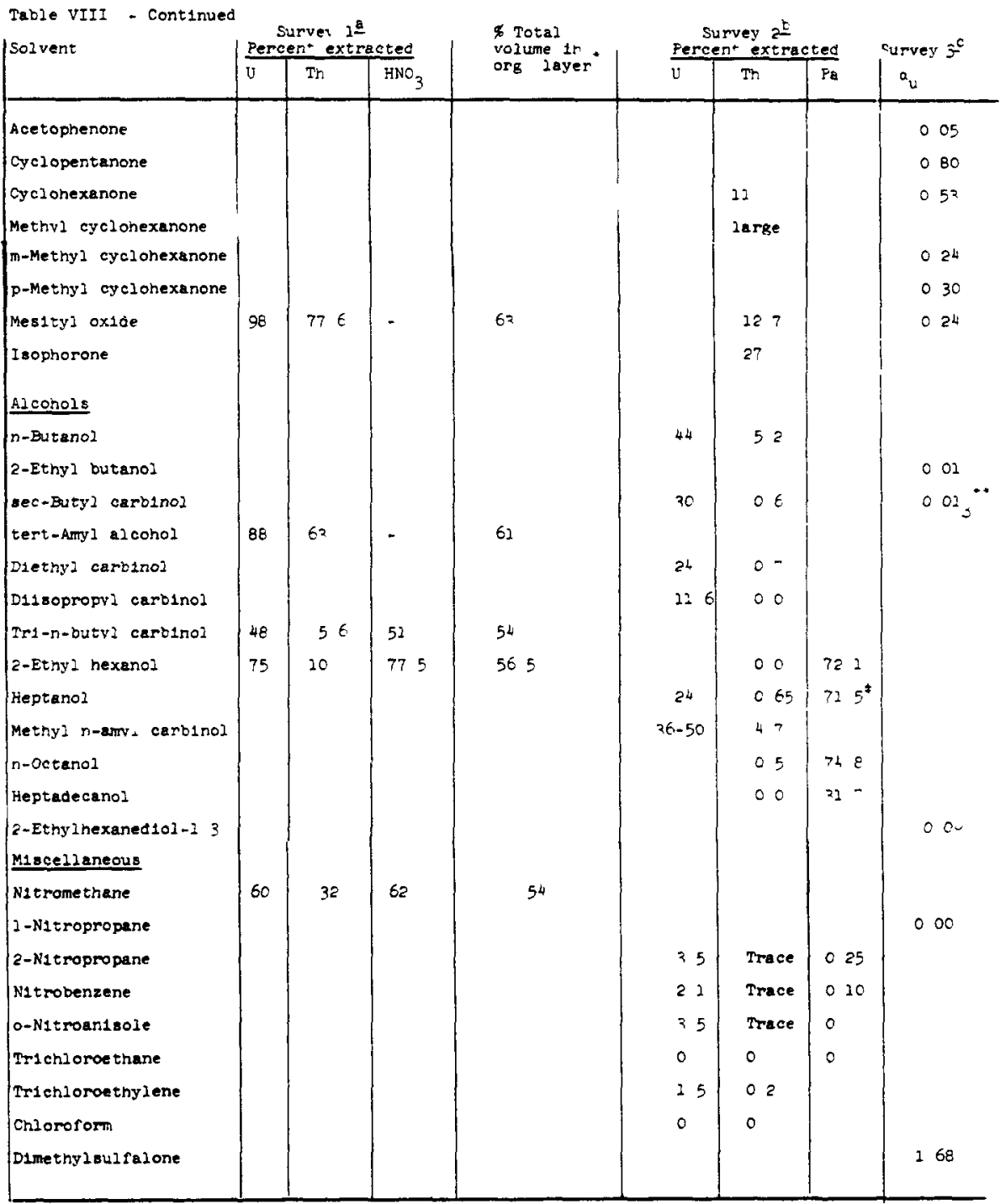

I $C$ A Johnson and $A$ S Newton, reference $31 E$

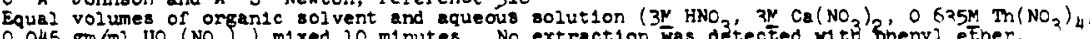
p-bromoanisole? p-bromophenetol, anisole, lsoamyl nitrite, chlorobenzene, xylene, ethyl 1odide, butyl bromide, and trichloroethylene

- Indicates mutual solubility or aqueous solution and organic aolvent

$\underline{E} K$ Hyde and $M \quad J$ Wolf, reference 329

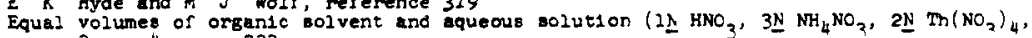
$5 \times 10^{3}-10^{4} \mathrm{c} /$ mis. $U^{233}$ at $52 \%$ counting yield) mixed 5 minutes

- Aqueous phase $2 \mathrm{~N} \mathrm{HNO}_{3}, 2 \mathrm{~N} \mathrm{Nh}_{4} \mathrm{NO}_{3}, 2 \mathrm{~N} \operatorname{Tr}\left(\mathrm{NO}_{3}\right)_{4}, 10^{4}-3 \times 10^{5} \mathrm{c} / \mathrm{m} \mathrm{Pa}$ a 3 at $10 \%$ counting yield

4 Aqueou phase $1 \mathrm{~N} \mathrm{HNO}_{3}, 2 \mathrm{~N} \mathrm{Al}\left(\mathrm{NO}_{3}\right)_{3}, 3 \mathrm{~N} \mathrm{Tm}\left(\mathrm{NO}_{3}\right)_{4}, 10^{4}-3 \times 10^{5} \mathrm{c} / \mathrm{m} \mathrm{Pa}^{223}$ at $30 \%$ countins yield

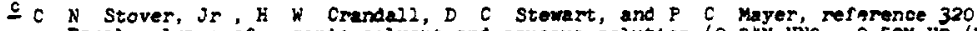

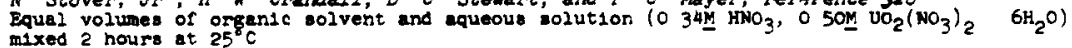

- Solvent ident1fled as methyl loobutyl carbinol, formula $\mathrm{G}$ iven as $\left.\mathrm{CH}_{3} \mathrm{CH}_{2} \mathrm{CH}_{(\mathrm{CH}}\right) \mathrm{CH}_{2} \mathrm{OH}$ (nee-butyl carbinol). 
ETHERS

\section{Diethyl ether}

Agueous n1trate systems. The extraction of uranyl nitrate by diethyl ether is widely used in radiochemical separations because of the selectivity of the extraction. Disadvantages of the method are the high volatility and low flash point of the solvent and the relatively low distribution of uranium into the solvent.

The partition of uranyl nitrate between diethyl ether and water is 1llustrated in figure $1 . \underline{185,321}$ with both phases saturated with uranyl nitrate at $25-26^{\circ} \mathrm{C}$, the distribution coefficient is about $0.68 . \underline{326}$ The effect of nitric ac1d upon the partition of uranium $\frac{333,334}{3}$ and nitric acid $\frac{326}{\text {, }}$ 333-335 1tself is represented in figure 8. Furman, Mundy, and Morrison 326 report that the $\mathrm{pH}$ of the aqueous phase should be 4 or less for complete extraction of uranium to occur. The influence of ammonlum nitrate and calclum nitrate upon the extraction of nitric acid is also shown in figure $8 . \underline{326}$

Figures 9 and 10 demonstrate the influence of varlous salting-out agents on the distribution of urany nitrate. $\frac{326,328}{3}$ The nitrate concentration plotted in figure 9 includes that of the salting-out agent plus that of uranyl nitrate left after extraction by an equal volume of ether. The latter contributes only a few percent to the total nitrate concentration in most cases. A notable exception is the 1ron (III) point at 1.18M nitrate concentration. In this instance, $0.82 \mathrm{M}$ nitrate ion is attributable to ferric nitrate and the remainder to uranyl nitrate. The nitrate concentration of the salting-out agent is plotted in figure 10. Urany nitrate contributes little to the nitrate concentration since only one gram of uranyl nitrate was used per 100 grams of initial aqueous solution. Furman, Mundy, and Morrison 326 


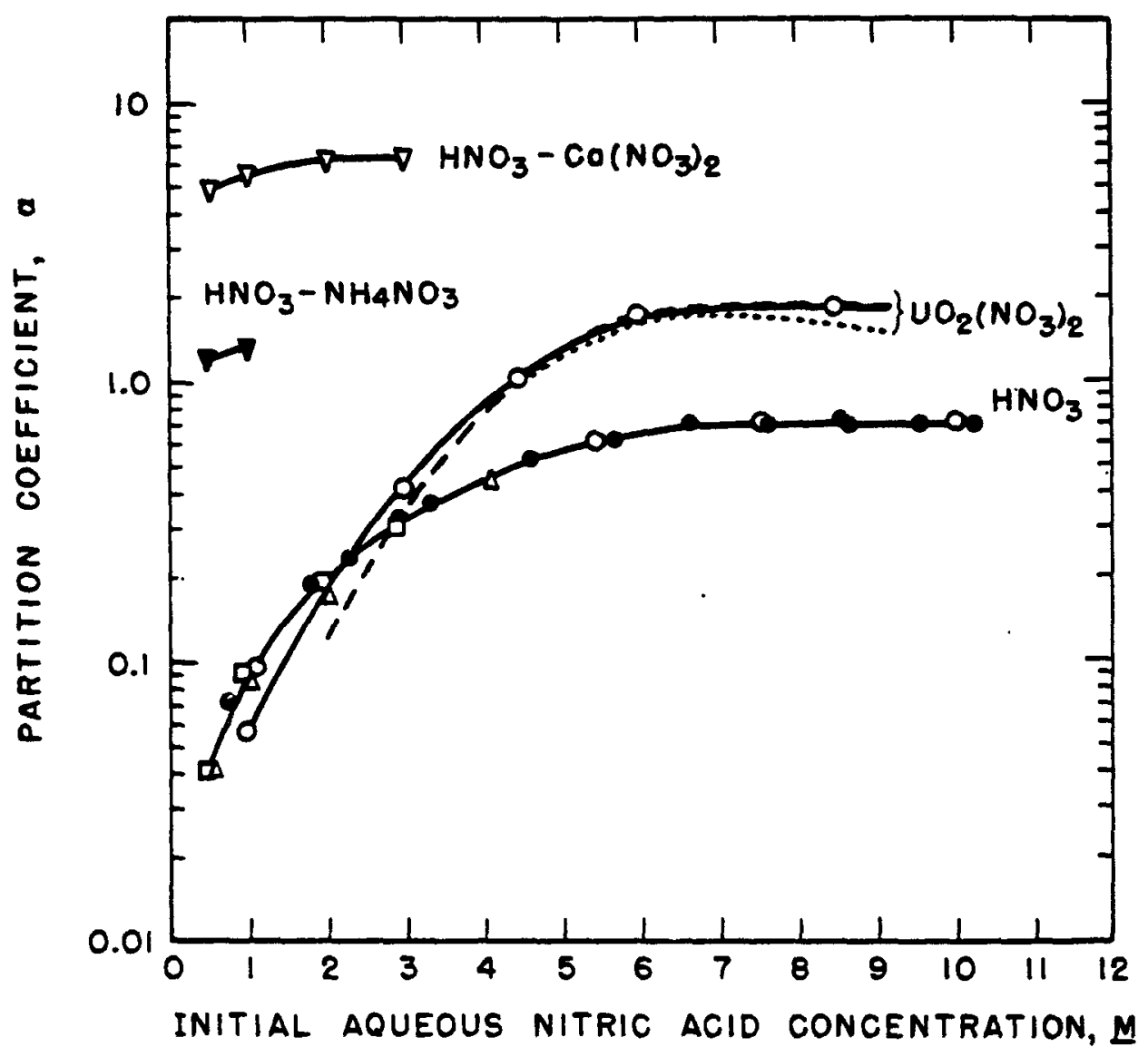

Figure 8. The extraction of uranyl nitrate and nitric acid by diethyl ether.

Uranyl nitrate extraction:

$O$, after $R$. Bock and $E$. Bock, reference 333. In1tial U concentration, $0.1 \mathrm{M}$; Temperature, $20^{\circ} \pm 1{ }^{\circ} \mathrm{C} ; \mathrm{V}_{0} / \mathrm{V}_{\mathrm{a}}=1$. Dashed and dotted curves, affter J. Koo1, refereñce 334 . Temperature, $25^{\circ} \mathrm{C} ; \mathrm{V}_{\mathrm{O}} / \mathrm{N}_{\mathrm{a}}=1$; Init1al U concentration, ........... (hexahydrate) per $15 \mathrm{ml} ; \ldots \ldots \ldots \ldots .350 \mathrm{mg}$ uranyl nitrate (hexahy drate) per $15 \mathrm{ml}$.

Nitric acid extraction:

$O$, after R. Bock and $E$. Bock, reference 333. Temperature, $19^{\circ} \pm$ $10 \mathrm{C} ; \mathrm{V}_{0} / \mathrm{V}_{\mathrm{a}}=1.0$, after J. Koo1, reference 334 . Temperature, $25.0 \pm 0.10 \mathrm{C} ; \mathrm{V}_{\mathrm{O}} / \mathrm{V}_{\mathrm{a}}=1$. $\mathrm{a}$, after A. Grinberg and G. Lozhkina, reference 335 . Temperature, $200^{\circ} \mathrm{C} ; \mathrm{v}_{0} / \mathrm{v}_{\mathrm{a}}=1 . \Delta, \nabla, \nabla$, after $N$. Furman, $R$. Mundy, and $G$. Morrison, reference $V_{0} / V_{a}=1 ; \mathrm{HNO}_{3}$ $\mathrm{Ca}\left(\mathrm{NO}_{3}\right)_{2}, 100 \mathrm{~g}$. of $\mathrm{Ca}\left(\mathrm{NO}_{3}\right)_{2}$. $4 \mathrm{H}_{2} \mathrm{O}$ per $100 \mathrm{ml}$ of initial solution plus $\mathrm{HNO}_{3}$; $\mathrm{HNO}_{3}-\mathrm{NH}_{4} \mathrm{NO}_{3}$, $80 \mathrm{~g}$. of $\mathrm{NH}_{4} \mathrm{NO}_{3}$ per $100 \mathrm{ml}$ of indtial solution plus $\mathrm{FNO}_{3}$. 


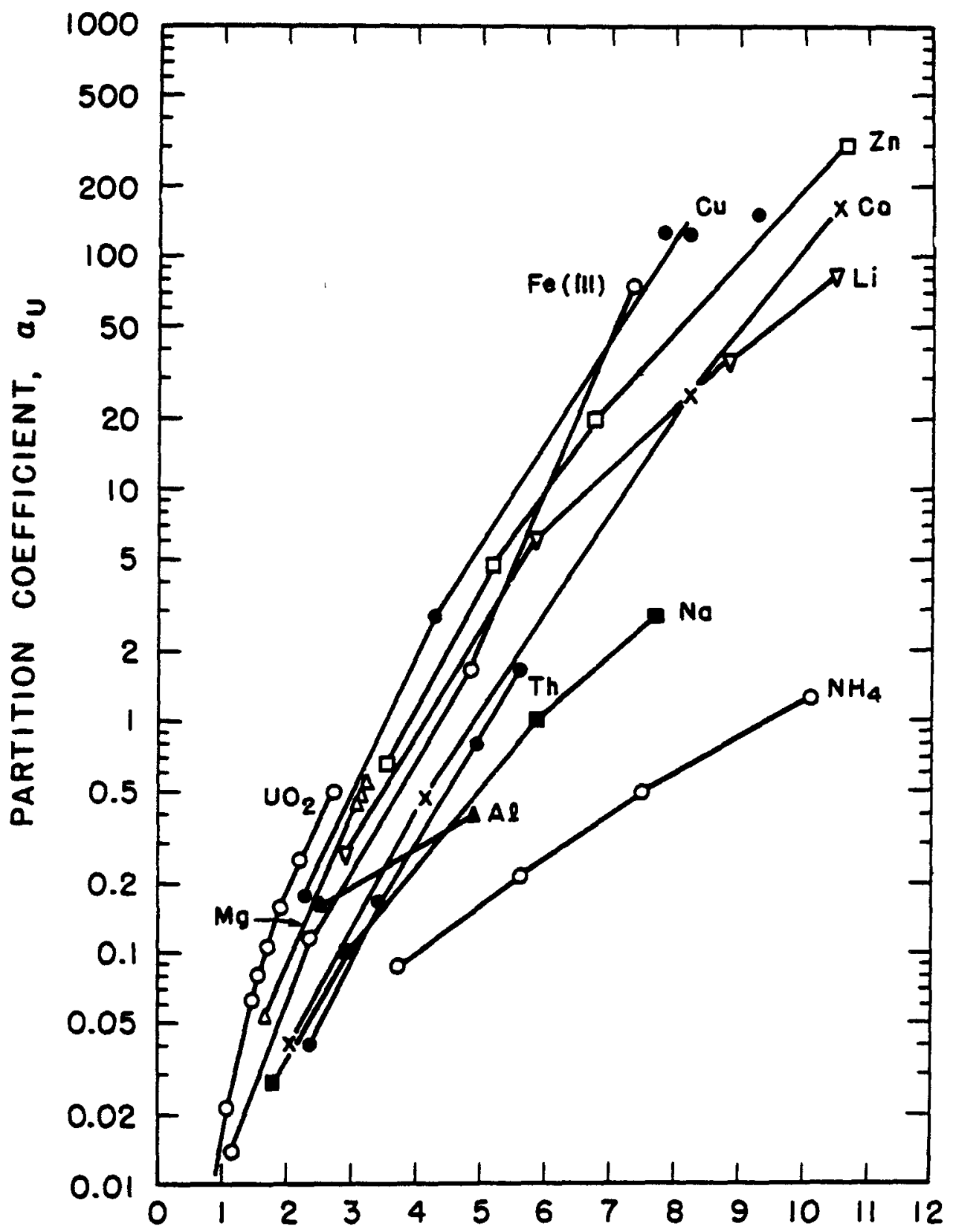

NITRATE CONCENTRATION OF AQUEOUS PHASE, $M$

(See facing page for legend.) 
Figure 9.

Effect of various nitrates upon the partition coefficient of uranium with diethyl ether.

After N. Furman, R. Mundy, and G. Morrison, reference 326.

The nitrate concentration plotted as the abscissa includes that attributable to the equilibrium concentrations of uranyl nitrate in addition to that of the 1nitial concentration of salting-out agent.

Conditions :

$\begin{array}{lccc}\text { Salting-out Agent } & {[\mathrm{U}], \mathrm{g} / \mathrm{T}} & \mathrm{T}{ }^{\circ} \mathrm{C} & \mathrm{V}_{0} / \mathrm{Na} \\ \mathrm{NH}_{4} \mathrm{NO}_{3} & 25 & 25-6 & 1 \\ \mathrm{NaNO}_{3} & (25) & 24-6 & 1 \\ \mathrm{LINO} & (25) & & 1 \\ \mathrm{Ca}\left(\mathrm{NO}_{3}\right)_{2} & (25-100) & 25-29 & 1 \\ \mathrm{Mg}\left(\mathrm{NO}_{3}\right)_{2} & (25-100) & 27-28 & 1 \\ \mathrm{Zn}\left(\mathrm{NO}_{3}\right)_{2} & (50) & 28-31 & 1 \\ \mathrm{Cu}\left(\mathrm{NO}_{3}\right)_{2} & (-8->600) & & \\ \mathrm{Fe}\left(\mathrm{NO}_{3}\right)_{3} & (-8->200) & & 1 \\ \mathrm{Al}\left(\mathrm{NO}_{3}\right)_{3} & (25-100) & 29 & 1 \\ \operatorname{Tr}\left(\mathrm{NO}_{3}\right)_{4} & (50) & & 1\end{array}$

The uranium concentrations in parentheses have been estimated by roughly adding the equilibrium uranium concentrations of both aqueous and solvent phase. 


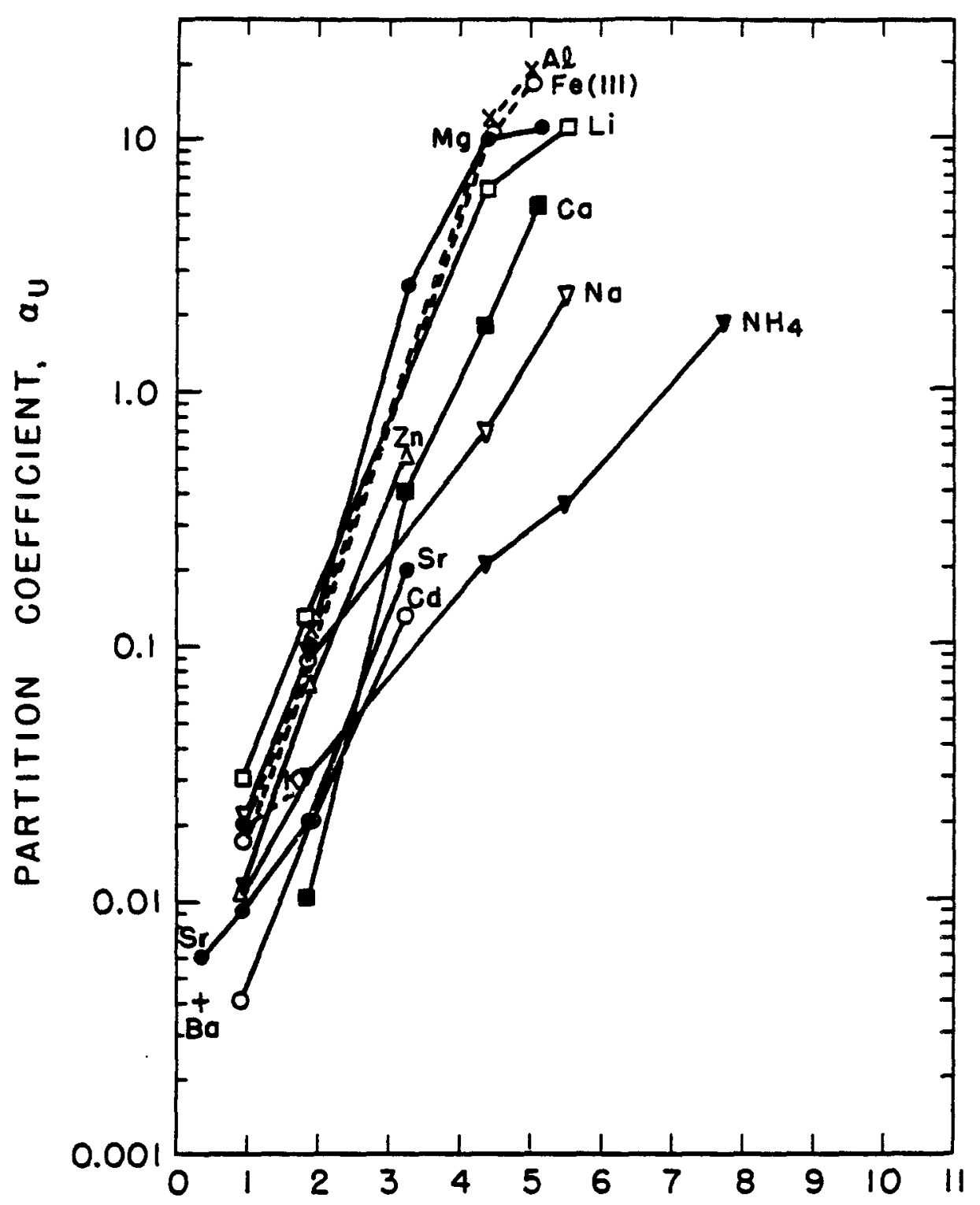

GRAM EQUIVALENTS OF NITRATE per $1000 \mathrm{~g}$ OF INITIAL AQUEOUS SOLUTION

F1gure 10. Effect of various nitrates upon the partition coefficlent of uranlum with diethyl ether.

After V. Vdovenko and T. V. Kovaleva, reference 328 .

Conditions: I g. $\mathrm{UO}_{2}\left(\mathrm{NO}_{3}\right)_{2}$ in $100 \mathrm{~g}$. of initial aqueous solutions;

Temperature, $25^{\circ} \mathrm{C}$; and $\mathrm{V}_{0} / \mathrm{V}_{\mathrm{a}}=1$. 
observed that the salting action of a mixture of nitrates could be reasonably predicted by the following method:

The logarlthm of a for each salt at a given total nitrate molarity 1 divided by the total nitrate molarity. These individual quotients are then multiplied by the nitrate molarity of the respective salts. The sum of the resulting products is then equal to the logarithm of the predicted partition coefficient.

Helimen and Wolf $\frac{336}{3 a v e}$ studied the salting action of various nitrates in the presence of nitric acid and thorium nitrate. Some of their results are listed in Table IX. From the data 1 may be observed that (I) thorium nitrate Is generally a less effective salting-out agent on a normality basis than other metal nitrates and (2) the extraction of uranium becomes less efficlent as the amount of extracted thorium becomes appreciable.

The effect of several foreign anions on the extraction of uranyl nitrate by diethyl ether is given in figure 11337 and Table X. $\underline{326}$ Arsenate, molybdate, and vandate lons also Interfere with the extraction of uranium. The effect of these 1ons may be offset by the addition of ferric nitrate to the solution. 338

The partition of a large number of elements between various aqueous nitrate systems and diethyl ether is given In Table XI and 1llustrated in figures 12-14. The increased distribution of heavy elements and fission product elements with Increased nitric acld concentration should be noted. For a selective uranium extraction the nltric acid concentration should be minimal. Hyde 339 has recommended an aqueous phase $0.5-1 \mathrm{M}$ in nitric acid and $2.5 \mathrm{M}$ in magnesium nitrate for the quantitative extraction of uranium by diethyl ether. More selective extraction of uranyl nitrate may be made from a saturated ammonium nitrate-solution, 0.05-0.1M in nitric ac1d. The extraction can be made quantitative by repeated contacts with ether. 
Table DX Diatribution of Uranium and Thorlum between Diethyl Ether and Aqueous Solutions Contalning Various Amount of Metal Nitreteo:

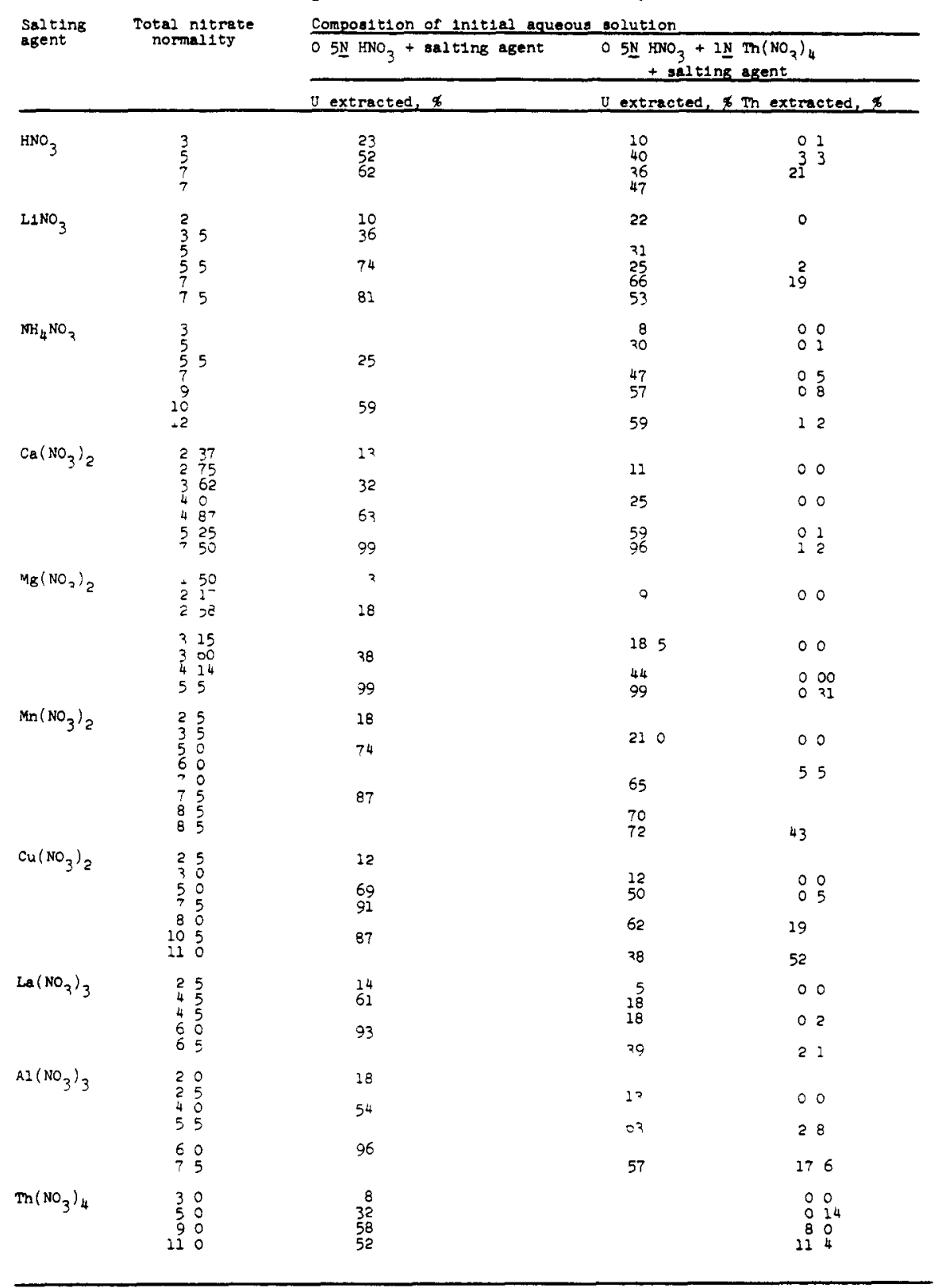

a Arter N N Hillman and M J wolf, reference 336

Five $\mathrm{ml}$ of ether were shaken 10 ninuteg with $5 \mathrm{mi}$ of the aqueous phase of appropriate composition 5,000 to $8,000 \mathrm{c} / \mathrm{m}$ of $\mathrm{U} 223$ tracer ( $52 \%$ counting y1eld) were supplied to the aqueous phase Variation of the tracer from 100 to $100,000 \mathrm{c} / \mathrm{m}$ in $5 \mathrm{ml}$ did not change the extracted 


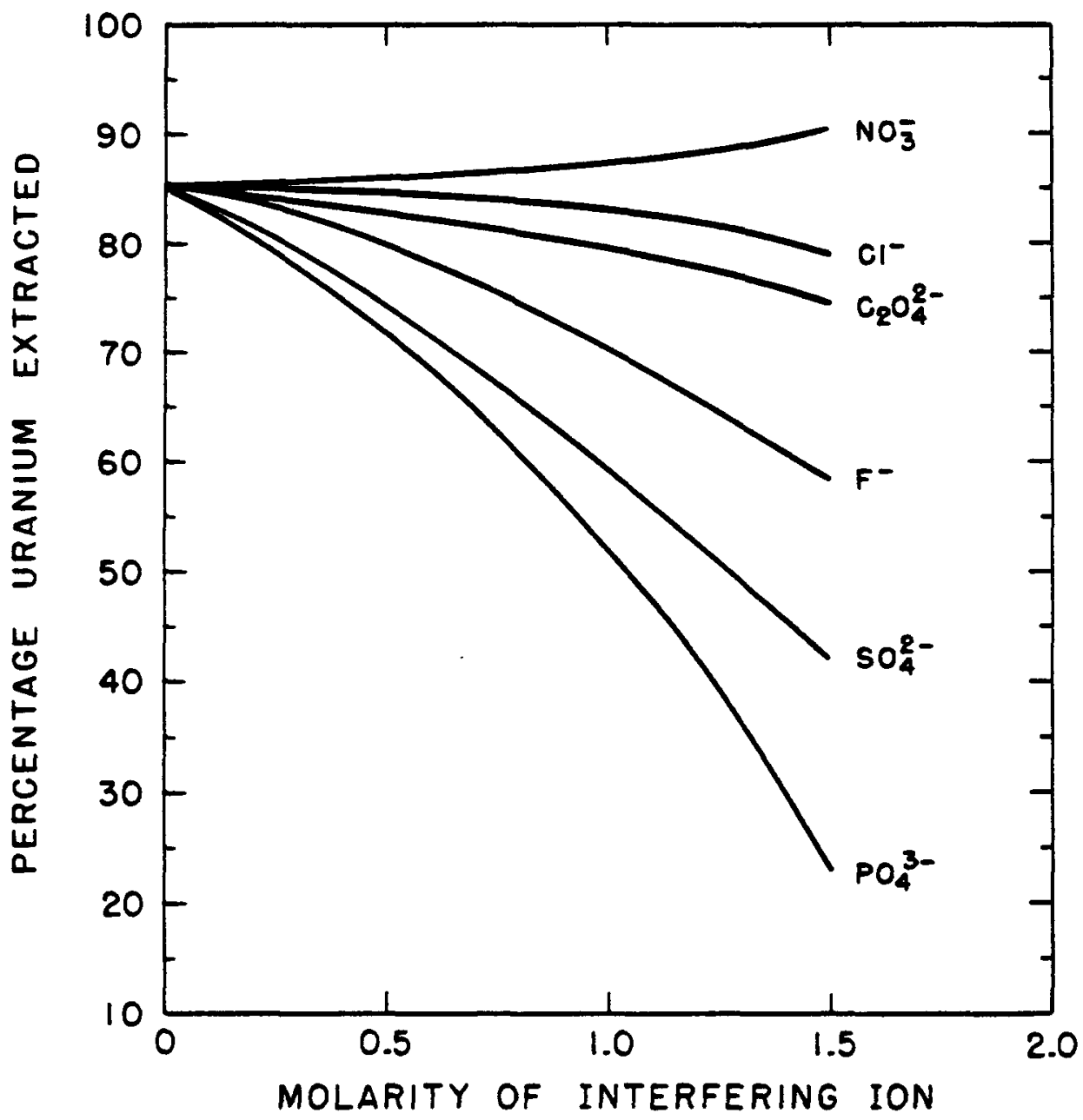

Figure 11. The effect of various anions on the extraction of uranyl nitrate by diethyl ether.

After T. R. Scott, reference 337 .

Conditions: Aqueous phase - varying amount of anion, $3 \mathrm{~N} \mathrm{HNO}_{3}$, IM $\mathrm{Fe}\left(\mathrm{NO}_{3}\right)_{3}$; aqueous phase and organic phase shaken 1 minute at room temperature. 
Table $X$. The Effects of Various Acids and inions upon the Vistribution csefficient of Uranyl Nitrate to Diethyl Ether. a

\begin{tabular}{|c|c|c|c|}
\hline \multirow{2}{*}{$\begin{array}{l}\text { Ac1d or salt } \\
\text { present }\end{array}$} & \multicolumn{3}{|c|}{ Composition of aqueous phase } \\
\hline & $\begin{array}{c}4.23 \mathrm{M} \mathrm{Ca}\left(\mathrm{NO}_{3}\right)_{2} \cdot 4 \mathrm{H}_{2} \mathrm{O} \\
(1000 \mathrm{~g} / \mathrm{I})\end{array}$ & 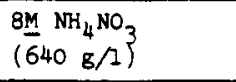 & $\begin{array}{l}6.86 \mathrm{M} \mathrm{NH}_{4} \mathrm{NO}_{3} \\
(549 \mathrm{~g} / \mathrm{A})^{-}\end{array}$ \\
\hline None & 19.95 & 0.645 & 0.364 \\
\hline $\mathrm{HCl}, 1 \mathrm{~N}$ & 10.24 & 0.336 & \\
\hline $\mathrm{HCl}, 2 \underline{\mathrm{N}}$ & 6.34 & 0.182 & \\
\hline $\mathrm{HNO}_{3}, 1 \mathrm{~N}$ & 43.56 & 2.162 & \\
\hline $\mathrm{HNO}_{3}, 2 \underline{\mathrm{N}}$ & 71.2 & 1.95 & \\
\hline $\mathrm{CH}_{3} \mathrm{CO}_{2} \mathrm{H}, 1 \underline{\mathrm{N}}$ & 15.7 & $0.662,0.616$ & \\
\hline $\mathrm{CH}_{3} \mathrm{CO}_{2} \mathrm{H}, 2 \underline{\mathrm{N}}$ & 10.52 & $0.720,0.762$ & \\
\hline $\mathrm{H}_{2} \mathrm{SO}_{4}, 0.0039$ & & 0.613 & \\
\hline $\mathrm{H}_{2} \mathrm{SO}_{4}, 2 \underline{\mathrm{N}}$ & 29.6 & 0.024 & \\
\hline $\mathrm{H}_{2} \mathrm{SO}_{4}, \quad 2 \mathrm{~N}$ & 23.5 & 0.019 & \\
\hline $\mathrm{H}_{3} \mathrm{PO}_{4}, 0.0058$ & & 0.609 & \\
\hline $\mathrm{H}_{3} \mathrm{PO}_{4}, 1 \mathrm{~N}$ & 0.01 & 0.01 & \\
\hline $\mathrm{H}_{3} \mathrm{PO}_{4}, 2 \underline{\mathrm{N}}$ & 0.01 & 0.01 & \\
\hline $\begin{array}{l}\mathrm{H}_{3} \mathrm{PO}_{4}, 2 \underline{\mathrm{N}} \\
\mathrm{HNO}_{3}, 2 \underline{\mathrm{N}}\end{array}$ & 3.98 & 0.067 & \\
\hline$\left(\mathrm{NH}_{4}\right)_{2} \mathrm{C}_{2} \mathrm{O}_{4}^{-\cdots}$ & $.7 \mathrm{~g} / 100 \mathrm{ml}$ & & 0.0847 \\
\hline $\mathrm{H}_{2} \mathrm{C}_{2} \mathrm{O}_{4} \cdot 2 \mathrm{H}_{2} \mathrm{O}$ & $\mathrm{g} / 100 \mathrm{ml}$ & & 0.0800 \\
\hline
\end{tabular}

a After Furman, Mundy and Morrison, reference 326.

The initial volumes of ether and aqueous solution were equal. Room temperature. 


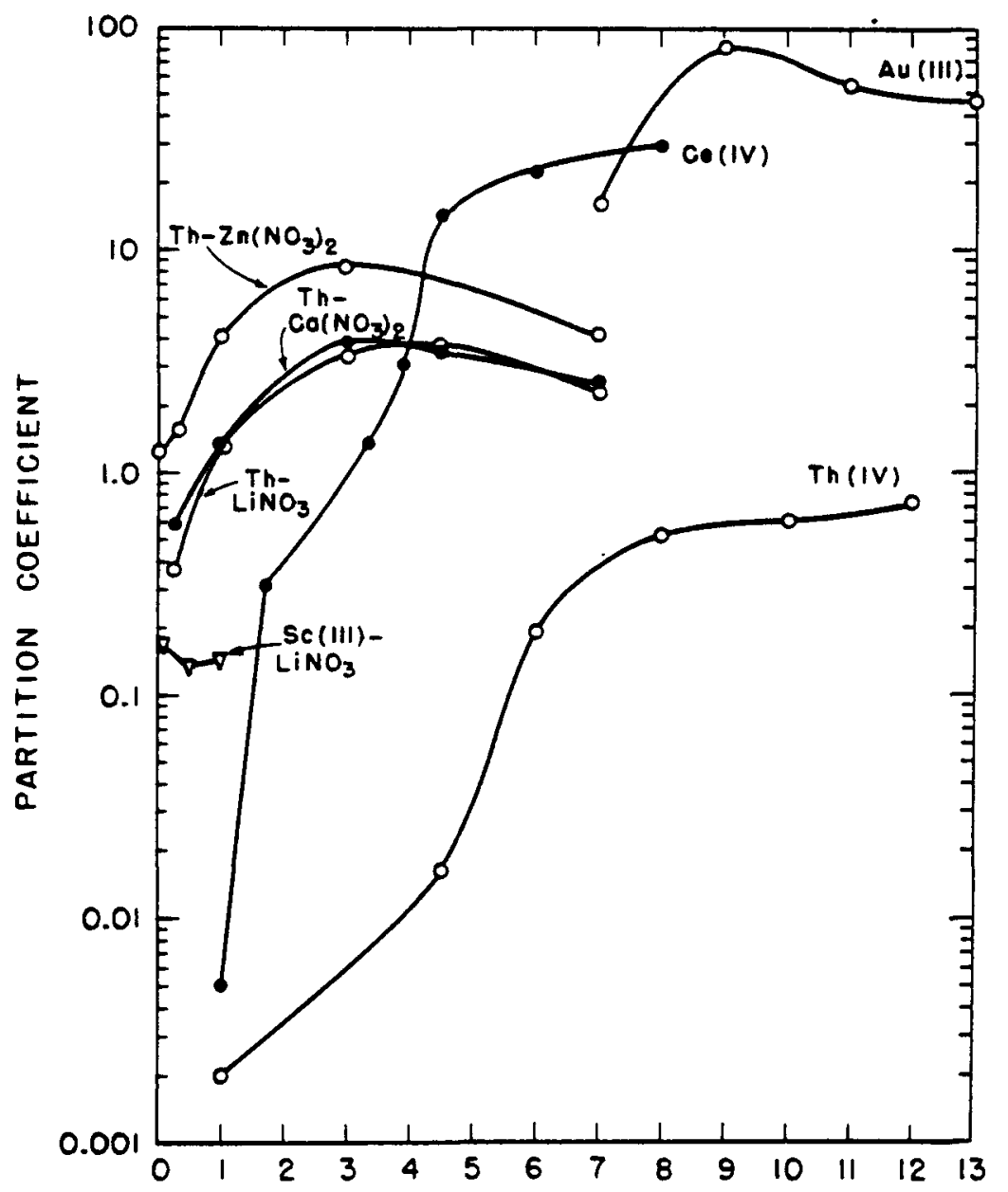

INITIAL AQUEOUS NITRIC ACID CONCENTRATION, M

F1gure 12. The extraction of various metal nitrates by diethyl ether.

After R. Bock and E. Bock, reference 333. Conditions: equal phase volumes. Metal nitrate Inftial aqueous Temperature

Th

$0.1 \mathrm{M} \quad 20 \pm 1^{\circ} \mathrm{C}$

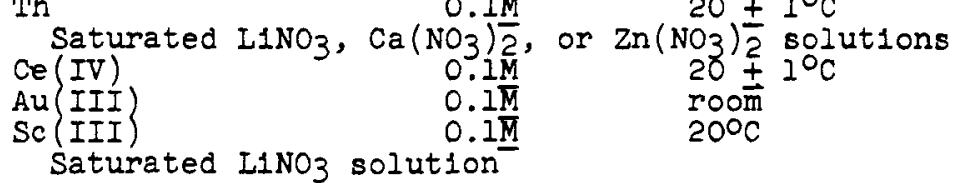


Table XI. D1stribution Coefficients of Elements between Diethyl Ether and Varlous Nitrate Solutione.

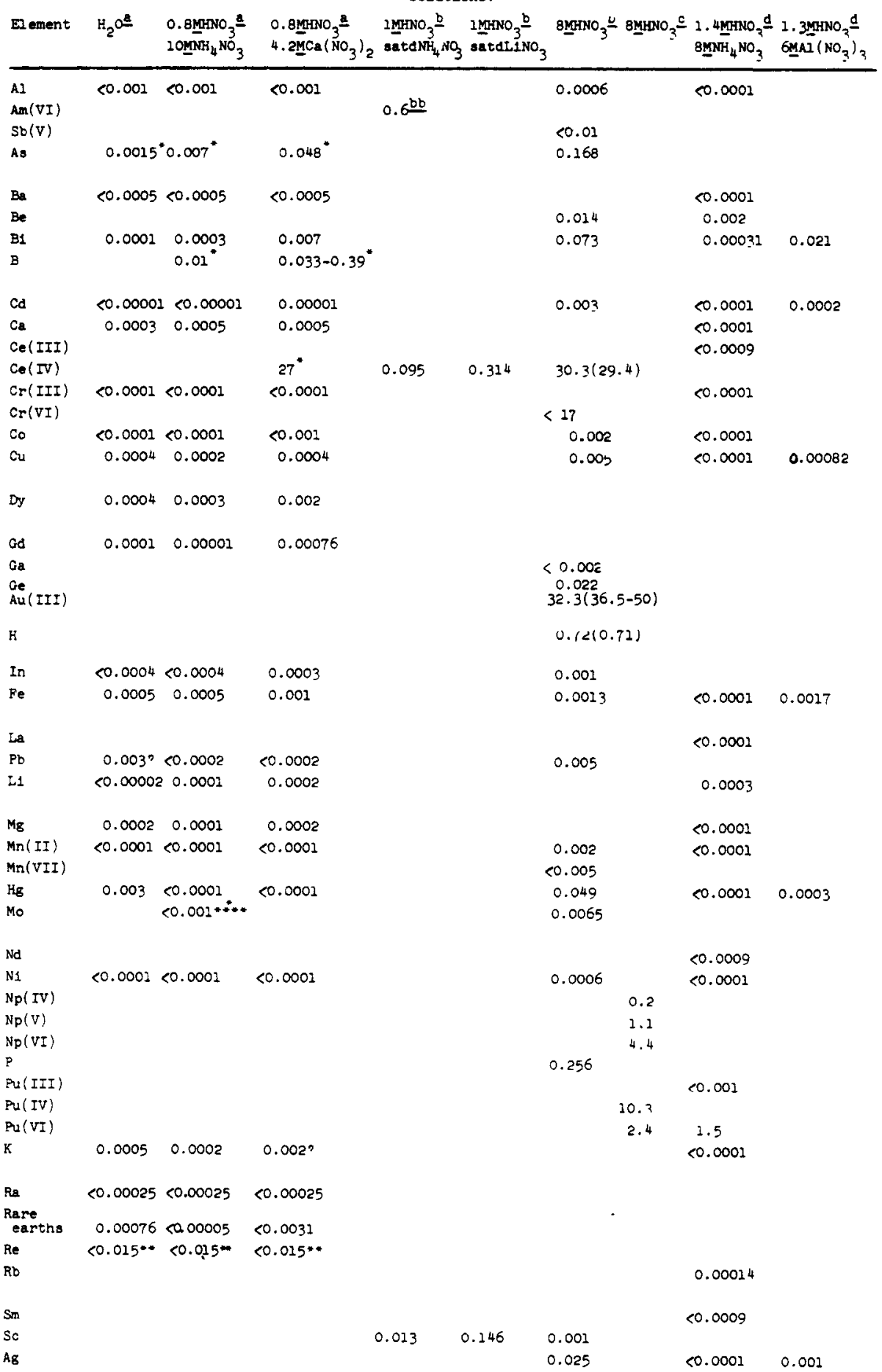


Table XI - Continued

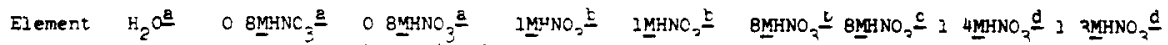

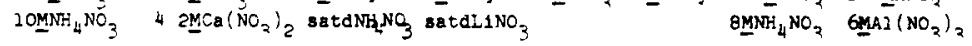

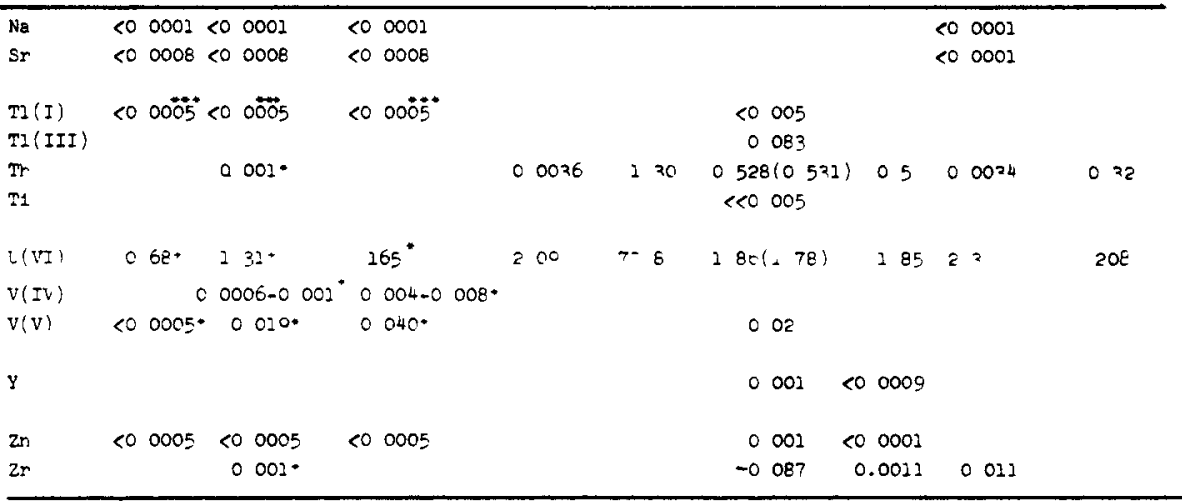

a After Furmar, Mundv, and Morrisor, reference $32 t$

Cond1:1ons were arranged, in general so that approximately 58 of $\mathrm{U}_{3} \mathrm{O}_{8}$ were recovered from the ether extract prior to spectographic examination In general survev studies 015 of eacr of the eiements $\mathrm{AS}_{\mathrm{S}} \mathrm{Al}, \mathrm{E}, \mathrm{Ea}, \mathrm{B}, \mathrm{Ca}, \mathrm{Cd}, \mathrm{Co}, \mathrm{Cr}, \mathrm{Cu}, \mathrm{Pe}, \mathrm{Hg}, \mathrm{K}, \mathrm{Li}$

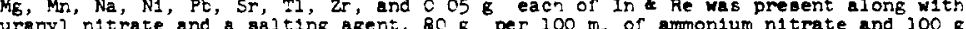

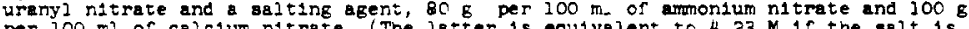

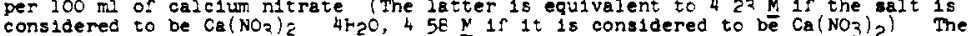
description of the experiment giver is reference zes gives the nitric acid concentradescription or the experiment glver $1 \mathrm{~T}$ reference $\mathrm{ze}$ gives the nitric aclo concentra-
tior as $5 \mathrm{~mL}$ of concentrated acid per $100 \mathrm{mi}$ a tabie or the partition coefricients tior as $5 \mathrm{~mL}$ or concentrated acld per $100 \mathrm{ml}$ a table or the partition coefricients glves he acld concentratior as $5 \mathrm{~g}$ or $\mathrm{H}_{3}$ per $100 \mathrm{~m}$. If the concentrated acid concercration is considered to be approximatelv $16 \mathrm{~N}$ both of the above values give were ghaken to equiliorium with an equel volume of ether at $20^{\circ} \mathrm{C}$

were haken to equilton coes, 8 so, The ur
figure 9)

Rare eartis were present ir amounts such tha* onl limiting values could be given for individual elements py spectrographil a means except for Dy and I

- Large amourts of clements ware used V 1-2g, As or Cr 16-20g, Na or Ca nttrate 70-100g, Fe is Mo 038 per $100 \mathrm{~m}$ Analys1s of ine etner phase made by means otner than spectrograpnic

** IImit aet by lack of aensitivity of epectrographic test a probably much amaljer

*** Valence state not desigrated

-.* a 18 much gregter for Mo present as a heteropoly ac10

b After Bock and Bock, reference 337

Values of a ror $\mathrm{BM} \mathrm{NO}_{3}$ solutions have been calculated from $\mathrm{F}$-values glven by Bock and Bock Those valūes In parentheses are a-values given directly by Bock and Bock or interposated fror their data

Concertratior of element concerned in 1nitial solution 0 iM with the exception of

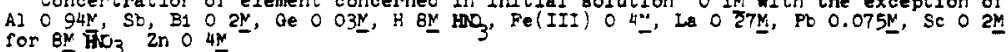

Elements were present as the nitrate with the following exceptions $\mathrm{Ge} a \mathrm{Ge} \mathrm{O}_{2}$,

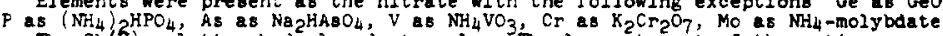
The $S b(6)$ solution hydrolyzed stronsiy The largest part of the antimony was

precipitated as hydroxide and onlv traces were detected in the ether phase

Cr(VI) extracted well but an exact value could not be determined because of reduction of the chromilum

$\mathrm{Mn}$ (VII) was reduced with the eeparation of $\mathrm{MnO}_{2}$ from the ether so that practically

no $\mathrm{Mn}$ was extracted

Temperature $20^{\circ}$ for the saturated $\mathrm{NH}_{4} \mathrm{NO}_{3}$ and $\mathrm{L}_{1} \mathrm{NO}_{3}$ solutions Room temperature

for the $8 \mathrm{~N} \mathrm{HO}_{3}$ olutions

DO Asprey, Stephanon and Pennemen, reference 343

$A m(V I)$ was prepered peroxydisulfate oxidation

c Arter Koo1, reference 334

The values given in this colum are values taken from curves given in this reference

(dee, also, figures 8 and 13 )

Concentrations of the varlous elements in the indtiel aqueous oolution $\mathrm{m}, 22 \mathrm{mg}$

per $\mathrm{mI}$ of $\mathrm{Th}_{\left(\mathrm{NO}_{3} \mathrm{I}_{4}\right.} 4 \mathrm{H}_{2} \mathrm{O}, \mathrm{U}, 3,3,10,30$ and $90 \mathrm{mg}$ per $\mathrm{mI}$ of $\mathrm{UO}_{2}\left(\mathrm{NO}_{3}\right)_{2} 6 \mathrm{H}_{2} \mathrm{O}, \mathrm{Np}^{2}$ ind

Pu, tracer quantitiea No detectable difference was observed in the pertition data for the flrst three quantities of 0 listed, a lower a (I 7) wa observed for the latter concentration

Shwiking times for the Np and Pu experiments were $k$ kept short (15 sec to $3 \mathrm{~min}$ ) to minimize diaproportionation to other oxidation states The shaking time for $U$ solution. was never leas than 5 minutes in increase to two hours did not make alfrerence in the result:

S Arter vdovenko, reference 344

The 1nitial aqueous layer contained, in addition to the acid and salting agent, about - IM of the nitrate exemined Equal volumes of the aqueous solution and diethyl ether were shaken for 5 minutea After 12 hours equilibration a sample of the organic

solution was taken for analysis 


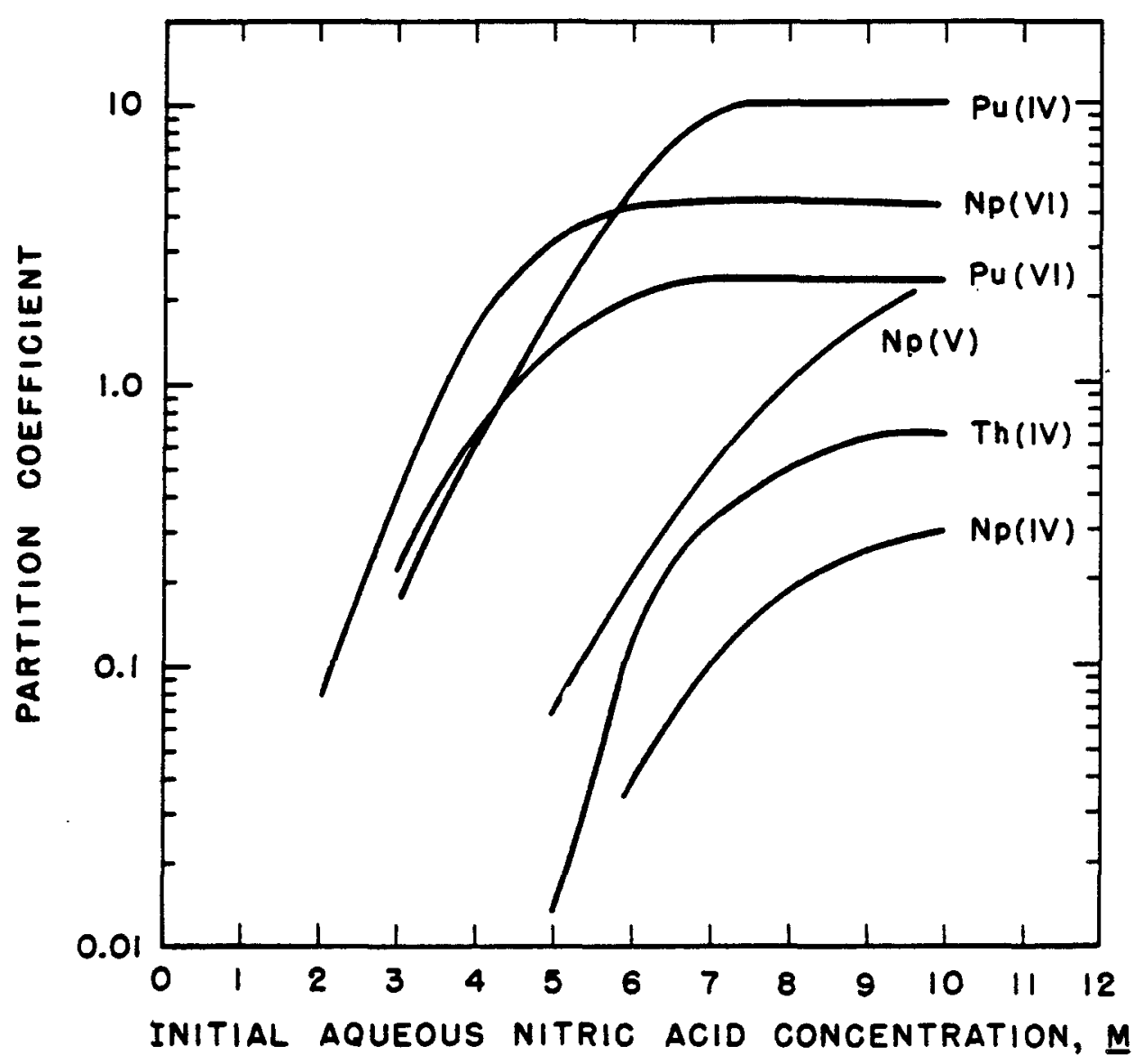

Figure 13.

The extraction of actinide nitrates by diethyl ether.

After J. Koo1, reference 334 .

Cond1tions :

Tracer amounts of $\mathrm{Np}^{239}$ and $\mathrm{Pu}^{239}$ in aqueous solutions were equilibrated with an equal volume of diethyl ether at $25^{\circ} \mathrm{C}$ and room temperature, respectively. $330 \mathrm{mg}$ of $\mathrm{Th}\left(\mathrm{NO}_{3}\right)_{4} \cdot 4 \mathrm{H}_{2} \mathrm{O}$ per $15 \mathrm{ml}$ of InItlal aqueous solution was equilibrated with an equal volume of ether.

The oxidation states of neptunium have been the subject of some question. 345 


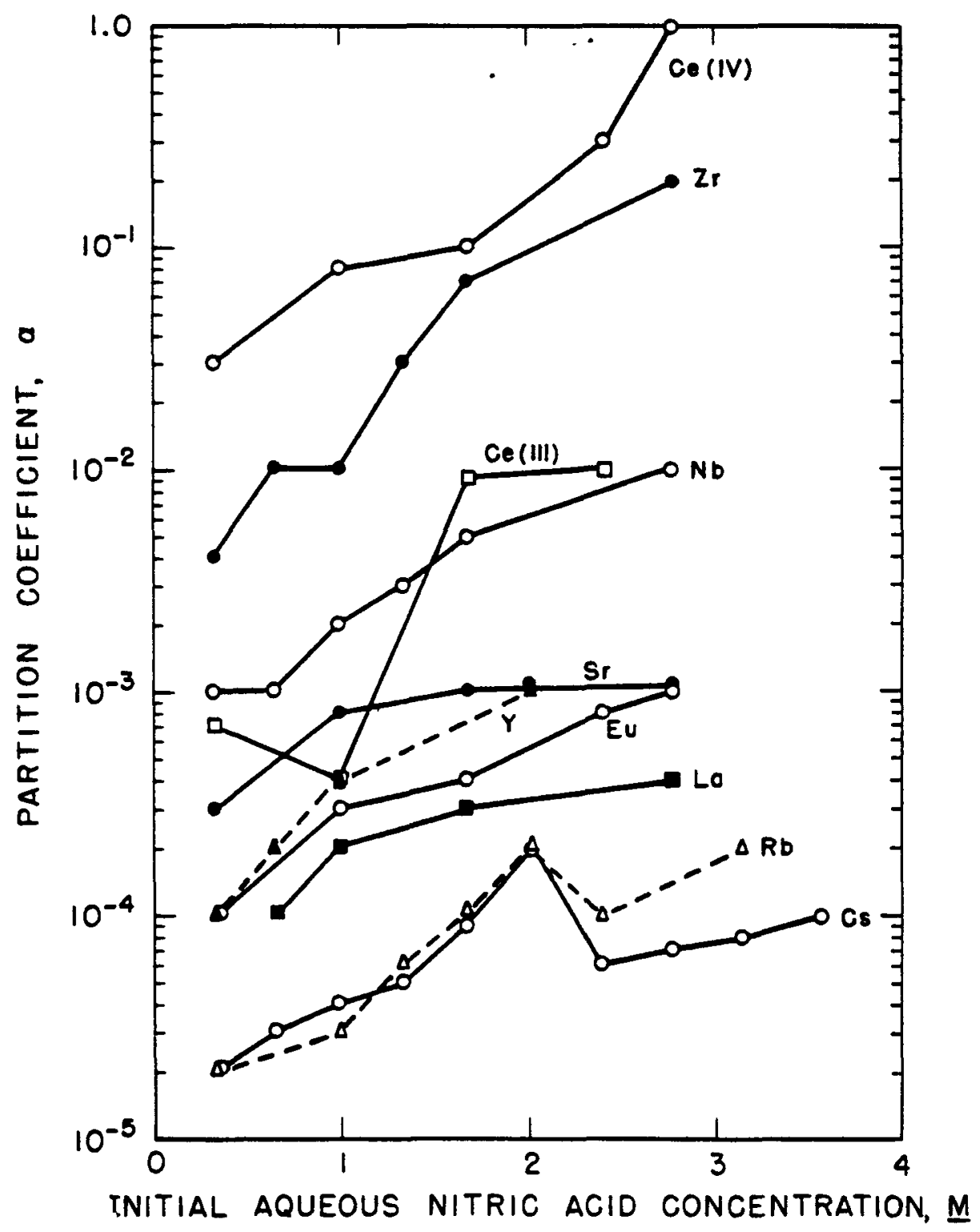

Figure 14. Partition coefficlents of fission products between diethyl ether and aqueous solution containing $\mathrm{Ca}\left(\mathrm{NO}_{3}\right)_{2}$ and different. initial acidities. After V. Vdovenko, reference 344 . Conditions: Aqueous solution--required amounts of nitric acid and radioactive material added to $3.5 \mathrm{M}$ solution of $\mathrm{Ca}\left(\mathrm{NO}_{3}\right)_{2} ; \mathrm{Vo} / \mathrm{V}_{\mathrm{a}}, 1$. 
Aqueeous th1ocyanate.systems. Uranium may be extracted from aqueous thiocyanate solutions by diethyl ether. 340,341 Table XII lists the partition coefficients of several elements from aqueous solutions of various thlocyanate con-

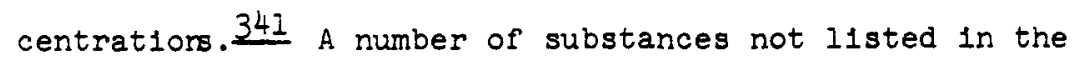
table give negligible distributions or distributions of only a few percent under the conditions tested: $\mathrm{NH}_{4}, \mathrm{Sb}$ (III), $\mathrm{As}$ (III), $\mathrm{As}(\mathrm{V}), \mathrm{BI}, \mathrm{Cd}, \mathrm{Cu}(\mathrm{I}), \mathrm{Cr}$ (III), Ge(IV), L1, $\mathrm{Hg}(\mathrm{II})$,

Table XII. - Partition Coefficients of Various Elements between Dlethyl Ether and Aqueous Thiocyanate Solutions. a Composition of the initial aqueous solution

\begin{tabular}{|c|c|c|c|c|c|c|}
\hline & $\begin{array}{c}\mathrm{HCl} \\
\underline{\mathrm{M}}\end{array}$ & ${ }^{\circ} \mathrm{t}$ & $\underline{I M}$ & $\mathrm{NH}_{4} \underset{3 \mathrm{M}}{\mathrm{SCN}}$ & $\begin{array}{c}\text { concentrat } 1 \\
5 \mathrm{M}\end{array}$ & Ion \\
\hline $0.1 \mathrm{M} A I \underline{b}$ & 0.5 & 20 & & 0.011 & 0.099 & $0.275^{c}$ \\
\hline $0.2 \mathrm{M} \mathrm{BeCl} \mathrm{Bl}_{2}$ & 0.5 & $\mathrm{RT}$ & 0.039 & 0.987 & 5.29 & 11.9 \\
\hline $0.1 \mathrm{M} \mathrm{CoCl}_{2}$ & 0.5 & $\mathrm{RT}$ & 0.037 & 1.39 & 2.98 & 3.04 \\
\hline $0.1 \mathrm{M} \mathrm{GaCl}_{3}$ & 0.5 & RT' & 1.89 & 9.56 & & 152 \\
\hline $\mathrm{HCl}$ & 0.5 & 20 & 2.67 & 12.7 & 31.1 & 59.4 \\
\hline $0.1 \mathrm{M} \mathrm{InCl}_{3}$ & 0.5 & $\mathrm{RT}$ & 1.06 & 3.05 & 2.15 & 0.908 \\
\hline $0.1 \mathrm{M} \mathrm{FeCl}_{3}$ & 0.5 & $\mathrm{RT}$ & 8.00 & 5.13 & 3.08 & 1.14 \\
\hline $0.1 \mathrm{M} \mathrm{MoOCl} \mathrm{C}_{3}$ & -0.5 & $\mathrm{RT}$ & 140 & 34.9 & & $36.4^{d}$ \\
\hline 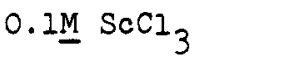 & 0.5 & $\mathrm{RT}$ & 0.145 & 3.95 & . & 8.06 \\
\hline $0.1 \mathrm{M}\left(\mathrm{NH}_{4}\right)_{2} \mathrm{SnCl}_{6}$ & 0.5 & $\mathrm{RT}$ & 144 & 950 & $=1000$ & $>1000$ \\
\hline $0.1 \mathrm{M} \mathrm{TICl}_{3}$ & 0.5 & RT & 1.43 & 5.25 & $3 \cdot 94$ & 3.22 \\
\hline $0.1 \mathrm{M} \mathrm{TICl}_{4}$ & 0.5 & $\mathrm{RT}$ & & & & -0.15 \\
\hline $0.1 \mathrm{M} \mathrm{UO}_{2} \mathrm{Cl}_{2}$ & 0.5 & RT & 0.821 & 0.417 & 0.160 & 0.072 \\
\hline $0.1 \mathrm{M} \mathrm{VOCl}_{2}$ & 0.5 & $\mathrm{RT}$ & 0.176 & 0.095 & & 0.022 \\
\hline $0.1 \mathrm{M}_{-} \mathrm{ZCI}_{2}$ & 0.5 & $\mathrm{RT}$ & 23.7 & 37.8 & $18 \cdot 3$ & 12.9 \\
\hline
\end{tabular}

a After R. Bock, reference 341 .

$\underline{b}$ as $\mathrm{AlCl}_{3}$ ?

c $6.2 \mathrm{M}$

d $6.6 \underline{\mathrm{M}}$

Equal phase volumes equilibrated at room temperature. 
N1, Pd(II). Figure 15 represents the change in $\alpha_{u}$ with thlocyanate concentration for aqueous solutions of different acidities $\frac{3 \text { H }}{4}$ Analysis of the ammonium, uranium, thiocyanate concentration of the ether phase indicates that uranium is extracted as $\mathrm{UO}_{2}(\mathrm{SCN})_{2} \frac{341}{2}$

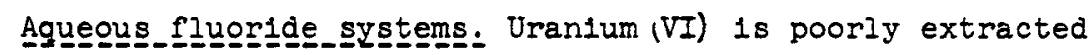
by diethyl ether from aqueous fluoride solutions. 342 Table XIII lists the partition coefficients of a number of elements from aqueous solutions of various hydrofluorlc acld concentrations.

\section{Dibutyl ether}

Agueous_nftrate_systems. The applicab1l1ty of dibutyl ether as an extractant for uranium has been investigated extensively by workers in the Soviet Union. $\frac{344,346-349}{D 1-}$ butyl ether offers several advantages over diethyl ether. It is less soluble in water, less volatile, and has a higher flash point. The distribution coefficlent of uranyl nitrate 18, however, less for dibutyl ether than for diethyl ether. The partition of urantum between water and dibutyl ether is represented in figure $1.185,321$ The distribution of uranyl nitrate and nitric acid is plotted as a function of aqueous nitric acid concentration in figure 16.346 Karpacheva, Knorkhov1na, and Agashkina $\frac{348}{4}$ have studied the effect of various salting-out agents on the distribution of uranyl nitrate. The salting-out action was found to increase with increasing valence of the cation. The partition coefficient of uranium from an aqueous solution initially $0.5 \mathrm{M} \mathrm{UO}_{2}\left(\mathrm{NO}_{3}\right)_{2}$, $4.5 \mathrm{M} \mathrm{Ca}\left(\mathrm{NO}_{3}\right)_{2}$, and $0.5 \mathrm{M} \mathrm{HNO}_{3}$ 1nto an organtc phase $85 \%$ (by volume) dibutyl ether and $15 \%$ carbon tetrachloride is 0.70 ; $a_{\mathrm{Pu}(V I)}$ is $0.42 . \frac{347}{\mathrm{z}} \mathrm{zrconium,} \mathrm{niobium,} \mathrm{and} \mathrm{ruthentum} \mathrm{are}$ the maln fission product elements extracted. 344,348 Heyn and Banerjee 350 have studied the extraction of bismuth nitrate by dibutyl ether and several other solvents. 


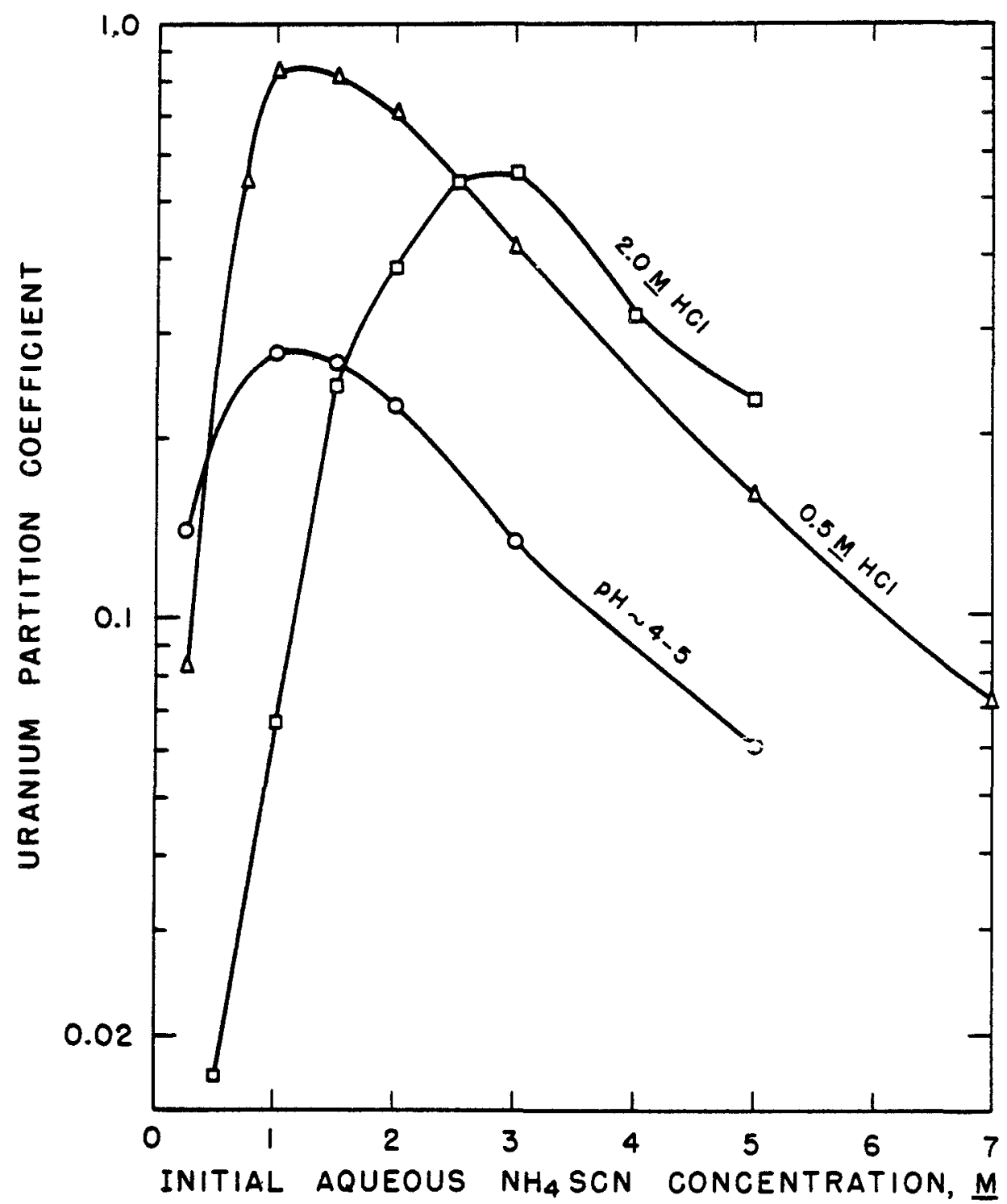

F1gure 15.

The extraction of uranyl thiocyanate by diethyl ether at varlous inftial $\mathrm{NH}_{4} \mathrm{SCN}$ and $\mathrm{HCl}$ concentrations.

After $R$. Bock, reference 341 .

Cond1tions :

Aqueous phase--initially $0.1 \mathrm{M}, \mathrm{UO}_{2} \mathrm{Cl}_{2}$ and $\mathrm{NH}_{4} \mathrm{CNS}$ and $\mathrm{HCl}$ concentration indicated.

Equal phase volumes equilibrated at room temperature. 
Table XIII.- Partition Coefficlents of Various Elements between Aqueous HF Dolutions and Diethyl Ether?

HF concentration of the starting aqueous solutior

\begin{tabular}{|c|c|c|c|c|c|}
\hline Element $\mathrm{b}$ & 1. OMHF & 5. OMHF & 10. OMHF & 15. OMHF & 20. OMHF \\
\hline Sb(III) & $<0.0005$ & 0.003 & 0.019 & 0.040 & 0.067 \\
\hline As (III) & 0.111 & 0.227 & 0.432 & 0.530 & 0.605 \\
\hline As $(V)$ & $<0.001$ & 0.017 & 0.048 & 0.121 & 0.157 \\
\hline Be & $<0.0005$ & $<0.0005$ & 0.005 & 0.019 & 0.042 \\
\hline Cd & $<0.0005$ & 0.002 & 0.006 & 0.009 & 0.014 \\
\hline Co & $<0.002$ & $<0.002$ & $<0.002$ & 0.005 & 0.017 \\
\hline $\mathrm{Cu}(I I)$ & $<0.001$ & $<0.001$ & $<0.001$ & 0.010 & 0.013 \\
\hline $\mathrm{Ge}(I V)$ & $<0.002$ & $<0.002$ & 0.005 & 0.028 & 0.072 \\
\hline$M n(I I)$ & $<0.0005$ & $<0.0005$ & 0.002 & 0.005 & 0.013 \\
\hline $\mathrm{Hg}(I I)$ & $<0.0005$ & $<0.0005$ & $<0.0005$ & 0.009 & 0.028 \\
\hline $\mathrm{Mo}(\mathrm{VI})$ & 0.007 & 0.018 & 0.031 & 0.062 & 0.103 \\
\hline $\mathrm{Ni}$ & $<0.0005$ & $<0.0005$ & $<0.0005$ & 0.005 & 0.007 \\
\hline $\mathrm{Nb}(\mathrm{V})$ & 0.006 & 0.044 & 0.480 . & 1.08 & 1.92 \\
\hline$P(V)$ & $<0.001$ & 0.011 & 0.032 & 0.110 & 0.173 \\
\hline $\operatorname{Re}(V I I)$ & 0.0005 & 0.121 & 1.58 & 1.78 & 1.62 \\
\hline $\mathrm{Se}$ (IV) & 0.0006 & 0.022 & 0.080 & 0.131 & 0.148 \\
\hline $\mathrm{Ta}$ & 0.012 & 0.774 & 3.80 & 3.82 & 3.84 \\
\hline $\mathrm{Te}(\mathrm{IV})$ & 0.0001 & 0.020 & 0.071 & 0.237 & 0.298 \\
\hline$S n(I I)$ & & 0.020 & 0.029 & & 0.052 \\
\hline $\operatorname{Sn}(I V)$ & $0.006^{c}$ & $0.006^{d}$ & $0.053^{\mathrm{e}}$ & & 0.055 \\
\hline$U(V I)$ & $<0.002$ & $<0.002$ & $<0.002$ & 0.005 & 0.011 \\
\hline$V(I I I)$ & $<0.0005$ & 0.003 & 0.03 & 0.10 & 0.13 \\
\hline$V(v)$ & $<0.001$ & 0.004 & 0.017 & 0.056 & 0.093 \\
\hline $\mathrm{Zn}$ & $<0.001$ & $<0.001$ & $<0.001$ & 0.002 & 0.009 \\
\hline $\mathrm{Zr}$ & 0.004 & 0.005 & 0.005 & 0.012 & 0.030 \\
\hline
\end{tabular}

a After Bock and Hermann, reference 342 .

Equal phase volumes equilibrated at $20.0 \pm 0.5^{\circ} \mathrm{C}$.

b The concentration in the initial aqueous solution of the ionic species of the element listed in the table was $0.1 \mathrm{M}$ in each case with the exception of $\operatorname{Re}(V I I)$ which was $0.05 \mathrm{M}$.

Fluoride stock solutions were prepared in the following manner: carbonates (Cd, $\mathrm{Co}, \mathrm{Cu}, \mathrm{Mn}$ (II), $\mathrm{NI}, \mathrm{Zn}$ ), oxides ( $\mathrm{Sb}$ (III), Ge(IV), $\mathrm{Hg}(\mathrm{II}), \mathrm{Nb}(\mathrm{V}), \mathrm{Se}(\mathrm{IV}), \mathrm{Ta}(\mathrm{V}), \mathrm{Te}(\mathrm{IV}), \mathrm{V}(\mathrm{III}))$ or hydroxides or hydrated oxides ( $S N(I V), Z_{r}$ ) were dissolved in an excess of $\mathrm{HF}$; $\mathrm{As}_{2} \mathrm{O}_{3}$ was dissolved in a known volume of $0.1 \mathrm{~N} \mathrm{NaOH}$ and the calculated amount of $\mathrm{HF}$ added to the solution; $\mathrm{BeF}_{2}$ and $\mathrm{SnF}_{2}$ were dissolved; $\mathrm{K}_{2} \mathrm{HAsO}_{2}$ $\mathrm{Na}_{2} \mathrm{HPO}_{4}$, $\mathrm{KReO}_{4}$, ammonlum vanadate, ammonium molybdate, and sodium uranate were dissolved in HF.

$\underline{c} 1.2 \underline{\mathrm{M}} \mathrm{HF}$

d 5.4 M HF

e 10.4 M HF 


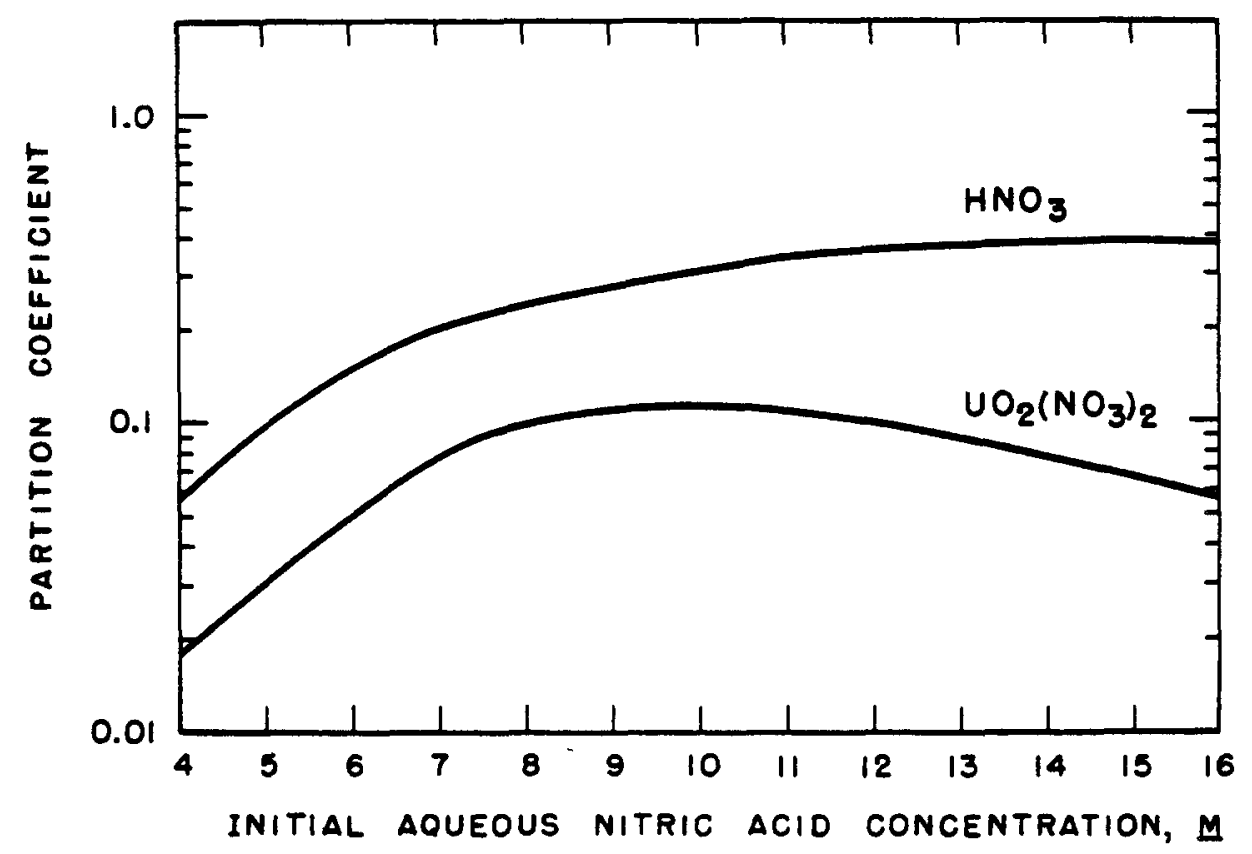

F1gure 16.

Partition of uranyl nitrate and nitric acld between dibutyl ether and aqueous solution.

After V. Vdovenko, A. L1povsk11, M. Kuz1na, reference 346. Cond1tions :

Equal phase volumes equilibrated at room temperature for both $\mathrm{UO}_{2}\left(\mathrm{NO}_{3}\right)_{2}$ and $\mathrm{HNO}_{3}$ extractions. For nitric acid, points corresponding to an acid content in the aqueous solution of greater than 13.4M were obtalned by the extraction of previously acldified dibutyl ether with concentrated nitric acid. For uranyl nitrate, points greater than 12.OM $\mathrm{HNO}_{3}$ were similarly obtalned. The uranium concentration was $78 \mathrm{mg} / \mathrm{ml}$.

Dibutyl "Cellosolve" (Dibutoxymonoethyleneglycol)

Agueous_nitrate_systems. A number of cellosolve derivatives have been investigated for the extraction of uranium (Table VIII). Diethyl cellosolve is an excellent extractant. 332 Unfortunately its solubility in water is large $\left(21 \%\right.$ by welght at $20^{\circ} \mathrm{C}$ ). Dibutyl cellosolve is less soluble in water $\left(0.2 \%\right.$ by welght at $\left.20^{\circ} \mathrm{C}\right)$. However, it does not extract uranium as well as diethyl ether, elther from water 
solution (figure $2 \frac{185,321}{\text { ) }}$ ) or from aqueous aluminum nitrate solution (figure $6 \frac{332}{}$ ). The partition coefficient of uranium into dibutyl cellosolve from nearly saturated solutions of ammonium, calclum, or ferric nitrate is 1,50 , and 20 , respectively. 332

\section{Dibutyl "Carb1tol" (D1butoxydiethyleneglycol)}

Agueous_n1trate_systems. Dibutyl carbitol (Butex) is used in the recovery of irradiated fuel material. 351 As a solvent, It has been subject to considerable study. $\frac{332,352}{2}$ The partition of uranium between water solution and solvent is given in figure $2.176,185,321$ The partition of uranium between nitric acid solution and dibutyl carbitol is 1liustrated in figure $17 . \frac{353}{}$ For aqueous solutions in this range of acid concentration, the partition coefficient is observed to increase with increased uranyl nitrate concentration. The partition coefficient of nitric acid is plotted as a function of acid concentration in figure $18 . \underline{334,353,354}$ In figures 19 and 20 , the partition coefficients of uranium and several other heavy elements are plotted against nitric acid concentration. The initial acid concentration of the aqueous phase is plotted in figure 19.334 The equilibrium acid concentration of the aqueous phase is given in figure 20.245 Best, et al $\frac{345}{4}$ have observed that the steepness of the extraction curves (figure 20) is compatible with the formation of the species $\mathrm{HMO}_{2}\left(\mathrm{NO}_{3}\right)_{3}$ and $\mathrm{H}_{2} \mathrm{M}\left(\mathrm{NO}_{3}\right)_{6}$ in the organic phase rather than just $\mathrm{MO}_{2}\left(\mathrm{NO}_{3}\right)_{2}$ and $\mathrm{M}\left(\mathrm{NO}_{3}\right)_{4}$. The curves given in figures 19 and 20 are in generai agreement considering the difference in acid concentration plotted. There is a large discrepancy between $N p(I V)$ data. The ability to malntain neptunium in the pentavalent state during extraction may be subject to question. The partition of some fission product elements is given in figure 21 for various 


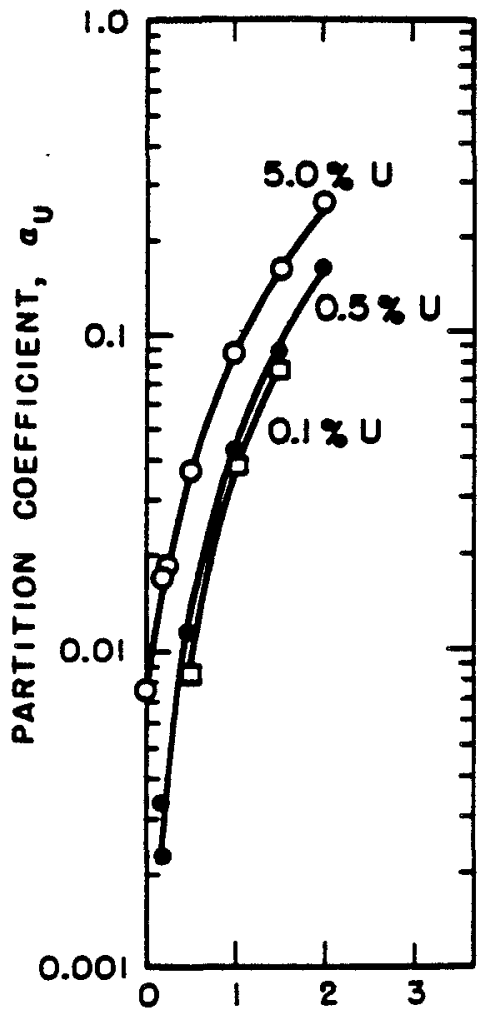

F1gure 17. Distribution of uranyl nitrate between dibutyl carbitol and nitric acid solution. Adapted from C. A. Kraus, reference 353. Conditions: Approximately equal volumes of organic and aqueous phase, 1nitially at the uranium and nitric acld concentrations indicated, equilibrated at about $27^{\circ} \mathrm{C}$.

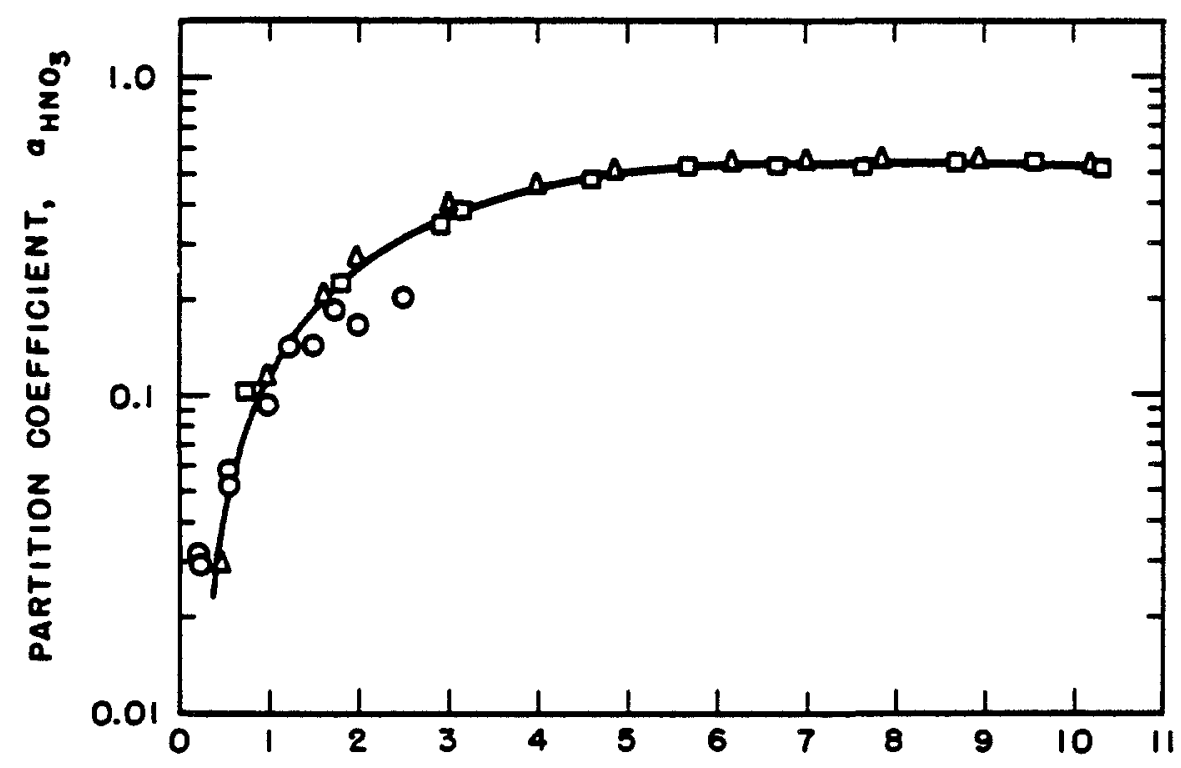

INITIAL AQUEOUS NITRIC ACIO CONGENTRATION, M

Figure 18. Distribution of nitric acld between dibutyl carbitol and aqueous solution.

O, After C. A. Kraus, reference 353. ロ, After J. Koo1, reference 334. $\Delta$, After D. G. Tuck reference 354. Conditions: Equal334,354 or approximately equal353 volume portions of solvent and aqueous solution equil1brated at $\sim 27^{\circ} \mathrm{C}, 35325^{\circ} \mathrm{C}, 334$ and $\sim 21^{\circ} \mathrm{C} .354$ 


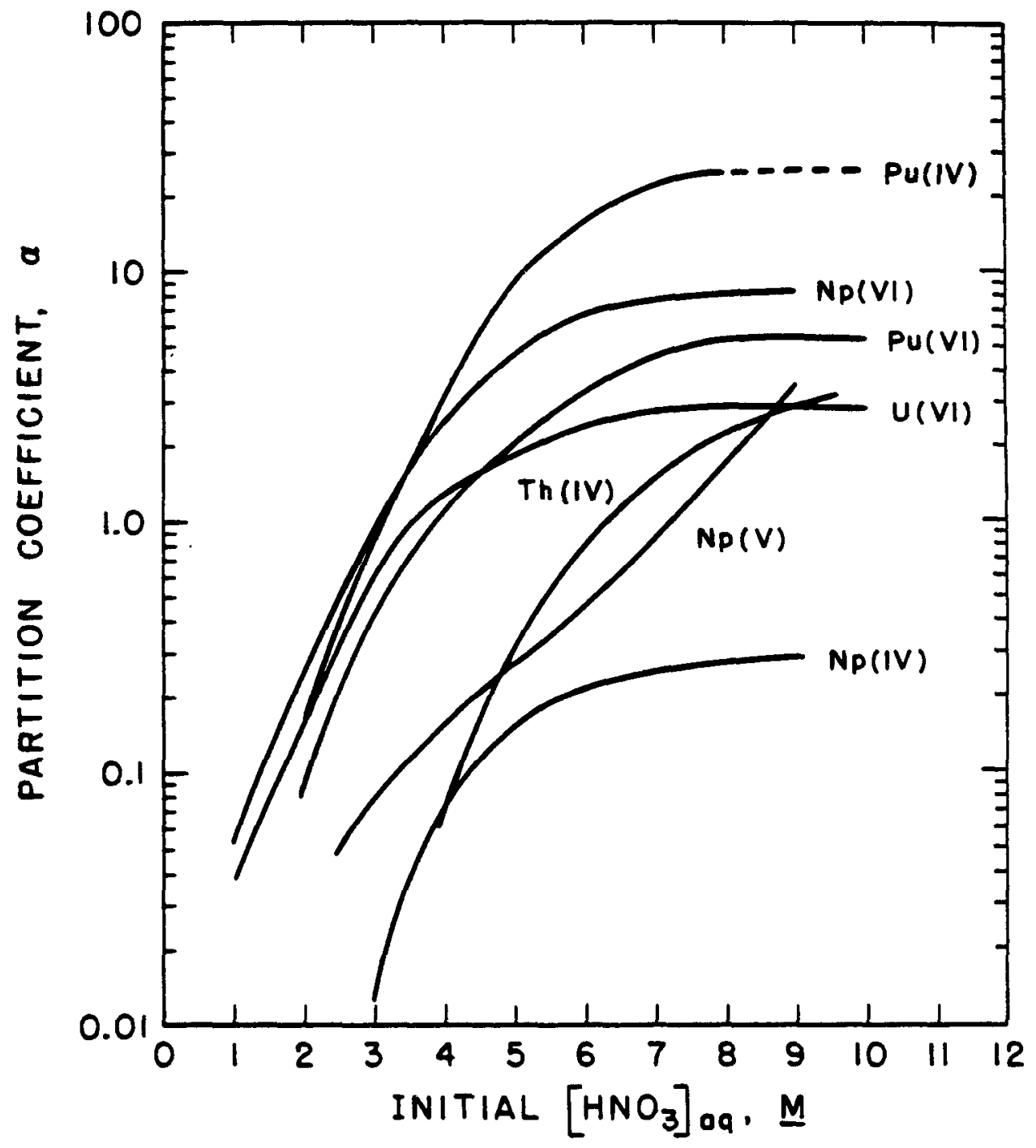

\section{Figure 19.}

The extraction of actinide nitrates by dibutyl carbitol. After J. Koo1, reference 334.

\section{Cond1tions :}

Tracer amounts of $\mathrm{Np}^{239}$ or $\mathrm{Pu}^{239}, 330 \mathrm{mg}$ of $\mathrm{Th}\left(\mathrm{NO}_{3}\right)_{4}$ $4 \mathrm{H}_{2} \mathrm{O}$ per $15 \mathrm{ml}$, or $300 \mathrm{mg}$ of $\mathrm{UO}_{2}\left(\mathrm{NO}_{3}\right)_{2}$ (hexahydrate) per $15 \mathrm{ml}$ in aqueous nitric ac1d solution equilibrated with an equal volume of dibutyl carbitol at $25^{\circ} \mathrm{C}$ or room temperature.

The oxldation states of neptunium have been the subject of some question. $\underline{345}$ 


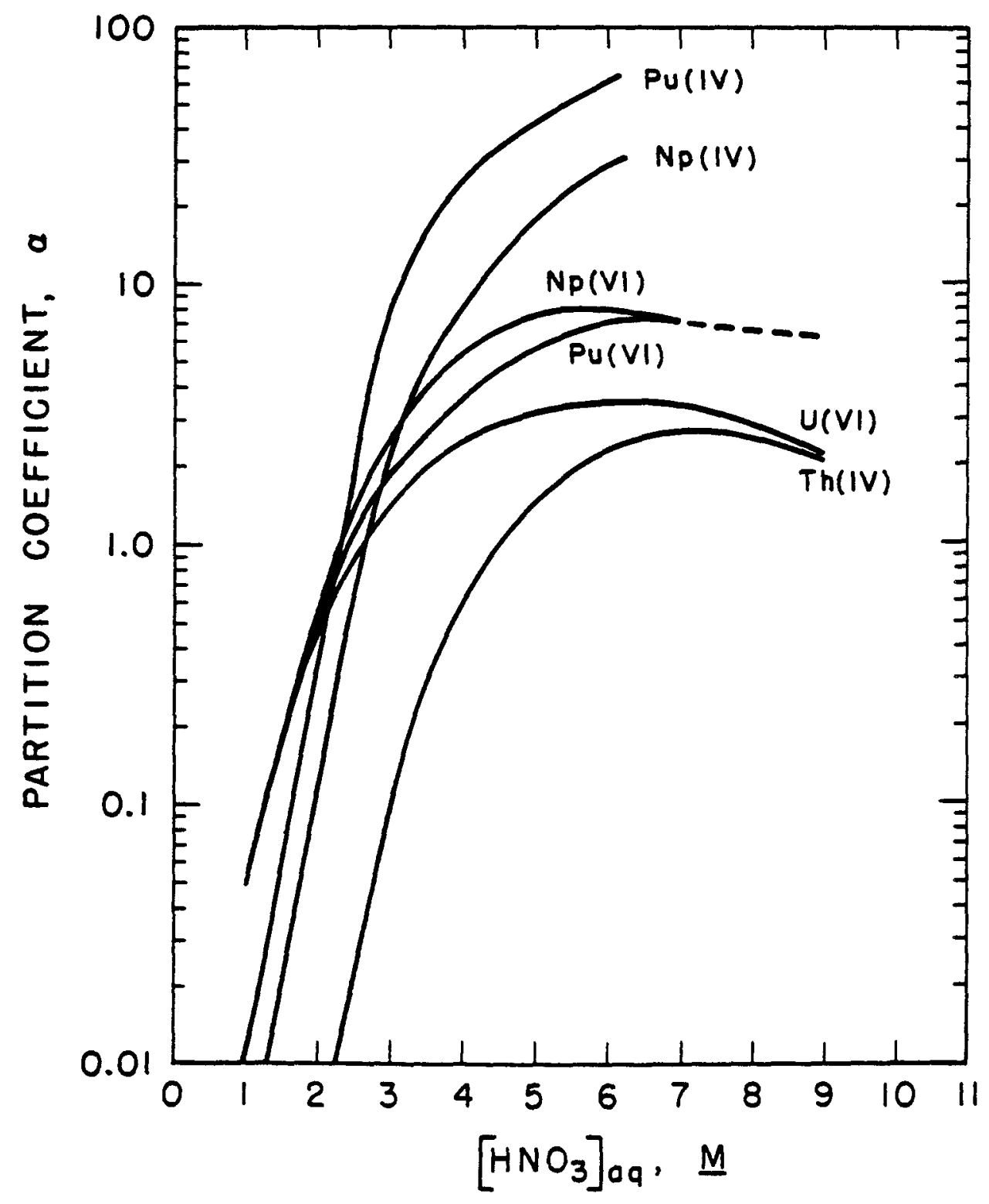

F1gure 20.

The distribution of actinide elements between dibutyl carbitol and aqueous solution as a function of equilibrium aqueous nitric acld concentration.

After G. Best, E. Hesford, and H. McKay, reference 345 .

Conditions :

Tracer concentrations $\left(-10^{-3} \underline{M}\right)$ of actinfde. Temperature, $25^{\circ} \mathrm{C}$. 


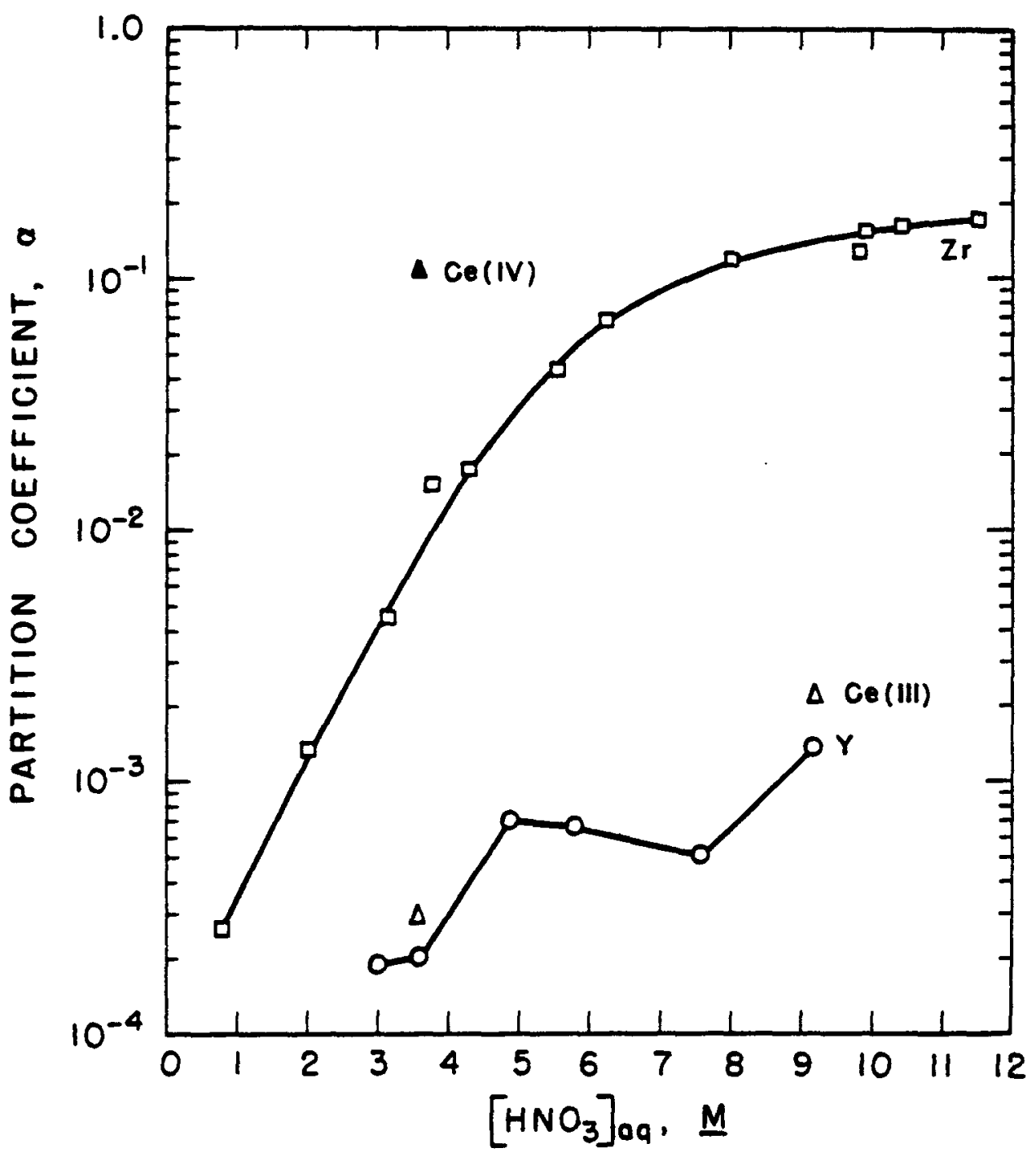

Figure 21.

The partition of tracer amounts of yttrium, cerium, and zirconium between dibutyl carbitol and aqueous solution as a function of aqueous nitric ac1d concentration. After H. McKay, K. Alcock, and D. Scarg111, reference 355. 


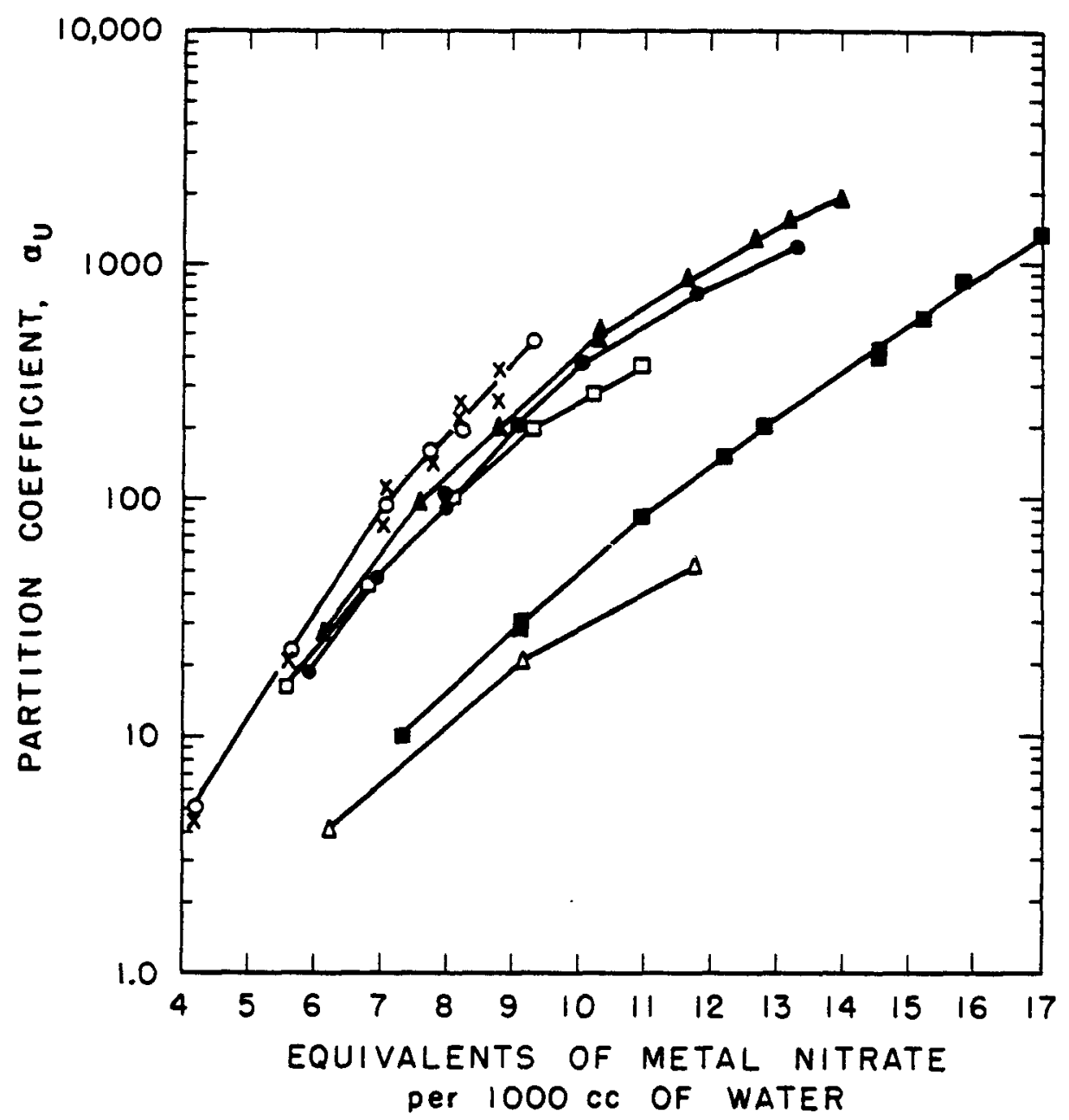

Figure 22. The effect of salting-out agents on the extraction of uranium by dibutyl carbitol. $-\mathrm{Cu}\left(\mathrm{NO}_{3}\right)_{2},-\mathrm{Ca}\left(\mathrm{NO}_{3}\right)_{2}, \Delta \mathrm{Zn}\left(\mathrm{NO}_{3}\right)_{2}$, $\mathrm{OAI}\left(\mathrm{NO}_{3}\right)_{3}, \mathrm{are}\left(\mathrm{NO}_{3}\right)_{3}, \triangle \mathrm{La}\left(\mathrm{NO}_{3}\right)_{3}$. After E. Evers and $\mathrm{C}$. Kraus, reference 332. Conalions: Uranlum concentration, 2-6 g/100 cc of phase. Temperature, $27^{\circ} \mathrm{C} ; \mathrm{V}_{0} / \mathrm{Va}_{\mathrm{a}}=1 . \mathrm{X} \mathrm{Al}\left(\mathrm{NO}_{3}\right)_{3}$. After D. Lee, R. Woodward, G. Clewett, reference 358. Conditions: Trace amounts of uranium. Temperature, $27^{\circ} \mathrm{C} ; \mathrm{V}_{0} / \mathrm{V}_{\mathrm{a}}$, varied.

aqueous nitric acid concentrations. $\frac{355}{25}$ The distribution of iron into dibutyl carbitol is increased by an increase in acldity. 352 Chloride ion promotes the extraction of iron. Boron is extracted by butex, especially in the presence of copper nitrate as salting-out agent. 352 Vanadium and molybdenum are extracted to several per cent. $\underline{352}$ The extraction of cadmium, chronium, nickel and titanium is small. 352 
The effect of salting-out agents on the distribution of uranium into dibutyl carbitol has been sutdied. 332,352 , 356-358 Some of the results are presented in figure 22. Aguegus_chIoride_systems. Uranlum (IV) and (VI) and thorlum are poorly extracted by dibutyl carbltol from aqueous solutions 2-6M in hydrochloric ac1d. 359 The extraction of protactinium is Increased as the acid concentration 1s 1ncreased. From $6 \mathrm{M} \mathrm{HCl}, a_{\mathrm{Pa}}$ is 10 . The extraction of hydrochloric acid is negligible from aqueous solutions less than $6 \mathrm{M}$ in hydrochloric ac1d. A third phase is formed upon equilibration with $7.5 \mathrm{M} \mathrm{HCl}$. The third phase contalns a large amount of the ac1d. One phase results upon equilibration w1th $8.5 \mathrm{M} \mathrm{HCl}$.

Pentaether (D1butoxytetraethyleneglycol)

Agueous_n1trate_systems. References 332 and 360 summerize much of the data pertinent to the extraction of uranium by pentaether. The distribution of uranyl nitrate between solvent and water is given in figure $2 A \frac{176,185}{4}$ The partition coefficient of uranyl nitrate from various nitrate medis is plotted in figure 23.360 The distribution of nitric acid as a function of aqueous acld concentration is also shown in figure $23 . \frac{361}{1}$ The effect of salting-out agents on the partition of uranium is 1llustrated in figure $24 . \frac{332}{3}$ Table XIV lists the partition coefficients of a number of elements other than uranium between pentaether and various aqueous media. 362 Uranium is extracted by pentaether from aqueous solutions containing ammonium nitrate and/or nitric acld in the presence of sulfate, phosphate, or sllicate 1ons. $\frac{362}{2}$ Phosphate 1on, in large quantity, and soluble sllicate ions are extracted by the solvent. $\frac{362}{6}$ Fluoride ion, in significant quantity, interferes with uranyl nitrate extraction. Th1s effect may be overcome by complexing the fluoride ion w1th calcium or aluminum nitrate. $\underline{362}$ 


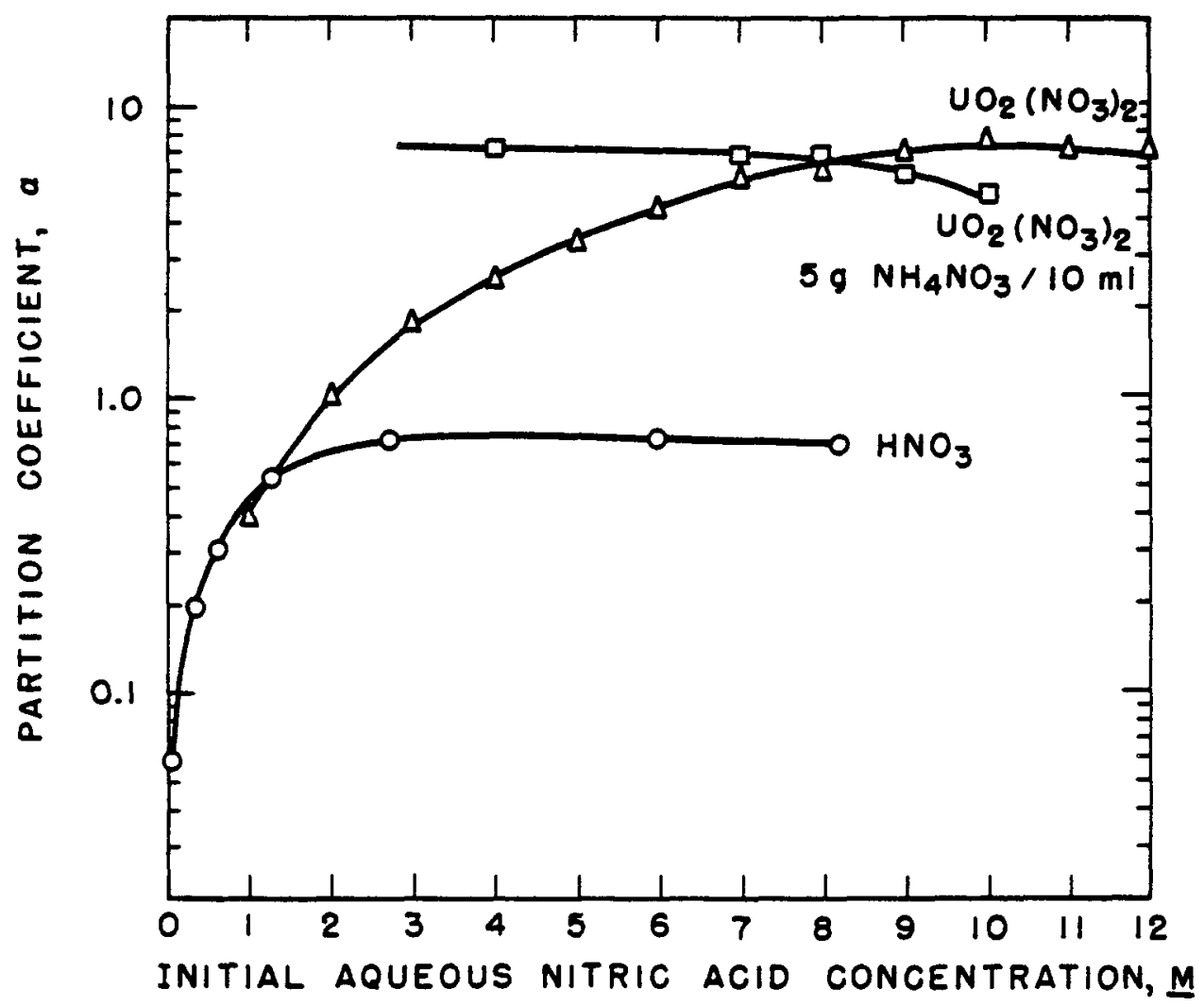

F1gure 23. The partition coefficlents of uranyl nitrate and nitric acid between pentaether and aqueous solution. $\triangle \mathrm{UO}_{2}\left(\mathrm{NO}_{3}\right)_{2}: 1.0 \mathrm{~g}$. $\mathrm{U}_{3} 08$ dissolved in $\mathrm{HNO}_{3}$, diluted to $50 \mathrm{ml}$ with acld of desired strength, and shaken 1 minute with an equal volume of pentaether. 口UO2 $\left(\mathrm{NO}_{3}\right)_{2}+\mathrm{NH}_{4} \mathrm{NO}_{3}: 1.0 \mathrm{~g}$. U $\mathrm{U}_{3} \mathrm{O}_{8}$ dissolved in $10 \mathrm{ml}$ of $\mathrm{HNO}_{3}$ of desired strength after addition of $5 \mathrm{~g}$. $\mathrm{NH}_{4} \mathrm{NO}_{3}$; shaken with an equal volume of pentaether for I minute at room temperature. Adapted from D. Musser, D. Krause, and R. Smellie, Jr., reference 360. $\mathrm{OHNO}_{3}$ : equal volumes of nitric acid solution and pentaether equilibrated for $I$ hour at $25^{\circ} \mathrm{C}$. After $\mathrm{C}$. Stover, Jr. and $\mathrm{H}$. Crandall, reference 361 .

Cyclic ethers.

A number of cyclic ethers have been investigated as ex-

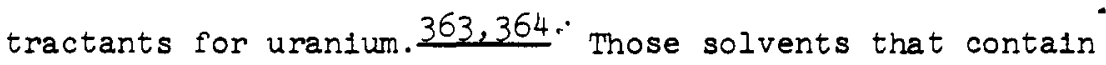
the furane nucleus have been found to give good extractions of uranyl nitrate from aqueous solutions. Solvents of the hydrocarbor substituted tetrahydrofurane type have been

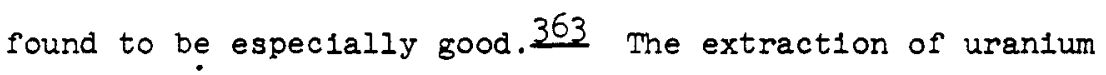
and thorlum by four cyclic ethers is illustrated in figure 25 as a function of acid concentration in the aqueous phase. 364 


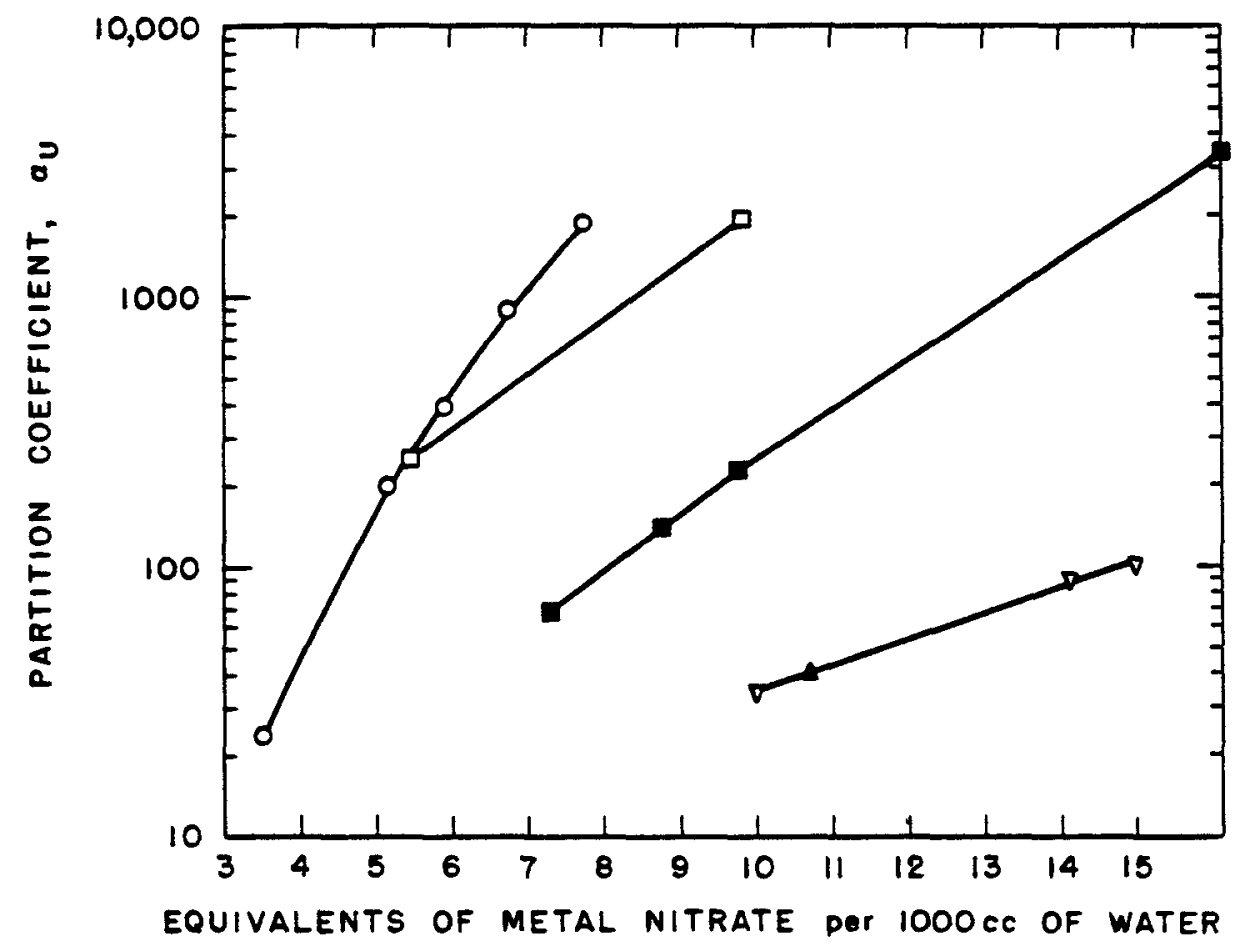

Figure 24. Effect of salt1ng-out agents on the extraction of uranium by pentaether. $\triangle \mathrm{NaNO}_{3}, \nabla \mathrm{NH}_{4} \mathrm{NO}_{3}, \quad \mathrm{Ca}\left(\mathrm{NO}_{3}\right)_{2}, \mathrm{OAl}\left(\mathrm{NO}_{3}\right)_{3}, \square \mathrm{Fe}\left(\mathrm{NO}_{3}\right)_{3}$. After E. Evers and C. Kraus, reference 332. Conditions: Uranium concentration, $2-6 \mathrm{~g} / 100 \mathrm{cc}$ of phase. Temperature, $270 \mathrm{C}$ or room temperature.

From figure $25-A$, it can be seen that uranyl nitrate is extracted more efficiently by the varlous solvents than is uranyl perchlorate. Better separation of uranium and thorium is also achieved from nitrate solution rather than perchlorate.

\section{ESTERS}

Information is less complete or less readily avallable for the extraction of uranium by esters than by ethers. The distribution of uranyl nitrate between iso-amyl acetate and water is represented in figure $3-4.185$ Karpacheva, et al. $\frac{348}{4}$ have found the extraction capacity of butyl acetate to be intermediate between diethyl ether and dibutyl ether. Hyde and wolf, 116 in addition to their 
Table XIV. Partition Loefficients of Elements between Penta-ether and Various Aqueous Media: $\underline{\text { a }}$

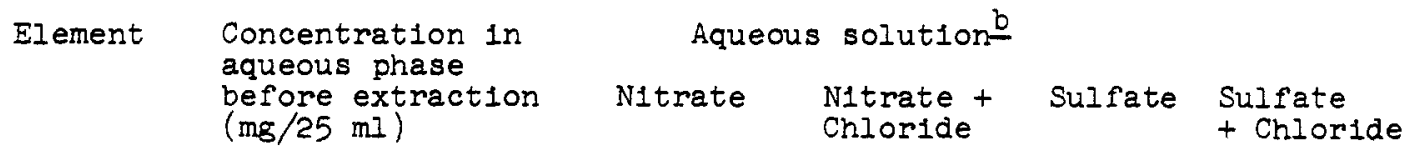

\begin{tabular}{|c|c|c|c|c|c|}
\hline A. & 500 & 0.003 & 0.003 & 0.000 & 0.003 \\
\hline $\mathrm{Ba}$ & 362 & 0.02 & & & \\
\hline " & 7 & 0.35 & & & \\
\hline $\mathrm{Cd}$ & 501 & 0.024 & & 0.003 & \\
\hline$"$ & 500 & & 0.026 & & \\
\hline$"$ & 10 & 0.053 & 0.01 & & \\
\hline$"$ & 10.5 & & & 0.004 & \\
\hline $\mathrm{Ca}$ & 521 & 0.011 & & $--c$ & \\
\hline$"$ & 500 & & 0.0001 & & $-\underline{-c}$ \\
\hline$"$ & 10.4 & 0.020 & & & $0 . \overline{00}$ \\
\hline CI & 496 & 0.026 & & & \\
\hline$"$ & 494 & & & 0.02 & \\
\hline$"$ & 10.3 & 0.025 & & & \\
\hline$n$ & 9.9 & & & 0.03 & \\
\hline $\operatorname{Cr}(I I I)$ & 500 & 0.003 & 0.004 & 0.0001 & \\
\hline$"$ & 10 & 0.0023 & 0.013 & 0.0004 & \\
\hline Co & 555 & 0.007 & & & \\
\hline$"$ & 500 & & 0.002 & 0.00013 & \\
\hline$"$ & 11 & 0.012 & & & \\
\hline$"$ & 10 & & 0.009 & 0.0065 & \\
\hline $\mathrm{Cu}(\mathrm{II})$ & 500 & 0.026 & 0.024 & 0.000 & \\
\hline$"$ & 10 & 0.017 & 0.018 & 0.000 & \\
\hline $\mathrm{Fe}(I I I)$ & 515 & 0.031 & & 0.003 & \\
\hline$"$ & 500 & & 1.2 & & \\
\hline$"$ & 10.3 & 0.035 & & 0.002 & \\
\hline
\end{tabular}

\begin{tabular}{|c|c|c|c|c|c|}
\hline$" 1$ & 10.0 & & 0.046 & & \\
\hline $\mathrm{Pb}$ & 500 & 0.017 & & $-\underline{-c}$ & \\
\hline$"$ & 10 & 0.007 & & 0.005 & \\
\hline $\operatorname{Mn}(I I)$ & 500 & 0.0011 & & 0.00006 & \\
\hline$"$ & 10 & 0.0014 & & 0.00075 & \\
\hline $\mathrm{Hg}(I I)$ & 497 & & 0.21 & & 0.015 \\
\hline$"$ & 127 & 0.19 & & 0.036 & \\
\hline$"$ & 10 & 0.41 & 0.176 & 0.23 & 0.03 \\
\hline Mo (VI) & 500 & 0.028 & 0.10 & 0.001 & 0.001 \\
\hline$"$ & 10 & 0.10 & & 0.015 & \\
\hline
\end{tabular}


Table XIV. - Continued

Element Concentration in aqueous phase before extraction (mg/25 ml)

Aqueous solution $\frac{\mathrm{b}}{2}$

Nitrate + Sulfate Sulfate Chloride + Chloride

\begin{tabular}{llll}
\hline $\mathrm{N} 1$ & 516 & & 0.0001 \\
$"$ & 500 & 0.0018 & \\
$"$ & 10.3 & & 0.0008
\end{tabular}

$"$

10

0.0032

0.00064

$\mathrm{P}\left(\mathrm{PO}_{4}^{3-}\right) \quad 500$

0.00005

0.00001

"

10

0.00024

0.00

$\mathrm{Ag}$

500

0.09

0.005

"

10

0.32

0.005

$\mathrm{SO}_{4}^{2-} \underset{10}{\left(\operatorname{as}\left(\mathrm{NH}_{4}\right)_{2} \mathrm{SO}_{4}\right)} \quad 500$

0.00

0.00

Th

500

9.12

11.5

0.0001

0.0001

"1

10

87.5

0.005

$\operatorname{Sn}(I V)$

500

0.0024

0.37

0.00015

0.000

"1

10

0.019

0.0006

$\mathrm{Ti}(I V)$

11

0.003

0.00

0.035

$\mathrm{W}$

10

0.081

0.0025

$\mathrm{V}(\mathrm{V}) \quad 140$

107

0.22

"

14

0.12

\section{5}

0.07

0.12

$"$

497

$2 n$

447

0.018

10

$"$

8.9

0.022

0.000

Zr

10

0.040

0.013

a Adapted from A. G. Jones, C-4.360. 3(1945).

Equal volume portions of aqueous solution and pentaether.

b Nitrate : $3 / 4$ saturated ammonium nitrate solution.

Sulfate : saturated ammonium sulfate solution.

Chloride: chloride added as ammonium chloride equivalent to the metal present.

$\subseteq$ Precipitates of insoluble sulfate obtained in amonium sulfate layer. 


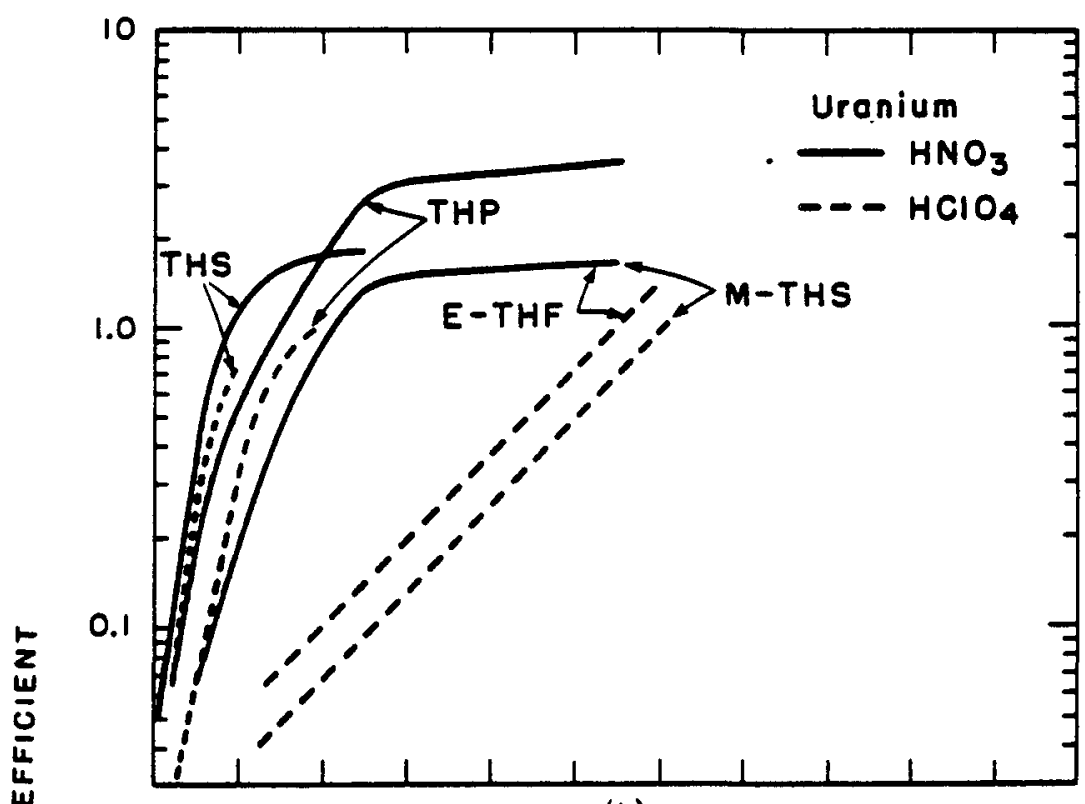

(A)

$\frac{2}{12}$

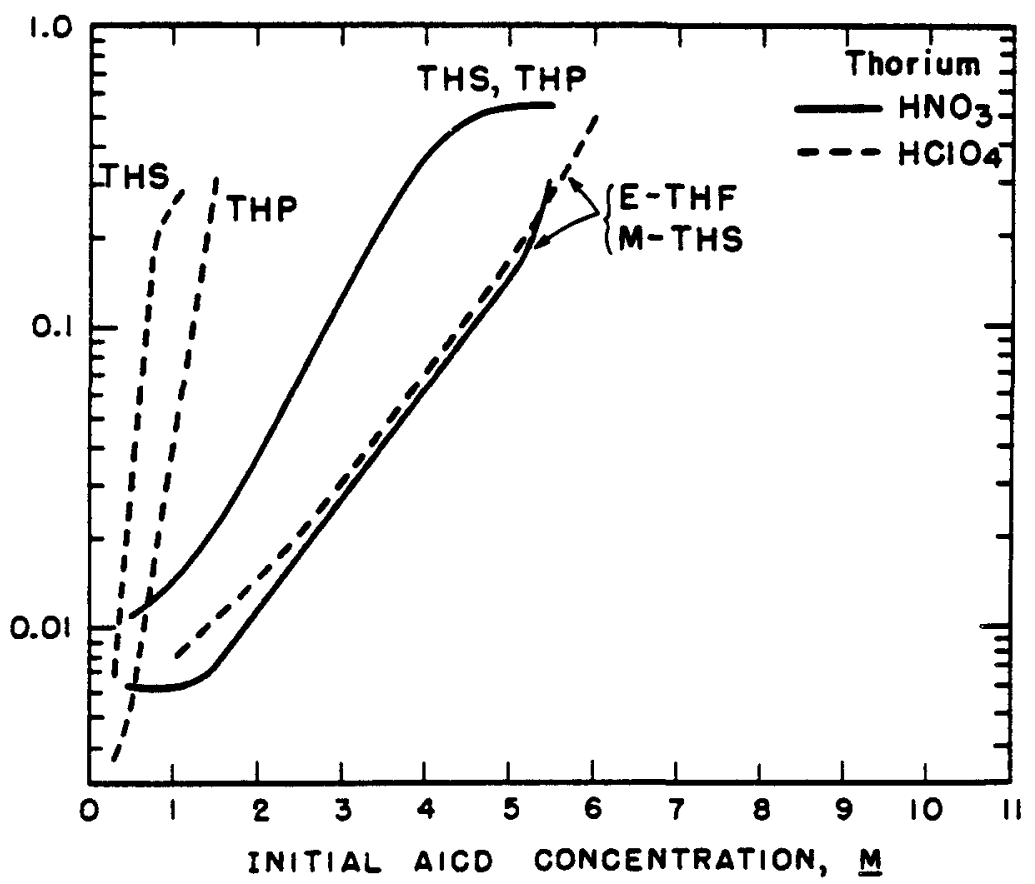

(B)

Figure 25. The effect of 1nitial nitric and perchloric acid concentration on the extraction of uranyl salts (F1g. 25-A) and thorlum salts (F1g. 25-B) by tetrahydrosylvane (THS), tetrahydropyrane (THP), 2 ethyltetrahydrofurane (ETHF), and 2,5-dlmethyltetrahydrofurane (MTHS). After $M$. Branica and $E$. Bona, reference 364 . Conditions: Uranium concentration, $2 \times 10-3 \mathrm{M}$. Thorium concentration, tracer $\mathrm{UX}_{1}$. Temperature, $25 \pm 0.2^{\circ} \mathrm{C}$. $\mathrm{v}_{0} / \overline{\mathrm{v}}, 1$. 
general survey work (Table VIII), have studied the extraction of thorlum and uranium by ethyl acetate, n-propyl acetate, and 1so-propyl acetate as a function of the nitrate concentration of the aqueous phase. It was the observation of the latter group 316 that the extraction of uranium tends to decrease with increasing molecular welght of the ester. Therefore, only acetates and proplonates need to be considered serlously. Increased protactinum extraction was observed with increasing length of the alcohol portion of the ester. 316 It was further observed that hydrolysis of the ester tends to increase the extraction of both thorium and uranium. 316 It was not determined whether the addition of alcohol or organic acid causes the increased extraction.

\section{Ethyl acetate}

Agueous_n1trate_systems. The distribution of uranyl nitrate between ethyl acetate and water has been studied by deKeyser, Cypres, and Hermann. 164 The partition coefficient was found to vary from 0.17 at $22 \% \mathrm{UO}_{2}\left(\mathrm{NO}_{3}\right)_{2} \cdot 6 \mathrm{H}_{2} \mathrm{O}$ in the aqueuus phase to 0.78 at $43 \%$ aqueous concentration. In laboratory practice, uranium is extracted by the solvent from aqueous nitrate media. The following conditions have been used by various groups to extract uranlum:

Grimaldi and Levine 365 : $9.5 \mathrm{~g}$. of $\mathrm{Al}\left(\mathrm{NO}_{3}\right)_{3} \cdot 9 \mathrm{H}_{2} \mathrm{O}$ are added to $5 \mathrm{ml}$ of solution approximately $2.4 \mathrm{~N}$ In $\mathrm{HNO}_{3} \cdot 10 \mathrm{ml}$ of ethyl acetate are added and shaken at least 30 seconds.

Rodden and Tregonning 366 : Uranium precipitated in the presence of aluminum ( $20 \mathrm{mg}$ ) with $\mathrm{NH}_{4} \mathrm{OH}$ is dissolved In $1 \mathrm{ml}$ of $\mathrm{HNO}_{3}\left(1\right.$ to 1 ). $8 \mathrm{~g}$. of $\mathrm{Mg}\left(\mathrm{NO}_{3}\right)_{2} \cdot 6 \mathrm{H}_{2} \mathrm{O}$ is added and the volume adjusted to $10 \mathrm{ml}$ with water. $5 \mathrm{ml}$ of ethyl acetate are added and vigorously shaken for 2 minutes. (Used with $20-400 \mathrm{mg}$ samples of $\mathrm{U}_{3} \mathrm{O}_{8}$ ) 


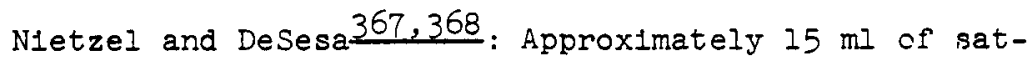
urated aluminum nitrate solution are added to $3 \mathrm{ml}$ or less of sample containing 0.30 to $15 \mathrm{~g}$. of $\mathrm{U}_{3} \mathrm{O}_{8}$ per liter. $20 \mathrm{ml}$ of ethyl acetate are added and shaken for 1 minute.

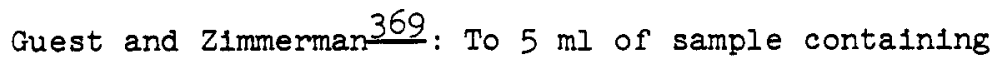
$5 \%$ concentrated $\mathrm{HNO}_{3}$ by volume, $6.5 \mathrm{ml}$ of hot aluminum nitrate solution, having a boling point of $130^{\circ} \mathrm{C}$, are added. The resulting solution is cooled, $20 \mathrm{ml}$ of ethyl acetate are added, and the mixture shaken for 45 to 60 seconds.

Steele and Taverner 198: Approximately $5 \mathrm{ml}$ of aqueous solution are saturated with aluminum nitrate. The resulting solution 1 s shaken with $10 \mathrm{ml}$ of ethyl acetate for 1-2 minutes.

In the procedure of Rodden and Tregonning, $\frac{366}{6 l u m i n u m} \mathrm{n} 1-$ trate is used instead of magnesium nitrate if extraction Is to be made in the presence of phosphate. DeSesa and

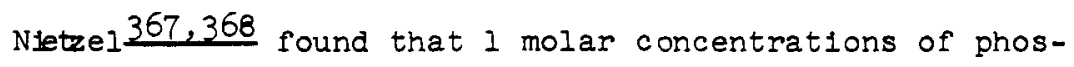
phate, sulfate, or carbonate ion could be tolerated with no 11 effect on uranium extraction. Small amounts of sodium phosphate have been used to suppress the extraction of thorium without affecting the extraction of uranium. 198 Steele and Taverner 198 report the extraction of appreclable amounts of thorium and zirconium and smali amounts of vanadium, molybdenum, and platinum by ethyl acetate. irimaldi and Levine, $\underline{365}$ Guest and Zimmerman, $\underline{369}$ and Nietzel and DeSesa $\frac{367,368}{2}$ have Investigated the effect of a number of elements on the recovery and/or determination of uranium according to their respective procedures. Nietzel and

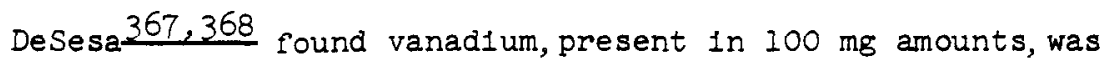
precipltated and uranium was occluded in the precipitatate. Titanium was observed to partlally extract. This was prevented by precipitation of titanium with p-hydroxyphenylarsonic acid before extraction. 
Aqueous thiocyanate_systems. Vanossilo has described a procedure in which uranium is extracted by ethyl acetate from an aqueous phase containing an excess of ammonium thiocyanate. Dizdar and Obrenovic $\frac{371}{1}$ have also investigated the extraction of the uranyl-thlocyanate complex by ethyl acetate.

\section{KETONES}

Methyl ethyl ketone.

Agueous_nitrate_systems. The distribution of uranyl nitrate between methyl ethyl ketone and water and between methyl ethyl ketone and saturated ammonium nitrate solution is given in figure 4-B.․․ Pale1 196 reports a uranium partition coefficient of approximately 25 between methyl ethyl ketone and an aqueous solution of $60 \% \mathrm{NH}_{4} \mathrm{NO}_{3}$ and IN $\mathrm{HNO}_{3}$. Methyl ethyl ketone is not as selective as diethyl ether. 321 Homogeneous solutions are formed between the ketone and an equal volume of saturated ferric or cupric nitrate at $20^{\circ} \mathrm{C}$. 321

Miscellaneous_agueous_systems. The partition coefficlent of uranium between methyl ethyl ketone and an aqueous $60 \% \mathrm{NH}_{4} \mathrm{NO}_{3}, 3 \% \mathrm{NH}_{4} \mathrm{SCN}$ solution 1s about 2000.196 Iron is extracted.

M1lner and Wood $\frac{372}{2 e p o r t ~ t h e ~ s e p a r a t i o n ~ o f ~ t a n t a l u m ~}$ and niobium from uranium by extracting the fluorides of the former elements with methyl ethyl ketone.

Hexone (Methyl 1so-butyl ketone).

Aqueous_nitrate_systems. The partition of uranyl nitrate between hexone and water is represented in figure 4.185,321 The partition coefficients of uranium, nitric acid, and several other actinide elements are plotted as a function of aqueous nitric acid concentration in figure 26.234 The effect of several salting-out agents on the partition coeffi- 


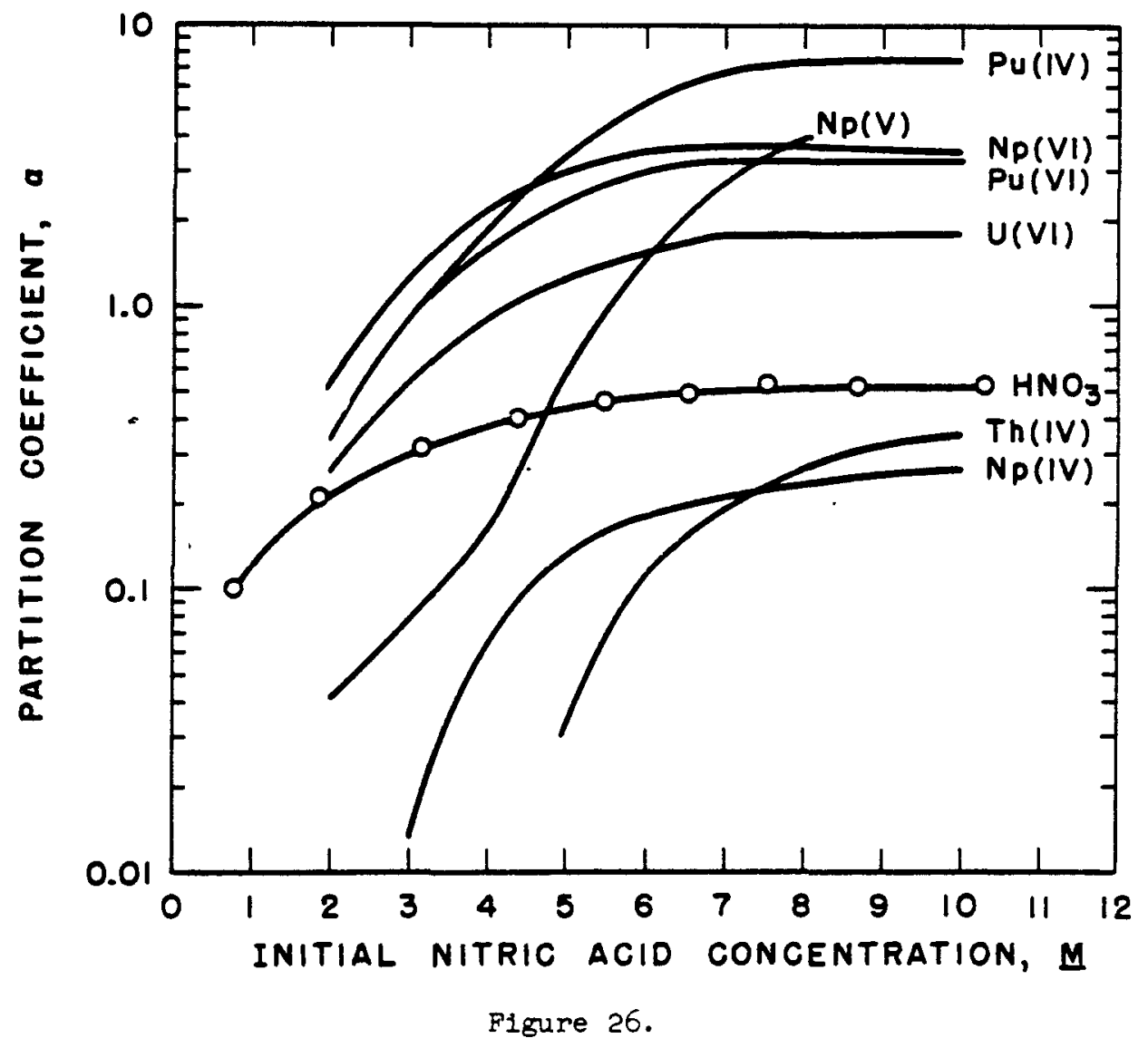

The extraction of niticic acld and actinide nitrates, Th, $U$, $\mathrm{Np}$, and Pu, by methyl 1sobutyl ketone (hexone).

After J. Koo1, reference 334.

Conditions :

Tracer amounts of $\mathrm{Np}^{239}$ or $\mathrm{Pu}^{239}, 330 \mathrm{mg}$ of $\mathrm{Th}\left(\mathrm{NO}_{3}\right)_{4}$. $4 \mathrm{H}_{2} \mathrm{O}$ per $15 \mathrm{ml}$, or $300 \mathrm{mg}$ of $\mathrm{UO}_{2}\left(\mathrm{NO}_{3}\right)_{2}$ (hexahydrate) per $15 \mathrm{ml}$ in nitric acid solution or nitric acid alone equilibrated w1th an equal volume of hexone at $25^{\circ} \mathrm{C}$ or room temperature.

The oxidation states of neptunium havt been the subject of some question. $\underline{345}$ 
cient of uranium is given in figure $27 . \underline{319}$ Vdovenko and co-workers $\frac{325}{2}$ have observed an increase in the partition coefficlents of cesium, calclum, strontium, and lanthanum when the uranyl nitrate concentration in the initial aqueous solution is increased. This has been related to the extraction of the elements as metal uranyl trinitrate salts. The partition coefficient of uranium from a highly salted aqueous solution is decreased by an increase in uranium concentration. Kraus $\frac{373}{3}$ observed $a_{u}$ to decrease from 153 to 78.3 as the initial uranium concentration was increased from 5 to 100 grams in an aqueous solution containing 580 grams of aluminum nitrate. Jenkins and McKay $\frac{374}{4}$ found $a_{u}$ to decrease from 1.58 to 1.28 as the initial uranium concentration was increased from 144 to 348 grams per liter in an aqueous solution $8 \mathrm{M}$ in $\mathrm{NH}_{4} \mathrm{NO}_{3}$ and $0.3 \mathrm{~N}$ in $\mathrm{HNO}_{3}$. In the latter case, comnerclal hexone adjusted to $0.15 \mathrm{~N} \mathrm{HNO}_{3}$ was used as the extractant. Figure 28 represents the extraction of uranium by hexone from aqueous solutions containing various amounts of nitric acid and calcium or sodium nitrate. $\underline{375}$ The distribution of U(VI), Pu(VI), Pu(IV), Th, Ia, Ca, Na, and $\mathrm{HNO}_{3}$ by hexone from aqueous solutions containing nitric acid and calcium nitrate has been investigated by Rydberg and Bernström. 376 Hyde and co-workes's have studied the extraction of uranium $\frac{316}{}$ and thorium $\frac{316,377}{1}$ by hexone as a function of the total nitrate concentration of the aqueous phase. Distribution curves ( $a$ or $P$ versus nitric acid or total nitrate concentration of the aqueous phase) are presented for the various elements in the different papers. The effect of aluminum nitrate concentration on the extraction of fission product gamma-activity in general and zircontum-niobium, cerium, and ruthenium in particular is shown in figure 29. 378 Increased extraction is effected by an increase in salting-out agent. An increase in nitric acid concentra- 


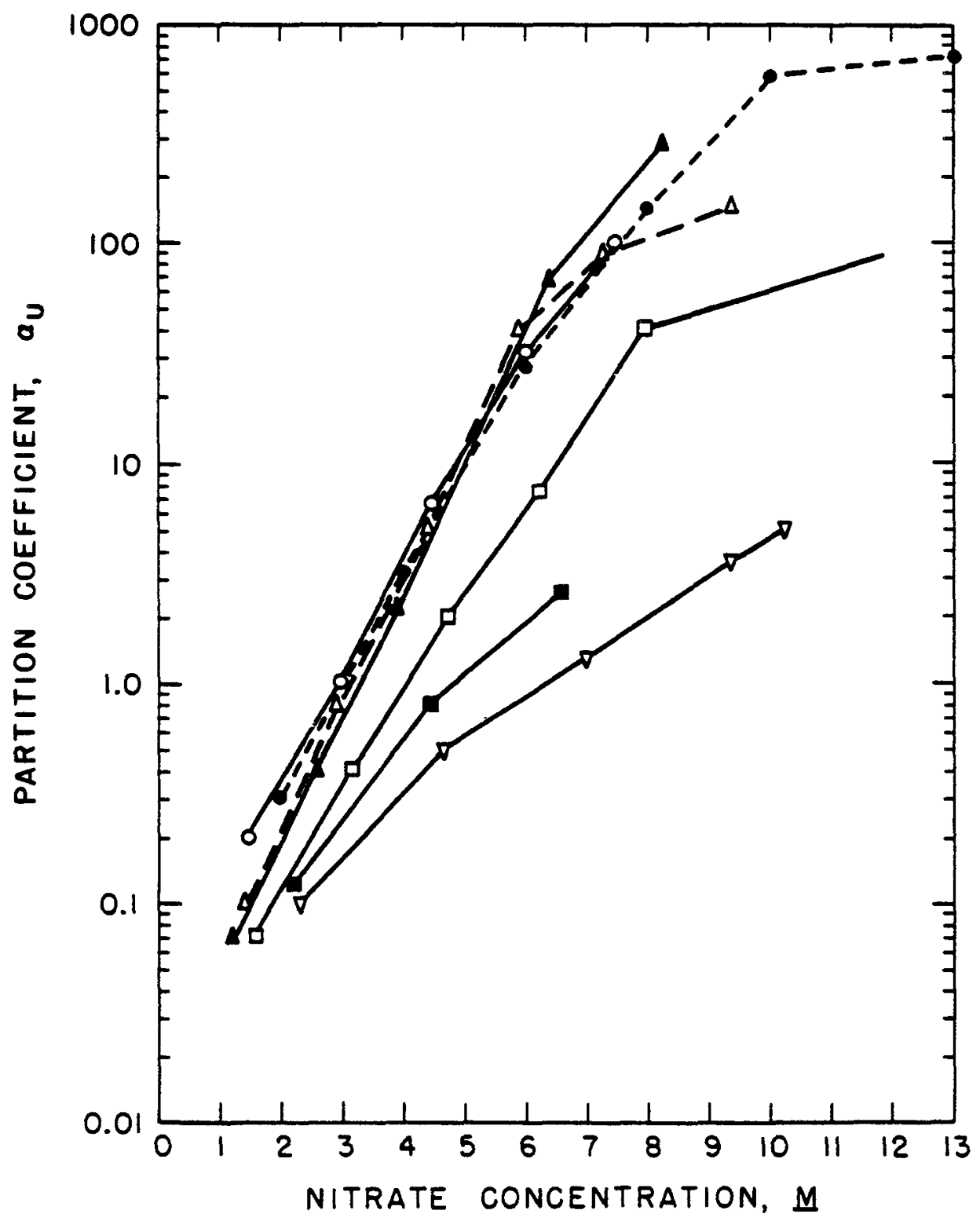

Figure 27. The effect of various salting-out agents on the extraction of uranium by hexone. $\nabla \mathrm{NH}_{4} \mathrm{NO}_{3}, \mathrm{NaNO}_{3}, \square \mathrm{Ca}\left(\mathrm{NO}_{3}\right)_{2}, \Delta \mathrm{Co}\left(\mathrm{NO}_{3}\right)_{2}, \Delta$ $\mathrm{Mg}\left(\mathrm{NO}_{3}\right)_{2},-\mathrm{Be}\left(\mathrm{NO}_{3}\right)_{2}, \mathrm{OAI}\left(\mathrm{NO}_{3}\right)_{2}$. After $\mathrm{W}$. $\mathrm{H}$. Baldwin, reference 319. Conditions: Equal volumes of pure hexone used to extract aqueous contalning $30 \mathrm{~g}$ U/liter. 


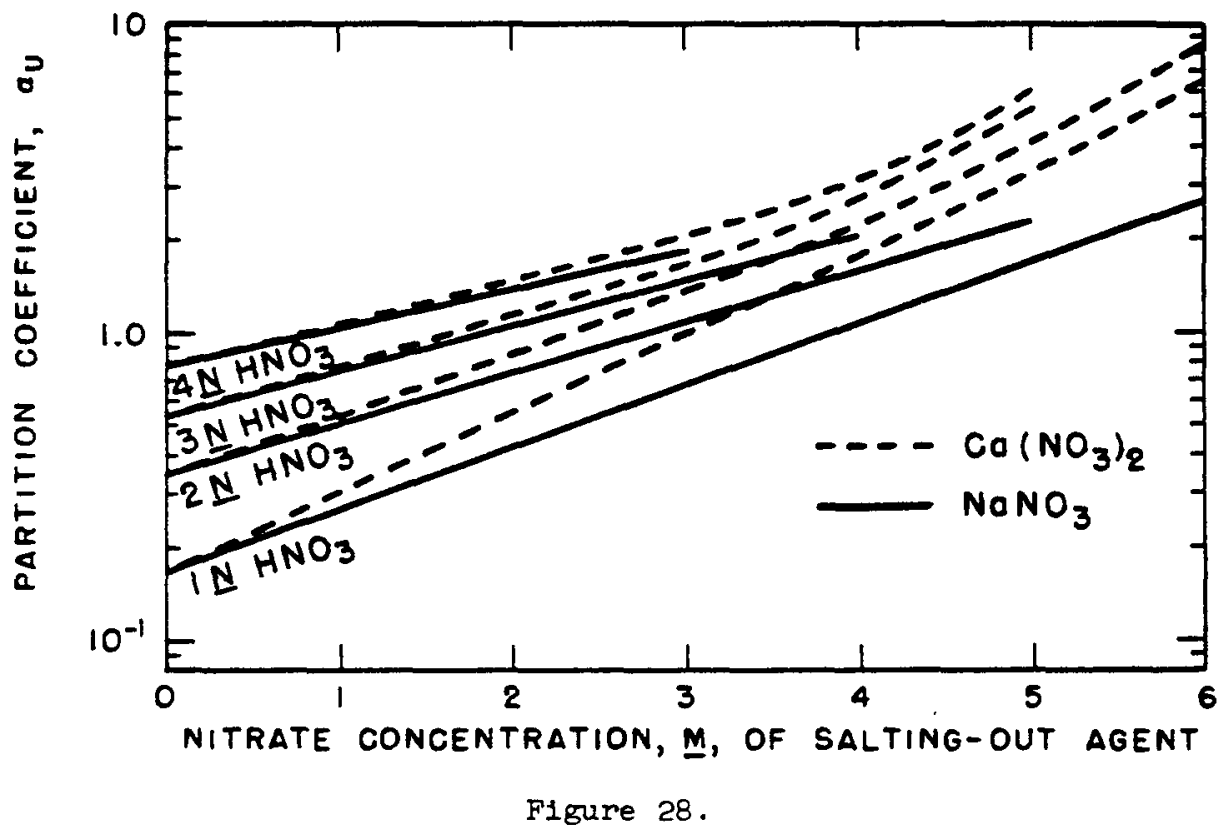

The partition coefficient of uranium as a function of the nitrate concentration of the salting-out agents, $\mathrm{Ca}\left(\mathrm{NO}_{3}\right)_{2}$ and $\mathrm{NaNO}_{3}$, for an initial concentration in the aqueous phase of $100 \mathrm{~g} / \mathrm{l}$ of uranium and $1,2,3$, or $4 \mathrm{M} \mathrm{HNO}_{3}$. After A. Cacclari, R. DeLeone, C. Fizzott1, and M. Gabagl10, reference 375 .

tion also causes an increased extraction of fission products (figure 29). 378

The extraction of uranium by hexone is facilitated by the presence of substituted ammonium nitrates which are sufficlently soluble in the organic solvent. A number of these salts and their effect on the extraction of uranium are listed in Table XV. 78 Tri-n-butylamine, 2-hexyl pyridine, and dibenzoyl methane increase the extraction of fission products. $\frac{378}{}$ Maeck, et al. $\frac{379}{3}$ have investigated the extraction of uranium by hexone from an aqueous solution containing aluminum nitrate and tetrapropylammonlum nitrate. The extraction conditions adapted as a result of the 


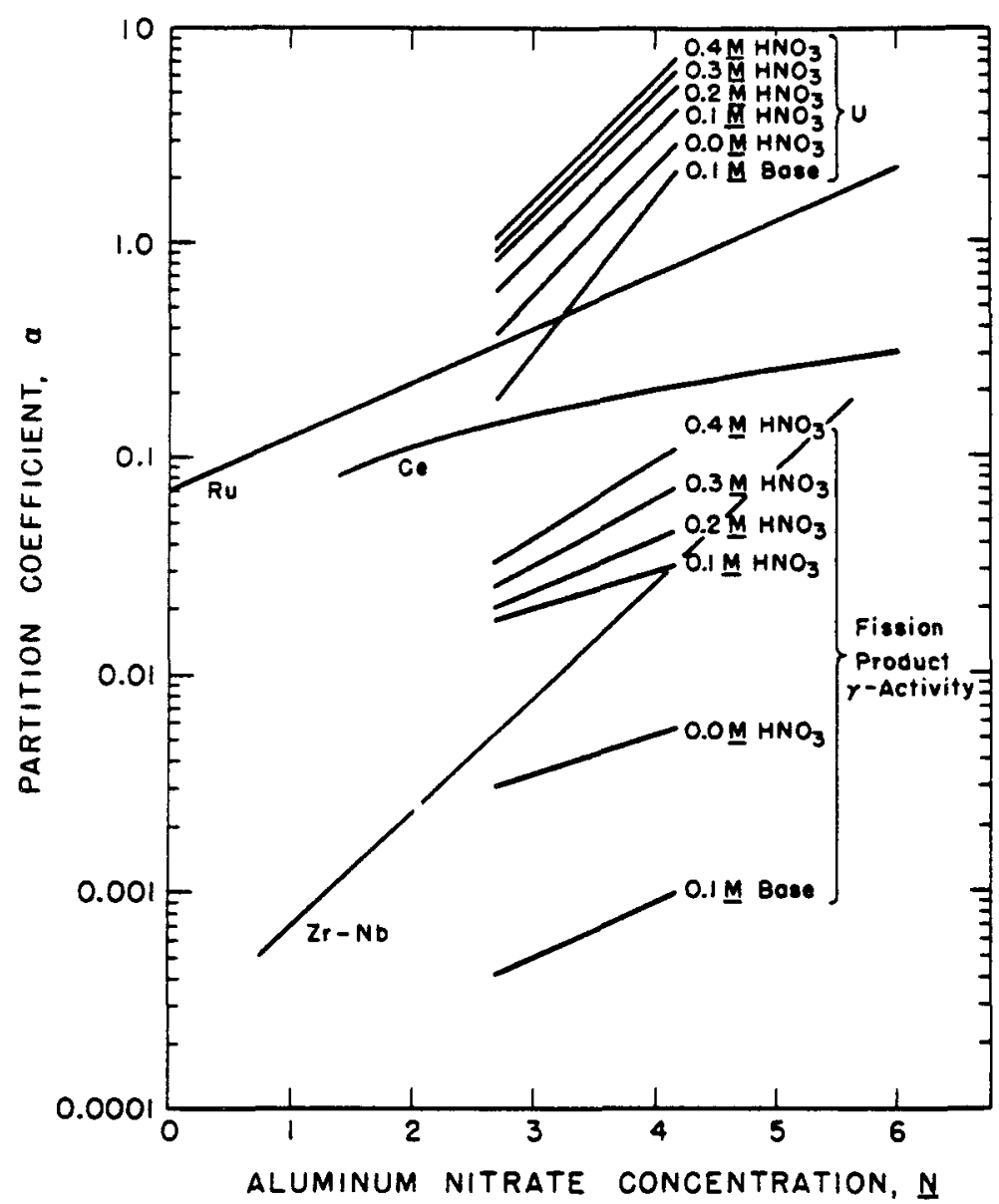

Figure 29. The effect of salting-out agent, $\mathrm{Al}\left(\mathrm{NO}_{3}\right)_{3}$, on the extraction of uranium and fission products by hexone from aqueous solution at various nitric acid concentrations. After F. R. Bruce, reference 378 .

\section{Conditions:}

The results on urantum and gross fission product activity were obtained using C.P. $\mathrm{AI}\left(\mathrm{NO}_{3}\right)_{3}$ as salting-out agent and pretreated hexone as solvent. An 1rradiated uranium slug, cooled 144 days and dissolved in $\mathrm{HNO}_{3}$, was used as activity source. Extractions were made at $30^{\circ} \mathrm{C}$ from an aqueous phase oxidized 1 hour w1th $0.1 \mathrm{M} \mathrm{Na}_{2} \mathrm{Cr}_{2} \mathrm{O}_{7}$ at this temperature. The nitric acid is the sum of that in the aqueous and organic phases, expressed as moles of nitric acid per liter of aqueous phase.

Ruthentum extraction:aqueous phase--0.1M $\mathrm{K}_{2} \mathrm{Cr}_{2} 07,0.2 \mathrm{M}$ $\mathrm{HNO}_{3}, \mathrm{AI}\left(\mathrm{NO}_{3}\right)_{3}$

Cerium extraction:aqueous phase--0.025M $\mathrm{Na}_{2} \mathrm{Cr}_{2} \mathrm{O}_{7}, 0.5 \mathrm{M}$ $\mathrm{HNO}_{3}, \mathrm{Al}\left(\mathrm{NO}_{3}\right)_{3}$. Z1rconlum-nioblum extraction:aqueous phase--0.1M $\mathrm{K}_{2} \mathrm{Cr}_{2} \mathrm{O}_{7}$,
$0.25 \mathrm{M} \mathrm{HNO}_{3}, 8 \mathrm{~g} \mathrm{U}$ per liter. 
Table XV. Effect of Substituted Ammonium Nitrates $\left(\mathrm{RNO}_{3}\right.$ ) on the Extraction of Uranyl Nitrate by Hexone. 2

\begin{tabular}{ll} 
Cation, $\mathrm{R}$ & Total $\mathrm{RNO}_{3}$ \\
& concentration \\
& $\left(\right.$ mol $\left./ 1 \times 10^{3}\right)$ \\
\hline
\end{tabular}

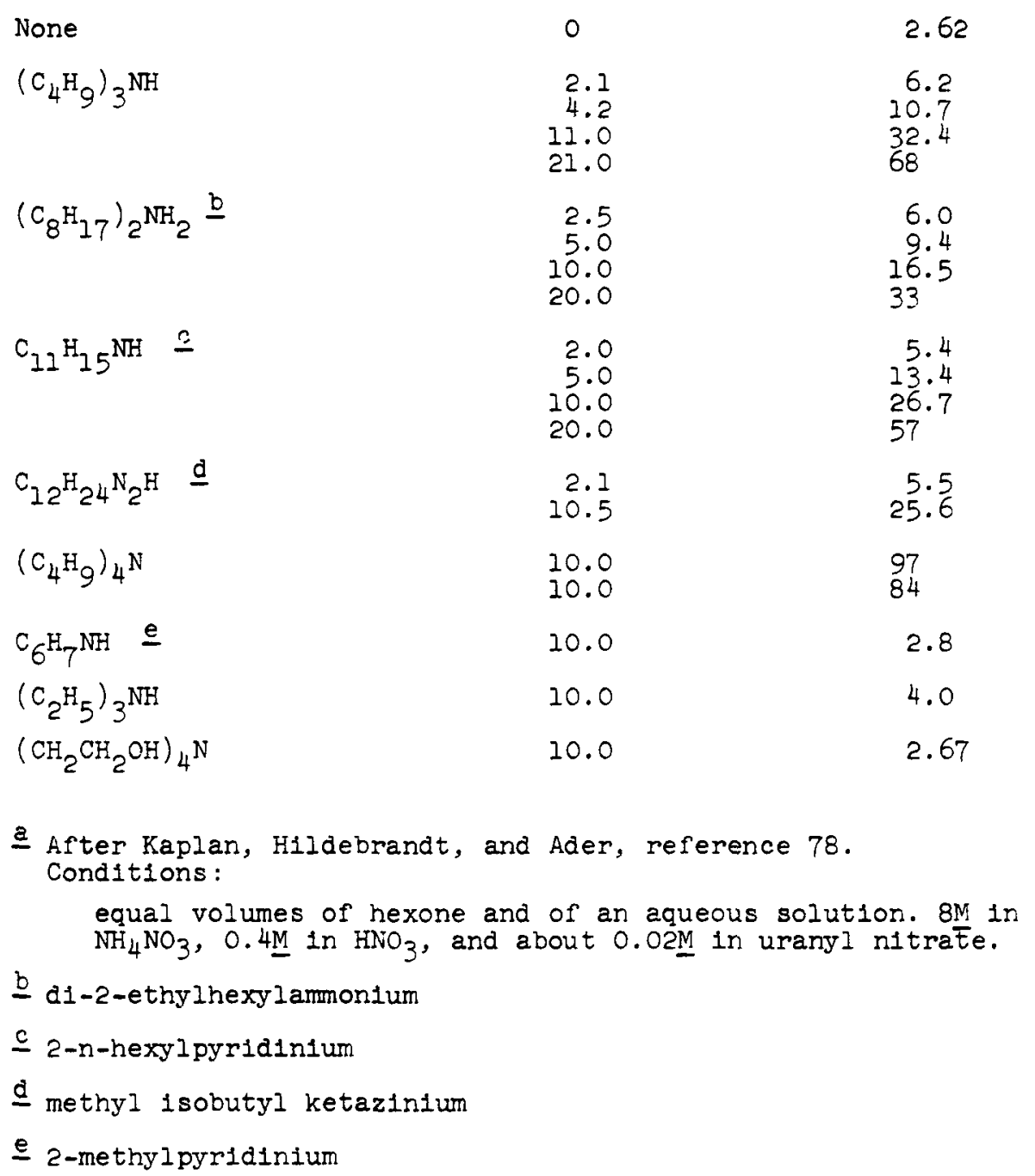

investigation were $4.0 \mathrm{ml}$ of $2.8 \mathrm{M}$ aluminum nitrate, IN acio-deficient, containing $0.1 \%$ (weight/volume) tetrapropylammonium nitrate; $2.0 \mathrm{ml}$ hexone; and a sample size of $0.5 \mathrm{ml}$ (-2 $\mathrm{mg}$ of uranlum). These conditions provide a good separation of uranium from many ions. The separation from zirconium-niobium is particularly good. The recovery 
of urantum is excelient even in the presence of forelgn anions ( 10 to 1 mole ratio of anion to uranium). Of those anions tested, tungstate ion interferes most seriously (only 64.28\% uranlum extracted). Chlorlde, sulfate, phosphate, acetate, oxalate, etc., in the amounts tested, exh1b1t no appreciable interference in the extraction of uranium. Chloride does promote the extraction of those lons which form anionic chloride complexes, eg. gold (III). Certain other anions enhance the extraction of fission products, eg. dichromate and thiosulfate increase cerium extraction.

Agueous_th1ocyanate_systems. Uranlum $(V I)$ is extracted by hexone from aqueous thiocyanate solution. $\frac{371,380}{2}$ Reas $\frac{380}{20}$ has investigated the separation of uranium and thorlum by this means. Some of his results are given in Table XVI. The effect of sulfate ion (experimental conditions $B$ ) is to hinder the extraction of both thorium and urantum. The effect, however, is greater for thorlum than for uranium. Consequently, greater separation of thorlum and uranium can be made in the presence of the complexing sulfate 1 on. The extraction of protactinium from an aqueous solution 1.2M In $\mathrm{NH}_{4} \mathrm{NO}_{3}, 0.20 \mathrm{M}$ in $\mathrm{HNO}_{3}$, about $0.01 \mathrm{M}$ in $\mathrm{Th}\left(\mathrm{NO}_{3}\right)_{2}, 0.00987 \mathrm{M}$ in $\mathrm{Na}_{2} \mathrm{SO}_{4}$, and $0.501 \mathrm{M}$ in $\mathrm{KSCN}$ by an equal volume of hexone was $\leq 4.4 \%$. Decontamination from fission products is not too good. Equilibration of equal volumes of hexone and an aqueous solution approximately $0.04 \mathrm{M}$ in $\mathrm{UO}_{2}\left(\mathrm{NO}_{3}\right)_{c}$, $0.504 \mathrm{M}$ in $\mathrm{Th}\left(\mathrm{NO}_{3}\right)_{4}, 0.485 \mathrm{M}$ in $\mathrm{Na}_{2} \mathrm{SO}_{4}$, and $1 \mathrm{M}$ in $\mathrm{HNO}_{3}$ resulted in a beta decontamination factor of about 6.6 and a soft gamme decontamination factor of about 1.5. Z1rconlum was found to be the principal fission product extracted.

\section{Methylcyclohexanone}

Agueous n1trate systems: This solvent has been studied 
Table XVI. Separation of $U(V I)$ from $T h(I V)$ by Thiocyariate systems. a

\begin{tabular}{|c|c|c|c|c|}
\hline ExperimentaI & conditions & $\begin{array}{c}\mathrm{KSM} \\
\mathrm{M} \\
\end{array}$ & $\frac{x^{e x t r a c t e d}}{\not}$ & Th extracted \\
\hline & A & 0.27 & 64.5 & $1.03-1.6$ \\
\hline & A & 0.54 & 82 & $1.5-1.8$ \\
\hline & A & 0.97 & 89.5 & $2.1-3.1$ \\
\hline & A & 1.62 & 95 & $5.2-6.2$ \\
\hline & A & $\begin{array}{l}0.32+0.11 \mathrm{M} \\
\text { antipyrine }\end{array}$ & 79 & $3 \cdot 3$ \\
\hline & B & 0.501 & 63 & $0.14^{*}$ \\
\hline & B & 0.25 & 35 & $0.015^{*}$ \\
\hline
\end{tabular}

E After W. H. Reas, reference 380 .

Experimental conditions:

A: $\quad 0.16 \mathrm{M} \mathrm{VO}\left(\mathrm{NO}_{3}\right)_{2}, 0.81 \mathrm{M} \operatorname{Th}\left(\mathrm{NO}_{3}\right)_{4}$, volume of aqueous phase $=6.2 \mathrm{mI}$, volume of hexone $=10 \mathrm{ml}$.

B: $0.0974 \mathrm{M} \mathrm{UO}_{2}\left(\mathrm{NO}_{3}\right)_{2}, 0.252 \mathrm{M} T h\left(\mathrm{NO}_{3}\right)_{4}, 0.2 \mathrm{M} \mathrm{HNO}_{3}, 0.224 \mathrm{M}$ $\mathrm{Na}_{2} \mathrm{SO}_{4}$, volume of aqueous phase $=10 \mathrm{ml}$, volume of hexone $=10 \mathrm{ml}$.

The thorlum extraction was performed under slightly different conditions in that $\mathrm{NH}_{4} \mathrm{NO}_{3}$ was substituted for $\mathrm{UO}_{2}\left(\mathrm{NO}_{3}\right)_{2}$. An 1onfum ( $\mathrm{Th}_{2} 23 \mathrm{O}$ ) Eracer was added to the solution and the distribution was measured by the determination of lonium in each phase.

by workers in Czechoslovakia as a means of separating uranium from thorium $\frac{381}{2}$ and fission products. 323,382 The extractability of uranlum by methylcyclohexanone from sodium nitrate solution (6-8M) is considerably better than that of thortum? 381 From nitric acid solution (8M), the extractability of uranium Is only two- to three-fold greater than that of thorium. 381 Ammonium nitrate is comparable to sodium nitrate as a salting-

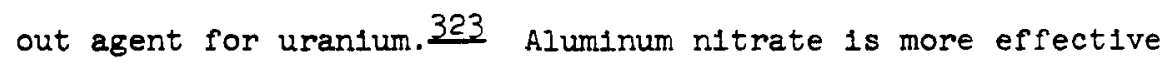
than elther. However, the order of salting-out agents in causing increased fission product extractability is $\mathrm{AI}>\mathrm{Na}>$ $\mathrm{NH}_{4}$. The best separation of uranium from fission products Is achleved with ammonium nitrate as the salting-out agent. 323 Methylcyclohexanol present in commercial methylcyclohexanone suppresses the extraction of uranium and fission 
products. The separation factor between the two activities, however, is increased since the partition coefficient of fission products is decreased more than that of uranium. $\frac{323}{3}$ The partition of uranium between methylcyclohexanone and water and methylcyclohexanone and $6 \mathrm{M}$ ammonium nitrate solution is given in figure $4-B . \underline{323}$

\section{Other ketonic solvents}

Hyde and Wolf $\frac{316}{}$ have studied the extraction of uranium and thorlum by methyl $n$-amyl ketone and disopropyl ketone as a function of total nitrate concentration in the aqueous phase. In both cases, uranium was better extracted than thorium. The extraction of thorium did not become appreciable $(<5 \%)$ until the aqueous nitrate concentration was greater than 5M. Dilsopropyl ketone was found to be an excellent extractant of protactinium. 316

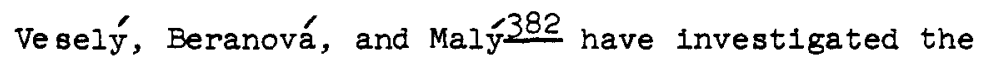
extraction of uranium and fission products by several methylalkyl ketones: methylhexyl, methylamyl, methlbutyl, and methylpropyl in addition to methyl isobutyl and methylcyclohexanone. The partition coefflclents of both uranium and fission product activity rere measured as a function of acid concentration in the range of -0.4 to $3 \mathrm{M}$ nitric acid. In this acidity range, fission product extraction was found to be maximum in the 0-IM nitric acid region. The partition coefficient, $a_{F P}$, in this region was greatest with methylpropyl ketone $\left(22 \times 10^{-3}\right.$ at $\left.0.61 \mathrm{M}\right)$ and least with methylhexyl ketone $\left(2.4 \times 10^{-3}\right.$ at $\left.0.03 \mathrm{M}\right)$. In the acid-deficlent region, $\alpha_{F P}$ increased as the acld-deficiency was decreased (the solution was made more acidic). After the maximum $\alpha_{F P}$ was reached in the $0-1 M$ acid region, the partition coefficlent was decreased and then increased as the aqueous solution was made more acldic up to $3-4 \mathrm{M}$. The partition 
coefficient of uranium, $\alpha_{u}$, increased as the nitric acid concentration was increased over the entire range. At $3 \mathrm{M}$ nitric acid, $\alpha_{u}$ varied from about 0.7 for methylhexyl ketone to about 2 for methylpropyl ketone and 3 for methylcyclohexanone. The greatest separation, $\beta$, of uranium from fission products was found in the $0.1 \mathrm{M}$ ac1d deflcien region $(-0.1 M)$. For methylhexyl ketone, $\beta$ was found to be $>1500$; for methylpropyl ketone, $\beta$ was about 400 . The extraction coefficients of uranium were $<0.2$ for methylhexyl ketone and about 0.5 for methylpropyl ketone at this acid concentration. Allen $\frac{383}{3}$ has tested disobutyl ketone, disopropyl ketone, and methylhexyl ketone as solvents for the purif1cation of uranium from 1ron, copper, chromium, and nickel. Di1sobutyl ketone was found most satisfactory under the conditions tested. Dilsopropyl extracted some iron and chromium. Methylhexyl ketone extracted 1ron, chromium, and copper.

Uranium and thorium may be extracted quantitatively from a nitrate medium by mesityl oxide. 384 Under the conditions tested ${ }^{*}$ zirconium is extracted to a large extent; vanadium and yttrium to a lesser extent; cerium only slightly.

\section{ALCOHOLS}

Hyde and Wolf $\frac{316}{6}$ found alcohols to be only falr extractants of uranium and the extraction capacity to decrease rapidly with the length of the carbon chain. This is bome out by the work of Poston, et al. $\frac{385}{}$ who measured the extraction coefficients of uranium and ruthenium as a function of aluminum nitrate concentration of the aqueous phase for

\footnotetext{
* Experimental conditions: A salt of the elements tested was dissolved in $10 \mathrm{ml}$ of $\mathrm{HNO}_{3}(15+85)$. Nineteen grams of alumInum nitrate crystals were added and dissolved. The solution was shaken for 15 seconds with $20 \mathrm{ml}$ of mesityl oxide. The extract was washed once with $20 \mathrm{ml}$ of aluminum nitrate solution and analyzed.
} 
hexone and several tertiary alcohols: tertiary amyl alcohol, 2-methyl 2-pentanol, 2-methyl 2-hexanol, 2-methyl 2-heptanol. only tertiary amyl alcohol extracted uranium better than hexone $\left(0.5-1.5 \mathrm{M} \mathrm{Al}\left(\mathrm{NO}_{3}\right)_{3}, 0.2 \mathrm{MHNO}_{3}\right)$ and all four alcohols extracted mathenlum better than hexone. Ruthenlum was extracted as well or nearly as well as uranium by the alcohols.

Dilsobutylcarbinol extracts ruthenium nearly as well as uranium. 386 Thorlum and z1rconium-rablum are poorly extracted. Protactinium is extracted much more efficiently than uranium.

\section{MISCELIANEOUS SOLVENTS}

Nitromethane has been recommended by Warner 322 as an extractant for uranium. It is resistant to oxidation, stable to high concentrations of nitric acid, and highly selective. The distribution of uranyl nitrate between nitromethane and water and nitromethane and saturated ammonIum nitrate solution is given in figure 3-B. The extraction of thorium nitrate by nitromethane from aqueous solution is much less than that of uranium. Color tests indicate that neither copper, cobalt, iror. (II), nor chromium nitrate is extracted by the solvent. W1th diethyl ether, considerable amounts of copper nitrate and trace amounts of ferric nitrate are extracted. Nitric acid enhances the extraction of uranyl nitrate by nitromethane. However, above a critical acid concentration ( $-5 \mathrm{~N}$ inftial acid concentration with equal phase volumes at $20^{\circ} \mathrm{C}$ ) only one liquid phase is formed.

ORGANOPHOSPHORUS COMPOUNDS. W1thin recent years, a large number or organophosphorous compounds have been developed and Investigated as extractants for uranium. These compounds have been subdivided in the present paper Into neutral and ac1dic organophosphorus compounds. 
Solvents included in this category are trialkylphosphates. $(R O)_{3} P \rightarrow 0$; dialkyl alkylphosphonates, $(R O)_{2} R P \rightarrow 0$; alkyl dialkylphosphinates, $(R O) R_{2} P \rightarrow 0$; and trialkylphosphine oxides $R_{3} P \rightarrow 0$. The ability of the solvents to extract uranium is in the order

$$
(R O)_{3} P \rightarrow 0<\left(R O_{2}\right) R P \rightarrow 0<(R O) R_{2} P \rightarrow 0<R_{3} P \rightarrow 0 .
$$

This is also the order of increasing base strengthe of the phosphoryl oxygen. 302 In Table XVII, the four types of compounds are compared as extractants of uranium (VI), plutonium (IV), thorlum, f1ssion products, and ac1as. $\frac{387}{1}$ It should be noted that although uranium is extracted almost quantitatively by tributylphosphine oxide (Table XVII), other elements are also highly extracted. In fact, in spite of lower extraction coeficlents, tributyl phosphate affords a better separation of uranium from thorlum, plutonium (IV), and fission products under the conditions isted in Table XVII than does tributylphosphine oxide.

Tables XVIII $\frac{388,389}{3}$ and XIX $\frac{390}{11 s t}$ the distribution coefficients of uranium and some associated elements for a number of neutral organophosphorus extractants. Similar information on other solvents may be found in papers by Burger, 391 Healy and Kennedy, $\underline{188}$ and in numerous ORNL reports. The latter have been summarized by Blake, et $21 . \underline{302}$ and Brown, et al 303,305

The mechanism of extraction by neutral organophosphorus reagents appears to be similar to that of tributyl phosphate. 188 , 302,387 From nitrate systems, the extraction of uranium by tributyl phosphate and trloctylphosphine oxide is described falrly well by the equili'srium reaction

$$
\mathrm{UO}_{2}^{2+}+2 \mathrm{NO}_{3}^{-}+2 \mathrm{~S}=\mathrm{UO}_{2}\left(\mathrm{NO}_{3}\right)_{2}(\mathrm{~S})_{2},
$$

where $S$ represents the solvent molecule. 302 Extraction may be made by tributyl phosphate from chloride solution. Stronger 
Table XVII. Comparison of the Extractive Capac1ties of Various Types of Organophosphorus Compounds:

\begin{tabular}{|c|c|c|c|c|c|c|c|c|c|c|c|c|c|c|}
\hline & \multicolumn{5}{|c|}{ Extraction of $\mathrm{UO}_{2}\left(\mathrm{NO}_{3}\right)_{2}$} & \multicolumn{7}{|c|}{$\begin{array}{c}\text { Extraction of } U_{G} \mathrm{Pu}, \text { and Fission } \\
\text { Products }\end{array}$} & \multicolumn{2}{|r|}{$\begin{array}{l}\text { Extraction of } \\
\text { The }\end{array}$} \\
\hline & \multicolumn{5}{|c|}{ N1tric acid concentration } & \multirow{2}{*}{\multicolumn{4}{|c|}{ No added $\mathrm{HNO}_{3}$}} & \multirow{2}{*}{\multicolumn{4}{|c|}{$0.6 \mathrm{M} \mathrm{HNO}_{3}$}} & \multirow[b]{3}{*}{$\begin{array}{l}\text { Th } \\
\text { ext'd } \\
\left(\begin{array}{c}\alpha \\
\phi\end{array}\right)\end{array}$} \\
\hline & OM & $0.6 M$ & & $3 M$ & & & & & & & & & & \\
\hline & $\begin{array}{l}0 \\
\operatorname{ext} ' d\end{array}$ & $\begin{array}{l}U \\
\operatorname{ext}(\phi)\end{array}$ & $\begin{array}{l}\text { Ac1d } \\
\text { ext'd } \\
(x)\end{array}$ & $\left\{\begin{array}{l}0 x t^{\prime} d \\
(\phi)\end{array}\right.$ & $\begin{array}{l}\text { Acra } \\
\text { ext'd } \\
(\phi)\end{array}$ & $\begin{array}{l}U \\
\left(\begin{array}{l}\mathrm{VI} \\
(\mathrm{f})\end{array}\right)\end{array}$ & $\left.\mid \begin{array}{l}\text { Pu } \\
(\mathscr{X})\end{array}\right) \mid$ & $\begin{array}{l}\text { Gros } \\
\beta \\
(\phi)\end{array}$ & $\left|\begin{array}{l}\text { Gross } \\
(\%)\end{array}\right|$ & $\left(\begin{array}{l}v I \\
(x)\end{array}\right)$ & $\left\{\begin{array}{l}\text { Pu } \\
\text { IV) }\end{array}\right.$ & $\begin{array}{l}\text { aross } \\
\beta \\
(\not)\end{array}$ & $\begin{array}{l}\text { Gross } \\
\gamma_{(\phi)}\end{array}$ & \\
\hline $\begin{array}{l}\text { Tributyl } \\
\text { phosphate }\end{array}$ & 11 & 56 & 4 & 96.5 & 8 & 17.4 & 0,7 & 0.01 & 0.01 & 58 & 6.6 & 0.07 & 0.08 & 3.5 \\
\hline $\begin{array}{l}\text { Dibutyl } \\
\text { butylphos- } \\
\text { phonate }\end{array}$ & 55 & 97 & 6 & 99.4 & 11 & 64 & 1.13 & 0.05 & 0.13 & 97 & 54 & 0.72 & 1.0 & 18 \\
\hline $\begin{array}{l}\text { Butyl } \\
\text { dibutylphos- } \\
\text { ph1nate }\end{array}$ & 98.5 & 99.9 & 15 & 99.9 & 14 & 94 & 20 & 1.9 & $7 \cdot 9$ & 99.9 & 98 & 23 & 38 & 74 \\
\hline $\begin{array}{l}\text { Tributyl } \\
\text { phosphine } \\
\text { oxide }\end{array}$ & 99.7 & 99.9 & 39 & $99 \cdot 9$ & 17 & 99.9 & $97 \cdot 3 \mid$ & 37 & 64 & 999 & 99.8 & 72 & 77 & 98.7 \\
\hline
\end{tabular}

a After Higgins, Baldwin, and Ruth, reference 387 .

Experimental conditions: equal phase volumes equilibrated 30 minutes at $25 \pm 0.2^{\circ} \mathrm{C}$; organic phase - $0.75 \mathrm{M}$ phosphorus compound dissolved in $\mathrm{CCl}_{4}$; aqueous phase - $0.1 \mathrm{M}$ uranyl salt with or without saIting agent.

b Aqueous phase - $0.1 \mathrm{M} \mathrm{JO}_{2}\left(\mathrm{NO}_{3}\right)_{2}$ from dissolving Irradiated U slugs in $\mathrm{HNO}_{3}-6$ months cooling.

c Aqueous phase - $0.1 \mathrm{M} \mathrm{Th}\left(\mathrm{NO}_{3}\right)_{4}$. 


\begin{tabular}{|c|c|c|c|c|c|c|c|c|c|c|c|}
\hline & \multirow{2}{*}{\multicolumn{2}{|c|}{$\begin{array}{l}\text { Extraction } \\
\text { of } \mathrm{UO}_{2} \mathrm{SO}_{4} \mathrm{~d} \\
\mathrm{H}_{2} \mathrm{SO}_{4} \text { concen- } \\
\text { tration }\end{array}$}} & \multicolumn{2}{|c|}{$\begin{array}{l}\text { Extraction } \\
\text { of } \mathrm{UO}_{2} \mathrm{Cl}_{2}\end{array}$} & \multicolumn{7}{|c|}{ Extraction of acids $\underline{r}$} \\
\hline & & & $\mathrm{HCl} \begin{array}{c}\text { conce } \\
\text { trat }\end{array}$ & & & & 8 extr & acted & & & \\
\hline & OM & $2 \underline{M}$ & OM & $1 \underline{M}$ & $\begin{array}{l}\text { Ace } \\
\text { t1c }\end{array}$ & $\begin{array}{l}\text { c1t- } \\
\text { r1c }\end{array}$ & \begin{tabular}{|l|} 
Tar- \\
tarid
\end{tabular} & $\mathrm{HNO}_{3}$ & $\mathrm{H}_{2} \mathrm{SO}_{4}$ & $\mathrm{H}_{3} \mathrm{PO}_{4}$ & $\mathrm{HC1}$ \\
\hline \multirow{2}{*}{$\begin{array}{l}\text { Tr1butyl } \\
\text { phosphate }\end{array}$} & $\begin{array}{l}U \\
\text { ext'd } \\
(\not p)\end{array}$ & $\begin{array}{l}U \\
\text { ext'd } \\
(\%)\end{array}$ & $\begin{array}{l}U \\
\text { ext'd } \\
(\mathscr{g})\end{array}$ & $\begin{array}{l}U \\
\text { ext'd } \\
(\mathscr{c})\end{array}$ & \multirow{3}{*}{25} & \multirow[b]{2}{*}{0} & \multirow[b]{2}{*}{0} & \multirow[b]{2}{*}{7} & \multirow[b]{2}{*}{0} & \multirow[b]{2}{*}{0} & \multirow[b]{2}{*}{0} \\
\hline & 0.001 & 0.001 & 0.3 & 0.8 & & & & & & & \\
\hline $\begin{array}{l}\text { D1butyl } \\
\text { butylphos- } \\
\text { phonate }\end{array}$ & 0.1 & 0.03 & 1 & 26 & & & & & & & \\
\hline $\begin{array}{l}\text { d lbutyl- } \\
\text { phosphinate }\end{array}$ & 16 & 48 & 40 & 92 & 49 & 20 & 20 & 27 & 2 & 3 & 0 \\
\hline $\begin{array}{l}\text { Tributyl } \\
\text { phosph1ne } \\
\text { oxide }\end{array}$ & 95 & $96.8^{e}$ & $\begin{array}{l}90 \\
\text { some ppt. } \\
\text { formed }\end{array}$ & $\begin{array}{l}\text { all pre- } \\
\text { c1pitated }\end{array}$ & 58 & 39 & 23 & 39 & 0 & 10 & 7 \\
\hline
\end{tabular}

d Aqueous phase - $0.1 \underline{M} \mathrm{UO}_{2} \mathrm{SO}_{4}$; ac1d as indicated.

e Three phases were present, two of wh1ch were largely aqueous.

$\underline{\mathbf{f}}$ Aqueous phase - approximately $1 \underline{N}$ acid. 
Table XVIII. Extraction of Actinides and Zirconium by Phosphates and Phosphonates at $30^{\circ} \mathrm{C} \frac{\mathrm{a}}{\mathrm{c}}$

\begin{tabular}{|c|c|c|c|c|c|c|c|}
\hline Solvent & Th & $\mathrm{Np}(\mathrm{IV}) \underline{\mathrm{b}}$ & $\operatorname{Pu}(I V) \stackrel{c}{=}$ & $\mathrm{U}(\mathrm{VI})^{\mathrm{EJ}}$ & $\begin{array}{l}\operatorname{traction} \\
\operatorname{Np}(\mathrm{VI}) \underline{a}\end{array}$ & $\begin{array}{l}\text { Coefficient } \\
\text { Pu(VI)d }\end{array}$ & $\mathrm{Zr}$ \\
\hline $\begin{array}{l}\text { n-butyl } \\
\text { 1sobutyl } \\
\text { n-amyl } \\
\text { 1 so-amy } 1 \\
\text { n-hexy1 } \\
\text { n-octyl } \\
\text { 2-ethylhexy } 1 \\
\text { 2-butyl } \\
\text { 3-amyl } \\
\text { 3-methyl-2-butyl } \\
\text { 4-methyl-2-amyl } \\
\text { cyclohexyl }\end{array}$ & $\begin{array}{l}2.9 \\
2.4 \\
2.9 \\
4.2 \\
3.0 \\
2.4 \\
2.5 \\
0.45 \\
0.22 \\
0.18 \\
0.047 \\
3.5\end{array}$ & $\begin{array}{l}3.2 \\
2.7 \\
4.2 \\
4.7 \\
3.6 \\
3.4 \\
4.3 \\
4.9 \\
3.5 \\
3.0 \\
3.5\end{array}$ & $\begin{array}{l}16.1 \\
11.8 \\
15.6 \\
17.8 \\
15.6 \\
15.3 \\
25 \\
28 \\
18.1 \\
24 \\
22\end{array}$ & $\begin{array}{l}26 \\
22 \\
32 \\
34 \\
38 \\
33 \\
58 \\
42 \\
49 \\
47 \\
38 \\
106\end{array}$ & $\begin{array}{l}15.6 \\
15.9 \\
19.3 \\
18.9 \\
20.0 \\
15.7 \\
23 \\
20 \\
22 \\
25 \\
24\end{array}$ & $\begin{array}{l}3.5 \\
3.4 \\
4.1 \\
4.4 \\
4.5 \\
3.9 \\
5.7 \\
4.6 \\
5.0 \\
5.4 \\
4.9\end{array}$ & $\begin{array}{l}0.22 \\
0.12 \\
0.14 \\
0.14 \\
0.14 \\
\\
0.64\end{array}$ \\
\hline $\begin{array}{l}\text { Dialkyl alkylphosphonate } \frac{f}{} \\
\text { d1-n-butyl n-butyl } \\
\text { d1-n-butyl cyclohexyl } \\
\text { d1-n-amyl n-amyl } \\
\text { di-n-hexyl n-hexyl } \\
\text { d1-2-ethylhexyl 2-ethyl- } \\
\text { hexyl }\end{array}$ & $\begin{array}{l}24 \\
17 \\
33 \\
26 \\
10.6\end{array}$ & & & $\begin{array}{l}92 \\
125 \\
133 \\
89 \\
176\end{array}$ & & & $\begin{array}{l}0.17 \\
0.14 \\
0.092 \\
0.070 \mathrm{~g} \\
0.12\end{array}$ \\
\hline
\end{tabular}

a After T. H. S1ddall III, references 388 and 389.

b Aqueous phase contained $0.01 \mathrm{M}$ ferrous sulfamite.

c Aqueous phase contained $0.01 \mathrm{M} \mathrm{NaNO}_{2}$.

d Aqueous phase contalned $0.01 \mathrm{M}$ cerlc ammonium sulfate.

e $1.09 \mathrm{M}$ trialkyl phosphate in $\mathrm{n}$-dodecane; extractants washed with $1 \mathrm{M} \mathrm{NaOH}$, water, and nitric 2c1d before use; aqueous phase 3. $\mathrm{M} \mathrm{HNO}_{3}$ at equ1librium; tracer concentration of element.

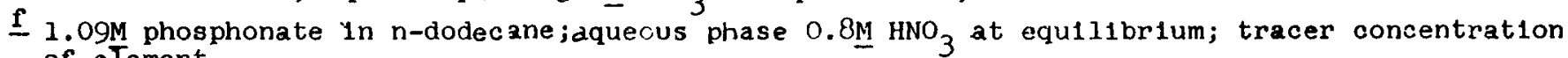
of eTement.

E Etrapolated value. 
extractants may extract uranium from sulfate and phosphate solutions, especially if a small amount of nitrate is added to the solution.

Tributyl phosphate (TBP)

Aqueous n1trate systems. Invest1gations on the extraction of metal nitrates by TBP 1ndicate the cations are extracted as single, well-defined specles: $\mathrm{M}\left(\mathrm{NO}_{3}\right)_{3}(\mathrm{MBP})_{3}$, $\mathrm{M}\left(\mathrm{NO}_{3}\right)_{4}(\mathrm{TBP})_{2}$, and $\mathrm{MO}_{2}\left(\mathrm{NO}_{3}\right)_{2}(\mathrm{TBP})_{2} \cdot 168,187,311,392,393$ This differs from the extraction of ethers, esters, and other oxygen-contalning solvents, considered previously, in which a whole series of complexes containing varying numbers of nitrate, solvate, and water molecules is extracted. The stablilty of the TBP-solvate molecules increases in the order 31 I $\mathrm{H}_{2} \mathrm{O}(\mathrm{TBP})<\mathrm{Pu}\left(\mathrm{NO}_{3}\right)_{3}(\mathrm{TBP})_{3}<\mathrm{Pa}\left(\mathrm{NO}_{3}\right)_{5}(\mathrm{TBP})_{3}<\mathrm{HNO}_{3}(\mathrm{TBP})$, $\mathrm{HNO}_{3}(\mathrm{TBP})\left(\mathrm{H}_{2} \mathrm{O}\right)<\mathrm{Th}\left(\mathrm{NO}_{3}\right)_{4}(\mathrm{TBP})_{2}<\mathrm{PuO}_{2}\left(\mathrm{NO}_{3}\right)_{2}(\mathrm{TBP})_{2}<$ $\mathrm{Pu}\left(\mathrm{NO}_{3}\right)_{4}(\mathrm{TBP})_{2}<\mathrm{UO}_{2}\left(\mathrm{NO}_{3}\right)_{2}(\mathrm{TBP})_{2}$.

The unexpectedly large extraction of nitric ac1d, thorium, ano zirconlum at very high acio concentrations indicates higher complexes may be extracted. 311

The distribution of uranyl nitrate between TBP and water 1s represented in figure $30 . \frac{394}{3}$ The extraction coefficient of uranium 18 plotted as a function of ac1d concentration for various concentrations of TBP in f1gure 31.395 The observed effects of (1) decreased $a_{u}$ with increased acid concentration and (2) Increased $\alpha_{u}$ with increased TBP concentration, may be explained on the basis of free solvent concentration. First, as the ac1d concentration is 1ncreased, more nitric acid is extracted resulting in less free solvent. Second, more free solvent 18 obviously avaliable as a result of increasing the solvent concentration. Since the partition coefflclent of uranium depends upon the second power of the free solvent concentration, $a_{u}$ w1ll decrease in the first cast 
Table XIX. Extractive Power of Tributyl Phosphate, Alkyl Phosphonates, D1phosphonates, and Phosphine Ox1des

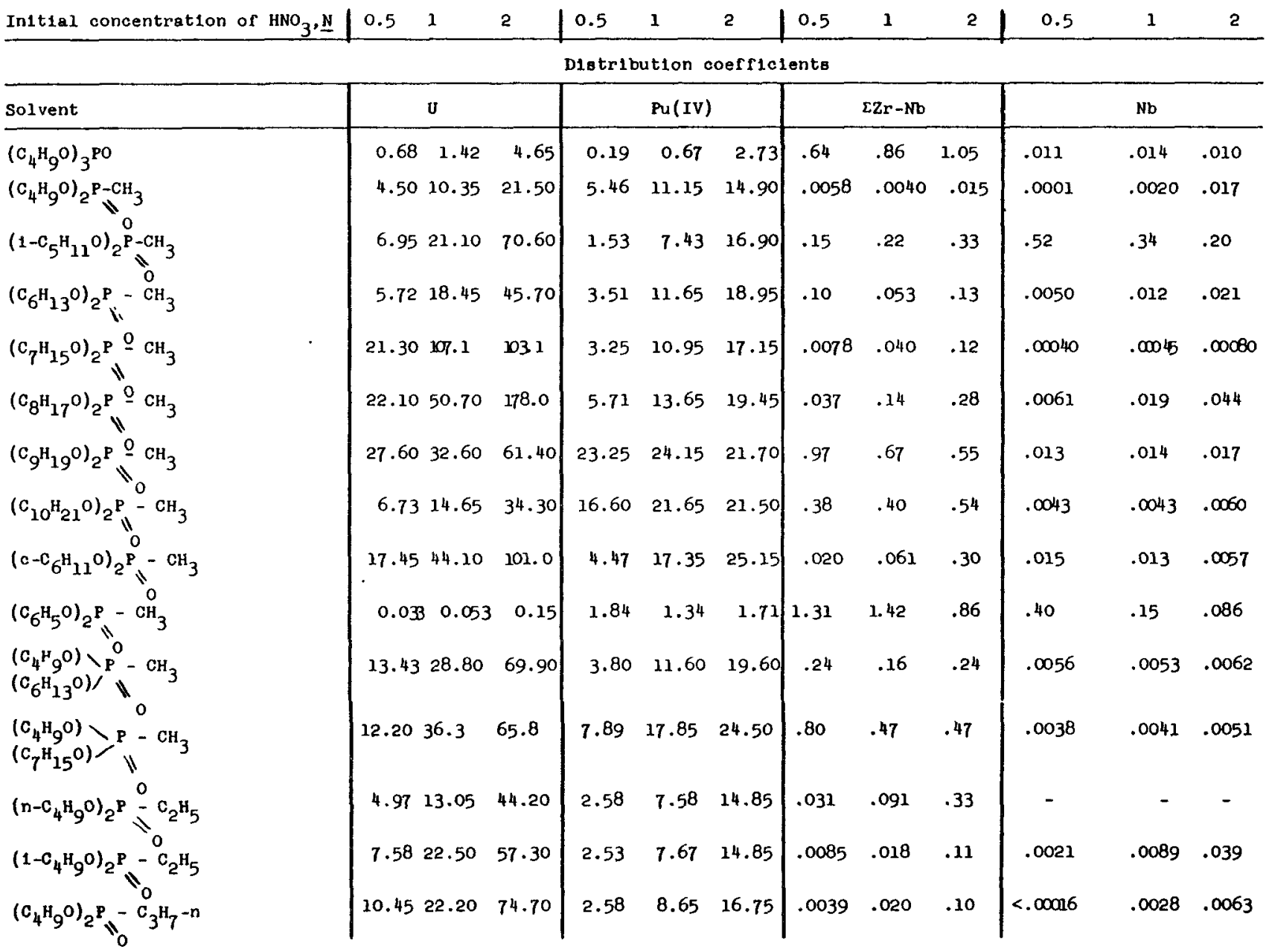





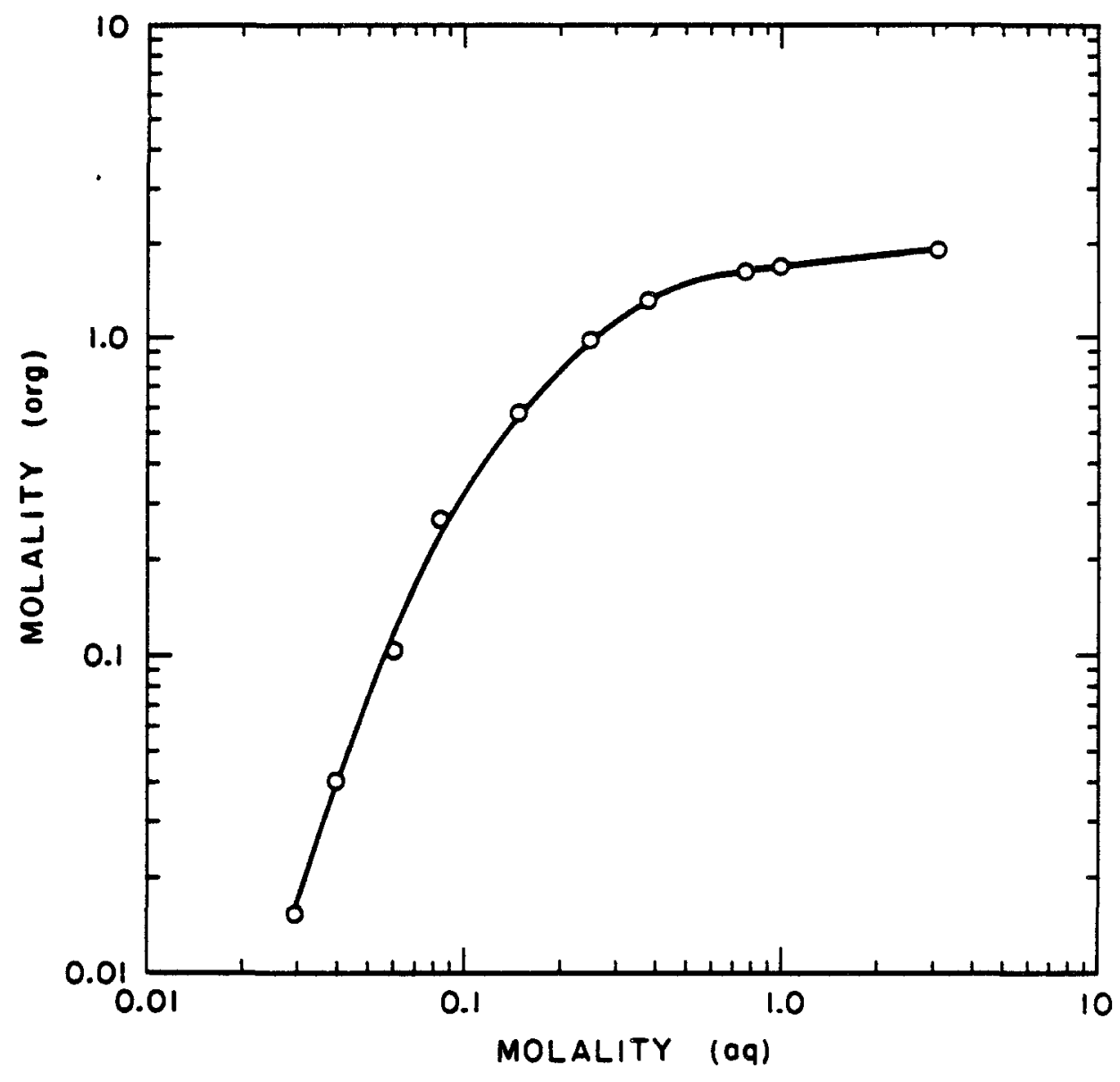

P1gure 30.

The partition of uranyl nitrate between $100 \%$ TBP and water at $25^{\circ} \mathrm{C}$. After T. Healy, J. Kennedy, G. Waind, reference 394.

and Increase in the second. The effect of uranium concentration on $\alpha_{u}$ is given 2 lso as a function of nitric acid concentration In f1gure 32.396 The decreased extraction with increased uranium concentration may again be interpreted in terms of the solvent avaliable. The partition coefficients of other metal nitrates are also decreased, in general, by increased uranium concentration. More efficient separation may therefore be achleved by increased urantum loading of the solvent. For small amounts of uranium, a high uranium concentration may be attained in an organic phase suitable for handling by 


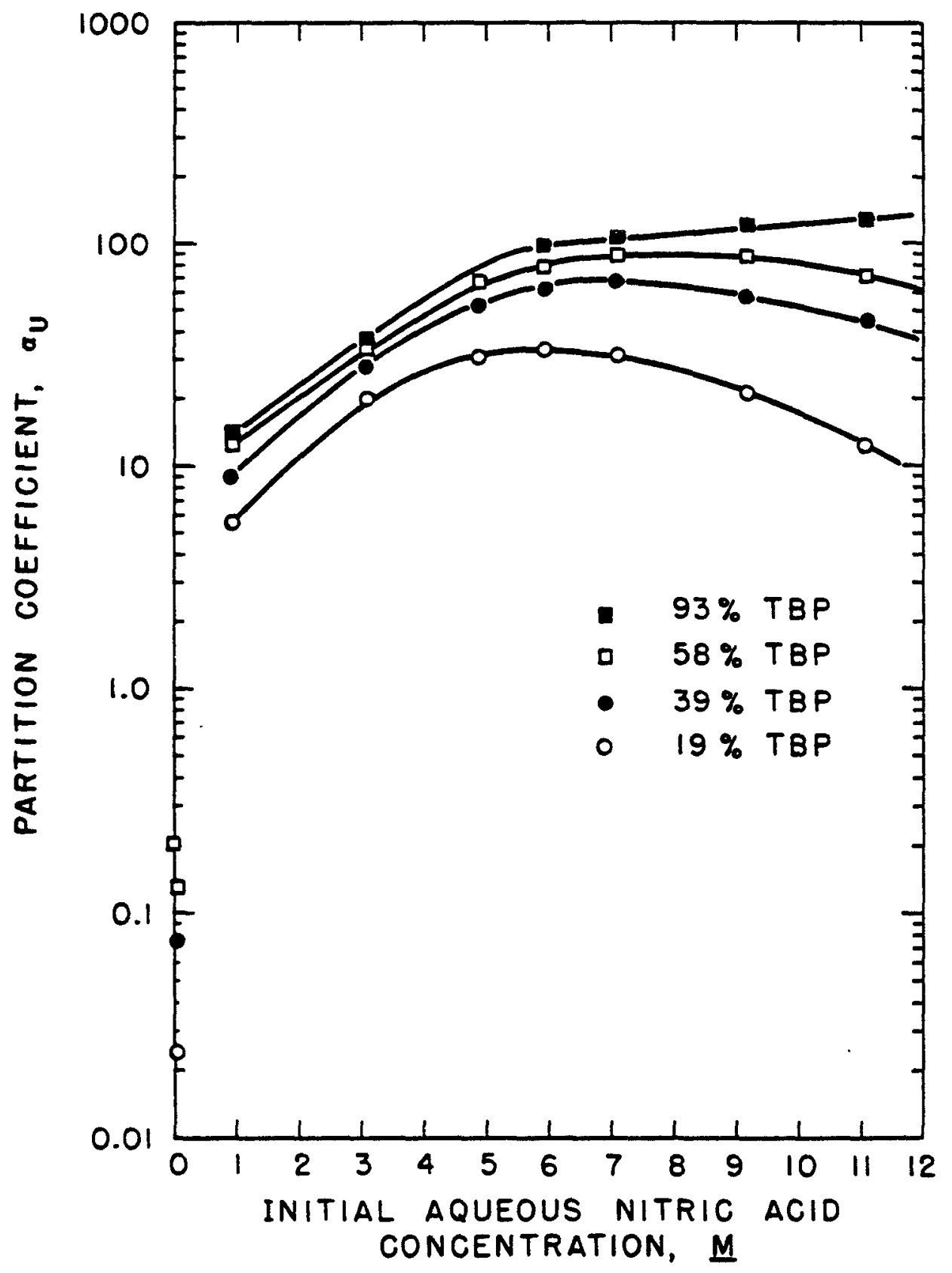

Figure 31. The extraction of uranyl nitrate by various concentrations of TBP in kerosene as a function of inltial aqueous acid concentration. After $T$. Sato, reference 395. Conditions: organic phase - volume of TBP in kerosene as indicated. Aqueous phase - $5 \mathrm{~g}$. uranyl nitrate per ilter, nitric acid concentration indicated. Temperature, $200 \mathrm{C} ; \mathrm{V}_{\mathrm{O}} / \mathrm{V}_{\mathrm{a}}, \mathrm{I}$. 


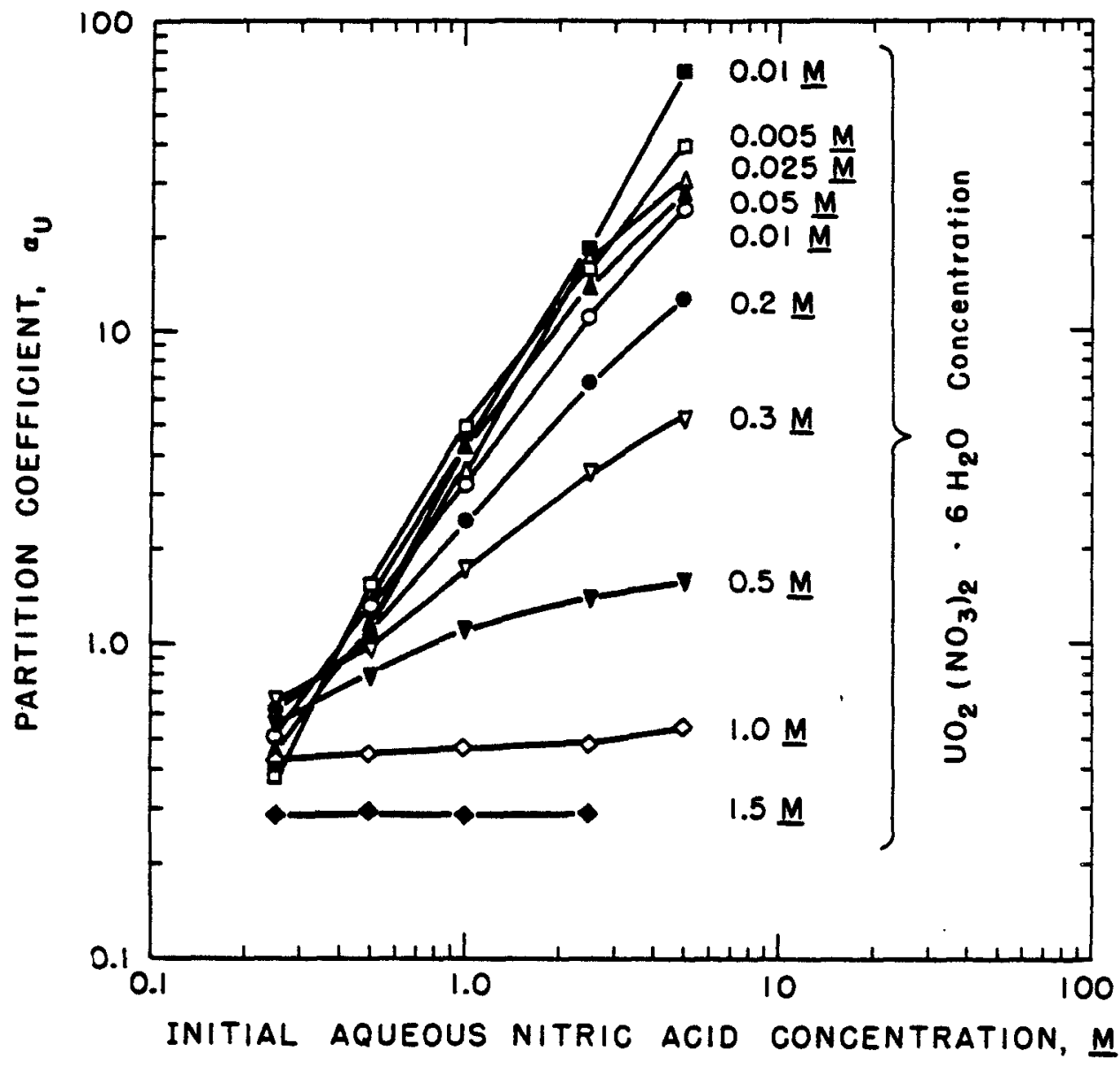

F1gure 32.

The effect of 1nitial uranium concentration on the extraction of urangl nitrate by 20 volume per cent TBP in $\mathrm{CCl}_{4}$ as a function of initial aqueous nitric acid concentration. After R. I. Moore, reference 396.

Cond1tions :

Equal volumes of phases shaken in a water bath at $25^{\circ} \mathrm{C}$.

dilution of the solvent. Duncan and Holburt $\frac{397}{\text { have measured }}$ the distribution of uranium, in1tially present in 1.2 to 1200 micrograms per liter between $20 \%$ TBP in kerosene and nitric ac1d solution. Although the results were somewhat erratic, 1t was generally shown that the partition coefficlent is nearly constant over this range of uranium concentrations. 
The extractive capac1ty of TBP is affected considerably by the cholce of diluent. Taube 398 extracted U(VI), Np(IV), $\mathrm{Np}(\mathrm{VI})$, and $\mathrm{Pu}(\mathrm{VI})$ from $5 \mathrm{M}^{\mathrm{m} \mathrm{HN}_{3}}$ aqueous solutions w1th $0.15 \mathrm{M}$ TBP dissolved in a number of solvents, including benzene and chloroform. Iarger extraction coefficients were obtalned for 21 the elements tested with benzene rather than chloroform 28 diluent. In the case of uranium, the difference in $\alpha_{u}$ was greater than ten-fold. Little difference in extractive capac1ty was observed with TBP diluted by benzene or carbon tetrachioride. Similar results were obtained by Dizdar, et 21.399 Urany I nitrate (0.0038M) was extracted from $2 M$ nitric ac1d solutions by various concentrations of TMP diluted with carbon tetrachloride, xylene, kerosene, hexane, dibutyl ether, diethyl ether, and 1sopropyl ether. The partition coefficient was found to increase with 1ncreasing TBP concentration to 2 maximum for pure TBP. For carbon tetrachiorlde and xylene the maximum value was already attained at 40 mole per cent TBP. The other diluents are listed above in the approximate order in which they inhibit the extraction of uranium by TBP. Differences in $\alpha_{u}$, for varlous diluents, were found to become smailer with increased uranium concentration. Bruce 378 has found that the extraction of fission products is also affected by the cholce of diluent.

The extraction of uranium by TBP is considerably enhanced by the presence of salting-out agents in the aqueous phase. $400-406$ The results of Sato 406 are given in Table $X X$ and figure 33.

The extraction of uranium by TBP decreases with increased temperature. $407-411$

Phosphate, sulfate, and fluoride lons reduce the extraction of uranium by TBP from nitrate media. 409 Uranium is extracted from chloride solution but less efficlently than from nitrate solution. Silica causes poor phase separation 
Table XX. Extraction of Uranyl N1trate by TBP Using Various Nitrate Salting-out Agents. $\underline{2}$

Salting-out agent

Percentage extracted

\begin{tabular}{|c|c|c|c|c|}
\hline & $\mathrm{OM}^{\mathrm{HNO}} 3$ & $1 \mathrm{M} \mathrm{HNO}_{3}$ & $3 \mathrm{M} \mathrm{HNO}_{3}$ & $6 \mathrm{M} \mathrm{HNO}_{3}$ \\
\hline$\left(\mathrm{HNO}_{3}\right)$ & 2.96 & 82.10 & 95.52 & 97.10 \\
\hline $\mathrm{NH}_{4} \mathrm{NO}_{3}$ & 70.00 & 92.30 & 96.50 & 97.40 \\
\hline $\mathrm{LLNO}_{3}$ & 73.05 & 94.60 & 97.50 & 97.95 \\
\hline $\mathrm{NaNO}_{3}$ & 72.50 & 93.00 & 97.10 & 97.80 \\
\hline $\mathrm{KNO}_{3}$ & 65.00 & 90.50 & 96.00 & 97.10 \\
\hline $\mathrm{Cu}\left(\mathrm{NO}_{3}\right)_{2}$ & 86.02 & 97.50 & 97.70 & 99.00 \\
\hline $\mathrm{Mg}\left(\mathrm{NO}_{3}\right)_{2}$ & 84.35 & 97.20 & 97.50 & 99.40 \\
\hline $\mathrm{Ca}\left(\mathrm{NO}_{3}\right)_{2}$ & 82.48 & 96.60 & 96.60 & 97.50 \\
\hline $\mathrm{Zn}\left(\mathrm{NO}_{3}\right)_{2}$ & 79.75 & 98.05 & 98.10 & 99.40 \\
\hline $\mathrm{Al}\left(\mathrm{NO}_{3}\right)_{3}$ & 99.90 & 99.60 & 98.20 & 99.50 \\
\hline $\mathrm{Fe}\left(\mathrm{NO}_{3}\right)_{3}$ & 99.80 & 99.50 & 98.20 & 98.90 \\
\hline
\end{tabular}

a After T. Sato, reference 406.

Organic phase - 19\% TBP in kerosene.

Aqueous phase - $5 \mathrm{~g} / \mathrm{I}$ urany 1 nitrate, IM salting-out agent, initial acid concentration indicated.

Equal phase volumes shaken together for 30 minutes at $20^{\circ} \mathrm{C}$.

and the formation of emulsions.

Uranium may be re-extracted from TBP by contact with sodium carbonate solution. $\frac{409}{}$ Ammonium sulfate, sodium sulfate, and urea solutions have been used satisfactorily. 409 Water or hydrogen peroxide is Ineffective for TBP containing considerable nitric ac1d. 409

The distribution of nitric acid between aqueous solution and 100\% TBP is demonstrated in figure 34 . 412 The distribution of various metal nitrates between TBP and nitrate 


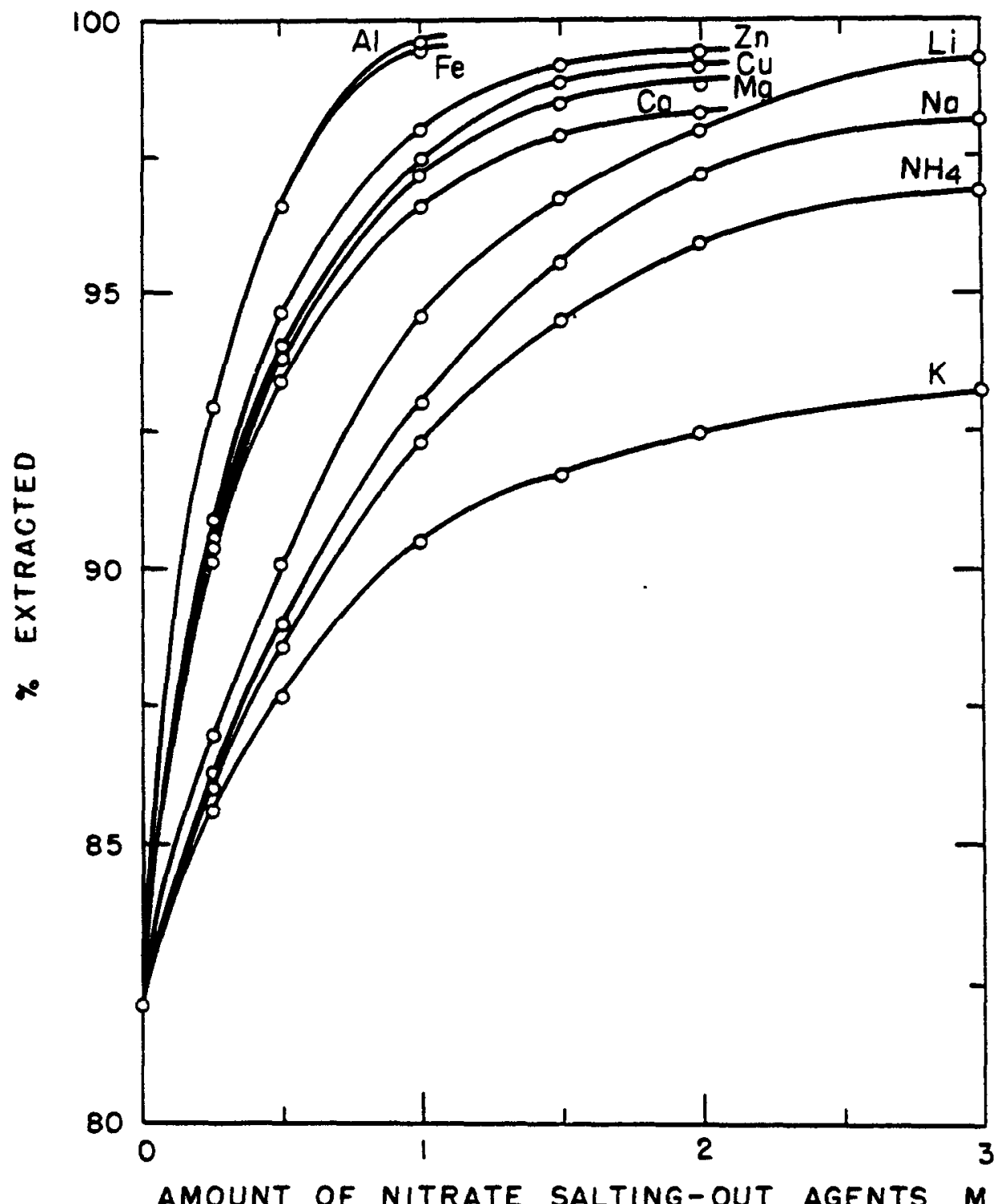

Figure 33.

Effect of nitrate salting-out agents upon the extraction of uranyl nitrate at $1 M$ InItial nitric acid concentration. After T. Sato, reference 406.

Conditions :

Organic phase - $19 \%$ TBP in kerosene. Aqueous phase $-5 \mathrm{~g} / 1$ uranyl nitrate, IM $\mathrm{HNO}_{3}$, salting-
out agent concentration indicated.

Equal phase volumes shaken together for 30 minutes at $20^{\circ} \mathrm{C}$. 


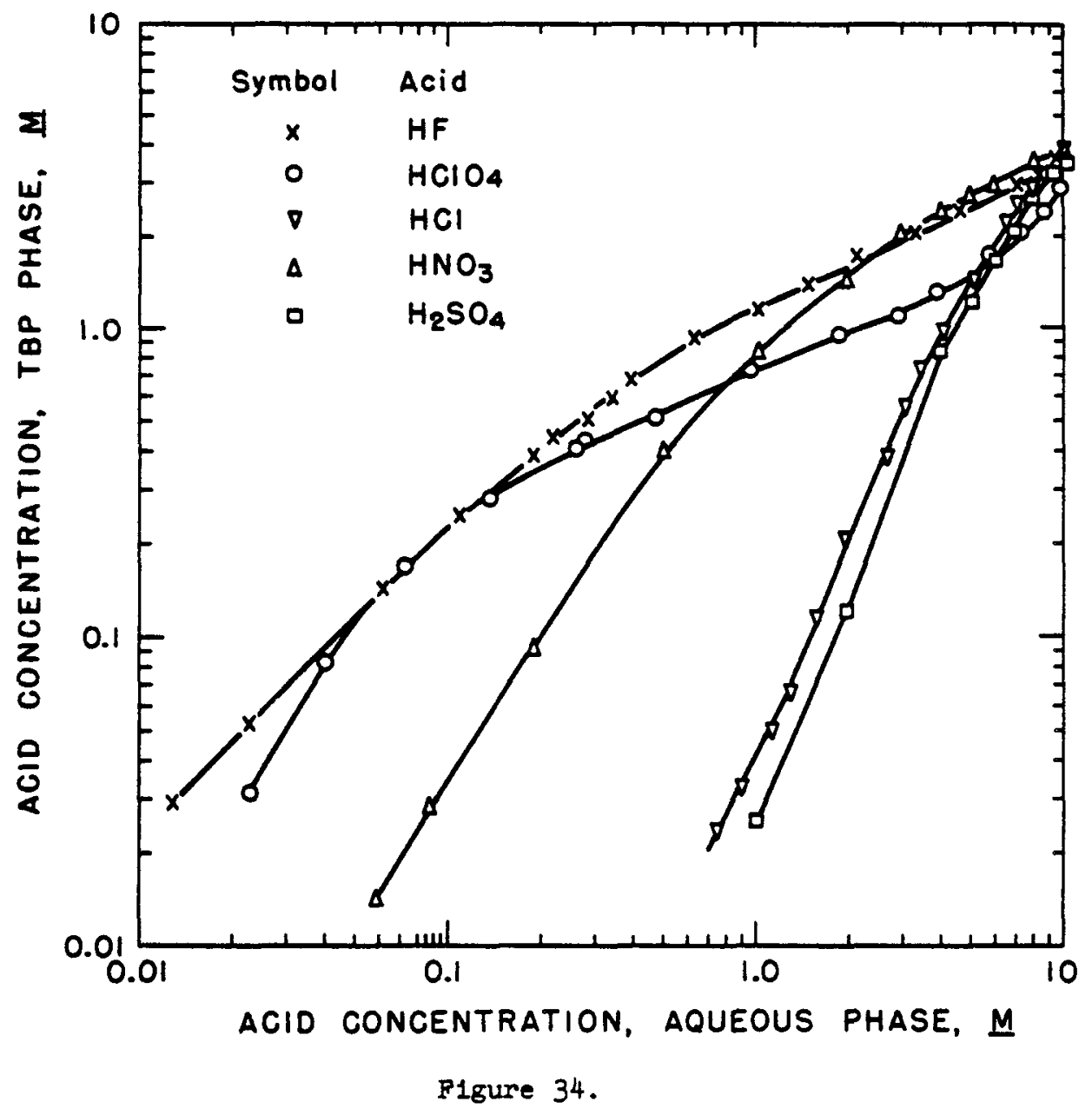

The distribution of mineral acids between $100 \%$ TBP and aqueous solution at $25^{\circ} \mathrm{C}$.

After E. Hesford and H. A. C. McKay, reference 412.

solutions has been extensively investigated. The extraction coefficlents of some actinide elements are plotted against aqueous nitric acid concentration in pigures 35 and 36. 413-416 Ish1mort and Nakamura $\frac{417}{4}$ have also measured the partition coefficients of Hf, Th, $P a, U(V I), N p(I V)(V)(V I)$, and $P u(I V)(V I)$ at various aqueous nitric acld concentrations. Figure 37 represents the partition coefficient of several fission products as a function of the nitric ac1d concentration. $418-420$ 


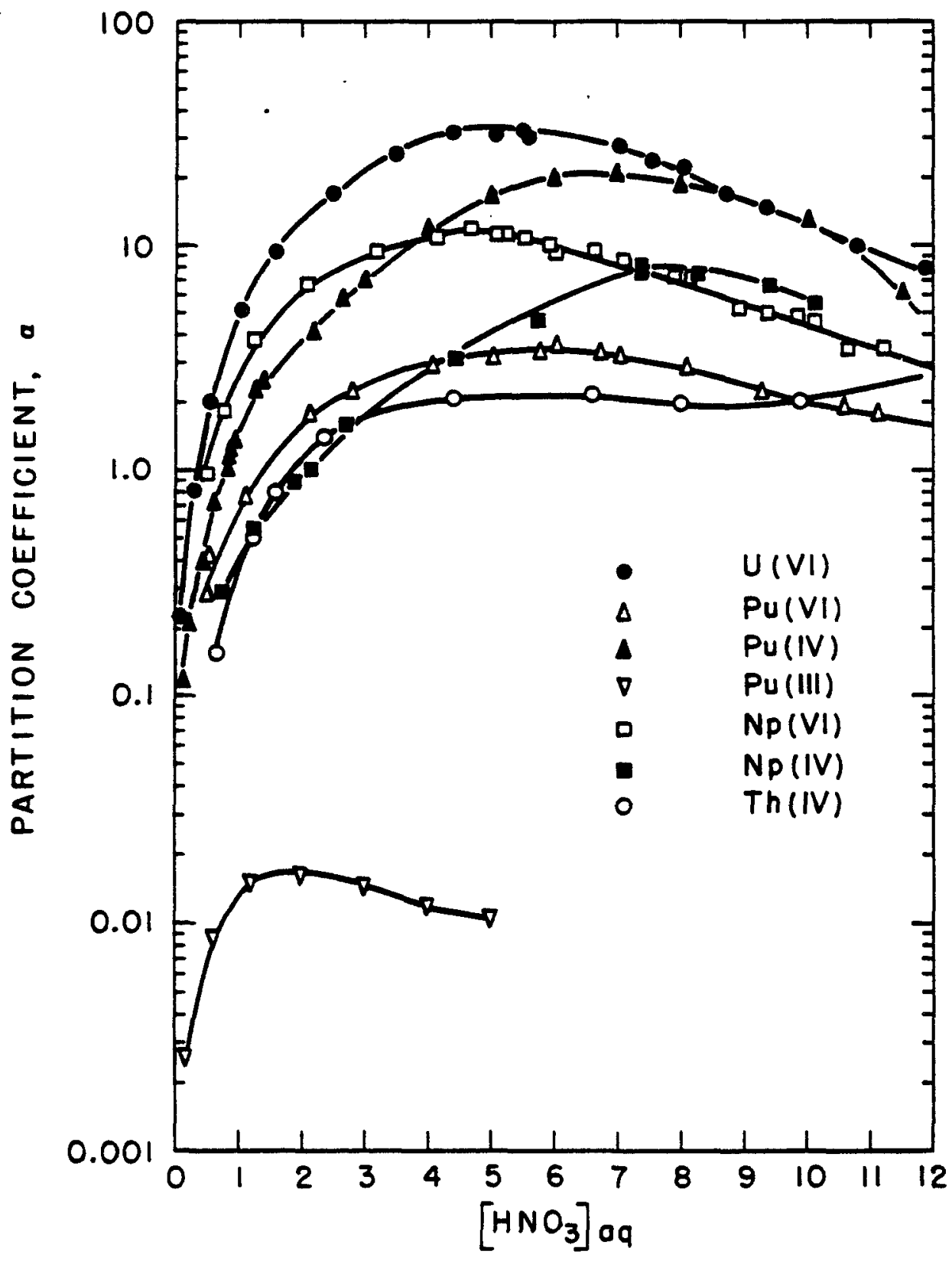

Figure 35. The partition coefficient of actinlde nitrates between 19\% TBP in kerosene and aqueous solution as a function of equilibrium nitric ac1d concentration. $\bullet U$ (VI), $\square \mathrm{Np}$ (VI), Np (IV), $\triangle P U(V I)$ at $20^{\circ}-23^{\circ} \mathrm{C}$., after $K$. Alcock, G. F. Best, E. Hesford, H. A.C. McKay, reference 4I3. $\triangle \mathrm{Pu}$ (IV), $\nabla \mathrm{Pu}$ (III), at $25^{\circ} \mathrm{C}$. or $20-23^{\circ} \mathrm{C}$, after G. F. Best, H. A. C. McKay, P. R. Woodgate, reference 414 . O Th (IV) at $25^{\circ} \mathrm{C}$., after E. Hesford, H. A. C. McKay, D. Scargili, reference 415. 


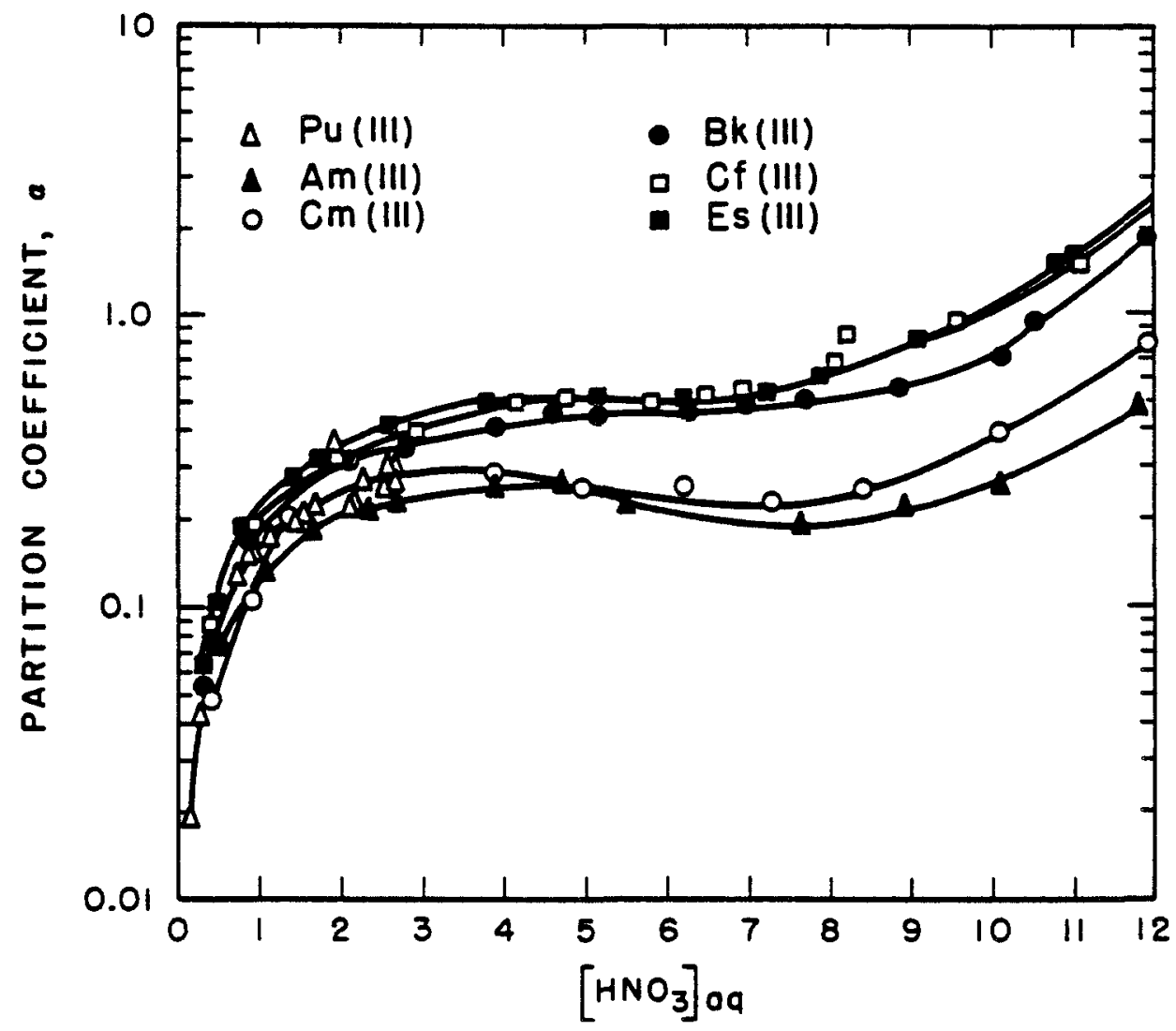

F1gure 36.

The distribution of trivalent actinides between 100\% TBP and aqueous solution $2 s$ function of equilibrium nitric acid concentration at $25^{\circ} \mathrm{C}$.

After G. F. Best, E. Hesford, and H. A. C. McKay, reference 416.

The extraction of rare earths, $\mathrm{Y}, \mathrm{Zr}$, Sc, Th, and Am by TBP from aqueous nitric acid solution has been investigated by Peppard and co-workers. 421,422 Iodine is extracted. It forms addition compounds with carbon-unsaturated compounds in the solvent. The extraction of lodine is minimized by keeping it in a reduced state and by careful selection of TBP diluents. $\frac{378}{8}$ Ruthenlum is also extracted by TBP. Its extraction may be reduced by increased solvent saturation with uranium, by digestion in a nitrate solution of very high ionfc 


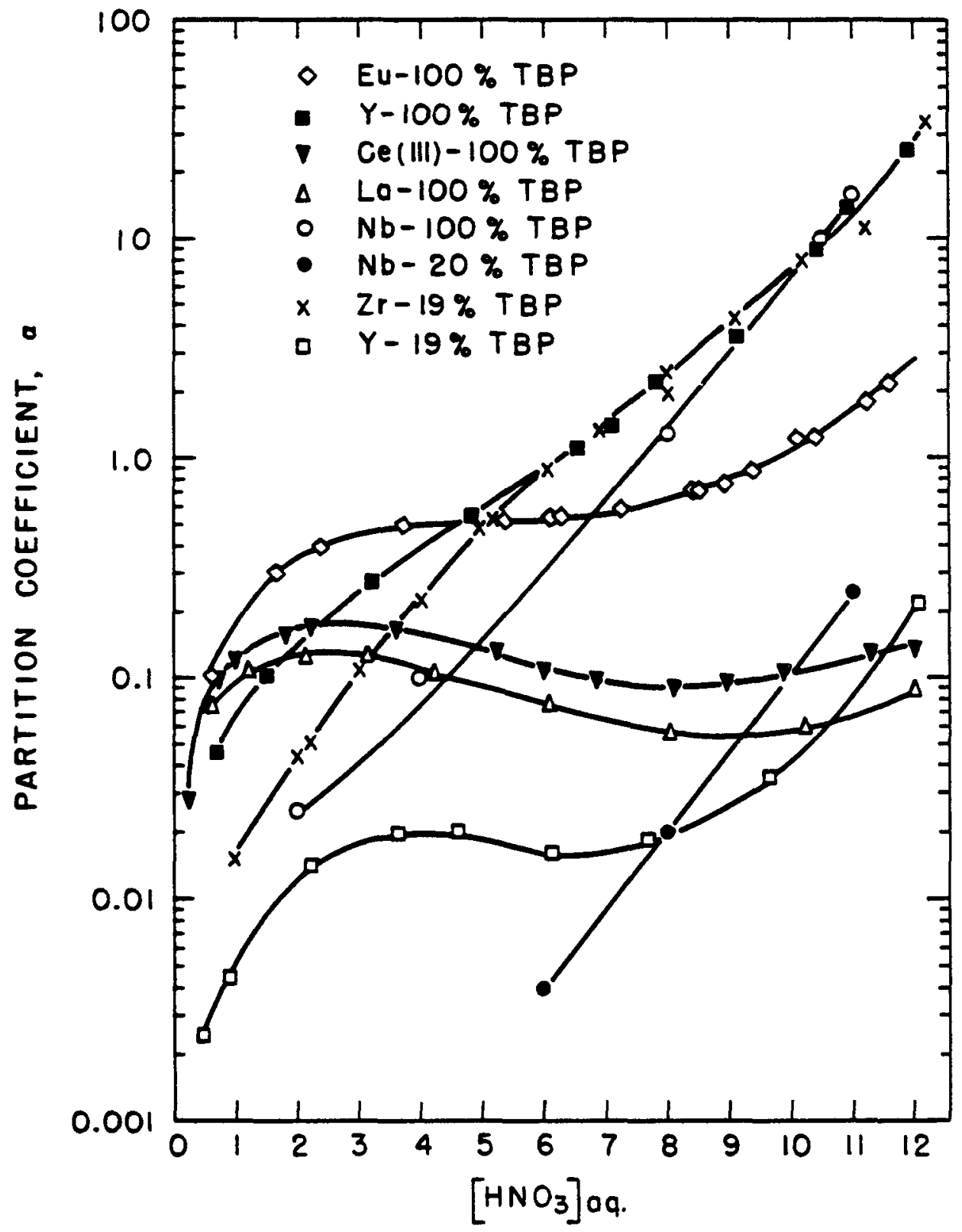

F1gure 37. The distribution of fission product elements between TBP of several concentrations and aqueous solution as a function of equilibrium nitric ac1d concentration. $Z \mathrm{r}$, after $K$. Alcock, F. C. Bedford, W. H. Hardwick, and H. A. C. McKay, reference 418. Y, La, Ce, Eu, after D. Scargili, K. Alcock, J. M. Fletcher, E. Hesford, and H. A. C. McKay, reference 419. ND, after C. J. Hardy and D. Scargili, reference 420. Conditions: Tracer, carrier-free or with less than $1 \mathrm{~g} / 1$ of carrier, used 1 all cases, $2 r$ equilibrations made at $20-230 \mathrm{C}$.; $\mathrm{Nb}, \sim 20^{\circ} \mathrm{C}$; all others at $25^{\circ} \mathrm{C}$. TBP diluted with kerosene. 
strength, or by treatment with a reducing agent. 378 sus1c and Jel1c $\frac{423}{}$ and Sato 406 have studied the TBP extraction of metal nitrates that may be used as salting-out agents. The order of extraction of $0.1 \mathrm{mg}$ per $\mathrm{ml}$ concentrations of metal from $2 \mathrm{~N} \mathrm{HNO}_{3}$ solutions by $20 \% \mathrm{TBP} /$ kerosene with no uranium present is $\mathrm{BI}>\mathrm{Co}>\mathrm{Cu}>\mathrm{Fe}>\mathrm{Zn}>\mathrm{Cd}>\mathrm{Pb} . \underline{423}$ The partition coefficlent of bismuth under such conditions, w1th equal phase volumes, is about 0.1 . The results of Sato 406 are I1sted in Table XXI.

The partition of uranium and other metal nitrates between tributyl phosphate and aqueous solution is affected greatly by the presence of hydrolysis products in the organic

Table XXI. Extraction of Metal Nitrates by TBP. 2

$\mathrm{OM} \mathrm{HNO}_{3} \quad$ IM $\mathrm{HNO}_{3}$

$$
\begin{aligned}
& \mathrm{ILNO}_{3} \\
& \mathrm{NeNO}_{3} \\
& \mathrm{KNO}_{3}
\end{aligned}
$$

$\begin{array}{lll}\mathrm{Cu}\left(\mathrm{NO}_{3}\right)_{2} & 0.050 & 0.025\end{array}$

$\mathrm{Mg}\left(\mathrm{NO}_{3}\right)_{2}$

$\mathrm{Ca}\left(\mathrm{NO}_{3}\right)_{2} \quad 0.118$

0.064

$\mathrm{Zn}\left(\mathrm{NO}_{3}\right)_{2}$

0.005
$\mathrm{Al}\left(\mathrm{NO}_{3}\right)_{3}$
0.004
0.003
$\mathrm{F} \in\left(\mathrm{NO}_{3}\right)_{3}$
0.010
0.008

a After T. Sato, reference 406.

Aqueous phase - $5 \mathrm{~g} / \mathrm{l}$ uranyl nitrate and IM metal nitrate at inftial nitric ac1d concentration indicated. Organ1c phase - 19\% TBP diluted in kerosene.

Equal phase volumes shaken together for 30 minutes at $20^{\circ} \mathrm{C}$. 
phase, eg., mono- and d1-butyl phosphates. These products may be eliminated by washing or bolling the solvent with an 2lkaline solution. Two procedures for the removal of TBP 1mpurities are given.

Procedure 1 424: TBP is purlfled by bolling with a dilute caustic soda solution. Add $500 \mathrm{ml}$ of $0.4 \% \mathrm{NaOH}$ solution to $100 \mathrm{ml}$ of Impure TBP. Distill at atmospheric pressure unt1l $200 \mathrm{ml}$ of distiliate have been collected. The remaining TBP is washed repeatediy with water. It may be dried by warming under vacuum.

Procedure 2421.: TBP is stirred with an equal volume of $6 \mathrm{M}$ HCl $2 t 60^{\circ} \mathrm{C}$ for 12 hours. The separated TBP is cooled to room temperature and scrubbed with two equal-volume portions of water, three equal volume portions of 5\% aqueous sodium carbonate solution, and three equal volume portions of water. The resultant TBP is dried by heating to $30^{\circ} \mathrm{C}$ under reduced pressure.

Aqueous chlorioride_oystems. Urantum 18 extracted from chloride solution as $\mathrm{UO}_{2} \mathrm{Cl}_{2} \cdot 2 \mathrm{MBP}$ 2lthough higher uranyl chloride complexes may 2180 be extracted.느-428 The par-. tition of uranium between TBP and aqueous hydrochloric ac1d Bolution is shown in figures $38 \underline{422,429}$ and 39.430 The effect of uranium concentretion on the distribution is given in f1gure $40 ; \frac{428}{}$ the effect of TBP concentration, in figure 41. 426,427 In Table XXII, the Influence of salting-out agents on the extraction of urangl chloride by $30 \%$ TBP in dibutyl ether is recorded. 43 The distribution of hydrochloric ac1d between TBP and aqueous solution is shown in rigure 34.412 In figure 37 , the partition coefficients of $\mathrm{Pa}, \mathrm{Th}, \mathrm{Zr}$, and Sc are plotted as functions of aqueous HCI conoentration. 422,429 In figure 39 , the partition coefficients of $N 1, \mathrm{Nin}, \mathrm{Cu}, \mathrm{Co}, \mathrm{Zn}$, In, and Fe (III) are similarly plotted. 430 Ishimor1 and Nakamura 417 have measured the partition coefficlents of Hr, Th, $\mathrm{Pa}, \mathrm{U}(\mathrm{VI})$, and $\mathrm{Np}(\mathrm{IV})(\mathrm{V})(\mathrm{VI})$ as functions of aqueous acld concentration. Gal and Ruvarac $43 I$ have similarly 


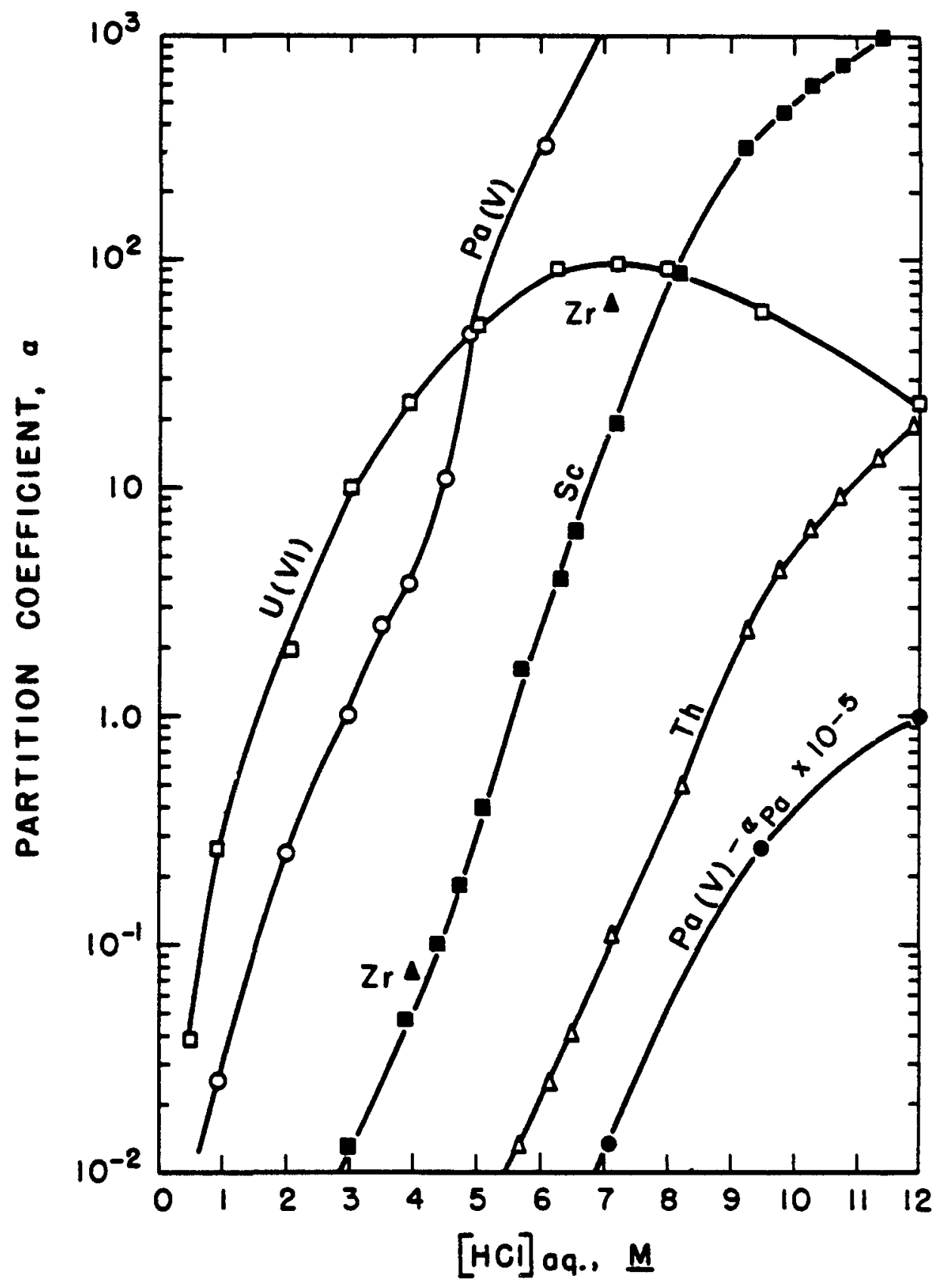

F1gure 38. The extraction coefficlent of $U, P a, T h, \mathrm{Zr}$, and Sc between pre-equilibrated $100 \%$ TBP and aqueous hydrochlorlc acid at $22^{\circ} \pm 2^{\circ} \mathrm{C}$. After D. F. Peppard, G. W. Mason, and M. V. Gergel, reference 429, and D. F. Peppard, G. W. Mason, and J. I. Ma1er, reference 422 . 


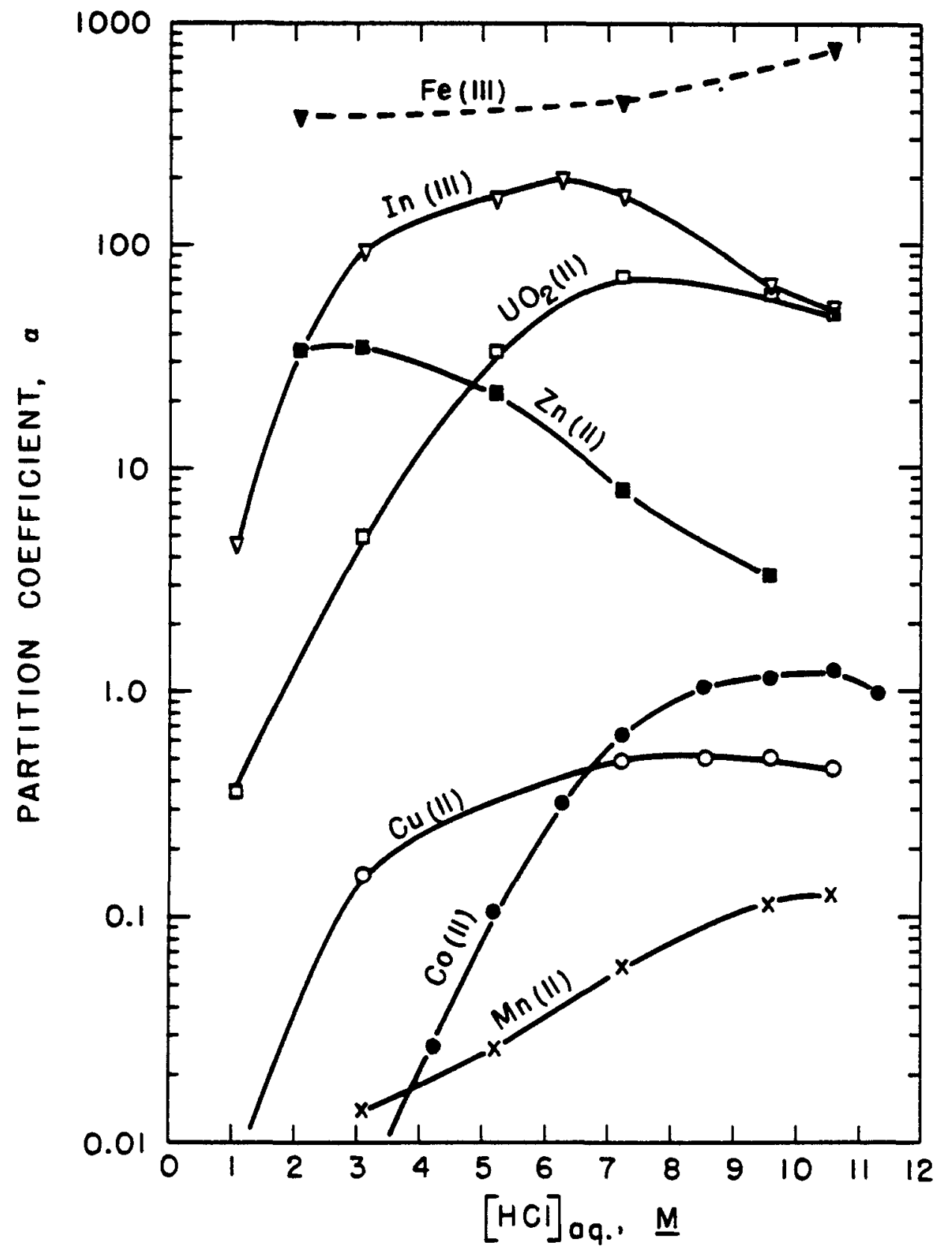

Figure 39. The extraction coefficients of $\mathrm{U}, \mathrm{In}, \mathrm{Zn}, \mathrm{Cu}, \mathrm{Co}, \mathrm{Fe}$, and $M n$ between pre-equilibrated $100 \%$ TBP and aqueous HCl solution at $21+0.1^{\circ} \mathrm{C}$. After $H$. Irving and $D$. N. Edglngton, reference 430. Conditions: TBP and HCI pre-equilibrated by stirring equal volumes together for about 10 minutes. Tracer concentrations or about $0.02 \mathrm{M} U$ and $\mathrm{Cu}$ used. Equal volumes of pre-equilbrated phares stirred toḡether about 5 minutes. 


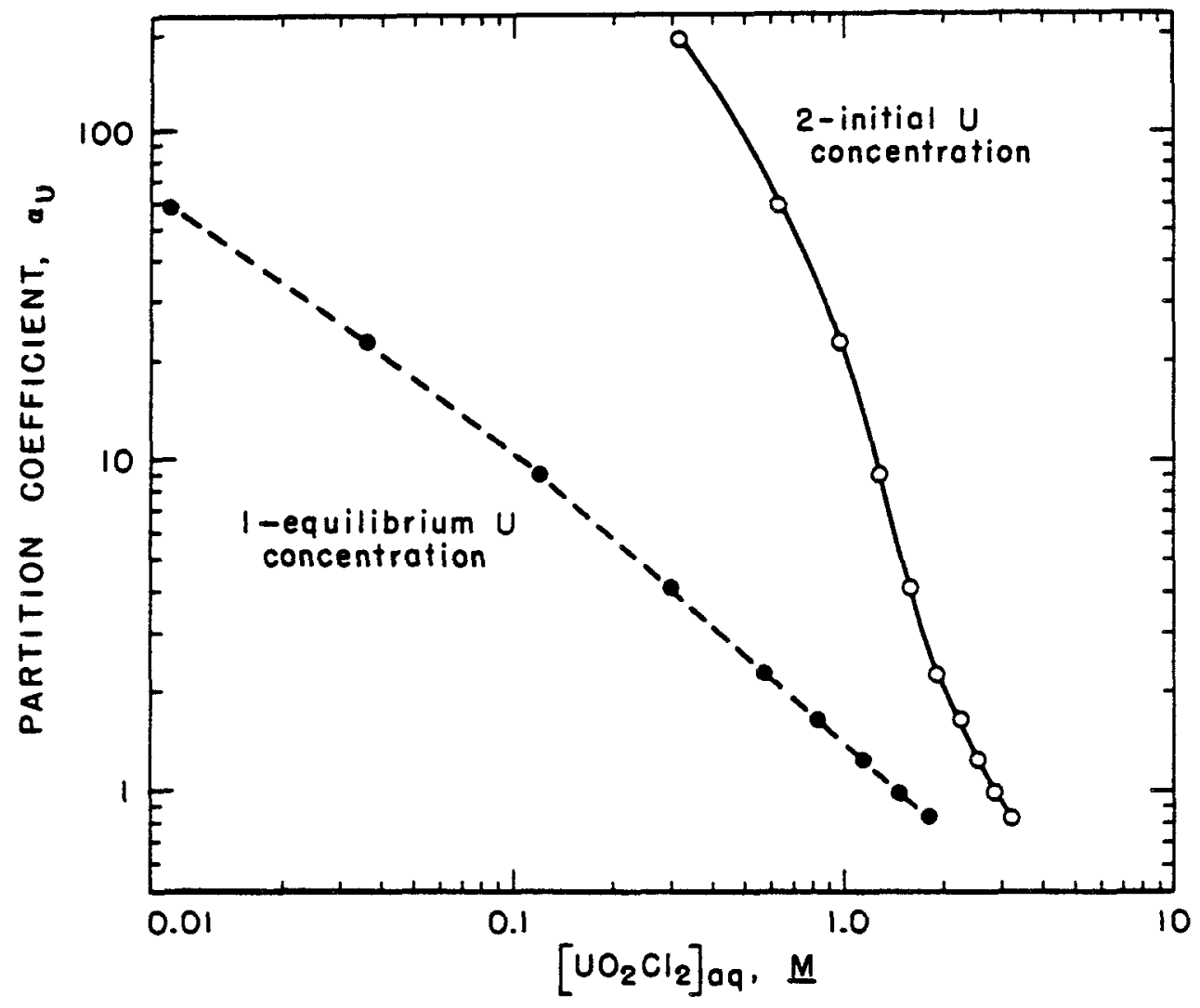

P1gure 40.

The distribution of $\mathrm{UO}_{2} \mathrm{Cl}_{2}$ between $100 \%$ TBP and aqueous $\mathrm{HCl}$ solution as a function of uranium concentration of the aqueous phase. Curve 1 represents the partition with the equilibrium aqueous uranium concentration plotted as abscissa; curve 2 , the partition with inftial aqueous uranium concentration as abscissa.

After A. S. Kertes, and M. Halpern, reference 428.

Conditions :

Constant $\mathrm{HCl}$ acid concentration of $8.83 \mathrm{M}$; equal phase volumes equilibrated for 15 minutes at room temperature, $18^{\circ}-22^{\circ} \mathrm{C}$. 


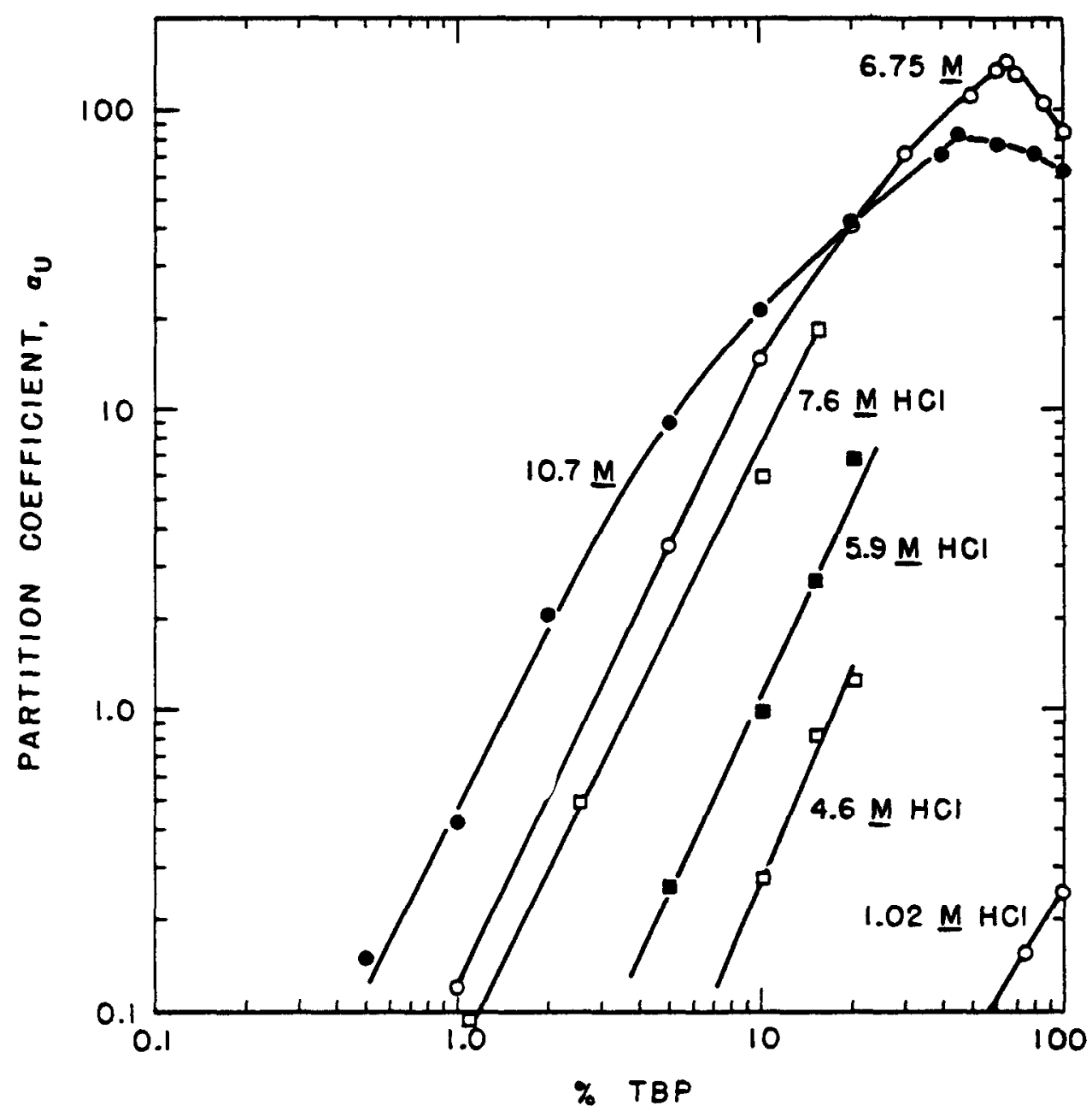

Figure 41. Partition coefficlent of uranium as a function of TBP concentration for various inftial aqueous HCl concentrations. $10.7 \mathrm{M}, 6.75 \mathrm{M}$, and $1.02 \mathrm{M} \mathrm{HCl}$ curves, after V. M. Vdovenko, A. A. LIpovski1, and S. A. NIKkitina, reference 426. Conditions: TBP dissolved in benzene. Extraction made at room temperature using U233. 4.6M, 5.9M and $7.6 \mathrm{M} \mathrm{HCl}$ curves, after V. B. Shevchenko, I. G. Slepchenko, V. S. Schmldt, and E. A. Nenarokomov, reference 427. Conditions: TBP dissolved in CC14. Equal phase volumes $(10 \mathrm{ml})$ mixed together for 30 minutes and allowed to stand for 12-15 hours.

examined the partition coefficients of Fe (II)(III), U (VI), $\mathrm{Co}$ (II), $\mathrm{Sr}$ (II). $\mathrm{Zr}$ (IV), Ce (III), Ru (IV), and V (V).

Agueous_perchlorate_systems. The distribution of uranyl perchlorate between TBP and water at $25^{\circ} \mathrm{C}$ is shown in figure 42.169 Figure 43 gives the partition coefficient of uranium as a function of the aqueous perchloric acid concentration. 169 
Shevchenko et al. 432 have studied the extraction of uranyl perchlorate in the presence of $\mathrm{HClO}_{4}, \mathrm{LiClO}_{4}$, and $\mathrm{NaClO}_{4}$. The salting-out capacity of these salts increases in the order 11sted. The choice of TBP diluent also affects the extraction of uranyl perchlorate. From an aqueous solution of $0.065 \mathrm{M}$ $\mathrm{HClO}_{4}$ and $1 \mathrm{M} \mathrm{NaClO}_{4}$, the extraction of uranium by 2.2OM TBP was found to decrease in the following order of diluents: 432

1soamyl acetate >n-butyl acetate > isoamy alcohol > toluene > xylene > benzene > carbon tetrachloride.

The distribution of perchloric acid between TBP and aqueous solution is given in figure 34.412 The partition coefficients of $\mathrm{Th}, \mathrm{Zn}, \mathrm{Pm}, \mathrm{Y}$, and $\mathrm{Ce}$ are plotted against aqueous perchloric acid concentration in figure 44.433 Ishimorl and

Table XXII. Effect of Salting-out Agents on the Extraction of Uranyl Chloride by TEP. $\underline{a}$

Salting-out agent $\alpha_{\mathrm{u}}$

\begin{tabular}{lc}
\hline & 0.03 \\
$\mathrm{NaCl}$, sat'd & 2.85 \\
$\mathrm{KCl}$, sat'd & 0.38 \\
$\mathrm{NH}_{4} \mathrm{Cl}, 5 \underline{\mathrm{M}}$ & 0.71 \\
$\mathrm{LICl}, 5 \mathrm{M}$ & 0.90 \\
$\mathrm{HCl}, 5 \underline{\mathrm{M}}$ & 17.6 \\
$\mathrm{CaCl}_{2}, 2.5 \mathrm{M}$ & 5.06 \\
$\mathrm{MgCl}_{2}, 2.5 \mathrm{M}$ & 11.7 \\
$\mathrm{AlCl}_{3}, 1.67 \underline{\mathrm{M}}$ & \\
\hline
\end{tabular}

2 After Gal and Ruvarsc, reference 431. Inttlal composition of organic phase - $30 \%(\mathrm{v} / \mathrm{v})$ TBP in dibutyl ether, sat'd with $1.225 \mathrm{M}$ HCl. Initial composition of aqueous phase - $1.225 \mathrm{M} \mathrm{HCl}$, $0.1 \mathrm{M} \mathrm{VO} \mathrm{Cl}_{2}$, salting-out agent at concentration indicated.? 


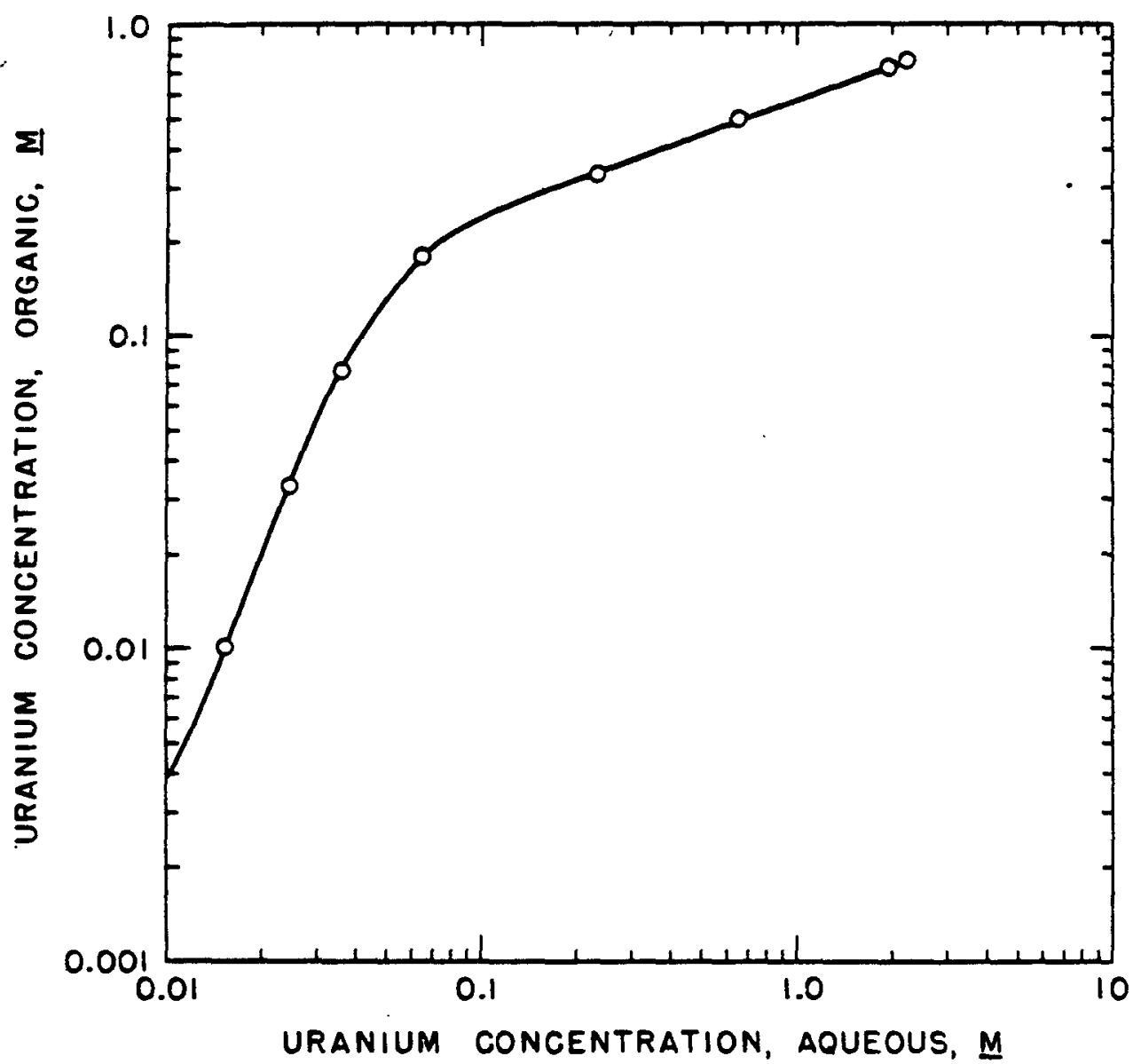

Figure 42.

The partition of uranyl perchlorate between $100 \%$ TBP and water at $25^{\circ} \mathrm{C}$.

After E. Hesford and H. A. C. Mckay, reference 269.

Nakamura 41 have studied the extraction of $\mathrm{Pa}$, and $\mathrm{Np}$ (IV) (V) (VI) by TBP as a function of perchlorate concentration. Agueous_sulfate systems. Sulfate ion is normaliy considered an interfering ion in the extraction of uranium from aqueous solution by TBP. Veereswararao, $\frac{434}{4}$ however, found that significant amounts of uranium may be extracted from sulfuric acid solution and that the extraction is increasta as the acid concentration is increased (figure 45). 434 


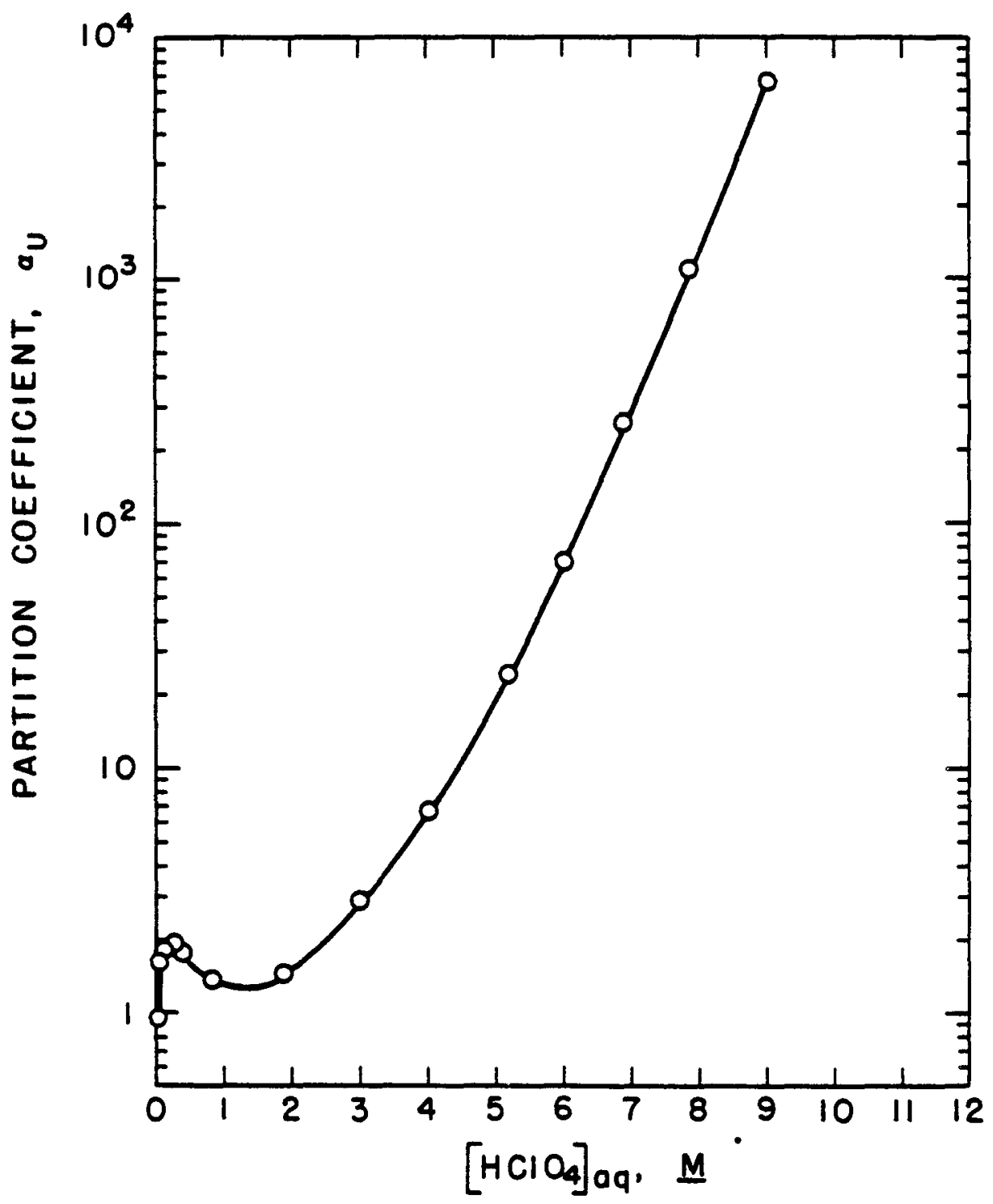

Figure 43.

The extraction coefficient of trace amounts of uranium between 100\% TBP and aqueous solution as a function of equilibrium aqueous $\mathrm{HClO}_{4}$ concentration. $25^{\circ} \mathrm{C}$.

After E. Hesford and H. A. C. McKay, reference 169. 


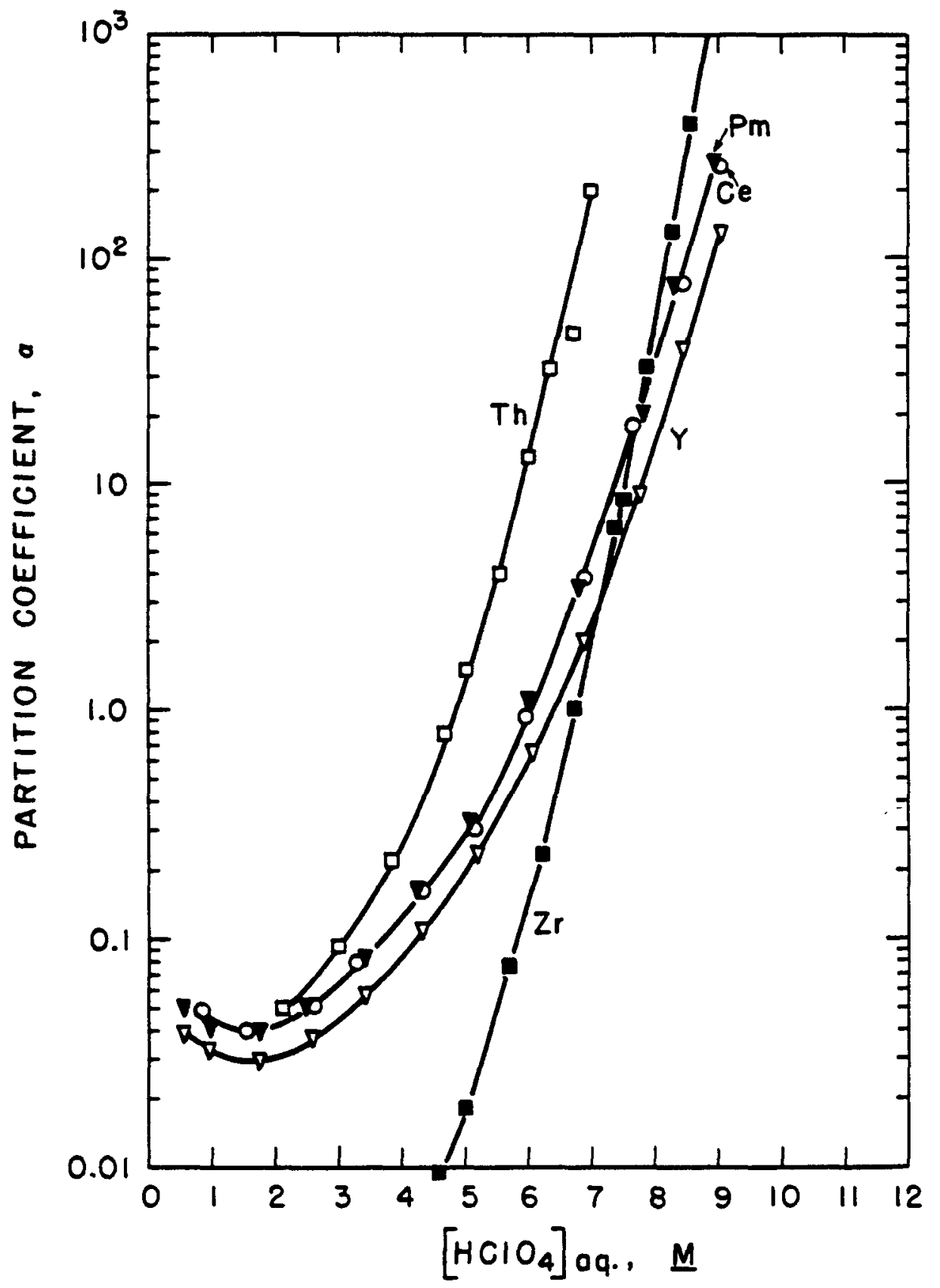

Figure 44. The distribution of $\mathrm{Th}, \mathrm{Pm}, \mathrm{Ce}, \mathrm{Zr}$, and $\mathrm{Y}$ between $100 \%$ TBP and aqueous solution as a function of inftial equilibrium aqueous $\mathrm{HClO}_{4}$ concentration. After $\mathrm{S}$. Sieklersk1, reference 433 . Conditions: Equal phase volumes $(15 \mathrm{ml})$ shaken together for about 20 minutes at $21^{\circ}-25^{\circ} \mathrm{C}$. 


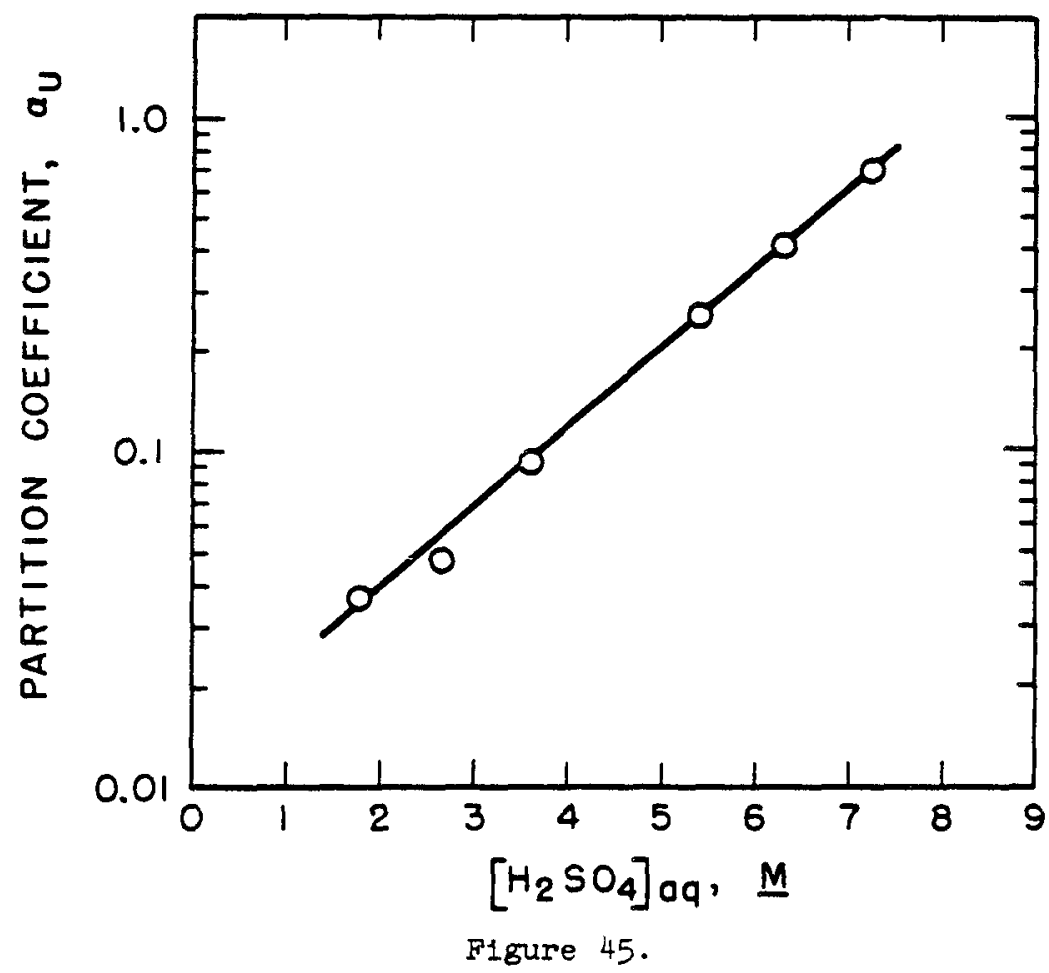

The partition coefficlent of uranium between $30 \%$ TBP $(v / v)$ in kerosene and aqueous solution as a function of equilibrium aqueous $\mathrm{H}_{2} \mathrm{SO}_{4}$ concentration.

After U. Veereswararao, reference 434.

Conditions :

Equal phase volumes $(10 \mathrm{ml}$ ) equilibrated by shaking for 5 minutes at $18^{\circ} \pm 1^{\circ} \mathrm{C}$.

The presence of sodium chloride in sulfuric acid solution augments the extraction of uranium by TBP. 434 Molybdeizum and iron (III) are well extracted from such solutions. Vanadium and iron (II) are poorly extracted compared to uranium. 434 The districution of sulfuric acid between TBP and aqueous solution is represented in figure 34.412

Aqueous th1ocyanate solution. Petrow and Marenburg $\frac{435}{4}$ have studied the effect of thiocyanate ion on the extraction of uranlum from sulfate liquors by TBP. From an aqueous solution containing $1.5 \mathrm{~g} / \mathrm{l}$ of $\mathrm{U}_{3} \mathrm{O}_{8}$ as uranyl sulfate and 
$2.1 \mathrm{~g} / 1$ total sulfate concentration at $\mathrm{pH} 1.5$, the partition coefficlent of uranium varied from 3.5 to 100 as the thiocyanate to uranyl molar rat10 was increased from 2 to 6 . Twenty per cent TBP dissolved in kerosene was used as extractant. The partition coefficient, $\alpha_{u}$, 1ncreases with Increased TBP concentration, Increases with increased $\mathrm{pH}$, and decreases with increased sulfate concentration. Vanadium and 1ron (III) are appreclably extracted by TBP from th10cyanate solutions. Copper, t1tanium, cobalt are weakly extracted. Iron (II), cadmium, molybdenum, magnesium and zluminum are essentially not extracted. Phosphate ion may cause the precipitation of uranium or complex formation when present in large amounts. Okada, et 21.436 report the extraction of uranlum by TBP, mesityl oxide, and methyl ethyl ketone from phosphoric ac1d solutions having 20 times as mach ammonium thlocyanate as uranium.

\section{Tri-n-octylphosphine oxide (TOPO)}

Much of the work on this solvent has been reported by White and co-workers. $437-444$ Uranium is extracted by TOPO from nitrate and chlorlde solutions and to a smalier extent from sulfate and perchlorate solutions. It is essentially not extracted from phosphate solutions. $\frac{44}{4}$ The extraction of $U$, Th, B1, Mo, $\mathrm{Zn}$, and $\mathrm{Cr}$ by $0.1 \mathrm{M}$ TOPO from aqueous solutions is given as a function of nitric acid concentration in figure 46 ; 25 a function of hydrochloric acid concentration in f1gure $47.440,441$ Iron and titantum extraction curves are 2lso included in figure 47 . The extraction of over 40 ions by $0.1 \mathrm{M}$ TOPO from hydrochloric, sulfuric, perchloric, and nitric acld solutions is qualitatively indicated in Table XXIII. 438 The extraction of mineral acids by $0.1 \mathrm{M}$ TOPO as a function of acid concentration is given in figure 48.441 Uranium may be stripped from TOPO solutions by contact 


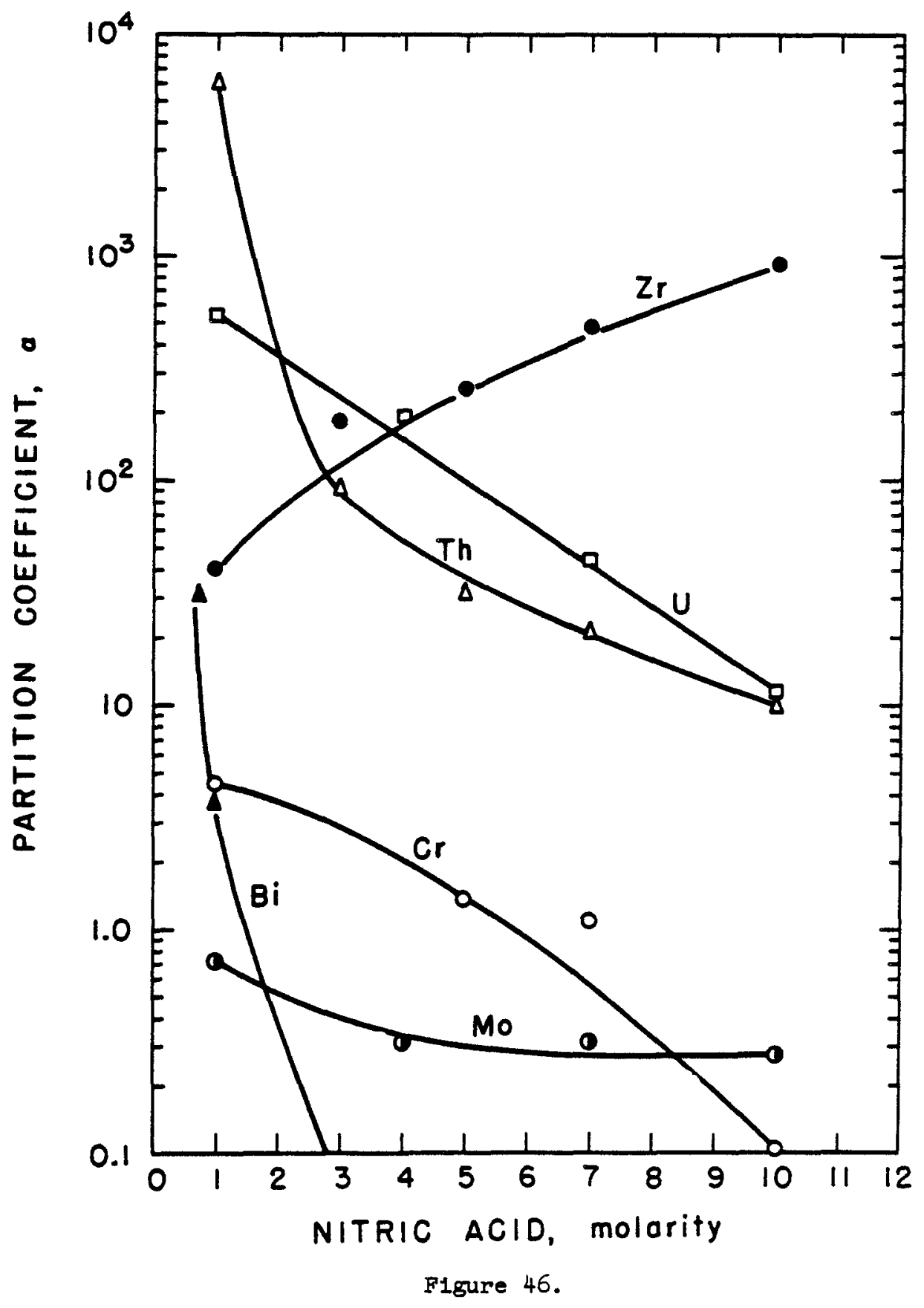

Extraction of some metal lons by $0.1 \mathrm{M}$ tri-n-octylphosphine oxide from nitric acid solutions. After J. C. White, references 440 and $44 I$. 


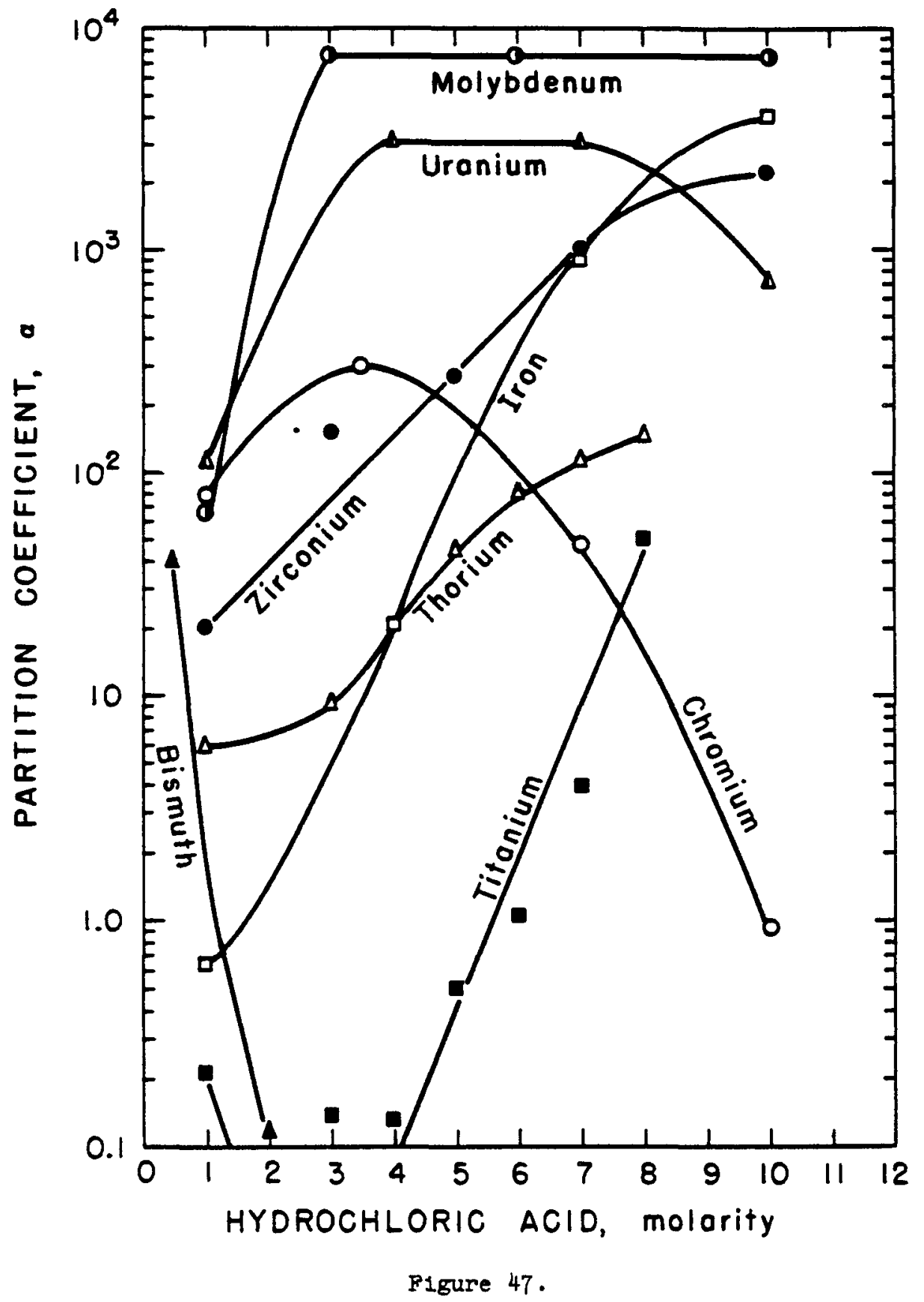

Extraction of metal lons by $0.1 M$ trl-n-octylphosphine oxide from hydrochloric acid solutions.

After J.C. White, references 440 and 441 . 
Table XXIII. Extraction of Ions from Ac1d Solutions with $0.1 M$ TOPO in cyclohexane. 므

\begin{tabular}{|c|c|c|c|c|c|c|c|c|}
\hline Ion & & & & & & & & \\
\hline & III & $7 \underline{1}$ & III & IIM & III & $7 \underline{M}$ & III & $7 \underline{M}$ \\
\hline $\mathrm{Al}^{+3}$ & $N$ & $\mathrm{~N}$ & $\mathrm{~N}$ & $\mathbf{N}$ & N & $\mathrm{N}$ & $N$ & $\mathrm{~N}$ \\
\hline $\mathbf{s b}+3$ & $\mathbf{P}$ & $E$ & E & $E$ & $P$ & $E$ & $\mathbf{P}$ & P \\
\hline $\mathrm{As}^{+5}$ & $N$ & N & $P$ & N & $P$ & $\mathbf{P}$ & $\mathrm{N}$ & $\mathrm{N}$ \\
\hline $\mathrm{Ba}^{+2}$ & $\mathrm{~N}$ & $N$ & - & - & $\mathrm{N}$ & $N$ & $N$ & $\mathrm{~N}$ \\
\hline $\mathrm{Be}^{+2}$ & $\mathrm{~N}$ & $N$ & $\mathrm{~N}$ & $\mathbf{N}$ & P & $N$ & $\mathrm{~N}$ & N \\
\hline $\mathrm{BI}+3$ & $\mathbf{P}$ & N & $\mathbf{E}$ & $?$ & $P$ & $\mathrm{~N}$ & $\mathbf{P}$ & $\mathrm{N}$ \\
\hline $\mathrm{B}^{+3}$ & $N$ & N & - & - & $\mathrm{N}$ & $N$ & $\mathrm{~N}$ & $\mathrm{~N}$ \\
\hline $\mathrm{Cd}^{+2}$ & $P$ & $\mathbf{P}$ & $\mathbf{N}$ & $?$ & $E$ & $E$ & $\mathrm{~N}$ & $\mathrm{~N}$ \\
\hline $\mathrm{Ca}^{+2}$ & $N$ & N & - & - & $\mathrm{N}$ & $\mathrm{N}$ & N & $N$ \\
\hline $\mathrm{Ce}^{+3}$ & $\mathbf{N}$ & $N$ & $N$ & $\mathrm{~N}$ & $N$ & $\mathrm{~N}$ & $\mathrm{~N}$ & $\mathrm{~N}$ \\
\hline$c r^{+6}$ & E & E & $E$ & $E$ & $E$ & $\mathbf{E}$ & $E$ & $E$ \\
\hline $\mathrm{Co}^{+2}$ & $N$ & N & $\mathbf{N}$ & $\mathbf{N}$ & $\mathrm{N}$ & $\mathrm{N}$ & $\mathrm{N}$ & $\mathrm{N}$ \\
\hline $\mathrm{cu}^{+2}$ & $N$ & $\mathbf{P}$ & $N$ & $N$ & $N$ & $\mathrm{~N}$ & N & $\mathrm{N}$ \\
\hline $\mathrm{Dy}^{+3}$ & $N^{\prime}$ & $\mathrm{N}$ & N & $N$ & $\mathrm{~N}$ & $\mathrm{~N}$ & N & $\mathrm{N}$ \\
\hline $\mathrm{Er}+3$ & $N$ & N & $\mathrm{N}$ & $N$ & $N$ & $N$ & $\mathrm{~N}$ & $\mathrm{~N}$ \\
\hline $\mathrm{Bu}+3$ & $\mathrm{~N}$ & $\mathrm{~N}$ & $\mathbf{N}$ & $N$ & $\mathrm{~N}$ & $\mathbf{N}$ & $\mathbf{N}$ & $\mathrm{N}$ \\
\hline $\mathrm{ad}^{+3}$ & $\mathbb{N}$ & $\mathrm{N}$ & $\mathrm{N}$ & $N$ & $\mathrm{~N}$ & $\mathrm{~N}$ & $\mathbf{N}$ & $\mathrm{N}$ \\
\hline $\mathrm{Ca}^{+3}$ & $\mathrm{~N}$ & $\mathbf{E}$ & $\mathrm{N}$ & $\mathbf{E}$ & $\mathbf{N}$ & $E$ & $\mathrm{~N}$ & $\mathrm{~N}$ \\
\hline$a e^{+4}$ & $?$ & $\mathbf{P}$ & $?$ & $\mathbf{P}$ & $?$ & $P$ & $?$ & $?$ \\
\hline $\mathrm{Au}^{+}$ & $E$ & $\mathbf{E}$ & $\mathbf{E}$ & $\mathbf{E}$ & $E$ & $E$ & $E$ & $\mathbf{P}$ \\
\hline $\mathrm{HF}^{+4}$ & $\mathbf{E}$ & $\mathbf{E}$ & $\mathbf{E}$ & $?$ & $E$ & E & $P$ & $P$ \\
\hline $\mathrm{Ho}^{+3}$ & $N$ & $\mathbf{N}$ & $N$ & $\mathrm{~N}$ & $\mathrm{~N}$ & $\mathbf{N}$ & $N$ & $\mathrm{~N}$ \\
\hline $\mathrm{In}^{+3}$ & $\mathbf{P}$ & $\mathbf{P}$ & $\mathbf{E}$ & E & $P$ & $N$ & $\mathrm{~N}$ & $\mathrm{~N}$ \\
\hline $\mathrm{Fe}^{+3}$ & $\mathbf{E}$ & E & $N$ & $\mathbf{N}$ & $\mathrm{N}$ & $\mathbf{N}$ & $\mathrm{N}$ & $N$ \\
\hline $\mathrm{L}_{2}+3$ & $\mathbf{N}$ & $\mathbf{N}$ & $\mathrm{N}$ & $\mathbf{N}$ & $N$ & $N$ & $N$ & $N$ \\
\hline $\mathrm{Pb}^{+2}$ & - & - & - & - & $N$ & $\mathrm{~N}$ & $\mathrm{~N}$ & $\mathrm{~N}$ \\
\hline $\mathrm{Mg}^{+2}$ & $N$ & $\mathbf{N}$ & - & - & $\mathrm{N}$ & $\mathrm{N}$ & $N$ & $\mathrm{~N}$ \\
\hline $\mathrm{Hg}^{+2}$ & $P$ & $N$ & $P$ & $?$ & $\mathrm{~N}$ & $\mathrm{~N}$ & $\mathrm{~N}$ & $\mathrm{~N}$ \\
\hline $\mathrm{Mo}^{+6}$ & $\mathbf{E}$ & $E$ & $E$ & $E$ & E & $E$ & $\mathrm{~N}$ & $P$ \\
\hline
\end{tabular}


Table XXIII.-Continued.

\begin{tabular}{|c|c|c|c|c|c|c|c|c|}
\hline Ion & & & & & & & & \\
\hline & IM & $7 \underline{M}$ & IM & IIM & IM & $7 \underline{M}$ & $I M$ & $7 \underline{9}$ \\
\hline $\mathrm{Nd}^{+3}$ & $\mathrm{~N}$ & $\mathrm{~N}$ & $N$ & $N$ & $\mathrm{~N}$ & $\mathrm{~N}$ & $N$ & $N$ \\
\hline $\mathrm{NI}^{+2}$ & $\mathrm{~N}$ & $\mathbf{N}$ & $\mathrm{N}$ & $\mathrm{N}$ & $\mathrm{N}$ & $\mathrm{N}$ & $N$ & iv \\
\hline $\mathrm{Pd}^{+2}$ & $\mathrm{~N}$ & $\mathrm{~N}$ & $\mathrm{~N}$ & $\mathrm{~N}$ & $\mathrm{~N}$ & $\mathrm{~N}$ & $N$ & iv \\
\hline $\mathrm{Pt}^{+2}$ & $P$ & $P$ & $P$ & $\mathrm{~N}$ & $\mathrm{~N}$ & $N$ & $\mathrm{~N}$ & $N$ \\
\hline $\mathrm{Pr}^{+3}$ & $N$ & $\mathrm{~N}$ & $N$ & $N$ & $\mathrm{~N}$ & $N$ & $\mathrm{~N}$ & Iv \\
\hline$R u^{+2}$ & $\mathrm{~N}$ & $\mathrm{~N}$ & $\mathrm{~N}$ & $?$ & $N$ & $?$ & $\mathrm{~N}$ & iv \\
\hline $\mathrm{Sm}^{+3}$ & $N$ & $N$ & $\mathrm{~N}$ & $N$ & $\mathrm{~N}$ & $\mathrm{~N}$ & $\mathrm{~N}$ & ii \\
\hline $\mathrm{Ag}^{+}$ & - & - & - & - & $N$ & $\mathrm{~N}$ & $\mathrm{~N}$ & iv \\
\hline$S r^{+2}$ & $\mathrm{~N}$ & $N$ & - & - & $\mathrm{N}$ & $\mathrm{N}$ & $N$ & $N$ \\
\hline $\mathrm{Tb}+3$ & $\mathrm{~N}$ & $\mathrm{~N}$ & $N$ & $\mathrm{~N}$ & $N$ & $N$ & $N$ & $\mathrm{~N}$ \\
\hline $\mathrm{Th}^{+4}$ & - & - & - & - & $?$ & $?$ & $\mathrm{P}$ & $P$ \\
\hline $\mathrm{Tm}+3$ & $\mathrm{~N}$ & $N$ & $\mathrm{~N}$ & $N$ & $N$ & $N$ & $\mathrm{~N}$ & $N$ \\
\hline $\mathrm{Sn}^{+4}$ & $E$ & $E$ & $E$ & E & $E$ & $\mathrm{E}$ & $E$ & $E$ \\
\hline $\mathrm{TI}^{+4}$ & $\mathrm{~N}$ & $E$ & $P$ & $E$ & $P$ & $E$ & $P$ & $\mathrm{~F}$ \\
\hline$u^{+6}$ & $E$ & $E$ & $E$ & $E$ & $E$ & $E$ & $\mathbf{E}$ & $E$ \\
\hline$v^{+4}$ & $N$ & $E$ & $N$ & $N$ & $N$ & $N$ & $\mathrm{~N}$ & $N$ \\
\hline$Y \mathrm{~b}+3$ & $\mathrm{~N}$ & $\mathrm{~N}$ & $\mathrm{~N}$ & $\mathrm{~N}$ & $\mathrm{~N}$ & $\mathrm{~N}$ & $\mathrm{~N}$ & iv \\
\hline$y^{+3}$ & $\mathrm{~N}$ & $\mathrm{~N}$ & $N$ & $?$ & $\mathrm{~N}$ & $N$ & $N$ & $\mathrm{~N}$ \\
\hline $\mathrm{zn}^{+2}$ & $P$ & $P$ & $\mathrm{~N}$ & $\mathrm{~N}$ & $\mathrm{~N}$ & $N$ & $N$ & $\mathrm{~N}$ \\
\hline $\mathrm{zr}^{+4}$ & $E$ & $E$ & $E$ & $E$ & $E$ & $E$ & $E$ & $E$ \\
\hline
\end{tabular}

$E=$ complete extraction $P=$ partial extraction $N=$ no extraction

2 After J. C. White, reference 438.

Equal phase volumes equilibrated 10 minutes. 


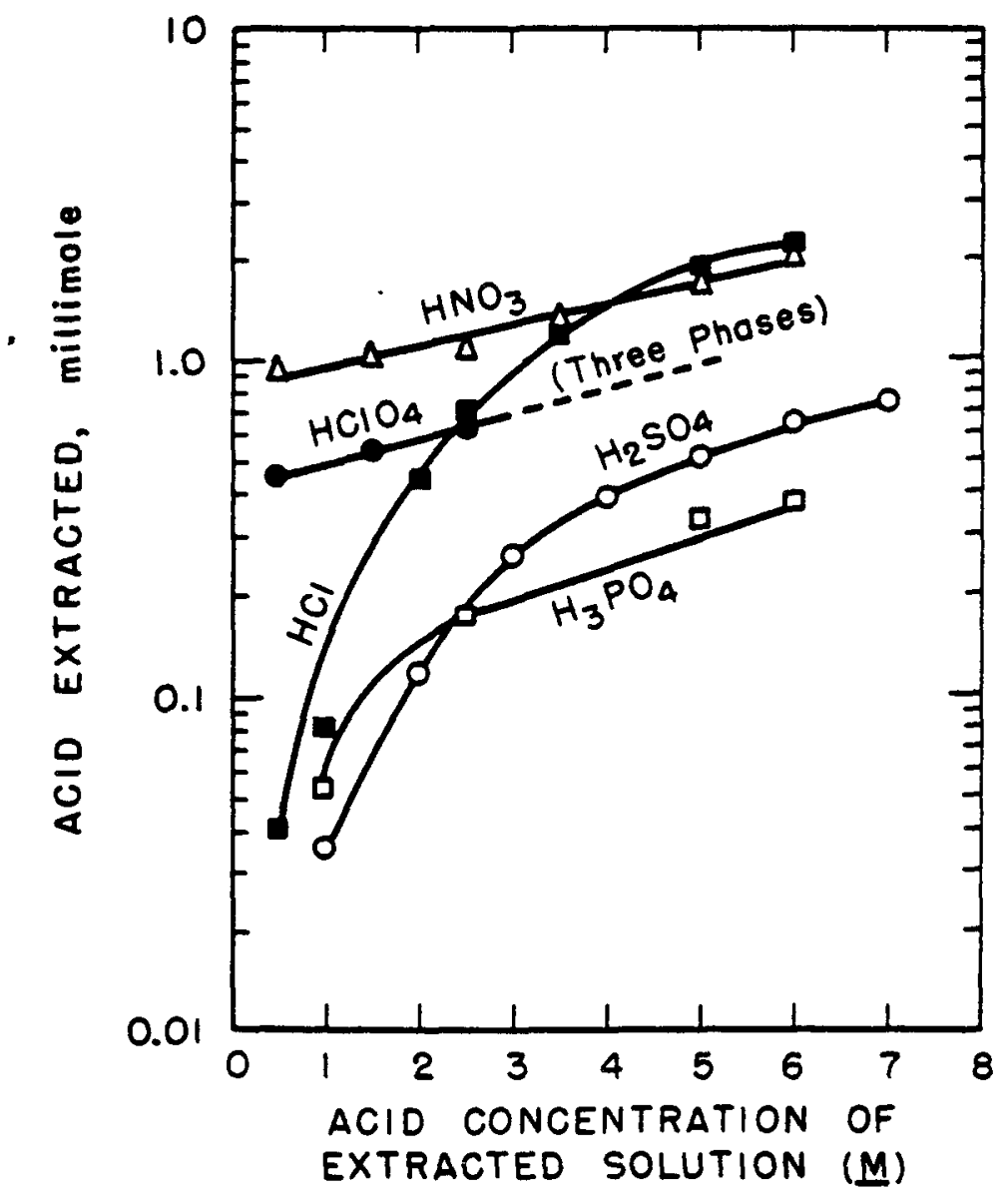

F1gure 48.

Extraction of mineral acids by tri-n-octylphosphine oxide. After J. C. White, reference 441.

\section{Conditions :}

Aqueous phases - acid solution of indicated molarity. Organic phase - $10 \mathrm{ml}$ of 0.1M TOPO in cyclohexane. $v_{0} / v_{2}-i$

with acid ( $\mathrm{HF}, \mathrm{H}_{3} \mathrm{PO}_{4}$, or concentrated $\left(\mathrm{NH}_{4}\right)_{2} \mathrm{SO}_{4}$ solutions at $\mathrm{pH} 2)$, hydroxide ( $\mathrm{NaOH}$ or $\left.\mathrm{NH}_{4} \mathrm{OH}\right)$, or carbonate $\left[\left(\mathrm{NH}_{4}\right)_{2} \mathrm{CO}_{3}\right.$ or $\mathrm{Na}_{2} \mathrm{CC}_{3}$ ] solutions. 445 Sodium carbonate is the most effective stripping agent.

\section{Tetraphenylphosphonium chloride (TPPC)}

A recent study has been reported in which uranium was extracted into chloroform as the tetraphenylphosphonium uranyl 
tribenzoate complex. 446 Uranyl ion was converted to an anionic form by benzo1c ac1d. Tetraphenylphosphonium chloride was used as extractant. The extraction of uranium was found to depend upon PH, TPPC concentration, and uranium concentration. At $\sim \mathrm{pH} 3-9$, the extraction of uranium was nearly quant1tative. The partition coefficient, $\alpha_{u}$, was increased with increased TPPC concentration and was decreased with increased uranium concentration. The decrease in $\alpha_{u}$ with increased uranium concentration was observed w1th a constant uranium-to-TPPC molar ratio. At $25^{\circ} \mathrm{C}$ and pH 5.2, zinc, zirconium (niobium), and ruthentum were appreclably extracted ( $10-20 \%$ compared to $100 \%$ for uranium). The extraction of zinc and zirconium may be depressed by the use of a complexing agent, EDTA, in solution.

\section{ACIDIC ORGANOPHOSPHORUS COMPOUNDS}

Uranium is efficiently extracted by acidic organophosphorus compounds which 1nclude di-and mono-alkylphosphoric acids, $(\mathrm{HO})(\mathrm{RO})_{2} \mathrm{P} \rightarrow \mathrm{O}$ and $(\mathrm{HO})_{2}(\mathrm{RO}) \mathrm{P} \rightarrow \mathrm{O}$; dialkylphosphinic acids, (HO) $R_{2} P \rightarrow 0$; 2Ikylphosphonic aclds, $(\mathrm{HO})_{2} \mathrm{RP} \rightarrow 0$; and d12lky Ipyrophosphor1c ac1ds, $\mathrm{H}_{2} \mathrm{R}_{2} \mathrm{P}_{2} \mathrm{O}_{7}$. The latter acids are discussed separately.

Table XXIV compares the extractive capacities of severai dialkylphosphor1c, d12lkylphosphinic, and monoalkylphosphoric acids for uranium. 302 The ab1lity to extract uranium, within a. Given class, appears to decrease with increased branching of the alkyl chain near the phosphate group. The acidity of the reagent decreases roughly in the same order. 302 where comparisons can be made for the same $21 \mathrm{kyl}$ group between classes of reagent, the extraction coefficient of uranium increases in the order

dialkylphosphor1c ac1d < dialkylphosphinic acid < monoalkylphosphoric acid.

The cholce of diluent affects the extraction of uranium. For 
Table XXIV. Extraction of Uranlum by Acldic Organophosphorus Reagents. a

Reasent

D1alkylphosphoric ac1ds

n-octy 1

3,5,5-trimethylhexyl

2-ethylhexyl

2-ethyl-4-me thy lpentyl

2-propy 1-4-methylpentyl

octy $1-2$

d11sobutylmethyl

D1alky lphosphinic ac1ds

$\gamma$-phenylpropyl

phenyl-2-ethylhexyl

$n$-decyl

$n$-octyl

$3,5,5$-trimethyinexy 1

2-ethylhexy 1

Monoalkylphosphorlc ac1ds

n-octyl

$3,5,5-\operatorname{tr} 1$ methylhexy 1

2-ethylhexyl

di1sobutylmethy?

2, 6,8-trime thy I rony $1-4$

1-1sobutyl-4-ethyloctyl

3,9-die thyl tridecanol-6
Uranium extraction coefficlent, $a_{u}$ Carbon tetrachloride Kerosene 
organic solvents, dlalkylphosphoric aclas are largely associated as aimers. $158,159,448$ on this basis, the reaction $\mathrm{UO}_{2}^{2+} x \mathrm{q}+2(\mathrm{HDAP})_{2}>\mathrm{rg}=\mathrm{UO}_{2}(\mathrm{DAP})_{2}(\mathrm{HDAP})_{2}$ org $+2 \mathrm{H}^{+}$

is indicated. 158,159 The number of dialkylphosphate groups associated with the uranyl ion in equation (1) may be accounted for by a chelate structure 158,302

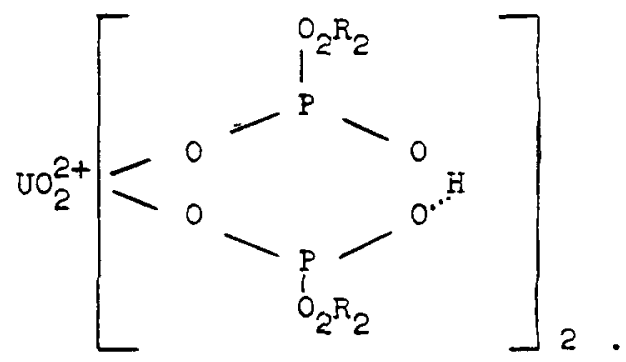

At higher uranium concentrations, isopiestic and viscosity measurements indicate that polymeric uranyl-dialkylphosphate chains are formed. 158

The extraction coefficient of uranium by dibutylphosphoric acid, HDBP, is given in figure 49 as a function of nitric acid concentration. 188 The shape of the curve has been explained by Healy and Kennedy in the following manner: 188

The initial decrease in ou between $0.1 \mathrm{M}$ and $3 \mathrm{M}$ $\mathrm{HNO}_{3}$ is expected on the basis of hydrogen ion replacement by Uolt Ion. However, for $\alpha_{\text {u }}$ greater than 10 not enough HDBP is present in the organic phase to give the monomeric species $\mathrm{UO}_{2}(\mathrm{DBP})_{2}(\mathrm{HDBP})_{2}$ demanded by equation (I). In this region, the extraction mechanism is likely to be governed by the reaction

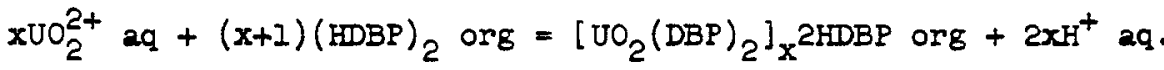

The shape of the extraction curve from $3 \mathrm{M}$ to $10 \mathrm{M}$ $\mathrm{HNO}_{3}$ is similar to that obtained with TBP and indicates 2 change in extraction mechanism. The likely reaction is

$\mathrm{UO}_{2}^{2+} \mathrm{aq}+2 \mathrm{NO}_{3}^{-} \mathrm{aq}+(\mathrm{HDBP})_{2}$ org $=\mathrm{UO}_{2}\left(\mathrm{NO}_{3}\right)_{2} 2 \mathrm{HDBP}$ org

The decrease in ou above $7 \underline{\mathrm{M}} \mathrm{HNO}_{3}$ is probably due to the competing reaction

$$
(\mathrm{HDBP})_{2} \text { org }+2 \mathrm{HNO}_{3} \text { aq }=2 \mathrm{HDBP} \cdot \mathrm{HNO}_{3} \text { org. }
$$

It is likely that mechanisms (2) and/or (3) $21 s 0$ occur to some extent at high acid concentrations. 
The extraction mechanism of dialkylphosphinic acids is expected to be similar to that of dialkylphosphoric ac1ds. The former are often found as dimers in organic solvents and the partition coefficlent of uranium, $\alpha_{u}$, exhibits 2 power dependence on extractant concentration at low uranium levels similar to that of dialkylphosphorlc aclds. 302 Mono2lkylphosphoric and monoalkylphosphonic aclds have been found In larger polymer1c aggregates. 302,448 Partition coefficients for these extractants exhlbit first to second power dependencies on extractant concentration. $\frac{302}{2}$

Interference to uranium extraction by anions increases In the order $\mathrm{ClO}_{4}^{-}<\mathrm{Cl}^{-}<\mathrm{SO}_{4}^{2-}<\mathrm{PO}_{4}^{3-}$.

Stripping is essentlaliy the inverse process of extraction. Uranium may be stripped from dialkylphosphoric acids by contact with hydrofluoria sulfuric, phosphoric, or even hydrochloric acids. The stripping efficlency is generally increased with

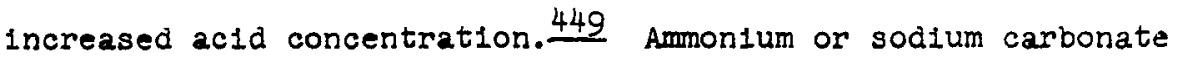
stripping is efficient. 449

Synergism. ${ }^{*}$ In a search for reagents to modify kerosene as the diluent for dialkylphosphoric acids, " 1t was discovered that neutral organophosphorus compounds provided a synergistic enhancement of the uranium partition coefficient. The enhancement is increased in the following order of neutral reagent:

trialkylphosphate < alkyl dialkylphosphonate < dlalkyl alkylphosphinate < trialkylphosphine oxide.

Table XXV lists $\alpha_{u}$ for several synergistic systems. 302 The reason for the enhanced partition coefficlent, $\alpha_{u}$, has been

* Co-operative action of discrete agencies such. that the total effect is greater than the sum of the two effects taken independently.

**Kerosene is modified to prevent separation of a dialkylphosphate salt as a separate phase when alkaline stripplng is useu. Iong chaln alcohols have been used as chemical modiflers. These, however, depress the extraction coefficient of uranium and other metals. 


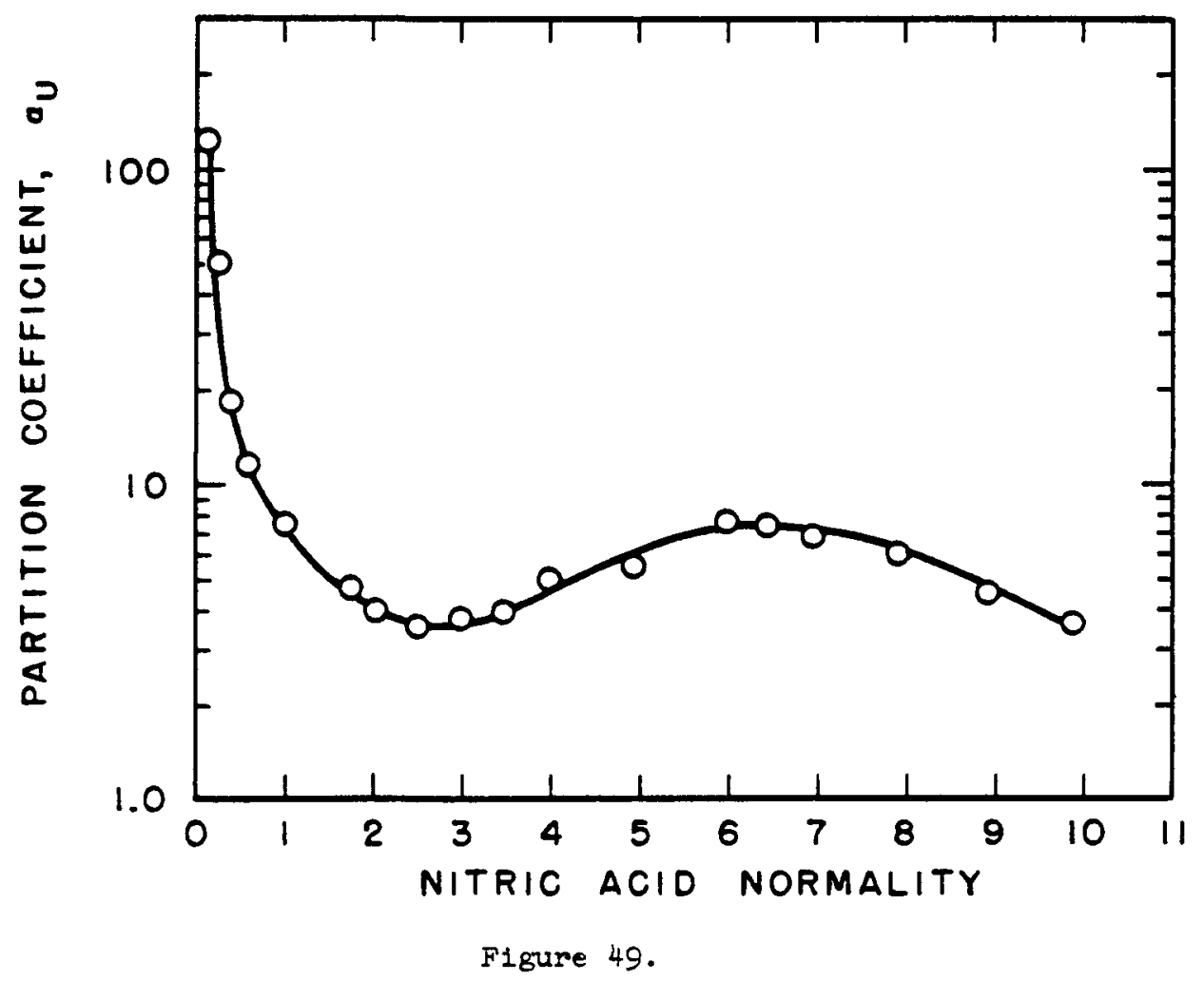

Variation of $a_{u}$ with nitric acid concentrations for $0.14 \mathrm{M}$ dibutylphosphoric acid in benzene using $20 \mathrm{ml}$ organic phase, and $50 \mathrm{ml}$ aqueous phase, and an initial uranium concentration of $0.018 \mathrm{M}$.

After T. V. Healy and J. Kennedy, reference 188.

explained on the basis of (1) the addition of neutral reagent to the uranyl-dialkylphosphate complex through hydroge.. bonding 302 or of (2) eliminating the need of monomerizing a mole of dimeric extractant 450 in the extraction mechanism (see equation (1)). A recent study of the synergistic system, thenoyltrifluoroacetone-neutral organophosphorus compound, indicates that nore investigation is necessary for a more precise explanation of synergistic effects. 451 Much of the work done on synergistic systems involving dialkylphosphoric acids is summarized in reference 452 . 
Table XXV. Synergist1c Enhancement of Uranfum Extraction Coefficient.a

\begin{tabular}{|c|c|c|c|}
\hline & & & \\
\hline rganophosphorus reagent & Conc., $\underline{M}$ & $\begin{array}{l}\text { Reagent } \\
\text { Alone }\end{array}$ & $\begin{array}{l}\text { In synergistic } \\
\text { combination with } \\
0.1 \mathrm{M} \text { neEHP }\end{array}$ \\
\hline
\end{tabular}

D1 (2-ethylhexyl) phosphoric

ac1d (D2EHPA)

$0.1 \quad 135$

Phosphates

tr1-n-butyl

tr1-2-ethy Ihexyl

$0.1 \quad 0.0002$

0.0002

470

0.1

270

Phosphonates

$\begin{array}{llll}\text { d1-n-butyl n-butyl } & 0.1 & 0.0002 & 1700 \\ \text { d1-n-angl n-any } 1 & 0.1 & 0.0003 & 2000 \\ \text { d1-n-hexgl n-hexjl } & 0.1 & 0.0004 & 2200 \\ \text { d1-2-ethylnexyl 2-ethylhexyl } & 0.1 & 0.0002 & 870\end{array}$

Phosphinates

n-butyl d1-n-butyl

n-butyl d1-n-hexyl

0.1

0.002

0.002

3500

0.1

3500

Phosphine oxides

$\operatorname{tr1-n-buty1}$

$\operatorname{tr1-n-octyI}$

0.05

tr1-2-ethylnexyl

0.1

0.0025

0.06

0.2

0.02

7000

3500

650

a After C. A. Blake, Jr., C. F. Baes, Jr., K. B. Brown, C. F. Coleman, J. C. White, reference 302 .

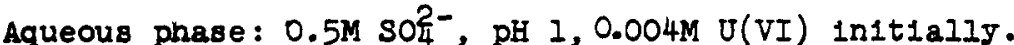

Organic phase: Reagents in kerosene diluent.

Temperature, $25^{\circ} \mathrm{C}$; $\mathrm{V}_{\alpha} / \mathrm{v}_{2}$, 1 .

D1 (2-ethy Ihexyl) phosphor1c ac1d (D2EHPA, HDEHP)

This reagent may also be known by a less descriptive name, dioctylphosphate (DOF). The extraction of uranium by D2EHPA is revlewed in reference 453. The effect of ac1d concentration on the extraction of uranium by D2EHPA is shown in figure 50.453 The uranium extraction curve for D2EHPA from nitric ac1d is simllar in shape, for the few polnts given, to that for dibutylpirosphoric acld given in f1gure 49. F1gure 51 1llustrates the effect of nitrate ion on the extraction of uranium by D2EHPA. 453 The presence of a small amount of nitrate in an aqueous sulfate solution increases the extraction of uranlum significantly. An increase in temperature causes a decrease in uranium extraction. $\frac{453}{3}$ 


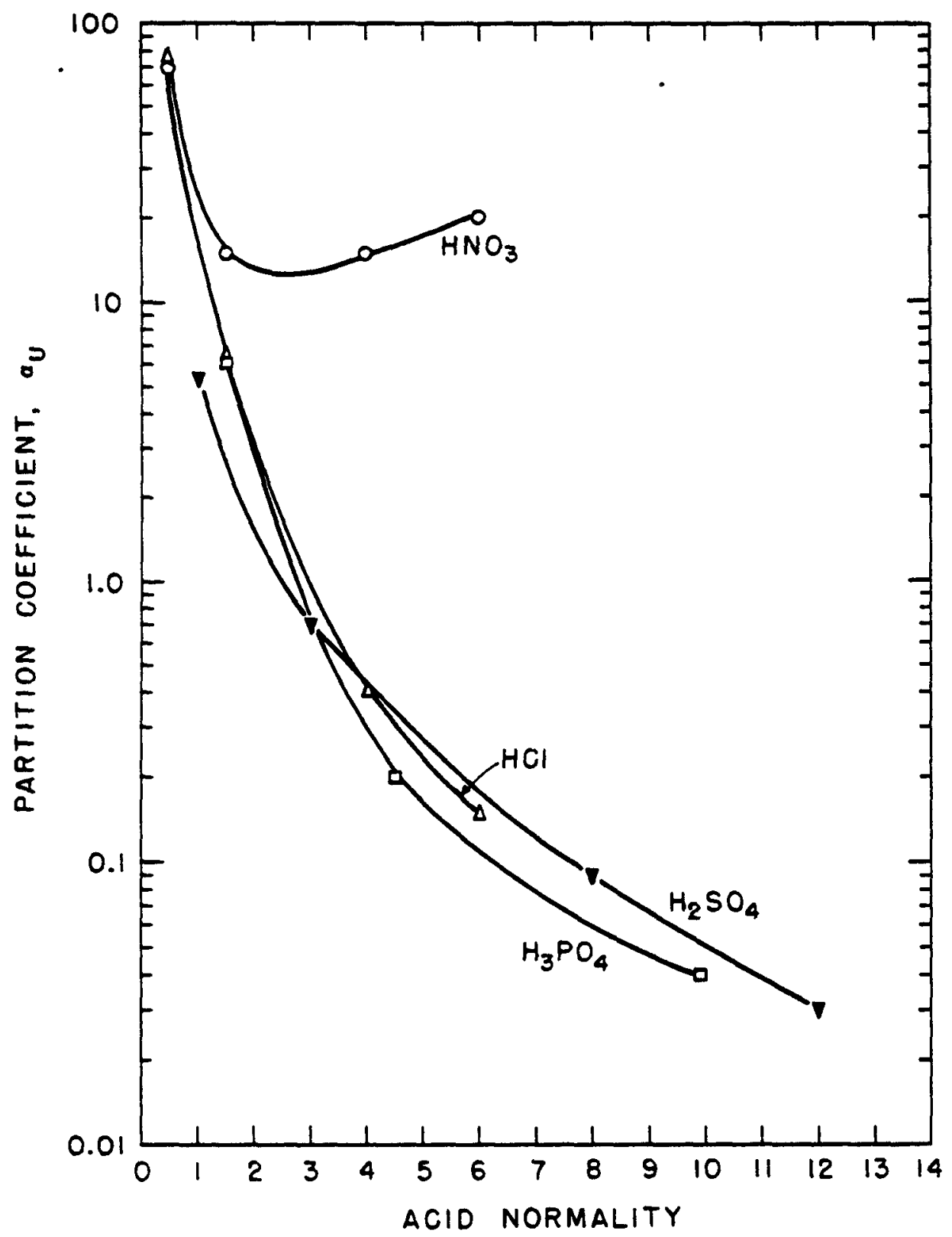

F1gure 50. Extraction of uranium by di(2-ethylhexyl) phosphoric acld in kerosene from mineral acid solutions. After $C$. A. Blake, K. B. Brown, and C.F. Coleman, reference 453. Conditions: organlc phase - 0 .IM D2EHPA in kerosene, 2\% $(\mathrm{w} / \mathrm{v}) 2$-ethylhexanol. Aqueous phase - $1 \mathrm{~g} / / \mathrm{l}$ for all acld solutions except $\mathrm{H}_{3} \mathrm{PO} 4$ in whlch case the U concentration was $100 \mathrm{ppm}$. Agitation time - 2 minutes. $\mathrm{V}_{0} / \mathrm{V}_{\mathrm{a}}=1$ for all aclds but $\mathrm{HNO}_{3}$ in which $\mathrm{V}_{\mathrm{n}} / \mathrm{V}_{\mathrm{a}}=2$. 


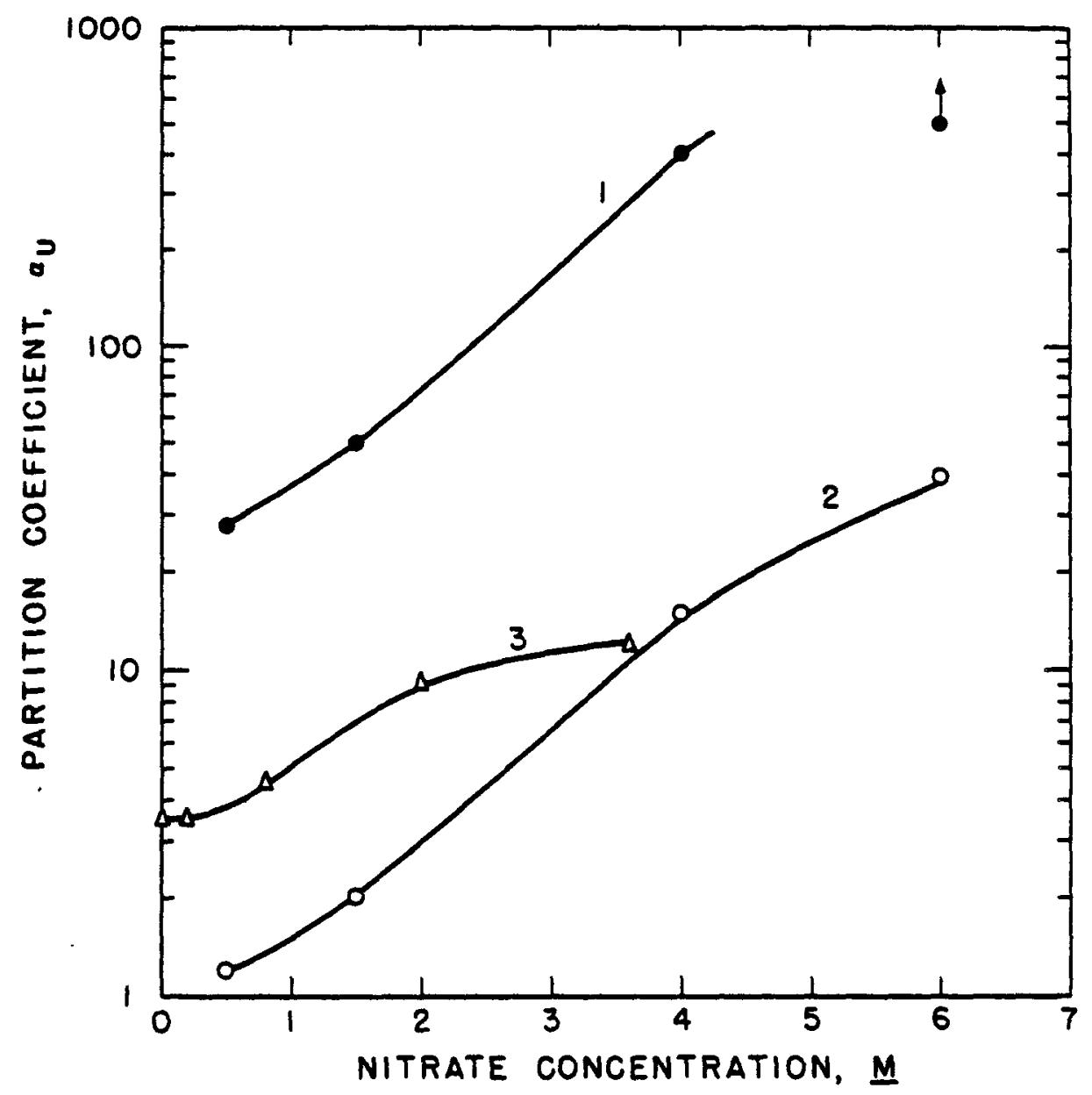

Figure 51. The effect of nitrate 1on on the extraction of uranium by di (2-ethylhexyl) phosphorlc ac1d. Curve $1-$ intilal $\mathrm{pH}=1.5-$ 1.85; Curve 2 - initial $\mathrm{pH}=0.5-0.75$. Conditions: $0.01 \mathrm{M}$ D2EHPA in kerosene ( $1.3 \%$ 2-ethylhexanol), $1 \mathrm{~g} \mathrm{U} / 1$ in aqueous phase, $\mathrm{V}_{0} / \mathrm{V}_{\mathrm{a}}=$ 2, $2 \mathrm{~min}$. contact t1me. Curve $3-0.5 \mathrm{M} \mathrm{SO}_{4}, \mathrm{pH}=1.2$. Cond1tions: $0.05 \mathrm{M}$ D2EHPA in CCl4, $1 \mathrm{~g} \mathrm{U} / 1$ in aqueous phase, $V_{0} / \mathrm{V}_{2}=1,20 \mathrm{~min}$. contäct time. After C. A. Blake, K. B. Brown, and ${ }^{\circ}$. F. Coleman, reference 453 .

The effect of diluent on $a_{u}$ is given in Table XxVI. 453 The enhanced extraction of uranium by D2HPA in synergistic combination with neutral organophosphorus reagents has already been noted (Table XXV). 302 The extent to which other lons are extracted is 1ndicated qualitatively in Tables XXVII and XXVIII. 454 
Table XXVI. Cho1ce of D1luent w1th D1(2-ethylhexyl)

\section{Phosphoric Acid.a}

Diluent

Kerosene

Hexane

Carbon tetrachloride

Isopropyl ether

Benzene

chloroform

2-Ethylhexanol

Octanol-2 (capryl alcohol)

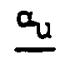

135

110

20

17

13

3

0.1

0.08

a After C. A. Blake, K. B. Brown, and C. F. Coleman, reference 453.

$0.1 \mathrm{M}$ D2EHPA, $0.004 \mathrm{M} \mathrm{U}$ (VI), $0.5 \mathrm{M} \mathrm{SO} \mathrm{C}^{-}, \mathrm{pH}=1.1$, $v_{0} \bar{v}_{a}=1$, agitation time $=10 \overline{\mathrm{m}} \mathrm{in}$. (wrist-action shaker).

\section{Dialky lpyrophosphoric acids}

Dialkylpyrophosphorlc acids are used in the recovery of uranium from low-grade phosphate ores. Much of the work that has been reported in project ilterature has been summarized by Ellis, $\frac{455}{6 y}$ bong, Ellis, and Balles, 456 and by Brown and Coleman. 305 The acids are prepared just prior to use by adding alcohol to a slurry of $\mathrm{P}_{2} \mathrm{O}_{5}$ in kesosene with stirring and cooling. A concentration of about $0.18 \mathrm{P}_{2} \mathrm{O}_{5}$ per ml of kerosene is optimum. 455 A $2: 1$ mole ratio of alcohol: $\mathrm{P}_{2} \mathrm{O}_{5}$ is used to form the dialkylpyrophosphor1c acid. A $3: 1$ mole ratio should give about equal mole quantities of mono- and d1-alkyl orthophosphoric acids. 455 The reactions are complex and mixtures of various phosphoric acids are formed. W1th pyrophosphoric ac1ds, uranium extraction increases with carbon chain length from butyl to octyl. 455 Nonyl and 
Table XXVII. Extraction of lletal Ions from Acidic Solutions with $0.1 \mathrm{M} D 1(2-e t h y l h e x y I)$ Phosphoric Acld in Cyclohexane.a Metal Sodium Chloride (2M) Amnonium Sulfate (IM) Sodium Nitrato Ion $\mathrm{pH} O \mathrm{pH} 0.5 \mathrm{pH} 1.5 \quad \mathrm{pH} 1.5$ (IM)

\begin{tabular}{|c|c|c|c|c|c|}
\hline $\mathrm{Al}^{+3}$ & - & - & $N$ & $\mathbf{N}$ & $\frac{\mathrm{pH} 2.5}{\mathrm{~N}}$ \\
\hline $\mathrm{As}^{+5}$ & - & - & $\mathrm{N}$ & $\mathrm{N}$ & $\mathrm{N}$ \\
\hline $\mathrm{Ba}^{+2}$ & - & - & $N$ & - & $N$ \\
\hline $\mathrm{Be}^{+2}$ & $P$ & $P$ & $P$ & $P$ & $P$ \\
\hline $\mathrm{B}^{+3}$ & - & - & $\mathrm{N}$ & - & $\mathrm{N}$ \\
\hline $\mathrm{Cd}^{+2}$ & - & - & $\mathrm{N}$ & $\mathrm{N}$ & $\mathrm{N}$ \\
\hline $\mathrm{Ca}^{+2}$ & - & - & $N$ & - & $\mathrm{N}$ \\
\hline $\mathrm{Cr}^{+6}$ & $P$ & $P$ & $P$ & $P$ & $P$ \\
\hline $\mathrm{Co}^{+2}$ & - & - & $\mathrm{N}$ & $\mathrm{N}$ & $\mathrm{N}$ \\
\hline $\mathrm{Cu}^{+2}$ & - & - & $\mathbf{N}$ & $N$ & $\mathrm{~N}$ \\
\hline $\mathrm{Ca}^{+3}$ & - & - & $N$ & $\mathrm{~N}$ & $N$ \\
\hline $\mathrm{Au}^{+}$ & - & - & $N$ & $\mathrm{~N}$ & $\mathrm{~N}$ \\
\hline $\mathrm{HF}^{+4}$ & $\mathbf{E}$ & $E$ & $E$ & $E$ & $E$ \\
\hline $\mathrm{In}^{+3}$ & $N$ & $\mathrm{~N}$ & $P$ & $P$ & $P$ \\
\hline $\mathrm{Fe}^{+3}$ & $P$ & $P$ & $P$ & $P$ & $P$ \\
\hline $\mathrm{La}^{+3}$ & $\mathrm{~N}$ & $\mathrm{~N}$ & $\mathrm{~N}$ & $\mathbf{N}$ & $\mathrm{N}$ \\
\hline $\mathrm{Mg}^{+2}$ & - & - & $N$ & - & $\mathrm{N}$ \\
\hline $\mathrm{Hg}^{+2}$ & - & - & $\mathrm{N}$ & $N$ & $\mathrm{~N}$ \\
\hline $\mathrm{MO}^{+6}$ & $E$ & $E$ & $\mathbf{E}$ & E & $E$ \\
\hline $\mathrm{N1}^{+2}$ & - & - & $\mathrm{N}$ & $N$ & $\mathrm{~N}$ \\
\hline $\mathrm{Pd}^{+2}$ & - & - & $N$ & $N$ & $\mathrm{~N}$ \\
\hline $\mathrm{Pt}^{+2}$ & - & - & $\mathrm{N}$ & $N$ & $\mathrm{~N}$ \\
\hline $\mathrm{Ru}^{+2}$ & - & - & $\mathrm{N}$ & $\mathrm{N}$ & $N$ \\
\hline $\mathrm{Sr}^{+2}$ & - & - & N & - & $\mathrm{N}$ \\
\hline $\mathrm{Tn}^{+4}$ & $E$ & $E$ & $E$ & $\mathbf{E}$ & $E$ \\
\hline $\mathrm{Sn}^{+4}$ & $E$ & $E$ & $\mathbf{P}$ & $\mathrm{N}$ & $\mathbf{E}$ \\
\hline $\mathrm{Ti}^{+4}$ & $E$ & $E$ & $E$ & $E$ & $E$ \\
\hline$u^{+6}$ & $E$ & $E$ & $E$ & $E$ & $\mathbf{E}$ \\
\hline$y^{+3}$ & $\mathrm{~N}$ & $E$ & $\Sigma$ & $E$ & $E$ \\
\hline$v^{+4}$ & $\mathrm{~N}$ & $\mathrm{~N}$ & $P$ & $E$ & $P$ \\
\hline $\mathrm{Zn}^{+2}$ & $\mathbf{N}$ & $\mathbf{N}$ & $P$ & $\mathrm{~N}$ & $P$ \\
\hline $\mathrm{zr}^{+4}$ & $E$ & $\mathbf{E}$ & $E$ & $E$ & $E$ \\
\hline
\end{tabular}

$E=$ complete extraction, $P=$ partial extraction, $N=$ no extraction, - = no test was conducted.

a After W. J. Ross and J. C. White, reference 454. Aqueous phase: 1-2 mg of 1on, salt at concentration indicated, pH indicated.

Organic phase: $0.1 \mathrm{M}$ D2HPA in cyclohexane. $5 \mathrm{ml}$ portions of each phase shaken together for one hour. 
Table XXVIII. Extraction of Rare Earths from Chloride Solutions with D1(2-ethylhexyl) Phosphorlc Acld in Cyclohexane.a Ion $\mathrm{pH} 1.9 \quad \mathrm{pH} 1.0 \quad \mathrm{pH} 1 . \mathrm{O}^{\mathrm{b}} \mathrm{pH} 0.5 \quad \mathrm{pH} 0.5^{\mathrm{b}} \quad \mathrm{pH} 0$

\begin{tabular}{|c|c|c|c|c|c|}
\hline$Y^{+3}$ & $\mathbf{E}$ & $\mathbf{E}$ & $\mathbf{E}$ & $\mathbf{E}$ & $P$ \\
\hline $\mathrm{Ie}^{+3}$ & $\mathbf{N}$ & $\mathbf{N}$ & $\mathrm{N}$ & $\mathbf{N}$ & $\mathrm{N}$ \\
\hline $\mathrm{Ce}^{+3}$ & $P$ & $\mathrm{~N}$ & $\mathbf{N}$ & $\mathbf{N}$ & $N$ \\
\hline $\mathrm{Pr}^{+3}$ & $\mathbf{P}$ & $\mathbf{N}$ & $\mathbb{N}$ & $\mathbf{N}$ & $\mathbb{N}$ \\
\hline $\mathrm{Na}^{+3}$ & $\mathbf{E}$ & $\mathrm{N}$ & $P$ & $\mathrm{~N}$ & $N$ \\
\hline $\mathrm{Sm}^{+3}$ & $E$ & $\mathbf{N}$ & $P$ & $\mathbf{N}$ & $\mathbb{N}$ \\
\hline $\mathrm{Eu}^{+3}$ & $\mathbf{E}$ & $E$ & $E$ & $P$ & $\mathrm{~N}$ \\
\hline $\mathrm{Oa}^{+3}$ & $\mathbf{E}$ & $\mathbf{E}$ & $\mathbf{E}$ & $P$ & $N$ \\
\hline $\mathrm{Tb}+3$ & $\mathbf{E}$ & $\mathbf{E}$ & $E$ & $\mathbf{E}$ & $E$ \\
\hline $\mathrm{Dy}^{+3}$ & $\mathbf{E}$ & $\mathbf{E}$ & $E$ & E & $E$ \\
\hline $\mathrm{HO}^{+3}$ & $\mathbf{E}$ & $E$ & $E$ & $E$ & $\mathbf{E}$ \\
\hline $\mathrm{Er}^{+3}$ & $\mathbf{E}$ & $\mathbf{E}$ & $\mathbf{E}$ & $\mathbf{E}$ & $E$ \\
\hline $\mathrm{Tm}^{+3}$ & $E$ & $\mathrm{E}$ & $\mathbf{E}$ & $\mathbf{E}$ & $E$ \\
\hline $\mathrm{Yb}^{+3}$ & $E$ & $E$ & $E$ & $\mathbf{E}$ & $\mathbf{E}$ \\
\hline
\end{tabular}

$E=$ complete extraction, $P=$ partial extraction, $N=$ no extraction.

a After W. J. Ross and J. C. White, reference 454. Aqueous phase: standard solution of $2 \mathrm{mg} / \mathrm{ml} \mathrm{Ce}^{+3}$; $1 \mathrm{mg} / \mathrm{ml} \mathrm{Pr}+3 \mathrm{Na}+3 \mathrm{Sm}+3^{\mathrm{Dy}}+3 \mathrm{Ho}+3.0 .5 \mathrm{mg} / \mathrm{ml} \mathrm{Tb}+3$; $0.2 \mathrm{~ms} / \mathrm{ml} \mathrm{Y}+3, \mathrm{Ia}+3, \mathrm{Eu}+3, \mathrm{ad}^{+3}, \mathrm{Er}+3 ; 0.1 \mathrm{mg} / \mathrm{ml} \mathrm{Yb}_{\mathrm{b}}+$ I ml of standard solution, I ml $5 \mathrm{M} \mathrm{NaCl}, \mathrm{NaOH}$ or $\mathrm{HCl}$ to give desired $\mathrm{pH}$ in $5 \mathrm{mI}$ of Bolution.

Organic phase: $5 \mathrm{ml}$ of $0.1 \mathrm{M}$ D2EHPA in cyclohexane extraction I'or 1 hour.

bithout NaCl.

decyl give about the same extraction as octyl. 455 No appreclable difference in extracting ability was observed between pysophosphoric acids prepared with octanol-1 or octanol-2. 455 Most of the studies have been made with octylpyrophosphoric ac1d (OPPA). Pyrophosphoric acids deteriorate falrly rapidiy w1th t1me at room temperature. At elevated temperatures, the rate of deterioration is even greater. Contact with mineral ac1d causes pyrophosphoric acids to hydrolyze to orthophosphor1c ac1ds. The rate of hydrolysis is slower with basic solutions. 455 
Kerosene is a satisfactory diluent for OPPA. $\stackrel{455}{\text { The }}$ ac1d is used in 1-10\% concentration.

The partition coefficient of uranium, $\alpha_{u}$, is considerably higher with OPPA than with the corresponding mixture of orthophosphoric acids, OPA. The partition coefficient is a function of the oxidation potential of the ac1d. With OPPA, satisfactory uranium recovery can be made if the e.m.f. is -0.250 volts or greater. 455 Reduction of the acid increases the extraction of uranium considerably. At zero to +100 volts $a_{u}$ is about twenty times that at -300 to -200 volts. 450 The extraction of iron is decreased in reduced solution, 1.e. $a_{\mathrm{Fe}}(I I)<\alpha_{\mathrm{Fe}}(I I I) \cdot$

Uranium is stripped from the organic solvent by precipitation as uranous fluoride.

Several papers have recently appeared in open 11terature publications concerning the extraction of uranium by pyrophosphoric acids. Zangen 457 has shown that OPPA prepared by the alcoholysis of $\mathrm{P}_{2} \mathrm{O}_{5}$ is a mixture of several components. OPPA prepared in this manner was found to be more effective in the extraction of uranium than pure dioctylphosphoric ac1c by two orders of magnitude. The pure acld was prepared by synthesis, starting from $\mathrm{POCl}_{3}$.

In an effort to determine the uranium species extracted by OPPA, Grdenic and Korpar $45^{8}$ have isolated the species $\mathrm{U}\left(\text { Oct }_{2} \mathrm{P}_{2} \mathrm{O}_{7}\right)_{2}$. The species, however, was insoluble in $11 \mathrm{gro}$ in, the OPPA diluent. It was soluble in ligroin containing OPPA In a ratio of one mole of $U(I V)$-salt and 2 moles of OPPA. This indicates $U\left(\operatorname{Oct}_{2} \mathrm{HP}_{2} \mathrm{O}_{7}\right)_{4}$ is the extractable species. The same formula was obtained by determination of the uranium content in a saturated 11 groin phase.

Habash 159 has investigated the extraction of urantum and other metals by OPPA from phosphoric ac1d solutions. Uranium (VI) was found to be more highly extracted than uranium 
(IV). This is surprising in view of the increased extraction of uranium from reduced acid solution mentioned previously. AIso, cerlum (III) was found to extract more readily than cerfum (IV). The partition coefficlents of several metal 1ons are given for varlous phosphoric acid concentrations in Table XXIX. The partition coefficients decrease with $\mathrm{H}_{3} \mathrm{PO}_{4}$ concentration for all the metal lons tested except cerlum. The extraction coefficients of both cerium (IV) and (III) pass through maxima in the region of $4 \mathrm{M} \mathrm{H}_{3} \mathrm{PO}_{4}$. The partition coefficlent of uranium is decreased by increased initial uranium concentration. The addition of $\mathrm{Na}_{3} \mathrm{PO}_{4}$ to the solution causes $a_{u}$ to increase greatly-apparently by decreasing the hydrogen ion concentration in the aqueous phase. Fluoride Ion interferes most seriously with the extraction of uranium by OPPA.

Zangen 460 has studied the extraction of uranium (IV) from phosphoric ac1d by di-(2-butyloctyl) pyrophosphate, BOPPA. AMINES AND QUATERRARY AMMONIUM SALTS. A large number of amines, quaternary amonium salts, and other organonitrogen compounds have been investigated as possible extractants of uranium. $461-463$ The physical chemistry of uranium extraction by amines has been studied by McDowell, Baes, and Allen $464-468$ and Bo1re 469,470 Much of the above work has been summarized by Coleman, et al. 304 More recently, Moore 471 has reviewed the extraction of a large number of elements, including uranium, by amines.

The reactions involved in the extraction of uranium by amines have been reviewed by coleman, et al. 304 organic solutions of amines extract acids from aqueous solution to form alkylamonium salts

$$
\mathrm{R}_{3} \mathrm{~N} \text { org }+\mathrm{HX} \text { aq } \rightleftharpoons \mathrm{R}_{3} \mathrm{NHX} \text { org. }
$$

The amine salt in the organic phase can exchange its ion for another in the aqueous phase 
Table XXIX. Partition Coefricients or Several Metal Ions Between $O P P A$ and $\mathrm{H}_{3} \mathrm{PO}_{4} \cdot \underline{a}$

\begin{tabular}{|c|c|c|c|c|}
\hline \multirow{2}{*}{ Ion ${ }^{b}$} & \multicolumn{4}{|c|}{$\begin{array}{l}\text { Partition coefficient } \\
4 \text { concentration }\end{array}$} \\
\hline & $2 M$ & $4 M$ & $6 \underline{M}$ & 84 \\
\hline$U(V I)$ & 190 & 46 & 23 & 20 \\
\hline$U(I V)$ & 18.6 & 14.2 & 13.5 & \\
\hline $\operatorname{Tr}_{4}(I V)$ & 24 & 23 & 18 & 13 \\
\hline $\mathrm{Fe}$ (III) & 18 & 8 & 5 & \\
\hline $\operatorname{Fe}(I I)$ & 1 & $<1$ & $<1$ & \\
\hline$V(I V) \underline{c}$ & 2 & 0.8 & 0.1 & \\
\hline $\mathrm{Ce}$ (IV) & 5 & 8 & 3 & 1 \\
\hline $\mathrm{Ce}$ (III) & 7 & 22 & 4 & 2 \\
\hline
\end{tabular}

2 After F. Habash1, reference 459.

The coefficients, with the exception of $\alpha_{u(I V)}$, were determined from figures which appear in reference 459.

$\underline{b} 0.4 \mathrm{mg}$ metal ion per $\mathrm{ml} ; 2 \not 0$ OPPA in $n$-hexane; $V_{\sigma} / V_{a}=0.1$. $\stackrel{c}{v_{\alpha} / v_{a}}=1$

$$
\mathrm{R}_{3} \mathrm{NHX} \text { org }+\mathrm{Y}^{-} \mathrm{aq} \rightleftharpoons \mathrm{R}_{3} \mathrm{NHY} \mathrm{O}_{2} \mathrm{y}+\mathrm{X}^{-} \mathrm{aq} \text {. }
$$

The order of preferences for antons in the organic anine solution $1 \mathrm{ClO}_{4}^{-}>\mathrm{NO}_{3}^{-}>\mathrm{Cl}^{-}>\mathrm{HSO}_{4}^{-}>\mathrm{F}^{-}$. 304

In this anion exchange representation, metals are then extracted from aqueous solutions in which they are present as anions or anionic complexes. For example,

$$
\begin{aligned}
& \mathrm{UO}_{2}^{2+} \mathrm{aq}+3 \mathrm{X}^{-} \text {aq } \rightleftharpoons \mathrm{UO}_{2} \mathrm{X}_{3}^{-} \mathrm{aq} . \\
& \mathrm{R}_{3} \mathrm{NHCX} \text { org }+\mathrm{UO}_{2} \mathrm{X}_{3}^{-} \mathrm{aq} \rightleftharpoons \mathrm{R}_{3} \mathrm{NHUO}_{2} \mathrm{X}_{3} \text { org }+\mathrm{X}^{-} .
\end{aligned}
$$

This mechan1sm, however, is indistinguishable from one in whlch a neutral complex is extracted.

$$
\begin{gathered}
\mathrm{UO}_{2}^{2+} \text { aq }+2 \mathrm{X}^{-} \text {aq } \rightleftharpoons \mathrm{UO}_{2} \mathrm{X}_{2} \text { aq. } \\
\mathrm{R}_{3} \mathrm{NHX} \text { org }+\mathrm{UO}_{2} \mathrm{X}_{2} \text { as. } \rightleftharpoons \mathrm{R}_{3} \mathrm{NHUO}_{2} \mathrm{X}_{3} \text { org. }
\end{gathered}
$$


The factors that influence uranium extraction have been studied most extensively for amine-sulfate systems. 304 The effect of amine structure on the extraction of uranium and other metal 1ons is illustrated in Table XXX. 304 Uranium (IV) is efficiently extracted by primary amines. The efficlency decreases with secondary and tertiary amines. With uranium (VI) there does not seem to be much correlation tetween $\alpha_{u}$ and amine class. With primary, seconoary, ani turtiary laurylamines, $\alpha_{u(V I)}$, under the conditions given I.r. Table $X X X$, is $<0.1,80$, and 140 , respectively. 30 t with primary laurylamine an emulsion is formed. 304 The extraction of uranium is also affected by carbon chain branchine near the nitrogen atom in tertiary amines (Table XXX). Certain n-benzyl-branched-alkyl secondary amines have been found to extract uranium extremely wel1. 304 The uranium (VI) partition coefficients of N-benzylheptadecylamine, N-benzyltetradecylamine, N-benzyldodecylamine, and N-(2-naphthylmethyl) dodecy Iamine, under the conditions outlined in Table XXX, are 2000, $>1000,>1000,-1000$, respectively. 304 The partition coefficient depends upon the amine-diluent combination. The effect of diluent on $u_{u}(v I)$ is indicated in Table XXX.

The partition coefficient, $a_{u}(V I)$, is influenced by uranium concentration in that it changes the amount of free amine sulfate concentration. $\underline{304}$ In sulfate sulution, bisulfate complexes the amine more strongly than does sulfate. The uranium partition coefficient, therefore, decreases with increased acidity. 304 Excess aqueous sulfate causes a decrease in $a_{u}(V I) \cdot \frac{3 C 4}{}$ The partition coefficient is also decreased by increased temperature. 304 Extrastion 1sotherms indicate that four to $s 1 x$ amine molecules are assoclated with each uranium (VI) 1on. 304 The number depends upon the particular amine used. With vigorous shaking, the partition coefficient, $\alpha_{u}$, varies approximately as the first power of the free amine 
Table XXX. Effect of Amine structure on the Extraction of Metal Sulfates.

Metal 1on

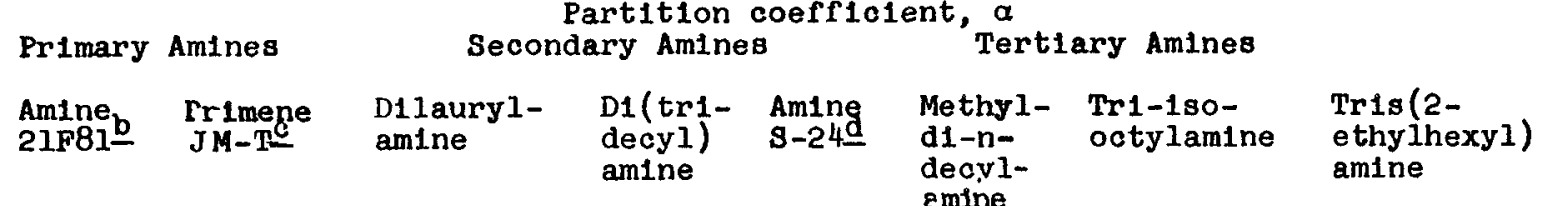
emine

\begin{tabular}{|c|c|c|c|c|c|c|c|c|}
\hline $\begin{array}{l}\mathrm{Mg}, \mathrm{Ca}, \mathrm{Al} \\
\mathrm{v}(\mathrm{IV}) \\
\mathrm{Mn}(\mathrm{II}), \\
\mathrm{Co}(\mathrm{Fe}(\mathrm{III}), \\
\mathrm{Cu}\{\mathrm{II} \\
\mathrm{NI}(\mathrm{II}), \\
\mathrm{Zu}\end{array}$ & $<0.1$ & & $<0.01$ & $<0.01$ & $<0.01$ & $<0.01$ & $<0.01$ & \\
\hline $\begin{array}{l}\text { V(III) } \\
\mathrm{Fe} \text { (III) } \\
\text { R.E. (III) }\end{array}$ & $\begin{array}{l}40 \\
20\end{array}$ & ${ }_{4} \mathbf{f}, g$ & $<0.5$ & $\begin{array}{l}0.1 \frac{f . g}{8} \\
<0.5 \\
<0.1\end{array}$ & $\begin{array}{l}<0.1 \\
<0.01\end{array}$ & & $\begin{array}{l}<0.01 \\
<0.01\end{array}$ & \\
\hline $\begin{array}{l}\mathrm{Ce}(\mathrm{IV}) \\
\mathrm{T} 1(\mathrm{IV}) \\
\mathrm{Zr} \\
\left.\text { Th(O.5 } 5 \mathrm{SO}_{4}\right) \\
\mathrm{U}(\mathrm{IV})\end{array}$ & $\begin{array}{l}>50 \\
10 \\
>1000 \mathrm{r} \\
>5000= \\
3000\end{array}$ & $\begin{array}{l}15 \frac{f, g}{10} \\
>5000 \frac{f, g}{f, g} \\
>500 \underbrace{2}\end{array}$ & $\begin{array}{l}<0.1 \\
5 \\
200\end{array}$ & $\begin{array}{l}350 \\
>50 c \mathrm{r}\end{array}$ & $\begin{array}{c}<0.01 \\
0.2 \\
0.7 \\
50.8\end{array}$ & & $\begin{array}{l}<0.01 \\
<0.1 \\
200 \\
<0_{1} 1 \\
<1\end{array}$ & $<1$ \\
\hline $\begin{array}{l}v \\
v\end{array}\left(\begin{array}{l}v \\
v\end{array}\right\}_{(\mathrm{pH} 2)}$ e & -20 & & $\begin{array}{l}<1 \\
\sim 20\end{array}$ & $<1$ & $\begin{array}{l}<1 \\
\sim 20\end{array}$ & $\sim 20$ & $\begin{array}{l}<1 \\
-20\end{array}$ & \\
\hline $\begin{array}{l}\text { Mo } \\
\text { Mo }\end{array}\left(\begin{array}{l}V I \\
V I\end{array}\right) \frac{e}{(p H 2)}$ & $\begin{array}{l}150 \\
>1000\end{array}$ & & $\begin{array}{l}200 \\
>1000\end{array}$ & & $\begin{array}{l}400 \\
>1000\end{array}$ & $\begin{array}{l}400 \\
>1000\end{array}$ & $\begin{array}{l}150 \\
>1000\end{array}$ & 3 \\
\hline 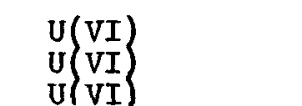 & $\begin{array}{l}40 \\
258 \\
50=\end{array}$ & $\begin{array}{l}10 \\
38 \\
90-\end{array}$ & 80 & $\begin{array}{l}120 \\
800 \\
40=\end{array}$ & $\begin{array}{l}20 \\
1 \mathrm{~h}^{\mathrm{g}}\end{array}$ & 50 & 90 & 0.2 \\
\hline
\end{tabular}

a After C. F. Coleman, K. B. Brown, J. G. Moore, K. A. Allen, reference 304.

IM SO4, $\mathrm{pH} 1, \sim 1 \mathrm{~g}$ metal ion per 1iter except as noted. $\mathrm{V}_{\mathrm{O}} / \mathrm{v}_{\mathrm{a}} \sim 1,0.1 \mathrm{M}$ amine in aromat1c hỹdrocarbon diluent. 
b 1-(3-ethylpentyl)-4-ethylootylamine

c trialkylmethylamine, homologous mixture, 18-24 carbon atoms

$$
\because \because \mathrm{N}^{\mathrm{H}}
$$

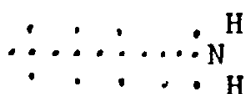

d b1s-(1-1sobutyl-3,5-d1methylhexyl) amine

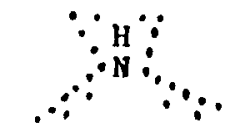

e ciofficients at loadings of $-5 \mathrm{~g}$ V or $\sim 3 \mathrm{~g}$ Mo per ilter of extrastent. Extraction coefficlents of these metals decrtase as thelr concentration dc: eases.

f Extraction from $0.5 \mathrm{M} \mathrm{SO}_{4}$ solution.

g Diluent kerosene instead of aromatic hydrocarbon.

$\underline{h}$ Diluent chloroform instead of aromatic hydrocarbon. 
sulfate concentration,

$$
a_{u(V I)}=k[\underline{M}(\Sigma \text { amine })-n \underline{M}(U(V I)) \text { org }] \text {, }
$$

where $n$ has a value between 4 and 6 , characteristic of the amine. $\frac{304}{4}$ with slow equilibration, in which the liquid-I1quid Interfacial area is strongly limited and interfacial turbulence is prevented, nearly theoretically ldeal results have been obtained; $\frac{468}{1 . e .,}$

$$
c_{u}(V I)=k[\underline{M}(\Sigma \text { amine })-n \underline{M}(U(V I)) \text { org }]^{n} .
$$

Small amounts of forelgn anions added to suliate solutions hinder the extraction of uranium more than similar amounts of added sulfate. The order of increasing interference Is $\mathrm{SO}_{4}<\mathrm{PO}_{4}<\mathrm{CI}<\mathrm{F}<\mathrm{NO}_{3} . \underline{304}$

Effective separations between uranium and other metal ions may be made by choice of amine and/or diluent (Table XXX). 304 Modification of the diluent with long-chaln alcohols or other modiflers affects the extractive powers of the organic solvent phase. A possible synergistic enhancement of $\alpha_{u}(V I)$ hae heen sound with 3,9-diethyltridecyl-6 amine and d1(2-ethylhexyl) phosphoric acid. 452

The amine extraction of uranium $(\dot{V} I)$ from aqueous phosphate or fluoride solutions is qualitatively similar to that from sulfate solution. Uranium is extracted from relatively low anion concentrations. As the latter concentration is increased, $\alpha_{u}$ is decreased. $\frac{304}{4}$ The opposite 1 s true for chioride or nitrate solutions. Uranium extraction is increased as the concentration of either of the latter two anions is increased 304 Uranium may be stripped from the amine solvent phase by a number of methods. Uranium extracted as the amine-sulfate complex may be stripped by contact with a nitrate or chloride solution. Alkaline stripping with sodium carbonate results in an aqueous uranyl tricarbonate solution. Amonium or sodium hydroxide forms preclpitates that are difficult to handle. A slurry of magnesium oxide causes uranium to precipitate 
as a magnesium polyuranate. $\frac{305}{2}$

Tr1-n-octylamine (TnOA)

The partition coefficients obtained by Keder, et al. 472 , 473 for the extraction of actinide metals from nitric acid solutions by 10 volume percent TnOA in xylene are given in f1gure 52. Carswell 359 has studied the extraction of uranium and thorlum by $0.2 \mathrm{M}$ TnOA in toluene, also, from nitric acid solution. Thorium appears to be more strongly extracted than uranium in the latter system. Uranlum, however, is extracted pract1cally to the same extent in both systems for acid concentrations up to $6 \mathrm{M}$.

The extraction of uranium from hydrochloric ac1d solutions by InOA in $\mathrm{CCl}_{4}$ has been studied by Bizct and Tremilion 474 The extraction curve as a runction of $\mathrm{HCl}$ concentration is similar in shape and magnitude to that for tri1sooctylamine plotted in figure 53.

Allen and co-workers $\stackrel{465-468}{2}$ have made fundamental studies on the extraction of uranium from sulfate solution by TnOA.

Extraction of uranium from acetic acid solution by ThOA In Amsco D-95 appears to be Intermediate between extraction from sulfuric and phosphoric acids on one side and hydrochloric and nitric acids on the other. $\frac{304}{4}$ Ir11800ctylamine (T1OA)

The results of Moore $\frac{475}{70}$ for the extraction of uranium (VI), thorium, and fission products from hydrochloric ac1d solution by 5\% T1OA in wlene are presented in figure 53. The extraction of strontium-85 is negliglble from 2-12M HCl. Americium (III) and curium (III) are not extracted. Elements which are extracted Include $\mathrm{Fe}$ (III), $\mathrm{Co}(\mathrm{II}), \mathrm{Zn}$ (II), Hf(IV), $V(V), \operatorname{Pa}(V), \operatorname{Cr}(V I), M o(V I), U(I V), N p(V I, V, I V)$, and $P u(V I, I V)$ In addition to those shown in figure 53. The extraction of Iron, vanadium, and chromium may be suppressed by reduction to a lower oxidation state. Ruthenium remains in the organic 


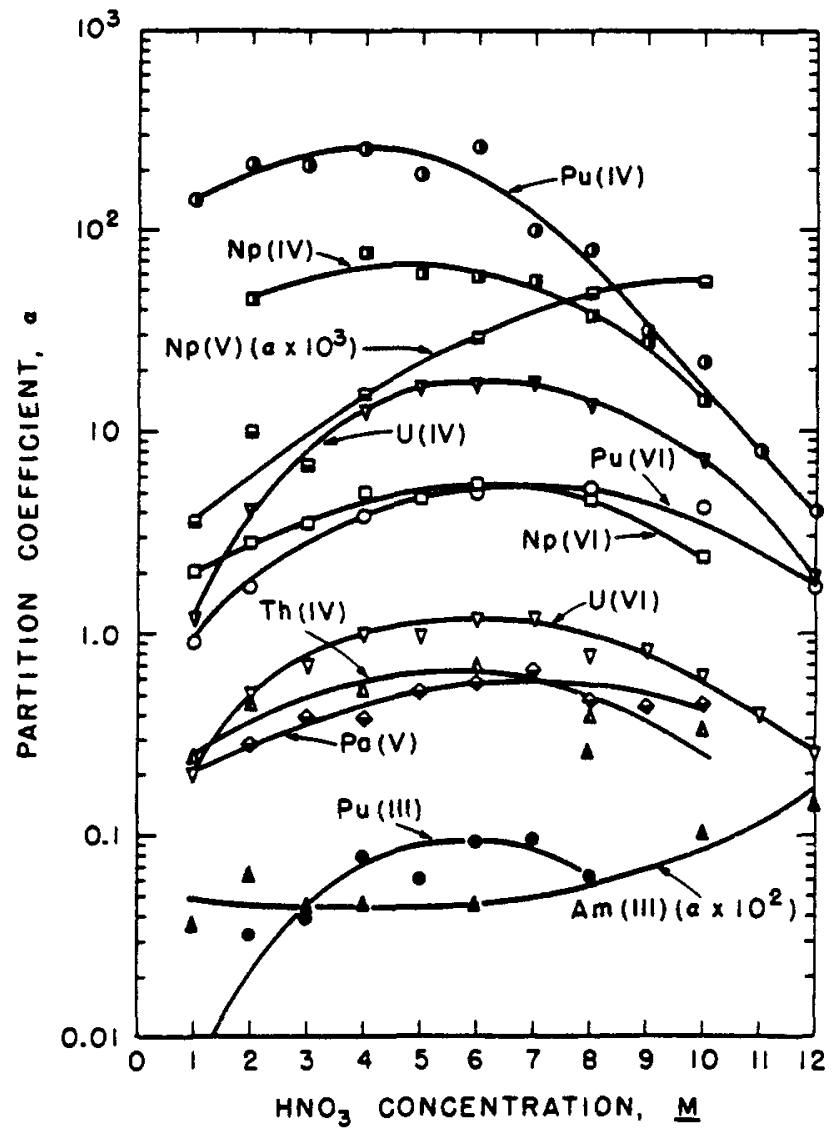

Figure 52. The extraction of actinide lons by ten volume percent tri-n-octylamine in xylene from aqueous nitric acid solution. After (1) W. E. Keder, J. C. Sheppard, and A. S. W1Ison, reference 472 and (2) A. S. Wilson and W. E. Keder, reference 473 .

\section{Conditions :}

(I) Ten volume percent InOA in xylene were stirred with an equal volume of nitric acid of the desired composition for 3-5 minutes at room temperature $\left(-25^{\circ} \mathrm{C}.\right)$. Phases were separated by centrifugation after contacting.

(2) Uranium (IV) data only. Aqueous solutions were prepared at each nitric acid concentration by dilution of a stock solution which was $-\mathrm{IM}$ U(IV), $0.1 \mathrm{M} \mathrm{HIIO}_{4}$, and - IM $\mathrm{Zn}$ (II). Solutions for extraction experiments were $0.015 \mathrm{M} U(I V)$. TnOA was contacted by an equal volume of $12 \mathrm{M} \mathrm{HNO}_{3}$ followed by three contacts of one volume each of the nitric acid concentration used. Equal volumes of aqueous and amine solutions were contacted at room temperature for 5 minutes. Phases were separated by centrifugation. 


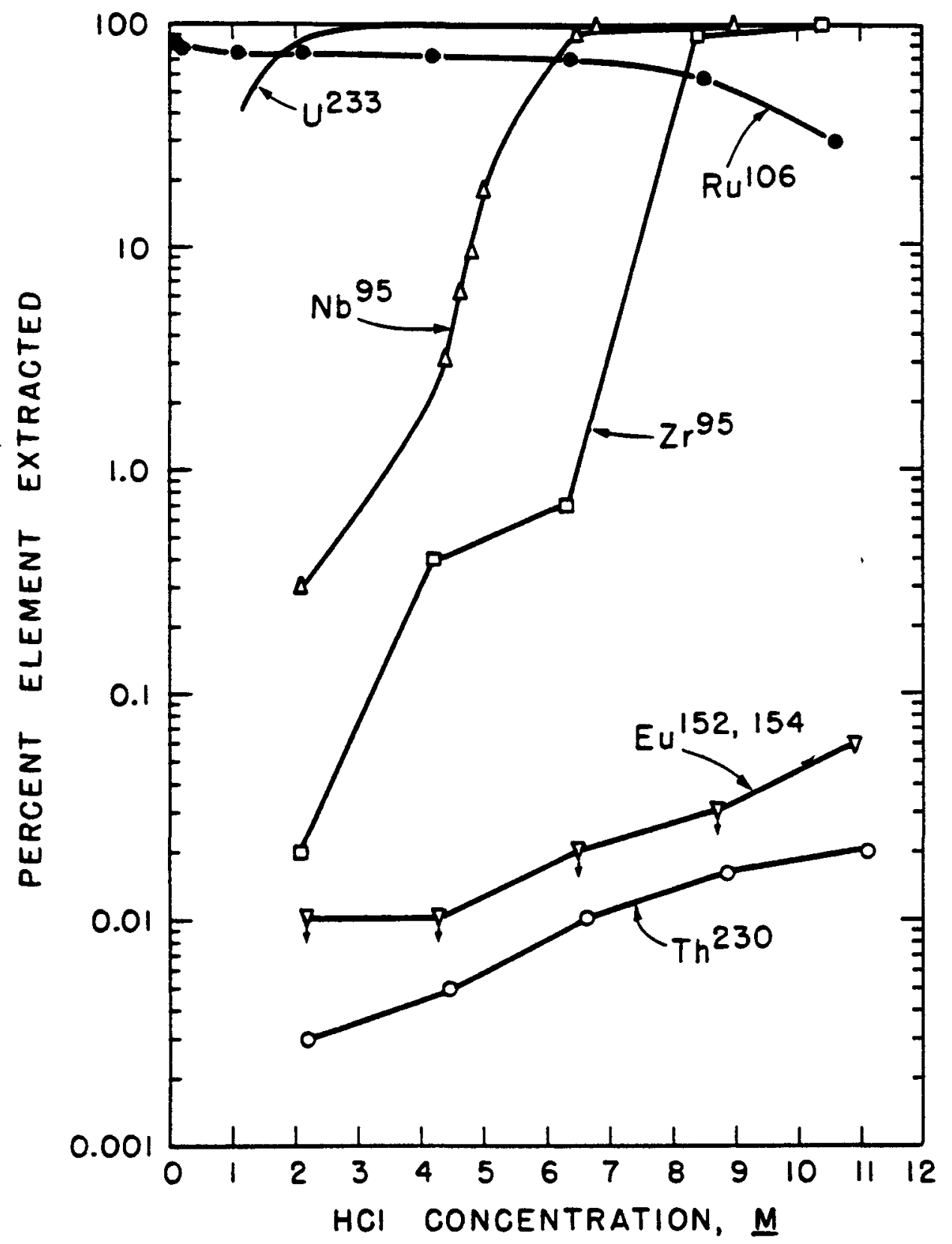

Figure 53. The extraction of $\mathrm{U} 233, \mathrm{Th} 230$, and fission products by $5 \%$ (w/v) trisooctylamine in xylene as a function of $H C l$ concentration. After F. L. Moore, reference 475. Conditions: Equal phase volumes extracted for two minutes at room temperature $(240 \mathrm{C}$.$) .$ 
phase when washed with $0.1 \mathrm{M}$ HCI solution. Uranium is stripped Into the aqueous phase. Excellent extraction (>90\%) of macro amounts of uranium ( $60.4 \mathrm{mg} \mathrm{U} / \mathrm{ml}$ initial aqueous concentration) can be obtalned from 9M HCl w1th $20 \%$ T1OA in hexone. Moore 476 ias also investigated the extraction of uranium (VI) from acetic acid solution by T1OA. Extractions were carried out in the same manner as those from hydrochlortc acid solution (figure 53). Aqueous solutions of varying acetic acid concentration containing $2 \times 10^{4}$ alpha counts per minute per $\mathrm{ml}$ of $\mathrm{U}^{233}$ tracer were extracted with equal volumes of $5 \%(\mathrm{w} / \mathrm{v})$ TIOA in $x y l e n e$. It was found that maximum uranium extraction $(>90 \%)$ is obtalned from $0.5 \mathrm{M}$ to $1 \mathrm{M}$ acetic acla solutions. The addition of $3 \%(v / v)$ butyl cellosolve to the T1OA-xylene solution Inhibits foaming during the extraction process. By increasing the TIOA concentration, macro amounts of uranium are efficiently extracted. Greater than 95\% stripping may be achieved by contacting the aminexylene phase with an equal volume of $0.5 \mathrm{M} \mathrm{HNO}_{3}, 3 \mathrm{M} \mathrm{H}_{2} \mathrm{SO}_{4}$, $6 \mathrm{M} \mathrm{H}_{2} \mathrm{SO}_{4}$, IM $\mathrm{NH}_{4} \mathrm{HCO}_{3}$, concentrated $\mathrm{NH}_{4} \mathrm{OH}$, or $0.25 \mathrm{M} \mathrm{HF}-0.25 \mathrm{M}$ $\mathrm{HNO}_{3}$ solution. From $0.5 \mathrm{M}-1 \mathrm{M}$ acetic acid solution, ruthenium (11.5\%), zirconium (27.9\%), and niobium (11.1\%) are extracted. Separation is made from strontium (alkaline earths), cesium and europium (rare earths), plutonium (III) (trivalent actinides), thorium, protactinium, hafnium, tantalum, 1ron, lead, nickel, cobalt, manganese, chrami um (III), alumlnum, copper, zinc, bismuth, tin, and antimony. 471,476 The selectivity may be improved if the uranium is first precipitated by hydroxide, dissolved w1th IM acetic acid, and then extracted as previously described. Iron hydroxice is us ac to cury tiace amounts of uranium in the precipitation step. 476

\section{Other amine extractants.}

As stated at the beginning of this section, many organonitrogen compounds have been investigated as extractants of 
uranium. A large number of these investigations are reported

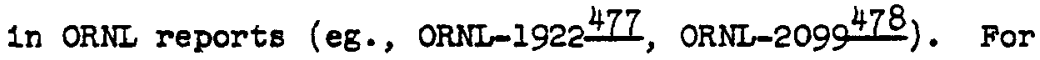
further information, one may refer to these reports, the summaries $304,461-463$ previousiy mentioned, or the review by Moore. 471

\section{Quaternary ammonium 8alts.}

The enhanced extraction of uranium by hexone containing tetrabutylammonium nitrate 78 or tetrapropylamonium nitrate 379 has already been noted (see Hexone). Haeffner, N1lsson, and Hultgren $\frac{479}{}$ have also used tetrabutylammonium nitrate to extract uranyl n1trate with chloroform.

Quaternary ammonium salts, unlike amines, may be useo to extract uranium from alkaline carbonate solutions. $477,478,480$ The Rohm and Haas compound Quaternary B-104* converted to the carbonate form has been used successfully to extract uranium from aqueous solutions having carbonate concentrations up to one molar. 480 Amsco $G$ alone or modifled with a long-chain alcohol, tridecanol, and kerosene modified with tridecanol have been used as diluents. The alcohol modifier improves both the phase separation time and the extraction coefficient. 480 The partition coefficient exhibits a negative two power

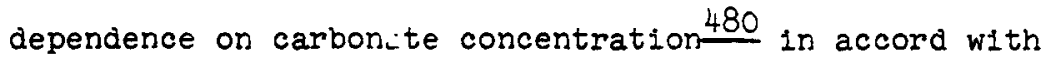
the reaction 305

$$
\begin{aligned}
2\left(\mathrm{R}_{4} \mathrm{~N}\right)_{2} \mathrm{CO}_{3} \text { org }+\mathrm{UO}_{2}\left(\mathrm{CO}_{3}\right)_{3}^{4-} \text { aq } & \rightleftharpoons \\
\rightleftharpoons & \left(\mathrm{R}_{4} \mathrm{~N}\right)_{4} \mathrm{UO}_{2}\left(\mathrm{CO}_{3}\right)_{3} \text { org } \\
& +2 \mathrm{CO}_{3}^{2-} \text { aq. }
\end{aligned}
$$

The extraction coefficient is virtualiy independent of the bicarbonate concentration with the carbonate-bicarbonate total concentration held constant. 480 The coefficient is decreased by an increase in temperature. 480 Uranium may be stripped from the organic phase by solutions of $\mathrm{HCl}$, $\mathrm{HCl}-\mathrm{NH}_{4} \mathrm{Cl}, \mathrm{HNO}_{3}$, and $\mathrm{HNO}_{3}-\mathrm{NH}_{4} \mathrm{NO}_{3} \cdot \frac{478,480}{}$ Nitrate solutions

\footnotetext{
An 1sopropanol solution of dimethyldiodecylammonium chloride.
} 
are more effective than chloride. 478 sodium hydroxide (2M3M) may also be used as a stripping agent. 480

Clifford, et al. 481 report the extraction of uranium from aqueous carbonate solutions by (1) forming a singly charged anion, $\mathrm{UO}_{2} \mathrm{X}_{3}^{-}$, with a complexing agent, and (2) extracting this anion into an organic solvent with a singly charged cation. Extractions were obtained with benzoin 2oxline, cupferron, hydroxylamine, peroxide, pyrogaliol, and 8-quinolinol (oxine). The latter was used for further study. Arquad 2C, $\mathrm{R}_{2}^{\prime} N\left(\mathrm{CH}_{3}\right)_{2} \mathrm{Cl}$, where $\mathrm{R}^{\prime}$ is about a 16-carbon chain, was found to be the most effective extractant tested. Hexone was found to be the most effective solvent tested. Kerosene gave no extraction. With oxine as complexing agent, the extracted species was identifled as $\mathrm{R}_{4} \mathrm{NUO}_{2}(\mathrm{Ox})_{3}$. The extraction coefficlent of uranium was found to increase with increased $\mathrm{pH}$; to Increase with increased oxine concentration and with increased $R_{4} \mathrm{NCl}$ concentration (to an optimum value); to decrease with increased carbonate concentration. An extraction coefficient, $\alpha_{u}$, of 10.9 was obtained by extracting two volumes of an aqueous solution containing $0.01 \mathrm{M} \mathrm{UO}_{2}\left(\mathrm{NO}_{3}\right)_{2}$, $0.92 \mathrm{M} \mathrm{Na} \mathrm{CO}_{3}, 0.04 \mathrm{M} \mathrm{NaOH}$, and $0.02 \mathrm{M}$ Arquad $2 \mathrm{C}$ with one volume of hexone containing 0.100M oxine. Both uranium and oxine were removed from the organic phase by strong acids. Sod1um b1carbonate was found the most efficient stripping agent on a counter-current bas1s.

\section{CARBOXYLIC ACIDS.}

Holk-Bernstrom $\frac{138,482}{2}$ has studied the extraction of uranium (VI), thorium, and lanthanum by several carboxylic ac1ds: salicylic, methoxybenzo1c, 3,5-dinitrobenzo1c, and cinnamic. Table XXXI lists the $\mathrm{pH}$ at which 50 percent of the metal 1ons are extracted from perchlorate solutions by $0.1 \mathrm{M}$ solutions of the carboxylic acid in hexone. Chloroform was found to be a poor solvent for the extraction of 
Table XXXI. pH for 50 Percent Extraction of U(VI), Th, La by Carboxylic Ac1d. $a$

Ac10

\begin{tabular}{|c|c|c|c|}
\hline Ac1d & $\mathrm{UO}_{2}^{2+}$ & $\begin{array}{l}\mathrm{pH}_{50} \\
\mathrm{Th}^{4+} \\
\end{array}$ & $\mathrm{La}^{3+}$ \\
\hline Salicylic & 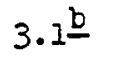 & $3.33^{b}$ & $4.93^{c}$ \\
\hline Methox ybenzoic & $3.4^{b}$ & $3.8^{\mathrm{b}}$ & \\
\hline 3,5-DInitrobenzo1c & $2.75^{\mathrm{c}}$ & $2.85^{c}$ & $4 \cdot 38^{c}$ \\
\hline Cinnamic & $3.50^{c}$ & $3.07^{c}$ & $6.13^{c}$ \\
\hline
\end{tabular}

a After B. Hök-Bernstrom, references 138,482 . Aqueous phase: metal concentration, $10^{-5} \mathrm{M}$ Th or $\mathrm{La}, 10^{-3} \mathrm{M} \mathrm{U}$; Ionic strength, $0.1 \mathrm{M}$ adjusted by the addition of $\mathrm{NaClO}_{4}$; $\mathrm{pH}$ adjusted with $\mathrm{NaOH}$ and $\mathrm{HClO}_{4}$.

Organic phase: $0.1 \mathrm{M}$ carboxylic ac1d in hexone. $\mathrm{V}_{0} / \mathrm{V}_{\mathrm{a}}, \mathrm{I}$; temperature, $25^{\circ} \mathrm{C}$.

$\underline{b}$ Iog $a=0$, reference 138 .

c Calculated from data given in reference 482 .

the metals by the carboxylic ac1ds studied.

Cole and Brown 483 have studied the extraction of U(VI), Th, Hf and $2 r$ from aqueous nitrate solutions by salicylic acid in furfural. Satisfactory separations between uranium and thorium were obtalned depending largely upon the two metal concentrations.

Sudarlkov, et 21.484 have studied the extraction of $U$ (VI), Th, Ce, La, Y, and Sc from aqueous solutions by sal1cylic acld in isoaryl alcohol. The uranium complex was observed to extract at $\mathrm{pH} 1.5$ and to be completely extracted at $\mathrm{pH} 2.5$ to 5.0. Up to $\mathrm{pH} 6.5, a_{u}$ was found to decrease from 100 to $0.3-0.4$ and to remain unchanged at $\mathrm{h} 1 \mathrm{gher} \mathrm{pH}$ values. MIIIs and Whetsel $\frac{485}{2}$ have extracted uranium (VI) with perfluorobutyric acid dissolved in diethyl ether. 
CHELATING AGENTS. The chelating agents descrtbed below are listed in the same general order as they may be found in the book by Morrison and Freiser. 290

Acetylasetone, $\mathrm{CH}_{3}-\stackrel{\stackrel{\prime}{C}}{\mathrm{C}}-\mathrm{CH}_{2}-\stackrel{\stackrel{O}{\mathrm{C}}}{\mathrm{C}}-\mathrm{CH}_{3}$

The extraction of both uranium (VI) and (IV) from perchlorate solutions with acetylacetone as chelating agent has been investigated by Rydberg. The percentage extracted is given as a function of equilibrium $\mathrm{pH}$ in figures $54 \mathrm{~A},-\mathrm{B}$, and - for the three solvents, chloroform, benzene, and hexone, respectively. The extraction of other actinides, fission products, and hafnium is also included in the figures. $14 b, 51$, 486-488 stront1um and potassium are poorly extracted by

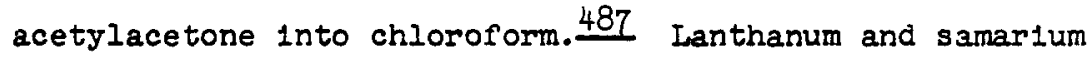
are poorly extracted by the chelating agent into all three solvents. 487

Krishen $\frac{489}{}$ has investigated the extraction of uranium (VI) with acetylacetone used both as chelating agent and solvent. The results are given in f1gure 55-A together with the extraction curves of several other metals. The effect of masking agents, ethylenediaminetetraacetate, fluoride, and tartrate, on the extraction of these metals is given in figures $5,-B, \approx$ and $\rightarrow$, respectively. 489

The extraction of uranium by acetylacetone-chloroform in the presence of sodium chloride and EDTA has been studied by Tabush1. 490 Sod1um chloride increases the extraction yield and broadens the favorable pH range. EDTA permits the separation of uranium from thorium and fission products by more effective masking of the latter. Uranium has also been extracted w1th acetylacetone using butylacetate as solvent. 491 


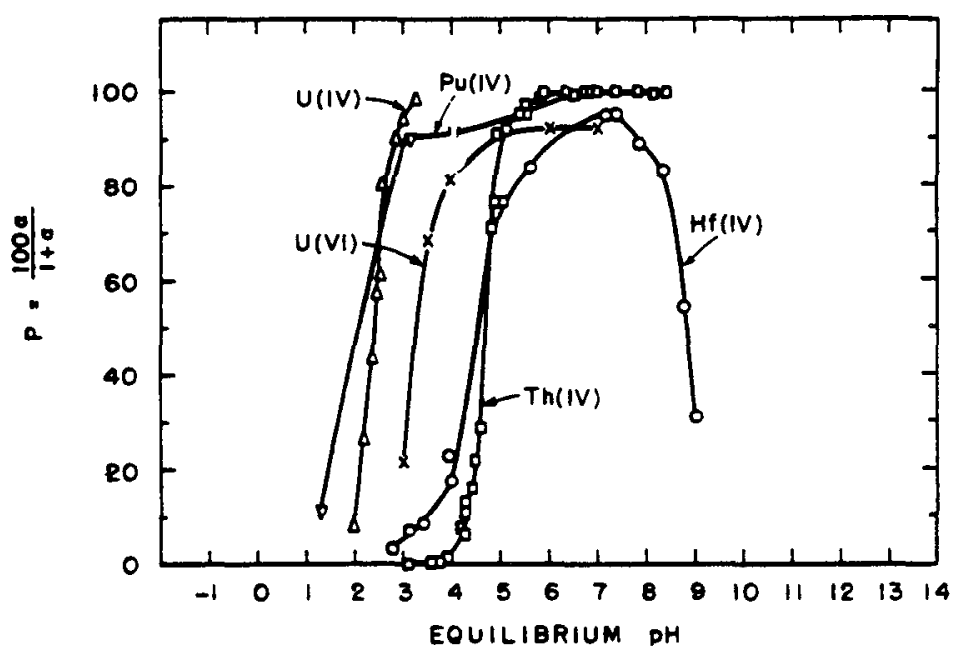

Figure 54-A. The extraction of various elements from $0.2 \mathrm{M} \mathrm{NaClO} 4$ solutions by an equal volume of acetylacetone-chloroform solution at $25^{\circ} \mathrm{C}$. Acetylacetone concentrations used: U(VI), $0.0210 \mathrm{M}$ [ HAa] aq; U(IV), 0.50M [HAa] org; Pu(IV), 1.00M [HAa] 1n1t; $T$ Th(IV), $0.0489 \mathrm{M}$ [ HAa] init; HfTIV), $0.050 \mathrm{M}$ [ HAa] ${ }^{\mathrm{O}}$ org. After J. Rydberg, refereñces $51,486-488$.

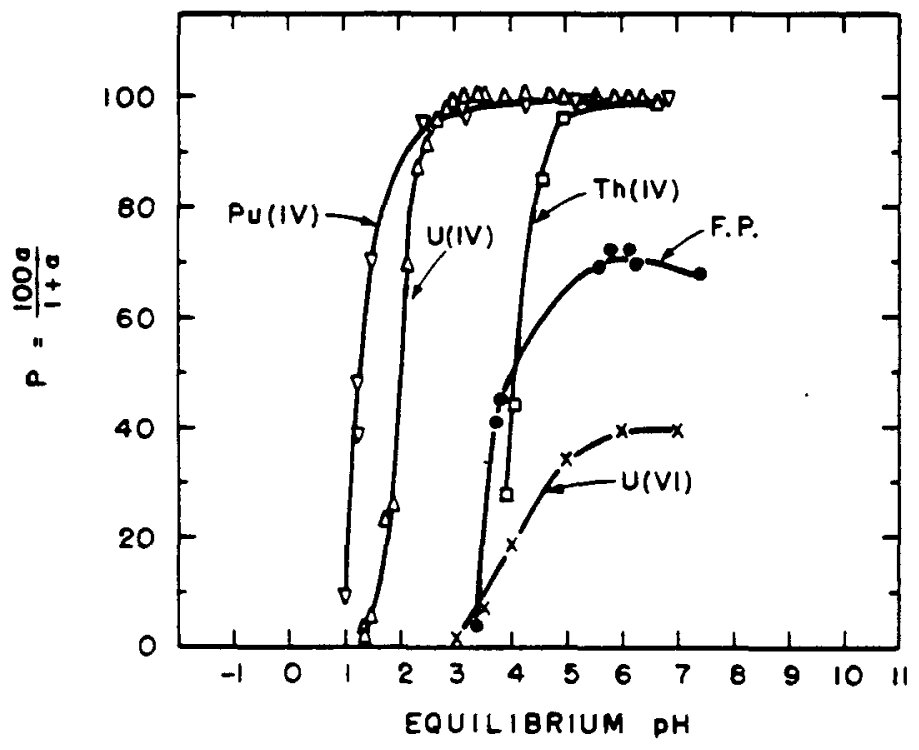

F1gure 54-B. The extraction of various elements from $0.1 \mathrm{M} \mathrm{NaClO} 4$ solutions by an equal volume of acetylacetone-benzene solution at $25^{\circ} \mathrm{C}$. Acetylacetone concentrations used: U(VI), 0.02lOM [HAa]aq; U(IV), $0.072 \mathrm{M}$ [HAa] aq; Pu(IV), 1.00M [ HAa] 1n1t; Th(IV), J.0673M

[HAa] Oorg; F.P., O.70M [HAa] OOrg. F.P. Irradiation time $=$ cooling time $=1$ year." Afte $\bar{r} \mathrm{~J}$. Rydberg, references $51,487,488,492$ and $\mathrm{J}$. Rydberg and B. Rydberg, reference $14 \mathrm{~b}$. 


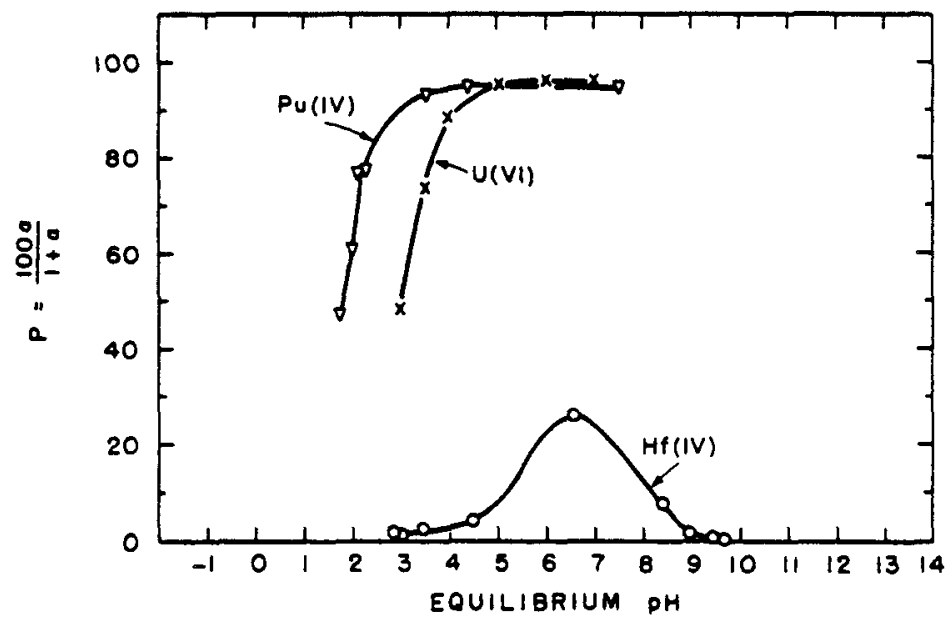

Figure 54-C. The extraction of various elements from $0.1 \mathrm{M} \mathrm{NaC1O} 4$ solutions by an equal volume of acetylacetone-hexone solution at $25^{\circ} \mathrm{C}$. Acetylacetone concentrations used: U(VI), $0.0210 \mathrm{M}$ [ HAa] aq; $\mathrm{Pu}(\mathrm{IV}), 1.00 \mathrm{M}$ [ $\mathrm{HAa}$ ) Init; Hif, $0.050 \mathrm{M}$ [ HAa ${ }^{\circ}$ org. After J. Rydberg, references $5 \bar{I}, 487,488$.

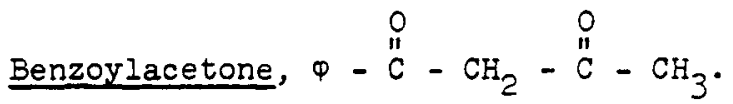

Stary 493 has determined the stability constants of uranyl acetate, oxalate, tartrate, and EDTA complexes. The effect of these ions was observed on the extraction of uranium (VI) from $0.1 \mathrm{M} \mathrm{NaClO}_{4}$ solutions by $0.1 \mathrm{M}$ benzoylacetone in benzene.

2-Acetoacetylpyridine, ${ }_{N^{\prime}}^{\prime}-\stackrel{0}{\mathrm{n}}-\mathrm{CH}_{2}-\stackrel{0}{\mathrm{C}}-\mathrm{CH}_{3}$.

The extraction of uranium from a $0.2 \mathrm{~N} \mathrm{NaOH}, 0.2 \mathrm{~N}$ acetic acid solution at pH 5.0 to 6.5 by $0.12 \%$ acetoacetylpyridine in butylacetate is reported by Hara. 494

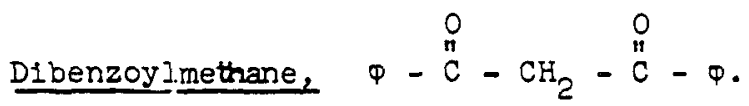
Uranium (VI) $(0.05-0.5 \mathrm{mg})$ is extracted from aqueous solution by a $0.5 \%$ solution of dibenzoylmethane in ethyl acetate. 495 In the presence of other cations, the extraction is made more selective by the addition of complexone III (EDTA sodium salt). Excess complexore is complexed by a $1, \% \mathrm{Ca}\left(\mathrm{NO}_{3}\right)_{2}$ 


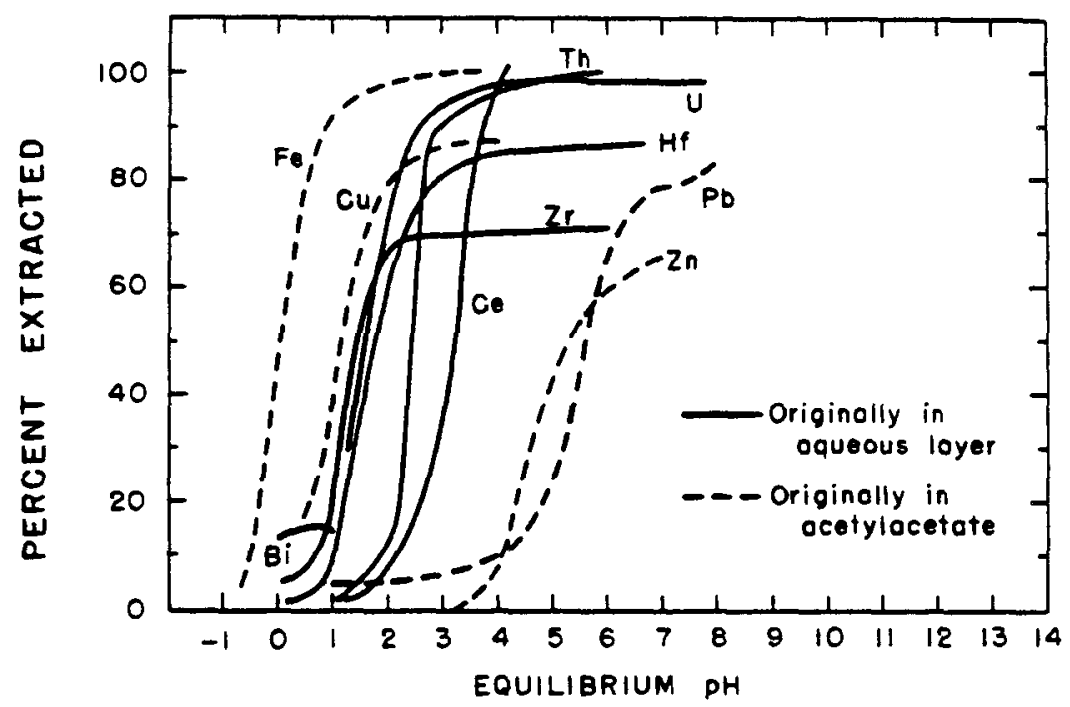

Figure 55-A. The extraction of various metals from aqueous solution by an equal volume of acetylacetone at $25^{\circ} \mathrm{C}$. Solld lines indicate the metal was originally contained in the aqueous phase. The dashed Iines indicate the metal was originaliy in the organic phase. The $\mathrm{pH}$ was adjusted to the desired value by sulfuric acid or sodium hyaroxide. After A. Krishen, reference 489.

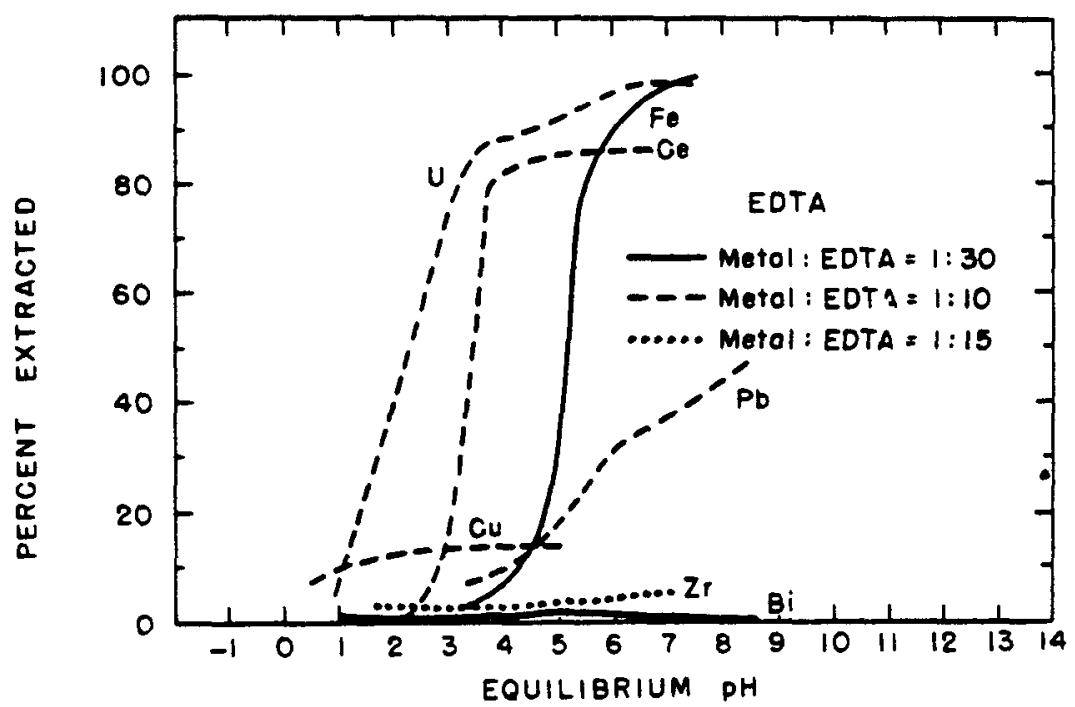

F1gure 55-B. The effect of ethylenediaminetetraacetate (EDTA) on the extraction of various metals from aqueous solution by an equal volume of acetylacetone at $250 \mathrm{C}$. The mole ratio of metal to EDTA is shown by the line texture. After A. Krishen, reference 489. 


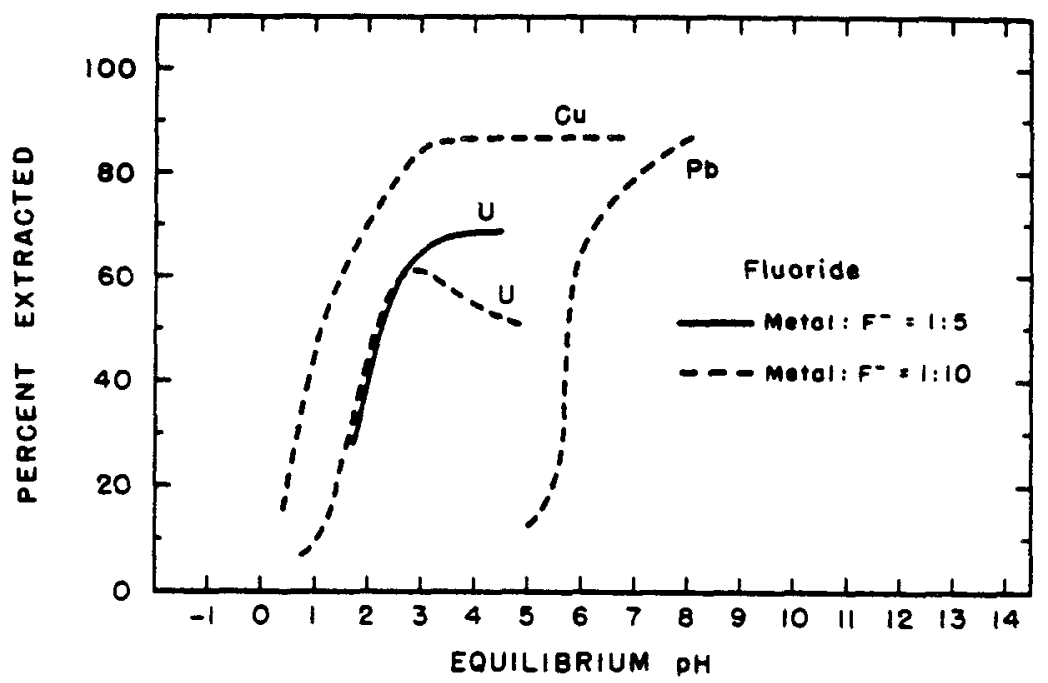

Figure 55-C. The effect of fluoride on the extraction of various metals from aqueous solution by an equal volume of acetylacetone at $25^{\circ} \mathrm{C}$. The mole ratio of metal to fluoride is shown by the line texture. After A. Kr1shen, reference 489.

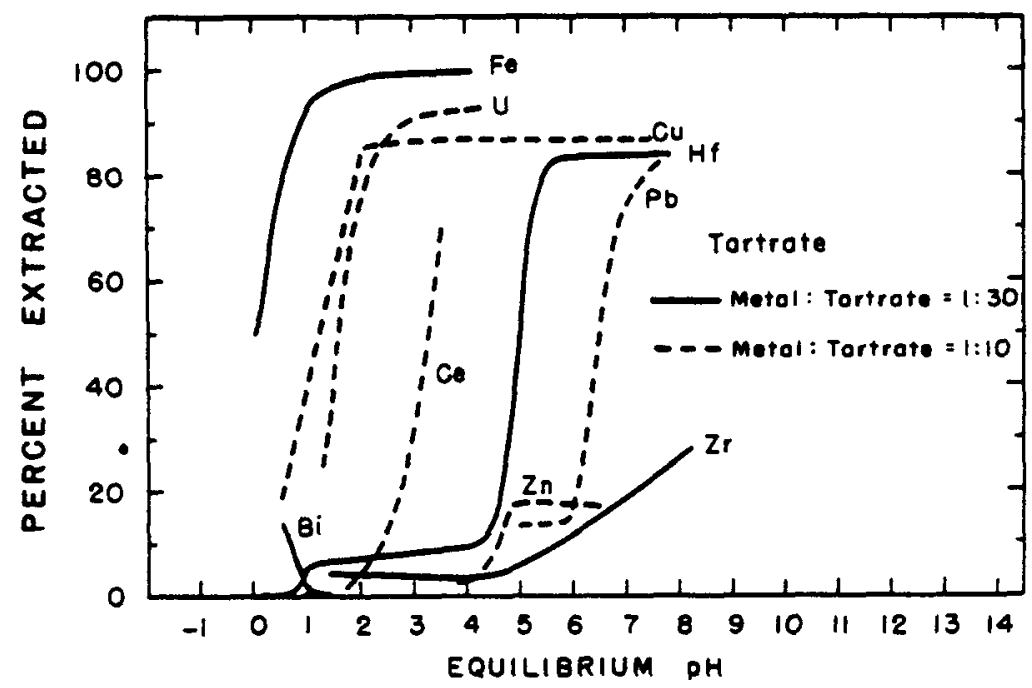

F1gure 55-D. The effect of tartrate on the extraction of various metals from aqueous solution by an equal volume of acetylacetone at $25^{\circ} \mathrm{C}$. The mole ratio of metal to tartrate 1 s shown by the line texture. After A. Krishen, reference 489. 
solution. The resulting solution is neutralized with ammonia to $\mathrm{pH} 7$ and is then contacted several times with the extractIng solution.

The dibenzoylmethane extraction of uranium with chloroform, benzene, and carbon tetrachloride has been investigated by Moucka and Starý. 496

Thenoyitrifluoroacetone (TTA), $\left|\prod_{S}\right|-\underset{0}{\mathrm{C}}-\mathrm{CH}_{2}-\underset{0}{\mathrm{C}}-\mathrm{CF}_{3}$.

Considerable effort has been expended in the study of TTA as an extractant for uranium. KIng, 497 orr, $\underline{498}$ He1sig and Crandall, 499 walton, et al. , $\underline{500}$ and Peterson $\underline{501}$ have made fundamental studies on the extraction of uranium (VI) from aqueous perchlorate 497,498 and nitrate 499,500 media by TTA dissolved in benzene, 497,498,500,501 hexone, 499 cyclohexanone, 499 and pentaether. 499 The partition coefficient, a $u(V I)$, is increased by Increased TTA concentration in the organic phase; decreased by increased initial uranium concentration. 500 The effect of $\mathrm{pH}$ and various salting agents on the extraction of uranium (VI) and thorium from nitrate solutions by $0.2 \mathrm{M}$ TTA in benzene is shown in figure 56.202 Salting agents increase the extraction of uranium by TTAbenzene from low $\mathrm{pH}$ solutions. There is no apparent effect on the extraction of thorium with or without $1 \mathrm{~N} \mathrm{Al}\left(\mathrm{NO}_{3}\right)_{3}$. A $4 \mathrm{M} \mathrm{NH}_{4} \mathrm{NO}_{3}$ concentration in the aqueous phase (not shown), In fact, depresses the extraction of thorium. 502 The effect of foreign anions on the extraction of $U(V I) I 7$ and $U(I V) \underline{58}$ from aqueous perchlorate solutions by $0.5 \mathrm{M}$ TTA in benzene is shown in figures $57 \mathrm{~A}$ and $57 \mathrm{~B}$, respectively. Poskanzer and Foreman 503 have recently reviewed the extraction of elements throughout the periodic table by TTA. Th pH values for 50 percent extraction into an equal volume of $0.2 \mathrm{M}$ TTA in benzene at room temperature or $25^{\circ} \mathrm{C}$. I1sted by these authors 


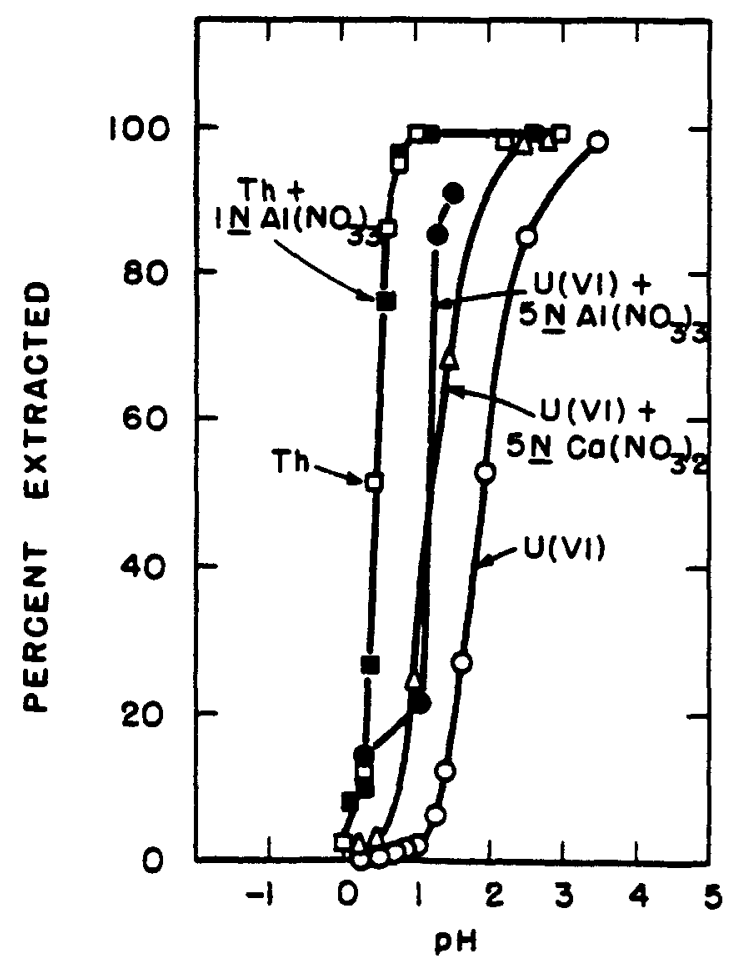

F1gure 56. The effect of $\mathrm{pH}$ and salting-out agents on the extraction of uranium (VI) and thortum by TTA-benzene solutions. After $E$. $K$. Hyde and J. Tolmach, reference 502. Conditions: An equal volume of $0.2 \mathrm{M}$ TTA in benzene was stirred vigorously for 20 minutes with an aqueous solution contalning $0.003 \mathrm{M}$ thorium or trace amounts of uranium-233 w1th or without the saiting-out agent indicated at the $\mathrm{pH}$ given.

are: for U(VI) from dilute nitric ac1d, $\underline{502} \mathrm{pH}_{50}=1.97$; for $U(V I)$ from $\mathrm{HClO}_{4}+\mathrm{LIClO}_{4}, \frac{498}{\mu}=2, \mathrm{pH}_{50}=1.79$; for $U(I V)$ from $\mathrm{HClO}_{4}+\mathrm{NaClO}_{4}, \frac{14 a}{\mu}=2, \mathrm{pH}_{50}=-0.58$; for $U(I V)$ from $\mathrm{HNO}_{3}, \frac{504}{\mathrm{pH}_{50}}=-0.31$.

Irving and Edgington 451 have observed a synergistic enhancement of the uranium partition coefficient with tributylphosphate (TBP) - or tributylphosphine oxide (TBPO) - TTA m1xtures. The results, $\alpha_{u}$ versus percent TBP or TBPO in the extractant mixture, are given in figure 58.

The anclysis of metals with TTA has been reviewed by Moore. 505 Sheperd and Meinke 506 have published, w1th references, the extraction curves of a large number of elements w1th TTA. 


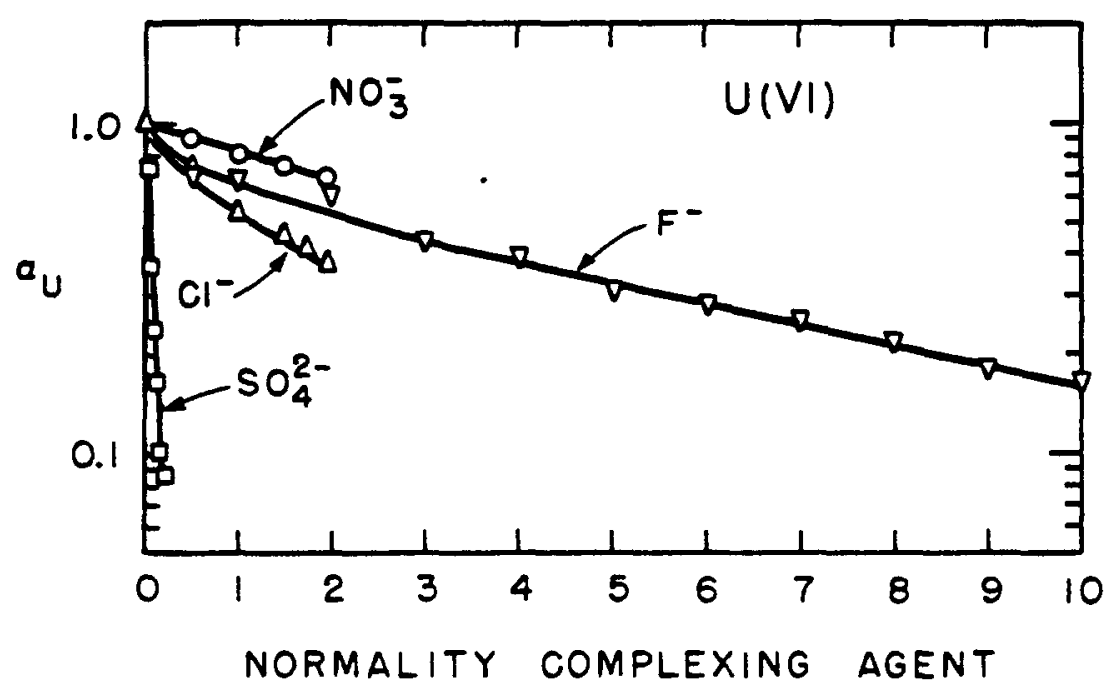

Figure 57-A. The effect of forelgn anions on the extraction of uranium (VI) from agueous perchlorate solution by TTA-benzene. After R. A. Day, Jr. and R. M. Powers, reference 77 . Conditions: organic phase - $0.50 \mathrm{M}$ TTA $1 \mathrm{n}$ benzene pre-treated by shaking with dilute perchloric ac1dovernight. Aqueous phase - 10-5M U233, anion at concentration indicated, $0.05 \mathrm{M}$ HClO4, plus sufficient $\mathrm{NaClO}_{4}$ to maintain an Ionic strength of 2.0 . Equal phase volumes shaken together for 2 hours at $25^{\circ} \mathrm{C}$.

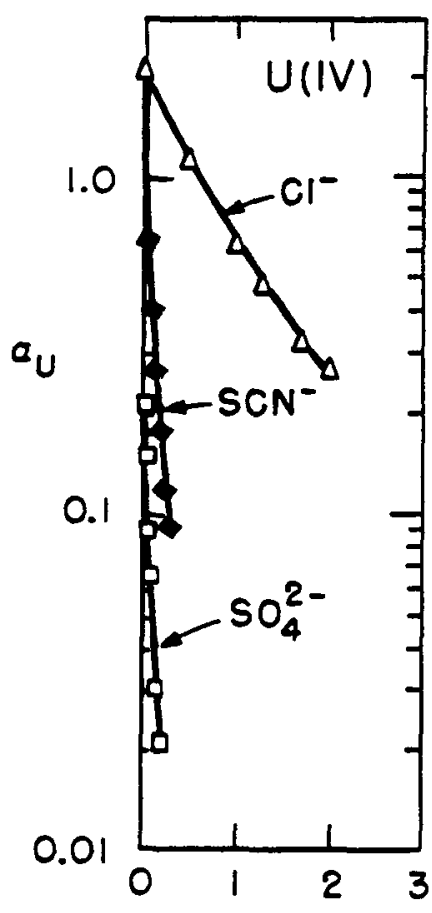

Figure 57-B. The effect of foreign anions on the extraction of uranium (IV) from aqueous perchlorate solution by TTA-benzene. After R. A. Day, Jr., R. N. Wilhite, F. D. Hamilton, reference 58. Conditions: organic phase - $0.05 \mathrm{M}$ TTA in benzene pre-treated with d1lute ac1d. Aqueous phase - $0.0016 \mathrm{M}-0.0037 \mathrm{M}$ $\mathrm{U}$ (IV), anion at concentration indicated, $1.000 \overline{\mathrm{M}}$ $\mathrm{H+}$ (HClO4 used for all experiments except chloride in which HCl was used), plus sufficlent $\mathrm{NaClO}_{4}$ to ma1ntain an lonic strength of 2.0 . Equal phase volumes shaken together for $30 \mathrm{~min}$ utes.

NORMAIITY COMP LEXING AGENT 


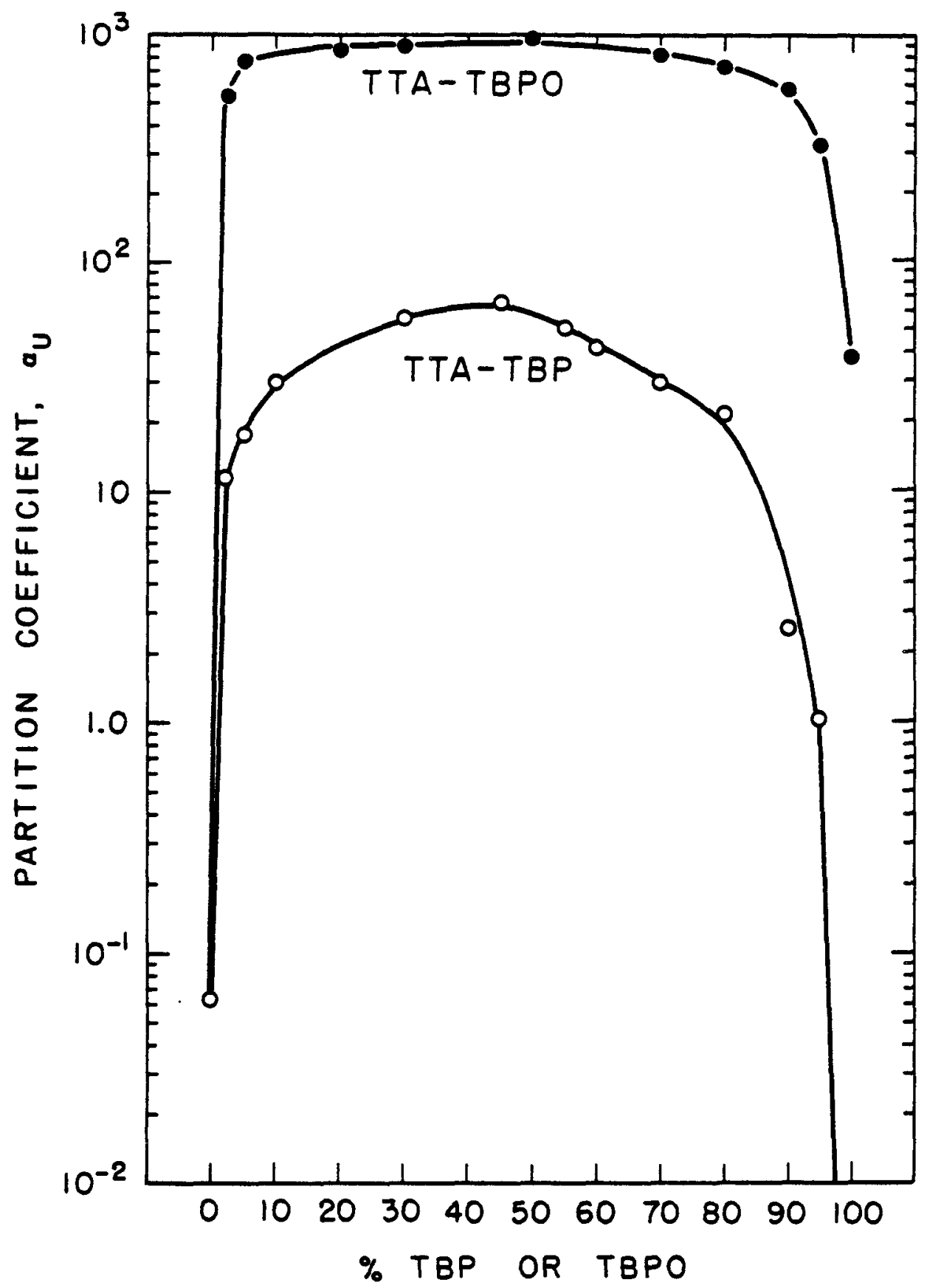

F1gure 58. The synergistic enhancement of the uranium (VI) part1tion coefficlent between aqueous nitrate solutions and mixtures of TTA and TBP or TBPO in cyclohexane. After H. Irving, D. N. Edgington, reference 45I. Conditions: organ1c phase - $0.02 \mathrm{M}$ mixture of TTA and TBP or TBPO in cyclohexane. Aqueous phase - $1.025 \times 10-4 \mathrm{M}$ $\mathrm{U} 233,0.01 \mathrm{~N} \mathrm{HNO}_{3}$. Equal phase volumes shaken together for 24 hours at room temperature $\left(21^{\circ}-2300\right.$.) 
Subst1tuted 1-phenyl-3-methyl-4-acyl-pyrazolones -5 ,<smiles>[R]C(=O)[C@H]1C(=O)N(C)N=C1C(=O)O</smiles>

Skytte Jensen 160 has studied the possibility of using subst1tuted 1-phenyl-3-methyl-4-acyl-pyrazolones-5 as extractants for a number of elements including uranium (VI), thorium, and lanthanum. The pif for $50 \%$ extraction of trace amounts of these elements by a IM solution of chelating agent in chloroform is given in Table XXXII. The $\mathrm{pH}_{50}$ for TTA is given for comparison.

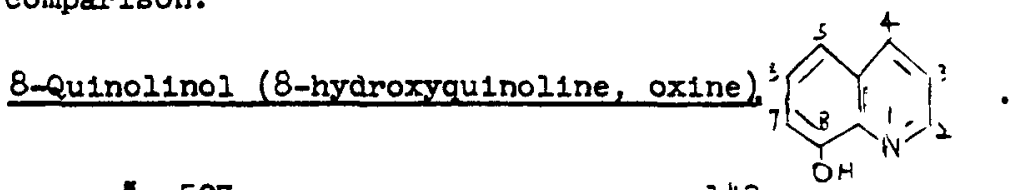

Hok, 507 and Dyrssen and Dahlberg 143 have studied the extraction of uranium (VI) from aqueous perchlorate solutions by oxine dissolved in chloroform or hexone. Results of the latter group, $\frac{143}{2}$ percent extracted versus rinal aqueous $\mathrm{pH}$, are shown in figure 59. These results are in agreement with those of Hok 507 (0.1M oxine $-\mathrm{CHCl}_{3}, 10^{-3}{ }_{\mathrm{M}} \mathrm{O}$, aqueous perchlorete solution, $\mu=0.1 \mathrm{M}, 25^{\circ} \mathrm{C}$ ). No apprec1able difference was observed with urantum concentrations of $10^{-4}$ and $10^{-3} \mathrm{M}$ (open and solld clrcles, respectively, in figure 59). Chloroform is shown to be a silghtiy better solvent for the uranyloxine complex then hexone. The extraction curves for Th, 208 La and $\mathrm{Sm}^{509}$ are also ahown in the figure. A tabulation of pH for $50 \%$ extraction of varlous metal oxinates by chloroform has been made by Dyrssen and Dahlberg $\stackrel{143}{=}$ and 18 reproduced in Table XXXIII.

The extraction of uranium (VI) by solutions of $1 \%$ axine in chloroform from buffered aqueous solutions is shown in figure 60 as a function of aqueous $\mathrm{pH} .510$ 
Table XXXII. pH for 50\% Extraction of Tracer Amounts of Uranium (VI), Thorlum, and Lanthanum by IM Solutions of Subst1tuted (R) 1-Pheny1-3methyl-4-acyl-pyrazolones -5 in Chloroform. $a$

$\underline{\underline{R}}$

$\mathrm{pH}_{50}$ of Metal Ion

\begin{tabular}{lccc} 
& $\mathrm{UO}_{2}^{2+}$ & $\mathrm{Th}^{4+}$ & $\mathrm{La}^{3+}$ \\
\cline { 2 - 4 } acetyl & -0.15 & 0.10 & 2.60 \\
proplonyl & 0.05 & 0.05 & 2.65 \\
butyryl & 0.52 & 0.42 & 2.47 \\
valleryl & 0.24 & 0.24 & 2.84 \\
capronyl & 0.7 & -0.25 & 3.15 \\
ethoxycarbonyl & 1.00 & not meas & 2.50 \\
chloroacetyl & 0.65 & 0.05 & 2.28 \\
trifluoracetyl & 0.8 & not meas & not meas. \\
benzoyl & 1.0 & 0.4 & 2.45 \\
p-bromobenzoyl & 0.9 & 0.30 & 2.3 \\
p-nitrobenzoyl & - & - & - \\
TTA & 0.70 & -0.30 & 3.75
\end{tabular}

a Values for $\mathrm{pH}_{50}$ were calculated from data presented by $B$. Skytte Jensen, reference 160 .

Aqueous perchlosate media. 


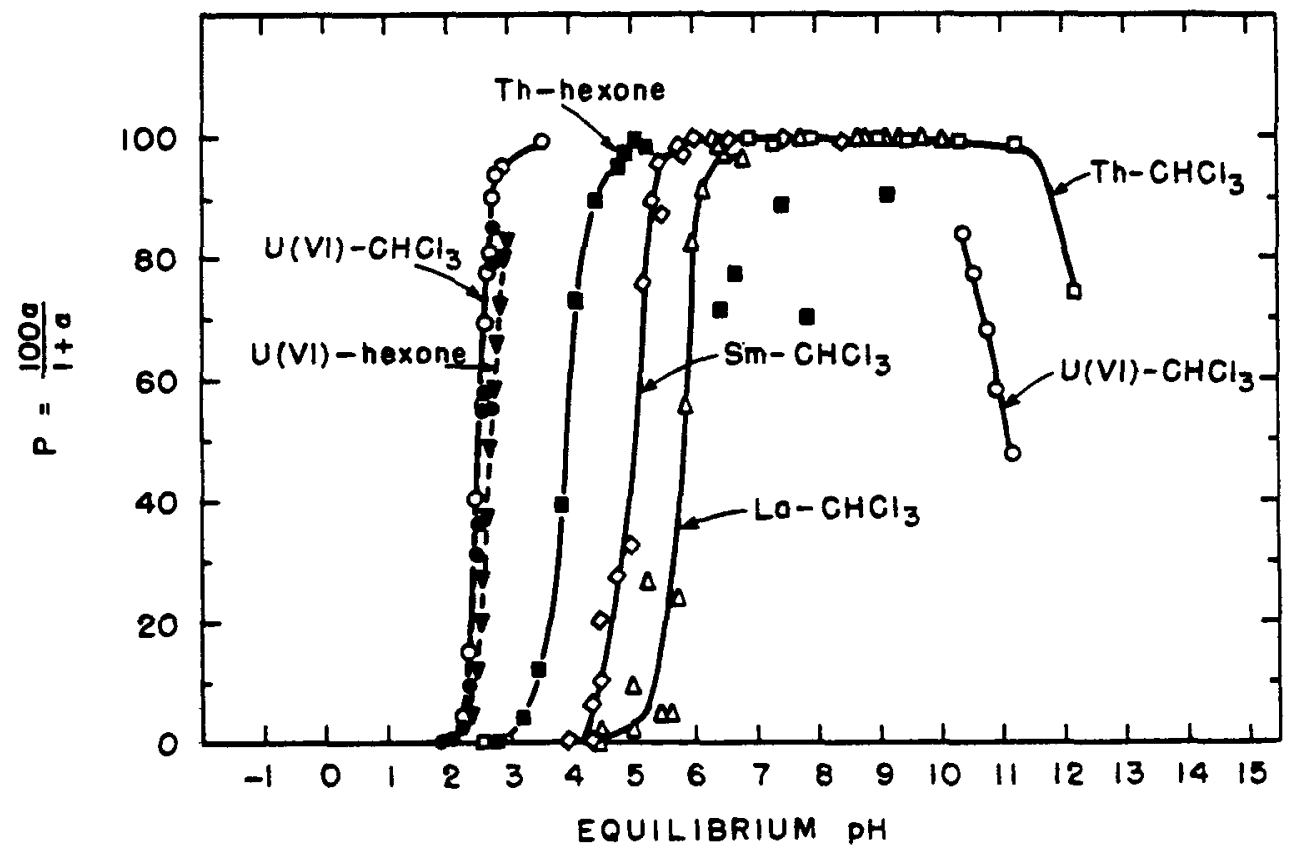

Figure 59. The extraction of tracer amounts of uranium (VI), thorium, samarlum, and lanthanum from perchlorate solution by solutions of oxine-chloroform or oxine-hexone. After D. Dyrssen and V. Dahlberg, reference 143; D. Dyrssen, references 508 and 509. Conditions: Aqueous phase - lonic strength $=0.1 \mathrm{M}$ w1th NaOH, $\mathrm{HClO} 4$, and $\mathrm{NaClO} 4$; for uranium, open circles represent $0.0001 \mathrm{M} U$ concentrations, sol1d circles and triangles, $0.001 \mathrm{M} \mathrm{U}$. Orgañic phase - oxine concentrations: for U, $0.100 \mathrm{M}$; for Th, $0.050 \mathrm{M}$; for La and SM, $0.5 \mathrm{M}$; solvent indicated. Equal phase volumes equilibräted at $25^{\circ} \mathrm{C}$.

Substituted quinolinols.

RuIfs, et al 510 and Dyrssen, et 21.514 have studied the extraction of uranium by dihalogen derivatives of 8-quinolinol. The urantum extraction curves with $1 \%$ solutions of 5,7-dichloro- and 5,7-dibromo-8-quinolinol in chloroform are shown as functions of final aqueous $\mathrm{pH}$ in figure 60.510 Use of the halogen-substituted oxines permits extraction of . urailum from more acidic aqueous solutions. Similar curves for uranium, thorlum, and lanthanum are given in flgure 61 for extraction with $0.05 \mathrm{M}$ 5,7-dichloro-oxine in chloroform. 514 Hynek $\frac{515}{2}$ has studied the extraction of various metals by 8-hydroxyquinaldine (2-methyl-8-quinolinol). The uranium complex was found to be extracted, but not quantitatively, 
Table XXXIII. pH for 50\% Extraction of Metal Oxinates with Chloroform. a Metal ion $\mathrm{pH} \quad$ Procedure Reference

\begin{tabular}{|c|c|c|c|}
\hline $\begin{array}{l}\mathrm{Ga}^{3+} \\
\mathrm{In}^{3+} \\
\mathrm{Al}^{3+}\end{array}$ & $\begin{array}{l}1.0 \\
2.1 \\
3.4\end{array}$ & $\begin{array}{l}\mathrm{V} \text { aq }=\mathrm{V} \text { org, } 0.1 \mathrm{M} \text { total oxine. } \\
\text { Anlons in aqueous solution: chloride. }\end{array}$ & 511 \\
\hline $\begin{array}{l}\mathrm{Fe}^{3+} \\
\mathrm{Cu}^{2+} \\
\mathrm{In}^{3+} \\
\mathrm{Bl}^{3+} \\
\mathrm{Al}^{3+} \\
\mathrm{NI}^{2+} \\
\mathrm{Co}^{2+}\end{array}$ & $\begin{array}{l}1.6 \\
2.0 \\
2.2 \\
3.0 \\
4.2 \\
6.1 \\
6.5\end{array}$ & $\begin{array}{l}\text { Pour successive extractions with } \\
0.01 \mathrm{M} \text { solution of oxine in } \mathrm{CHCl}_{3} \text {. } \\
\text { Anlons In aqueous solution: sulfate, } \\
\text { acetate, nitrate, chloride. }\end{array}$ & 512 \\
\hline $\begin{array}{l}\mathrm{Sn}^{4+} \\
\mathrm{Mo}^{3+} \\
\mathrm{Fe}^{3+} \\
\mathrm{Cu} \\
\mathrm{NI} \\
\mathrm{Al}^{2+}\end{array}$ & $\begin{array}{l}0.0 \\
1.0 \\
2.0 \\
2.1 \\
3.7 \\
3.8 \\
6.4\end{array}$ & $\begin{array}{l}\mathrm{V} \text { aq }=5 \mathrm{~V} \text { org, } 0.07 \mathrm{M} \text { oxine. } \\
\text { Anions in aqueous solution: } \\
\text { acetate, chloride, tartrate. }\end{array}$ & 513 \\
\hline $\begin{array}{l}\mathrm{Hr}^{4+} \\
\mathrm{UO}_{2}^{2+} \\
\mathrm{Tm}^{4+} \\
\mathrm{Sm}^{3+} \\
\mathrm{Ia}^{3+}\end{array}$ & $\begin{array}{l}1.3^{*} \\
2.6 \\
3.1 \\
5.7 \\
6.5\end{array}$ & $\begin{array}{l}\mathrm{V} \text { aq }=\mathrm{V} \text { org, } 0.1 \mathrm{M} \text { total oxine. } \\
\text { Anlons in aqueous solution: } \\
\text { perchlorate. }\end{array}$ & 143 \\
\hline
\end{tabular}

a After D. Dyrssen and V. Dahlberg, reference 143 .

${ }^{*} \mathrm{pH}=-\log \left[\mathrm{H}^{+}\right]+0.1$.

by chloroform from an aqueous phase at $\mathrm{pH} 9.5$ containing tartrate and acetate 1ons. Cyanide or $\mathrm{H}_{2} \mathrm{O}_{2}$ prevented extraction.

1-Nitroso-2-naphthol,<smiles>O=NC1=C(O)C=CC2C=CC=CC12</smiles>

Alimarin and zolotov 516 have investigated the extraction of uranium (VI) by organic solutions of 1-nitroso-2-naphthol. It was found that a mole ratio of naphthol to $\mathrm{U}_{3} \mathrm{O}_{8}$ of 125 


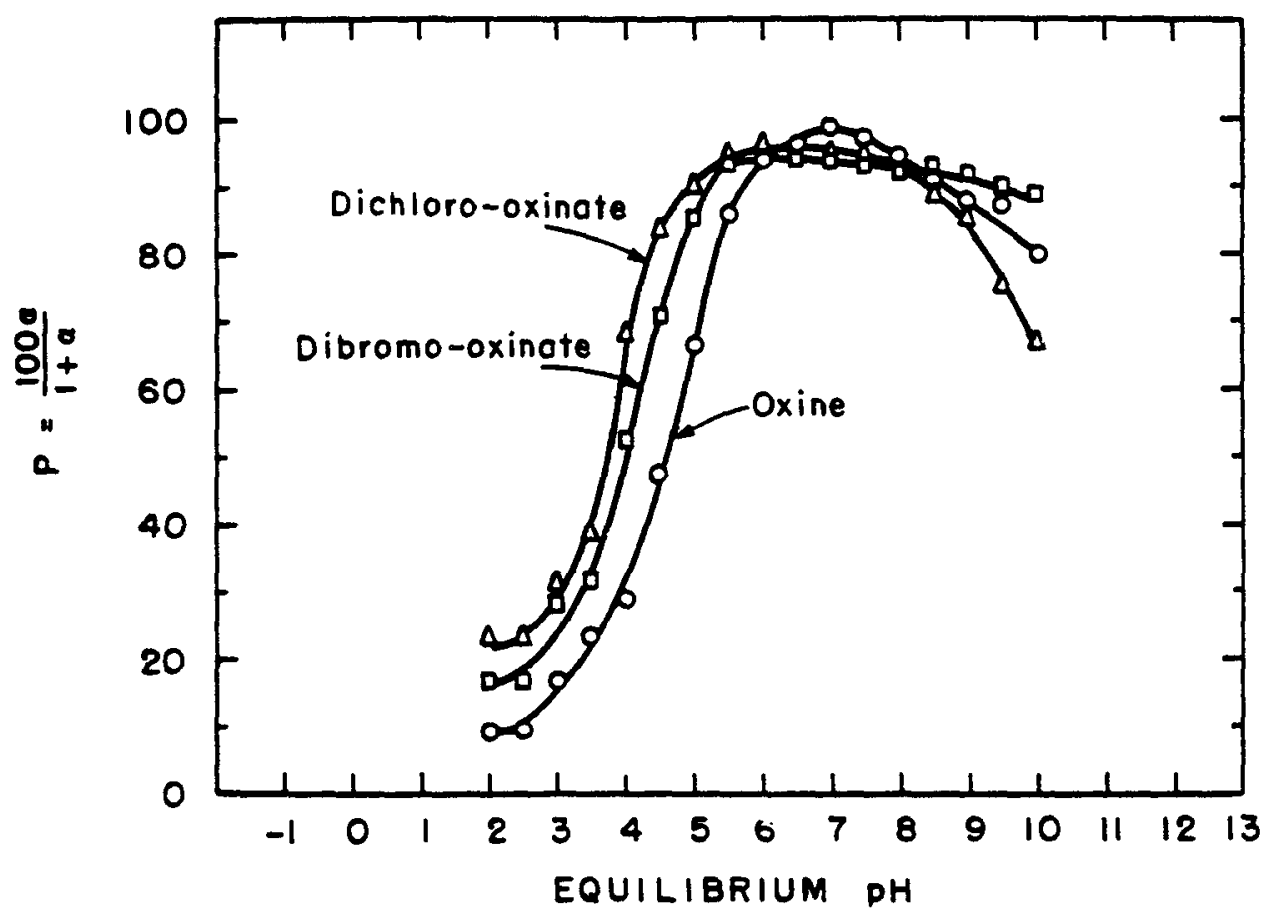

F1gure 60.

The extraction of urantum (VI) by oxine and 1ts 5,7-dichloroand 5,7-dibromo-derivatives. The percent extracted, $P$, was calculated from the values of the distribution coefficient given in the paper by C. I. Rulfs, A. K. De, Jr., J. Iakritz, and P. J. Elving, reference 510.

Conditions:

$2.1 \mathrm{mg}$ of uranium in $10 \mathrm{ml}$ and $25 \mathrm{ml}$ of an approximately $1 \mathrm{M}$ buffer solution were shaken 6 to 8 minutes with $20 \mathrm{ml}$ of 2 1\% oxine-chloroform solution. The aqueous phase was rinsed twice with $5 \mathrm{ml}$ of chloroform. The $\mathrm{pH}$ of the final aqueous phase was measured. 


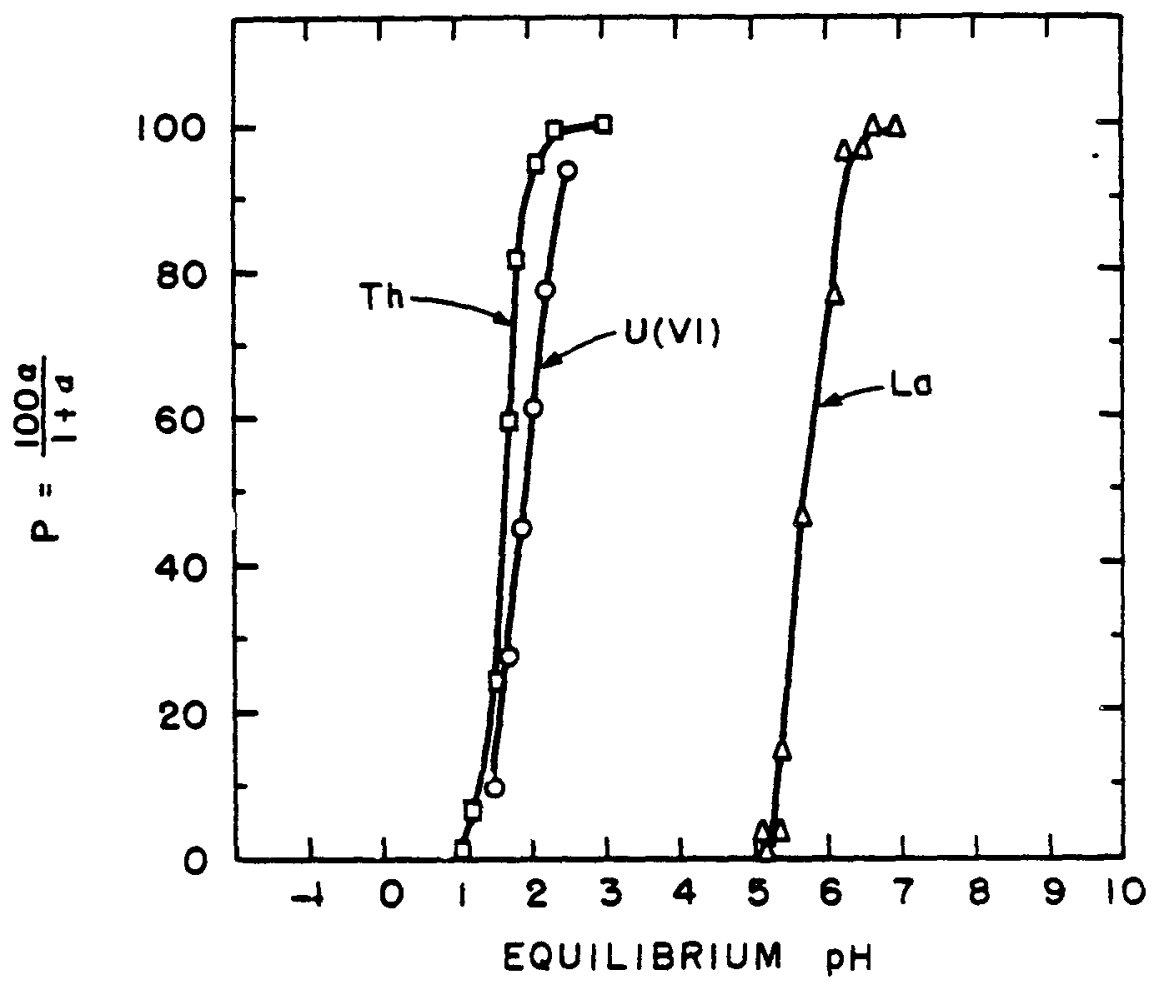

Figure 61.

The extraction of tracer amounts of $U(V I), T h$, and $\mathrm{La}$ by 0.05M 5,7-dichloro-oxine dissolved in chloroform from $0.1 \mathrm{M} \mathrm{HClO}_{4}-\mathrm{NaClO}_{4}$ solutions at $25^{\circ} \mathrm{C}$.

After D. Dyrssen, M. Dyrssen, and E. Johansson, reference 514.

and 2 volume phase ratio of organic to aqueous of 0.25 is more than adequate to give quantitative extraction of uranium 1nto 1soambl alcohol at a pH of 5 to 6 . Two minute shaking is sufficlent for quantitative uranium extraction. Ethyl acetate, n-butanol, diethyl ether, amyl acetate, benzene, and chloroform also extract the uranium-naphtholate complex. Quant1tative extraction is obtained with ethyl acetate and nbutanol at a $\mathrm{pH}$ of 3.0 to 8.5; w1th 1soamyl alcohol at $\mathrm{pH}$ 4.5 to 7.5 . Quantitative extraction can be achleved at temperatures of $0^{\circ}$ to $100^{\circ} \mathrm{C}$. Chlorlde or nitrate fons at con- 
centrations up to $0.2 \mathrm{M}$ do not seriously interfere with the extraction of uranium. Iron (III) is completely extracted; vanadium (IV) and (V) and thorlum are partially extracted. The extraction of all four metal ions is considerably suppressed by complexing with complexone III (sodium salt of EDTA). The pH range for quantitative separation of $u$ rantum with isoamyl alcohol is increased in the presence of complexoneIII ( 25 mg complexone per mg of metal) to $6.5-9$. Aluminum and zinc are not extracted with 1-n1troso-2-naphthol. Dyrssen, et 21.517 have studied the extraction of uranium and thorlum from aqueous perchlorate solutions $(\mu=0.1 \mathrm{M})$ by $0.1 M$ l-nitroso-2-naphthol in chloroform. Fifty percent of the uranium was extracted at $\mathrm{pH} 3.07$ and fifty percent of the thorium at $\mathrm{pH}$ 1.66. Ianthanum and samarium were not extracted. Other metals that have been extracted as nitrosonaphtholates include $\mathrm{Mn}$ (II), $\mathrm{Fe}$ (II), Co, N1, Cu(II), PO(II), $\mathrm{Ag}, \mathrm{Cd}, \mathrm{Hg}(\mathrm{II}), \mathrm{Pu}(\mathrm{IV}) \underline{517}$ and $\mathrm{Np}(\mathrm{V}) . \underline{518}$

Ammonlum salt N-nitrosophenylhydroxylamine (cupferron),

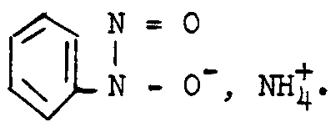

Cupferron is an important reagent in the analytical separation of uranium. The reagent precipitates uranium (IV) from acidic $\left(\mathrm{H}_{2} \mathrm{SO}_{4}\right.$ or $\mathrm{HCl}$ ) solution but not uranium (VI). By converting uranium to 1ts two oxidation states, separation can be made alternatively from elements not precipitated by cupferron and from those precipitated by the reagent. The uranium (IV) cupferrate complex, U(Cup) 4 , was found by Auger $\frac{519}{20}$ be soluble in chloroform and neutral

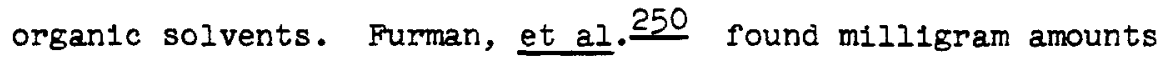
of uranium (IV) to be incompletely extracted from aqueous acld solution by hydrogen cupferrate in ciloroform but to be almost completely extracted by ethereal hydrogen cup- 
ferrate; 1.e., cupferron extracted by ether from an ac1d solution. Ethereal hydrogen cupferrate was also found to extract quantitatively macroamounts of uranium (IV) from $(1+19)$ sulfuric acid containing hydroxylamine hydrochloride and submiligram amounts from $(1+19)$ sulfuric acid in the presence of saturated mercury-zinc amalgam. 250 The partition coefficlent, $\alpha_{u(I V)}$, is increased with increased cupferrate concentration and is decreased with increased ac1d concentration. $\frac{250}{20}$

A uranium (VI) cupferrate complex is precipitated by the reagent from neutral solutions. There appear to be two forms, one of which is soluble in ethyl ether. 250 From $(1+9)$ sulfuric acid, mililgram amounts of uranium (VI) are extracted by an equal volume of chloroform with an excess of cupferron present. $\underline{250}$

The extraction of urantum (VI) cupferrate from aqueous perchlorate solution by hexone and chloroform is given in figure 62 as a function of the $\mathrm{pH}$ of the final aqueous solution. 143 Chloroform is a poor solvent for the complex. Hexone is bettex, hut quantitative extraction is not achieved by a single contact of the solvent with an equal volume of the aqueous solution. The extraction curves for $\mathrm{Th}, \underline{508} \mathrm{sm}$, and $L_{2} \frac{509}{2 r e}$ also given in the figure.

The properties of other metal cupferrates have been reviewed by Furman, Mason, and Pekola. 250

N-Benzoy Iphenylhydroxylamine.

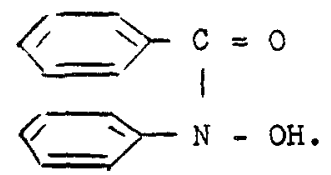

Dyrssen $\frac{520}{2}$ has studied the extraction of uranium (VI) with N-benzoylphenylhydroxylamine in chloroform from aqueous perchlorate solutions. The results, $P$ versus $p H$, are shown in figure 63 together with those for thorium and lanthanum. 


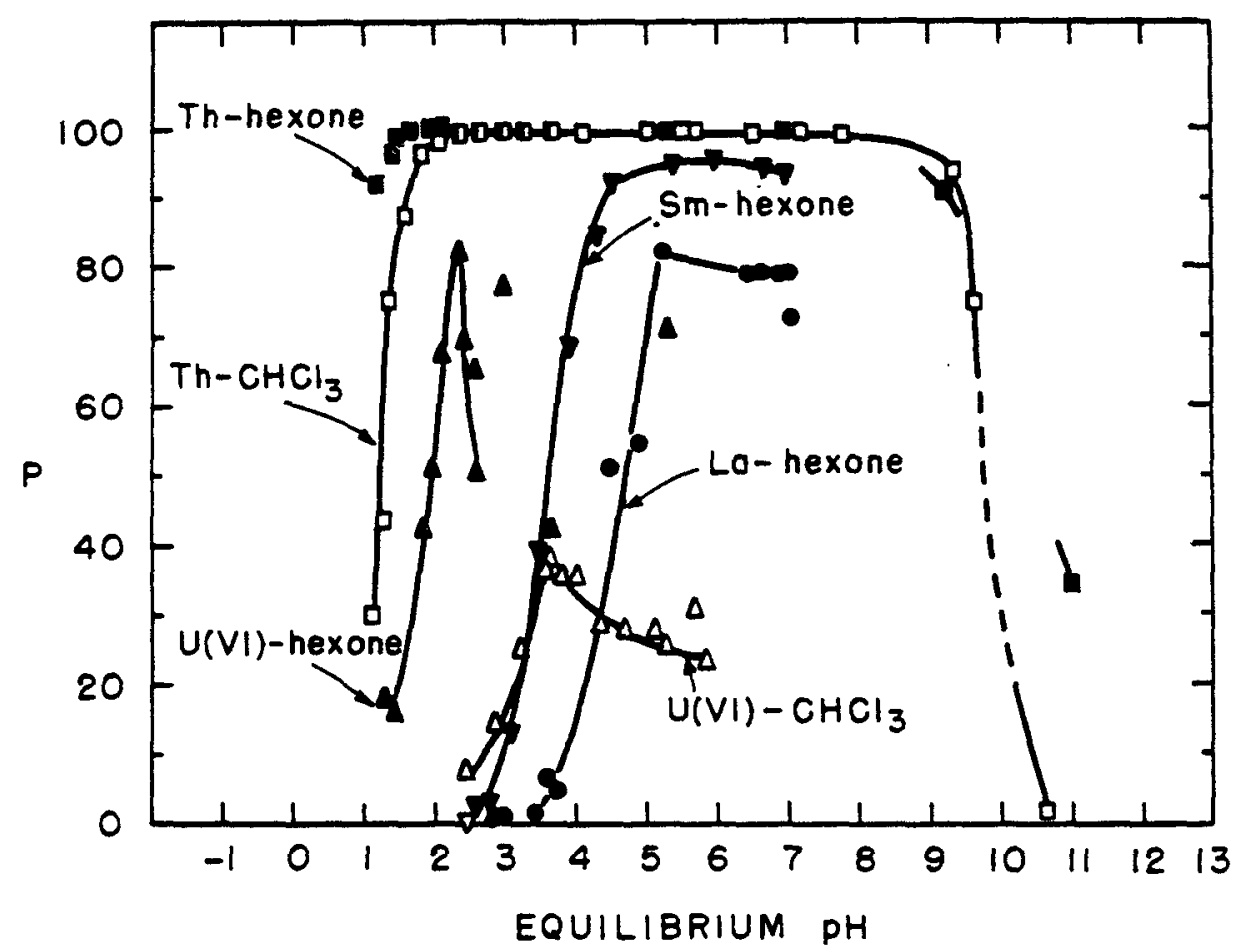

Figure 62.

The extraction of tracer amounts of uranium (VI), thorium, samarium, and lanthanum cupferrates from perchlorate solutions by hexone or chloroform.

After D. Dyrssen and V. Dahlberg, reference 143; D. Dyrssen, references 508 and 509.

Conditions :

Aqueous phase - ionic strength $=0.1 \mathrm{M}$ with $\mathrm{NaOH}, \mathrm{HClO}_{4}$ and $\mathrm{NaClO}_{4}$. Na cupferrate added to aqueous phase: for $U$, $0.01 \mathrm{M}$, for $\mathrm{Th}, \mathrm{Sm}$, and Ia, $0.005 \mathrm{M}$.

Equal volumes of aqueous and organic solvent indicated equilibrated at $25^{\circ} \mathrm{C}$.

1-(2-Pyr1dylazo)-2-naphthol (PAN),

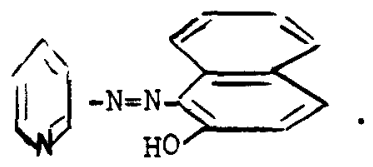

1-(2-Pyrtdylazo)-2-naphthol forms colored complexes (generally red) with a large number of polyvalent metal ions. 521 The uranyl-PAN complex is insoluble in alcohols, carbon tetrachloride, chloroform, and ethers. 522 ortho- 


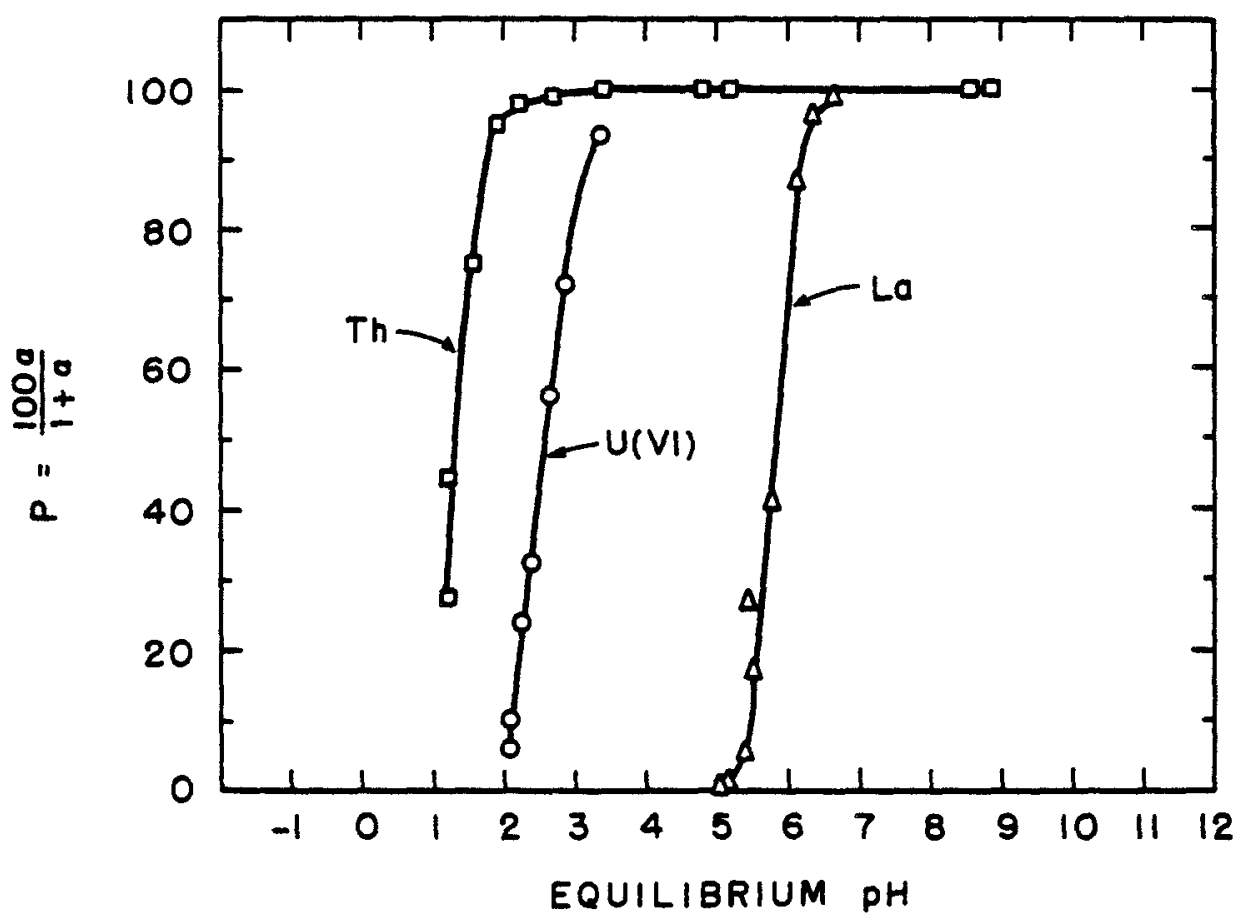

F1gure 63.

The extraction of tracer amounts of uranium (VI), thorium, and lanthanum from perchlorate solutions by N-benzoylphenylhydroxylamine dissolved in chloroform.

After D. Dyrssen, reference 520.

Conditions :

Aqueous phase - lonic strength $=0.1 \mathrm{M}$ with $\mathrm{HClO}_{4}, \mathrm{NaOH}$, and $\mathrm{NaClO}_{4}$. The aqueous phase was sometimes buffered with I ml of $0.1 \mathrm{M}$ anilinium perchlorate, sodium acetate, or hydrozinium perchlorate per $15 \mathrm{ml}$.

organic phase - $0.1 \mathrm{M}$ N-benzoylphenylhydroxylamine in chloroform.

Temperature, $25^{\circ} \mathrm{C}$.

or meta-dichlorobenzene and bromobenzene are excellent solvents for the complex. The maximum color of the uranyl-PAN complex is developed at pH 10. At pH less than 5 or greater than 12 I1ttle complex formation occurs. $\underline{52}$ Urantum may be select1vely separated from a large number of elements by PAN-dichlorobenzene extraction in the presence of masking 
agents (EDTA, trinitrilotriacetic acid, cyanide) and with proper pH control.

Sodium diethyldithiocarbomate (DDTC) $\left(\mathrm{C}_{2} \mathrm{H}_{5}\right)_{2} \mathrm{~N}-\mathrm{C}^{1 / 5} \mathrm{Na}^{+}$. Bode $\frac{523}{2}$ reports that the $U(V I)$ - DDTC complex, unlike other heavy metals, is soluble in water. A preclpitate is formed only with high concentrations of uranium and reagent. The uranyl-DDTC complex is practically inextractable by carbon tetrachloride but is readily extracted by isoamyl alcohol, diethyl ether, and anyl acetate. $\underline{523}$ others have

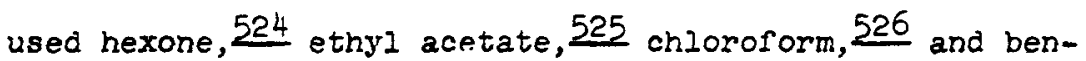
zene 527 to extract the complex. Employing the above solvents, the $U(V I)-D D T C$ complex has been extracted from aqueous solutions having a wide range of $\mathrm{pH}, \mathrm{e.g} ., \mathrm{pH} 1-5 \frac{527}{2}$ and $\mathrm{pH} 6 \cdot 5-8 \cdot 3.225$ Sodium tartrate has been used to prevent hyarolysis at higher $\mathrm{pH}$ values. $\frac{525}{\mathrm{~T}}$ The U(VI)-DDTC complex is extracted in the presence of EDTA. Uranium may then be separated from elements, such as thorium, that form strong EDTA complexes. $524,527,528$ Uranium may be further separated from those elements extracted as DDTC complexes by stripping the former into an ammonium carbonate solution. 196,525 D1salicylethylenedilmine,<smiles>O=NCCN=Cc1ccccc1O</smiles>
Dyrsse 529 reports that uranium (VI) is somewhat extractable (60-90\%) with solutions of disalicylethylenedilmine in chloroform. Hafnium and thorlum are extracted (90-99\%) from weakly ac1dic solutions ( $\mathrm{pH} \mathrm{1.5)} \mathrm{with} \mathrm{a} 0.1-$ $0.5 \mathrm{M}$ chloroform solution of the reagent. Lanthanum and samarium are not extracted.<smiles>Cc1cc(=O)n(-c2ccccc2)n1C</smiles> 
Rodden $\frac{192}{2}$ has mentioned that chloroform extracts uranyl complexes with antipyrine. Reas $\frac{380}{2}$ has reported that both uranium (VI) and uranium (IV) are almost completely extracted with antipyrine-chloroform solutions from perchlorate media. Uranium may be separated from thorium using the antipyrinechloroform system. From an aqueous solution of $20.6 \mathrm{ml}$ containing 5 mmoles of $\mathrm{Th}\left(\mathrm{NO}_{3}\right)_{4}$, I mole of $\mathrm{UO}_{2}\left(\mathrm{NO}_{3}\right)_{2}$ and 48.6 mmoles of $\mathrm{HCl}, 93-94 \%$ of the uranium and only $5 \%$ of the thorlum was found to extract with 36 moles of antipyrine in chloroform. The uranyl-antipyrine complex is soluble in nitrobenzene. but not very soluhle in hexone. Tropolone,<smiles></smiles>

The extraction of $U(V I)$ and Th from $0.1 \mathrm{M}$ perchlorate solutions by $0.05 \mathrm{M}$ tropolone in chloroform is given as a function of $\mathrm{pH}$ in figure 64.230 The $\mathrm{pH}$ of $50 \%$ extraction for $U(V I), T h$, and $Y$ under the above conditions is approximately $0.9,1.1$, and 4.0 , respectively. Less than $50 \%$ lanthanum is extracted at $\mathrm{pH} 6.5 . \underline{530}$

Dyrssen 531 reports the extraction of a uranium (VI)beta-1sopropyl tropolone complex w1th chloroform and hexone.

Ion Exchange. A number of articles are avallable in which the venavior of uranium toward ton exchange resins is revlewed and in which reference to much of the literature is glven. Hyde, $\underline{399} \mathrm{Katz}$ and Seaborg, $\underline{2}$ Choppin, $\underline{52}$ Pale1, $\frac{197}{1}$ and Kuznetsov, et a1. 200 have reviewed the ion exchange of a number of the actinide elements including uranium. Steele and Taverner 198 have outlined several anion exchange separations of uranium. Clegg and Foley 533 have described the use of Ion exchange resins in the processing of uranium ores. 


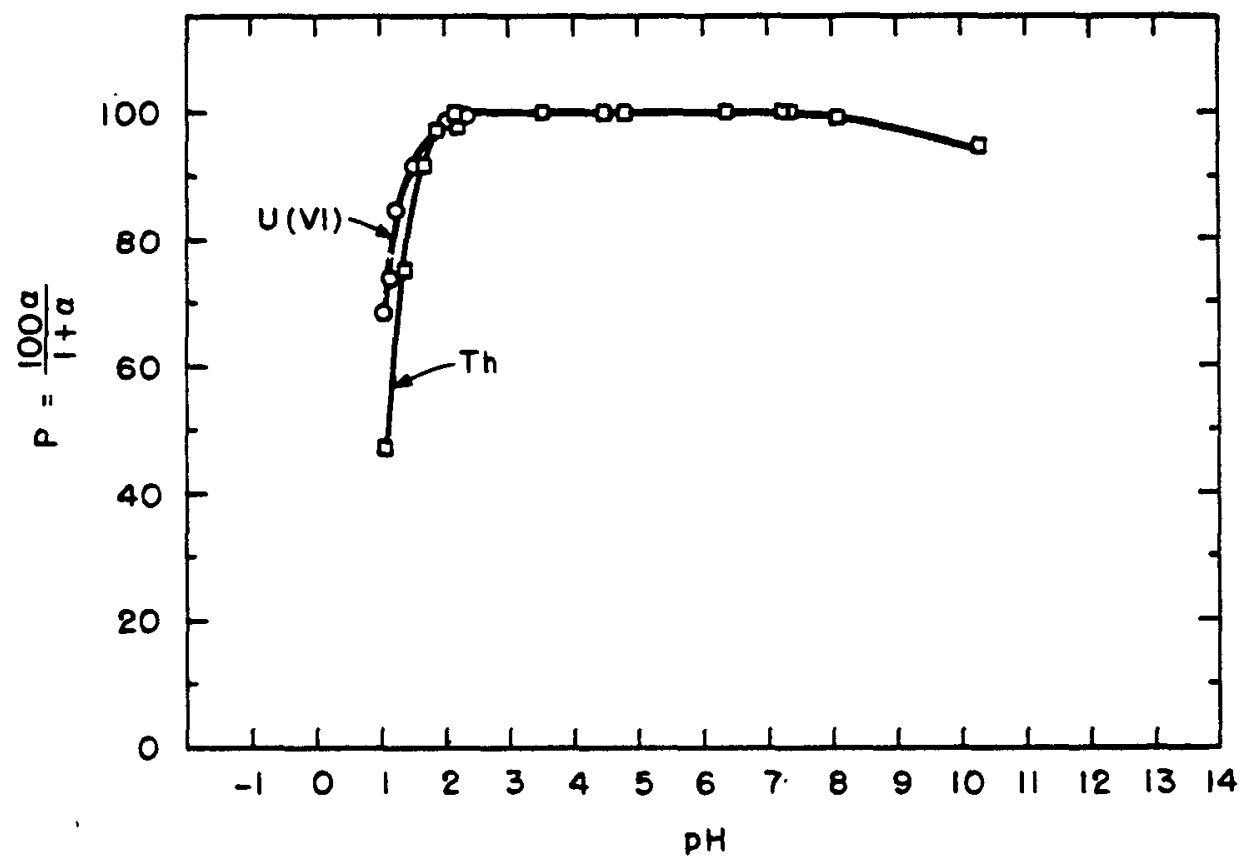

Figure 64.

The extraction of trace amounts of uranium (VI) and thorlum from $0.1 \mathrm{M}$ perchlorate solution by $0.05 \mathrm{M}$ tropolone in chloroform at $25^{\circ} \mathrm{C}$. After D. Dyrssen, reference 530.

In the following paragraphs, the distribution of urantum (and of other elements) between an ion exchange resin and a particular solution is described in terms of the distribution coefficients, $D$ and $D_{v}$. These are defined as

$$
D=\frac{\text { amount } M^{+X} / \text { gram dry resin }}{\text { amount } M^{+X} / \text { ml solution }}
$$

and

$$
D_{v}=\frac{\text { amount } M^{+X} / m \text { resin bed }}{\text { amount } M^{+X} / m \text { solution }}
$$

The two coefficlents are related by the density of the resin bed, $D_{V}=P D$. The coefficlent $D$ is referred to as $K_{D}$ by many authors. 
Anion exchange. Anion exchange resins commonly used In the radiochemical laboratory are the strong base resins such as Dowex-1 and-2 and AmberI1te IRA-4I0 and IRA-400. The capacity of these resins is approximately 2.5 mill1equivalents per gram of resin. Weak base resins are also avallable. However, their use is more limited. These resins have capacities ranging from about 6 to $10 \mathrm{mill1-}$ equivalents per gram of resin.

Spivey, et al. $\frac{534}{4}$ have investigated various factors such as resin capacity, resin phase volume anion adsorption, etc, that affect the sorption of uranium. Irivisonno 535 has made a literature survey of factors that influence the adsorption and elution of uranium by and from strong base anion exchange resins. These are similar to the factors Influencing solvent extraction and include, other than those already mentioned, uranium concentration, anion concentration, $\mathrm{pH}$, the presence of other metallic lons and forelgn anions, temperature, resin size, porosity, crosslinkage, etc.

The various systems from which uranium may be adsorbed by anion exchange resins are described below. The resin may be converted to a particular anionic form by washing with an appropriate solution.

Chloride systems.

Kraus and Neison $\frac{536}{2}$ have measured the distribution coefflclents for a number of elements between a strong base anion exchange resin (Dowex-I, 10\% DVB, $200 \mathrm{mesh}$ ) and hydrochloric acid solutions of varying molarity. Their results are shown in figure 65. The results of Marcus, $\frac{537}{2}$ obtalned under conditions similar to those used by Kraus and Nelson, $\underline{56}$ are given in figure 66. The concentrations of the various elements used in the study by Marcus were such that the oxidation states could be determined spectro- 

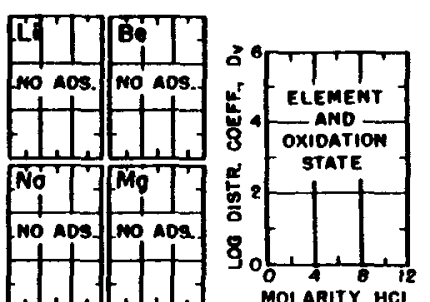

NO ADS. - MO ADSORPTION O.IE HCt a 12 SL. ADS. - SLIGHT ADSORPTION IN $12 \mathrm{M}$ HCI
(0.340<11)

STR. ADS. - STRONO ADSORPTION D $>1$
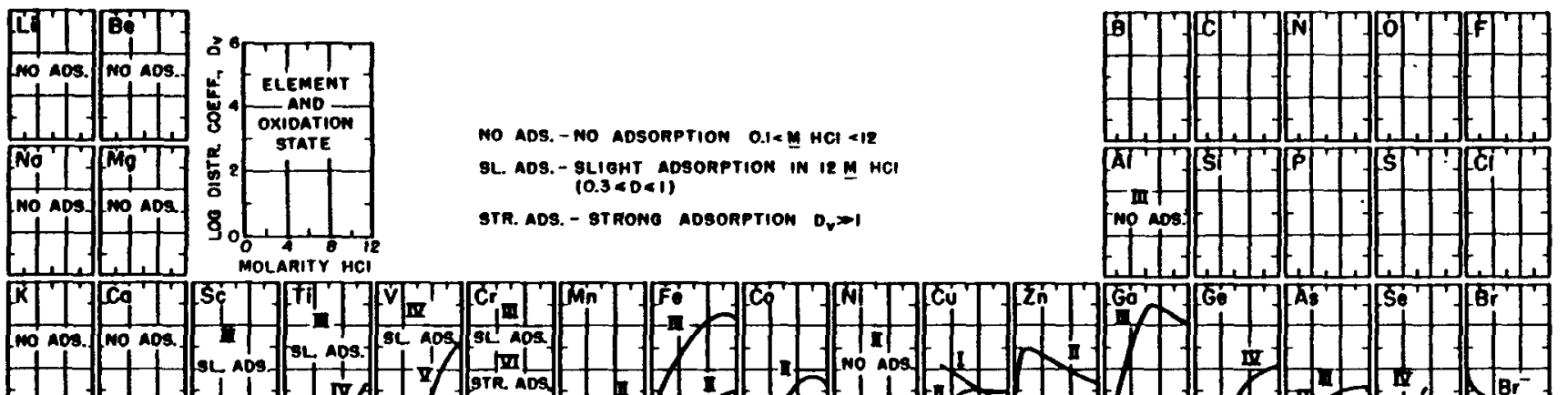

SL AOS.
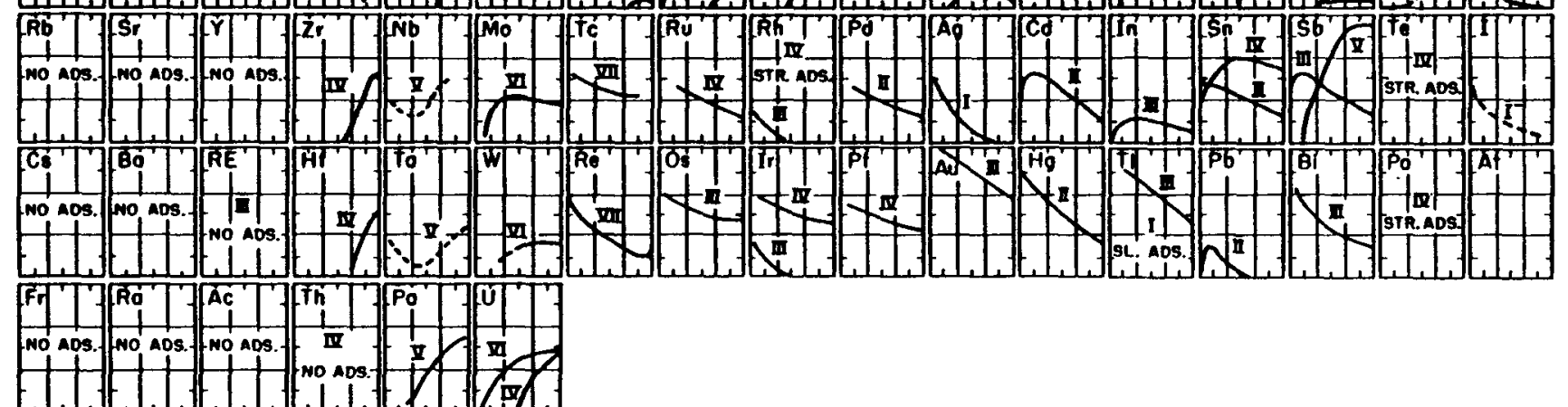

Figure 65. Adsorption of elements from hydrochloric acid solution with anion exchange resin (quaternary amine polystyrene divinyl benzene resin, 200 mesh, 10\% DVB). After K. A. Kraus and F. Nelson, reference 536 . 


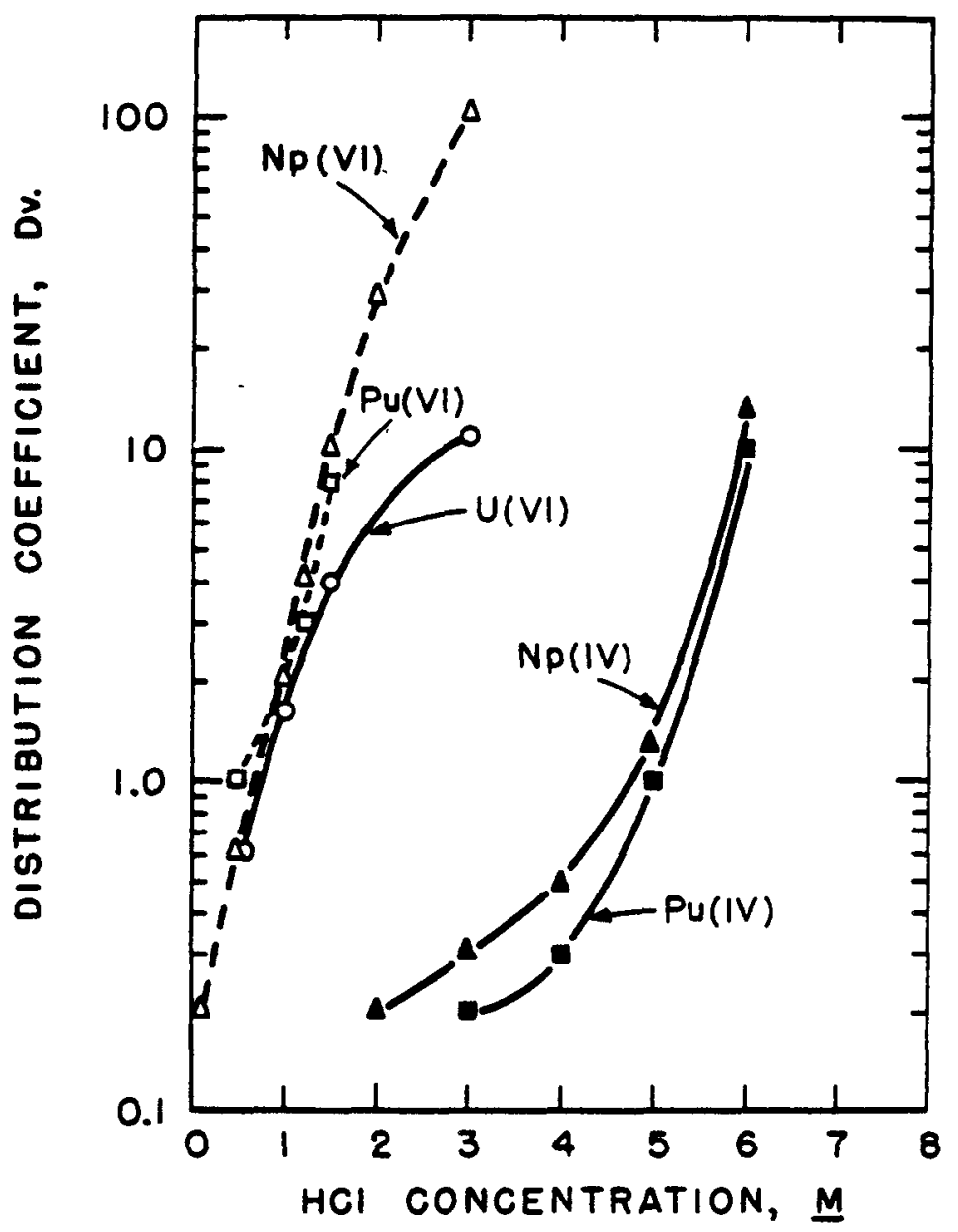

Figure 66.

Adsorption of elements from hydrochloric ac1d solution with Dowex-1 anion exchange resin ( $10 \%$ DVB).

After Y. Marcus, reference 537. 
photometrically. No adsorption of $\mathrm{Np}(\mathrm{V}), \mathrm{Pu}(I I I)$, or $\mathrm{Am}$ (III) was found. The data presented by Wish $\frac{538}{6}$ for the adsorption of various elements by Dowex-2 ( $x 8,200-400$ mesh) is repre-

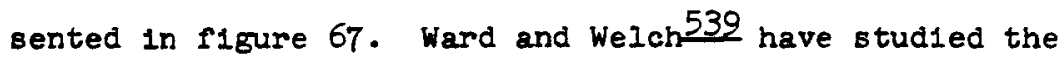
distribution of neptunium in various oxidation states between Amberlite IRA-400 and hydrochloric acid solutions of varying concentration. Their results show that $\mathrm{Np}(V I)$ is strongly adsorbed at $>6 \mathrm{MHCl}, \mathrm{Np}(\mathrm{V})$ is exponentially adsorbed from $3 \underline{M}$ to $6 \underline{M} \mathrm{HCl}$ (D Increases from 1 to 10 ), and $\mathrm{Np}$ (IV) is s1milarly adsorbed from about 6M to 1OM HCI (D Increases from about 2 to 400 ). Prevot, et al. 540 have Investigated the adsorption of $U, P u, T h, F e, C e$, and $\mathrm{Zr}$ by anion exchange resin A3OOD from hydrochloric acid solutions rangling in molarity from 4 to 7 . Quantities of $7 \mathrm{mg}$ Pu, $6.9 \mathrm{mg} U$ and $5.9 \mathrm{mg} F e$ per $m \mathrm{l}$ of solution and 2 grams of resin were used in the determination of $D$. Their results are considerably different than those shown in figures 65-67. The distribution coefficients of $U(V I)$, and $F e(I I I)$ are lower roughly by an order of magnitude. The distribution coefficient. of $\mathrm{Pu}(I V)$ is almost an order of magnitude higher. For Pu(III), $D$ is about 0.1 at $4 \underline{M} \mathrm{HCl}$ and about $I$ at $7 \underline{M} \mathrm{HCl}$. 21rconium adsorption is similar to that shown in the figures. Thorium and cerlum are poorly or not at all adsorbed.

Kork1sch, et $21.541,542$ have found the distribution coefficlent of uranlum between Dowex- - and hydrochloric ac1d solutions to increase with increased alcohol concentration of the solution. With $80 \%$ ethanol, $D$ is increased from about. 40 to 6000 as the $\mathrm{HCl}$ concentration is increased from $0.2 \mathrm{M}$ to $2.4 \mathrm{M} .54 \mathrm{I}$ The distribution coefficient at $2.4 \mathrm{M} \mathrm{HCl}$ without alcohol is about 40. Alcohol also increases the adsorption of thorium, titanium, and zirconium. The distribution co-

* 95\% alcohol denatured with benzene is considered $100 \%$ alcohol. 


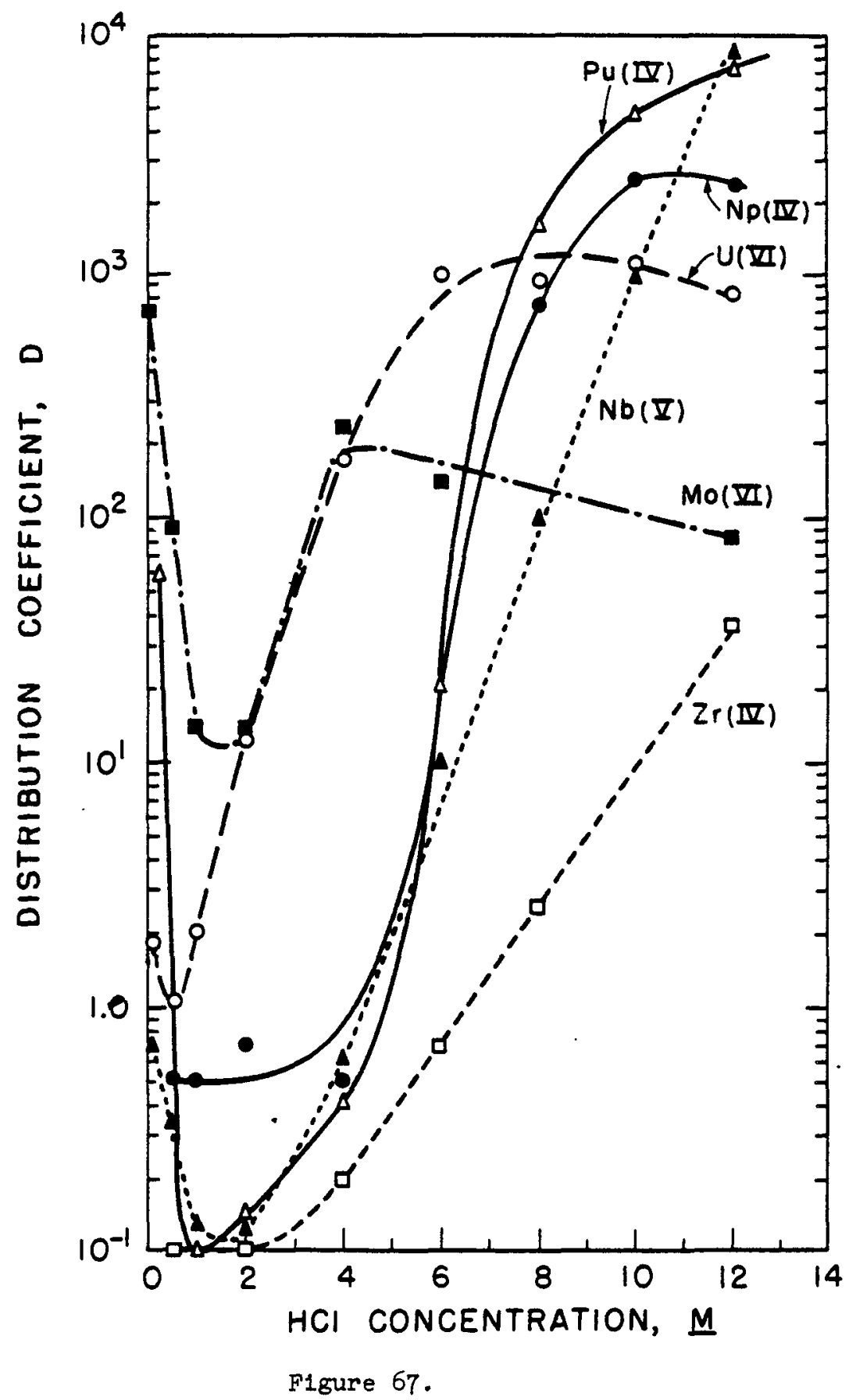

Adsorption of elements from hydrochloric ac1d solution with Dowex-2 anion exchange resin ( $x 8,200-400$ mesh). After I. W1sh, reference 538 . 
efficlents of these elements vary roughly between $I$ and 10 from $80 \%$ alcohol solutions contalning $\mathrm{HCl}$ in the range of $0.2 \mathrm{M}$ to $2.4 \mathrm{M} . \underline{542}$

Numerous separations of urantum from other elements are possible using hydrochloric ac1d systems. The more obvious ones are those in which uranium is adsorbed and the other element is not. Consideration of figure 65 , indicates that uranium can be separated from alkall metals, alkaline earths, aluminum, yttrium, rare earths, actinium, and thorium by adsorption as uranium (VI) on a strong base anion exchange resin from a concentrated hydrochloric acid solution. Trivalent actinide elements are not adsorbed from hydrochloric acid solutions. Plutonium is eluted as Pu (III) with 12M $\mathrm{HCl}$ containing hydroxylamine hydrochloride and $\mathrm{NH}_{4} \mathrm{I}$, $\mathrm{NH}_{4} \mathrm{I}$ alone, or HI. Separations may be made by adsorption of the contaminating element and elution of uranium with dilute hydrochloric acid. For example, molybdenum is adsorbed from $0.1 \mathrm{M} \mathrm{HCl} .543$ Bismuth is also adsorbed from dilute (<IM) $\mathrm{HCl} .544,545$ other elements that show strong adsorption from dilute HCl include many of the transition metals, tin, tellurlum, and polonium. $\underline{56}$ Kraus and Moore 546 have effected the separation of protactinium and uranium by adsorbing them from $8 \mathrm{M} \mathrm{HCl}$ on a column of Dowex $\mathrm{A}-1$ resin and developing the column with $3.8 \mathrm{M} \mathrm{HCl}$. Protactinium appeared first in tise eluent, separated from uranium. The uranium fraction contained, however, a falr amount of protactinium 'taling'. Advantage may be taken of the different distribution coefficients exhibited by ions in various oxidation states to effect their separation from urantum. Iron reduced to ferrous ion by hydrogen 1odide $\frac{547}{4}$ or ascorbic acid $\frac{548}{4 s}$ separated by elution W1th $4 \mathrm{M} H C I$. $U(I V)$ may be separated from $\mathrm{Pa}(I V)$ and $T h(I V)$. U(IV) is adsorbed by Amberlite IRA-401 (100 mesh) and Dowex-I (100-200 mesh) from $>8 \mathrm{~N}$ HCl. 
Ne1ther $\mathrm{Pa}(\mathrm{IV})$ nor $\mathrm{Th}(\mathrm{IV})$ is adsorbed from $6 \mathrm{M}-12.6 \mathrm{M} \mathrm{HC1.} 549$ The elution of $\mathrm{Pu}$ (III) by $12 \mathrm{M} \mathrm{HCl}$ from strong base anton exchange resin has already been mentioned. W1sh and Rowell 550 have effected the separation of $\mathrm{Th}, \mathrm{Pu}, \mathrm{Zr}$, and $\mathrm{Np}$ from $\mathrm{U}$ by elution with hydrochloric acid in a sequence of concentrations. The elements are adsorbed on the resin (Dowex-2) from 12M HCl. Thorlum does not adsorb. Plutonium is eluted In the trivalent state w1th $12 \mathrm{M}$ HCl saturated with hydroxylamine hydrochloride and ammonium lodide. Zirconium is elutec with 7.5M HCI; neptunium (IV) with a $6 \mathrm{M} \mathrm{HCl}-5 \% \mathrm{NH}_{2} \mathrm{OH} \cdot \mathrm{HCl}$ solution. Uranium is finally eluted with $0.1 \mathrm{~N} \mathrm{HCl}$. Korkisch, et al. $\frac{51}{1}$ have separated uranium from tungsten by means of anion exchange. The uranium is adsorbed on Dowex $I$ resin from a solution containing $20 \% 4 \underline{\mathrm{M}} \mathrm{HCl}$ and $80 \%$ ethanol (volume $\%$ ). Ascorbic acid is used to reduce any iron present. The resin is washed with a similar solution and uranium is eluted with an ether-saturated 0.IM HCl solution. No tungsten is observed in the final eluate.

\section{Fluorlde systems.}

Faris $\frac{52}{2}$ has reported the adsorption of elements from hydrofluoric acid solutions with Dowex-1 anion exchange resin $(x 10,200$ mesh). H1s results are shown in figure 68. Uranium (VI) adsorption is strong from dilute HF solutions and decreases with increased ac1d concentration. Separation from elements exhibiting no or strong adsorption from HF solutions may be achleved by proper selection of the ac1d concentration. Elements such as Be, B, Sc, T1, $\mathrm{Zr}$, Mo, $\mathrm{Sn}, \mathrm{Te}, \mathrm{Hf}, \mathrm{Ta}, \mathrm{W}, \mathrm{Re}$, and Hg have adsorption curves similar in shape to that of uranium (VI). Separation from these elements using an $\mathrm{HF}$ system should prove difficult to almost Impossible, depending upon the distribution coefflaients involved. 

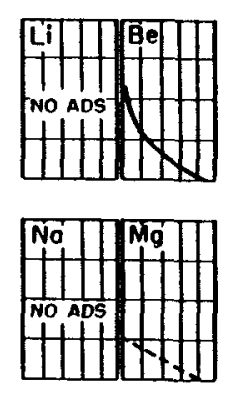

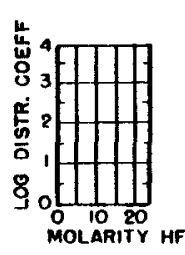

NO ADS - NO ADSORPTION FROM IM-24M HF

SL ADS - SLIGHT ADSORPTION

STR ADS - STRONG ADSORPTION. LOO DIST. COEFF $>2$

ROMAN MUMERALS REFER to OXIDIZATION STATE

IN INITIAL SOLUTION.
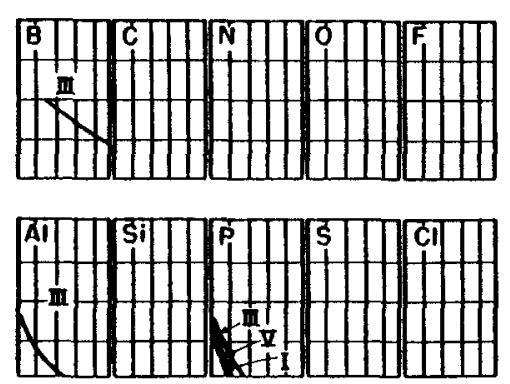

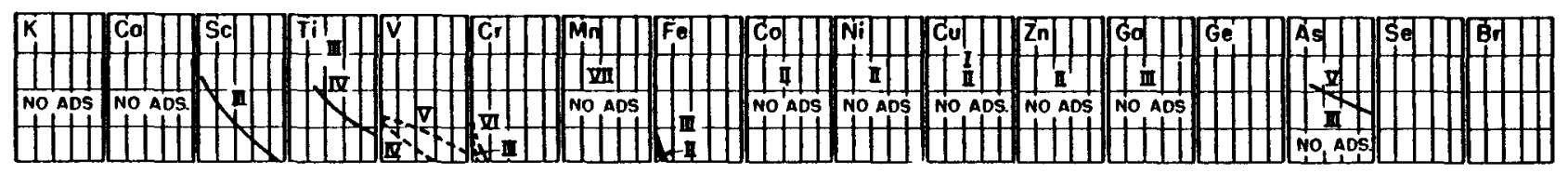

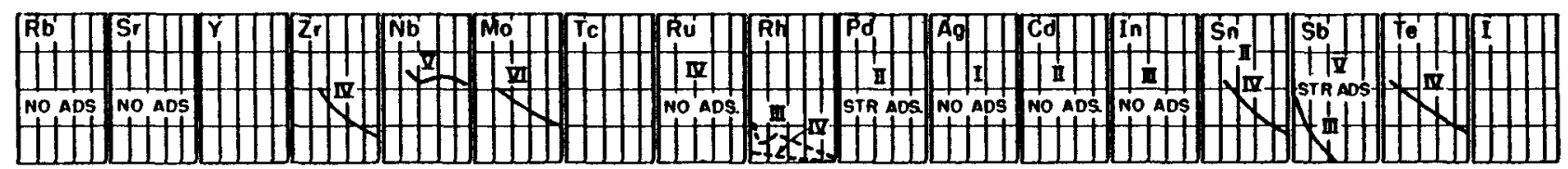

(1)

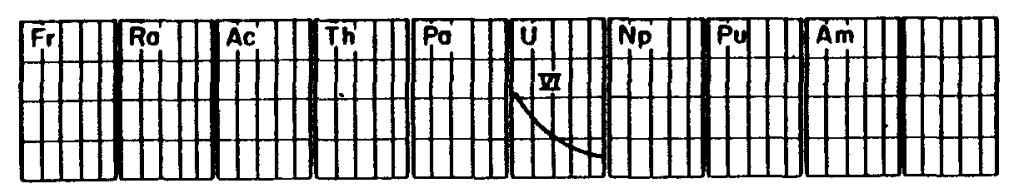

F1gure 68. Adsorption of elements from hydrofluoric acid solution with Dowex-1 anion exchange resin (x10, 200 mesh). After J. P. Faris, reference 552. 
Bhat and Gokhale $\frac{553}{3}$ have found evidence for the adsorption of the anionic species $\mathrm{UO}_{2} F_{3}^{-}$with Amberlite IRA-400. $\mathrm{HCl}-\mathrm{HF}$ systems.

Certain elements are efficientiy separated from uranium by anion exchange when a combined HCl-HF eluting system is used. Such systems have been studied by a number of workers. $538,554-559$ The resuits of NeIson, Rush, and Kraus 558 are shown in figure 69. Faris and Brody 259 have examined the distribution coefficient $D$ of uranium as a function of $\mathrm{HCl}$ concentration in the presence of 0,1 , and $8 \mathrm{M} \mathrm{HF}$ and as a function of $\mathrm{HF}$ concentration in the presence of 0 and $0.2 \mathrm{M}$ HCl. The former three curves are similar in shape but decrease in magnitude as the IF corcentration is increased. The presence of $0.2 \mathrm{M} H C I$ also causes a decrease in magnitude of the $D$ vs.[HF] curve. However, the shapes of the 0 and $0.2 \mathrm{M}$ $\mathrm{HCl}$ curves for varying HF concentration are dissimilar for HF concentrations less than $4 \mathrm{M}$.

Table XXXIV lists a number of separations of $U$ from other elements using $\mathrm{HCl}-\mathrm{HF}$ eluting solutions. N1trate systems.

The distribution of uranium between anion exchange resins and nitric ac1d solutions has been reported by a number of workers. $536,540,543,550,557,560-562$ The results of Buchanan and Faris $\frac{562}{2}$ are given in figure 70 . From the non- or only slight adsorption of most of the elements from nitric acid media, It appears that anion exchange affords an excellent means for purtfying urantum. Uranium is adsorbed more strongly from nitrate salt solutions than from nitric ac1d solutions alone. $536,557,562,563$ with DeAc1dite FF resin, the adsorption of uranium (VI) is greatest from $\mathrm{Al}\left(\mathrm{NO}_{3}\right)_{3}$ solutions and decreases in the order $\mathrm{Ca}\left(\mathrm{NO}_{3}\right)_{2}>\mathrm{LINO}_{3}>\mathrm{NH}_{4} \mathrm{NO}_{3} \cdot \frac{563}{}$ Ethanol increases the distribution of uranium to the resin phase. 541 With an $80 \%$ alcoholic solution, the distribution coefficient 
Table XXXIV. Separation of Uranium from Various Elements by Anion Exchange Using HCl-HF Eluting Solutions. a

Elemental mixture

$W, U$

U, W, Mo

Fe(III), U

R.E. as EU(III), U(IV),

$U(V I), Z n(I I)$

$\mathrm{Te}(I V), U(V I)$

$\operatorname{Th}(I V), \mathrm{Pa}(\mathrm{V}), \mathrm{U}(\mathrm{VI})$

Fa, U

$\mathrm{Zr}, \mathrm{Np}, \mathrm{Nb}, \mathrm{U}, \mathrm{Mo}, \mathrm{Tc}$
Element eluted

Eluting solution

$7 \mathrm{M} \mathrm{HCI-IM} \mathrm{HF}$

$0.1 M \mathrm{HCl}$

$\mathrm{U}$

$0.5 \mathrm{M} \mathrm{HCI}$

7M HCI-IM HF

IM $\mathrm{HCl}$

Mo

$7 \underline{\mathrm{M} \mathrm{HC}}-4-4 \mathrm{MF}$

$7 \mathrm{M} \mathrm{HCl}-0.2 \mathrm{M} \mathrm{HF}$

IM HCI-4M HF

$24 \mathrm{M}$ HF or $4 \mathrm{M} \mathrm{NH}_{4} \mathrm{Cl}-$

IM $\mathrm{NH}_{4} \mathrm{~F}$

$\mathrm{Fe}$ (III) IM HF-0.0IM HCI

$\mathrm{U} \quad$ IM HCI

R.E. $\quad 8 \mathrm{M} \mathrm{HCI}$

$\mathrm{U}$ (IV) $8 \mathrm{M} \mathrm{HCI-0.IM} \mathrm{HF}$

$\mathrm{U}(\mathrm{VI}) \quad 0.5 \mathrm{M} \mathrm{HCl}$

$\mathrm{Zn}(I I) \quad 0.01 \mathrm{M} \mathrm{HCI}$

$U(V I) \quad 3 M \mathrm{HCI}-1 \underline{M}($ to $8 \underline{M}) \mathrm{HF}$

$\mathrm{Te}(I V) \quad$ IM HCI

Th (IV) IOM HCI

$\mathrm{Pa}(\mathrm{V}) \quad 9 \mathrm{M} \mathrm{HCl}-\mathrm{MM} \mathrm{HF}$

$\mathrm{U}(\mathrm{VI}) \quad 0.1 \mathrm{M} \mathrm{HCI}$

9M HCI

$7 \mathrm{M} \mathrm{HCI}-0.11 \mathrm{M} \mathrm{HF}$

$\mathrm{Pa}$

U

$0.5 \mathrm{M}$ HCI

$\mathrm{Zr}$

$12 \mathrm{M} \mathrm{HCl}-0.06 \mathrm{M} \mathrm{HF}$

$\mathrm{Np}$

$6.5 \mathrm{M} \mathrm{HCl}-0.004 \mathrm{M} \mathrm{HF}$

$\mathrm{Nb}$

$6.0 \mathrm{M} \mathrm{HCl}-0.06 \mathrm{M} \mathrm{HF}$

air dry column and alcohol wash

U $\quad 0.1 \mathrm{M} \mathrm{HCl}-0.06 \mathrm{M} \mathrm{HF}$

Mo, TC
Reference

555

555

559

555

556

559

556

554

538

a Dowex-1 or -2 anton exchange resin used. 


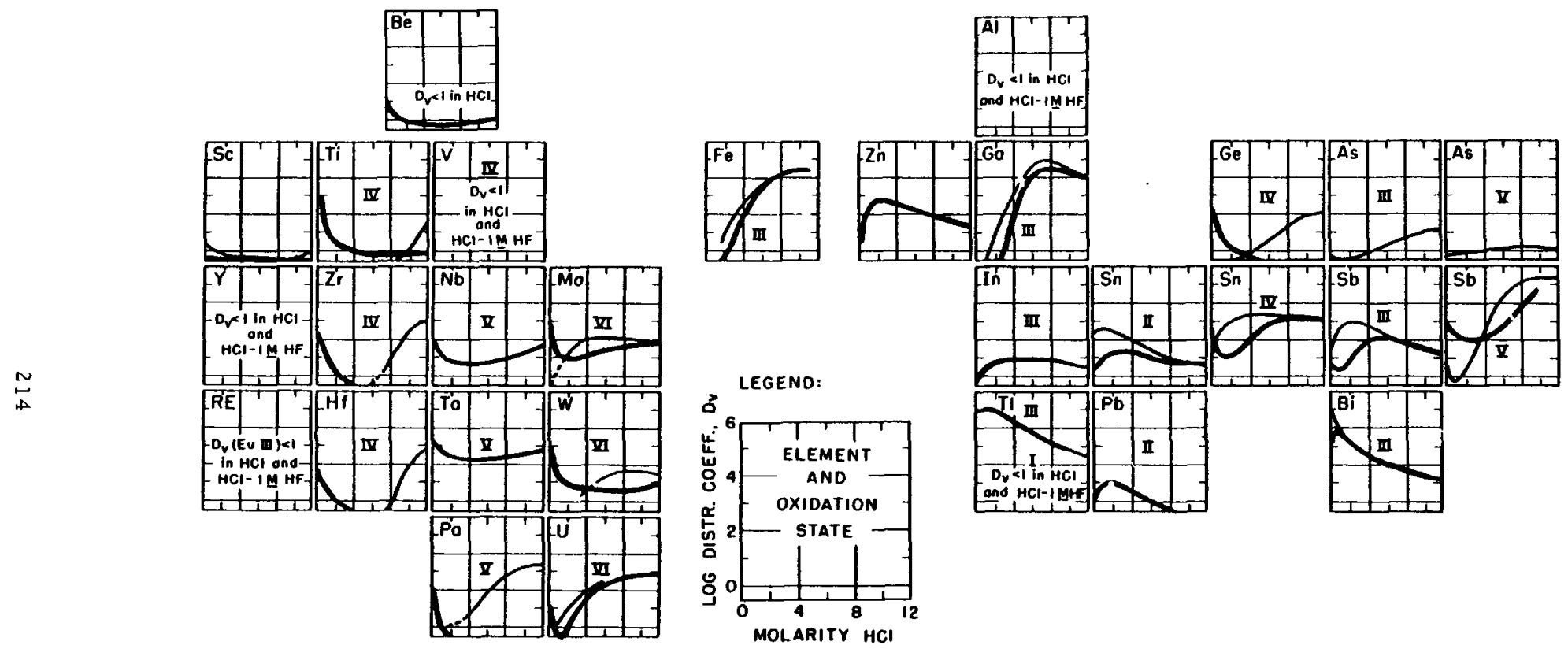

Figure 69. Adsorption of elements from HCl and HCl-HF solutions with anion exchange re'sin. Distribution coefficients in absence of HF. Distribution coefficients in $\mathrm{HCl}-\mathrm{HF}$ mixtures (usually $1 \mathrm{M} \mathrm{HF}$ except $\mathrm{Zr}(\mathrm{IV}), \mathrm{Hf}(\mathrm{IV}), \mathrm{Nb}(\mathrm{V}), \mathrm{Ta}(\mathrm{V})$, and $\mathrm{Pa}(\mathrm{V})$ where $\mathrm{M} \mathrm{HF}=0.5)$. After $\mathrm{F}$. Nelson, R. M. Rush, and $\mathrm{K}$. A. Kraus, reference 558. 


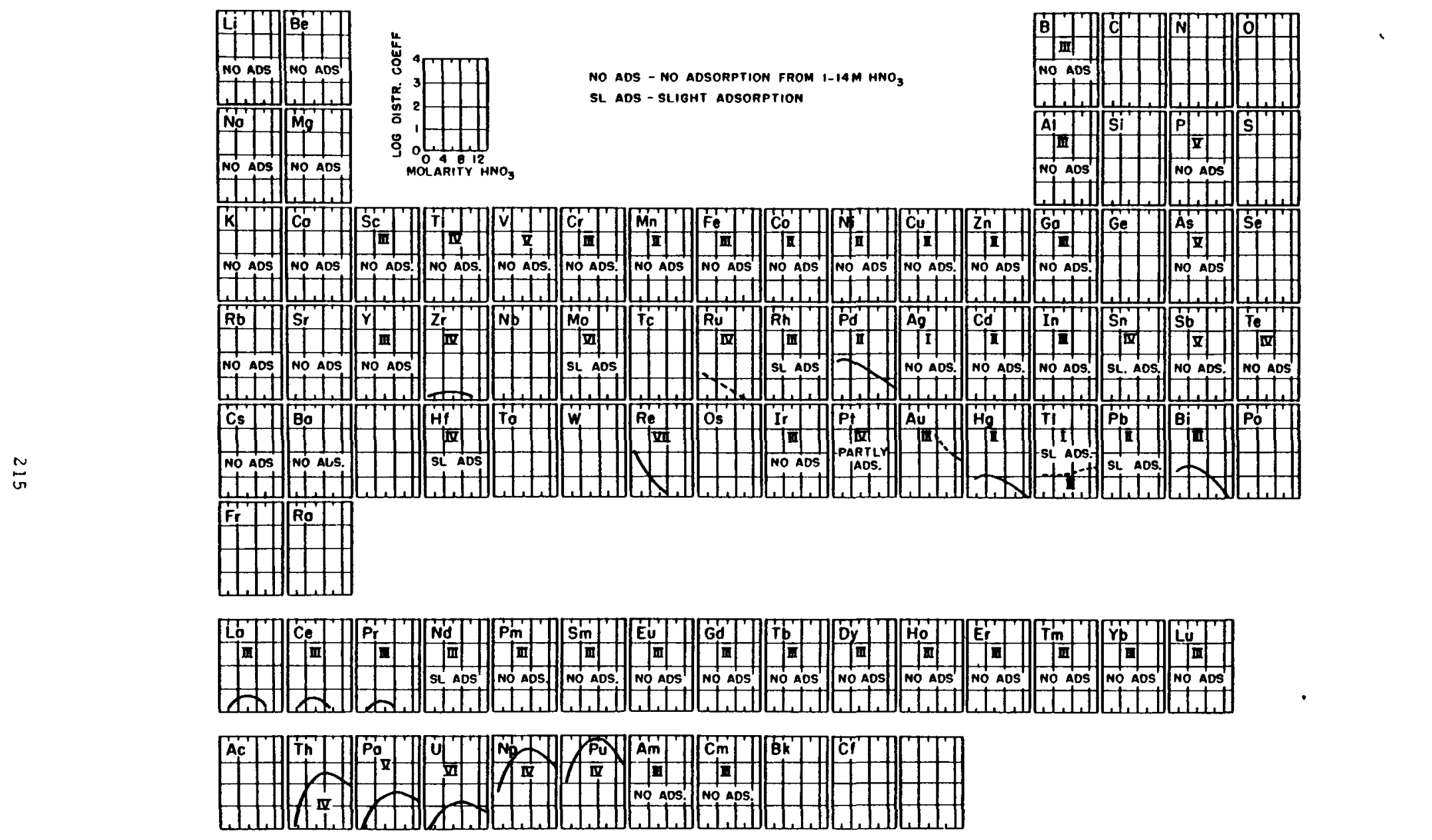

Figure 70. The adsorption of elements from nitric acid solutions with Dowex-1 anion exchange resin $(\mathbf{x} 10,200-400$ mesh). After R. F. Buchanan and J. P. Faris, reference 562. 
Table XXXV. Separation of Uranium from Various Elements by AnIon Exchange Using N1tric Acid Solutions.

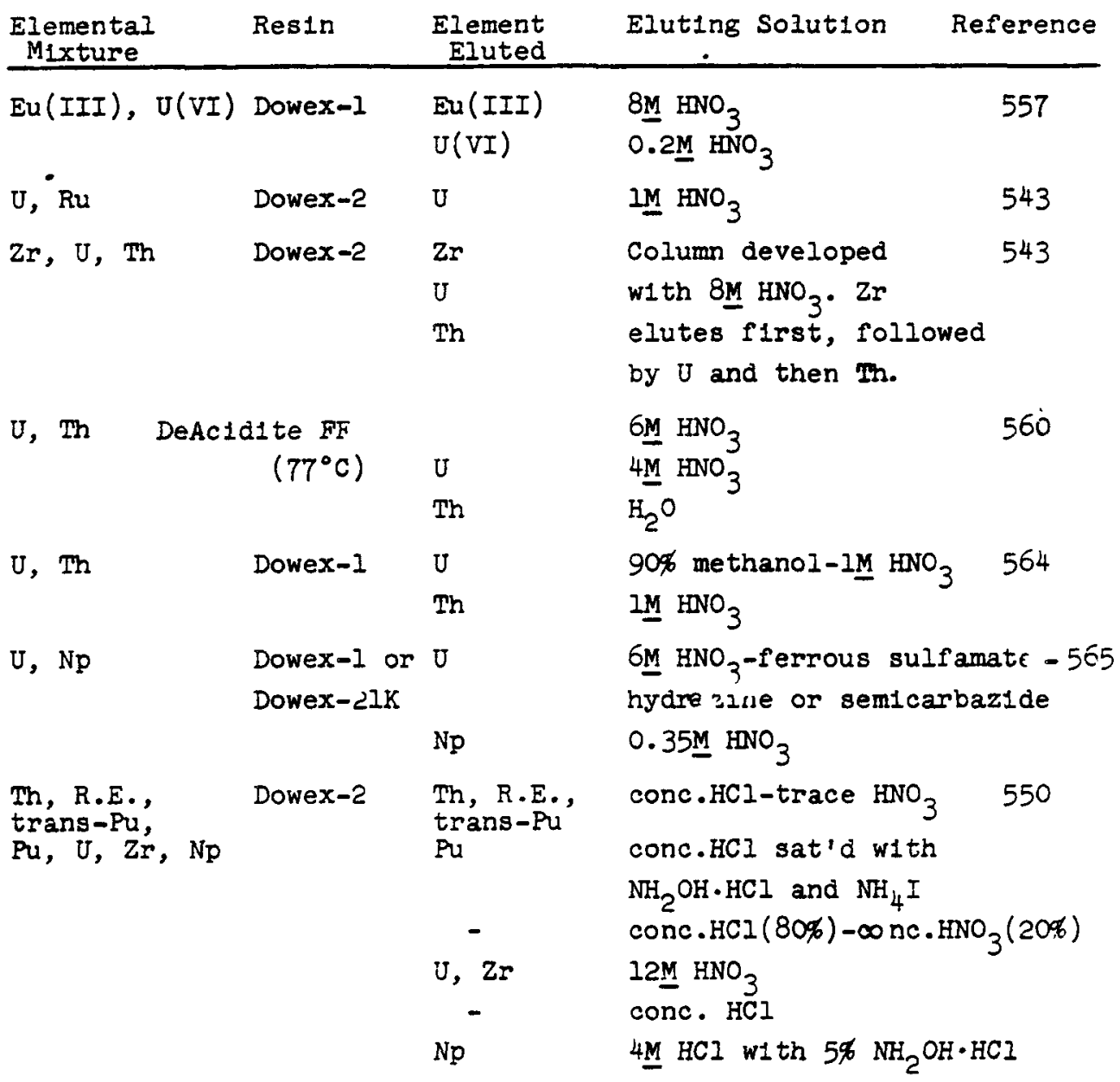

for uranium is about 12 between Dowex-1 resin and $1.2 \mathrm{M} \mathrm{HNO}_{3}$ solution; for a $40 \%$ alcoholic solution, $D$ is about 7 .

Table XXXV lists a number of separations of $U$ from other elements using nitrate media. The last procedure listed in the table may be revised to include $P a$ separation. Following the elution of $\mathrm{U}$ with $12 \mathrm{M} \mathrm{HNO}_{3}$, in which a small amount of $\mathrm{Pa}$ is eluted, the remaining $\mathrm{Pa}$ is eluted with $12 \mathrm{M} \mathrm{HNO}_{3}-0.1 \mathrm{M}$ HF. 550 


\section{Sulfite systems.}

The recovery of uranium from sulfate liquors by anion exchange methods is important industrially. Laboratory-wise, a number of procedures have been developed for the determination of uranium that make use of the adsorbability of the anionic uranyl sulfate complexes. The nature of these complexes has also

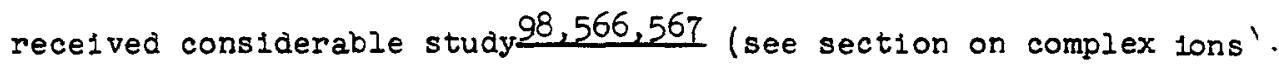
The distribution of uranium between anion exchange resins and sulfate media has been reported by a number of investigators. $\underline{56}$, $\underline{543,550,557,561,568}$ The results of Bunney, et al. .543 are given In flgure 71. Strontium, yttrium, cerium, and americium do not show any significant adsorption by the resin (Dowex-2) at any acid concentration. $\frac{543}{3}$ The distribution coefficient of Pu(IV) is approximately twice that of $U(V I)$ in the acid range of 0 to $10 \mathrm{~N} \mathrm{H}_{2} \mathrm{SO}_{4} \cdot 550$ The adsorption of uranium (and thorium) from solutions of $\left(\mathrm{NH}_{4}\right)_{2} \mathrm{SO}_{4}$ is similar to that from $\mathrm{H}_{2} \mathrm{SO}_{4}$. The decrease in adsorption is less rapid, however, with increased ammonium sulfate concentration than with sulfuric ac1d. 536,557 , 568 The adsorption of uranium from sulfate solution exhibits a $\mathrm{pH}$ dependence ( $D$ increases as the $\mathrm{pH}$ is increased from 1 to 4) which decreases as the sulfate concentration is decreased. 534 The distribution coefficient of uranium between Dowex-I resin and 0 to $1.2 \mathrm{~N}$ sulfurlc acld solutions is one to three orders of magnitude greater from $80 \%$ ethanol solutions than from aqueous solutions. 241

A number of procedures have been developed for the separation of uranium from various elements by anion exchange in sulfate solution. These generaliy involve the adsorption of the uranyl complex from a sulfate solution at $\mathrm{pH} 1$ to 2 from which the foreign element is not adsorbed. After thoroughly washing the resin bed to remove 1mpurities, uranium is eluted with a dilute solution of hydrochloric, nitric, or perchloric acid. Mixtures of elements that have been or may be separated 


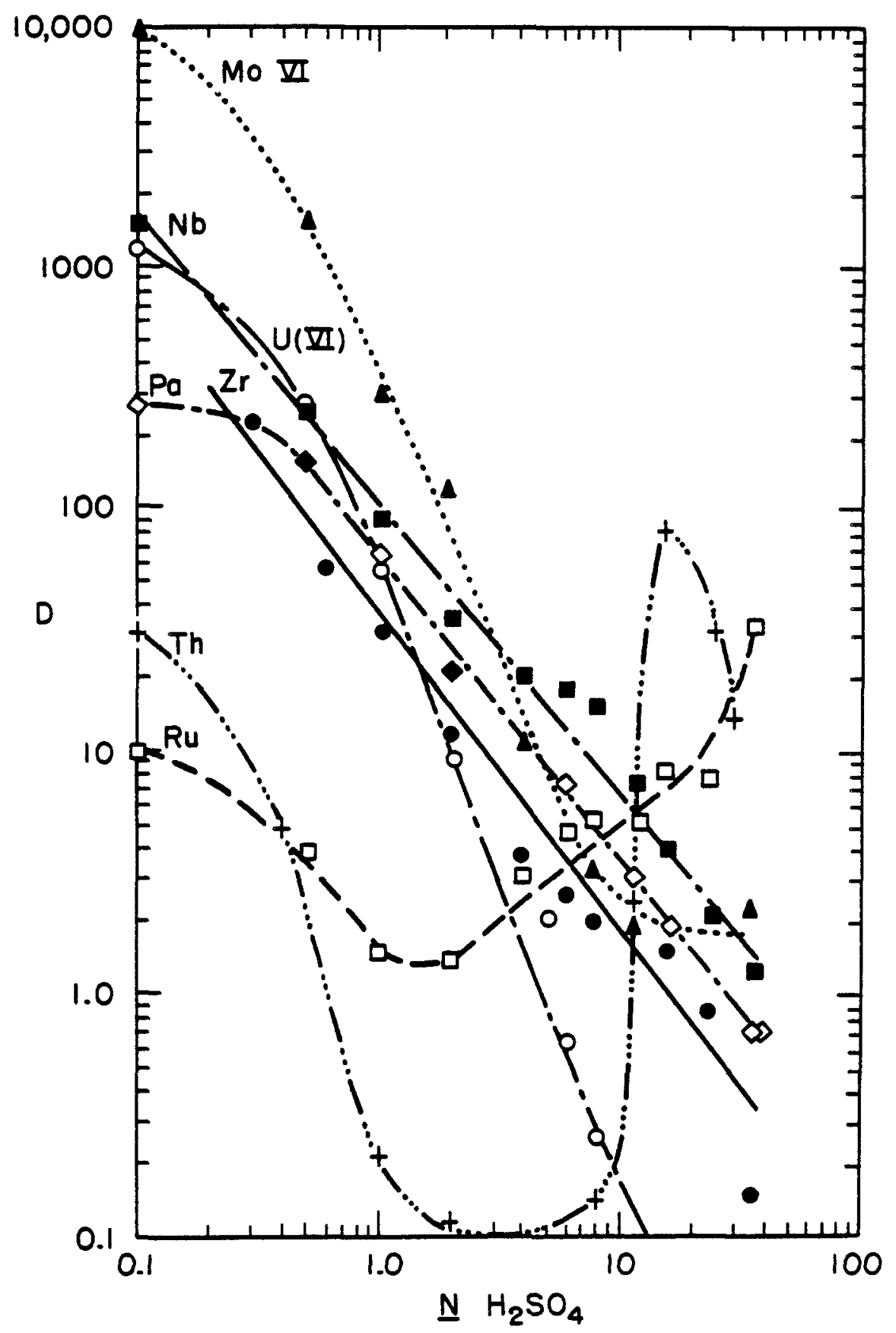

Figure 71 .

The adsorption of elements from sulfuric acid solutions with Dowex-2 anion exchange resin ( $x 8,200-400$ mesh). After I. R. Bunney, N. E. Ballou, J. Pascual, S. Foti, reference 543. 
from uranium by procedures similar to the one described 1nclude Am, Th; $\frac{543}{\mathrm{Fe}}, \mathrm{Al}, \mathrm{Mg} ; \underline{569} \mathrm{Fe}, \mathrm{V} ; \underline{570} \mathrm{zn}, \mathrm{N1}, \mathrm{Co}, \mathrm{Cd}, \mathrm{Mn}, \mathrm{Cu}, \mathrm{Fe}$, alkall metals; $571 \mathrm{zr}, \mathrm{Ce}, \mathrm{Cs}, \mathrm{Ag}, \mathrm{Cd}, \mathrm{V} ; 272 \mathrm{B1} ; \frac{573}{\mathrm{R} . \mathrm{E} . ; 243,571,574}$ and metals contained in ores. $575-578$ The literature references should be consulted for exact experimental conditions.

\section{Carbonate systems.}

Uranium is recovered from carbonate leach liquors by anion exchange in industrial operations. Its anion exchange behavior is similar in carbonate solution to that in sulfate solution. That 1s, the distribution coefficlent is decreased with increased carbonate concentration. This is 1llustrated in figure 72 for ammonium carbonate solutions. 575 A similar decrease in $D$ is observed for increased sodium carbonate concentration. 568 The distribution coefficient is also decreased by a decrease in $\mathrm{pH}$ of the solution. The increase in bicarbonate concentration at the lower $\mathrm{pH}$ 1nterferes with uranium adsorption. Other anions such as sulfate, nitrate, and chloride may also interfere with uranium adsorption from carbonate solution. To prevent gassing with carbon doxide, uranium is eluted with salt solutions rather than acids.

Vanadium 576 and phosphate and molybdate ${ }^{572}$ have been separated from uranium in carbonate solutions by anion exchange. The 1mpurities are adsorbed on the resin together with uranium and eluted with a $10 \% \mathrm{Na}_{2} \mathrm{CO}_{3}$ solution. Uranium is eluted with a $5 \%$ $\mathrm{NaCl}$ solution.

\section{Phosphate systems.}

The distribution of uranium and other elements between Dowex2 anion exchange resin and phosphoric ac1d solutions is represented in figure 73.579 Marcus 91 has studied the Dowex 1-uranyl phosphate system. His distribution coefficients are lower by factors of 2

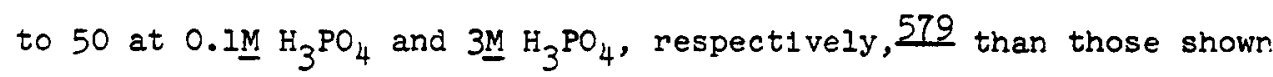
in figure 73. 


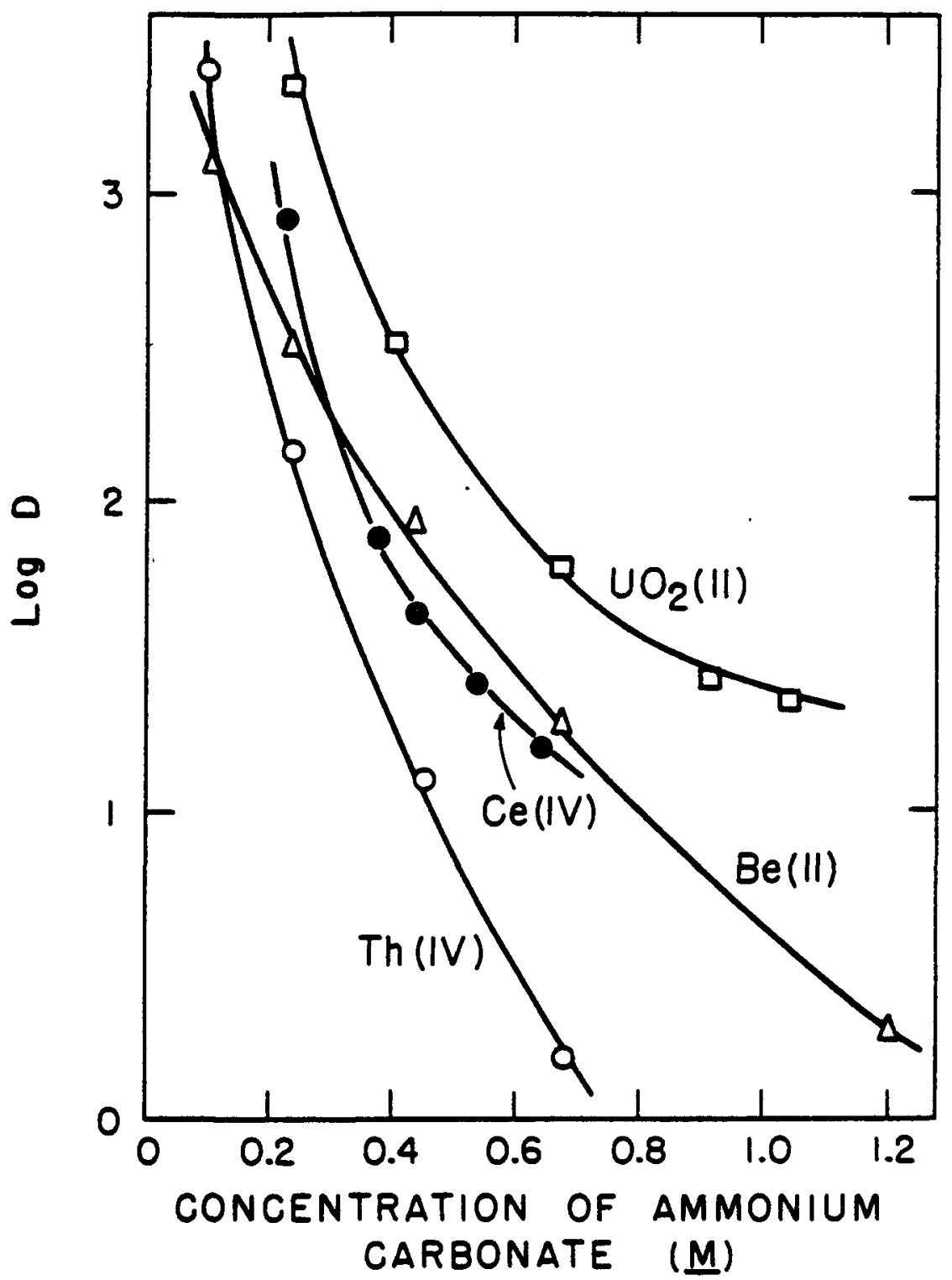

Figure 72. The adsorption of elements from ammonium carbonate solutions with Dowex-1 anion exchange resin ( $x 8,50-100$ mesh). After S. M1sum1, T. Taketatsu, reference 575. Conditions: Amounts taken, $\mathrm{Be}^{+}+11.7 \mathrm{mg}$ ( $\mathrm{EeO}$ ); $\mathrm{Ce} 4+, 7.3 \mathrm{mg}\left(\mathrm{CeO}_{2}\right) ; \mathrm{Th} 4+, 26.9 \mathrm{mg}\left(\mathrm{ThO}_{2}\right)$; and UO ${ }^{2+}, 61.0 \mathrm{mg}$ (U308): I gram of resin and $200 \mathrm{mr}$ of solution in contact $12-20$ hours at $20^{\circ} \mathrm{C}$. 


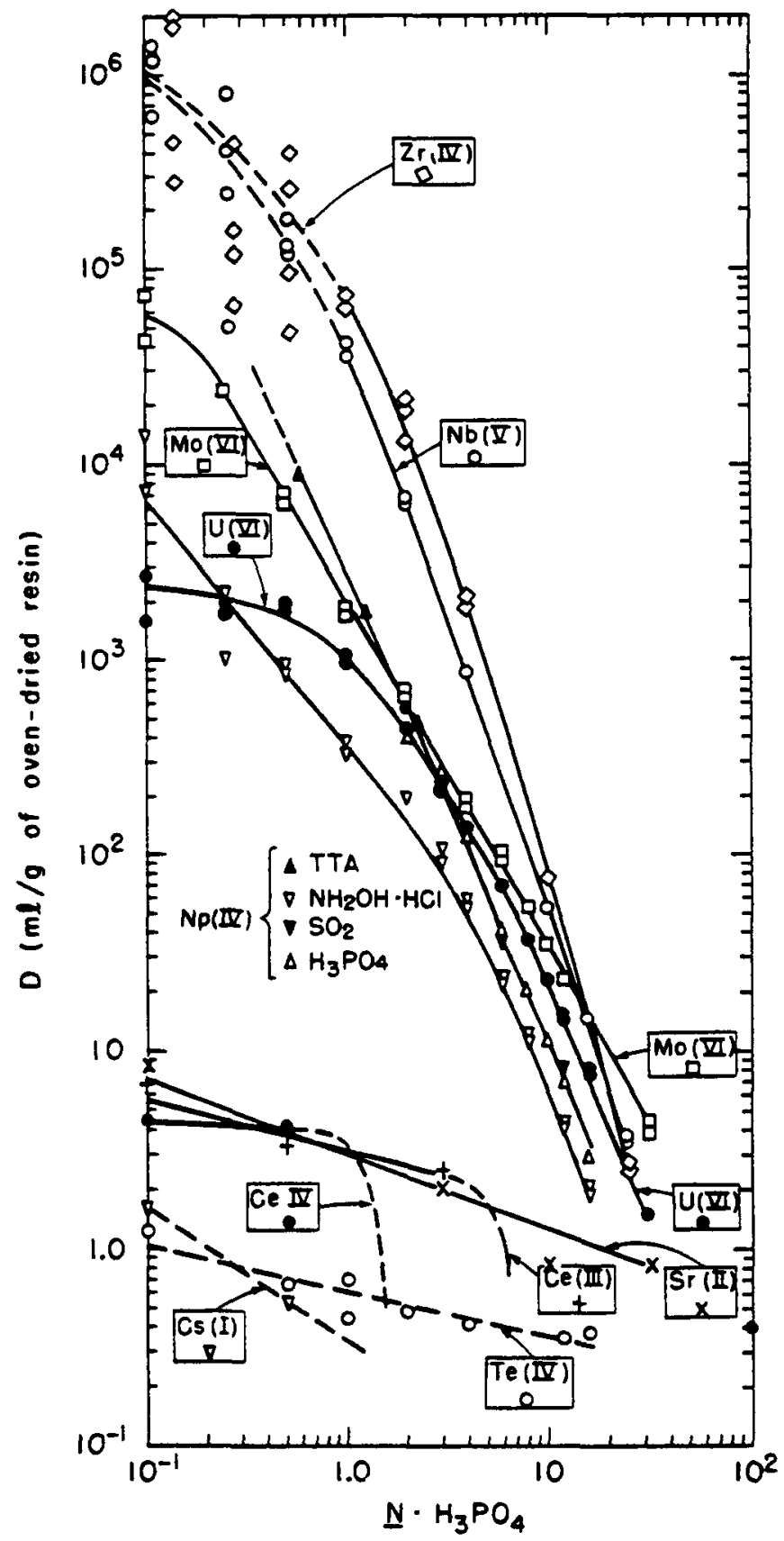

Figure 73.

The adsorption of elements from phosphoric acid solutions with Dowex-2 anion exchange resin ( $x 8,200$ mesh). After E. C. Frelling, J. Pascual, and A. A. Delucch1, reference 579. 
Separations between uranium and the rare earths $\left(\mathrm{Ce}^{3+}\right.$, $\left.\mathrm{Ce}^{4+}\right)$, alkaline earths $\left(\mathrm{Sr}^{2+}\right)$, alkali metals $\left(\mathrm{Cs}^{+}\right)$, and tellurium are possible using Dowex $2-\mathrm{H}_{3} \mathrm{PO}_{4}$ systems. The latter separation has been used by W1sh $\frac{580}{2}$ wo loaded a column of Dowex-2 resin from a $0.1 \mathrm{~N}_{3} \mathrm{PO}_{4}$ solution. Tellirium passed through and uranium was adsorbed. The column was then converted to the chloride form with concentrated hydrochloric acid and urantum was eluted with $0.1 \mathrm{M} \mathrm{HCI} \mathrm{-} \mathrm{0.06M} \mathrm{HF.} \mathrm{An} \mathrm{alternat1ve} \mathrm{method}$ Involved loading the column from concentrated HCl. Tellurlum was eluted with $1.0 \mathrm{~N}_{3} \mathrm{PO}_{4}$ after washing the column with an alcoholic phosphorlc solution. The column was then washed with an alcoholic HCI gas solution. Uranium was eluted with a 0.1M $\mathrm{HCl}-0.06 \mathrm{M} \mathrm{HF}$ solution and molybdenum with $12 \mathrm{M} \mathrm{HNO}_{3}$.

Miscellaneous systems.

Uranyl ion forms an anionic complex with acetate lons at $\mathrm{pH} 4.25$ to 5.25. The complex has been adsorbed on Amberlite IRA-400 strong base resin in the determination of small amounts of uranium in stones and natural waters. 581,582

Uranium is also adsorbed on Amberlite IRA-400 resin as an ascorbate complex. $\frac{58,584}{4}$ Thorium, titanium, zirconium, tungsten, and molybdenum are also adsorbed.

Uranium complexed with sulfosalicyl1c acld has been separated from $\mathrm{Zn}, \mathrm{Cu}, \mathrm{N} 1$, and $\mathrm{Cd} .585$ The latter are complexed with EDTA. The pH of the solution is kept between 8 and 10 . Separation has been made on Amberlite IRA-401 and Dowex-1 resins.

The uranyl cyanate complex formed by adding potassium cyanate solution to a uranyl salt is adsorbed by Dowex-l anion exchange resin. 586 Uranium is eluted by a dilute hydrochloric acid solution.

Cat1on exchange. Although a number of separations of uranium from varlous elements have been reported in the literature, the amount of quantitative data reported is rather meager. Hardy $\frac{587}{2}$ has summarized much of the data available on the dis- 
tribution of uranlum between cation exchange resins and nitric and hydrochloric acld solutions. His curves are reproduced in flgure 74. Distribution coefficlent curves for other actinide elements: $\mathrm{Th}, \mathrm{Pa}, \mathrm{Np}$, Pu, are given for comparison. Prevot, et 21.540 have published the distribution curve for uranium between cation exchange resin $C .50$ and nitric acid solution. Its shape and magnitude are similar to that shown for the Zeokarb$225-\mathrm{HNO}_{3}$ system in f1gure 74 . Ishimorl and Okuno 568 have found that increasing amounts of methanol in nitric acid solution (0.18M) Increase the distribution coefficient of urantum for Dowex-50 resin.

The elution peak positions of a number of ions including uranium (IV) and (VI) are given in figure 75 for various hydrochloric acid concentrations. The conditions under which the peak positions were determined are described in the figure caption. Ionescu, et al. 588 nave studied the effect of acetone on the distribution of several elements between cation exchange resins, $K U-2$ and $R-21$, and dilute hydrochloric ac1d solutions. For flxed hydrochlorlc ac1d concentrations of 1,2 , and $3 \%$, maximum uranyl distribution coefficients were found between 60 and $80 \%$ acetone solutions. For 4 and $5 \%$ ac1d solutions, D was found to be considerably lower than for the more dilute ac1a solutions.

Ishimorl and Okuno 568 have investigated a number of cation exchange systems other than those already noted. Some of their results, D versus sodium sulfate, sodium acetate, and oxal1c ac1d concentration, are illustrated in figure 76 . The adsorption of uranium by Dowex-50 from solutions of hydroxylamine was found to be $\mathrm{pH}$ dependent. As the $\mathrm{pH}$ of the solution was increased, a sharp decrease in $D$ was observed between pH 5 and 6. Urany 1 ion was not adsorbed by Dowex -50 res in from carbonate solution.

Khopkar and $\mathrm{De} \frac{589}{}$ have investigated the behavior of 

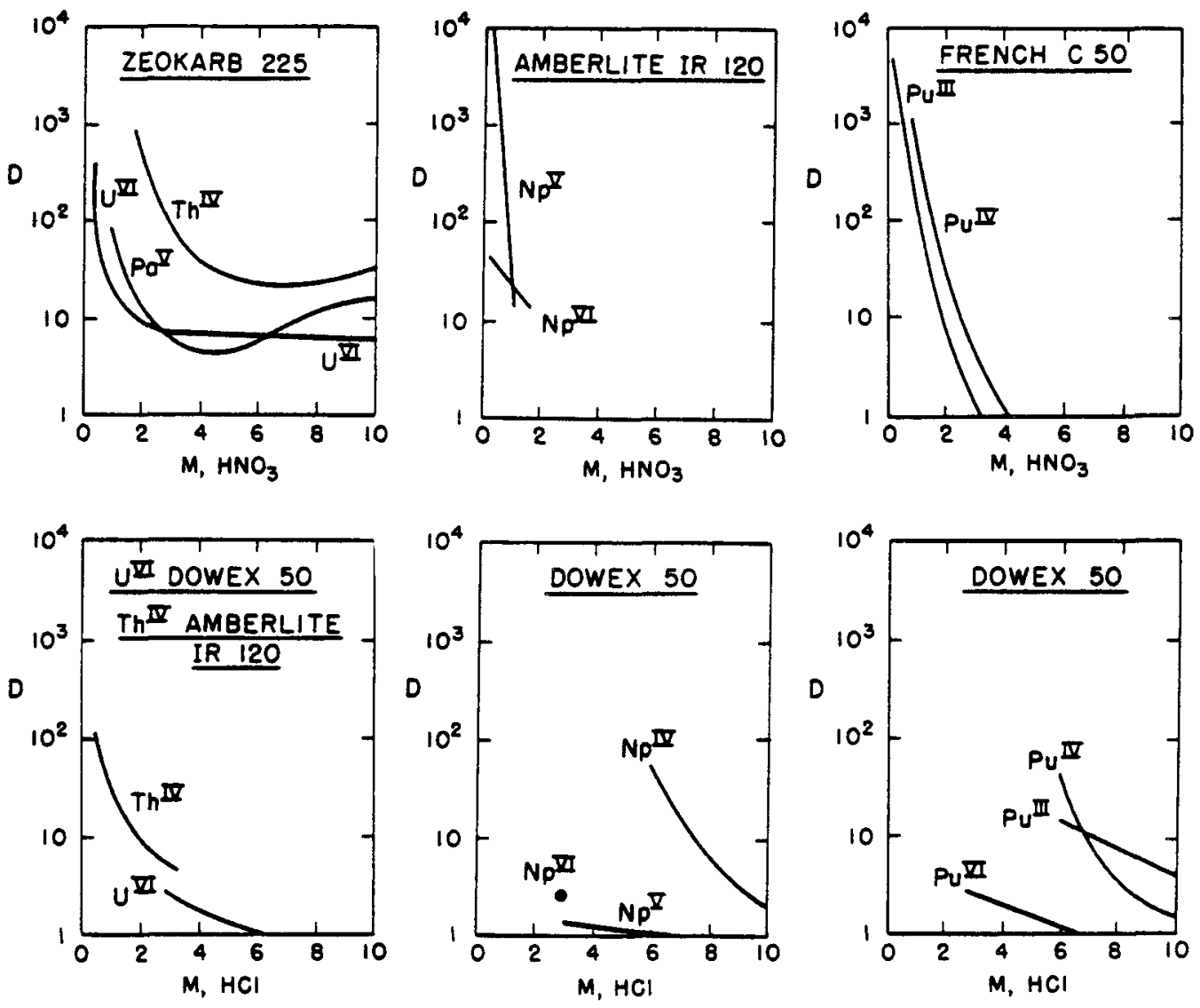

Figure 74 .

The adsorption of uranium and other actinide elements by cation exchange resins from nitric and hydrochloric ac1d solutions. After C. J. Hardy, reference 587.

The curves present the data of the following investigators:

C. J. Hardy D. Scarg11l, J. M. Fletcher, J. Inorg. Nuclear Chem. I, 257 (1958): $\mathrm{Th}(\mathrm{IV}), \mathrm{Pa}(\mathrm{V}), \mathrm{U}(\mathrm{VI})-\mathrm{HNO}_{3}$.

K. F. Sculz, M. J. Herak, Croat. Chem. Acta 29, 49 (1957):

$\operatorname{Th}(\mathrm{IV})-\mathrm{HCl}$.

R. M. Diamond, K. Street, Jr., G. T. Seaborg, J. Am. Chem. Soc. 76, 1461 (I954): U(VI), Np(IV), (V), (VI), Pu(III), (IV), (VI)-HCI. M. Ward, G. A. Welch, Unpublished data, U.K.A.E.A., WIndscale: $\mathrm{Np}(\mathrm{V}),(\mathrm{VI})-\mathrm{HNO}_{3}$.

I. Prevot, P. Regnaut, Progress in Nuclear Energ̈y, Series III, 2, $377(1958): \mathrm{Pu}(\mathrm{III}),(\mathrm{IV})-\mathrm{HNO}_{3}$. 
$3.2 \mathrm{M} \mathrm{HCl}$

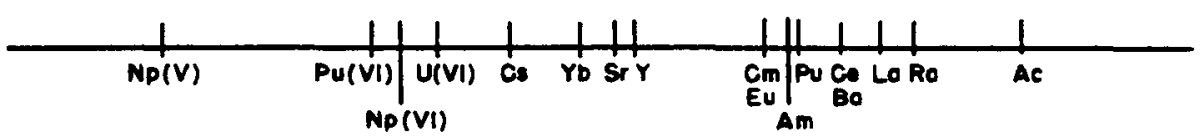

$6.2 \mathrm{M} \mathrm{HCl}$

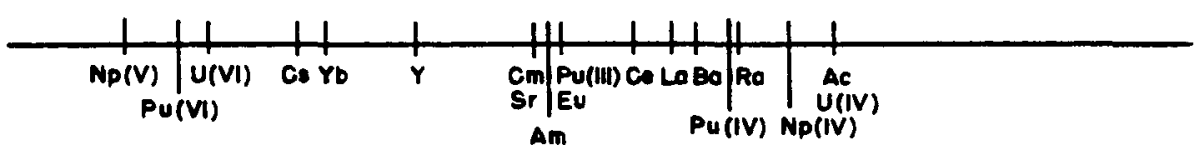

$9.3 \mathrm{M} \mathrm{HCl}$

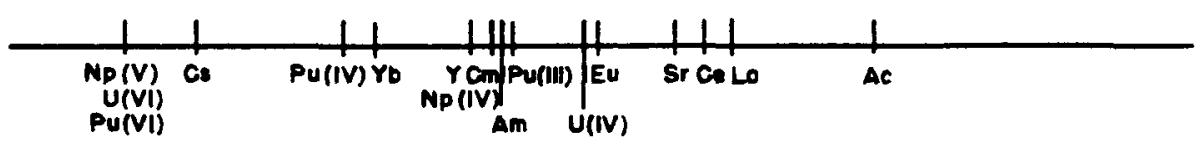

$12.2 \underline{M} \mathrm{HCl}$
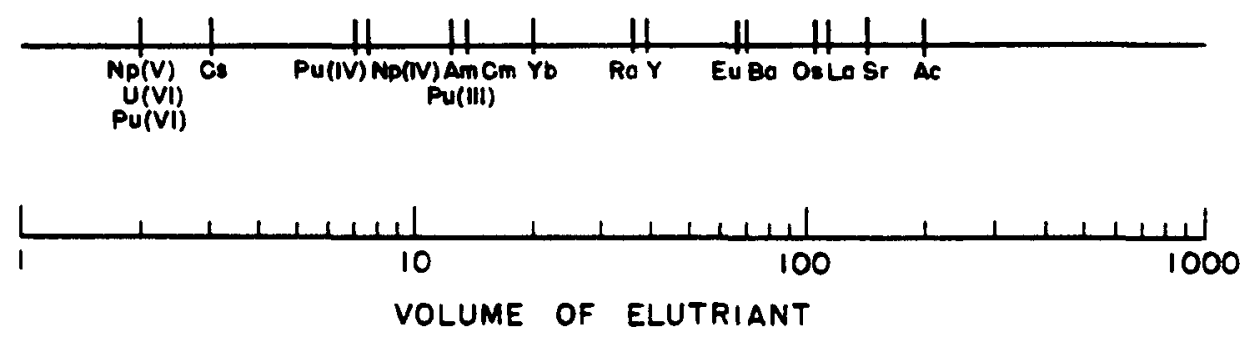

Figure 75.

Elution peak positions of various lons with $3.2,6.2,3.3$, and $12.2 \mathrm{M}$ HCI from Dowex-50 cation exchange resin. Elutrient volume given in drops.

After R. M. Dlamond, K. Street, Jr., and G. T. Seaborg, reference 591.

Cond1tions:

Dowex-50 resin, HR form, 250-500 mesh, settilng rate approximately $0.5 \mathrm{~cm} / \mathrm{m} 1 \mathrm{n}$.

Column, $10 \mathrm{~cm}$ long $x 1 \mathrm{~mm}$ diameter.

Plow rate, approximately $0.1 \mathrm{~cm} / \mathrm{min}$.

Room temperature. 

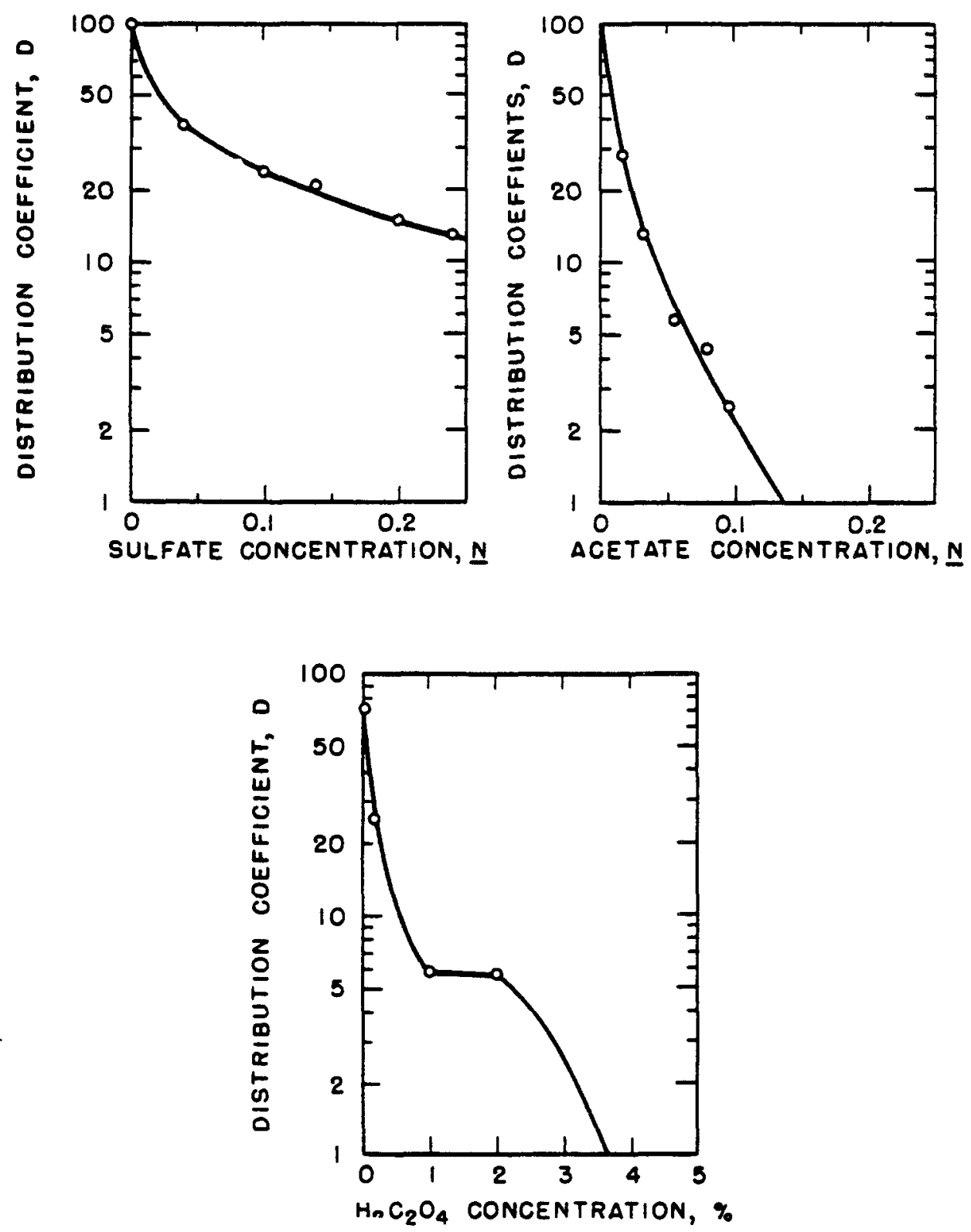

Figure 76. The adsorption of uranium by Dowex -50 cation exchange resin from solutions of sodium sulfate, sodium acetate, and oxalic acid. After T. Ishimor1 and $H$. Okuno, reference 568 .

Conditions :

Sulfate - $0.5 \mathrm{~g}$ resin, $\mathrm{NaR}$ form; $5.4 \mathrm{mg} \mathrm{U} / 25 \mathrm{ml}$; $\mathrm{Na}_{2} \mathrm{SO}_{4}-$ $\mathrm{NaNO}_{3}$ mixed solution, $[\mathrm{Na}]=0.30 \mathrm{~N}$.

Acetate - $0.5 \mathrm{~g}$ resin, $\mathrm{NaR}$ form; $5.4 \mathrm{mg} \mathrm{U} / 25 \mathrm{ml}$; NaOAc$\mathrm{NaNO}_{3}$ mixed solution, [Na] $=0.16 \mathrm{~N}$.

Oxalic acid - $0.5 \mathrm{~g}$ resin, HR form; $10.8 \mathrm{mg} \mathrm{J} / 25 \mathrm{ml}$. 
uranium (VI) on Amberlite IR-120 cation exchange resin with hydrochloric, nitric, sulfurlc, acetic, citric, and perchloric ac1ds. Urantum ( $1.7 \mathrm{mg})$ adsorbed on a resin bed $(1.4 \times 14.5$ $\mathrm{cm})$ was eluted w1th $200 \mathrm{ml}$ of various eluants. Urantum was quantitatively recovered with $2-4 \mathrm{M} \mathrm{HCl}, 2-4 \mathrm{M} \mathrm{HNO}_{3}$, and $1-2 \mathrm{M}$ $\mathrm{H}_{2} \mathrm{SO}_{4}$. Uranlum was incompletely recovered with $2 \mathrm{M} \mathrm{HCl}, 1 \mathrm{M}$ $\mathrm{HNO}_{3}, 2 \mathrm{M} \mathrm{HClO}_{4}, 2 \mathrm{M}$ acetic ac1d, and 2-5\% citric acid.

Sullivan, et 21.590 have 1nvestigated the distribution of uranlum between Dowex-50 1on exchange resin and perchloric ac1d media as a function of time and bisulfate ion concentration.

Tabie XXXVI lists a number of separations of uranium from various elements that have been achieved by cation exchange.

4. Chromatography. The subject of paper and cellulose chromatography for the separation of uranium has been reviewed by Rodden $\frac{192}{1}$ and by Steele and Taverner. 198 Work of Soviet scientists in the fleld has been reviewed by Pale1 197 and by Senyavin. $\frac{612}{}$ References to much of the literature may be found in the review article by Kuznetsov, Savvin, and Mikhailov. $\underline{200}$ Books by Pollara 613 and by Blasius $\frac{614}{4}$ include chromatographic separations of uranium.

One of the most successful separations of uranium by filterpaper chromatography makes use of the solvent, 2-methyltetrahydrofuran. 615 of thirty-one metals tested, only ruthentum and rhodium, measured as $\mathrm{Ru}^{106}-\mathrm{Rh}^{106}$, and tungsten $\left(\mathrm{W}^{185}\right)$ were incompletely separated from uranium $\left(U^{233}\right)$. The results for tin $\left(\mathrm{Sn}^{113}\right)$ and antimony $\left(\mathrm{Sb}^{124}\right)$ were inconclusive and the behavior of mercury $\left(\mathrm{Hg}^{203}\right)$ was similar to that of uranium.

An example of the use of celiulose columns in combination with organic solvent for the separation of uranium is that given by Burstall and Wells. $\frac{616}{}$ An ethereal solution contalning 5 per cent $v / v$ of nitric acid is used to extract uranium from a cellulose column. The nitrates of the alkall metals, alkaline earths, rare earths, $\mathrm{Cu}, \mathrm{Ag}, \mathrm{Zn}, \mathrm{Cd}, \mathrm{Al}, \mathrm{In}, \mathrm{Tl}, \mathrm{TI}, \mathrm{Hf}, \mathrm{Ge}, \mathrm{S}, \mathrm{Y}$, 
Table XXXVI. Separation of Uranium from Various Elements by Cation Exchange.

Elemental mixture Element eluted + eluting agent Resin

Reference

U, Th

$\mathrm{U}, \mathrm{Th}$

$\mathrm{U}, \mathrm{Th}$

$\mathrm{U}, \mathrm{Th}$

$\mathrm{U}, \mathrm{Th}$

U, Th

$\mathrm{U}, \mathrm{Th}$

U, Np(IV)

$\underset{\infty}{\mathbb{N}}$
$\mathrm{U}-1.7 \mathrm{OM} \mathrm{HCl}$; Th-1.1M $\left(\mathrm{NH}_{4}\right)_{2} \mathrm{CO}_{3}$

$\mathrm{U}, \mathrm{Th}-90 \%$ acetone, $5 \% \mathrm{HCl}, \mathrm{H}_{2} \mathrm{O}$ (U eluted first)

$\mathrm{U}-1 \underline{\mathrm{M}} \mathrm{HCl} ; \mathrm{Th}-3 \underline{\mathrm{M}} \mathrm{H}_{2} \mathrm{SO}_{4}$

$\mathrm{U}$-dil. $\mathrm{HCl}$; Th-complexing agent ( $\left.\mathrm{HSO}_{4}^{-}\right)$

$\mathrm{U}-2 \mathrm{M} \mathrm{HCl} ; 0.5 \mathrm{M} \mathrm{H}_{2} \mathrm{C}_{2} \mathrm{O}_{4}$

dilute $\mathrm{HNO}_{3}$

$\mathrm{U}-0.1$ to $0.4 \mathrm{M} \mathrm{H}_{2} \mathrm{SO}_{4} ; \mathrm{Th}-0.5 \mathrm{M} \mathrm{H}_{2} \mathrm{C}_{2} \mathrm{O}_{4}$

$\mathrm{U}$-d11. $\mathrm{HCl} ; \mathrm{Np}(\mathrm{IV})$-complexing agent

adsorb from $1 \mathrm{M} \mathrm{HNO}_{3}$; eluted $\mathrm{Np}$ ahead of $\mathrm{U}$ with $2 \mathrm{M} \mathrm{HNO}_{3}$

$\mathrm{Sr}-0.1 \underline{\mathrm{M}} \mathrm{HCl}$; Ce, Y-1M $\mathrm{HCl} ; \mathrm{U}-6 \underline{\mathrm{M}} \mathrm{HCl} ; \mathrm{Cs}-5 \underline{\mathrm{M}} \mathrm{NH}_{4} \mathrm{Cl}$

adsorb from uranyl nitrate solution at pH 1-3;

U-0.2 to $0.3 \mathrm{M} \mathrm{H}_{2} \mathrm{SO}_{4}$; F.P. -phosphoric acid and 1 IM $\mathrm{HNO}_{3} ; \mathrm{Pu}-\overline{0} .8 \mathrm{H}_{3} \mathrm{HO}_{4}$ and $1 \mathrm{M} \mathrm{HNO}_{3}$

U, F.P.

U, La

$\mathrm{U}$, Eu

U, Ce, Eu, Y

U, R.E.

U, R.E.

$\mathrm{U}, \mathrm{Pe}, \mathrm{Cu}, \mathrm{Cd}, \mathrm{N} 1$,

Co, Mn, R.E.
F.P. $-3 \% \mathrm{Na}_{2}$ EDTA; U-3\% NaOAc, $0.25 \mathrm{M} \mathrm{Na}_{2} \mathrm{CO}_{3}$

La-0.06\% Na 2 EDTA, pH 4.0; U-3\% NaOAC, 0.25M $\mathrm{Na}_{2} \mathrm{CO}_{3}$

$\mathrm{U}-0.75 \underline{\mathrm{M}} \mathrm{H}_{2} \mathrm{SO}_{4} ; \mathrm{Eu}-6 \underline{\mathrm{M}} \mathrm{HCl}$

$\mathrm{U}-\mathrm{IM} \mathrm{H}_{2} \mathrm{C}_{2} \mathrm{O}_{4} ; \mathrm{Ce}, \mathrm{Eu}, \mathrm{Y}-5 \underline{\mathrm{N}} \mathrm{HCl}$

R.E. - $\mathrm{Na}_{2}$ EDTA

$\mathrm{U}-2.5 \mathrm{M}$ HF

$\mathrm{U}, \mathrm{Fe}, \mathrm{Cu}-0.5 \mathrm{~N} \mathrm{H}_{2} \mathrm{C}_{2} \mathrm{O}_{4} ; \mathrm{Cd}, \mathrm{N1}, \mathrm{Co}, \mathrm{Mn}-\mathrm{IN} \mathrm{HCl}$; R.E. $-5 \%$ ammoñum oltrate
Amberlite IR-120 592

KU-2 588

Amberl1te IR-120 589

phenol formaldehyde 593

type

Wofatit KS

Amberlite IR-100

alginic acid 595

Wofat1t KS

596

Amberl1te IR-120 597

Amberlite IR-120 597

zircontum phosphate 598

sulfonated phenol 599

formaldehyde type

sodium dialkyl

600

phosphate

sodium d1alkyl

600

Dowex-50 601,602

Amberlite IR-120 603

Amberlite IRC-50 604

Dowex-50

605

Amberl1te IR-120 606 


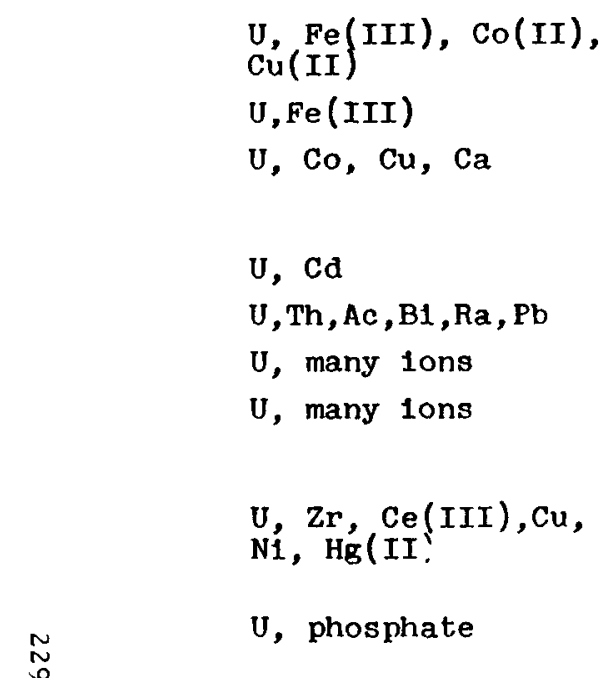

U, Fe(III), $\operatorname{Co}(I I)$, $\mathrm{U}, \mathrm{Fe}$ (III)

$\mathrm{Fe}, \mathrm{Co}, \mathrm{Cu}-2 \% \mathrm{Na}{ }_{2} \mathrm{EDTA}, \mathrm{pH} 3.0 ; \mathrm{U}-3 \% \mathrm{NaOAc}, 0.25 \mathrm{M}$ $\mathrm{Na}_{2} \mathrm{CO}_{3}$ $\mathrm{U}, \mathrm{Fe}-0.8 \mathrm{M} \mathrm{HCl}$ (U eluted first)

adsorb from $0.1 \mathrm{M} \mathrm{HNO}_{3}$; $\mathrm{Co}, \mathrm{Cu}, \mathrm{Ca}-0.2 \mathrm{MNO}_{3}$; U-resin removed from column and washed with' $0.25 \mathrm{M} \mathrm{Na}_{2} \mathrm{CO}_{3}$

Cd-0.5N HCl

$\mathrm{U}, \mathrm{Th}, \mathrm{Ac}, \mathrm{B} 1-5 \% \mathrm{H}_{2} \mathrm{C}_{2} \mathrm{O}_{\text {, }}$

forelgn lons-EDTA ( $\mathrm{Na}$ salt);: $\mathrm{pH}$ 7: $\mathrm{U}-\mathrm{H}_{2} \mathrm{SO}_{4}$

forelgn lons-EDTA (Na sait, , a) $\mathrm{p}_{-1}$ 1.7-1.9 or (b) $\mathrm{pH}$ 5.5-7.0 following $\mathrm{Fe}(\mathrm{OH})_{3}$ precipitation; $\mathrm{U}-3 \mathrm{~N} \mathrm{H}_{2} \mathrm{SO}_{4}$

$\mathrm{Zr}$ as anionic oxalate complex, $\mathrm{Ce}$ (III), $\mathrm{Cu}, \mathrm{N} 1$ as antontc EDTA complexes, Hg(II) as antonic lodide complex are not adsorbed; U-4M HCl

phosphate $\left(\mathrm{Na}_{2} \mathrm{HPO}_{4}\right)$ not adsorbed; U-4M $\mathrm{MCl}$

sodium dialkyl

600

phosphate

Lewat1t $\$ 100$

607

dialky -

phosphor1c ac1d

Dowex-50

608

KU-2

Amberlite IRC-50

(a) KU-2 or (b)

Amberlite IRC-50

Amber11te IR-120

Amberlite IR-120

589

F.P. [ [ ] fission products .

R.E. $[=$ ] rare earth elements.

EDTA $[=]$ ethylenediaminetetraacet1c ac1d. 
$\mathrm{Pb}, \mathrm{Nb}, \mathrm{Ta}, \mathrm{Cr}, \mathrm{W}, \mathrm{Te}, \mathrm{Mn}, \mathrm{Fe}, \mathrm{Co}$, and $\mathrm{N} 1$ remain stationary or move only slightly. Gold reduced with $\mathrm{FeSO}_{4}$ is retained by the column. Mercury (II), selenium, arsen1c, antimony, and b1smuth move less rapidly through the column than uranium. Cer1c nitrate is extracted as are thorium, zirconium, and scandium nitrates. Cerium in the III-state is not extracted. Thorfum extraction is sensitive to the acid concentration. Zirconium extraction is Inhibited by phosphate, sulfate, oxalate, and tartrate 1ons. Scandium extraction is also inhibited by tartrate 1on. Tin is precipitated as meta-stannic acld. Large amounts of tin may be first removed by volatilization as the lodide. Vanadium is retalned if peroxides are absent. Ferrous sulfate reduces vanadium to an immobile salt. Phosphoric acid is extracted. Ferric nitrate inhibits the extraction of this acid. The behavior of molybdenum is complex. Irldium and rhodium are not extracted. Traces of ruthenium and platinum may be found in the eluent. Palladium is extracted. Reduction of platinum and palladium with $\mathrm{FeSO}_{4}$ results in retention of bulk amounts by the column. Small amounts of sulfate do not interfere with the extraction of uranium. Sulfuric acid is retained by the column under normal conditions. Halides increase the extraction of other elements, e.g., Au, Sn. Under normal conditions, $\mathrm{HCl}$ is retained in the column; $\mathrm{HBr}$, HI, bromine and lodine move slowly down the column. Molybdenum and arsen1c may be adsorbed by the use of activated alumina in conjunction with cellulose. 617

The use of silica gel columns combined with organic solvents, dibutyl carbitol and tributyl phosphate, and nitric acid have been used for the separation of uranium and plutonium. 618,619

A non-ionic phosphorylated resin, dethyl polystyrenemethylenephosphonate, may be used to separate uranium (VI) from Iron (III), lanthanum, zlrconium, nloblum, thorlum, and mixed fission products. 620 Uranium is adsorbed by the resin from 2 wi cent solutions of dibutyl phosphoric ac1d. The other elements 
are not absorbed. Uranium is eluted with a dimethyl formamidebenzene solution.

The feasiblilty of using tributyl phosphate gels for the separation of uranium from Iron (III) and thorlum has recently been demonstrated. $\underline{621}$

5. Volatilization. Uranium may be separated from many elements by fractional distillation of the volatile compound, uranium hexafluoride. This method of separation has been applied to the recovery of uranium from 1rradiated fuel elements. Katz and Rabinowitz I have reviewed many of the early methods for the preparation of UF 6 : fluorination of varlous uranium compounds with elemental fluorine or cobalt trifluoride, disproportionation of $U_{5}$ which results in both $U_{4}$ and $U_{6}$, and the reaction between $\mathrm{UF}_{4}$ and dry oxygen which results in $\mathrm{UO}_{2} \mathrm{~F}_{2}$ and $\mathrm{UF}_{6} \cdot$ The latter two methods are not very practical from an analytical stanopoint. Other fluorinating agents that form UF 6 include ceric fluoride, manganic fluoride, silver difluoride, halogen fluorides (e.g., $\mathrm{BrF}_{3}$ and $\mathrm{ClF}_{3}$ ) and fused metall1c fluorides. Most elements form fluorldes under the conditions that UF 6 is obtalned. However, only a small number of these fluorldes are volat1le. Hyman, et al. 3 have published a table of some 26 elements having fluorldes with bolling or sublimation points of $550^{\circ} \mathrm{C}$ or less. Included in this group are the fluorides of boron, s1licon, phosphorus, vanadium, sulfur, tungsten, blsmuth, plutonlum, and the f1ssion products, germanium, arsenic, selentum, nloblum, molybdenum, ruthenlum, antimony, tellurium, and lodine. The bolling point of $\mathrm{UF}_{6}$ is $54.6^{\circ} \mathrm{C}$. Non-volatile fluorides from which uranium is readily separated include those of the alkall metals, alkaline earths, rare earths, $\mathrm{Fe}, \mathrm{Co}, \mathrm{N} 1, \mathrm{Ag}, \mathrm{Al}, \mathrm{Be}, \mathrm{Mn}, \mathrm{Tl}, \mathrm{Pb}, \mathrm{Zn}, \mathrm{Cu}$, $\mathrm{Hg}, \mathrm{Cd}$, and $\mathrm{zr} \cdot \frac{34,622}{4}$

Uranium does not form a volatile compound by Interaction with anhydrous hydrogen fluoride. Materials such as $\mathrm{Nb}, \mathrm{Ta}$, As, 
$\mathrm{Sb}, \mathrm{S1}, \mathrm{Te}, \mathrm{Se}$, etc. do.느 The ox1des of titanium, tungsten, and molybdenum react slowly with FF. $\mathrm{V}_{2} \mathrm{O}_{5}$ and $\mathrm{VN}$ also react slowly. vo, $\mathrm{V}_{2} \mathrm{O}_{4}$ and $\mathrm{V}_{2} \mathrm{O}_{3}$ are not volatilized. 34 Rodden and Warf 34 describe a procedure that makes use of both anhydrous hydrogen fluoride and fluorine in the separation of uranium. Possible contaminants of the separated UF 6 include $\mathrm{Cr}, \mathrm{Ta}, \mathrm{W}, \mathrm{Mo}$, or $\mathrm{V}$.

Uran1um hexachloride and urantum (IV) borohydride are volatile compounds for which procedures might be developed for the separation of uranium.

Uranium may be separated from arsenic, antimony, b1smuth, selenium, and tin by volatilization of the latter elements with a mixture of hydrobromic ac1d and bromine. 198

6. Electrochemical methods. The electrolysis of dilute sulfuric acid solutions with a mercury cathode results in the quantitative deposition of $\mathrm{Cr}, \mathrm{Fe}, \mathrm{Co}, \mathrm{Ni}, \mathrm{Cu}, \mathrm{Zn}, \mathrm{Ga}, \mathrm{Ge}, \mathrm{Mo}, \mathrm{Rh}, \mathrm{Pd}, \mathrm{Ag}, \mathrm{Cd}$, In, Sn, Re, Ir, Pt, Au, Hg, and $T I$ in the cathode. $\frac{213}{3}$ Arsenic, selenlum, tellurlum, osmium, and lead are quantitatively separated from the electrolyte, but are not quantitatively deposited in the cathode. $\frac{213}{3}$ Manganese, ruthenlum, and antimony are incompletely separated. $\frac{213}{}$ Uranium and the remaining actinide elements, rare earth elements, the alkall and alkaline earth metals, aluminum, vanadium, zirconium, nloblum, etc. remain in solution. 213 Casto 623 and Rodden and Warf $\frac{34}{}$ have reviewed the effects of many variables in the electrolyt1c separation of the abovenamed elements from uranium. According to Rodden and Warf, 34 optimum conditions for the purification of uranium in sulfuric acid solutions with a mercury cathode are: electrolyte volume, $50 \mathrm{ml}$; free sulfuric acid concentration, $1 \mathrm{~N}$; current density, as high as practicable with the given acid concentration (about 10 amp maximum); anode, flat platinum spiral or grid just making contact with the surface of the electrolyte; cathode area, 
as large as practicable; stirring, surface of the mercury cathode is stirred rather rapidy; temperature of electrolyte, between $25^{\circ}$ and $40^{\circ} \mathrm{C}$; mercury for the cathode, pure; anlons, chloride, nitrate, and phosphate 1ons should be absent, or present in only small amounts.

Uranium may be deposited electrolytically at the cathode of a cell from acetate, $\underline{624-631}$ carbonate, $\underline{632}$ oxalate, $\underline{633-638}$

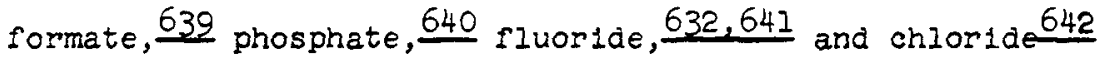
solutions. Many of the uranium electrodeposition procecures have been developed in an effort to prepare thin, uniform films for alpha and fission counting rather than to separate the element from any particular impurity. However, in the work of Smith and co-workers $\frac{624,626}{6}$ and coomans $\frac{627}{6}$ uranium was separated from alkall and alkaline earth metals and zinc. Casto $\frac{623}{3}$ and Rodden and Warf 34 review much of the material pertinent to the electrodeposition of uranium.

Electrodialysis has achleved a certaln amount of 1mportance in the recovery of uranium from leach liquors. In a review article by Kunin, $\frac{643}{3}$ the following cells are presented for consideration:

$$
\begin{array}{l|l|l}
\text { (-) cathode } & \text { anion permeable membrare } & \text { anode (+) } \\
\mathrm{UO}_{2}\left(\mathrm{NO}_{3}\right)_{2} \\
\mathrm{H}_{2} \mathrm{SO}_{4} \\
\mathrm{NH}_{4} \mathrm{NO}_{3}
\end{array} \mid \begin{aligned}
& \mathrm{NH}_{4} \mathrm{NO}_{3} \\
&
\end{aligned}
$$

(-) cathode $\mathrm{UO}_{2} \mathrm{SO}_{4}$ $\mathrm{H}_{2} \mathrm{SO}_{4}$ $\mathrm{H}_{3} \mathrm{PO}_{4}$

$$
\begin{aligned}
& \text { (-) cathode } \\
& \mathrm{UO}_{2} \mathrm{Cl}_{2} \\
& \mathrm{NaCl} \\
& \mathrm{H}_{2} \mathrm{SO}_{4}
\end{aligned}
$$

$$
\underset{\mathrm{H}_{2} \mathrm{SO}_{4}}{\text { anode (t) }}
$$




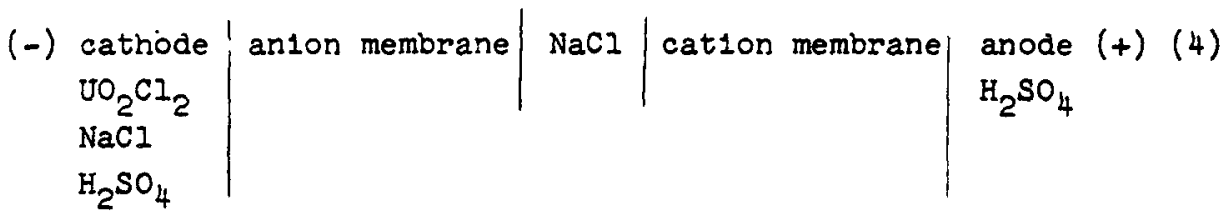

\begin{tabular}{l|l} 
(-) cathode \\
$\mathrm{UO}_{2}^{2+}, \mathrm{Nb}_{2} \mathrm{CO}_{3}$ \\
$\mathrm{NaHCO}_{3}$
\end{tabular} \mid cation permeable membrane $\mid \begin{aligned} & \text { anode (+) } \\
& \mathrm{Na}_{2} \mathrm{CO}_{3}\end{aligned}$

In acle systems (cells $1,2,3$, and 4), the transport of sulfate, nitrate, and chloride ions to the anode results in a removal of acld and a subsequent increase in pH in the cathode compartment. The uranium, reduced during electrolysis, is precipitated as $\mathrm{UO}_{2}$ or $\mathrm{U}\left(\mathrm{HPO}_{4}\right)_{2}$. In the alkaline system, the transport of sodium lons is also accompanted by a rise in $\mathrm{pH}$ in the cathode compartment and uranium is again precipitated as the dioxide or as a mixture of dioxide and sodium polyuranate.

The electrodialytic separation of uranium from metals in a complex mixture has been demonstrated by W1llard and Finley. 644 An ammonium bicarbonate solution containing $\mathrm{U}, \mathrm{Fe}, \mathrm{N1}, \mathrm{Cu}, \mathrm{Cr}$, $\mathrm{Zn}, \mathrm{Al}, \mathrm{Mo}$, $\mathrm{ikg}$, and $\mathrm{Na}$ salts, and traces of other elements was electrolyzed in a two-compartment cell having a cation permeable membrane and a mercury cathode. The solution was flrst made the catholyte (electrolyte in the cathode compartment) and electrolyzed. Iron (80\%), nickel and copper (95\%), t1n, and zinc were removed from solution by deposition. The bicarbonate solution was then made the anolyte and electrolyzed at a platinum anode. All aluminum, molybdenum, ammonium, and s1l1con, and some sodium and magnesium were separated from the uranium by migration. Uranium was retalned as the carbonate complex and was racovered as the oxide by evaporation of the anolyte.

other features of the electrodialytic behavior of uranium that may be useful in 1ts separation and purification are (1) the retention of uranium during electrodialysis from a perchloric 
catholyte using an anion selective membrane, (2) the dissolution and separation of impure $\mathrm{UF}_{4}$, and (3) the feasibility of electrodialysis in organic solutions.

7. Pyrometallurgical processes. Although pyrometallurglcal or high temperature processes have been deslgned primarliy for large scale recovery of fertile materlal from 1rradiated fuel elements, some of the methods may find application in the radiochemistry labolatory. Types of pyrometallurgical operations that have recelved considerable attention are(1) distillation,(2) salt extraction, (3.) molten metal extraction, (4) oxidative slagging, (5) electro-rerining, and (6) decomposition of uranium lodide. These methods have been reviewed by Lawrosk1.21]

1. Plutonium is concentrated by vacuum distiliation from molten uranium at $1500-1800^{\circ} \mathrm{C}$.

2. Plutonium is extracted from molten uranlum by salts such as UF or $\mathrm{MgCl}_{3}$. Uranlum remains in the metalif state. Plutonium is recovered as a halide salt.

3. Plutonium is extracted by molten metals, such as silver or magnesium, that are immiscible with molten uranium. F1ssion products are also extracted.

4. Oxidative slagging Involves the preferential formation of the most stable oxides by a molten irradiated fuel element in a limited oxygen environment. These oxides (rare earths) float to the surface of the molten materlal and are skimmed off. Other oxides diffuse into the cructble and through the slag layer.

5. In electro-refining, uranium is dissolved anodically in a fused salt bath of alkali or alkaline earth halides that contain a uranlum compound. Noble metals do not dissolve and are deposited as anode sludge. Uranium and chemically similar materials are deposited at the cathode. Alkal1, alkaline earth, and rare earth fission products concentrate in the salt bath.

6. Uranium is recovered as the metal from the thermal decomposition of $\mathrm{UI}_{4} \cdot \mathrm{Zirconium}$ and niobium are the principal contaminants.

It is not the purpose of this section to describe the

techniques involved in pyrometallurgical processes. The interested reader may consult the many papers presented in "Progress in Nuclear Energy, Series III, Process Chemistry," volumes I(I956) and $2(1958)$, and in the "Proceedings of the International Con- 
ference on Peaceful Uses of Atomic Energy," volumes 9(1956) and $17(1958)$.

\section{IV-E Determination of Uranium}

The amount of uranium in a sample may be determined by standard methods of analysis: gravimetric, volumetric, color 1metr1c, spectrophotometr1c, etc. 34, 191-195,197,198,200,645

Because of 1ts natural radioactivity, uranium may also be determined by counting techniques. The applicability, in terms of mass range, of various methods for the determination of uranium is given in Table XXXVII. 199

1. Counting techniques. Principles of alpha, beta, and gamma counting are considered in review articles by Steinberg, Hanna, $\frac{647}{}$ Deutsch and Kofold-Hansen, $\underline{648}$ Crouthamel, $\underline{649}$ and Jaffey. 650 All three methods of counting are applicable to the radiometric determination of uranium since both alpha- and beta-emitting 1sotopes exist (Section III). Spontaneous fission half-lives have been determined for several uranium 1sotopes: $u^{232}, u^{234}, u^{235}, u^{236}, U^{238}$. These isotopes are too long-lived, however, to make fission counting a practical method for their determination.

Ionization chambers are most commonly used for the detection of alpha particles. In flgures 77 and 78 are shown the alpha spectra of $U^{235}$ and $U^{233}$, respectively. The spectra were obtained with a parallel plate, Frisch grid ionization chamber using P-10 (90\% argon, 10\% methane) gas. A mult1-channel analyzer was used in confunction with the ionization chamber. Both $U^{235}$ and $U^{233}$ samples were prepared by volatilization. Figure 79 represents the $U^{233}$ alpha spectrum obtained with a surface barrier silicon sol1d state detector. Data for this f1gure was taken from the same sample as that for figure 78 . It is readily apparent from the two flgures that the solid state detector gives much better resolution of the alpha groups than does the 1onization chamber. 
Table XXXVII. Range of Application of Various Methods for the Determination of Uranium. a

Method

Neutron activation

Fluoroscopy

Emission spectroscopy

Visual chromatography on paper

Volumetric (including microvolumetr1c) methods

Autoradiography ( $\alpha$ emission) counting of tracks

Colorimetry

dibenzoylme thane

thiocyanate

$\mathrm{H}_{2} \mathrm{O}_{2}-\mathrm{HClO}_{4}$

Alpha counting -

Polarography

Potentlometry

Gravimetric methods

\section{Range of application (micrograms)}

$10^{-4}-10^{4}$

$10^{-4}-1$

$5 \times 10^{-2}-50$

$10^{-1}-10^{2}$

$1-5 \times 10^{5}$

$1-10^{4}$

$10-10^{4}$

$50-5 \times 10^{4}$

$10^{3}-10^{5}$

$50-5 \times 10^{3}$

$10^{2}-10^{4}$

$2 \times 10^{2}-10^{4}$

$5 \times 10^{4}$.
Range of error (per cent)

\pm 2 to 5

\pm 5 to 50

\pm 1 to 10

\pm 0.5 to 5

\pm 1 to 10

\pm 1 to 3

\pm 1 to 3

\pm 1 to 5

\pm 1 to 10

\pm 2 to 5

\pm 1 to 5

\pm 0.1 to 2

a Adapted from a table Given by A. Simenauer, reference 199.

b $50 \mu g$ of $U^{238}$ gives about $20 \mathrm{cpm}$ at $52 \%$ geometry. Uranium238 may be detected in samples having much lower counting rates than this, depending upon the physical condition of the sample and the presence of extraneous alpha activity. For a thin source with low alpha backgrgund, 1 alpha cpm of uranium should be readily detected. For U238 this is the equivalent of about $2 \mu \mathrm{G}$; for other uranium 1sotopes, the mass is even less.

The data for f1gure 79, however, was taken in 1000 minutes. The data for flgure 78 was taken in 10 minutes.

Alpha particles may be counted also by gaseous, liquid, plastic, and crystalline scintillation detectors. The resolution of these detectors is, in general, less than ionization chambers and their application more limited. Nuclear emulsions are used to record alpha activity. Such devices as cloud chambers are generally not used in the radioohemistry laboratory.

Gelger-Miller counters, proportional counters, and IIquid, plastic, and crystaline scintillation detectors are suitable for the counting of $\mathrm{B}^{-}$-emitting isotopes, $U^{237}, v^{239}$, and $v^{240}$. 


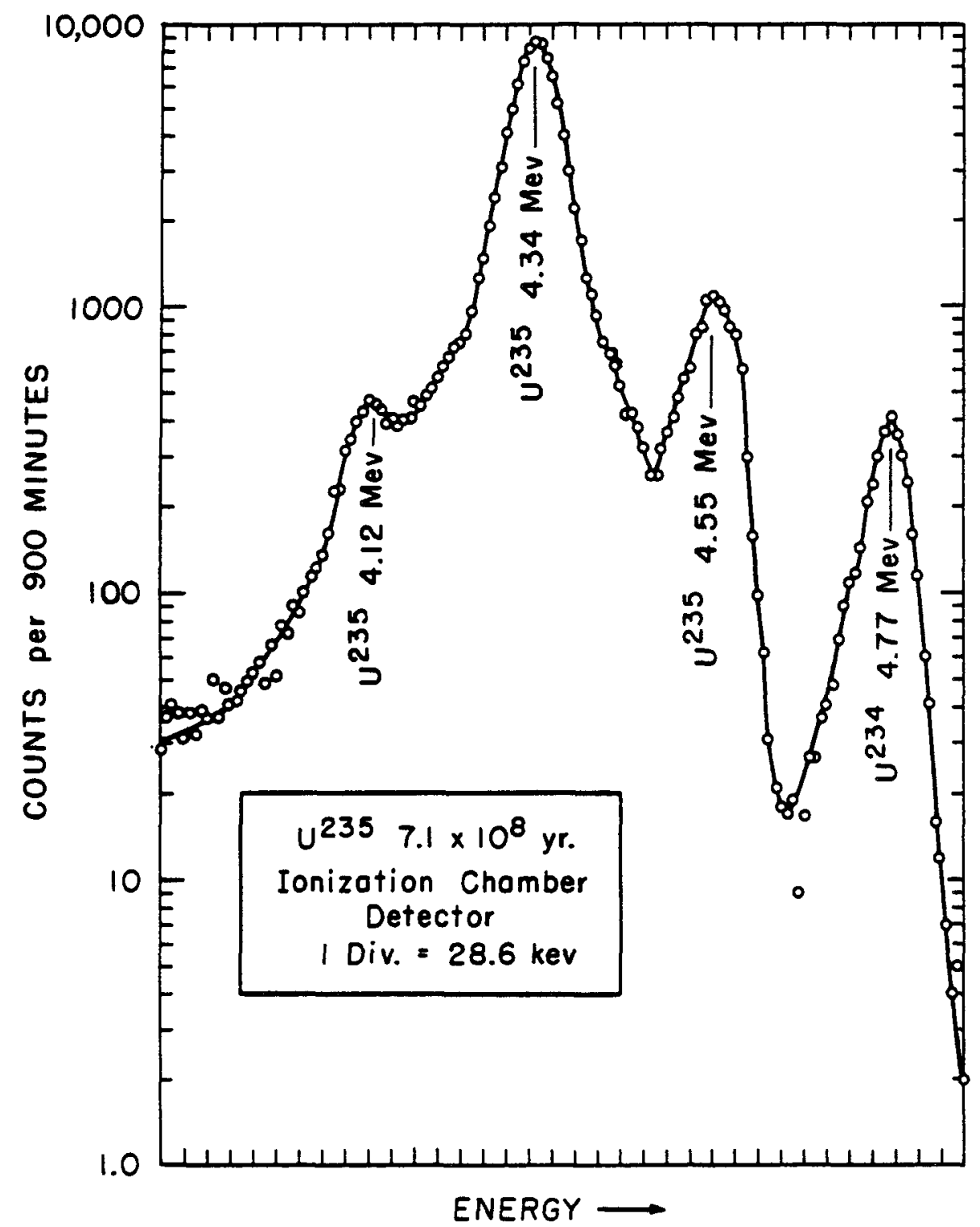

\section{F1gure 77.}

Alpha spectrum of a volatilized source of $U^{235}$ obtained with a parallel plate, Frisch grid lonization chamber using $90 \%$ argon - $10 \%$ methane gas.

D. J. Henderson, Argonne National Laboratory, Unpubl1shed data. 


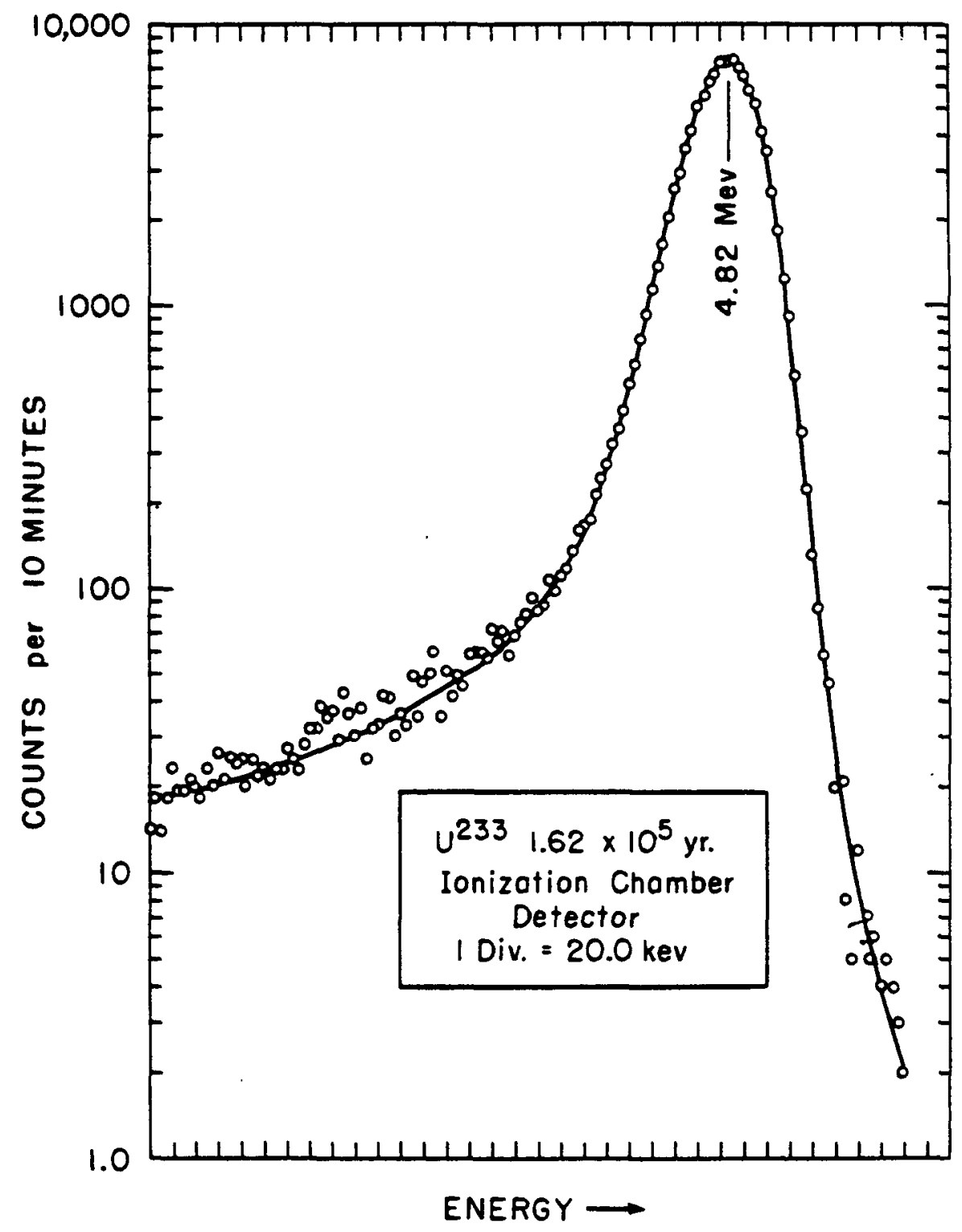

Pigure 78 .

Alpha spectrum of a volatilized source of $U^{233}$ obtained with a parallel plate, Frisch grid Ionization chamber using $90 \%$ argon - $10 \%$ methane gas.

D. J. Henderson, Argonne National Laboratory, Unpublished data. 


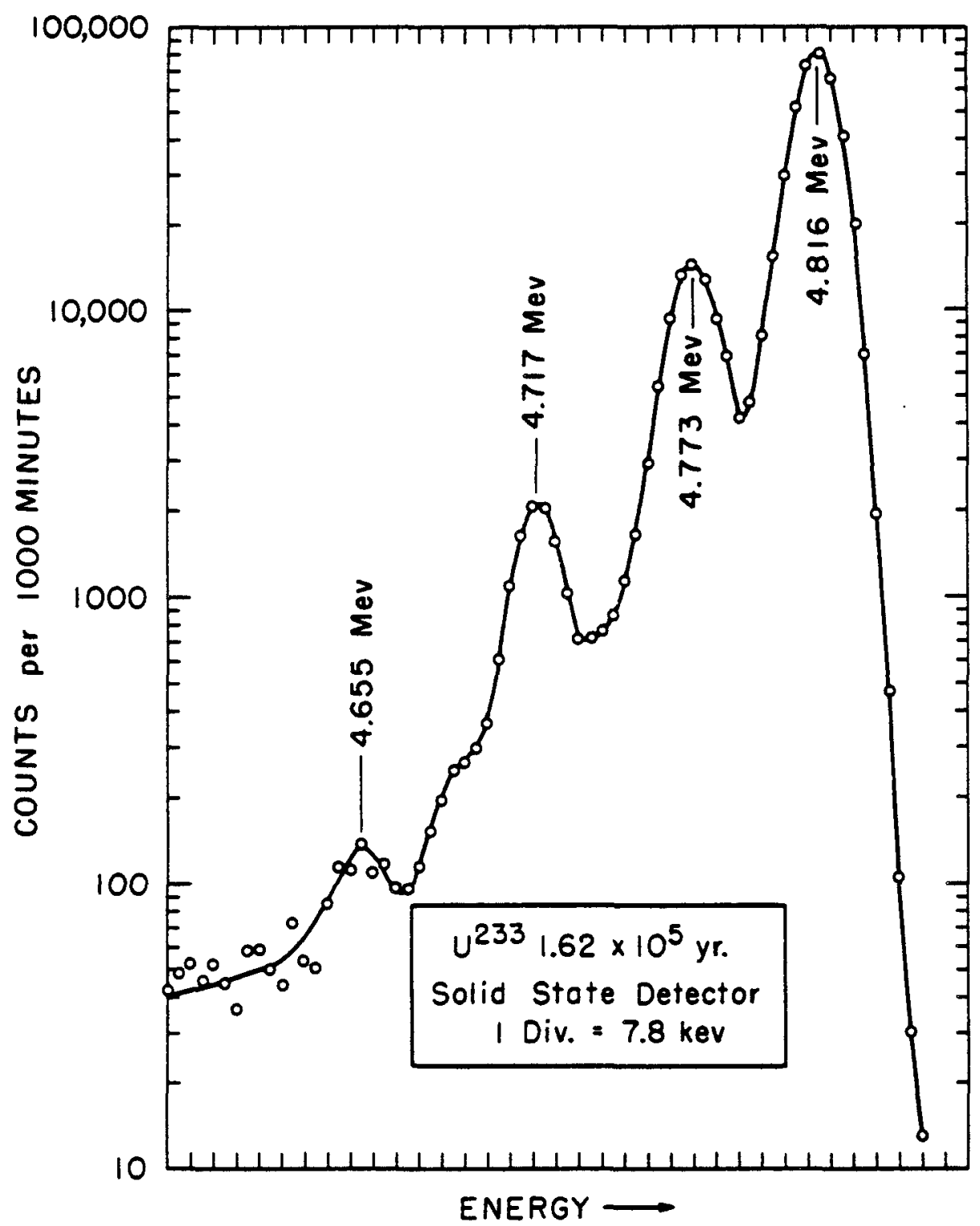

Figure 79.

Alpha spectrum of a volat1lized source of $U^{233}$ obtained w1th a surface barrier silicon detector.

D. W. Engelkeme1r, Argonne Nat1onal Laboratory, Unpublished data. 
Sodlum lodide-thallium activated crystals have galned widespread acceptance as detectors of gamma radiation. The gammaray spectra of $v^{239}, v^{237}, v^{235}, v^{233}$, and a uranium are from the Belgian Congo are 1llustrated in figures 80-84. The spectra were measured by Crouthamel, Gatrousis, and Goslovich $\frac{649}{61 \text { th a }}$ 4-1nch diameter $x$ 4-inch thick cylindrical NaI(TI) crystal.

Not only can the amount of uranium in a sample be determined directly by measuring the disintegration rates of the various 1sotopes, it can also be measured indirectly by determining the activity of daughter products. For such a measurement to be meaningful, however, the equilibrium condition between the uranium 1sotope and 1ts daughter must be known.

Information on the radioactive decay of the uranium 1sotopes is given in Section III. Further information on these 1sotopes and their daughter products may be obtained by consulting the "Table of Isotopes" complled by Stromminger, Hollander, and Seaborg $\frac{651}{1}$ and the references given therein. Volumes 8 (1956), 3 (1958), and 28 (1958) of the "Proceedings of the International Conference on the Peaceful Uses of Atomic Energy" contain a number of articles on the radiometric determination of uranium. Reference to many more articles is made in the review papers by Me1nke. 652

2. Sample preparation. One of the most Important problems to overcome in the detection of alpha particles and in direct fission counting is the preparation of thin folls or sample deposits. This subject has recelved considerable attention and has been reviewed by several authors. $632,647,650,653,654$ Several techniques are available. The simplest and most quantitative is the direct evaporation of an allquot of a sample. The distribution of such deposits are generaliy not very uniform. This may be 1mproved upon by the addition of a spreading agent such as tetraethyleneglycol, TEG. Painting techniques may be used to bulld up falrly unifom deposits of several milligrams 
per square centimeter. 655,656 Uranyl nitrate is dissolved in alcohol and added to a dilute solution of Zapon in Zapon thinner or cellulose in amsl acetate. This solution 18 painted over a metal backing, allowed to dry, and then baked or 1gnited at a sultable temperature. For aluminum back1ng, temperatures of $550^{\circ}$ to $600^{\circ} \mathrm{C}$ are satisfactory. For platinum, higher temperatures $\left(800^{\circ} \mathrm{C}\right)$ are preferred. The thickness of the uranium deposit is increased by repeatediy painting and baking the fo11.

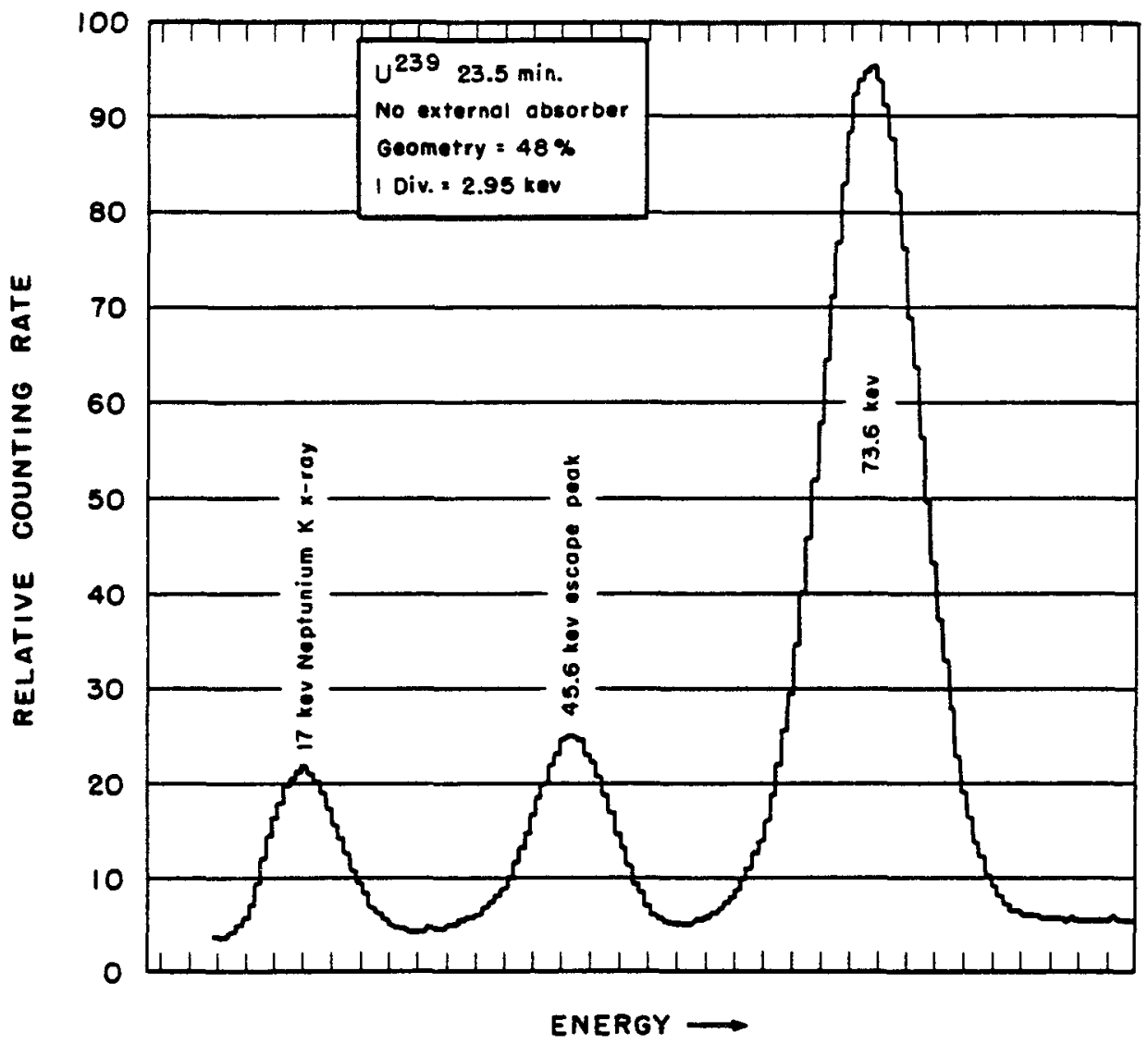

Figure 80.

Gamma-ray spectrum of $\mathrm{U}^{239}$ obtalned with a 4-inch diameter $x$ 4-1nch thick cylindrical $\mathrm{NaI}(\mathrm{TI})$ crystal.

After C. E. Crouthamel, C. Gatrous1s, S. J. Goslov1ch, reference 649. 


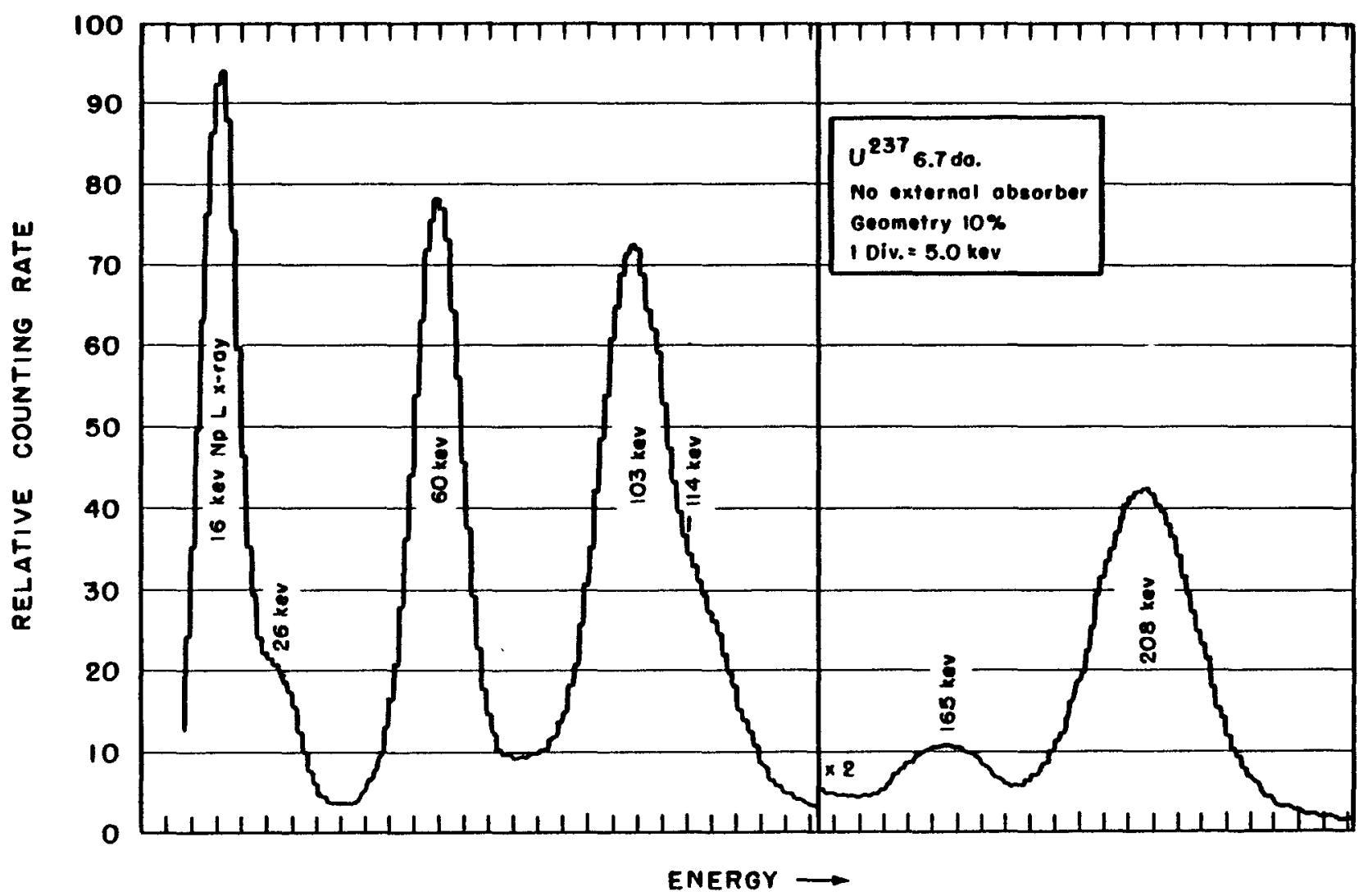

F1gure 81. Gamma-ray spectrum of $\mathrm{U}^{237}$ obtalned w1th a 4-1nch diameter $\times$ 4-1nch th1ck cylindrical NaI(T1) crystal. After C. E. Crouthamel, C. Gatrousis, S. J. Goslovich, reference 649. 


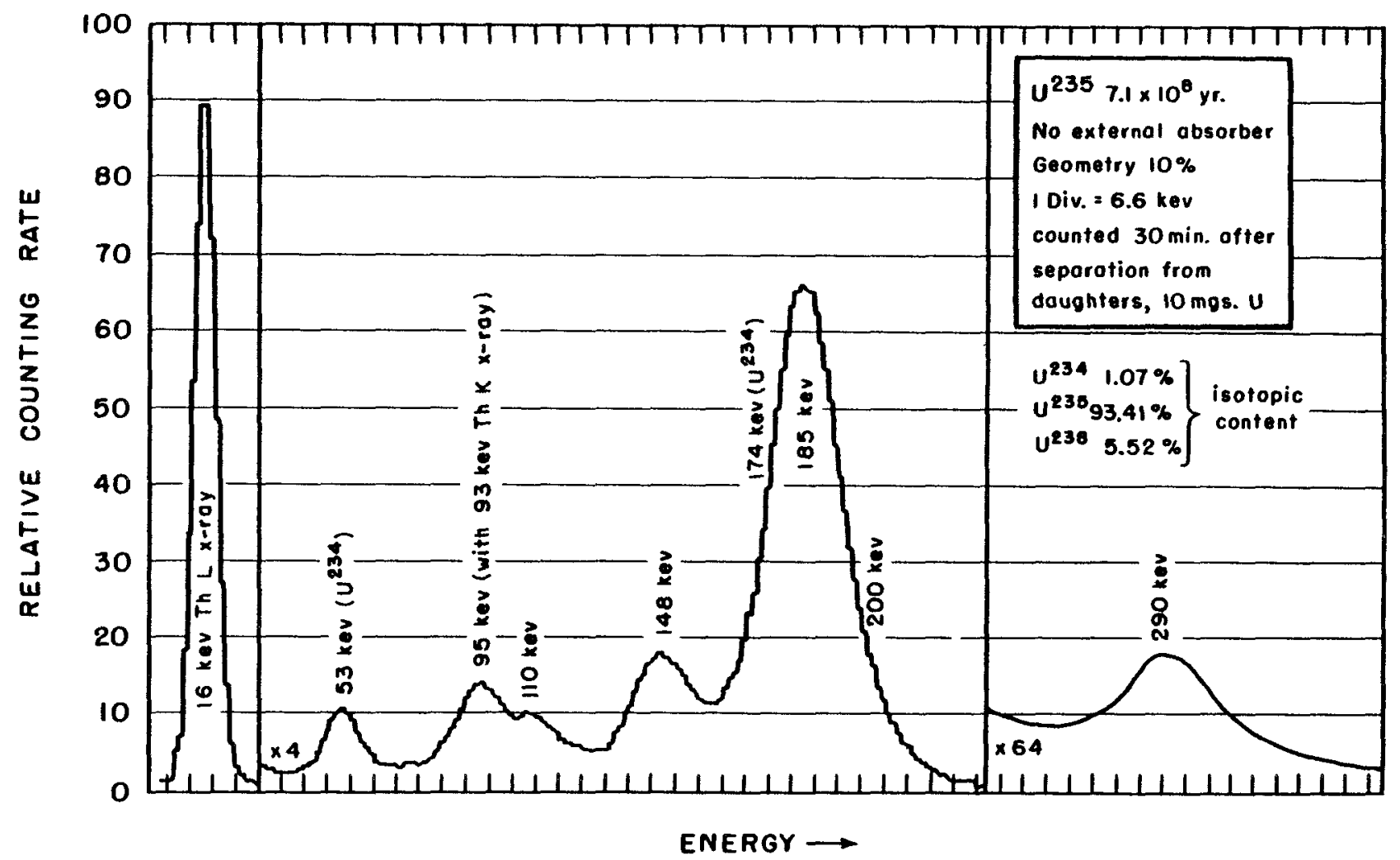

F1gure 82. Gamma-ray spectrum of $\mathrm{U}^{235}$ obtalned with a 4-inch diameter $\times$ 4-inch thick cylindrical NaI(Tl) crystal. After C. E. Crouthamel, C. Gatrousis, S. J. Goslovich, reference 649. 
100
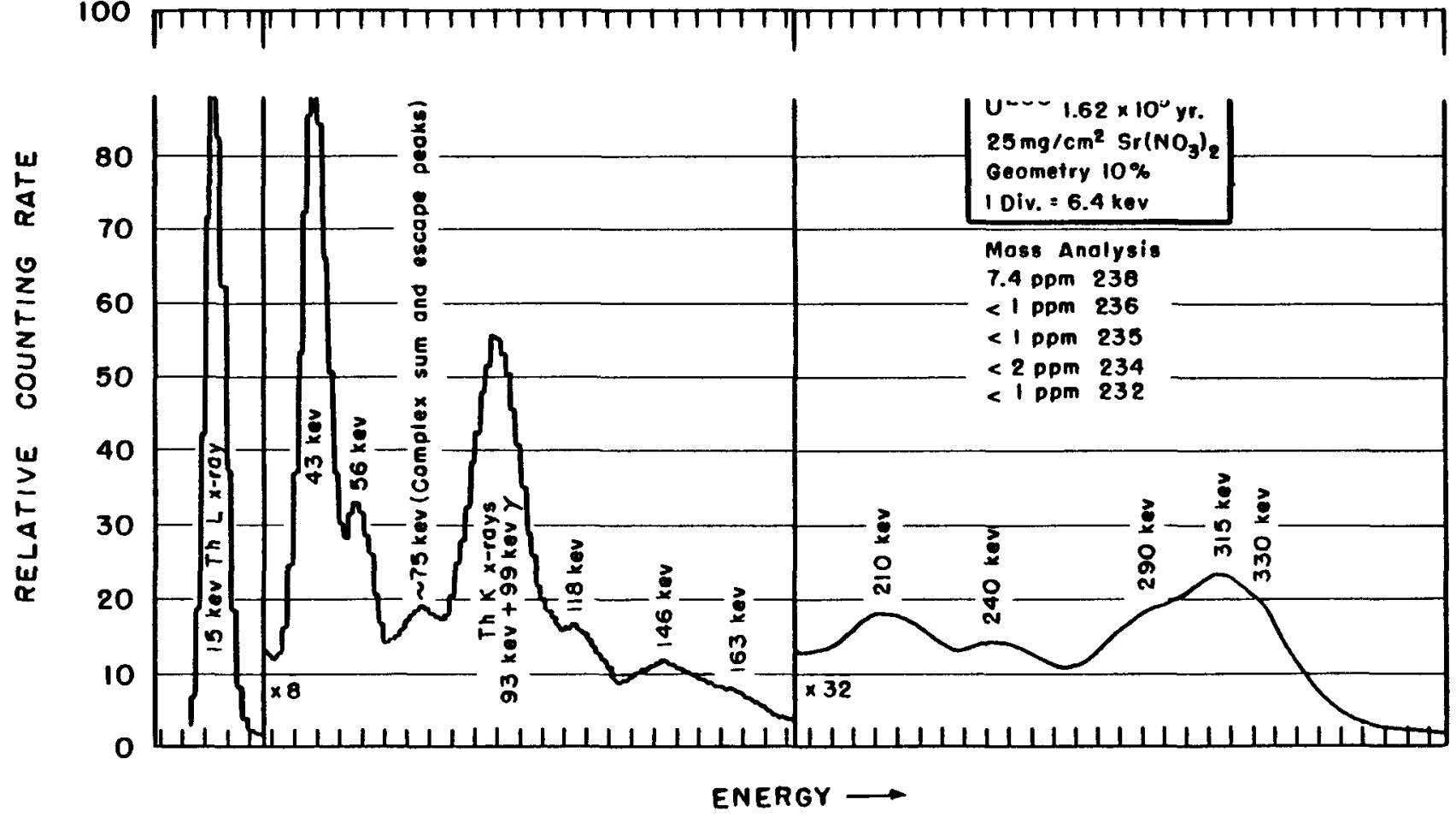

F1gure 83. Gamma-ray spectrum of $\mathrm{U}^{233}$ obtalned w1th a 4-1nch diameter $x$ 4-1nch thick cylindrical NaI(T1) crystal. After C. E. Crouthame1, C. Gatrous1s, S. J. Gaslovich, reference 649. 


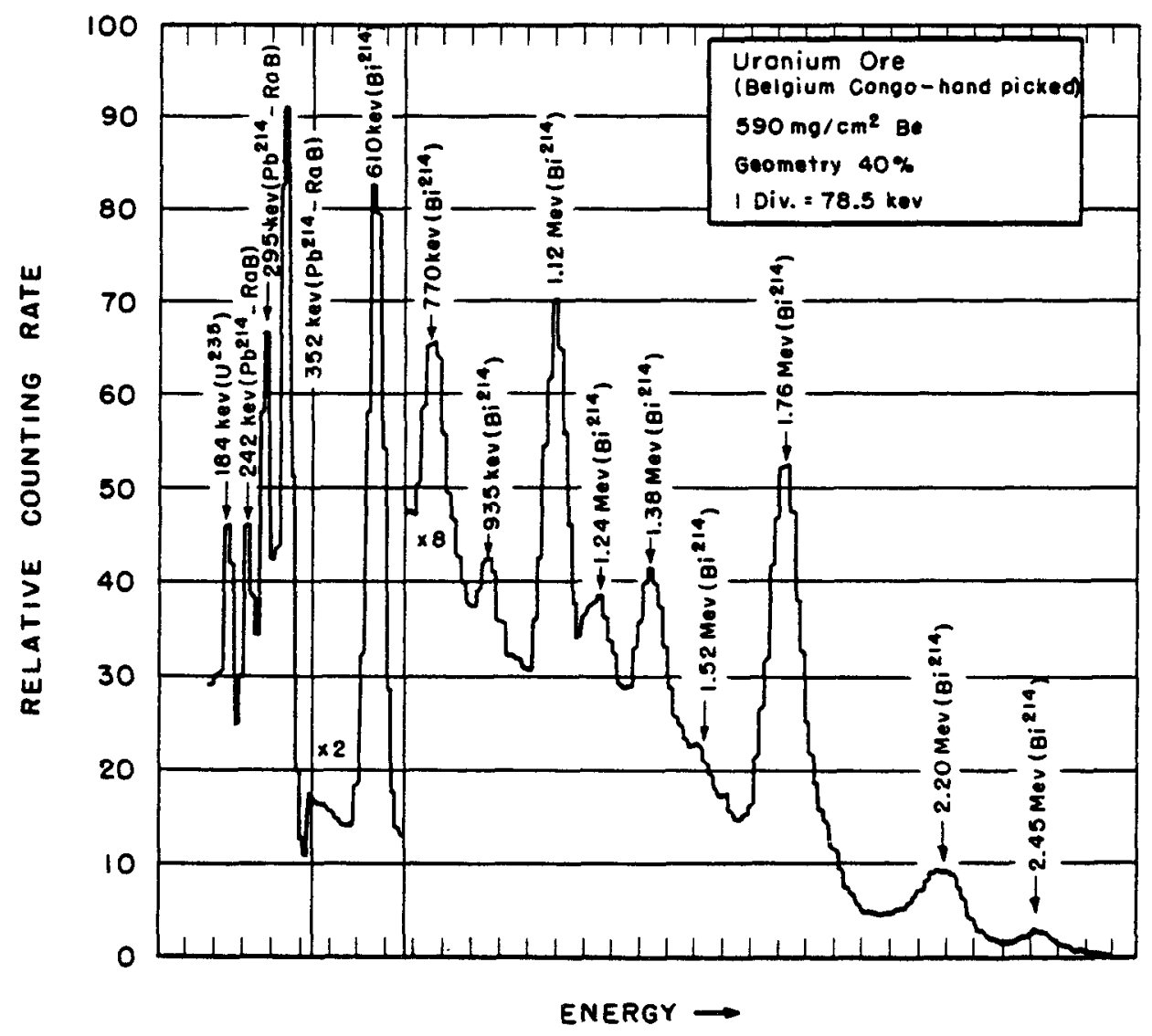

F1gure 84.

Gamma-ray spectrum of uranium ore from the Belgian Congo obtained with a 4-inch diameter $x$ 4-1nch thick cylindrical NaI(TI) crystal. After C. E. Crouthamel, C. Gatrousis, S. J. Goslovich, reference 649.

Samples of the metastable $U^{235}$ 1somer have been prepared by electrostatically collecting the recoll atoms of $\mathrm{Pu}^{239}$ in air. 657,658 A negative potent1al of several hundred volts was applied to the metallic collection plate.

Carswell and Milsted 659 have succeeded in preparing thin sources by a spraying technique. The materlal to be deposited is dissolved as the nitrate in an organic solvent (alcohol or acetone). The solution is drawn into a fine gla s capillary 
tube and sprayed onto the backing materlal by applying an electric rleld.

Electrodeposition is a generally satisfactory method for preparing uniform samples with quantitative or nearly quantitat1ve jields. Uranium has been plated from a varlety of solut1ons: acetate, $\underline{34,623,628-631}$ formate, $\underline{639}$ oxalate, $\underline{623,633-638}$ carbonate, $\underline{34,632}$ Iluoride, $\underline{623,632,641}$ and chloride. $\underline{642}$ A sat1sfactory electrolyte for the deposition of uranium is $0.4 \mathrm{M}$ armonium oxalate. 654 A rotating platinum anode is used to stir the solution placed in a vertical cylindrical cell. The cell Is made of glass, luclte, or some other chemlcally inert materlal. The cathode on which the uranturn is to be depasited is thoroughly cleansed and made the bottom of the cell. The assembled cell is placed in a hot water bath and the temperature kept at about $80^{\circ} \mathrm{C}$. A current dens1ty of approximately $0.1 \mathrm{amp} / \mathrm{cm}^{2}$ is used. The deposition is influenced strongly by the rate of stirring, current density, and presence of fore1gn 1ons. $\frac{654}{5}$

Vacuum sublimation provides an excellent means for the preparation of thin deposits of uranium. The sublimation of uranium acetylacetonate, $U\left(\mathrm{C}_{5} \mathrm{H}_{7} \mathrm{O}_{2}\right)_{4}$, has been used. A more convenient method is the sublimation of uranium oxides. A uranium salt solution is placed on a tungsten or tantalum ribbon supportec between two electrodes. The solution 18 dried by a heat lamp or by passing a low-current through the metal ribbon. The sample backing material is suspended at a sultable helght above the metal ribbon. A bell far is placed over the assembled unit and evacuated. The uranium is volatilized by increasing the current through the metal ribbon. The uniformity of the deposit depends upon the distance between the ribbon and the backing plate. The collection efflciency also depends upon this distance but in an Inverse manner to that of deposit uniformity. Usually a compromise is made between collection efflelency and sample uniformity. Much of the uranium that is 
not collected on the sample plate can be recovered from masking plates and glass chlmneys placed between the fllament and backing materlal. The collection efficlency may also be improved by subliming from furnaces so that the beam of uranium molecules is directed toward the backing plate. The furnace is heated by electron bombardment or Induction heating.

3. Activation Analysis. In activation analysis, a nuclide Irradiated by neutrons, gamma rays, or charged particles is transformed Into a radioactive nuclide more easily detected than the orfginal one. The amount of original materlal may be determined elther absolutely or comparatively. For an absolute determination, the cross section of the reaction, the irradiation flux, and the disintegration rate of the reaction product must be known or determined. For comparative analysis, a substance of unknown mass is 1rradiated simultaneously with a similar substance of known mass. The positions of these two substances are elther side by side or, if separated, in positions of like flux. The reaction product activities of the two samples are compared to give the relative masses of the starting materials. The comparative technique is, in general, much easier to apply. The uncertalnties of many variables are eliminated by relative measurements.

Activation with thermal neutrons may be successfully employed as a method of analysis for natural uranium, urantum236, and the fissionable 1sotopes of uranium. Natural uranium cons1sts of $U^{238}(99.3 \%), U^{235}(0.72 \%)$, and $U^{234}(0.0057 \%) .651$ The principal reaction of these nuclides $w 1$ th thermal neutrons are:

$$
v^{238}+n^{1} \rightarrow v^{239} \frac{\beta^{-}}{23.54 m} \cdot N p^{239} \frac{\beta^{-}}{2.346 a} P u^{239} \frac{\alpha}{24,300 \mathrm{y}_{6}} u^{235},
$$

* Half-lives given below the arrow are taken from the "Table of Isotopes," reference 651. The value of $v$ for the fission of $U^{235}$ is taken from "Neutron Cross Sections," reference 660. 


$$
\begin{aligned}
& v^{235}+n^{2} \rightarrow \text { Fission Products }+2.47 \text { neutrons, } \\
& v^{234}+n^{2} \rightarrow v^{235} .
\end{aligned}
$$

The amount of natural uranium present in a sample may then be determined from the amount of $\mathrm{U}^{239}, \mathrm{~Np} 239$, or $\mathrm{Pu}^{239}$ activity formed after 1rradiation. Measurement of the Pu239 act1vity, however, requires elther a falrly large amount of $\mathrm{U}^{238}$, a long irradiation period, or a combination of the two. The amount of natural urantum may also be determined from the f1ssion of urantum-235 either by (1) f1ssion counting the sample, (2) 180lating and counting a fission product such as $\mathrm{Ba}^{140}$ or $\mathrm{Te}^{132 *}$, or (3) measuring the total garma activity Induced in the sample by a short neutron 1rradiation. 645 Thermal neutron 1rradiation of $v^{234}$ results in $U^{235}$ and is of little value in the determination of natural uranium.

Neutron Irradiation of $U^{236}$ gives $U^{237}$, a beta-emiter having a half-life of 6.75 days. 65 It is readily identifled through Its beta decay, assoclated gamma rays, and half-life. Uranlum-238 1rradiated with fast neutrons also produces $U^{237}$, $U^{238}(n, 2 n) U^{237}$. The cross section for this reaction has been determined with incident neutron energies from 6 to $10 \mathrm{Mev}$ and at $16 \mathrm{Mev} .66 \mathrm{I}$

Activation analysis by fission counting is of value only if one fissioning nuclide is present or if the amounts of other fissioning nuclides present are known and corrections can be made for them. The same is true for the isolation and determination of fission products. Uranium 1sotopes that are fissionable with thermal neutrons together with their thermal neutron fission cross sections are:

$$
\begin{array}{ll}
U^{230} & 25 \pm 10 \text { barns } \\
U^{231} & 400 \pm 300 \text { barns }
\end{array}
$$

\footnotetext{
*The fission product nuclides $\mathrm{Ba}^{140}$ and $\mathrm{Te}^{132}$ are chosen since they are free from interfering reactions and are produced in good yields.
} 


$$
\begin{array}{ll}
u^{232} & 80 \pm 20 \text { barns } \\
u^{233} & 527 \pm 4 \text { barns } \\
u^{235} & 582 \pm 6 \text { barns } \\
U^{239} & 14 \pm 3 \text { barns }
\end{array}
$$

Other than $U^{235}, U^{233}$ is the best uranium 1sotope to determine by f1ssion counting or f1ssion product analys1s. Uranium-232 may possibly be determined in this manner. The other isotopes are of such short half-life that analysis of their own radiations is a much better means for their 1dentification.

Exc1tation functions have been determined for a number of reactions with charged particles or gamma rays incldent on uranium 1sotopes. These reactions may be used for activation analysis. For absolute analysis, it should be pointed out that (1) the cross sections reported are sometimes subject to considerable error; (2) energy determinations of the incoming particle or ray are also subject to error; and (3) the reaction product can often be produced by a number of reactions. Comparat1ve analys1s appears to be a much better method for the determination of uranium. For gamma-ray (bremsstranlung) activation, simitaneous 1rradiations in a like flux are falrly easy to accomplish. The two samples, unknown and standard, are mechan1cally rotated in the gamma-ray beam. For charged particle activation, the simulaneous irradiation of two samples in a like flux may require some ingenulty on the part of the experimenter.

A partial 11st of reactions between uranlum 1sotopes and charged particles or gama rays for which excitation functions

\footnotetext{
*P1le neutrons.
}

* Because of the short range of charged particles, 1rradiations are generally made with targets attached to or within the vacuum system of the accelerator. To maintain the system's vacuum requirements, to cool the samples properly, and to irradiate the samples simultaneousiy in a like flux may present some difrailty in equipment design. 
or Individual cross sections have been determined is given below:

Protons

$$
u^{238}(p, t) u^{236} \underline{662}
$$

Deuterons

$$
\begin{aligned}
& U^{238}(a, 2 n) N p^{238} \frac{663,664}{663,664} \quad U^{234}(a, n) N p^{235} \underline{666} \\
& U^{238}(a, 4 n) N^{236} \underline{663,664} \quad U^{234}(a, 2 n) N p^{234} \frac{666}{666} \\
& U^{238}(\alpha, p) U^{239} \frac{664,665}{(\alpha, t)} \quad U^{234}(a, 3 n) N p^{233} \underline{666} \\
& u^{238}(\alpha, t ; d, p 2 n) u^{237} \underline{664} \\
& u^{238}(a, t) u^{237} 662 \\
& \mathrm{U}^{235}(\mathrm{a}, \mathrm{n}) \mathrm{Np}^{236} \underline{664,666} \\
& U^{235}(\alpha, 2 n) N p^{235} \frac{664,666}{664,666} \\
& U^{235}(a, 3 n) N^{234} \frac{664,666}{666} \\
& U^{235}(\alpha, 4 n) N^{233} \underline{666}
\end{aligned}
$$

\section{Alpha particles}

$$
\begin{aligned}
& U^{238}(\alpha, n) \mathrm{Pu}^{24 I} \\
& +U^{238}(a, p) N^{24 I} B^{-} \quad 24 I 66 U^{235}(\alpha, 5 n) \mathrm{Pu}^{234} \frac{669}{238} \\
& U^{238}(\alpha, 2 n) P^{240} \frac{664}{664} \\
& v^{238}(\alpha, 3 n) \text { Pu } 239 \underline{664} \\
& U^{238}(\alpha, 4 n) P u{ }^{238} \underline{664}, 668 \\
& v^{238}(\alpha, p n) \mathrm{Np}^{240} \underline{699} \\
& U^{238}(\alpha, p 2 n) N p^{239} \frac{669}{669} \\
& \mathrm{U}^{238}(\alpha, \mathrm{p} 3 \mathrm{n}) \mathrm{Np} 238 \underline{669} \\
& u^{238}(\alpha, \alpha n) u^{237} \frac{669}{662} \\
& u^{238}(a, t) N^{2} 39 \underline{662} \\
& U^{238}(a, F) \underline{664,669} \\
& U^{236}(\alpha, 4 n) \text { Pu } 236 \underline{668} \\
& U^{235}(\alpha, n) P u^{238} 664,669 \\
& U^{235}(\alpha, 2 n) \text { Pu } 237 \frac{669}{664} \\
& \mathrm{U}^{235}(\alpha, 3 n) P u^{236} \underline{664,669} \\
& U^{235}(\alpha, 4 n) \mathrm{Pu}^{235} \underline{699} \\
& U^{235}(\alpha, p 2 n) N^{236} \underline{669} \\
& u^{235}(\alpha, F) \underline{669} \\
& U^{234}(a, 4 n) P u^{234} \underline{668,670} \\
& u^{233}(\alpha, n) P u^{236} \underline{669} \\
& u^{233}(\alpha, 2 n) P^{235} \underline{69} \\
& \mathrm{U}^{233}(\alpha, 3 n) \mathrm{Pu}^{234} \underline{669} \\
& U^{233}(\alpha, 4 n) \mathrm{Pu}^{233} \underline{669} \\
& \mathrm{U}^{233}(\alpha, 5 n) \mathrm{Pu}^{233} \underline{669} \\
& \mathrm{U}^{233}(\alpha, p) \mathrm{Np}^{236} 669 \\
& \mathrm{U}^{233}(\alpha, \mathrm{pn}) \mathrm{Np} 235 \underline{669} \\
& u^{233}(\alpha, p 2 n) N p^{234} \underline{699} \\
& v^{233}(\alpha, p 3 n) N p^{233} 669 \\
& u^{233}(\alpha, F) \underline{669}
\end{aligned}
$$

Carbon Ions

Gamma rays, bremsstrahlung

$$
\begin{aligned}
& U^{238}(\gamma, n) U^{237} \underline{672,673} \\
& U^{238}(\gamma, N) \underline{674} \\
& U^{238}(\gamma, F) \underline{672,673,675}
\end{aligned} \quad U^{233}(\gamma, N) \underline{674}
$$


The analysis of uranium by activation methods is reviewed by Koch, $\frac{676}{6}$ wo also gives references to much of the literature.

\section{TV-F. Dissolution of Uranium Samples}

\section{Metallic urantum.}

$\mathrm{HNO}_{3}$. Uranium metal dissolves in nitric acld to form uranyl nitrate. W1th massive amounts of uranium the rate of dissolution is moderately rapid. 677 The reaction between urantum turnings, powder, or sintered metal and nitric ac1d vapors or nitrogen dioxide may occur with explosive violence. 677 oxides of nitrogen are the principal gaseous products in the dissolution of the metal by $\mathrm{HNO}_{3}$. The presence of oxygen in the dissolver system tends to reduce the emission of these oxides. $\frac{678}{6}$ The rate of dissolution of large amounts of metallic uranium may be Increased by the addition of small amounts of sulfur1c, 679 phosphoric, $\underline{679,680}$ or perchlor1c $\frac{681}{2}$ ac1d to the nitric ac1d. $\mathrm{H}_{2} \mathrm{SO}_{4}$. Hot concentrated sulfurlc ac1d attacks uranium metal slowly forming uranium (IV) sulfate. 677 sulfuric ac1d-hydrogen peroxide mixtures react slowly with the metal at $75^{\circ} \mathrm{C}$ forming uranyl sulfate. 682 The addition of small amounts of chloride or fluoride to $\mathrm{H}_{2} \mathrm{SO}_{4}-\mathrm{H}_{2} \mathrm{O}_{2}$ mixtures increases the dissolution rate. $\frac{682}{}$

$\mathrm{H}_{3} \mathrm{PO}_{4}$. Cold 85\% phosphorlc acid attacks uranium metal slowly. 677 Concentration of the acid by heating produces a falriy rapid reaction in which uranium (IV) phosphate is formed. If heated too long, a chemically inert, glassy substance is formed. $\mathrm{HClO}_{4}$. Uranlum metal is inert toward cold, dilute perchloric acid. As the concentration is increased by heating a point is reached at which the reaction proceeds with violence. 577,682 oxidizing agents added to dilute perchlorlc ac1d dissolve the metal.677 HCl. Concentrated hydrochloric acld vigorously attacks uranium metal. Dilution of the acid diminishes the attack. But even with $4 \mathrm{M} \mathrm{HCl}$ there is a rap1d evolution of hydrogen. $\frac{682}{\mathrm{~A}}$ 
finely divided, black precipitate soon forms after dissolution begins. This precipitate is not dissolved by heating. Only by the addition of uxidizing agents (hydrogen peroxide, bromine, chlorate, nitrate, persulfate, dichromate, or ferric lons) does the precipitate dissolve. Gaseous chlorine, alded by small amounts of 1ror. or lodine, also oxidizes and solubilizes the uranium precipltate. The addition of small amounts of fluosilicic ac10 $\frac{682,683}{6}$ or large amounts of phosphoric ac1d $\frac{682}{}$ to the hydrochloric ac1d prevents formation of the black precipitate during the dissolution of uranium metal.

HF. The reaction of hydrofluoric acid with uranium metal is slow even at temperatures of $80^{\circ}-90^{\circ} \mathrm{C} .677$ The reaction is inhibited by the formation of insoluble $\mathrm{UF}_{4}$ on the surface of the metal. HBR. Hydrobromic acid attacks metallic uranium in manner similar to, but slower than, hydrochloric acid.677 The black precipitate is formed.

HI. The reaction between uranium metal and hydriodic acld is slow. 677

Organic acids. Acetic, formic, propionic, and butyric acids react rapidly with uranium in the presence of hydrogen chloride. 677 Benzolc acld in ether reacts with the metal, forming the benzoate. 677 Acetyl chloride and acetic anhydride react to form uranous acetate. 677

Miscellaneous solvents. Uranium is dissolved in a number of media other than ac1ds: $34,677,682$ solutions of heavy metal salts (s1lver perchlorate, $\underline{684}$ cupric ammonium chloride $\frac{685}{6}$ or acetate $\frac{686}{}$ ), alkaline peroxide solutions ( $\mathrm{NaOH}-\mathrm{H}_{2} \mathrm{O}_{2}$ or $\mathrm{Na}_{2} \mathrm{O}_{2}-\mathrm{H}_{2} \mathrm{O}$ solutions $(687)$, solutions of bromine and ethyl acetate, $\underline{622,688}$ hydrogen chloride and ethyl acetate, $\frac{682}{2}$ hydrogen chloride and acetone, $\frac{682}{}$ and nitrogen dioxide and hydroger fluoride. $\frac{089}{2}$

Table XXXVIII denotes qualitatively some solutions that satisfactorily dissolve uranium. $\frac{682}{2}$

Anodic dissolution. Metallic uranium may be dissolved elec- 
trolytically by anode oxidation. A variety of electrolytes have been used. $690-692$ satisfactory dissolutions have been made with sulfurlc acid, $\frac{682}{n}$ ntric ac1d, 691 tartaric ac1d, 691 phosphoric acid containing nitrate, $\frac{692^{\circ}}{}$ and sodium bicarbonate. $\frac{691}{}$ 2. Alloys of uranium. The ease with which uranium alloys are dissolved depends largely upon the chemical behavior of the alloying metal. Larsen $\frac{682}{2}$ has reviewed the dissolution of some of the more common uranirm alloys. Table XXXVIII summarizes the effect of varlous reagents on these alloys.

3. Compounds of uranium. Table II lists solvents for a number of uranlum compounds. General Review references 2, 4, 5, and 7 (Section I) cover the chemical properties of these and other compounds more fully.

Table XXXVIII. Reagents for the Dissolution of Uranlum and Its Alloys. a

$$
S=\text { satisfactory } \quad N=\text { unsatisfactory }
$$

\begin{tabular}{|c|c|c|c|c|c|c|c|}
\hline Description & $\mathrm{HNO}_{3}$ & $\begin{array}{l}\text { Aqua } \\
\text { Regia }\end{array}$ & $\underset{H F}{N 1 \operatorname{tr} 1 C-}$ & $\underset{\mathrm{Ox}}{\mathrm{HCI}}+$ & $\begin{array}{l}\mathrm{HCl}- \\
\text { EtOAC }\end{array}$ & $\begin{array}{l}\mathrm{Br}_{2}^{-} \\
\text {EtOAC }\end{array}$ & $\begin{array}{l}\mathrm{NaOH}- \\
\mathrm{H}_{2} \mathrm{O}_{2} \\
\end{array}$ \\
\hline$U$ & $S$ & $S$ & $S$ & $S$ & $S$ & $S$ & $S$ \\
\hline $\mathrm{U}-\mathrm{Zr}$ & $\mathrm{N}$ & $\mathrm{N}$ & $S$ & $\mathrm{~N}$ & $N$ & $S$ & $\mathrm{~N}$ \\
\hline $\mathrm{U}-\mathrm{Nb}$ & $\mathrm{N}$ & $\mathrm{N}$ & $S$ & $\mathrm{~N}$ & $\mathrm{~N}$ & $s$ & $S$ \\
\hline $\mathrm{U}$-Fe & $S$ & $s$ & $S$ & $S$ & $S$ & $S$ & $\mathrm{~N}$ \\
\hline $\mathrm{U}-\mathrm{Cr}$ & $\mathrm{N}$ & $\mathrm{N}$ & $\mathrm{N}$ & $S$ & $S$ & $S$ & $\mathrm{~N}$ \\
\hline U-Ru & $N$ & $s$ & $\mathrm{~N}$ & $N$ & $\mathrm{~N}$ & $N$ & $\mathrm{~N}$ \\
\hline U-Mo & $\mathrm{N}$ & $s$ & $\mathrm{~N}$ & $S$ & $N$ & $S$ & $S$ \\
\hline$U-F 1 s s$ Ium & $\mathrm{N}$ & $s \stackrel{c}{s}$ & $\mathrm{~N}$ & N & $\mathrm{N}$ & $\mathrm{N}$ & $\mathrm{N}$ \\
\hline 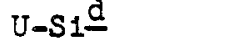 & $S$ & & $S$ & & & & \\
\hline$U-P u$ & se & $s$ & $\mathrm{~N}$ & $s$ & $S$ & $s$ & $\mathrm{~N}$ \\
\hline
\end{tabular}

a R. P. Larsen, reference 682 .

b Alloys contalning from 1 to $3 \not 2 \mathrm{Zr}, \mathrm{Mo}, \mathrm{Ru}, \mathrm{Rh}, \mathrm{Pd}$, and $\mathrm{Ce}$.

c Fluoride must be added to dissolve $\mathrm{Zr}$.

d Nitric acid dissolutions leave $S I$ residue, but nitric-hydrofluoric acld dissolutions can easily lead to volatilization of fluosilic1c ac1d.

e Pu itself is not readily dissolved in nitric acid, hydrochloric ac1d being preferable. 
The dissolution of uranium oxides is of considerable 1nterest since uranium samples prepared as accelerator targets, for neutron 1rradiations, or samples found in the natural state are frequently in the form of oxides. Also, many compounds of uranium may be transformed to the oxide by heating, hydrolys1s, or fusion. All of the oxldes, $\mathrm{UO}_{3}, \mathrm{U}_{3} \mathrm{O}_{8}$, and $\mathrm{UO}_{2}$, are soluble In nitric acid, forming uranyl nitrate. $\mathrm{UO}_{3}$ is soluble in other mineral acids. $\mathrm{U}_{3} \mathrm{O}_{8}$ and $\mathrm{UO}_{2}$ are dissolved by fuming with perchloric ac1d. 34 They are slowly dissolved in hot concentrated sulfuric ac1d. 34 The presence of fluorlde accelerates this dissolution. 693 Alkaline peroxides react with uranium oxides to form soluble peruranates. $\underline{34,687}$

4. Meteorites, minerals, and ores. The extraction of uranium from natural deposits may be accomplished by decomposition and dissolution of the entire sample including uranlum or by leaching the uranium from the sample. Grinding and roasting facilitate the recovery. Roasting removes organic material. It also helps form soluble uranium compounds.

Decomposition of the sample may be accomplished by acid attack, by fusion, or by a combination of the two. Mineral acids, Individualiy or in comblnation, may be used. The presence of hydrofluorlc acid generally alds in dissolution. Ores, sand, etc. may be fused with sodium carbonate, sodium hydroxide, sodxum peroxide, sodium bisulfate, sodium chloride and sodium hydroxide, ammonium sulfate, potassium bifluorlde, and magneslum oxide. $\frac{1,34,694}{4}$ The melt is solubilized in water or ac1d and the separation of uranium made by procedures outined in Section IV-D. Rodden and Warf 34 have described a number of procedures in which uranium was made soluble by ac1d attack or by fusion methods. The recovery of uranium from monazite sands has been reported by Calk1ns, et al. 694

Acid and alkaline leaching are used on an industrial scale for the recovery of uranium from 1ts ores. In ac1d leaching, 
hydrochloric, nitric, or sulfurlc ac1d may be used.I Industrially, sulfuric acld is used because of 1 ts economy. Oxldizing agents ( $\mathrm{Fe}$ (III), $\mathrm{MnO}_{2}$, etc.) are used to convert uranium (IV) to uranium (VI). A separation of uranium and thorlum with an oxalic acid-nitric ac1d leach solution has been reported. $\underline{69}$

In alkaline leaching, various combinations of alkaline carbonates, hydroxides, and peroxides have been used. 1 Industrially, uranium is dissolved by alkaline carbonates as the $\mathrm{UO}_{2}\left(\mathrm{CO}_{3}\right)_{3}^{4-}$ complex. oxygen or other sultable oxidants are used to convert uranium (IV) to uranium (VI). Hydroxyl 1ons are formed by the dissolution of uranium in carbonate solutions. The presence of bicarbonate ion in the dissolving solution prevents the precipitation of uranium. The recovery of uranium by acld and alkaline leaching is revlewed in General Review reference 13 (Section I).

5. Blological samples. The determination of uranium in biologlcal samples is reviewed by Steadman. 696 Uranium may be extracted and determined directly from liquid samples. The sample may also be ashed, as are solid samples, prior to uranium extraction. Ashing may be carried out as a wet or dry process. Wet-ashing is commonly done with a nitric acid solution. Ashing may be completed with perchlorlc acid. However, extreme caution must be exercised when heating organic materials with perchloric ac1d. The ashed residue is dissolved in acid and the uranium determination continued from there. Wet-ashing need not be carried to completion. Analysis may be made upon the sample after it has been thoroughly digested in ac1d.

6. Alr dust samples. Samples of a1r dust are commonly collected on fliter papers. The uranium may be dissolved by digesting the sample in nitric acid solution or the sample may be ashed and the residue dissolved in acid. 


\section{Collection of Detalled Procedures}

A procedure for the determination of uranium may enta1l one or more purification steps as outlined in the preceding sections. For example, uranium may be separated from impurities by a series of solvent extractions with one or more different solvents. These may be interspersed with precipitation and/or Ion exchange methods. The procedures described herein have been gathered from project reports, the open 11terature, and by private communication. Only a limited number are presented. They have been selected because they represent many of the separation methods already described or because they represent different problems in handing samples: problems of dissolution, extraction in the presence of high beta-gamma activity, etc. A number of the procedures described do not make use of the radiometric determination of uranium. The method of separation in these procedures, however, is applicable to radiochemical analysis and is, therefore, included. A number of papers and reports describe, in deta11, procedures for the determination of uranium. These should be noted. The work of Rodden and Warf 34 has frequently been mentioned in this paper. In addition to procedures for the precipitation, solvent extraction, volatilization, and electrodeposition of uranium, these authors have presented a number of selected procedures for the solution of ores and minerals and the separation and determination of uranium. Procedures for the analytical determination in naturaliy occurring materials have also been described by Rodden and Tregonning, $\frac{366}{6 r i m a l d 1, ~ M a y, ~ F l e t c h e r, ~ a n d ~ T i t c o m b, ~} \frac{697}{}$ schoeller and Powell, $\underline{209}$ and in the "Handbook of Chemical Determination of Uranium in Minerals and Ores." 698 The recent publication by Moore 471 on extraction with amines contains a collection of procedures, many of which have to do with the separation of uranium. 
ROCEDURE 1: Uran1UM-237.

Source: B. Warren, LA-1567 (1953) p. 18.

Ed1tor's note: Uranlum-237 may be separated from f1ssion products, neptunium. and plutonium more easily by ion exchange and/or solvent extraction techniques (see, for example, Procedure 7). The following procedure is, however, an excellent example of uranium purification by precipitation methods.

\section{Introduction}

The significant steps in the determination of $U^{237}$ in materlals containing fission products, neptunium and plutonium are the following. Rare-earth, neptunium, and plutonium activities are removed by appropriate lanthanum fluoride scavenging steps In the presence of hydroxylamine hydrochloride. The latter reagent serves to reduce both neptunium and plutonium so that they may be carried down, and also to complex uranium and prevent 1 ts later removal in Iron scaveng1ng steps. Barlum and zirconlum are prec1pitated by barlum fluozlrconate scavenging. following a cycle of ferric hydroxide scavenging and ammontum diuranate precipitation steps, uranium is reduced by zinc metal in hydrochloric ac1d medium and precipitated, presumably as $\mathrm{U}(\mathrm{OH})_{4}$, with ammonium hydroxide. The uranium is further purifled by alternate conversions to tetrafluoride and hydroxide. 24.10 $\mathrm{Th}^{234}\left(\mathrm{UX}_{1}\right)$ which has grown in from $U^{238}$ is removed by a zirconium lodate scavenge and the uranium is converted to ammonium diuranate. Uranlum is finally plated from nitric ac1d medium onto a platinum foll. After flaming of the foll and weighing, uranium is betacounted as $\mathrm{U}_{3} \mathrm{O}_{8}$. Chemical ylelds average 50 to 65\%. Quadrupl1cate determinations require approximately 8 nours.

\section{Reagents}

$U^{238}$ carrier: $1 \mathrm{ml}$ containing $10 \mathrm{mg}$ of $(5000 / 1)$ uranium. Preparation: Welgh out $1 \mathrm{gm}$ of $U$ metal, dissolve in conc. $\mathrm{HNO}_{3}$, transfer to a $100-\mathrm{ml}$ volumetrlc flask. Make up to volume, adjusting the final solution 
to $3 \mathrm{M}$ in $\mathrm{HNO}_{3}$. The carrier is standardized by plpeting $1 \mathrm{ml}$ aliquots into a 000-Coors procelain cruclble, evaporating to dryness, 1gniting at $800^{\circ}$ for $45 \mathrm{~min}$, and welghing as $\mathrm{U}_{3} \mathrm{O}_{8}$.

La carrier: $10 \mathrm{mg} \mathrm{La} / \mathrm{ml}$ (added as $\mathrm{La}\left(\mathrm{NO}_{3}\right)_{3} \cdot 6 \mathrm{H}_{2} \mathrm{O}$ in $\mathrm{H}_{2} \mathrm{O}$ )

Ba carrier: $10 \mathrm{mg} \mathrm{Ba} / \mathrm{ml}$ (added as $\mathrm{Ba}\left(\mathrm{NO}_{3}\right)_{2}$ in $\mathrm{H}_{2} \mathrm{O}$ )

$\mathrm{Zr}$ carrier: $10 \mathrm{mg} \mathrm{Zr} / \mathrm{ml}$ (added as $2 \mathrm{rO}\left(\mathrm{NO}_{3}\right)_{2} \cdot 2 \mathrm{H}_{2} \mathrm{O}$ in $1 \mathrm{M} \mathrm{HNO}_{3}$ )

Fe carrier: $10 \mathrm{mg} \mathrm{Fe} / \mathrm{ml}$ (added as $\mathrm{Fe}\left(\mathrm{NO}_{3}\right)_{3} \cdot 9 \mathrm{H}_{2} \mathrm{O}$ in very dilute $\mathrm{HNO}_{3}$ )

$\mathrm{HCl}$ : cone.

$\mathrm{HNO}_{3}: \quad \underline{M}$

$\mathrm{HNO}_{3}: 8 \underline{\mathrm{M}}$

$\mathrm{HNO}_{3}:$ conc.

HF : conc.

$\mathrm{H}_{2} \mathrm{SO}_{4}$ : conc.

$\mathrm{HIO}_{3}: 0.35 \mathrm{M}$

$\mathrm{NH}_{4} \mathrm{OH}$ : conc.

$\mathrm{NH}_{2} \mathrm{OH} \cdot \mathrm{HCl}: 5 \mathrm{M}$

$4 \%$ aqueous $\left(\mathrm{NH}_{4}\right)_{2} \mathrm{C}_{2} \mathrm{O}_{4}$

$\mathrm{Br}_{2}$ : 21qu1d

Zn metal: 20 mesh, granular

Methanol: anhydrous

Methy I red Indicator solution: $0.1 \%$ in $90 \%$ ethanol.

\section{Equipment}

Fisher burner

Centrifuge

Block for holding centrifuge tubes

40-ml centrifuge tubes: Pyrex 8140 (10 per sample)

000-Coors porcelain crucibles (one per standardization)

Pt-tipped tweezers

P1pets: assorted sizes 
Stirring rods

Plating assembly: 1 cell per allquot of sample

Source of current - F1sher Powerhouse (D.C.)

with variable resistance in series with cells.

Ce11 - Brass base $\left(3^{\prime \prime} \times 3^{n}\right)$ for hola1ng

Pt cathode; 5-m1l Pt c1rcular 2" dlameter disk (cathode);

gasket (Koroseal-Upholstery 36681) to seal cathode and chimney; glass chimney, 2" diameter, $4^{n}$ h1gh, w1th 4 ears at he1ght of $3^{\prime \prime} ; 1$ 1/4" steel springs for holding chimney to base; rotating Pt anode. The cell $1 \mathrm{~s}$ heated for $13 / 4$ hours at $105^{\circ}$ after assembly to insure formation of seal between glass and Pt.

$$
\text { Water bath for cell - Autemp heater; 6" }
$$

crystallizing dish (for water bath); rubber pad for holding cell.

\section{Procedure}

Step 1. Add $1 \mathrm{ml}$ of standard $U$ carrier to an allquot of sample in a 40-m long taper centrifuge tube. Dilute to about $10 \mathrm{ml}$, heat to bolling, and prec1pitate $\left(\mathrm{NH}_{4}\right)_{2} \mathrm{U}_{2} \mathrm{O}_{7}$ by the dropwise addition of conc. $\mathrm{NH}_{4} \mathrm{OH}$.

Step 2. Centrifuge and discard the supernate.

Step 3. Dissolve the precipitate 1 in 1 to $2 \mathrm{ml}$ of $\mathrm{IM}_{\mathrm{MNO}} \mathrm{HN}_{3}$, add $5.4 \mathrm{ml}$ of $\mathrm{H}_{2} \mathrm{O}, 3$ drops of La carrier, and 10 drops of $5 \mathrm{M}$ $\mathrm{NH}_{2} \mathrm{OH} \cdot \mathrm{HCl}$. Allow to stand for $5 \mathrm{~min}$.

Step 4. Add 3 drops of conc. HF and allow to stand for 5 min. Centrifuge for $5 \mathrm{~min}$, transfer supernate to a 40-m centrifuge tube, and discard the precipltate.

Step 5. Add 3 drops of Ia carrier and let stand for $5 \mathrm{~min}$. Centrifuge for $5 \mathrm{~min}$, transfer supernate to a $40-\mathrm{ml}$ centrifuge tube, and discard the precipltate.

Step 6. Add 3 drops of 2 r carrier and 15 drops of Ba 


\section{PROCEDURE I (Continued)}

carrier. Centrifuge for $5 \mathrm{~min}$ and transfer the supernate to a 40-m I centrifuge tube, discarding the prec1p1tate.

Step 7. Add 4 drops of conc. $\mathrm{H}_{2} \mathrm{SO}_{4}$ and centrifuge for $5 \mathrm{~min}$. Transfer the supernate to a 40-m I centrifuge tube and discard the precipitate.

Step 8. Add 2 drops of Fe carrier, heat the solution to bolilng, and preclpitate $\mathrm{Fe}(\mathrm{OH})_{3}$ by the addition of conc. $\mathrm{NH}_{4} \mathrm{OH}$. Cool the tube under cold $\mathrm{H}_{2} \mathrm{O}$, centrifuge for $2-1 / 2 \mathrm{mIn}$, and transfer the supernate to a 40-ml centrifuge tube, discarding the precipitate.

Step 2. Add 0.4 to $0.5 \mathrm{ml}$ of 11 quid $\mathrm{Br}_{2}$ (Note 1) slowly to slight excess and boll the solution to a light yellow color. Add conc. $\mathrm{NH}_{4} \mathrm{OH}$ until $\left(\mathrm{NH}_{4}\right)_{2} \mathrm{U}_{2} \mathrm{O}_{7}$ precipltate forms. $\mathrm{CoOl}$ under cold water, centrifuge, and save the precipitate.

Step 10. Add 1 to $2 \mathrm{mI}$ of $\mathrm{IM}^{\mathrm{HNO}} 3$ and $10 \mathrm{ml}$ of $\mathrm{H}_{2} \mathrm{O}$, heat the solution to bolling, and add conc. $\mathrm{NH}_{4} \mathrm{OH}$ to reprecipitate $\left(\mathrm{NH}_{4}\right)_{2} \mathrm{U}_{2} \mathrm{O}_{7}$. Centrifuge and save the precipitate.

Step 11. Add 1 to $2 \mathrm{ml}$ of $1 \mathrm{M} \mathrm{ENO}_{3}, 10 \mathrm{ml}$ of $\mathrm{H}_{2} \mathrm{O}, 10$ drops of $5 \mathrm{M} \mathrm{NH} \mathrm{NH}_{2} \mathrm{OHCl}$, and 2 drops of Fe carrier. Let stand for $5 \mathrm{~min}$. Heat the solution to bolling and precipitate $\mathrm{Fe}(\mathrm{OH})_{3}$ by addition of conc. $\mathrm{NH}_{4} \mathrm{OH}$. COOl the tube under cold $\mathrm{H}_{2} \mathrm{O}$, centrifuge for $2-1 / 2 \mathrm{~min}$, and transfer the supernate to a $40-$ ml centrifuge tube, discarding the precipitate.

Step 12. Repeat Step 9.

Step 13. Add $1 \mathrm{mI}$ of conc. $\mathrm{HCl}, 10 \mathrm{ml}$ of $\mathrm{H}_{2} \mathrm{O}$, heat the solution to bolling and precipitate $\left(\mathrm{NH}_{4}\right)_{2} \mathrm{U}_{2} \mathrm{O}_{7}$ with conc. $\mathrm{NH}_{4} \mathrm{OH}$. cool the tube, centrifuge, and save the precipltate.

Step 14. D1ssolve the precipitate in $1 \mathrm{ml}$ of conc. HCl and $10 \mathrm{ml}$ of $\mathrm{H}_{2} \mathrm{O}$. Add $2 \mathrm{gm}$ of $\mathrm{Zn}$ metal (20 mesh, granular), and heat the m1xture unt1l the solution turns brown. Heat 1 add1tional minute. 
Step 15. Let stand unt1l the v1gorous gas evolution subsides and decant into a 40-ml centrifuge tube. D1scard the $\mathrm{Zn}$.

Step 16. Heat the solution to boling and precipitate $\mathrm{U}(\mathrm{OH})_{4}$ (?) with conc. $\mathrm{NH}_{4} \mathrm{OH}$. (The precipitate w1ll be greenishblack.) Centrifuge and save the preolpltate.

Step 17. D1ssolve the prec1pitate in 10 drops of conc. HCl. Add $5 \mathrm{ml}$ of $\mathrm{H}_{2} \mathrm{O}$ and 4 drops of conc. HF. St1r vigorously until $\mathrm{UF}_{4}$ prec1pitates, add 7 drops of conc. $\mathrm{NH}_{4} \mathrm{OH}$ and st1r. Centrifuge $5 \mathrm{~min}$ and save the precipitate.

Step 18. Add $1 \mathrm{ml}$ of conc. HCl, heat slightly, add $10 \mathrm{ml}$ of $\mathrm{H}_{2} \mathrm{O}$, and heat the solution to bolling (the precipitate should dissolve). Add conc. $\mathrm{NH}_{4} \mathrm{OH}$ and precipitate $\mathrm{U}(\mathrm{OH})_{4}$ (?) (greenishblack precipitate).

Step 19. Repeat Step 17, except that $4 \mathrm{mI}$ of $\mathrm{H}_{2} \mathrm{O}$ are added Instead of 5 .

Step 20. Add $1 \mathrm{mI}$ of conc. $\mathrm{HNO}_{3}$ and heat unt1l $\mathrm{NO}_{2}$ ceases to be evolved. Add $10 \mathrm{mI}$ of $\mathrm{H}_{2} \mathrm{O}$ and precipitate $\left(\mathrm{NH}_{4}\right)_{2} \mathrm{U}_{2} \mathrm{O}_{7}$ with conc. $\mathrm{NH}_{4} \mathrm{OH}$. Centrifuge, discard the supernate, and dissolve the precipitate in $1 \mathrm{ml}$ of conc. $\mathrm{HNO}_{3}$.

Step 2l. Add $10 \mathrm{ml}$ of $\mathrm{H}_{2} \mathrm{O}, 4$ drops of $\mathrm{Zr}$ carrier, and $1 \mathrm{ml}$ of $0.35 \mathrm{M} \mathrm{HIO}_{3}$. Centr1fuge, transfer the supernate to a $40-\mathrm{ml}$ centrifuge tube, and discard the prec1pitate.

Step 22. Heat the solution to bolling and precipitate $\left(\mathrm{NH}_{4}\right)_{2} \mathrm{U}_{2} \mathrm{O}_{7}$ with conc. $\mathrm{NH}_{4} \mathrm{OH}$. Centrifuge and discard the supernate.

Step 23. Dissolve the precipitate in 1 to $2 \mathrm{ml}$ of $1 \mathrm{M} \mathrm{HNO}_{3}$, dilute with $10 \mathrm{ml}$ of $\mathrm{H}_{2} \mathrm{O}$, and centrifuge. Transfer the supernate to a 40-ml centrifuge tube and discard the precipitate.

Step 24. Reprec1pitate $\left(\mathrm{NH}_{4}\right)_{2} \mathrm{U}_{2} \mathrm{O}_{7}$ by boll1ng the solution and adding conc. $\mathrm{NH}_{4} \mathrm{OH}$. Centrifuge and save the precipitate.

Step 25. Add 5 drops of $8 \mathrm{M} \mathrm{HNO}_{3}$ and transfer to the plating cell which contalns $10 \mathrm{ml}$ of $\mathrm{H}_{2} \mathrm{O}$ and 3 drops of $8 \mathrm{M} \mathrm{HNO}_{3}$. Rinse the centrifuge tube with three washes each consisting of 5 
drops of $8 \mathrm{M} \mathrm{HNO}_{3}$ and $0.5 \mathrm{ml}$ of $\mathrm{H}_{2} \mathrm{O}$, transferring the washings to the plating cell.

Step 26. Add $10 \mathrm{ml}$ of $4 \%\left(\mathrm{NH}_{4}\right)_{2} \mathrm{C}_{2} \mathrm{O}_{4}$ and wash the cell walls down with approximately $5 \mathrm{ml}$ of $\mathrm{H}_{2} \mathrm{O}$. The total volume in the cell should be about $40 \mathrm{ml}$.

Step 27. Add 5 drops of methyl red solution, and conc. $\mathrm{NH}_{4} \mathrm{OH}$ drop-wise until the solution turns yellow. Add $8 \mathrm{M} \mathrm{KNO}_{3}$ until the solution turns red or orange (one drop is usually required); then add 3 drops of $\mathrm{HNO}_{3}$ in excess.

Step 28. Plate for $1-1 / 2$ hours at 1.5 amp and 8 volts at 80 to $90^{\circ}$. For the first $30 \mathrm{~min}$, at $10-\mathrm{m} 1 \mathrm{n}$ intervals add sufficient $8 \mathrm{M} \mathrm{HNO}_{3}$ to make the solution red to methyl red. At $40 \mathrm{~min}$, add 3 drops of conc. $\mathrm{NH}_{4} \mathrm{OH}$, or enough to make the solution yellow to the indicator.

Step 29. Wash down the cell walls with $\mathrm{H}_{2} \mathrm{O}$ to replenish that lost by evaporation, and continue electrolysis for an additional $50 \mathrm{~min}$.

Step 30. Remove plate, wash w1th $\mathrm{H}_{2} \mathrm{O}$ and methanol. Flame plate for $1 \mathrm{~min}$. Cool, welgh as $\mathrm{U}_{3} \mathrm{O}_{8}$, mount, and count. Correct for $\operatorname{Th}^{234}\left(U x_{1}\right)$ activity (see accompanying rlgure).

\section{Notes}

1. Liquid $\mathrm{Br}_{2}$ destroys $\mathrm{NH}_{2} \mathrm{OH}$ and also the uranium-hydroxylamine complex. 
PROCEDURE I (Continued)

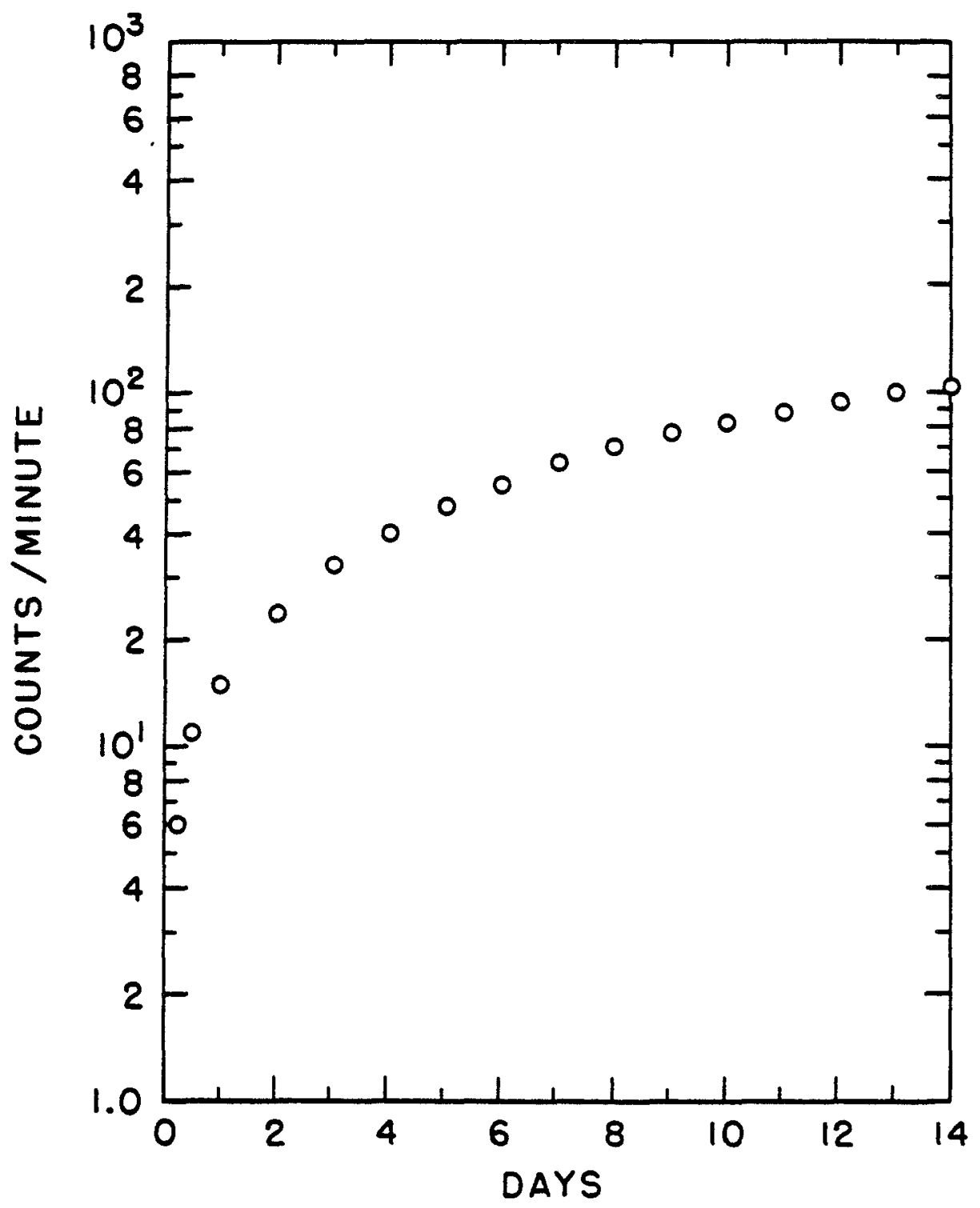

CORRECTION FOR UX ACTIVITY/mg U $\mathrm{U}_{3} \mathrm{O}_{8}$ ON PLATE. Procedure 1. 
PROCEDURE 2: PUr1f1cation of Uranium-240.

Source: E. K. Hyde and M. H. Studier, ANL-4182 (1948).

Egftor's note: The following procedure was useo to purify $U^{240}$ formed by the second order neutron capture of $0^{238}$. The principal decontaminating step is the ether extraction of uranium from a reducing aqueous solution. Uranium is further purified by a number of precipitations that are not described in deta1l. These, however, are falrly easy to perform.

\section{Irradiation and Chemical Procedure}

Two grams of depleted uranium ( 1 part $0^{235}$ per 30,000 parts $U^{238}$ ) as $U_{3} O_{8}$ in a small $2 s$ aluminum cepsule was irradiated in the Hanford pile for 12 hours including time for startup and shutdown. SIX hours after the end of the 1rradiation the capsule and 1 ts contents were dissolved in nitric ac1d, using mercurlc ion as catalyst for dissolving the aluminum. The uranium was extracted batchwise, the dissolved aluminum serving as a salting agent. The ether contalning the uranium was then passed through two static wash columns packed with $3 / 32$ inch stainless steel helices and fllled with a solution lOM in ammonium nitrate, $0.1 \mathrm{M}$ in nitric ac1d, $0.01 \mathrm{~N}$ in ferrous ion and $0.1 M$ in urea. Neptunium was reduced by the aluminum in the dissolver and by the ferrous ion in the wash columns to an unextractable oxidation state (Np IV and Np V). Additional ether was passed through the columns to strip out the uranium. These operations were carried out by remote control behind lead shlelding. The inftial dissolver solution measured roughls 50 roentgens per hour at 8 1nches. The ether solution emerging from the second column and containing the uranlum measured only about $3 \mathrm{mr}$ per hour at the surface, and most of this was ethersoluble lodine fission product activity. The uranium was extracted from the ether into an aqueous ammonium sulfate solution and washed several times with ether to remove lodine activity. LaP $_{3}$ was precipltated from the uranyl nitrate solution after reduction with sulfur dioxide to remove any traces of $\mathrm{Np}^{239}$ which might have come through the ether extraction. 
The uranium was further purifled by precipitation as diuranate, sodium uranyl acetate, and peroxide and by a final ether extraction. Throughout this final series of purifications there was no detectable decrease in B-act1vity; this Indicates that the uranium was radioactively pure.

Small aliquots of the final uranium solution were evaporated on platinum dises and 1gnited to $\mathrm{U}_{3} \mathrm{O}_{8}$ to study changes in activity. The remaining uranium solution was used for extraction of neptunium daughter fractions.

PROCEDURE 3: Pur1fication of Irradiated $U^{236}$. Source: S. Fried and H. Sel1g, Private communication. Editor's note: The present procedure was used in an experiment designed to measure the thermal neutron fission cross section of $U^{237}$. The amount of $U^{235}$ that can be tolerated in such an experiment is very small.

Two criterla were used in selecting the purification steps in the following procedure:

1) To obtain urantum free of fission products and other extraneous activities without introducing contaminant normal uranium in the procedure.*

2) The Inftial part should lend itself easily to remote control manipulation.

\footnotetext{
*The reagents used were carefully purifled. Thus, the nitric ac1d and perchloric ac1d were redistilled in a quartz still. The $\mathrm{NH}_{4} \mathrm{NO}_{3}$ was prepared from gaseous ammonia and dist1lled $\mathrm{HNO}_{3} \cdot$ The HCl was prepared by passing HCI gas into triply distilled $\mathrm{H}_{2} \mathrm{O}$, etc.
} 


\section{Procedure:}

A. In Cave

The 1rradiated uranium oxide $(-0.3 \mathrm{mg})$ was dissolved in concentrated $\mathrm{HNO}_{3}$ and made up to $2 \mathrm{M}^{2}$ in $\mathrm{HNO}_{3}$ with distilled $\mathrm{H}_{2} \mathrm{O}$ to give total volume of about $15 \mathrm{ml}$. Some $\mathrm{Fe}^{++}$was added to keep $\mathrm{Pu}$ and $\mathrm{Np}$ in +4 state. The solution was saturated with $\mathrm{NH}_{4} \mathrm{NO}_{3}$ and contacted four times w1th $10 \mathrm{ml}$ portions of ether. Each contact was scrubbed twice w1th $2 \mathrm{MHNO}_{3}$ saturated with $\mathrm{NH}_{4} \mathrm{NO}_{3}$. The combined ether extracts were back extracted three tImes with $5 \mathrm{mI}$ portions of $\mathrm{H}_{2} \mathrm{O}$. The $\mathrm{H}_{2} \mathrm{O}$ strip was evaporated to dryness and treated with $\mathrm{HCl}$ to destroy $\mathrm{NH}_{4} \mathrm{NO}_{3}$ carrled over.

\section{B. Outside Cave}

The sample could now be handled eas1ly outside the cave with a minimum of shielding, most of the activity being due to $0^{237}$. A mass spectrometric analysis showed it contained 0.5 weight of of $\mathrm{U}^{237}$. A fission count showed that additional pur1fication was necessary to remove $\mathrm{Np}^{238}$ formed by $(n, \gamma)$ on $\mathrm{Np}^{237}$ which had bullt up during 1rradiation.

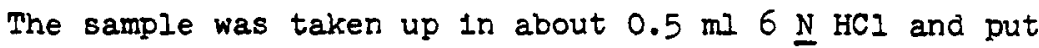
on a small Dowex-l column and washed. The Np comes off in 6 N HCI. F1nally the uranlum was eluted w1th $0.5 \mathrm{M}$ HCI. The eluate was evaporated to dryness and taken up $1 \mathrm{n} 0.2 \mathrm{ml}$ of $5 \mathrm{M}$ $\mathrm{HCl}, 0.1 \mathrm{M} \mathrm{KI}$ and $0.05 \mathrm{M} \mathrm{N}_{2} \mathrm{H}_{4} \mathrm{OH} \cdot 2 \mathrm{HCl}$. Th1s was heated at $90^{\circ}$ for 2 minutes, diluted to $0.5 \underline{M}$ in HCl and TTA extracted twice for 15 minutes. The original fraction was washed twice with benzene and evaporated to dryness.

In order to clean up the urantum for a mass spectrometric analysis, it was subjected to another ether extraction as in the f1rst step. After the $\mathrm{NH}_{4} \mathrm{NO}_{3}$ was destroyed the sample was fumed with $\mathrm{HClO}_{4}$ to destroy any organic residue from the ether extraction. 
PROCEDURE 4: Uranium and Plutonium Analysis

Source: B. F. Rider, J. L. Russell, Jr., D. W. Harr1s, J. P. Peterson, Jr., GEAP-3373 (1960).

Samples of dissolved irradiated fuel contaln highly radioactive fission products. For this reason, uranium and plutonium are separated prior to analysis. The following procedure glves a good yleld together w1th a good decontamination factor.

\section{Reagents :}

1. Distilled conc. $\mathrm{HNO}_{3}$.

2. $2 \mathrm{M} \mathrm{HNO}_{3}$ - distilled conc. $\mathrm{HNO}_{3}$, double distilled $\mathrm{H}_{2} \mathrm{O}$.

3. U-233 solution, standardized.

4. Pu-236 solution, standardized.

5. $\mathrm{KBrO}_{3}$ - Crystals, Reagent Grade. Low natural U blank.

6. $8 \underline{\mathrm{M}} \mathrm{NH}_{4} \mathrm{NO}_{3}$ in $2 \mathrm{MHNO}_{3}$ - Place $200 \mathrm{ml}$ distllied $16 \mathrm{M} \mathrm{HNO}_{3}$ $+100 \mathrm{ml}$ double distilled $\mathrm{H}_{2} \mathrm{O}$ in a large beaker. Bubble $\mathrm{NH}_{3}$ gas through solution until basic to $\mathrm{pH}$ paper. Bo1l off excess $\mathrm{NH}_{3}$ (solution neutral). Transfer to mixing cylinder, add $50 \mathrm{ml}$ of dist1lled $16 \mathrm{M} \mathrm{HNO}_{3}$, dilute to 400 ml. Check density of solution $\left(1.31 \pm 0.01\right.$ at $\left.20^{\circ} \mathrm{C}.\right)$.

7. Hexone - distilled.

8. $\mathrm{HCl}$ - C.P. reagent. Low natural U blank.

9. I $\mathrm{MNO}_{3}$ - distilled conc. $\mathrm{HNO}_{3}$, double distilled $\mathrm{H}_{2} \mathrm{O}$. 10. $30 \% \mathrm{H}_{2} \mathrm{O}_{2}$ - meets A.C.S. specification, low natural U blank.

11. 0.2 M T.T.A. In xylene $-4.44 \mathrm{gm} \mathrm{T.T.A.} \mathrm{dissolved} \mathrm{in} 100 \mathrm{ml}$ distilled xylene.

12. Xylene - dist1lled.

13. Ether - distilled.

14. $0.05 \mathrm{M} \mathrm{HNO}_{3}$ - distilled conc. $\mathrm{HNO}_{3}$, double dist1lled $\mathrm{H}_{2} \mathrm{O}$. 15. $\mathrm{H}_{2} \mathrm{O}$ - double distilled.

\section{Glassware:}

All glassware used is Pyrex which has been soaked overnight in 
$50 \% \mathrm{HNO}_{3}$ and rinsed with double distilled water. Pipets are rinsed with $50 \% \mathrm{HNO}_{3}$ and double distilled water before using. Separation and Decontamination Procedure:

1. Place the aliquot for analysis in a $15 \mathrm{ml}$ cone and evaporate to about $1 \mathrm{ml}$. Add a suitable $U-233$ and Pu-236 spike, one drop conc. nitric ac1d, and several $\mathrm{KBrO}_{3}$ crystals. Allow to stand for 1 hour to allow oxldation of $\mathrm{Pu}$ to $\mathrm{PuO}_{2}{ }^{++}$.

2. Add $1.5 \mathrm{ml} 8 \mathrm{M} \mathrm{NH}_{4} \mathrm{NO}_{3}$ in $2 \mathrm{M} \mathrm{HNO}_{3}$, and evaporate to about $2 \mathrm{ml}$.

3. Prepare 2 scrub solutions in separate $15 \mathrm{ml}$ coses, containing I $\mathrm{ml}$ of $8 \mathrm{M} \mathrm{NH}_{4} \mathrm{NO}_{3}$ in $2 \mathrm{M} \mathrm{HNO}_{3}$ and about $10 \mathrm{mgs} \mathrm{KBrO}_{3}$. Preoxldize about $10 \mathrm{ml}$ hexone with $2 \mathrm{ml}$ of $2 \mathrm{M} \mathrm{HNO}_{3}$ and $\mathrm{KBrO}_{3} \cdot$ Keep covered unt1I ready for use.

4. Extract the $U$ and $P u$ four times for five minutes with $2 \mathrm{~m}$ portions of hexone (methyl 1sobutyl ketone), adding 1 drop of $16 \mathrm{M} \mathrm{HNO}_{3}$ to the orlginal solution after each extraction. Scrub each extract in turn with the two solutions prepared in step 3.

5. Strip the combined hexone extracts with five $2 \mathrm{ml}$ portions of $\mathrm{H}_{2} \mathrm{O}$. Evaporate the comblned aqueous portions to dryness, add a rew drops of $\mathrm{HNO}_{3}$ and $\mathrm{HCl}$, take to dryness. Evaporate to dryness with $\mathrm{HNO}_{3}$ under a gentle stream of pure nitrogen on a bolling water bath.

6. Prepare $3 \mathrm{mI}$ of $1 \mathrm{M} \mathrm{HNO}_{3}$ and $\mathrm{I}$ drop of $30 \% \mathrm{H}_{2} \mathrm{O}_{2}$, add $\mathrm{I} \mathrm{ml}$ to the $P u$ and $U$ residue from step 5 and two $1 \mathrm{ml}$ portions to separate $15 \mathrm{ml}$ cones.

7. Extract immediately the Pu 2 times for $20 \mathrm{~min}$. With $2 \mathrm{ml}$ portions of 0.2 M.T.A. (thenoyltrifluoroacetone) in xylene. Scrub each in turn with solutions prepared in step 6 . Save the aqueous phase for uranium. Combine the T.T.A. extracts and add a few crystals of trichloroacetic acid. 
8. Mount the combined T.T.A. extracts on a platinum plate for alpha pulse analysis.

9. After pulse analysis, remove the Pu for mass analysis as follows: Cover disc w1th HF. Evaporate to dryness under a heat lamp. Again cover disc with HF and evaporate to dryness. Cover d1sc with conc. $\mathrm{HNO}_{3}$ and evaporate to dryness. Repeat 3 or 4 times. Cover disc with conc. nitric, reflux a few seconds, and transfer with a plpet to a $15 \mathrm{ml}$ cone. Repeat 3 or 4 times.

10. Evaporate the combined conc. $\mathrm{HNO}_{3}$ refluxes to dryness. Treat residue with aqua regla and evaporate to dryness. Evaporate to dryness with conc. $\mathrm{HNO}_{3}$ on a bolling water bath several times. Add $50 \lambda$ of $0.01 \mathrm{M} \mathrm{HNO}_{3}$ to the evaporated sample and submit sample for mass spectrographic analysis.

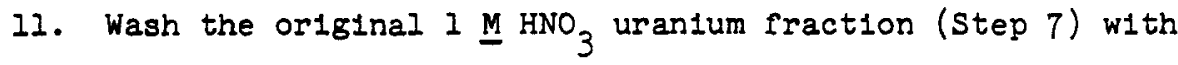
xylene. Add 1 drop of $\mathrm{HNO}_{3}$ and 3 drops of $\mathrm{HCl}$ to the washed $1 \mathrm{M} \mathrm{HNO}_{3}$ and reflux for about one-half hour to destroy the organ1c present. Evaporate to dryness, flame gently to destroy organic matter and dissolve the residue with 2 drops $\mathrm{HNO}_{3}$ and evaporate to dryness on a water bath.

12. Pipette three $1 \mathrm{ml}$ portions of $8 \mathrm{M} \mathrm{NH}_{4} \mathrm{NO}_{3}$ in $2 \mathrm{MHNO}_{3}$, dissolve the evaporated $U$ fraction in one $1 \mathrm{ml}$ portion. Place the other 2 portions in two $15 \mathrm{ml}$ cones for scrub solutions.

13. Extract the $U$ with four $2 \mathrm{ml}$ portions of diethyl ether, addIng $100 \lambda$ of conc. $\mathrm{HNO}_{3}$ before each extraction. Scrub each extract in turn with 2 scrub solutions prepared in Step 12. 14. Evaporate the combined ether extracts over $1 \mathrm{ml}$ of $\mathrm{H}_{2} \mathrm{O}$ in a $15 \mathrm{ml}$ cone. Evaporate to dryness.

15. Add 3 drops of $\mathrm{HCl}$ and 1 drop of $\mathrm{HNO}_{3}$, and evaporate to dry- 
ness repeatedly until the organic is destroyed. Flame gently to expell ammonium salts. Then dissolve in $\mathrm{HNO}_{3}$ and evaporate to aryness on a water bath. Add $50 \lambda$ of $0.05 \mathrm{M} \mathrm{HNO}_{3}$ to the dry cone and submit sample for mass spectrographic analysis.

\section{Plutonium Calculation:}

To determine the amount of $\mathrm{Pu}$ in the original sampie, it Is necessary to measure in a Frisch chamber the alpha spectrum of the plate prepared in Step 8. The rat10 of Pu-239 and Pu-240 activity to Pu-236 activity is calculated. If the ratio is miltiplied by the orlginal activity of Pu-236 added, the original activity of Pu-239 plus Pu-240 can be obtalned. From the mass analysis a Pu-239 to Pu-240 atom rat1o is obtained. The spec1flc activity of the mixture is calculated from that of the Indivicual 1sotopes. The Pu-239 plus Pu-240 activity can be converted to Pu-239 plus Pu-240 welght by dividing this activity by the specific activity of the mixture.

\section{Uranium Calculation:}

The ratio of the various $U$ isotopes to $U-233$ from the mass spectrometer data is multiplied by the amount of U-233 spike originaliy added to the sample to obtain the amount of each uranium 1sotope present in the original sample.

PROCEDURE 5: Spectrophotometric Extraction Methods Specific for Uran1um.

Source: W. J. Maeck, G. I. Booman, M. C. Elliott, and J. E. Re1n, Anal Chem. 31, 1130 (1959).

\section{Abstract}

Uranium as tetrapropylammonium uranyl trinitrate is quan- 


\section{PROCEDURE 5 (Continued)}

titatively separated from large quantities of diverse lons by extraction into methyl 1sobutyl ketone (4-methyl-2-pentanone) from an acid-deficient aluminum nitrate salting solution. M1lilgram levels are determined by a direct absorbance measurement of the trinitrate complex in the separated organic phase at $452 \mathrm{~m} \mu$. Microgram amounts are determined by adding dibenzoylmethane (1,3-diphenyl-1,3-propanedione) in an ethyl alcoholpyridine mixture to the separated organic phase and measuring the absorbance of the chelate at $415 \mathrm{m \mu}$. The coefficlent of varlation is less than $1 \%$ at the 10-mg. and 25- $\gamma$ levels. The limit of sensitivity is $0.8 \gamma$ for the dibenzoylmethane method.

\section{Apparatus and Reagents}

Absorbance measurements of the tetrapropylammonium urany trinitrate complex were made with a Cary Model 14 recording spectrophotometer and $1-\mathrm{cm}$. Corex cells. A Teflon $9 \times 9 \times 6 \mathrm{~mm}$. spacer placed in the bottom of the cells permits absorbance measurements with $2 \mathrm{ml}$. of sample. Absorbance measurements of the dibenzoylmethane complex were made with a Beckman DU spectrophotometer and $5-\mathrm{cm}$. Corex cells.

Extractions were made in $125 \times 15 \mathrm{~mm}$. test tubes with polyethylene stoppers. A mechanical extraction devicc ${ }^{7}$ was used for agitation.

Reagent grade inorganic and Eastman Kodak Co. White Label organic chemicals were used without puriflcation. D1stilled water was used throughout. The uranium solutions were prepared by dissolving purifled black oxlde, $\mathrm{U}_{3}{ }^{\circ}$, in a slight excess of nitric acid, and making to volume with water.

The dibenzoylmethane reagent is prepared by dissolving $0.1140 \mathrm{gram}$ of dibenzoylmethane in $500 \mathrm{ml}$. of a $5 \%$ solution (v./v.) of ethyl alcohol in pyridine.

Salting and Scrub Solutions. A. 0.005M Tetrapropylammonium 


\section{PROCEDURE 5 (Continued)}

Nitrate, IN Acid-Deficlent Salting Solution. Place 1050 grams of aluminum nitrate nonahydrate in a 2-11ter beaker and add water to a volume of $850 \mathrm{ml}$. Heat, and after dissolution add $67.5 \mathrm{ml}$. of concentrated amonium hydroxide. St1r for several minutes unt1l the hydroxide prec1pitate dissolves. Cool to less than $50^{\circ} \mathrm{C}$, add $10 \mathrm{ml}$. of $10 \%$ tetrapropylammonium hydroxide, and stir unt1l dissolved. Transfer to a l-11ter volumetric rlask and make to volume with water. A preliminary extraction with methyl isobutyl ketone 18 suggested to remove uranium contamination in which case tetrapropylammonium hydroxide will have to be re-added.

B. 0.025M Tetrapropylamonium N1trate, IN Acid-Deficlent Salting Solution. Same as A except that $50 \mathrm{ml}$. of $10 \%$ tetrapropylammontum hydroxide is used.

C. 0.25M Tetrapropylanmonium N1trate, IN Ac1d-Deficient Salting Solution. Neutralize $100 \mathrm{ml}$. of $10 \%$ tetrapropylanmonium hydroxide to $\mathrm{pH} 7 \mathrm{with} 5 \mathrm{~N}$ nitric ac1d. Transfer to a large evaporating dish and let stand until a thick crystal slurry forms (which may take as long as 4 days). Place 210 grams of aluminum nitrate nonahydrate in a 400-ml. beaker and transfer the tetrapropylammonium nitrate crystals into the beaker with $20 \mathrm{ml}$. of water. St1s and add water to a volume of approximately $180 \mathrm{ml}$. Add $13.5 \mathrm{ml}$. of concentrated ammonium hydroxide and stir until dissolution is complete (which may require several hours). Transfer to a 200-ml. volumetric flask and make to volume with water.

D. Scrub Solution for Dibenzoylmethane Method. Add 940 grams of aluminum nitrate nonahydrate, 33 grams of tartaric acid, 31 grams of oxalic acid, and 64 grams of (ethylenedin1tr110)tetraacet1c ac1d to $100 \mathrm{ml}$. of water and $150 \mathrm{ml}$. of concentrated ammonlum hydroxide. Heat with stirring unt1l dissolved. Cool, 


\section{PROCEDURE 5 (Continued)}

fliter, transfer to a l-ilter volumetric flask, and make to volume with water. Remove uranlum contamination by a methyl 1sobutyl ketone extraction.

E. Speclal Solutions. The following salting and scrub solutions are used in the dibenzoylmethane method for samples containing certum(IV) or thorium.

1. Prepare an aluminum nitrate salting solution as $A$, but omit the tetrapropylammonlum hydroxide.

2. Prepare a scrub solution by dissolv1ng 154 grams of ammonium acetate and 20 grams of the sodium salt of diethyld1thlocarbamate in water to a volume of approximately $900 \mathrm{ml}$. Adjust to $\mathrm{pH} 7$, f1lter, and make to a l-liter volume with water.

3. Prepare a mercuric nitrate solution by dissolving 0.063 gram of mercuric nitrate in $90 \mathrm{ml}$. of 1 N nitric acid and making to a 100-mi. volume with $1 \mathrm{~N}$ nitric acia.

\section{Procedures}

Mililgram Amounts of Urantum. W1th aqueous samples of 0.5 $\mathrm{ml}$. or less and contalning up to $2 \mathrm{meq}$. of acid, 0.5 to $12 \mathrm{mg}$. of uranium can be extracted from a salting solution which is $0.025 \mathrm{M}$ in tetrapropylammonium nitrate and $1 \mathrm{~N}$ acid-deficient. Samples of high acldity should be neutralized to less than 2 meq. of free acid, or a salting solution which is $2 \mathrm{~N}$ acid-deficient can be used for samples containing up to $6 \mathrm{meq}$. of acld. If cerlum(IV) and thorium are present, the absorbance from uranium will be maximum if the combined uranium(VI), thorlum, and cerIum(IV) do not exceed 0.05 mole in the sample al1quot. Samples that contain more than 0.05 mmole of combined uranium, cerlum(IV), and/or thorium can be analyzed after d1lution, provided the resulting sample aliquot contains more than 0.5 mg. of urantum. If this condition cannot be met, the $0.25 \mathrm{M}$ tetrapropylamonium nitrate salting solution is used, which can accommo- 
date up to 0.5 mole of combined uranium, cerlum(IV), and thorlum.

P1pet a sample of $0.500 \mathrm{ml}$. or less, contalning from 0.5 to $12 \mathrm{mg}$. of urantum, 1nto a test tube contalning $4.0 \mathrm{ml}$. of salting solution $B$ or $C$. Add $2.0 \mathrm{ml}$. of methyl 1sobutyl ketone, stopper, and extract for 3 minutes. Centrifuge to fac1litate phase separation. Transfer as much as possible of the organic phase with a microplpet to a l-cm. cell containing the Teflon spacer. Measure the absorbance at $452 \mathrm{m \mu}$ against a blank prepared by substituting IN nitric acid for the sample.

Microgram Amounts of Uranlum. Aqueous sample aliquots containing up to $2 \mathrm{mg}$. of uranium and as much as $8 \underline{\mathrm{N}}$ in acid can be quantitatively extracted from a salting solution $0.005 \mathrm{M}$ in tetrapropylamonium nitrate . Neutralize samples of higher acldity to less than $8 \mathrm{~N}$ before extraction.

SAMPIES WITHOUT CERIUM(IV) AND THORIUM Plpet a sample of $0.500 \mathrm{ml}$. or less, contalning from 0.8 to $75 \gamma$ of uranium, Into a test tube contalning $5.0 \mathrm{ml}$. of salting solution $A$. Add $2.0 \mathrm{ml}$. of methyl isobutyl ketone, stopper, and extract for 3 minutes. Centrifuge to facilitate phase separation. Transfer as much as possible of the organic phase to a test tube containing $5.0 \mathrm{ml}$. of scrub solution $D$, stopper, and $\mathrm{mix}$ for 3 minutes. Centrifuge to facilitate phase separation. Remove a 1.00-ml. aliquot of the organic phase and transfer to a 25$\mathrm{ml}$. flask. Add $15 \mathrm{ml}$. of the dibenzoylmethane-pyridine reagent and thoroughly mix. Allow to stand 15 minutes, transfer to a 5-cm. Corex cell, and measure the absorbance at $415 \mathrm{mp}$ compared to a blank prepared by substituting 1 N nitric acid for the sample aliquot.

SAMPLES CONTAINING CERIUM(IV) OR THORIUM. PIpet a sampIe of $0.500 \mathrm{ml}$. or less, containing from 0.8 to $75 \gamma$ of uranium, 


\section{PROCEDURE 5 (Continued)}

Into a test tube containing $5.0 \mathrm{ml}$. of the salting solution E-l. Add $4.0 \mathrm{ml}$. of methyl isobutyl ketone, stopper, and extract for 3 minutes. Centrifuge to facliltate phase separation. Transfer as much as possible of the organic phase to another tube containing $5.0 \mathrm{ml}$. of scrub solution E-2, stopper, and $\mathrm{mix}$ for 20 minutes. Centrifuge as before. Transfer at least $3 \mathrm{ml}$. of the organic phase to a test tube containing $5.0 \mathrm{ml}$. of salting solution E-1. Add $0.5 \mathrm{ml}$. of scrub solution E-3, stopper, mix for 10 minutes, and centrifuge. Remove a $2.00-\mathrm{ml}$. aliquot of the organlc phase and transfer to a $25-\mathrm{ml}$. flask. Add $15 \mathrm{ml}$. of the dibenzoylmethane-pyridine reagent and thoroughly mix. Let stand 15 minutes, transfer to a $5.0-\mathrm{cm}$. Corex cell, and measure the absorbance at $415 \mathrm{~m} \mu$ compared to a blank prepared by substitutIng IN nitric acld for the sample allquot.

Calibration. Two different standards contalning levels of uranium equivalent to approximately 0.1 and 0.7 absorbance are processed. The concentration of samples is established by the average absorpt1vity of these standards provided agreement within statistical limits ( $95 \%$ confldence level) is obtained.

a W. J. Maeck, G. I. Booman, M. C. Elllott, J. E. Re1n, Anal. Chem. 30, 1902 (1958).

PROCEDURE 6: Determination of Uranium in Uranium Concentrates. Source: R. J. Guest and J. B. Z1mmerman, Anal. Chem. 27, 931 (1955).

\section{Abstract}

A method is described for the determination of uranium in high grade uranium material. Uranium is separated from contaminants by means of an ethyl acetate extraction using aluminum nitrate as a salting agent. After the uranium has been stripped from the ethyl acetate 
layer by means of water, colorimetric determination of the uranium is carried out by the sodium hydroxide-hydrogen peroxide method. The procedure is accurate, rapid, and easily adaptable to routine work.

\section{Reagents and Apparatus}

Reagents. Ethyl acetate (Merck, reagent grade). ALUMINUM NITRATE SAITING SOLUTION. Place approximately 450 grams of reagent grade (Malinckrodt) aluminum-nitrate $\left[\mathrm{Al}\left(\mathrm{NO}_{3}\right)_{3}\right.$. $9 \mathrm{H}_{2} \mathrm{O}$ l in a $600-\mathrm{ml}$. beaker and add 25 to $50 \mathrm{ml}$. of distllied water. Cover the beaker and heat the mixture on a hot plate. If a clear solution does not result after 5 to 10 minutes of boling, add 20 $\mathrm{ml}$. of water, and continue the boling for 5 more minutes. Repeat this step until a clear solution is obtalned after bolling. Remove the cover glass and concentrate the solution by bolling unt1l a bolilng point of $130^{\circ} \mathrm{C}$. Is reached. Cover the beaker with a watch glass and elther transfer the solution to a constant temperature apparatus or keep the solution warm, flnally heating to just under bolling before use. If the solution is allowed to cool to approximately $60^{\circ} \mathrm{C}$. , recrystallization of aluminum nitrate will take place. It is necessary, therefore, to dilute the salting agent solution by about one third in order to prevent recrystallization if the solution cools to room temperature. Accordingly, if the solution is to stand overnight, add $35 \mathrm{ml}$. of distllled water per $100 \mathrm{ml}$. of saltIng agent solution, $\mathrm{mlx}$ well, and cover.

If the salting agent solution is to be stored, the following procedure has been found convenient. Adjust the solution to the proper concentration (bolling point, $130^{\circ} \mathrm{C}$ ) ) and transfer to a $100-$ $\mathrm{ml}$. three-necked reaction flask set on a heating mantle. Adjust the heating so that the temperature of the solution is kept at about $110^{\circ} \mathrm{C}$. In one of the necks place a water condenser, in another neck a thermometer, and in the third neck a removable ground-glass stop- 


\section{PROCEDURE 6 (Cont1nued)}

per. This third neck is utilized for pipetting the salting agent solution.

ALUMINUM NITRATE WASH SOLUTION. Add $100 \mathrm{ml}$. Of aluminum nitrate salting solution (bolling polnt, $130^{\circ} \mathrm{C}$ ) to $73 \mathrm{ml}$. of distilled water and $4 \mathrm{ml}$. of concentrated nitric ac1d.

Apparatus. Beckman DU spectrophotometer.

Heating mantle.

Three-necked reaction flask ( $1000 \mathrm{ml}$.).

Water condenser.

No. O rubber stoppers. Bo11 twice in ethyl acetate before use.

S1xty-mili1liter separatory funnels (Squibb, pear-shaped).

\section{Procedure}

Sample D1ssolution. Place an appropriate quantity ( 1 to 5 grams) of the sample in a tared welghing bottle, stopper the bottle, and welgh the bottle and contents lmmediately. Carry out a molsture determination on a separate sample if uranium is to be calculated on a dry welght basis.

Bring the sample into solution in one of three ways: (I) nitric acid treatment, (2) multiacid treatment, or (3) sugar carbon-sodium peroxide rusion.

For the nitric acld treatment, dissolve the sample in a sultable quantity of nitric ac1d and transfer the solution and insoluble residue into an appropriate volumetric flask and make up to volume. Regulate the dilution so that the allquot chosen for extraction will contain between 10 and $30 \mathrm{mg}$. of uranium oxide if the final dilution for the colorimetric finish is to be $250 \mathrm{ml}$. Adjust the acidity of the sample solution to about 5\% in nitric acid.

If nitric acid treatment is not sufficient, treat the sample with hydrochloric ac1d, nitric acid, perchloric acid, and finally sulfuric ac1d. If necessary, add a few mililiters 


\section{PROCEDURE 6 (Continued)}

of hydrofluoric acid. Fume the sample to dryness and leach the residue with nitric acid, finaliy transferring the solution and residue to an approprlate volumetric flask and adjusting to $5 \%$ in nitric acid as in the single acid treatment.

If the sample is refractory, use the sugar carbon-sodium peroxide fusion method described by Muehlberga. After dissolution of the sample in this manner, transfer the acldifled solution to an appropriate volumetric flask and dilute so that the final solution is $5 \%$ in nitric acid.

Allquot solution samples directly or dilute as required for an ethyl acetate extraction. If the sample is aliquoted directiy for an extraction, add 5 drops of concentrated nitric ac1d per 5-ml allquot of sample and standards before extraction. Where samples are diluted before aliquots are taken for extraction, adjust the acidity so that the final volume is $5 \%$ in nitric acid.

Ethyl Acetate Extraction. Place an appropriate aliquot (usualiy $5 \mathrm{ml}$.) in a $60-\mathrm{ml}$. separatory funnel, the stopcock of whlch has been lubricated with s1licone grease. Add, by means of a graduated pipet, $6.5 \mathrm{ml}$. of aluminum nitrate solution per $5 \mathrm{ml}$. of sample solution. The aluminum nitrate salting solution should be added whlle hot (above $110^{\circ} \mathrm{C}$. ). Cool the solution to room temperature and add $20 \mathrm{ml}$. of ethyl acetate. Stopper the separatory funnels with pretreated rubber stoppers. Shake the mixture for 45 to 60 seconds. Occasionally crystall1zation will take place in the separatory funnel near the stopcock. In such a case place the lower part of the separatory funnel in a beaker of hot water until the solidifled portion dissolves.

After the layers have separated, drain off the aqueous (lower) layer. Occasionally a cloudiness w1ll appear at the boundary of the aqueous and organic layer. This cloudy portion should not be drained off. Add $10 \mathrm{ml}$. of aluminum nitrate wash 
solution to the funnel and again shake the mixture for 45 to 60 seconds. Drain off the aqueous layer, once again being careful to retain the cloudy portion at the boundary in the funnel. Rinse Inside the stem of the separatory funnel with a stream of water from a wash bottle.

Water Stripping of Uranium from Ethyl Acetate Layer Followed by Sodium Hydroxide-Hydrogen Peroxide Colorimetric Finish. Add $15 \mathrm{ml}$. of water to the separatory funnel containing the ethyl acetate, stopper the flask, and shake the mixture for about 1 minute. After washing off the stopper with water, drain the aqueous layer into a volumetric flask of suitable size and wash the separatory funnel and ethyl acetate layer 4 or 5 times with $5-\mathrm{ml}$. portions of water by means of a wash bottle. Combine the aqueous fractions.

Add enough $20 \%$ sodium hydroxide solution (w./v.) to neutralize the solution and dissolve any precipltated aluminum hydroxide, then add $10 \mathrm{ml}$. In excess per $100 \mathrm{mI}$. of $\mathrm{flnal}$ volume. Add $1 \mathrm{ml}$. of $30 \%$ hydrogen peroxide per $100 \mathrm{ml}$. of final volume and make up the volume to the mark with distilled water. Read the absorbance after 20 minutes on the Beckman DU spectrophotometer at $370 \mathrm{mr}$ against a reagent blank, using $1-\mathrm{cm}$. Corex cells and a slit width of $0.2 \mathrm{~mm}$. Compare the absorbances of the samples against the absorbances of standard uranlum solutions which have been carried through the procedure at the same t1me. Choose the standards so that they cover the range into which the samples are expected to fall, using a ratio of one standard to six samples. In practice it is customary to work between the limits of 10 and $30 \mathrm{mg}$. Of urantum oxide. This is arranged by estimating the required sample welghts and diluting and sampling accordingly. The final volume for colorimetric reading is usually $250 \mathrm{ml}$. 


\section{Double Extraction of Uranium with Ethyl Acetate Followed} by Application of Differential Colorimetry. Uranium determinations requiring the highest accuracy may be carried out by a double extraction of uranlum w1th ethyl acetate followed by the application of differential colorimetry as described by Hiskey and others. $\frac{b-f}{f}$ In suct a case it is recommended that between 100 and $150 \mathrm{mg}$. of uranlum oxlde be extracted, and a wave length of $400 \mathrm{mr}$ be used during the colorimetric finish. The procedure described below has been found satisfactory.

Extract an approprlate aliquot of the sample solution with $20 \mathrm{ml}$. of ethyl acetate as described above. Draw off the aqueous layer into a second separatory funnel contalning $10 \mathrm{ml}$. of ethyl acetate. Stopper the funnels and shake the mixture for 45 to 60 seconds. Drain off and discard the aqueous layer. Add $10 \mathrm{ml}$. Of aluminum nitrate wash solution to the first ethyl acetate extract, stopper, and shake the mixture for 45 to 60 seconds. Drain off the aqueous layer into the separatory funnel containing the second ethyl acetate extract, stopper, and shake the mixture for 45 to 60 seconds. Drain off and discard the aqueous layer. Comblne the ethyl acetate fractions. Rinse the second separatory funnel with $20 \mathrm{ml}$. of water, draining the washings into the separatory funnel containing the comblned ethyl acetate fractions. Shake the mixture for I minute. Continue the water stripping as described above, collecting the fractions in an appropriate volumetric flask. Finish colorimetrically as described previously, allowing the strongly colored solution to stand 1 to 2 hours to ensure stablilty before reading as a fading effect of about 0.005 absorbance (opt1cal dens1ty) has sometImes been noted on freshly prepared samples.

Read the absorbance of the sample solution on the Beckman DU spectrophotometer at $400 \mathrm{~m} \mu$ against a reference solution 


\section{PROCEDURE 6 (Continued)}

which contains a known amount of uranlum and has been carried through the extraction and color development procedure in the same manner as the sample. Also carry along other standards contalning slightly higher and lower amounts of uranlum than the sample. Determine the concentration of uranium in the sample elther by the calibration-curve method or the correction method, as described by Neale. If the amount of uranium in the sample is not known, make a test run by taking an al1quot of the sample solution and assaying for uranlum by the more rapid single extraction method. The standard solutions to be used can then be chosen according to the result obtained.

Removal of Interfering Thorlum. After an ethyl acetate extraction, strip the uranium in water from the ethyl acetate and collect the uranium fraction in a 250-ml. beaker. Add enough $20 \%(\mathrm{w} . / \mathrm{v}$.$) sodium hydroxide solution to neutralize the solution$ and redissolve precipitated aluminum hydroxide. Then add 10$\mathrm{ml}$. excess of $20 \%$ sodium hydroxide solution and $1 \mathrm{ml}$. of $30 \%$ hydrogen peroxide per $100 \mathrm{ml}$. of final volume. Filter the solution through an $11-\mathrm{cm}$. $41 \mathrm{H}$ fllter paper (Whatman), collecting the filtrate in a volumetric flask of suitable size. Wash the paper and preclpitate once with $5 \mathrm{ml}$. of a solution of $2 \%$ sodium hydroxide containing $0.1 \mathrm{ml}$. of $30 \%$ hydrogen peroxide. Redissolve the preclpltate by washing the paper with $10 \mathrm{ml}$. of $10 \%$ nitric acld solution, collecting the washings in the original beaker. Neutralize the solution with $20 \%$ sodium hydroxide solution, and add $2 \mathrm{ml}$. In excess. Add $0.5 \mathrm{ml}$. of $30 \%$ hydrogen peroxide, and fliter off the precipitate on the original fllter paper, washing as before and collecting the filtrates In the original volumetric flask. If the precipitate on the paper is colored yellow, repeat this step. Make the solution In the volumetric flask up to volume and read the absorbance 


\section{PROCEDURE 6 (Continued)}

on the spectrophotometer. Carry standards through the same procedure as the samples.

a w. I. Muehlberg, Ind. Eng. Chem. 17, 690 (1925).

b c. F. H1skey, Anal. Chem. 21, 1440 (1949).

c C. F. Hiskey, J. Rabınowltz, and I. G. Young, Anal. Chem. 22, 1464 (1950).

d G. W. C. Milner and A. A. Smales, Analyst 79, 414 (1954).

e w. T. I. Neal, Analyst 79, 403 (1954).

$\underline{1}$ I. G. Young, C. F. Hiskey, Anal. Chem. 23, 506 (1951).

RROCEDURE 7: Uranium-237.

Source: B. Warren, IA-I72I (Fv) (1956).

\section{Introduction}

In the carrier-free method for the determination of $U^{237}$, the principal decontamination step (which is preceded by a $\mathrm{La}(\mathrm{OH})_{3}$ scavenge and partial removal of plutonium as the cupferron complex) is the extraction of uranium into $30 \%$ TBP (tert1ary butyl phosphate) in benzene. Additional decontamInation is effected by adsorption of uranium, first on an anion and then on a cation exchange resin. The uranium is finally electroplated on platinum. The chemical yielo is 40 to $60 \%$ and is determined through the use of $0^{233}$ tracer. The $U^{237}$ Is B-counted in a proportional counter with a $2.61 \mathrm{mg} / \mathrm{cm}^{2} \mathrm{Al}$ absorber, and from the number of counts the number of atoms of the isotope is calculated. Four samples can be run in about 6 hours. 


\section{Reagonts}

$U^{233}$ tracer: amount determined by the $\alpha$-counting technique employed

La carrier: $10 \mathrm{mg} \mathrm{La} / \mathrm{ml}$ [added as $\mathrm{La}\left(\mathrm{NO}_{3}\right)_{3} \cdot 6 \mathrm{H}_{2} \mathrm{O}$ ]

Fe carrier: $10 \mathrm{mg} \mathrm{Fe} / \mathrm{ml}$ [added as $\mathrm{Fe}\left(\mathrm{NO}_{3}\right)_{3} \cdot 9 \mathrm{H}_{2} \mathrm{O}$ in very dilute $\mathrm{HNO}_{3}$ ]

HCl. $0.1 \mathrm{M}$

$\mathrm{HCl}: 5 \mathrm{M}$

$\mathrm{HCl}: 10 \mathrm{M}$

$\mathrm{HCl}$ : cone.

$\mathrm{HNO}_{3}: 3 \mathrm{M}$

$\mathrm{HNO}_{3}: 5 \underline{\mathrm{M}}$

$\mathrm{HNO}_{3}$ : conc.

$\mathrm{NH}_{4} \mathrm{OH}$ : conc.

$\mathrm{NH}_{2} \mathrm{OH} \cdot \mathrm{HCl}: 5 \mathrm{M}$

$\left(\mathrm{NH}_{4}\right)_{2} \mathrm{C}_{2} \mathrm{O}_{4}$ in $\mathrm{H}_{2} \mathrm{O}: 4 \%$

TBP (terlary butyl phosphate): $30 \%$ by volume in benzene (Note 1)

Aqueous cupferron reagent: $6 \%$

Methyl red indicator solution: $0.1 \%$ in $90 \%$ ethanol

Methanol: anhydrous

Chloroform

$\mathrm{NH}_{3}: \operatorname{gas}$

$\mathrm{Cl}_{2}:$ gas

\section{Equipment}

Centr1fuge

F1sher burner

Block for holding centrifuge tubes

Pt-t1pped tweezers

Steam bath

5-ml syringe and transfer pipets

Mounting plates 
40-ml centrifuge tubes: Pyrex 8140 (three per al1quot of sample) Ion exchange columns:

$8 \mathrm{~cm} \times 3 \mathrm{~mm}$ tubing attached to bottom of 15-ml centrifuge tube

Anion resin: $5 \mathrm{~cm}$ Dowex A2-X8, 400 mesh, (Note 2) Cation resin: $5 \mathrm{~cm}$ Dowex 50-X8, 100 to 200 mesh, (Note 2) Stirring rods

Motor-driven glass stirrers

Plating set-up: same as that used in Procedure 1 except that the Pt cathode is a $I^{\prime \prime}$ disk and the glass chimney has a $7 / 8^{n}$ 1.d.

\section{Procedure}

Step 1. To an al1quot of sample not exceeding $20 \mathrm{ml}$ in a 40-m centrifuge tube, add $1 \mathrm{ml}$ of $\mathrm{U}^{233}$ tracer and 3 drops of La carrier, and bubble in $\mathrm{NH}_{3}$ gas until the precipitate which forms coagulates. Digest for $15 \mathrm{~min}$ on a steam bath, centrifuge, and discard the supernate.

Step 2. D1ssolve the precipitate in $0.6 \mathrm{ml}$ of conc. $\mathrm{HCl}$ and dilute to $10 \mathrm{ml}$ with $\mathrm{H}_{2} \mathrm{O}$. Add 5 drops of $5 \mathrm{M} \mathrm{NH}_{2} \mathrm{OH}$. $\mathrm{HCl}$ and 2 orops of Fe carrier ( $1 f$ this element is not already present), and allow to stand for $10 \mathrm{~min}$. Add $4 \mathrm{ml}$ of chloroform, $6 \mathrm{ml}$ of $6 \%$ cupferron, and extract the $\mathrm{Pu}(\mathrm{IV})$-cupferron complex by stirring for $2 \mathrm{~min}$. Remove the chloroform layer by means of a transfer plpet and discard. Extract the aqueous phase three additional times with chloroform. To the aqueous layer ado 3 drops of La carrier and bubble in $\mathrm{NH}_{3}$ gas unt1l the preclpitate formed coagulates. Digest for $15 \mathrm{~min}$ on a steam bath, centrifuge, and discard the supernate.

Step 3. D1ssolve the preclpitate in $1.6 \mathrm{ml}$ of conc. $\mathrm{HNO}_{3}$, dilute to $5 \mathrm{ml}$ with $\mathrm{H}_{2} \mathrm{O}$, add $2 \mathrm{ml}$ of TBP solution, and st1r for $2 \mathrm{~min}$. Draw off the TBP layer and transfer to a clean 40- 
ml centrifuge tube. Extract asain with $2 \mathrm{ml}$ of TBP solution and combine with the previous extract. Add $1 \mathrm{ml}$ of TBP solution to the original tube, draw it off, and combine with the other extracts.

Step 4. Wash the TBP extracts w1th two 3-ml portions of $5 \mathrm{M} \mathrm{HNO}_{3}$, discarding the washings. Bubble in $\mathrm{Cl}_{2}$ gas for $5 \mathrm{~min}$ at a vigorous rate.

Step 5. Transfer the solution to a Dowex A2 anion exchange column. Permit one-half of the solution to pass through the resin under 8 to $10 \mathrm{lb}$ pressure. Add $1 \mathrm{ml}$ of conc. HCl to the column and allow the remalnder of the solution to pass through under pressure. Wash the column tw1ce w1th 2-1/2 mI of $10 \mathrm{M} \mathrm{HCl}$ and then twice w1th $5 \mathrm{M} \mathrm{HCl}$, discarding the washings. Elute the $U$ with two $2-1 / 2-m I$ portions of $0.1 \mathrm{M} \mathrm{HCl}$, catching the eluate in a clean 40-ml centrifuge tube.

Step 6. Dilute the eluate to $10 \mathrm{ml}$ w1th $\mathrm{H}_{2} \mathrm{O}$ and pass through a Dowex 50 cation exchange column under 1 to $2 \mathrm{lb}$ pressure. Wash the resin three times with 2-1/2-mI portions of $0.1 \mathrm{M} \mathrm{HCl}$ and discard the washings. Elute the $U$ with two $2-1 / 2-\mathrm{ml}$ portions of $3 \mathrm{M} \mathrm{HNO}_{3}$ into the plating cell.

Step 7. Add $5 \mathrm{ml}$ of $4 \%\left(\mathrm{NH}_{4}\right)_{2} \mathrm{C}_{2} \mathrm{O}_{4}, 3$ drops of methy red indicator solution, and make basic by the dropwise addition of conc. $\mathrm{NH}_{4} \mathrm{OH}$. Make the solution just red to the indicator by the dropwise addition of $6 \mathrm{M} \mathrm{HNO}_{3}$, and add 3 drops in excess. Plate at $1.1 \mathrm{amp}$ and 8 volts for $1 \frac{1}{2} \mathrm{hr}$ at $80^{\circ} \mathrm{C}$. At the end of the first $10 \mathrm{~min}$, add 3 drops of methyl red solution and make ac1d with $6 \mathrm{M}^{-\mathrm{HNO}_{3}}{ }$. Check ac1dity at two additional 10-min intervals, and at the end of $40 \mathrm{~min}$ add 3 drops of conc. $\mathrm{NH}_{4} \mathrm{OH}$. At 10-min intervals thereafter check to see that the plating solution is just basic to the indicator. Remove the cell from the water bath, wash three times with methanol, 
and dismantle the cell, carefully keeping the Pt disk flat. Flame the disk over a burner. a-count the $U^{233}$, mount, and B-count in a proportional counter w1th a $2.61-\mathrm{mg} / \mathrm{cm}^{2} \mathrm{AI}$ absorber.

\section{Notes}

1. The TBP is purified before use by washing first with IM $\mathrm{NaOH}$ and then w1th $5 \mathrm{M} \mathrm{HNO}_{3}$.

2. Before use, both the anion and cation resin are washed alternately at least flve times each with $\mathrm{H}_{2} \mathrm{O}$ and $\mathrm{HCl}$, and are then stored in $\mathrm{H}_{2} \mathrm{O}$.

3. See Procedure 1 for the correction for UX activity per mg $\mathrm{U}_{3} \mathrm{O}_{8}$ on plate.

PROCEDURE 8: Radioassay of Uranium and Plutonium in Vegetation, So1l and Water.

Source: E. I. Gelger, Health Physics 1, 405 (1959).

\section{Abstract}

A method is discussed for the separation of uranium and plutonlum from vegetation, soll and water. The method is based on the extraction of uranium and plutonium from 4 to $6 \underline{N}$ nitric acid into $50 \%$ tri-n-butyl phosphate in n-tetradecane diluent. Uranium and plutonium are recovered together with sufficlent reduction in total solids to allow a-counting and pulse height analysis. Data from several hundred "spiked" samples to which uranium and plutonium were added indicate a nearly equal recovery of uranium and plutonium. Average recoveries are $76 \pm 14$ per cent for vegetation, $76 \pm 16$ per cent for so1l, and $82 \pm 15$ per cent for water. The procedure Is deslgned for samples that may be collected and analyzed 
for radloactivity as a part of a health physics regional monitorling program.

\section{Procedures}

\section{Preparation of samples}

Vegetation. Cut oven-dried vegetation into small pleces and welgh $10.0 \mathrm{~g}$ into a $150 \mathrm{ml}$ beaker. Heat the sample at $600^{\circ} \mathrm{C}$, starting with a cold muffle furnace. When only white ash remalns, remove the beaker from the muffle furnace and allow to cool. Carefully add $2 \mathrm{ml}$ of water, then add $10 \mathrm{ml}$ of $8 \mathrm{~N} \mathrm{HNO}_{3}-0.5 \mathrm{MAl}\left(\mathrm{NO}_{3}\right)_{3}$ solution. Cover the beaker w1th a watch glass and boll the solution for $5 \mathrm{~min}$. Allow to cool, add $I \mathrm{ml}$ of $2 \mathrm{M} \mathrm{KNO}_{2}$ solution and transfer the sample to a $100 \mathrm{ml}$ centrifuge tube. Use $4 \mathrm{~N} \mathrm{HNO}_{3}$ to complete the transfer. Centrifuge and decant the supernate into a $125 \mathrm{ml}$ cylindrical separatory funnel graduated at $30 \mathrm{ml}$. Wash the residue with $4 \mathrm{~N} \mathrm{HNO}_{3}$, centrifuge, and decant the wash solution to the separatory funnel. The acid normal1ty of the combined solutions at this point is 4-6 N and the total volume should not exceed $29 \mathrm{ml}$. Proceed to the extraction procedure.

So11. Grind 58 of oven-dried soll with a mortar and pestle unt1l the ent1re sample can pass through a 200-mesh sleve. We1gh $1.0 \mathrm{~g}$ of the 200 -mesh soll into a $50 \mathrm{ml}$ platinum crucible and heat the sample at $600^{\circ} \mathrm{C}$ for $4 \mathrm{hr}$. Remove the sample from the muffle furnace and allow to cool. Add $3 \mathrm{ml}$ of $70 \% \mathrm{HNO}_{3}$ and $10 \mathrm{ml}$ of $48 \%$ IF then stir the sample for $2-3$ min with a platinum rod. Heat the sample in a $200^{\circ} \mathrm{C}$ sand bath unt1l all traces of moisture are removed. Repeat this $\mathrm{HNO}_{3}-\mathrm{HF}$ treatment belng careful that the sample is completely dry before proceeding to the next step. Allow the sample to cool and then add $15 \mathrm{mI}$ of $6 \underline{\mathrm{N} \mathrm{HNO}} 3-0.25 \mathrm{M} \mathrm{Al}_{3}\left(\mathrm{NO}_{3}\right)_{3}$ solution. Cover with a watch glass and heat in the sand bath for $5 \mathrm{~min}$. 
Allow to cool and decant the solution through a filter, such as Whatman no. 40, Into a $125 \mathrm{ml}$ cylindrical separatory funnel graduated at $30 \mathrm{ml}$. Leave as much of the residue as possible in the cruclble and repeat the hot $6 \mathrm{~N} \mathrm{HNO}_{3}-0.25 \mathrm{M} \mathrm{Al}\left(\mathrm{NO}_{3}\right)_{3}$ treatment. Allow to cool and then fllter. Proceed to the extraction procedure.

Water. Place 1 l. of the sample in a 1.51 . beaker and 1 f basic, neutralize with nitric ac1d. Add $15 \mathrm{ml}$ of $70 \% \mathrm{HNO}_{3}$ and evaporate to $30-40 \mathrm{ml}$. Decant the solution through a filter, such as Whatman no. 40, Into a $100 \mathrm{ml}$ beaker. Wash the 1.51. beaker, the residue and the fliter with $4 \mathrm{~N} \mathrm{HNO}_{3}$. Evaporate the combined solution in the $100 \mathrm{ml}$ beaker to $5 \mathrm{ml}$. Add $20 \mathrm{ml}$ of $4 \mathrm{~N}$ $\mathrm{HNO}_{3}$, cover with a watch glass, and heat for $5 \mathrm{~min}$. Transfer the sample to a $125 \mathrm{ml}$ cylindrical separatory funnel graduated at 30 $\mathrm{ml}$. Wash the beaker with $4 \mathrm{~N} \mathrm{HNO}_{3}$ and transfer to the separatory funnel, belng careful that the total volume in the separatory funnel does not exceed $29 \mathrm{ml}$. Proceed to the extraction procedure. Extraction

Add $1 \mathrm{ml}$ of $2 \mathrm{M} \mathrm{KNO}_{2}$ to the sample in the $125 \mathrm{ml}$ cylindrical separatory funnel. Dilute to the $30 \mathrm{ml}$ mark with $4 \mathrm{~N} \mathrm{HNO}_{3}$ and stir the solution briefly. Add $30 \mathrm{ml}$ of $50 \%$ TBP in n-tetradecane. Agitate the solution vigorously for $4 \mathrm{~min}$ with an alr-driven stirrer. Discard the acid portion (lower layer). Wash the TBP portion with $4 \mathrm{~N} \mathrm{HNO}_{3}$ and again discard the acid portion. Back extract with seven $15 \mathrm{ml}$ portions of distilled water, collecting the strip solution in a $150 \mathrm{ml}$ beaker. Evaporate the combined aqueous portions to $10-15 \mathrm{ml}$, then quantitatively transfer the solution to a flamed stalnless steel planchet. Allow to dry under a heat lamp, flame the planchet to burn off organic residue, and count on an a-counter. Retain for pulse-height analysis if the $\alpha$-count exceeds a specified level. 
PROCEDURE 9: Separation of Uranium by Solvent Extraction with Tr1-n-octylphosphine oxide.

Source: C. A. Horton and J. C. White, Anal. Chem. 30, 1779 (1958).

\section{Abstract}

A simple, rapid method for the determination of uranium in Impure aqueous solutions was developed. Uranlum(VI) is extracted by $0.1 M$ tri-n-octylphosphine oxide in cyclohexane from a nitric acld solution. A yellow color is formed in an aliquot of the organic extract by addition of dibenzoylmethane and pyridine in ethyl alcohol. Interference by cations 1 s minimized or eliminated by selective reduction, by fluoride complexation, or by absorbance measurement at $416 \mathrm{~m}$ ' rather than $405 \mathrm{mH}$, the wave length of maximum absorbance. Interference by excess fluoride or phosphate is eliminated by addition of aluminum nitrate before extraction. The range of the method is 20 to $3000 \gamma$ of uranium in the original solution, and the standard deviation is $\pm 2 \%$.

\section{Apparatus and Reagents}

Absorbance measurements were made with a Beckman DU spectrophotometer, using $1.00-\mathrm{cm}$. Corex or silica cells.

Phase equilibration for most extractions was carried out in the bottom portion of the apparatus (see accompany1ng figure). Phase separation and removal of aliquots of the upper organic phase occurred after inverting the apparatus so that the solution was in the portion of this apparatus shown on top in the figure. Some extractions were carried out in 60- or $125-\mathrm{ml}$. separatory funnels. STANDARD URANIUM SOLUTIONS. A stock solution of $24.0 \mathrm{mg}$. Of uranium(VI) per $\mathrm{ml}$. was prepared by heating 7.10 gram of uranium (IV-VI) oxide $\left(\mathrm{U}_{3} \mathrm{O}_{8}\right)$, prepared from pure uranium(VI) oxide $\left(\mathrm{UO}_{3}\right)$, in $10 \mathrm{ml}$. of perchloric acld to dissolve $1 t$, and then diluting the resultant solution to $250 \mathrm{ml}$. With water. Dilutions of this solution were made as required. Another standard solution in 5\% sulfuric acid was also used in checking the spectrophotometric calibration curve. 
DIBENZOYIMETHANE. A solution that contained 1 gram of dibenzoylmethane (1,3-d1phenyl-1,3-propanedione), obtalned from Eastman Kodak Co., in $100 \mathrm{ml}$. of $95 \%$ ethyl alcohol was prepared for use as the chromogenic agent.

PYRIDINE. For most of the work, a solution prepared by mixing $I$ volume of redistilled reagent grade pyridine and I volume of $95 \%$ ethyl alcohol was used.

TRI-n-OCTYLPHOSPHINE OXIDE. A $0.10 \mathrm{M}$ solution of this material, prepared in the authors' laboratory, in cyclohexane, Eastman 702 or 7025, was used. This phosphine oxide is now avallable commerc1ally from Eastman (EK 7440).

Sod1um b1sulf1te, $10\left(w_{.} / v_{\text {. }}\right)$ \% in water, stored at about $10^{\circ} \mathrm{C}$. Hydroxylamine sulfate, $2 \underline{M}$ in water.

Potasslum rluoride, $I M$ in water, stored in a polyethylene bottle.

\section{Procedure}

Preliminary Treat ment A. Samples which do not contain interfering 1ons. P1pet a 0.5 - to $8 \mathrm{ml}$. aliquot of a solution in nitric, perchloric, or sulfuric acid, estimated to contain 15 to $2500 \gamma$ of uranium(VI), into the bottom portion of the extraction vessel. By the addition of strong 10M sodium hydroxide, nitric acid, or sodium nitrate, adjust the solution so that a total aqueous volume of $10 \mathrm{ml}$. W1ll be $I$ to $3 \underline{N}$ in hydrogen $10 \mathrm{n}$ and 2 to $4 M$ in nitrate 1on. For almost neutral solutions, $2 \mathrm{ml}$. of concentrated nitric ac1d W111 give the correct concentrations for a 10-ml. aqueous volume. Adjust the total volume to $10 \mathrm{ml}$. Up to $12 \mathrm{ml}$. of aqueous solution can be shaken with 5 or $10 \mathrm{ml}$. of extractant in the apparatus without undue splashing. If the total aqueous volume is greater than $12 \mathrm{ml}$. after adjusting the acidity and nitrate content, perform the extraction in a separatory funnel instead of the special extraction vessel. 
B. Samples containing iron(III), chromium(VI), or vana$\operatorname{dium}(V)$. Pipet a $0.5-$ to $6-\mathrm{ml}$. aliquot of a solution in dilute perchloric or sulfuric medium, estimated to contain 15 to $2500 \gamma$ of uranium(VI), into the bottom portion of the extraction vessel. Reduce the 1 ron(III) to 1 ron(II), the chromium(VI) to chromium(III), and the $\operatorname{vanadium}(V)$ to $\operatorname{vanadium}(I V$ or III) without reducing the uranium(VI) to uranium(IV). Sodium bisulfite is a satisfactory reductant if the solutions are bolled to remove excess sulfur dioxide. Hydroxylamine sulfate is also a satisfactory reductant, but amalgamated zinc is unsuitable. Add sufficlent nitric acid or souium nitrate and water so that the final aqueous volume of 8 to $12 \mathrm{ml}$. W11l be 1 to $3 \mathrm{~N}$ in hydrogen $10 \mathrm{n}$ and 2 to $4 \mathrm{M}$ in nitrate $10 \mathrm{n}$.

c. Samples containing titanium, thorium, hafnium, zirconium, or 1ron(III), but only traces of aluminum. P1pet a $0.5-$ to $6-\mathrm{ml}$. aliquot of a solution in dilute nitric, perchloric, or sulfuric acid, estimated to contain 15 to $2500 \gamma$ of uranium, into the bottom of an extraction vessel. Add sufficlent base or acid, nitrate, and water to give a volume of about $8 \mathrm{mI}$., such that the solution is 1 to $3 \mathrm{~N}$ in hydrogen $10 \mathrm{n}$ and 2 to $4 \mathrm{M}$ in nitrate lons. Add up to a maximum of $2.5 \mathrm{ml}$. of $1 \mathrm{M}$ potass 1 um fluoride when the concentrations of interfering lons are unknown. If high concentrations of these lons are known to be present, additional fluorlde can be tolerated.

D. Samples containing excessive fluoride or phosphate. P1pet an aliquot into an extraction vessel, and adjust the ac1d and nitrate contents as in Treatment $C$. Add sufficient aluminum nitrate to complex the fluorlde and phosphate estimated to be present. The total volume should be $12 \mathrm{ml}$. or less.

Extraction. For amounts of uranium estimated to be under about $1400 \%$, pipet $5 \mathrm{ml}$. of $0.1 \mathrm{M}$ tri-n-octylphosphine oxide in cyclohexane into the extraction vessel containing the treated 


\section{PROCEDURE 9 (Continued)}

sample. For 1400 to $3000 \gamma$ of uranium, use $10 \mathrm{ml}$. of extractant. Attach the top of the vessel and shake for 10 minutes on a reclprocating shaker. Invert the extraction apparatus for separation of the phases and removal of aliquots of the upper organic phase.

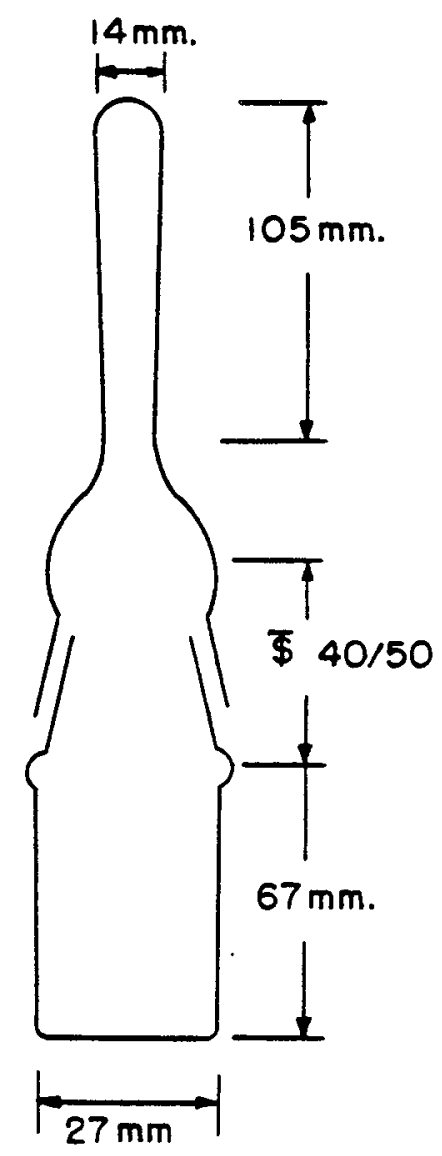

\section{EXTRACTION APPARATUS}

\section{USED IN Procedure 9.}

Color Development. Transfer by plpet a 1-, 2-, or 3-ml. aliquot of the organic extract into a 10- or 25-ml. volumetric flask such that the final solution will contain between 0.5 and $10 \gamma$ of uranium per $\mathrm{ml}$. For $10-\mathrm{ml}$. volumes, add $1.0 \mathrm{ml}$. of $50 \%$ 
pyridine in ethyl alcohol, $2 \mathrm{ml}$. of $1 \%$ (w./v.) $\%$ dibenzoylmethane in ethyl alcohol, and $95 \%$ ethyl alcohol to volume. For 25-ml. volumes, use $2.5 \mathrm{ml}$. of pyrldine and $5 \mathrm{ml}$. of dibenzoylmethane. After 5 or more minutes, measure the absorbance at $405 \mathrm{mp}$ in 1 -cm. cells, using $95 \%$ ethyl alcohol as a reference solution. For samples receiving Treatment $C$, also measure the absorbance at $416 \mathrm{m \mu}$. A blank should be carrled through the entire procedure da11s. Calculate the uranium content using the factors obtained by extracting standard pure uranfum solutions as directed in Treatment $A$, and measured at both 405 and $416 \mathrm{~mm}$.

PROCEDURE 10: Rad1ochemical Determination of Jran1um-237. Source: F. I. Moore and S. A. Reynolds, Anal. Chem. 31, 1080 (1959).

\section{Abstract}

A rad1ochemleal method for the determination of uranium-237 1. based on complexing the uranyl ion in alkaline solution with hydrox lamine hydrochloride, followed by scavenging with zirconium hydroxide and extraction of the uranium from hydrochloric ac1d solution with trilsooctylamine-xylene. The technique has been applied successfully to the determination of uranium-237 in homogeneous reactor fuel solutions.

\section{Preparation and Standardizetion of Uranium Carrier}

We1gh out approximately 50 grams of uranyl nitrate hexahydrate. Dissolve and make to 1 liter with 2 Mitric ac1d. Standardize the camier by plpetting 5-ml. aliquots 1nto 50-ml. glass centriruge cones and precipltating ammonium diuranate by adding concentrated amonium hydroxide. Filter quantitatively through No. 42 Whatman fliter paper and 1gnite in porcelain cruclbles at $800^{\circ} \mathrm{C}$. for 30 minutes. Weigh as $\mathrm{U}_{3} \mathrm{O}_{8}$. 


\section{PROCEDURE 10 (Continued)}

\section{Procedure}

In a 40-ml. tapered centrifuge tube add $1 \mathrm{ml}$. of uranlum carrier and $0.2 \mathrm{ml}$. of zirconium carrier (approximately $10 \mathrm{mg}$. per ml. of zirconium) to a sultable allquot of the sample solution. Dilute to approxlmately $10 \mathrm{ml}, \mathrm{mix}$ well, and precipltate ammonium diuranate by the addition of concentrated anmonium hydroxide. Centrifuge for 2 minutes and discard the supernatant solution. Wash the precipltate once with $15 \mathrm{ml}$. of ammonium hydroxide ( 1 to 1 ). Dissolve the precipitate in $I$ to $2 \mathrm{ml}$. of concentrated hydrochlorlc acld solution, dilute to about $10 \mathrm{ml}$, add $1 \mathrm{ml}$. of hydroxylamine hydrochloride $(5 \mathrm{M})$, and $\mathrm{mix}$ well. Precipitate. zirconium hydroxide by the addition of concentrated ammonium hydroxide. Centrifuge for 2 minutes, add $0.2 \mathrm{ml}$. of zirconium carrier, and stir the supernatant solution, being careful not to disturb the precipitate. Centrifuge for 2 minutes. Add $0.2 \mathrm{ml}$. of zirconium carrier and repeat.

Transfer the supernatant solution to another 40-ml. centr1fuge tube, add several drops of phenolphthalein, and adjust the pH to approximately 8 by adding concentrated hydrochloric acid solution dropwise. Add an equal volume of concentrated hydrochloric acid solution and extract for approximately 0.5 minute w1tha one-half volume portion of $5 \%(w . / v$.$) trisooctylamine-$ xylene. Discard the aqueous phase. Wash the organic phase by mixing for 0.5 minute with an equal volume portion of $5 \mathrm{M}$ hydrochloric ac1d solution. Repeat the wash step. Strip the uranium from the organic phase by mixing thoroughly with an equal volume portion of $0.1 \mathrm{M}$ hydrochloric ac1d solution for 0.5 minute. Discard the organic phase.

Add $0.2 \mathrm{ml}$. of $z 1$ rcontum carrier, $\mathrm{mlx}$ well, and repeat the above procedure, beginning with the precipltation of ammonium diuranate. 
Finally, preclpitate ammonium diuranate by the addition of concentrated ammonium hydroxide. Centrifuge for 2 minutes. Decant and discard the supernatant solution. F1lter on No. 42 whatman filter paper and 1 gnite at $800^{\circ} \mathrm{C}$. for 30 minutes.

We1gh the urantum oxide on a tared aluminum fo11 $(0.0009$ Inch), fold, and place in a $10 \times 75 \mathrm{~mm}$. culture tube. Insert a sultable cork and count the uranlum-237 gamma radioactivity in a well-type scintillation counter. Count the same day of the last chemical separation.

Apply a blank correction if very low uranium-237 levels are being determined. Determine this correction by taking the same aliquot of uranium carrier through the exact procedure described above. The blank correction is due primarlily to the gamma radioactivity associated with the uranium-235 in the uranium carrier.

PROCEDURE 1I: Separation of Uranium and B1smuth.

Source: A. Krishen and H. Freiser, Anal. Chem. 29, 288 (1957). Ed1tor's note: Uranium has been separated from a 5000-fold excess of bismuth by the following method. Uranium 1s, however, not completely extracted (only $98.48 \%$ at $\mathrm{pH}$ values greater than 6.5). If this correction is applied, uranium is quantitatively determined by polarographic means within an experimental error of $\pm 1 \%$.

\section{Reagents}

Acetylacetone. Commerclal acetylacetone was purified by the method described by Steinbach and Freiser.

\section{Procedure}

Analys1s. The method of Souchay and Faucherre, $\underline{b}$ using $0.1 \mathrm{M}$ EDTA and $2 \mathrm{M}$ sodium acetate as a supporting electrolyte, was found to be sultable in the presence of alssolved acetylacetone. The half-wave potential was shifted to -0.47 volt but the wave helght was not affected. 
PROCEDURE 11 (Continued)

Separation. Solutions of uranyl sulfate containing 0.1 and $1.0 \mathrm{mg}$. of uranium were mixed with different amounts of blsmuth trichloride solution. A solution of the disodium salt of EDTA was added to give a bismuth to EDTA ratio of 1 to 30 . The $\mathrm{pH}$ of the mixture was ralsed to 7.5 by careful addition of IN sodium hydroxide. Then approximately $10 \mathrm{ml}$. of acetylacetone was added and the $\mathrm{mix}-$ ture shaken for 10 minutes. The acetylacetone phase was separated, flitered, and made up to a volume of $10 \mathrm{ml}$., of which $2 \mathrm{ml}$. was withdrawn by a pipet into a 10-ml. borosilicate glass volumetric flask. The rlask was very gently warmed untll the liquid was reduced in volume to about $0.5 \mathrm{ml}$. Then the supporting electrolyte was added and the resulting solution deaerated for 5 minutes in a 10-ml. Iingane-Laitinen H-type polarographic electrolysis cell. The polarogram was then recorded and the concentration of uranium found from sultable calibration curves.

a J. F. Steinbach, H. Freiser, Anal. Chem. 26, 375 (1954).

b P. Souchay, J. Faucherre, Anal. Chlm. Acta 3, 252 (1949).

PROCEDURE 12: Isolation and Measurement of Uranium at the Microgram Level.

Source: C. L. Rulfs, A. K. De, and P. J. Elving, Anal. Chem. 28, 1139 (1956).

\section{Abstract}

A double cupferron separation of uranium using extraction has been adapted to the micro level. Uranlum(VI) does not extract In the first stage, which removes many potentlally interfering elements. Uranium(IV), obtained in the residual aqueous solution by reduction at a mercury cathode, is simultaneously extracted as the cupferrate into ether, from which it can be re-extracted into 
nitric ac1d. A relatively simple one-plece glass apparatus is used for all operations. The uranium recovery at the miligram level in an inftial $30-\mathrm{ml}$. sample was determined colorimetricaliy as $94 \%$. With 0.03 to $0.13 \gamma$ of radioactive uranium-233 tracer and $20 \gamma$ of natural uranium as carrier, the recovery is $86 \%$; the latter Includes the additional step of electrodeposition of the uranium onto a platinum planchet prior to measurement by alpha counting, which is only $94 \%$ complete. The decontamination possible with this procedure was checked with $0.07 \gamma$ quantities of urantum233 in the presence of high mixed fission product activities; $85 \%$ recovery was obtalned, containing only $0.9 \%$ of the fission product alpha activity (assumed to be uranium).

\section{Apparatus}

The reaction cell and simple electrical circult used is shown in the accompanying figure.

The electrolysis vessel, C, is protected from mercury lons diffusing from the working reference calomel electrode, $A$, by a medium glass frit between $B$ and $C$, and a fine frit backed with an agar plug between $B$ and $A$. Between runs, cell $C$ is kept fllled with saturated potassium chloride solution.

The apparatus for the electrodeposition of uranium onto platinum disks or planchets and for alpha-counting measurement of the resulting uranlum plates have been described. a Beta act1vity was measured by a chlor:ne-quenched argon-f11led GelgerMillier counter (1.4 mg. per sq. cm. of window) with a Model 165 scaler; a scintillation well counter with a thallium-activated sodium lodide crystal and a Model 162 scaler was used for gammaactivity measurement of solutions (ca. $5 \mathrm{ml}$.) contalned in a 13 $x 150 \mathrm{~mm}$. test tube. The scalers and counters are made by the Nuclear Instrument and Chemical Corp. For examination of the gamma-ray spectrum, a gamma-ray scintillation spectrometer (bullt 
In the Department of Chemistry, Un1versity of Michigan) was used through the courtesy of $w$. Wayne Melnke.

\section{Reggents}

All chemicals used were of C.P. or reagent grade unless otherwise specifled. The ethereal cupferron solution used (200 to $300 \mathrm{mg}$. of cupferron per $50 \mathrm{ml}$.) was actually a hydrogen cupferrate solution; the ether and cupferron were mixed in a mixing cylinder with 5 to $10 \mathrm{ml}$. of 10 to $20 \%$ sulfuric ac1d and shaken until dissolution was complete.

\section{Procedures}

Reductive Extraction. At the commencement of a run, bridge $B$ is flushed through stopcock 2 by filling $B$ with fresh potassium chloride solution from the funnel through $1 . C$ is drained and Ilnsed; 1 is left open for a time to flush the frit. With 3 closed, 4 to $5 \mathrm{ml}$. of triple-distilled mercury is placed in C. About $30 \mathrm{ml}$. of uranyl sulfate solution $(0.5$ to $5 \mathrm{mg}$. of uranium and 0.5 to $1.5 \%$ in sulfuric acid) is added and a potentlal of -0.35 volt vs. S.C.E. Is applied to the mercury. About 15 to $20 \mathrm{ml}$. of the ether cupferron solution is added. Stirring is adjusted at just over the minimal rate for efficlent current flow (usualiy about $0.2 \mathrm{ma}$. Flows without stirring and 1.2 to $2.6 \mathrm{ma}$. with stirring).

Stopcock $I$ is opened for about 30 seconds at approximately 5-minute 1ntervals throughout the run to minimize any loss of uranium into the bridge. At 15- or 20-minute intervals, stirring is interrupted, the ether extract is bled through stopcock 4 into cell $\mathrm{D}$, and 15 to $20 \mathrm{ml}$. of fresh ether-cupferron solution is added. Runs of 40- to 55-minute total duretion appear to be adequate. Three increments of ether-cupferron solution were usually used, followed by a 5- to $10 \mathrm{~m}$. pure ether rinse at the conclusion of the run. (See Note 2.) 


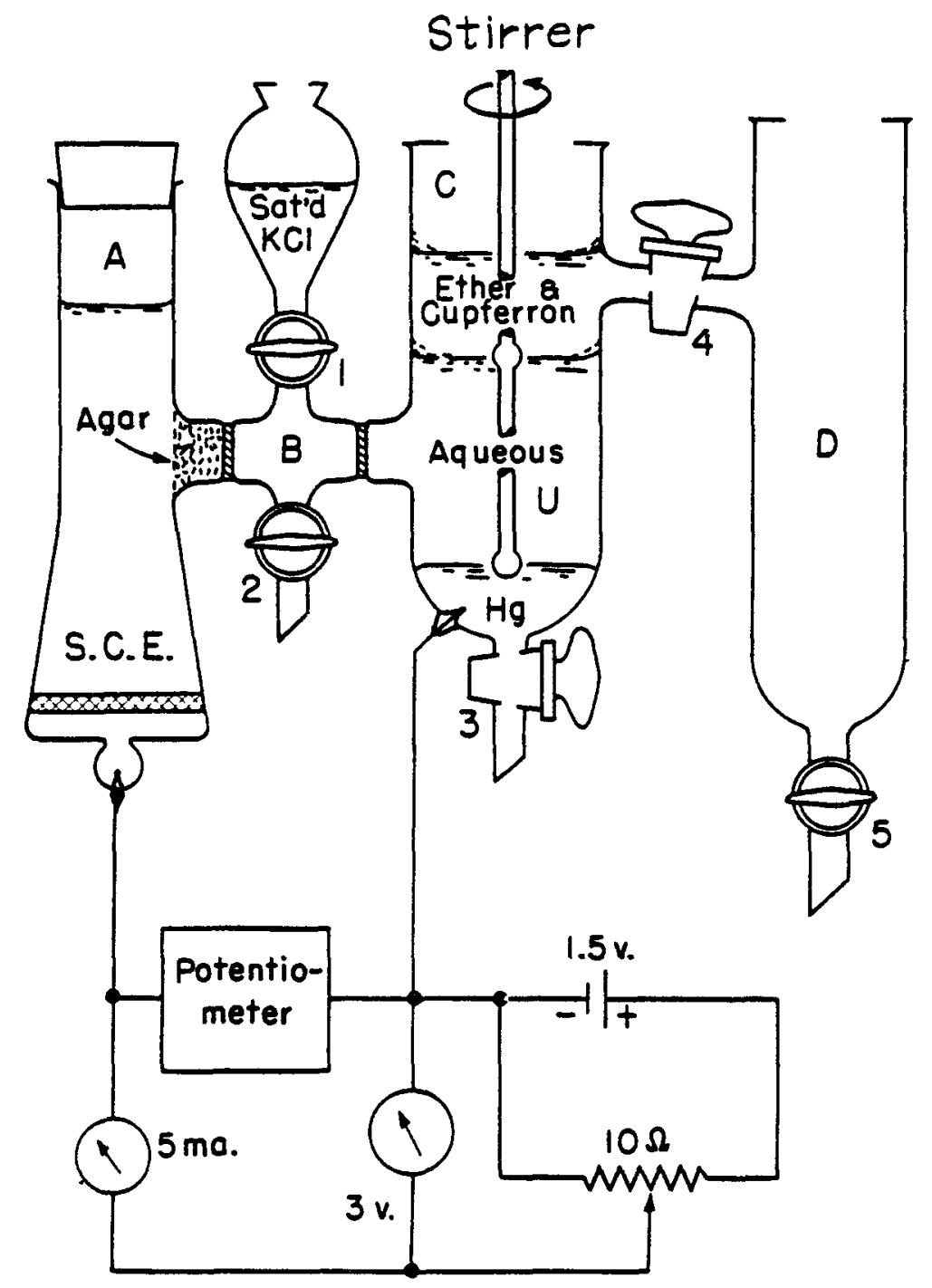

ELECTRICAL CIRCUIT FOR ELECTROCHEMICAL REDUCTION OF URANIUM FOR Procedure 12.

Extraction and Measurement at Microgram Uranium Level. A solution of uranium-233 $\left(10^{-7}\right.$ to $10^{-8}$ gram) together with about $20 \gamma$ of natural uranium (as sulfate) was submitted to reductive extraction with cupferron for about 50 to 60 minutes. The uranlum (IV/III) cupferrate was then re-extracted in cell D from the ether solution into three successive 15-ml. portions of $7 \mathrm{M}$ 
nitric acid. The combined nitric acid extract was evaporated to about $5 \mathrm{ml}$., treated with 25 to $30 \mathrm{ml}$. of concentrated $\mathrm{n} 1 \mathrm{tr} 1 \mathrm{c}$ and $2 \mathrm{ml}$. of perchloric acid, and then evaporated to dryness. The residue was digested with $10 \mathrm{ml}$. of $0.1 \mathrm{M}$ nitric acid for a few minutes; the solution obtained, after addition of about $10 \gamma$ more of natural uranium (as sulfate), was used for electrodeposition of the uranium onto a platinum planchet from an oxalate medium. A windowless flow counter with $Q$-gas was used for counting the alpha emission from the electrodeposited uranium. a

The whole operation took about 4 to 5 hours. Each measurement of alphas from the samples was calibrated by counting a uranium oxide standard (National Bureau of Standards No. 836-5).

Note 1 . In some runs the current dropped to a low level soon after the requisite number of coulombs had passed for about a 3electron reduction of the uranium present. In other cases, the current did not decrease, but discontinuance of the run beyond any point where twice the theoretical current had passed gave satisfactory uranium recovery. In the latter cases, a gray etherInsoluble, but alcohol-soluble precipltate (apparently a mercury cupferrate), was usually evident in the aqueous phase. The current efflciency for the desired process appeared to be good in most runs.

The comblned ether extracts may be re-extracted in cell $D$ by Inserting a clean stirrer, or they may be transferred with rinsing Into a clean separatory funnel. Three extractions with 20 to 30 $\mathrm{ml}$. each of $0.5 \mathrm{M}, 4 \mathrm{M}$, and $0.5 \mathrm{M}$ nitric acid were adequate to reextract uranium into aqueous solution.

a c. I. Rulfs, A. K. De, P. J. Elving, J. Electrochem. Soc. 104, 80 (1957). 
PROCEDURE 13: The Determination of Uranium by Solvent Extraction. Source: R. F. Clayton, W. H. Hardw1ck, M. Moreton-Sm1th and R. Todd, Analyst $\underline{83}, 13$ (1958).

\section{Abstract}

The development of solvent-extraction methods for determining trace amounts of uranium-233 in 1rradiated thorlum is described. Thorlum and 1ts alpha-emitting daughters are complexed with EDTA, and, when uranium-233 is extracted as 1 ts diethyld1thlocarbamate complex, only b1smuth-2l2 accompanies 1 . This is immaterial for colorimetric or fluorimetric finishes, but, for determination of the uranium-233 by alpha counting, the b1smuth-212 must first.be allowed to decay. If, however, the uranlum-233 is extracted as 1ts 8-hydroxyquinoline complex, no alpha emitter accompanies it and concentrations of uranium-233 ranging from $100 \mathrm{~kg}$ per $\mathrm{ml}$ down to $0.01 \mathrm{\mu g}$ per $\mathrm{ml}$ in $0.7 \mathrm{M}$ thorlum solution have been determined in this way. METHOD FOR DETERMINING URANIUM-233 IN THORIUM NITRATE SOIUTIONS BY EXTRACTION WITH OXINE

\section{REAGENTS --}

Oxine solution A--A 10 per cent $w / v$ solution of 8-hydroxyquinoline in 1sobutyl methyl ketone.

Oxine solution $B--A 2.5$ per cent $w / v$ solution of 8-hydroxyquinoline in 1sobutyl methyl ketone.

EDTA solution-Dissolve 372.9 g of the disodium salt of ethylenedlaminetetra-acetic ac1d in $500 \mathrm{ml}$ of water containing $80 \mathrm{~g}$ of sodium hydroxide and make up to 1 liter.

$I \mathrm{mI} \equiv 232 \mathrm{mg}$ of thorlum.

Nitric acid, $\mathrm{N}$.

Ammonia solution, sp. Gr. 0.880 .

Ammonia solution, $0.2 \mathrm{~N}$.

Bromothymol blue indicator solution.

Ant1-creeping solution--A 20 per cent solution of ammonium 
chloride containing 2 per cent of a water-soluble glue (Stephen's steflx was found to be sultable).

PROCEDURE FOR 0.01 TO I $\mathrm{Hg}$ OF URANIUM-233 PER ml--

With a pipette place a suitable volume of sample solution, containing not more than $600 \mathrm{mg}$ of thorlum, in a 40-ml centrifuge tube fitted with a glass stirrer. Add EDTA solution to give about a 10 per cent excess over the thorium equivalent and then add 3 drops of bromothymol blue indicator solution.

Ada ammonia solution, sp. gr. 0.880 , unt1l the indicator turns blue. Return the color of the indlcator to yellow by adding $\underline{N}$ nitric acid and then add $0.2 \underline{N}$ ammonia solution unt1l the color of the indicator Just turns back to blue ( $\mathrm{pH} \mathrm{7)}$. Add $2 \mathrm{ml}$ of oxine solution $A$, stir for 5 minutes, spin in a centrifuge to separate the phases and then stopper the tube.

Evaporate duplicate $0.25-\mathrm{ml}$ portions of the solvent phase slowly on stainless-steel counting trays that have had 1 drop of ant1-creeping solution evaporated at their centers. $\mathrm{a}$ Heat the trays to redness in the flame of a Meker burner, c00l and count. PROCEDURE FOR I TC 100 HE OF URANIUM-233 PER MI--

With a plpette place a sultable volume of sample solution, containing about $10 \mathrm{Hg}$ of uranium-233, in a 40-ml centrifuge tube and dilute to $3 \mathrm{ml}$ with water. Add EDTA solution to give a 10 per cent excess over the thorlum equivalent. Add 2 drops of bromothymol blue indlcator solution and adjust the $\mathrm{pH}$ to 7 as previousiy described.

Add $5 \mathrm{ml}$ of oxine solution $B$, stir for 5 minutes, spin in a centrifuge to separate the phases and then stopper the tube. Evaporate duplicate 0.1 or $0.25-\mathrm{ml}$ portions of the solvent phase for counting, as before.

Note that for a fluorimetric finish to either procedure, sultable duplicate portions of the solvent phase should be 
evaporated in platinum fluorimeter dishes before fusion with sodium fluoride.

METHOD FOR DETERMINING URANIUM-233 IN THORIUM NITRATE SOLUTIONS BY EXIRACTION WITH SODIUM DIETHYIDITHIOCARBAMATE

\section{REAGENTS--}

Hexone.

Sodlum diethyld1thlocarbamate solution--A freshly prepared and p1ltered 20 per cent $w / v$ aqueous solution. EDTA solution--Prepared as described in reagents list, p. 377. Amonium nitrate solution, 2 M. Ammon1a solution, sp. gr. 0.880 . Nitric acid, concentrated and $N$. Screened methyl orange Indicator solution. Ant1-creeping solution--A 20 per cent solution of ammonium chloride containing I per cent of a water-soluble glue. PROCEDURE FOR I TO $100 \mathrm{\mu g}$ OF URANIUM-233 PER mi--

With a pipette place a suitable volume of sample solution, contalning about $10 \mathrm{\mu g}$ of uran1um-233, in a 40-ml centrifuge tube fltted with a glass stirrer. Dilute to $4-\mathrm{ml}$ with $2 \mathrm{M}$ ammonium n1trate and add EDTA solution to glve a 10 per cent excess over the thorium equivalent. Stir and make just alkaline to screened methyl orange by adding ammonia solution and then add $0.5 \mathrm{ml}$ of sodium diethyld1thiocarbamate solution.

St1r and add $N$ nitric ac1d until the solution is malue (not red). Add $5 \mathrm{ml}$ of hexone, stir for 5 minutes and add more acid to maintain the mauve color if necessary. Spin in a centrifuge to separate the phases and then stopper the tube.

Evaporate sultable duplicate portions of the solvent phase on stainless-steel counting trays that have had 1 drop of anticreeping solution evaporated at their centers. Heat the trays to redness in the flame of a Meker burner, allow the bismuth-212 
to decay, and then count. Alternatively, for a fluorimetric finish, evaporate duplicate portions of the solvent phase in platinum fluorimeter dishes for fusion with sodium fluoride. Note that greater sensitivity can be obtained by starting with a larger volume of sample or by evaporating larger portions of the solvent phase.

a w. H. Hardw1ck, M. Moreton-Smith, Analyst $\underline{83}, 9$ (1958).

PROCEDURE 14: Uranium Radiochemical Procedure Used at the University of California Radiation Laboratory at Livermore. Source: E. K. Hulet, UCRI-4377 (1954).

Decontamination: $3 \times 10^{12}$ Atoms of $v^{237}$ isolated from a 3-dayold mixture contalning $10^{14}$ fissions showed no evidence of contamination when decay was followed through three half lives.

Y1eld: $\quad 30$ to 50 percent.

Separation time: About four hours.

Reagents: Dowex $A-I$ resin (fall rate of $5-30 \mathrm{~cm} / \mathrm{min}$ ).

Zinc dust, 1sopropyl ether.

$2 \mathrm{MB}\left(\mathrm{NO}_{3}\right)_{2}$ with $\mathrm{IM} \mathrm{HNO}_{3}$.

2M HCl with 2M HF.

1. To the solution containing the activity in $\mathrm{HCl}$ in an Erlenmeyer flask, add uranium tracer in $\mathrm{HCl}, 1 \mathrm{ml}$ of conc. formic acld and several $\mathrm{ml}$ of conc. $\mathrm{HCl}$.

2. Bo1l gently unt1l volume is $-2-3 \mathrm{ml}$, replenishing the solution with several $\mathrm{ml}$ of formic acid during the bolling.

3. Transfer to 20-ml Lusterold centrifuge cone, rinsing flask twice with $1-2 \mathrm{ml}$ of water and add 2-3 $\mathrm{mg}$ of $\mathrm{La}^{++}$. Add $\mathrm{I}$ $\mathrm{ml}$ of conc. HF, stir, heat, and centrifuge. 
4. Transfer supernatant to 20-ml Lustero1d centrifuge cone, add 2-3 mg Lat+, st1r, heat, and centrifuge.

5. Transfer supernatant to 20-ml Lustero1d, add 5-10 $\mathrm{mg} \mathrm{La}^{++}$, $1 / 2 \mathrm{ml}$ of conc. HCl and heat in a water bath. When the solution is hot, add small portions of zinc dust and stir. About three small additions of zinc dust should be made over a halfhour period with vigorous stirring after each addition. If the zinc dust tends to ball and sink to the bottom of the tube at any time, addition of more conc. HCl w1ll solve this problem. When all the zinc from the last addition has dissolved, add 4 or $5 \mathrm{ml}$ of water and $1 \mathrm{ml}$ of conc. HF. Stir, cool, and centrifuge, retalning the $\mathrm{LaF}_{3}$ precipltate. Wash prec1pitate w1th $2 \mathrm{ml}$ of $2 \underline{\mathrm{M}} \mathrm{HCl}+2 \underline{\mathrm{M}} \mathrm{HF}$.

6. Dissolve the precipitate with $6 \mathrm{M} \mathrm{HNO}_{3}$ saturated with $\mathrm{H}_{3} \mathrm{BO}_{3}$, stirring and heating. Transfer the solution to a 40-ml glass centrlfuge cone, washing out the Iusterold cone with water.

7. Add several drops of $\mathrm{H}_{2} \mathrm{O}_{2}$ and stir and heat. Add $2 \mathrm{mg} \mathrm{Fe}$ and make solution bas1c $\mathrm{w}_{1}$ th $\mathrm{NH}_{4} \mathrm{OH}$ and some $\mathrm{NaOH}$. Heat, st1r, and centrifuge. Wash the preclpitate with $2 \mathrm{ml}$ of water.

8. Dissolve the preclpitate in one to two drops of conc. $\mathrm{HNO}_{3}$ and heat. $\mathrm{CoOl}$, add $10 \mathrm{ml} 2 \mathrm{Mg}\left(\mathrm{NO}_{3}\right)_{2}+1 \mathrm{M} \mathrm{HNO}_{3}$ saturated w1th ether. Equilibrate twice with 10-15 ml of disopropyl ether.

9. P1pet the ether phase into a clean 40-ml cone and equilibrate ether layer w1th $3 \mathrm{ml}$ of corc. HCl. Plpet off and discard ether layer. Heat HCl for -30 seconds and again plpet off the ether layer.

10. Pass the HCI solution through a Dowex-1 anion resin bed ( 2 $\mathrm{cm} \times 3 \mathrm{~mm}$ ) by pushing the solution through the column with a1r pressure. Rinse the centrifuge tube once with $1 \mathrm{ml}$ of conc. HCl and push this solution through the column. Wash resin with $\sim \mathrm{I} l$ of conc. HCl. Discard effluent. 
11. To column, add $-3 / 4 \mathrm{ml}$ of $0.5 \mathrm{M} \mathrm{HCl}$. Collect the eluate and - evaporate to a small volume and plate on a platinum disc.

PROCEDURE 15: Use of Ion Exchange Resins for the Determination of Uranium in Ores and Solutions.

Source: S. F1sher and R. Kun1n, Anal. Chem. 29, 400 (1957).

\section{Abstract}

The separation of uranium from the lons interfering w1th 1 ts analysis is accomplished by the adsorption of the urantum(VI) sulfate complex on a quaternary ammonium anion exchange resin. Interference of such lons as $1 \mathrm{ron}$ (III) and vanadium(V) is avolded by their preferential reduction with sulfurous ac1d so that they, as well as other cations, are not retalned by the resin. Uranium is eluted for analysis by dilute perchloric ac1d. The method is applicable to both solutions and ores.

\section{Ore Solution}

Two methods for the opening of uranium-bearing ores were Investigated in conjunction with the fon exchange separation. The flrst is the standard digestion with hydrorluorlc and nitric ac1ds, with subsequent evaporation to dryness followed by a sodium carbonate fusion. The carbonate melt is dissolved in $5 \%$ sulfuric ac1d to form a solution for the separation. A second method for routine analysis, designed to eliminate the need for hood fac1l1ties and platinum vessels, involves an oxidative leach with an acidic manganese(IV) oxide system. This procedure is given in detail below. Other workers, using the authors' separation procedure, have recommended solution of the ore by treatment with 12M hydrochloric acid plus 16M nitric ac1d followed by fuming 
w1th sulfuric ac1d to produce a suitable uranium solution for the column influent.

Procedure. Welgh out samples of ore estimated to contain an amount of uranium oxide less than $100 \mathrm{mg}$. but sufficient to be detected by the chosen method of analysis. Add $20 \mathrm{ml}$. of $20 \%$ by volume sulfuric acid and 2 grams of manganese(IV) oxide. Heat the mixture to bolling. Allow to 6001 to room temperature. Dilute with approximately $50 \mathrm{ml}$. of water. Adjust to a $\mathrm{pH}$ between 1.0 and 1.5 by the dropwise add1tion of $20 \%$ sodium hydroxide. Filter through fine-pore fllter paper using two 10-ml. portions of water to wash the residue on the paper.

\section{Ion Exchange Separation}

Apparatus. Tubes 0.5 inch in diameter with high-porosity sintered glass filter disks fused to the lower end are used to contain the resin. The rate of flow of solutions through the tube is regulated by a screw clamp on rubber tubing below the illter. Small separatory funnels are attached to the top of the column to feed the sample and reagents.

Procedure. Convert a portion of quaternary ammonium anion exchange resin (Amberlite $X E-117$, Type 2) of mesh size 40 to 60 (U.S. screens) to the sulfate form by treating a column of it with 10\% sulfuric ac1d, using 3 volumes per volume of resin. Rinse the acid-treated resin with delonized water until the effluent is neutral to methyl red. Drain the resin so prepared free of excess water and store in a bottle. A $5-\mathrm{ml}$. portion of this resin is used for a single analysis. The resin is loaded into the filter tube and the bed so formed is backwashed with enough water to free it of a1r. After the resin has settled the excess water is drained off to within $1 \mathrm{~cm}$. Of the top of the bed prior to the passage of the sample through the bed.

Add 5 drops of $0.1 \%$ methylene blue to the partially neu- 
tralized ( $\mathrm{pH} 1.0$ to 1.5) solution from the dissolved sodium carbonate melt or from the flltered manganese(IV) oxide leach. Add 6\% sulfurous acld dropwise unt1 the methylene blue is decolorized and then add a 5-ml. excess. Pass the reduced sample through the resin bed at a rate not exceeding $2 \mathrm{ml}$. per minute. Wash the sample container with two 10-ml. portions of water, passing the washing through the resin bed at the same flow rate. Elute the uranium w1th $50 \mathrm{ml}$. of $1 \mathrm{M}$ perchloric ac1d. Determine the uranium content of the perchloric acid fraction colorimetrically by the standard sodium hydroxide-hydrogen peroxide methoda or volumetr1callyc. For colorimetric analysis standard uranium solutions containing perchloric acid should be used in establishing the curve.

a F. S. Grimald1, I. May, M. H. Fletcher, J. Titcomb, U. S. Geol. Survey Bull. 1006 (1954).

b H. J. Seim, R. J. Morris, D. W. Frew, U. S. Atomic Energy Comm. Document UN-TR-5 (1956).

c C. J. Rodden, "Analytical Chemistry of the Manhattan Project," McGraw-H111, New York, 1950.

PROCEDURE 16: The Use of a "Compound" Column of Alumina and Cellulose for the Determination of Uranium in Minerals and ores Containing Arsenic and Molybdenum.

Source: W. Ryan and A. F. W1lliams, Analyst 77, 293 (1952).

\section{Abstract}

A technique in inorganic chromatography, with alumina and cellulose adsorbents in the same extraction column, is described for the separation of urantum from minerals and ores. The purpose of the alumina is to retain arsenic and molybdenum, which 
are not readily retalned by cellulose alone when ether contalning 5 per cent $v / v$ of concentrated nitric ac1d, sp.gr. 1.42, is used as the extraction solvent.

METHOD FOR SAMPIES CONTAINING MOLYBDENUM OR ARSENIC OR BOTH Solvent--Add $5 \mathrm{ml}$ of concentrated nitric ac1d, sp.gr. 1.42, to each $95 \mathrm{ml}$ of ether. PREPARATION OF ALUNINA-CELLULOSE COLUMN--

The adsorption tube for the preparation of the column is a glass tube about $25 \mathrm{~cm}$ long and $1.8 \mathrm{~cm}$ in diameter. The upper end is flared to a dlameter of about $8 \mathrm{~cm}$ to form a funnel that permits easy transfer of the sample. The lower end terminates In a short length of narrow tubing and is closed by a short length of polyvinyl chloride tublng carrying a screw clip. The Inside surface of the glass tube is coated with a silicone in the manner described by Burstall and Wells. a

Welgh 5 or $6 \mathrm{~g}$ of celiulose pulp* into a stoppered rlask and cover 1t with ether-nitric ac1d solvent. Pour the suspension into the glass tube, agitate gently and then gently press down the cellulose to form a homogeneous column. Wash the column with about $100 \mathrm{ml}$ of ether-nitric acld solvent and finally allow the level of the solvent to fall to the top of the cellulose. Next pour about $15 \mathrm{~g}$ of activated alumintum oxide ${ }^{\dagger}$ on top of the cellulose, pour on $30 \mathrm{ml}$ of ether-nitric acid solvent and vigorously agitate the alumina with a glass plunger. Allow the packing to settle. Allow the level of the ether to fall to the surface of the alumina and the column is ready for use.

\footnotetext{
* Whatman's Standard Grade cellulose powder is suitable.

† Type H, Chromatographic Alumina, 200 mesh. Supplied by Peter Spence Itd.
} 


\section{PROCEDURE 16 (Continued)}

PREPARATION OF SAMPLE SOLUTION FROM MINERAL OR ORE--

Weigh into a platinum dish sufficient of the sample to give 100 to $150 \mathrm{mg}$ of $\mathrm{U}_{3} \mathrm{O}_{8}$, which is a convenient amount for a volumetric determination. Decompose the sample by treatment with nitrlc and hydrofluoric acids in the manner described by Burstall and Wells.a Finally remove hydrofluorlc acld by repeated evaporations with nitric acid and take the sample to dryness. If the addition of dilute nitric acld indicates the presence of undecomposed material, filter the insoluble residue on to a filter-paper and ignite and fuse 1 in a nickel crucible with a few pellets of potassium hydroxide. Then add the melt to the filtrate and take the whole to dryness.

Add $4 \mathrm{ml}$ of diluted nitric acid, 25 per cent $\mathrm{v} / \mathrm{v}$, to the dry residue, gently warm to dissolve the mixture and then cool the solution, which is then ready for chromatography. EXTRACTION OF URANIUM--

Transfer the sample on a wad of ary cellulose pulp to the top of the prepared alumina-cellulose columna and extract the uranium w1th 200 to $250 \mathrm{ml}$ of ether-nitric ac1d solvent if arsenic or molybdenum and arsenic is present in the original sample. If molybdenum alone is present, the amount of solvent can be reduced to $150 \mathrm{ml}$. Screen the column from direct sunlight. After removal of ether from the eluate, determine the uraniam volumetrically. a, b

a F. H. Burstall, R. A. Wells, Analyst 76, 396 (1951).

b F. H. Burstall, A. F. W1lliams, "Handbook of Chemlcal Methods for the Determination of Uranium in Minerals and Ores," H. M. Stationery Office, London, 1950. 
PROCEDURE 17: Determination of Uranium-235 in Mixtures of Naturaliy Occurring Uranium Isotopes by Radioactivation. Source: A. P. Seyfang and A. A. Smales, Analyst 78, 394 (1953).

\section{Abstract}

A method previously useda for determining uranium in minerals by neutron 1rradiation followed by measurement of the separated fission-product barlum has been extended to the determination of urantum-235 in admixture with urantum-234 and uran1um-238.

W1th microgram amounts of uran1um-235, short 1rradiations in the Harwell pile give ample sensitivity. Precision and accuracy of better than \pm 2 per cent have been achleved for a range of urantum-235 contents covered by a factor of more than $10^{5}$.

\section{Method}

\section{REAGENTS--}

Magneslum oxide--Analytical reagent grade.

N1tric ac1d, sp. gr. 1.42.

Barlum chlorlde solution--Dissolve 18 of $\mathrm{BaCl}_{2} \cdot 2 \mathrm{H}_{2} \mathrm{O}$ in water and make up to $500 \mathrm{ml}$.

Ianthanum nitrate solution--A I per cent $w / v$ solution of $\mathrm{La}\left(\mathrm{NO}_{3}\right)_{3} \cdot 6 \mathrm{H}_{2} \mathrm{O}$.

Ammonium hydroxide, sp. gr. 0.880 .

Strontlum carbonate solution--A 2 per cent $w / v$ solution.

Hydrochloric acld-diethyl ether reagent-A mixture of 5 parts of concentrated hydrochloric ac1d, sp. gr. 1.18, and I part of diethyl ether.

Sodlum tellurate solution--A 0.4 per cent $w / v$ solution.

Zinc metal powder.

Methyl orange Indicator.

Potassium 1odide solution--A 1 per cent $w / v$ solution. Sodium hypochlorite solution--A comerclal solution contalning 10 per cent of avallable chlorine. 
Hydroxylamine hydrochlor $1 d e$.

Ferric chloride solution--A $I$ per cent $w / v$ solution.

Sulfuric ac1d--A 20 per cent $v / v$ solution.

\section{IRRADIATION--}

Solids-- Samples contalning not much more uranium-235 than natural urantum (say, up to three times more or 2 per cent) may be 1rradiated as solid; this is usually $\mathrm{U}_{3} \mathrm{O}_{8}$. For these cut a $5-\mathrm{cm}$ length of $2-\mathrm{mm}$ polythene tubing and seal one end by warming and pressing. Introduce freshly 1 gnited analytical reagent grade magnesium oxide to form a compact layer 4 to $5 \mathrm{~mm}$ in height at the sealed end of the tube. Weigh the tube and contents, ado about $50 \mathrm{mg}$ of $\mathrm{U}_{3} \mathrm{O}_{8}$ and re-welgh. Add a further similar layer of magnesium oxide on top of the $\mathrm{U}_{3} \mathrm{O}_{8}$ and then seal the open end. Leave a free space about $1 \mathrm{~cm}$ long between the top of the magneslum oxide layer and the seal, for ease of opening. Treat standard and samples similarly. Place the tubes either in a special polythene bottle for irradiation in the pneumatic "rabbit" of the plie or in a 3-1nch aluminum can for irradiation in the "self-serve" holes in the plle. Irradiation is carried out for any required time; usualiy $1 \mathrm{t}$ is about 5 minutes. After irradiating, place the containers in lead shielding for about 15 hours. After this period, tap down the contents of the polythene tube away from one end and carefully cut off the top. Empty the contents into a 50-ml centrifuge tube. (The plug of magnesium oxide serves to "rinse" the sample tube as it is empt1ed.) Add $2 \mathrm{ml}$ of concentrated nitric ac1d (sp.gr. 1.42), gently warm to dissolve, and Inally bo1 off the nitrous fumes. Add $5.00 \mathrm{ml}$ of a barlum solution to act as carrier (a solution of $18 \mathrm{~g}$ of barlum chlorlde, $\mathrm{BaCl}_{2} \cdot 2 \mathrm{H}_{2} \mathrm{O}$, in $500 \mathrm{ml}$ of water).

Ligulds--For more highly enriched samples or when the amount of sample avaliable is small, solutions contalning weighed 
quantities of solid sample mist be irradiated in small silica ampoules. The ampoules, which have a capac1ty of about $1 \mathrm{ml}$, are prepared from silica tubing. After one end of each has been sealed, the ampoules are welghed, the sample solution added from a fine-pointed glass dropping-tube and the ampoules re-weighed. Pack the ampoules, after sealing the open ends, in cotton wool in a 3-1nch aluminium can and 1rradiate them in the "self-serve" position of the plle. The time of 1rradiation necessary can be calculated from the usual activation formula; as an example, 1 $\mathrm{Hg}$ of uranlum-235 irradiated for 24 hours in a flux of $10^{12}$ neutrons per sq. cm per second gives about 5000 counts per minute of barlum-140 at 5 per cent counting efflclency, 24 hours after the Irradiation.

After removing them from the plle, place the samples and standards in lead shielding for about 15 hours; the main activity Is due to s111con-31. Transfer the ampoules to 100-ml tal1-form beakers containing a few mlll1lters of water and $5.00 \mathrm{ml}$ of barium carrier solution, carefully break off both ends of each ampoule and warm to ensure thorough mixing. Decant into centrifuge tubes and wash out the ampoules and beakers with further small portions of water.

\section{CHEMICAI SEPARATION--}

Evaporate the solution containing the 1rradiated uranium and barlum carrier to 5 to $6 \mathrm{ml}$ and add two drops of 1 per cent lanthanum nitrate solution. Warm if necessary to dissolve any barlum nitrate that may have crystallized, add concentrated ammonium hydroxide dropwise unt1l a permanent precipitate is obtalned and then two drops in excess. Centrifuge and decant Into another centrifuge tube. Add methyl orange indicator, and then hydrochloric acld until the solution is ac1d. Add 2 drops of 2 per cent strontium solution, about $25 \mathrm{ml}$ of hydrochloric 
ac1d - diethyl ether reagent, mix thoroughly, centrifuge and decant. Wash the precipitate with $5 \mathrm{ml}$ of reagent, centrifuge and decant. Dissolve the barium chloride precipitate in 3 to 4 $\mathrm{ml}$ of water, re-precipitate 1 by adding $20 \mathrm{ml}$ of reagent, centr1fuge and decant. Wash with $5 \mathrm{ml}$ of reagent, centrifuge and decant. Dissolve the precipitate in about $5 \mathrm{ml}$ of water, add 6 drops of lanthanum solution and 6 drops of the 4 per cent tellurate solution and then about $3 \mathrm{mg}$ of zinc metal powder. When the effervescence ceases, make the solution just ammoniacal to methyl orange, centrifuge and decant into another tube. Add 4 drops of 1 per cent potassium 1odide solution and 2 drops of sodium hypochlorite solution. Warm and set aslde for 2 minutes. Acldify with about $1 \mathrm{mI}$ of hydrochloric acid, and add about $0.1 \mathrm{~g}$ of hydroxylamine hydrochlorlde. Boll under a hood unt1l all the lodine appears to be removed and the volume is reduced to 5 to $6 \mathrm{ml}$. Add 2 drops of strontium solution and 2 drops of lanthanum solution and repeat the double barlum chloride precipltation and washing, as above.

Dissolve the precipitate in about $5 \mathrm{ml}$ of water, add 6 drops of lanthanum solution, and 6 drops of 1 per cent ferric chloride solution. Make ammoniacal to methyl orange, add half a crumbled Whatman accelerator tablet, and heat just to bolling. F1lter through a 7 -cm Whatman No. 30 filter-paper into a centrifuge tube, wash twice with 2 to 3-ml portions of water. Dilute the filtrate to about $20 \mathrm{ml}$ and make slightly ac1d with hydrochloric acld. Heat nearly to bolilng and add dropwise $2 \mathrm{ml}$ of 20 per cent $\mathrm{v} / \mathrm{v}$ sulfuric acid. Allow the precipitate to settle, decant, wash with $10 \mathrm{ml}$ of water, centrifuge, decant and repeat the washing procedure to complete removal of the excess of ac1d.

Transfer as much as possible of the precipitate, by means of a dropping tube and a few drops of water, to a tared aluminium 


\section{PROCEDURE 17 (Cont1nued)}

counting tray. Dry under an infra-red lamp and finally heat in a muffle furnace at $500^{\circ} \mathrm{C}$ for 15 minutes. Cool, weigh and reserve fol: counting. COUNTING TECHNIQUE--

The counting equipment for this work consists of (1) a power un:Lt (type 1082A or 200 is sultable), (11) scaling unit (type 200 or 1009B), (111) time accessory unit (type 1003B), (1v) prolse unit (type $200 B$ or 1014A). Time pulses can be obtalned from a master electric clock serving several units. A mica end-window Geiger-Müller counter ( 2 mg per sq. $\mathrm{cm}$.), of type EHM2, is sultable; it is mounted in a lead castle with a Perspex lining and shelves.

Chesk the counting equipment in the normal fashion with a sultable beta-emitter, such as natural uranium oxide in equilibrium with $\mathrm{UX}_{I}$ and $\mathrm{UX}_{2}$. Place the sample to be counted in a Perspex carrier and insert it in a shelf at a sultable distance from the Gelger-Milizer tube to attain a counting rate of 2000 to 3000 counts per minute. Count for a surficlent time to obtain at least 10,000 counts for each barlum sulfate preclpitate, counting the precipitates one after another without undue delay. Correction for growth of lanthanum-140 is unnecessary if samples and staniards are counted with1n, say, 60 minutes of each other provided the barium sulfate precipitations are carried out on each nearly simultaneously.

CAICULATION OF RESULTS--

Correct all counts for background, colncldence loss and chemical yield and express as the results in counts per minute. Then $\frac{\text { Weight of } U^{235} \text { in standard }}{\text { Welght of } U^{235} \text { in sample }}=\frac{\text { Corrected count of standard }}{\text { Corrected count of sample }}$

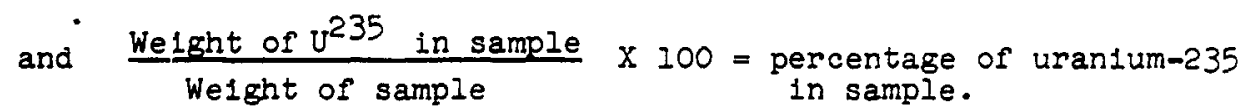
a A. A. Smales, Analyst 77, 778 (1952). 
PROCEDURE 18: Determination of Microgram and Submicrogram Quantities of Uranium by Neutron Activation Analysis. Source: H. A. Mahlman and G. W. Ledicotte, Anal. Chem. 27, 823 (1955).

\section{Abstract}

Microgram and submicrogram quantities of uranlum have been determined in synthet1c samples, ores, and solis by neutron radioactivation analysis. The principles of the activation analysis method used in this determination and the processing of irradiated samples are discussed. This method of analysis is a sensitive and specific method for determining uranium in concentrations as small as $0.1 \gamma$ per gram with a probable relative standard error of $10 \%$. Concentrations of uranium in quantities as small as $0.0001 \gamma$ per gram can be determined by neutron actik atior analysis.

\section{Radioactivation Analysis of Samples that Contain}

\section{Uranium}

Nuclear Irradiation of Sample. Weighed portions of the samples and the comparative standard are put into small quartz tubes. The tubes are closed w1th cork stoppers that are wrapped in aluminum. They are then irradiated in the reactor. After Irradiation, the samples are allowed to decay about 4 hours and are then chemically processed as described below. The synthetic samples used in this laboratory had been processed by a filter paper partition chromatography technique. After the separation, the paper was conveniently irradiated in short pieces of quartz tubing whose openings were plugged by means of cork stoppers.

Chemical Separation of Neptunium-239. In most neutron activation analyses, a chemical separation is made to isolate the radioactivity of the element from all other radioactive species in the sample. Usually an "1sotoplc carrier"-a known amount of the natural inactive element--1s added to the solutions 
of both the irradiated specimen and the comparison samples. The solutions are then processed chemically to 1solate the carrier and desired radioelement from other elements and contaminant radioactivities. Small amounts of other elements are added as holdback or scavenging carriers to assist in the decontamination process.

Although neptunium-239 has a convenlent half life; it does not have a stable 1sotope that can be used as an 1sotopic carrier. However, Seaborg a has shown that trace quantities of neptunium239 can be quantitatively carried on a nonisotopic carrier, such as cerlum. The method of analysis reported below uses lanthanum as a nonisotopic carrier for the neptunium-239 radioactivity. (See Note 1.)

Chemical Separation Procedure. PREPARATION. The 1rradiated ore and soll specimens are dissolved by digestion in a mixture of concentrated nitric, hydrofluor 1c, perchloric, and sulfuric ac1ds. (Additional hydrofluoric acid can be added if a residue of silica remains in the bottom of the crucible.) After dissolution, the sample is concentrated to heavy sulfur1c acld fumes, cooled, and transferred to a 15-ml. centrifuge tube. If a residue (sulfate salts) remalns after the transfer, the solution is centrifuged for 5 minutes, the supernatant transferred to another tube, and the residue washed with $1 \mathrm{ml}$. of $1 \mathrm{M}$ nItric ac1d. The wash is added to the supernatant and the residue discarded. (Centrifugation is always for the stipulated time and at full speed.) The sample is then further processed by the procedure reported herein.

The 1rradiated synthetic samples (paper chromatograms) are processed by carefully lgniting the paper contained in a porcelain crucible in a muffle furnace. The residue is dissolved in about $0.5 \mathrm{ml}$. of concentrated nitric ac1d. After dissolution, the 
sample is transferred to a $15-\mathrm{ml}$. centrifuge tube and the processIng continued with the procedure reported herein.

PROCEDURE. Three (3.0) milligrams of lanthanum and 0.250 $m$. of $5 M$ hydroxylamine hydrochloride solution are added to the supernatant solution and the mixture digested for 5 minutes with occasional stirring. The solution is cautiously neutralized with concentrated ammonium hydroxide to preclpitate lanthanum hydroxide, after which the mixture is centrifuged and the supernatant liquid discarded.

The precipitate of lanthanum hydroxide is dissolved in $2 \mathrm{ml}$. of $2 \mathrm{M}$ hydrochloric ac1d, and $1.0 \mathrm{mg}$. of strontium (added as a solution of strontium nitrate to serve as a holdback or scavenglng carrier) and $0.250 \mathrm{ml}$. of $5 \mathrm{M}$ hydroxylamine hydrochloride solution are added to the solution. The solution is again digested for 5 minutes with intermittent stirring, and $0.200 \mathrm{ml}$. of concentrated hydrofluoric ac1d is added dropwise to the solution to prec1pitate lanthanum fluoride. After centrifugation, the supernatant liquid is discarded and the precipltate washed with $0.5 \mathrm{ml}$. of $1 \mathrm{M}$ hydroIluorlo ac10-1M nitric ac1d solution.

After washing, the lanthanum fluoride precipitate 13 dissolved in $0.5 \mathrm{ml}$. of saturated borlc acid solution and $1.0 \mathrm{ml}$. of $6 \mathrm{M}$ nitric acid. One (1.0) milililter each of $10 \%$ potassium permanganate solution and water are added to this solution, and the resulting mixture is agitated well and digested for 5 minutes. Lanthanum fluoride is again precipitated w1th $0.250 \mathrm{ml}$. Of concentrated hydrofluoric ac1d; the solution is centrifuged and the supernatant liquid transferred to another centrifuge tube. The prec1pltate $1 \mathrm{~s}$ washed w1th $0.5 \mathrm{ml}$. of $1 \mathrm{M}$ hydrofluorlc ac1d-IM n1tric ac1d solution and the wash combined with the supernatant liquid. The precipitate is discarded.

Three m1lilgrams of lanthanum are added to the supernatant 
PROCEDURE 18 (Continued)

11quid, and the solution is digested for 5 minutes and centrifuged. An additional $3.0 \mathrm{mg}$. of lanthanum are added to the supernatant $11 q u 1 d$ and the solution agitated and digested for 5 minutes without disturbing the first preclpitate on the bottom of the tube; then the solution is centrifuged and the supernatant liquid transferred to another centrifuge tube. The precipitate is washed with 0.5 ml. of IM hydrofluoric acid-1M nitric acid solution; centrifuged, and the wash combined with the supernatant liquid. The precip1tate is discarded.

One milifgram of zircontum (added as a solution of zirconium nitrate to serve as a holdback or scavenging carrier) and $0.250 \mathrm{ml}$. of $5 \mathrm{M}$ hydroxylamine hydrochloride are acided to the solution and the mixture ag1tated and digested 5 minutes. Three (3.0) m1111grans of lanthanum and $2 \mathrm{ml}$. of $2 \mathrm{M}$ hydrofluoric acid are added to the solution, and the solution 1 digested for 20 minutes and then centrifuged. The supernatant liquid is discarded. The precipitate is washed with $0.5 \mathrm{ml}$. of IM hydrofluoric ac1d-IM nitric acid solution, and the resulting mixture is centrifuged. The wash solution is discarded after the centrifugation.

The precipitate is slurried in a smali amount of IM nitric acid (about $0.5 \mathrm{ml}$ ) and transferred to a small borosilicate glass culture tube by means of a transfer pipet. The centrifuge cone is rinsed with three $0.5-\mathrm{ml}$. portions of $I M \mathrm{M}$ tric acid and the rinses transferred to the culture tube. The tube is stoppered with a cork stopper and the $\gamma$ radioactivity measured by a welltype gamma scintillation counter.

The standard sample of uranium oxide $\left(\mathrm{U}_{3} \mathrm{C}_{8}\right)$ is dissolved In nitric acld and an aliquot of the solution processed under the same conditions as the specimen samples. The uranium content of the sample in question is determined by equating the ratio of the corrected neptunlum-239 radioactivity count in the unknown 


\section{PROCEDURE 18 (Continued)}

and the corrected neptunium-239 radioact1vity count in the standard sample.

Note 1. Hamaguch1 and co-workers $\underline{b}$ have used $\mathrm{Np}^{237}$ tracer to determine the chemical yleld.

\& G. T. Seaborg and co-workers, Metaliurgical Project Rept. CN2689,41 (Feb. 15, 1945) (classified).

b H. Hamaguch1, G. W. Reed, A. Turkevich, Geochim. et Cosmochim. Acta 12, 337 (1957).

\section{Acknowledgements}

It is a pleasure to acknowledge the assistance of Miss $M$. Tippet, Miss R. Cushing, Mr. N. Zalchick and others of the Argonne National Laboratory library staff in locating the many references used in writing this paper; Dr. E. K. Hyde, who kindly made avallable his flle on the radiochemistry of uranium; Mrs. D. E. W1lliams, who typed most of the manuscript; Miss F. Taylor, for preparling the final flgures; Dr. C. E. Crouthamel, who furnished the flgures of gamma-ray spectra; Dr. D. W. Engelkeme1r and Mr. D. J. Henderson, who supplied the data for the alpha spectra; and flnally, Miss B. Lore and $\mathrm{Mr}$. C. Ahlberg, without whom the completion of this paper would have been much, much later. 


\section{REFERENCES}

1. J. J. Katz and E. Rablnowitz, General Revlew reference 5. Discussion and/or reference to original literature may be found.

2. J. J. Katz and G. T. Seaborg, General Review reference 8. Discussion and/or reference to original literature may be found.

3. A. N. Holden, General Review reterence 12. Discussion and/or reference to original literature may be found.

4. I. Grainger, General Review reference 11. Discussion and/or reference to original literature may be f'ound.

5. W. M. Latimer, "Oxidation Potentials," 2nd edition, PrenticeHall, Inc., New York, 1952.

6. R. J. Meyer and E. Pletsch, "Gmelins Handbuch der Anorganischen Chemie," General Review reference 2. Discussion and/or reference to original Iiterature may be found.

7. A. Rosenheim and H. Loebel, Z. anorg. Chem. 27, 237 (1908).

8. H. Hecht, G. Jander, and H. Schlapmann, Z. anorg. Chem. 254, $255(1947)$.

9. D. C. Bradley, B. N. Chakravart1, A. K. Chatterjee, J. Inorg. Nuclear Chem. 3, 367 (1957).

10. H. R. Hokestra and J. J. Katz, General Revlew reference 7. Discussion and/or reference to original literature may be found.

11. G. T. Seaborg, General Review reference 6. Discussion and/or reference to original literature may be found.

12. D. Altman, Report Chem-S-166, 1943.

13. K. A. Kraus and F. Nelson, J. Am. Chem. Soc. 12, 3901 (1950).

14a. R. H. Betts and R. M. Leigh, Can. J. Research B28, 514 (1950).

14b. J. Rydberg and B. Rydberg, Arkiv Kem1 2, 81 (1956).

15. K. A. Kraus, F. Nelson, and G. L. Johnson, J. Am. Chem. Soc. 11, 2510 (1949).

16. R. H. Betts, Can. J. Chem. 33, 1775 (1955). 
17. S. Hetanen, Acta Chem. Scand. 10, 1531 (1956); Rec. Trav. ChIm. 75, 711 (1956).

18. J. C. Sullivan and J. C. Hindman, J. Phys. Chem. 63, 1332 (1959).

19. K. A. Kraus, Paper P/731, Proc. Internat. Conf. Peaceful Uses Atom1c Energy, Geneva, 1955, 1, 245 (1956).

20. J. Bjerrum, G. Schwarzenbech, and I. G. S1llén, "Stab1l1ty Constants," The Chemical Soclety, London. Part I: Organic I1gands, 1957. Part II: Inorganic Ligands, 1958.

21. R. W. Lawrence, J. Am. Chem. Soc. 56, 776 (1934).

22. K. A. Kraus and F. Nelson, J. Am. Chem. Soc. 77, 3721 (1955).

23. K. H. Gayer and H. Le1der, Can. J. Chem. 35, 5 (1957).

24. P. Herasymenko, Trans. Faraday Soc. 24, 267 (1928).

25. (a) W. E. Harris and I. M. Kolthoff, J.Am. Chem. Soc. 67, 1484 (1945); (b) $\underline{68}, 1175$ (1946); (c) $\underline{69}, 446$ (1947).

26. H. G. Heal, Trans. Faraday Soc. 45, I (1949).

27. E. S. Kritchevsky and J. C. Hindman, J. Am. Chem. Soc. 71, 2096 (1949).

28. R. A. Penneman and I. H. Jones, J. Chem. Phys. 2I, 542 (1953).

29. J. P. Nigon, R. A. Penneman, E. Staritzky, T. K. Keenan, and I. B. Asprey, J. Phys. Chem. 58, 403 (1954).

30. W. H. Zachariasen, Acta Cryst. I, 795 (1954).

31. K. A. Kraus and F. Nelson, J. Am. Chem. Soc. 71, 2517 (1949).

32. I. J. Heidt and K. A. Moon, J. Am. Chem. Soc. 75, 5803 (1953).

33. D. M. H. Kern and E. F. Orlemann, J. Am. Chem. Soc. 7I, $2102(1949)$.

34. C. J. Rodden and J. C. Warf, General Review reference 4. Discussion and/or reference to original literature may be found.

35. J. S. Johnson and K. A. Kraus, J. Am. Chem. Soc. 74 , $4436(1952)$.

36. J. S. Johnson, K. A. Kraus, and T. F. Young, J. Am. Chem. Soc. $76,1436^{\prime}(1954)$.

37. D. A. MacInnes and I. G. Iongsworth, MDDC-911, 1942.

38. H. Gulter, Bul1. Soc. chim. France, 1947, 64.

39. J. Faucherre, Compt. rend. 227, 1367 (1948).

40. J. Sutton, J. Chem. Soc. 1949, 5275.

41. T. V. Arden, J. Chem. Soc. 1949, 5299.

42. S. Ahrland, Acta Chem. Scand. 3, 374 (1949). 
43. S. Ahrland, S. Hietanen, and L. G. Sillén, Acta Chem. Scand. 8, 1907 (1954).

44. R. A. Robinson and C.K. L1m, J. Chem. Soc. 1951, 1840.

45. E. Orban, M. K. Barnett, J. S. Boyle, J. R. He1ks, and L. V. Jones, J. Phys. Chem. 60, 413 (1956).

46. J. A. Hearne and A. G. White, J. Chem. Soc. 1957, 2168.

47. S. Hietanen and L. G. S1llén, Acta Chem. Scand. 13, 1828 (1959).

48. K. H. Gayer and H. Leider, J. Am. Chem. Soc. 77, 1448 (1955).

49. I. J. Heldt, J. Phys. Chem. 46, 624 (1942).

50. N. P. Komar and Z. A. Tretyak, Zhur. Anal. Kh1m. 10, 236 (1955).

51. J. Rydberg, Arkiv Kem1 8, 113 (1955).

52. R. Schall and J. Faucherre, Bull. Soc. chim. France, 1947,927 .

53. J. Faucherre, Bul1. Soc. ch1m. France, 1954, 253.

54. F. J. C. Rossott1, H. Rossotti, and I. G. Sillén, Acta Chem. Scand. 10, 203 (1956).

55. C. I. Rulfs and P., J. Elving, J. Am. Chem. Soc. 77, $5502(1955)$.

56. C. K. Jörgensen, Acta Chem. Scand. 10, 1503 (1956).

57. S. Ahrland and R. Larsson, Acta Chem. Scand. 8, 137 (1954).

58. R. A. Day, Jr., R. N. Wlihlte, and F. D. Hamilton, J. Am. Chem. Soc. I7, 3180 (1955).

59. E. Strandell, Acta Chem. Scand. 11, 105 (1957).

60. J. C. Sullivan and J. C. Hindman, J. Am. Chem. Soc. 74, 6091 (1952).

61. R. A. Whitaker and N. Davidson, J. Am. Chem. Soc. 75, 3081 (1953).

62. K. A. Kraus, G. E. Moore, and F. Nelson, J. Am. Chem. Soc. $78,2692(1956)$.

63. I. A. MCClaine, E. P. Bullwinkel and J. C. Hugglns, Paper $\mathrm{P} / 525$, Proc. Internat. Conf. Peaceful Uses Atomic Energy, Geneva, 1955, 8,26 (1956).

64. G. H. T1shkoff, NNES, VI-1, Ch. I, Appendix B (1949).

65. I. V. Tananaev, M. A. Glushkova, and G. B. Selfer, Zhur. Neorg. Kh1m. 1, 66 (1956).

66. S. Ahrland, Acta Chem. Scand. 3, 1067 (1949). 
67. E. W. Davies and C. B. Monk, Trans. Faraday Soc. 53, 442 (1957).

68. J. A. Hevdall, Z. anorg. Chem. 146, 225 (1925).

69. E. P. Bullwinkel, USAEC RMO-2614, 1954.

70. C. A. Blake, C. F. Coleman, K. B. Brown, D. G. H1ll, R. S. Iowrie, and J. M. Schmitt, J. Am. Chem. Soc. 78, $5978(1956)$.

71. A. E. Klygin, I. D. Smirnova, Zhur. Neorg. KhIm. 4, 42 (1959).

72. E. V. Komarov, Zhur. Neorg. Kh1m. 4, 1313 (1959).

73. E. V. Komarov, I. D. Preobrazhenskaya, and A. M. Gurevich, Zhur. Neorg. Khim. 4, 1667 (1959).

74. R. H. Betts and R. K. Michels, J. Chem. Soc. 1949, 5286.

75. J. I. Hoard and Stroupe, NNES, III-2, 15 (1949).

76. S. Ahrland, Acta Chem. Scand. 5, 1271 (1951).

77. R. A. Day, Jr. and R. M. Powers, J. Am. Chem. Soc. 76, 3895 (1954).

78. I. Kaplan, R. A. Hildebrandt, and M. Ader, J. Inorg. Nuclear Chem. 2, 153 (1956).

79. V. M. Vdovenko, A. A. Lipovsk11, and M. G. Kuzina, Zhur. Neorg. Kn1m. $\underline{2}, 970$ (1957).

80. B. Jezowska-Trzeblatowska, A. Barteck1, M. Chmielowska, H. Przywarska, T. Mikulsk1, K. Bukietyńska, and W. Kakotow1cz, Paper P/1594, Proc. Internat. Conf. Peaceful Uses Atomic Energy, Geneva, 1958, 28, 253 (1958).

81. C. F. Baes, Jr., J. M. Schreyer, and J. M. Lesser, ORNL-Y12, ORNL-1577, 1953.

82. J. M. Schreyer and C. F. Baes, Jr., ORNL-Y-12, ORNL-1578, 1953.

83. C. F. Baes, Jr, and J. M. Schreyer, ORNL-1579, 1953.

84. J. M. Schreyer and C. F. Baes, Jr., J. Am. Chem. Soc. 76, $354(1954)$.

85. J. M. Schreyer and C. F. Baes, Jr., J. Phys. Chem. 59, 1179 (1955).

86. Y. Marcus, Dissertation, Hebrew University, Jemisalem, $1955,17$.

87. V. G. Chukhlantsev and S. I. Stepanov, Zhur. Neorg. KhIm. I, 478 (1956).

88. C. F. Baes, Jr., J. Phys. Chem. 60, 878 (1956).

89. B. J. Thamer, USAEC-IA-1996, 1956.

90. B. J. Thamer, J. Am. Chem. Soc. 79, 4298 (1957). 
91. Y. Marcus, Paper P/1605, Proc. Internat. Conf. Peaceful Uses Atom1c Energy, Geneva, 1958, 3, 465 (1958).

92. R. Iuther, 2. Elektrochem. 13, 294 (1907).

93. V. G. Chukhlantsev and A. K. Sharova, Zhur. Neorg. Khim. I, 36 (1956).

94. G. Nyir1, Acta Un1v. Szegediens1s, Chem. et Phys. I, 35 (1942).

95. A. E. Klygin and N. S. Kolyada, Zhur. Neorg. Khim. 4, 239 (1959).

96. S. Ahrland, Acta Chem. Scand. 5, 1151 (1951).

97. R. D. Brown, W. B. Bunger, W. L. Marshall, and C. H. Secoy, J. Am. Chem. Soc. 76, 1532 (1954).

98. T. V. Arden and G. A. Wood, J. Chem. Soc. 1956, 1596.

99. T. V. Arden and M. Rowley, J. Chem. Soc. 1957, 1709.

100. G. E. Moore and K. A. Kraus, ORNL-795, 1950.

101. C. A. Blake, R. S. Lowrie, and K. B. Brown, AECD-3212, 1951.

102. S. Ahrland and R. Larsson, Acta Chem. Scand. 8, 354 (1954).

103. R. D. Brown, W. B. Bunger, W. L. Marshall, and C. H. Secoy, J. Am. Chem. Soc. 76, 1580 (1954).

104. S. Ahrland, R. Larsson, and K. Rosengren, Acta Chem. Scand. 10, 705 (1956).

105. F. Nelson and K. A. Kraus, J. Am. Chem. Soc. 73, 2157(1951).

106. K. A. Kraus, F. Nelson, and G. E. Moore, J. Am. Chem. Soc. 77, 3972 (1955).

107. Y. Marcus, personal communicat1on, 1956; quoted in reference 20 .

108. V. M. Vdovenko, A. A. Lipovski1, and S. A. Nikitina, Zhur. Neorg. Kh1m. 4,862 (1959).

109. E. Rab1now1tz and W. H. Stockmayer, J. Am. Chem. Soc. 64, 335 (1942).

110. A. E. Klyg1n, I. D. Smlrnova, and N. A. N1kol'skaya, Zhur. Neorg. Kh1m. 4, 42 (1959).

111. J. Rydberg, Svensk. Kem. Tidskr. 67, 499 (1955).

112. J. Rydberg, J. C. Sullivan, Acta Chem. Scand. 13, 186 (1959).

113. J. Rydberg, Acta Chem. Scand. 14, 157 (1960).

114. Martell and Zebrosk1, unpublished results; quoted by A. E. Martell and M. Calvin, "Chemlstry of the Metal Chelate Compounds, Prentice-Hall, New York, 1953.

115. A. E. Klyg1n, I. D. Smirnova, and N. A. Nikol'skaya, Zhur. Neorg. KhIm $\underline{4}, 2766$ (1959). 
116. N. C. I1, W. M. Westfall, A. IIndenbaum, J. M. Wh1te, and J. Schubert, J. Am. Chem. Soc. 79, 5864 (1957).

117. E. N. Tekster, I. I. Vinogradov, and B. V. Pt1tsyn, Zhur. Neorg. KhIm. 4,764 (1959).

128. A. I. Moskvin and F. A. Zakharova, Zhur. Neorg. Kh1m. 4 , 2151 (1959).

119. B. V. Ptitsyn and E. N. Tekster, Zhur. Neorg. Khim 4 , 2248 (1959).

120. E. V. Komarov and A. M. Gurev1ch, Izvest. Akad. Nauk SSSR, Otdel. Khım Nauk 1959, 547.

121. S. Ahrland, Acta Chem. Scand. 2, 199 (1951).

122. N. C. LI, E. Doody, J. M. White, J. Am. Chem. Soc. 80 , 5901 (1958).

123. B. P. Nikolsky and V. I. Paramonova, Paper P/2204, Proc. Internat. Conf. Peaceful Uses Atomic Energy, Geneva, $1958, \underline{28}, 75$ (1958).

124. S. Ahrland, Acta Chem. Scand. I, 485 (1953).

125. S. Ahrland, Acta Chem. Scand. 3, 783 (1949).

126. N. C. I1, E. Doody, and J. M. White, J. Am. Chem. Soc. 79, 5859 (1957).

127. I. Feldman and J. R. Hav111, J. Am. Chem. Soc. 76, 2114 (1954).

128. I. Feldman, J. R. Hav1ll, and W. F. Neuman, J. Am. Chem. Soc. 76,4726 (1954).

129. R. M. Izatt, et al., J. Phys. Chem. 58, 1133 (1954); $59,80,235$ (1955).

130. I. Gal, Paper P/966, Proc. Internat. Conf. Peaceful Uses Atomic Energy, Geneva, 1955, 8, 358 (1956).

131. I. Feldman and W. F. Neuman, J. Am. Chem. Soc. 73, 2312 (1951).

132. W. F. Neuman, J. R. Hav111, and I. Feldman, J. Am. Chem. Soc. 73,3593 (1951).

133. C. Heitner and M. Bobtelsky, Bull. Soc. chim. France, 1954, 356 .

134. N. C. I1, A. IIndenbaum and J. M. White, J. Inorg. Nuclear Chem. 12, 122 (1959).

135. M. Bobtelsky, C. Heltner, and K. R. S. Ascher, Bull. Soc. chim. France, 1952, 943.

136. A. K. Babko and L. S. Kotelyanskaya, Chem. Coll. Kiev State Univ., No. 5, 1949, 75 ; quoted in reference 137.

137. K. B. Yatsimerski1 and V. P. Vas1l'ev, "Instab1lity Constants of Complex Compounds, "Acad. Sc1., USSR, Moscow, 1959; English translation, Consultants Bureau, New York, 1960. 
138. B. Hök-Bernström, Acta Chem. Scand. 10, 163 (1956).

139. B. E. Bryant and W. C. Fernelius, J. Am. Chem. Soc. 76, 535 (1954).

140. R. T. Foley and R. C. Anderson, J. Am. Chem. Soc. 71, 912 (1949).

141. A. K. Chakraburtty, D. Sen and P. Ray, J. Indian Chem. Soc. 30, 492 (1953).

142. H. Irving and H. S. Rossott1, J. Chem. Soc. 1954, 2910.

143. D. Dyrssen and V. Dahlberg, Acta Chem. Scand. I, 1186 (1953).

144. C. F. Richard, R. I. Gustafson, and A. E. Martell, J. Am. Chem. Soc. 8I, 1033 (1959).

145. A. K. Mukherf1 and A. K. Dey, J. Inorg. Nuclear Chem. 6 , 314 (1958).

146. E. C. Pitzer, N. E. Gordon, and D. A. Wilson, J. Am. Chem. Soc. 58, 67 (1936).

147. McGinn1s, Thes1s, Un1v. Cal1f, 1935; referred to by G. K. Rollefson, Chem. Rev. 17, 425 (1935).

148. J. M. HoJman, Bull. Inst. Nuclear Sc1., "Bor1s Kidrich," (Belgrade) 6, 113 (1956).

149. J. M. Hojman, Bulz. Inst. Nuclear Sc1., "Boris Kidrich," (Belgrade) I, 17 (1957).

150. J. M. Hojman, V. G. Dražlc, and A. A. Muk, Bull. Inst. Nuclear Sc1., "Boris Kidrich," (Belgrade) \&, 23 (1958).

151. J. M. Hojman, V. G. Dražlc, A. A. Muk, and M. B. Pravica, Bull. Inst. Nuclear Sc1., "Boris Kidrich," (Belgrade) 9 , 43 (1959).

152. M. J. Cabel1, AERE-C/R-813, 1951 Analyst 77, 859 (1952).

153. D. I. Ryabch1kov, P. N. Pale1, and Z. K. M1kha1lova, Zhur. Anal. Khim. 14, 581 (1959).

154. R. A. Zingaro, J. Am. Chem. Soc. 78, 3568 (1956).

155. R. E. Baes, Science 126, 164 (1957).

156. S. C. Tr1path1 and S. Prakash, J. Indian Chem. Soc. 35, $119(1958)$.

157. P. A. Zagorets, Naun Doklady Vysshe1 Shkoly, Kh1m. 1 Kh1m. Tekhnol, No. 4, 1958, 680 .

158. C. F. Baes, Jr., R. A. Zingaro, and C. F. Coleman, J. Phys. Chem. 62, 129 (1958).

159. D. Dyrssen and F. Krasŏvec, Acta Chem. Scand. 13, 561 (1959).

160. B. Skytte Jensen, Acta Chem. Scand. 13, 1890 (1959).

161. I. Yaffe, Can. J. Research B27, 638 (1949); 1b1d. B28, 171 (1950). 
162. C. C. Templeton and N. F. Hall, Can. J. Research B28, $156(1950)$.

163. I. I. Katzin and J. C. Sullivan, J. Phys. Chem. 25, 346 (1951).

164. W. I. de Keyser, R. Cypres, and M. Herman, Centre Phys. Nucleaire Univ. Libre Bruxelles Bull. No. 17 (1950); Chem. Abstr. 45, 3746 (1951).

165. R. K. Warner, Australian J. Appl. Sc1. 4, 581 (1953).

166. E. Glueckauf, quoted by $G$. Sauteron, General Review reference 9 .

167. H. A. C. McKay and A. R. Mathieson, Trans. Faraday Soc. 47, 428 (1951).

168. T. V. Healy and H. A. C. McKay, Trans. Faraday Soc. 52, $633(1956)$.

169. E. Hesford and H. A. C. McKay, J. Inorg. Nuclear Chem. $13,165(1960)$.

170. I. Kaplan, R. A. Hildebrandt, and M. Ader, ANL-4521 (1950).

171. G. Jander and H. Wendt, Z. anorg. Chem. 258, I (1949).

172. C. C. Add1so: and N. Hodge, Nature 171, 569 (1953).

173. V. M. Vdovenko, A. A. Ilpovski1, and M. G. Kuzina, Zhur. Neorg. Kh1m. 3, 975 (1958).

174. I. I. Katzin, J. Inorg. Nuclear Chem. 4, 187 (1957).

175. H. A. C. McKay, J. Inorg. Nuclear Chem. 4, 375 (1957).

176. A. W. Gardner, H. A. C. McKay, D. T. Warren, Trans. Faraday Soc. 48,997 (1952).

177. Ya. I. Ryskin, V. N. Zemlyanukhin, A. A. Solov'eva, N. A. Derebeneva, Zhur. Neorg. Kh1m. 4, 393 (1959).

178. Ya. I. Ryskin, V. P. Shvedov, A. A. Solov'eva, Zhur. Neorg. KhIm. 4,2268 (1959).

180. M. Bachelet and E. Cheylan, J. Chem. Phys. 44, 248 (1947).

181. A. R. Mathieson, J. Chem. Soc. 1949, s294.

182. G. W. Watt and A. R. Mochel, J. A. C. S. 72, 2801 (1950),

183. I. I. Katzin, D. M. Simon, and J. R. Ferraro, J, A. C. S. 74, 1191 (1952).

184. H. M. Feder, I. E. Ross, and R. C. Vogel, ANL-4868 (1952).

185. E. Glueckauf, H. A. C. McKay, and A. R. Mathieson, Trans. Feraday Soc. 47, 437 (1951).

186. H. A. C. McKay, Trans. Faraday Soc. 48, 1103 (1952). 
187. T. V. Healy and H. A. C. McKay, Rec. Trav. Chem. 75, 730 (1956).

188. T. V. Healy and J. Kennedy, J. I. N. C. 10, 128 (1959).

189. A. A. Smales and H. N. Wilson, Br. 150, Feb. 22, 1943.

190. M. von Stackelberg, "Handbuch der Analyt1schen Chemie," edited by $R$. Fresentus and $G$. Jander, Springer-Verlag, Berlin-He1delberg, 1948, Vol. VI, p.253.

191. C. J. Rodden, Anal. Chem. 21, 327 (1949).

192. C. J. Rodden, Anal. Chem. 25, 1598 (1953).

193. C. J. Rodden, Anal. Chem. 31, 1940 (1959).

194. C. J. Rodden, P/952, Proceed. Internat. Conf. Peaceful Uses Atomic Energy, Geneva, 1955, 8, 197 (1956).

195. C. J. Rodden, TD-7555 (1958), pp.24-42.

196. P. N. Pale1, P $/ 629$, Proceed. Internat. Conf. Peaceful Uses Atom1c Energy, Geneva, 1955, 8, 225 (1956).

197. P. N. Pale1, Zhur. Anal. Khim. 12, 647 (1957); J. Anal. Chem. USSR 12, 663 (1957).

198. T. W. Steele and L. Taverner, P/1117, Proceed. Internat. Conf. Peaceful Uses Atomic Energy, Geneva, 1958, 3, 510 (1958).

199. A. Simenauer, Chapter X of General Rev1ew reference 9. Discussion and/or reference to original literature may be found.

200. V. I. Kuznetsov, S. B. Savin, V. A. Mikha1lov, Uspekh1 Kh1m. 29, 525 (1960); Russian Chem. Rev. 29, 243 (1960).

201. F. P. Treadwe11, "Analyt1cal Chemistry," translated and revised by $W . T$. Hall, John Wlley and Sons, Inc., 9th edition, 1937, Vol. I.

202. A. A. Noyes and W. C. Bray, "A System of Qualitat1ve Analysis for the Rare Elements, "MacMlllan Co., New York, 1927.

203. H. H. Willard and H. Diehl, "Advanced Quantitative Analys1s," D. Van Nostrand and Co., Inc., New York, 1943. it

204. R. Fresenius and A. Gehring, "Elnfuhrung in die qual1tative Chemische Analyse," F. Vieweg and Sohn, Braunschwieg, 1949 .

205. W. F. Hillebrand, G. E. Lundell, H. A. Brlght, Jr, , and J. I. Hoffman, "Applied Inorganic Analysis, "John Wiley and Sons, Inc., New York, 2nd edition, 1953.

206. A. I. Vogel, "A Textbook of Macro and Semimicro Qualitative Inorganic Analysis, "Longmans, Green, and Co., Iondon, 4 th edition, 1954.

207. G. Charlot and D. Bézier, "Quantitative Inorganlc Analysis," translated by R. C. Murray, Methuen and Co., Ltd., London, John Wiley and Sons, New York, 1957. 
208. H. Holness, "Advanced Inorganic Qualitative Analysis by Sem1-Micro Methods," P1tman and Sons, Itd., London, 1957.

209. W. R. Schoeller and A. R. Powell, "Analysis of Minerals and Ores of the Rarer Elements," Charies Griffin and Co., Itd., London, 3rd edition, 1955.

210. F. Hecht, Mikrochem. ver M1krochemica Acta, 36-37, 1083 (1951).

211. S. Lawrowsk1, P/823, Proceed. Internat. Conf. Peaceful Uses Atomic Energy, Geneva, 1955, 9, 575 (1956).

212. P. W. West and A. O. Parks, Chapter IV, Section 2 in "Comprehensive Analytical Chemistry," edited by C. I. WIIson and D. W. WIIson, Elsevier Pub. Co., Amsterdam, New York, 1959.

213. G. E. F. Lundell and J. I. Hoffman, "Outlines of Methods of Chemical Analyses," John Wlley and'Sons, Inc., New York, 1938.

214. E. Ware, M-1633, February, 1945. Discussion and/or reference to original I1terature may be found.

215. E. Ware, MDDC-1432, August, 1945. D1scussion and/or reference to orlginal ilterature may be found.

216. S. E. Balley, MITG-A52, December, 1948.

217. B. Težak, $\mathrm{P} / 991$, Proceed. Internat. Conf. Peaceful Uses Atomic Energy, Geneva, 1955, I, 401 (1956).

218. M. Bachelet, E. Cheylan, M. Davis ano J. Goulette, Bull. Soc. chim. France I952, 55.

219. M. Bachelet, E. Cheylan, M. Davis and J. Goulette, Bull. Soc. chim. France 1954, 173.

220. C. A. Blake, C. F. Coleman, K. B. Brown, D. G. Hill, R. S. Lowr le, and J. M. Schm1tt, J. Am. Chem. Soc. 78 , $5978(1956)$.

221. G. N. Yakalev and D. I. Gorbenko-Gumanov, P/677, Proc. Internat. Conf. Peaceful Uses Atomic Energy, Geneva 1, 306 (1956).

222. B. Težak, H. Füred1, and M. Branica, P/24I3, Proc. Internat. Conf. Peacerul Uses Atomic Energy, Geneva 28, 250 (1958).

223. W. E. Bunce, N. H. Furman, and J. Mundy, M-4238 (revised) (1947), quoted in ref. 220.

224. J. Ebelman, Lieb1g's Ann. (3) 5, 189 (1852), quoted in ref. 63 .

225. K. B. Brown and J. B. Schm1tt, AECD-3229 (1950), quoted in ref. 63.

226. J, A. Hedvall, Z. anorg. Chem. 146, 225 (1925).

227. M. Kohn, z. anorg. Chem. 50, 315 (1906).

228. W. R. Schoeller and H. W. Webb, Analyst 6I, 235 (1936).

229. W. B. Folley, HW-35814, Feb. 1, 1955. 
$==0$. A. A. Grinberg, L. E. Nikolskaya, G. I. Petrzhak, B. V. Ft.tsyn and $\pi$. M. F1lirov, Zhur. Anal. Kh1m. 12, 92 (1957).

231. F. J. Armson, H. E. Dibber and H. Mason, SCS-R-30, JuIy $20,1949$.

232. R. A. Ewing, S. J. Kiehl, Jr., and A. E. Bearse, BMI-1115 (1956); Nuclear Sc1. Abstr. 10, 11157 (1956).

233. H. T. S. Britton and A. E. Young, J. Chem. Soc. 1932, 2407.

234. J. F. Riccl and F. J. Loprest, J. Am. Chem. Soc. 77, 2119 (1955).

235. J. Sutton, J. Inorg. Nucl. Chem. 1, 68 (1955).

236. J. Maly and V. Vesely, J. I. N. C. I, 119 (1958).

237. E. J. King, Paper 64 of "The Chemistry of Uranium, Collected Papers, "General Review reference 16, p. 662 .

238. E. S. Pryhevalskii, E. R. Nikolaeva, and N. I. Udaltsova, Zhur. Anal. Khim. 13, 567 (1958).

239. E. L. Zimmer, P/996, Proceed. Internat. Conf. Peaceful Uses Atomic Energy, Geneva, 1955, 8, 120 (1956).

239a. J. Patterson, ANL-5410, March, 1955.

240. I. P. Alimarin, E. R. Nikolatva, and G. I. Maloferva, Znur. Anal. Knim. 13, 464 (1958).

241. H. N. Rây and N. P. Bhattacharayya, Analyst 82, 164 (1957).

242. Iu. V. Morachevsk11, A. I. Beliaeva, and I. V. Ivanova, Zhur. Anal. Khim. 13, 570 (1958).

243. A. N. Bhat, B. D. Ja1n, Talanta 4, 13 (1960).

244. R. Rascanu, refererred to in 214.

245. F. M. Shemyakin, V. V. Adamovich, and N. P. Pavlova, Zavodskaya Lab. 5, 1129 (1936); Chem. Abstr. 31, 971 (1937).

246. W. Parr1, G1orn. farm. ch1m. 73, 177 (1924); Zentr. 1924II, 2190 .

247. E. T. McBee, M-2102, March 21, 1945.

248. A. E. Bearse, G. W. Kinzer, Y. A. Lutz, R. D. Morin, and R. H. Po1rier, BMI-JDS-182, Apr11 15, 1949.

249. R. Berg, Z. anorg. allgem. Chem. 204, 208 (1932).

250. N. H. Furman, W. B. Mason, and J. S. Pekola, Anal. Chem. 21, 1325 (1949).

251. J. F. Flagg and N. H. Furman, Ind. Eng. Chem., Anal. Ed. 12, 529 (1940).

252. F.-E. Raurich Sas, Anales soc. espãn. fís. quím. 32 , 979 (1934); Chem. Abstr. 29, 1210 (1935). 
253. J. A. Siemssen, Chem. Ztg. 35, 139 (1911); Chem. Abstr. 5, 1886 (1911).

254. H. Brintzinger and $G$. Hesse, $Z$. anorg. allgem. Chemie 249, 113 (1942).

255. St. We1l and St. Rozenblum, Buli. trav. 1nst. pharm., Poland, No. I, I; Chem. Abstr. 22, 4401 (1928).

256. Foucry, J. pharm. ch1m.ㅁ, 168 (1934); Chem. Abstr. 29, 1210 (1935).

257. D. H. Freeman and F. Lions, J. Proc. Roy. Soc. N. S. Wales 14, 520 (1941); Chem. Aostr. 35, 4772 (1941).

258. G. M. Saxena, T. R. Seshadr1, Proc. Indian Acad. Sc1. 47, 238 (1958).

259. R. Lobene and J. Flagg, experimental pesults quoted by $\mathrm{E}$. Ware, ref. 215 .

260. R. Berg, z. anal. Chem. 70, 341 (1927); 71, 23, 171, 3.21, 369 (1927); 72,177 (1927).

261. F. Hecht and $W$. Re1ch-Rohrw1E, Monatsh. 53-54, 596 (1929).

262. H. R. Fleck and A. M. Ward, Analyst 58, 388 (1933).

263. H. R. Fleck, Analyst 62, 378 (1937).

264. H. Hovorka and V. Sýhora, Collection Czechoslov. chem. :ommun. 10, 83, 182 (1938).

265. H. Hovorka and J. Vořlísèk, Collection Czechosiov, chem. commun. 11, 128 (1939).

266. H. Hovorka and J. Voř́sék, Chem. Ijsty 34, 55 (1940); Chem. Abstr. 34, 5783 (1940).

267. A. Nargini and R. Stratta, Gazz. chim. ital. 62, 686 (1932); Cnem. Abstr. 27. 285 (1933).

268. H. Hovorka and V. Sýkora, Collection Czechosolov. chem. zommun. 11, 70 (1939).

269. R. Berg and 0 . Wurm, Ber. 60B, 1564 (1927).

270. H. Brintzinger and $G$. Hesse, $Z$, anorg. aligem. Chemie 249, 299 (1942).

271. O. Baudisch, H. Gurevitsch, and S. Rothschild, Ber. 49, 180 (1916); Chem. Abstr. 10, 903 (1916).

272. K. Tan1, H. Hosimiya, and T. Ikeda, J. Chem. Soc. Japan 61, 269 (1940); Chem. Abstr. 34, 4687 (1940).

273. P. Rây and M. K. Bose, Z. anã. Chem. 95, 400 (1933).

274. P. Rày and A. K. Majundar, 2. anal Chem. 100, 324 (1935); Chem. Abstr. 29, 3626 (1935).

275. F. Feigl and H. A. Suter, Ind. Ens. Chem., Anal. Ed. I4, 840 (1942). 
276. E. K. Hyde, Radiochemical Review reference 1.

277. H. Bode, Z. anal. Chem. 144, 165 (1955).

278. A. R. Tourky and A. M. Amin, P/1107, Proceed. Internat. Conf. Peaceful Uses Atom1c Energy, Geneva, 1955, 8, 294 $(1956)$.

279. W. R. Schoeller and H. W. Webb, Analyst 6l, 585 (1936).

280. P. Lemaire, Répert. pharm. [3] 20, 433 (1908); Chem. Abstr. 3, 524 (1909).

281. R. H. Ba1les, DOW-22, Dec. 30, 1949.

282. D. R. George, MITG-228, Mar. 6, 1950.

283. Z. Hadar1, Israel Research Counc1l Bull. 6A, 168 (1957).

284. R. Pŕlb1] and J. Vorlíček, Chem. I1sty 45, 216 (1951); Chem. Abstr. 46, 11031 (1952).

285. G. W. C. Miliner and J. W. Edwards, Anal. Chlm. Acta 16, $109(1957)$.

286. R. Prib1l and J. Adam, Chem. Iisty 45, 218 (1951);

Chem. Abstr. 46, 11031 (1952).

287. M. M. T111u, Current Sc1. (Ind1a) 24, 45 (1955).

288. R. N. Sen Sarma and A. K. Mall1k, Anal. Ch1m. Acta 12, 329 (1955).

289. G. H. Morrison, Anal. Chem. 22, 1388 (1950).

290. G. H. Morrison, H. Frelser, General Review reference 17.

291. G. H. Morrison, H. Fre1ser, Anal. Chem. 30, 632 (1958).

292. G. H. Morrison, H. Freiser in "Comprehensive Analytical Chemistry," edited by C. I. W1lson and D. A. W1Ison, El sevier Publishing Co., Amsterdam, 1959, Vol. IA, Chapter 7, pp. 147-209.

293. H. Freiser, G. H. Morrison, Ann. Rev. Nuclear Sci. 9, 221 (1959).

294. G. H. Morrison, H. Freiser, Anal. Chem. 32, 37R (1960).

295. H. M. Irving, Quart. Rev. (London) 5, 200 (1951).

296. V. I. Kuznetsov, Uspekh1 Kh1m. 23, 654 (1954); AERE Lib./trans. 532 .

297. V. M. Vdovenko, Zhur. Neorg. Khim. 3, 145 (1958).

298. V. M. Vdovenko, L. N. Lazarev, KnIm. Nauka 1 Prom. 4, 230 (1959).

299. A. K. Babko, F. G. Zharovsk11, Zavodskaya Lab. 25, 42 (1959); Industrial Lab. 25, 39 (1959).

300. P. Mouret, General Review reference 9, pp. 111-115.

301. J. Sauteron, General Review reference 9, pp. 136-163. 
302. C. A. Blake, Jr., C. F. Baes, Jr., K. B. Brown, C. F. Coleman, J. C. White, $P / 1550$, Proceed. Internat. Conf. Peaceful Uses Atomic Energy, Geneva, 1958, 28, 289 (1958).

303. K. B. Erown, C. F. Coleman, D. J. Crouse, C. A. Blake, A. D. Fon, $\mathrm{P} / 509$, Proceed. Internat. Conf. Peaceful Uses Atomic Energy, Geneva, 1958, 3, 472 (1958).

304. C. F. Coleman, K. B. Brown, J. G. Moore, K. A. Allen, P/510, Proceed. Intermat. Conf. Peaceful Uses Atomlc Energy, Geneva, 1958, 28, 278 (1958).

305. K. B. Brown, C. F. Coleman, Progress Nuclear Energy, Serles III, Process Chemistry, 2., 3 (1958).

306. W. V. Ward, MITG-244 (1951).

307. N. M. Isaac, P. R. Fields, D. M. Gruen, paper given at 138 th meet1ng Amer. Chem. Soc., New York, N. Y., September, 1960, "Solvent Extraction of Actinides and Lanthanides from Molten Salts."

308. H. A. C. McKay, SRS-94 (1954); Chem. Ind. 1954, 1549.

309. J. M. Fletcher, P/413, Proceed. Internat. Conf. PeacefuI Uses Atomic Energy, Geneva, 1955, 2, 459 (1956).

310. A. M. Rozen, Atomnaya Energ11a 2, 445 (1957); Sov1et J. Atomic Energy 2, 545 (1957).

311. G. Carlson, Svensk. Kem. T1dskr. 70, 55 (1958).

312. K. Na1to, Bull. Chem. Soc. Japan 33, 363 (1960).

313. H. Irving, F. J. C. Rossott1, R. J. P. Williams, J. Chem. Soc. 1955, 1906.

314. J. Ryaberg, Ark1v Kem1 8, 101 (1955).

315. A. P. Zozulya, V. M. Peshkova, Uspekh1 KhIm. 29, 234 (1960); Russian Chem. Rev. 29, 101 (1960).

316. E. K. Hyde, M. J. Wolf. CC-2636 (1944), pp. 8-10; CB-3810 (1947); TID-5223, Part 1, p. 197.

317. I. Yaffe, J. Hebert, C. E. Mackintosh, M-2305 (1945).

318. O. Johnson, A. S. Newton, CC-2954 (1945).

319. W. H. Baldwin, Mon C-145 (1946).

320. C. N. Stover, Jr., H. W. Crandall, D. C. Stewart, P. C. Mayer, UCRL-576 (1950).

321. R. K. Warner, Australian J. Appl. Sc1. 3, 156 (1952).

322. R. K. Warner, Australian J. Appl. Sc1. 4, 427 (1953).

323. V. Veselý, H. Beranová, J. Malý, P/2100, Proc. Internat. Conf. Peaceful Uses Atomic Energy, Geneva, 1958, 17, 162 (1958).

324. A. Norström, I. G. Silién, Svensk. Kem. Tidskr. 60, $227(1948)$. 
325. V. M. Vdovenko, 4. A. L1pa-111, M. G. Kuz1na, Zhur. Neorg. Khim. 4, 2502 (1054); Fian J. Inorg. Chem. 4, 1152 (1959).

325. N. H. Furman, R. J. Mundy, G. H. Morrison, AECD-2938.

327. I. I. Jenk1ns, 4. A. C. McKay, Trans. Faraday Soc. 50, $109(1954)$.

328. V. M. Vdovenko, T. V. Kovaleva, Zhur. Neorg. Kn1m. 2, 1682 (1957); J. Inorg. Chem. USSR ․, No. 7, 368 (i957).

329. V. V. Fom1n, A. F. Morgunov, Zhur. Neorg. Kh1m. 5, 233 (i960); Russ. J. inors. Chem. 5, i12 (1960).

330. V. M. Vdoverico, 4. S. Krivokhatski1, Zhur. Neorg. Khim. 5, 494 (1960); Fiss. I. Inorg. Chem. 2, 236 (1960).

331. Wohlhuter, J. Esin:cron, auoted by J. Sauteron in General Review refersi:= $\because n, 147$.

332. E. C. Evers, C. - . 3-3. A-3329, Part 2 (1946).

333. R. Bock, E. Bock, Z. ansan. Cism. 263, 146 (1950).

334. J. Koo1, Jo1n Establ1shment. ar '. 'iear Energy Research 11, (1956).

335. A. A. Grinberg, G. S. Lozhkina, Zhur Nejrg. Kh1m. 5, 738 (1960); Russ. J. Inorg. Chem. 5, zr. (TS60).

336. N. N. Hellman, M. J. Wolf, General Review roferange 15, Paper No. 211, p. 175.

337. T. R. Scott, Analyst I4, 486 (1949).

338. J. A. Kennelly, G. I. Martin, S. W. Weldman, MCW-1397 (1956), pp. $27-32$.

339. E. K. Hyde, $P / 728$, Radiochemical Review reference 2.

340. W. Fischer, R. Bock, Z. anorg. allgem. Chem. 249, 146 (1942).

34I. R. Bock, Z. anal. Chem. 133, 110 (1951).

342. R. Bock, M. Herrmann, Z. anorg. Chem. 284, 288 (1956).

343. I. B. Asprey, S. G. Stephanou, R. A. Penneman, J. Am. Chem. Soc. 72, i 425 (1950).

344. V. M. Vdovenko, P/2206, Proceed. Internat. Conf. Peaceful Uses Atcmic Energy, Geneva, 1958, 17, 175 (1958).

345. G. F. Best, E. Fesford, H. A. C. McKay., International Congress of Pure and Applied Chem1stry, 16 th, Par1s, 1957. Mémolres présentés à la Section de Chimie Minérale, Sedes, Par1s, 1958 , p. 389.

346. V. M. Vdovenko, A. A. Lipovsk11, M. G. Kuz1na, Zhur. Neorg. Krim. $2,3^{75}$ (1957); J. Inorg. Chem. USSR $\underline{2}$, No. $4,415(1957)$.

34T. V. M. Vdovenko, M. P. Kovalskaya, P/2216, Proceed. Internat. Conf'. Peaceful Uses 4tomic Energy, Geneva, 1958, 17, 329 (1958). 
348. S. M. Karpacheva, I. P. Khorkhorina, G. D. Agashkina, Zhur. Neorg. Kh1m. 2, 961 (1957); J. Inorg. Chem. USSR, 2, No. 4, 392 (1957).

349. V. M. Vdovenko, I. G. Suglobova, Zhur. Neorg. Knim. 3, 1403 (1958); JPRS-2521; Chem. Abstr. 53, 21120 (1959).

350. A. H. A. Heyn, G. Banerjee, NYO-7567 (1957).

351. G. R. Howells, T. G. Hughes, D. R. Mackay, K. Saddington, $\mathrm{P} / 307$, Proceed. Internat. Conf. Peaceful Uses Atomic Energy, Geneva, 1958, 17, 3 (1958).

352. B. S. Weaver, C. E. Larson, AECD-3936 (1946).

353. C. A. Kraus, A-2327 (1946).

354. D. G. Tuck, J. Chem. Soc. 1957, 3202.

355. H. A. C. McKay, K. Alcock, D. Scarg111, AERE-C/R-2221 (1958).

356. J. M. Googin, T. P. Sprague, Y-327 (1949).

357. J. M. Googin, T. P. Sprague, Y-331 (1949).

358. D. A. Lee, R. W. Woodward, G. H. Clewett, AECD-4007 (1947).

359. D. J. Carswell, AERE-C/M-326 (1957).

360. D. F. Musser, D. P. Krause, R. H. Smellie, Jr., AECD-3907 (1947).

361. C. N. Stover, Jr., H. W. Crandall, UCRI-649 (1950).

362. A. G. Jones, E. F. Orlemann, C-4.360.3 (1945).

363. T. V. Arden, F. H. Burstall, K. P. Iinstead, Brit. Patent 781,721, reviewed in Nuclear Eng. 3, 90 (1958).

364. M. Branica, E. Bona, P/2412, Proceed. Internat. Conf. Peaceful Uses Atomic Energy, Geneva, 1958, 17, 172 (1958).

365. F. S. Grimald1, H. Levine, AECD-2824, declassifled April II, 1950; U. S. Geol. Survey Bull. 1006 (1954) p. 43 .

366. C. J. Rodden, J. J. Tregonning, "Manual of Analytical Methods for the Determination of Uranium and Thorlum in Their Ores", U. S. Government Printing office, Washington 25, D. C., (Revised, 1955).

367. M. A. DeSesa. O. A. N1etzel, ACCO-54 (1954).

368. O. A. N1etzel, M. A. DeSesa, P/532, Proceed. Internat. Conf. PeacefuI Uses Atomic Energy, Qeneva, 1955, 8,320 (1956).

369. R. J. Guest, J. B. Z1mmerman, Anal. Chem. 27, 931 (1955).

370. R. Vanossi, Anales soc. cient. Argentina 137, 3 (1944); Chem. Abstr. 39, 1117 (1945).

371. 2. I. D1zdar, I. D. Obrenov1ć, P/471, Proceed. Internat. Conf. Peaceful Uses Atomic Energy, Geneva, 1958, 28, 543 (1958). 
372. G. W. C. Milner, A. J. Wood, AERE-C/R-895 (1952).

373. C. A. Kraus, A-2324 (1945).

374. R. Jenk1ns, H. A. C. McKay, AERE-C/M-3I (Del.) (1949).

375. A. Cacclar1, R. De Ieone, C. Fizzott1, M. Gabagl10, Energ1a nucleare (Milan) 3, 176 (1956).

376. J. Rydberg, B. Bernstrom, Acta Chem. Scand. 11, 86 (1957).

377. E. K. Hyde, J. Tolmach, ANL-4019 (1947).

378. F. R. Bruce, ORNL-37 (1948); P/719 Proceed. Internat. Conf. Peaceful Uses Atomic Energy, Geneva, 1955, 7, 100 (1956); Progress Nuclear Energy, Series III, Process Chemistry, $\underline{1}$, $130(1956)$.

379. W. J. Maeck, G. L. Booman, M. C. Elliott, J. E. Re1n, Anal. Chem. 30, 1902 (1958).

380. W. H. Reas, CC-2730 (1945); CC-3017 (1945).

381. K. SeldI, M. Beŕanek. Chem. Ilsty 52, 337 (1958); Collection Czechoslovak chem. commun. 24, 298 (1959).

382. V. Veselý, H. Beranová, J. Maly', Collection Czechoslovak chem. commun. 25, 2622 (1960).

383. M. B. Allen, RL-316.45 (1944).

384. H. Levine, F. S. Grimald1, U. S. Geol. Survey BuII. 1006 (1954), p. 177 .

385. M. R. Poston, B. I. V. Bailey, W. H. Baldwin, ORNI-178 (1949).

386. J. R. Oliver, J. R. Merlwether, R. H. Rainey, ORNL-2668 (1959).

387. C. E. H1ggins, W. H. Baldw1n, J. M. Ruth, ORNL-I338 (1952).

388. T. H. S1ddaII III, P/521, Proc. Internat. Conf. Peaceful Uses Atomic Energy, Geneva, 1958, 17, 339 (1958); Ind. Eng. Chem. 51, 41 (1959).

389. T. H. SiddaIl III, J. Inorg. Nuclear Chem. 13, 151 (1960).

390. K. A. Petrov, V. B. Shevchenko, V. G. T1moshev, F. A. Maklyaev, A. V. Fokln, A. V. Rodlonov, V. V. Balandina, A. V. El'kina, Z. I. Nagnibeda, A. A. Volkova, Zhur. Neorg. Khim. 2, 498 (1960); Russian J. Inorg. Chem. 5, 237 (1960).

391. L. I. Burger, HW-44888 (1957); J. Phys. Chem. 62, 591 (1958).

392. H. A. C. McKay, P/441, Proc. Internat. Conf. Peaceful Uses Atom1c Energy, Geneva, 1955, 7,314 (1956); Progress in Nuclear Energy, Series III, I, 122 (1956).

393. H. A. C. McKay, T. V. Healy, Progress in Nuclear Energy, Series III, $\underline{2}, 546$ (1958).

394. T. V. Healy, J. Kennedy, G. M. Waind, J. Inorg. Nuclear Chem. 10, 137 (1959).

395. T. Sato, J. Inorg. Nuclear Chem. 2, 188 (1959). 
396. R. I. Moore, AECD-3196.

397. A. Duncan, G. A. Holburt, IGR-TM/W-055 (1956).

398. M. Taube, J. Inorg. Nuclear Chem. 15, 171 (1960).

399. 2. I. Dizdar, J. K. Rajnvajn, O. S. Gal, Bull. Inst. Nuclear Sc1., "Bor1s Kidrich," (Belgrade) \&, 59' (1958).

400. A. Cacclar1, R. De Ieone, C. F1zzott1, M. Gabagl10, Energia nucleare (Milan) 3 , 368 (1956).

401. W. B. Wright, Y-884 (1952).

402. B. Bernstrom, J. Rydberg, Acta Chem. Scand. 11, 1173 (1957).

403. J. W. Codding, Jr., IDO-14454 (1958).

404. T. J. Collopy, D. A. Stock, NLC0-801 (1959).

405. D. Beranova, J. Malý, V. Veselý, Jaderná energie 4, 145 (1958).

406. T. Sato, J. Inorg. Nuclear Chem. 16, 156 (1960).

407. D. E. Ferguson, T. C. Rumon, ORNL-260 (1949).

408. W. H. Hardwick, A. I. Mills, P. Stubbin, AERE-C/M-105, Apr11, 1951.

409. T. W. Bartlett, K-706 (1951).

410. Z. I. Dizdar, O. S. Gal, J. K. Rafnvajn, Bull. Inst. Nuclear Sc1., "Bor1s K1drich," (Beigrade) I, 43 (1957).

411. T. Sato, J. Inorg. Nuclear Chem. 6, 334 (1958).

412. E. Hesford, H. A. C. McKay, J. Inorg. Nuclear Chem. 13, 156 (1960).

413. K. Alcock, G. F. Best, E. Hesford, H. A. C. McKay, J. Inorg. Nuclear Chem. $\underline{6}, 328$ (1958).

414. G. F. Best, H. A. C. McKay, P. R. Woodgate, J. Inorg. Nuclear Chem. 4,315 (1957).

415. E. Hesford, H. A. C. McKay, D. Scarg111, J. Inorg. Nuclear Chem. 4, 321 (1957).

126. G. F. Best, E. Hesford, H. A. C. McKay, J. Inorg. Nuclear Chem. 12, i36 (1959).

417. T. Ish1mor1, E. Nakamura, Bul1. Chem. Soc. Japan 32, 713 (1959).

473. K. Alcock, F. C. Bedford, W. H. Hardw1ck, H. A. C. McKay, J. Inorg. Nuclear Chem. 4, 100 (1957).

113. D. Scargill, K. Alcock, J. M. Fletcher, E. Hesford, H. A. C. McKay, J. Inorg. Nuclear Chem. 4,304 (1957).

H20. C. J. Hardy, D. Scarg111, J. Inorg. Nuclear Chem. 13, 174 (1960).

'2.1. D. F. Peppard, W. J. Driscoll, R. J. Sironen, S. MeCarty, J. Inorg. Nuclear Chem. 4, 326 (1957).

lia?. D. F. Peppard, G.W. Mason, J. I. Ma1er, J. Inorg. Nuclear Chem. 3, 215 (1956). 
423. M. V. Susic, N. Jelic, Bull. Inst. Nuclear Sc1., "Boris Kidrich," (Belgrade) I, 29 (1957).

424. K. Alcock, S. S. Grimley, T. V. Healy, J. Kennedy, H. A. C. $\therefore$ Kay, Trans. Faraday Soe. 22,39 (1956).

426. V. M. Vdovenko, A. A. Ilpovsk11, S. A. N1k1tina, Zhur. Neorg. Khim. 5, 935 (1960); Rus3. J. Inorg. Chem. 2, 449 (1960).

427. V. B. Shevchenko, I. G. Slepchenko, V. S. Schmidt, E. A. Nenarokomov, Zhur. Neorg. Khim. 5, 1095 (1960); Russ. J. Inorg. Chem. 5, 526 (1960).

428. A. S. Kertes, M. Halpern, J. Inorg. Nuclear Chem. 16, 308 (1961).

429. D. F. Peppard, G. W. Mason, M. V. Gergel, J. Inorg. Nuclear Chem. 3, 370 (1957).

430. H. Irving, D. N. Edgington, J. Inorg. Nuclear Chem. 10, 306 (1959).

431. I. J. Gal, A. Ruvarac, Bull. Inst. Nuclear Sc1., "Bor1s Kidr1ch," (Belgrade) \&, 67 (1958).

432. V. B. Shevchenko, I. V. Sh1lin, A. S. Solovkin, Zhur. Neorg. Khim. 3, 225 (1958); AEC-tr-3655; Chem. Abstr. 52, 16109 (1958).

433. S. Sleklersk1, J. Inorg. Nuclear Chem. 12, 129 (1959).

434. U. Veereswararao, Bull. Inst. Nuclear SC1., "Borls K1dr1ch," (Belgrade) 8, 75 (1958).

435. H. G. Petrow, H. N. Marenburg, WIN-24 (1955).

436. S. Okada, T. N1sh1, K. Ueda, Da1-1-ka1 gensheryoku Symposium Hoblinshu, 1957, 511; Chem. Abstr. 53, 11084 (1959).

437. J. C. White, ORNL-2161 (1956).

438. J. C. White, CF-56-9-18 (1956).

439. J. C. White, W. J. Ross, A. S. Meyer, Jr., P1ttsburgh Conf. on Anal. Chem. and Appl. Spectroscopy, March, 1957.

440. J. C. White, First Conf. Anal. Chem. In Nuclear Reactor Tech., Nov., 1957; TID-7555, p. 240 (1958).

441. J. C. White, Symposium on Solvent Extraction in the Analysis of Metals, ASTM Spec. Tech. Publ., No. 238, 1958.

442. C. K. Mann, J. C. White, Anal. Chem. 30, 989 (1958).

443. C. A. Horton, J. C. White, Anal. Chem. 30, 1779 (1958).

444. W. J. Ross, J. C. White, Anal. Chem. 31, 1847 (1959).

445. C. A. Blake, K. B. Brown, C. F. Coleman, ORNL-1964 (1955).

446. M. Shinagawa, K. Katsura, J. Atomic Energy Soc. Japan 2, 147 (1960).

447. D. C. Stewart, T. E. Hicks, UCRL-86I (1960).

448. D. F. Peppard, J. R. Ferraro, G. W. Mason, J. Inorg. Nuclear Chem. I, 231 (1958). 
449. C. A. Blake, D. J. Crouse, C. F. Coleman, K. B. Brown,

- A. D. KeImers, ORNL-2172 (1957).

450. J. Kennedy, AERE-C/M-369 (1958).

451. H. Irving, D. N. Edglngton, J. Inorg. Nuclear Chem. 15, 158 (1960).

452. C. A. Blake, D. E. Horner, J. M. Schmltt, ORNI-2259 (1959).

453. C. A. Blake, K. B. Brown, C. F. Coleman, ORNL-1903 (1955).

454. R. J. Ross, J. C. Wh1te, CF-57-2-37 (1957).

455. D. A. Ellis, DOW-8I (1952).

456. R. S. Long, D. A. Ell1s, R. H. Balles, P/5?4. Proceed. Internat. Conf. Peaceful Uses Atomic Energy, Geneva. 1955, 177 (1955).

457. M. Zangen, J. Inorg. Nuclear Chem. 16, 265 (1960).

458. D. Grden1c, B. Korpar, J. Inorg. Nuclear Chem. 12, 149 (1959).

459. F. Habash1, J. Inorg. Nuclear Chem. 13, 125 (1960).

460. M. Zangen, Bull. Research Counc1l Israel, Sect. A, 7A, 153 (1958).

46I. K. B. Brown, C. F. Coleman, D. J. Crouse, J. O. Denis, J. G. Moore, AECD-4142 (1954).

462. J. G. Moore, K. B. Brown, C. F. Coleman, AECD-4145 (1955).

463. A. Preuss, J. Saunders, RMO-2533 (1955).

464. W. J. McDowe11, C. F. Baes, Jr., J. Phys. Chem. 62, 777 (1958).

465. K. A. Allen, J. Am. Chem. Soc. 80, 4133 (1958).

466. K. A. Allen, J. Phys. Chem. 62, 1119 (1958).

467. K. A. Allen, J. Phys. Chem. 64, 667 (1960).

468. K. A. Allen, W. J. McDowell, J. Phys. Chem. 64, 877 (1960).

469. Ch. Boire, Bull. Soc. chim. France, 1088 (1958).

470. Ch. Bo1re, CEA-1262 (1959).

471. ?. L. Moore, NAS-NS 3101 (1960).

472. W. E. Keder, J. C. Sheppard, A. S. W1lson, J. Inorg. Nuclear Chem. 12, 327 (1960).

473. A. S. W11son, W. E. Keder, J. Inorg. Nuclear Chem. 18,259 (1961).

474. J. B1zot, B. Trémilion, Bull Soc. chim. France 1959, 122.

475. F. L. Moore, CF-57-6-6I (1957); Anal. Chem. 30, 908 (1958).

476. F. I. Moore, Anal. Chem. 32, 1075 (1960).

477. J. G. Moore, K. B. Brown, C. F. Coleman, ORNL-1922 (1955). 
478. D. J. Crouse, K. B. Brown, W. D. Arnold, J. G. Moore, R. S. Lowrie, ORNL-2099 (1956).

479. E. Haeffner, G. N1lsson, A. Hultgren, $\mathrm{P} / 785$, Proceed. Internat. Conf. Peaceful Uses Atomic Energy, Geneva, 1955, 2, 498 (1956).

480. K. B. Brown, C. F. Coleman, D. J. Crouse, A. D. Ryon, ORNL$2269(1957)$.

481. W. E. Clifford, E. P. Bullwinkel, L. A. McCla1ne, P. Noble, Jr., J. Am. Chem. Soc. 80, 2959 (1958).

482. B. Hök-Bernstrom, Svensk. Kem. T1dskr. 68, 34 (1956).

483. F. K. Cole, L. H. Brown, Ind. Eng. Chem. 21, 58 (1959).

484. B. N. Sudarikov, V. A. Zaltsev, Yu. P. Puchkov, Nauch. Doklady Vysshe1 Shkoly, KhIm. i KhIm. Tekhnol. 1959, No. 1, 80; Chem. Abstr. 233, 13738 (1959).

485. G. F. M111s, H. B. Whetse1, J. Am. Chem. Soc. 77, 4690 (1955).

486. J. Rydberg, Arkiv Kem1 5, 413 (1953).

487. J. Rydberg, Ark1v Kem1 9, 95 (1956).

488. J. Rydberg, Arkiv Kem1 2, 109 (1956).

489. A. Krishen, NYO-6498 (1957).

490. M. Tabush1, Bull. Inst. Chem. Research, Kyoto Un1v. 37, 226 (1959).

491. M. Tabush1, Bull. Inst. Chem. Research, Kyoto Univ. 37, 252 (1959).

492. J. Rydberg, Acta Chem. Scand. 4, 1503 (1950).

493. J. Starý, Collection Czechoslov. chem. commun. 25, 2630 (1960).

494. T. Hara, J. Chem. Soc. Japan, Pure Chem. Sect. 78, 333 (1957); Chem. Abstr. 52, 7026 (1958).

495. R. Pribil, M. Jelinek, Chem. 11sty 47, 1326 (1953); Chem. Abstr. 48, 2636 (1954).

496. V. Moučka, J. Starý, Collection Czechosiov. chem. c smmun. 26, 763 (196i).

497. E. L. K1ng, CC-3618 (1946); General Beview reference 16, p. 269.

498. W. C. Orr, UCRL-196 (1948).

499. D. I. He1s1g, H. W. Crandall, UCRL-764 (1950).

500. G. N. Walton, F. Barker, G. Byfleet, AERE-C/R-768 (1955).

501. S. Peterson, J. Inorg. Nuclear Chem. 14, 126 (1960).

502. E. K. Hyde, J. Tolmach, ANL-4248 (Decl. 1955).

503. A. M. Poskanzer, B. M. Foreman, Jr., J. Inorg. Nuclear Chem. $16,323(1961)$. 
504. B. Rub1n, T. E. H1cks, UCRI-126 (Decl. 1955).

505. F. I. Moore, Symposium on Solvent Extraction in the Analys is of Metals, ASTM Spec. Tech. Publ. No. 238, 1958, pp. 13-25.

506. E. Sheperd, W. W: Meinke, AECU-3879 (1958).

507. B. Hôk, svensk. Kem. T1dskr. 65, 106 (1953).

508. D. Dryssen, Svensk. Kem. T1dskr. 65, 47 (1953).

509. D. Dryssen, Svensk. Kem. T1dskr. 66, 234 (1954).

510. C. I. Rulfs, A. K. De, J. Lakr1tz, P. J. Elving, Anal. Chem. 27, $1802(1955)$.

511. S. Lacro1x, Anal. Ch1m. Acta 1, 260 (1947).

512. T. Moeller, Ind. Eng. Chem., Anal. Ed. 15, 270, 346 (1943).

513. C. H. R. Gentry, L. G. Sherrington, Analyst 75, 17 (1950).

514. D. Dyrssen, M. Dyrssen, E. Johansson, Acta Chem. Scand. 10, $341(1956)$.

515. R. J. Hynek, Symposium on Solvent Extraction in the Analys is of Metals, ASTM Spec. Tech. Publ. No. 238, 1958, pp. 36-42.

516. I. P. Al1mar1n, Yu. A. Zolotov, Zhur. Anal. Kh1m. 12, 176 (1957); J. Anal. Chem. USSR 12, 173 (1957).

517. D. Dyrssen, M. Dyrssen, E. Johansson, Acta Chem. Scand. 10, 106 (2956).

518. I. P. Alimarin, Yu. A. Zolotov, E. S. Pal'shin, Doklady Akad. Nauk S.S.S.R. 124, 328 (1959); Chem. Abstr. 53, 9876 (1959).

519. V. Auger, Compt. rendus 170, 995 (1920).

520. D. Dryssen, Acta Chem. Scand. 10, 353 (1956).

521. K. L. Cheng, R. H. Bray, Anal. Chem. 27, 782 (1955).

522. K. I. Cheng, Anal. Chem. 30, 1027 (1958).

523. H. Bode, Z. anal. Chem. 143, 182 (1954).

524. W. H. Hardwick, M. Moreton-Sm1th, Analyst 83, 9 (1958).

525. E. S. Przheval'sk11, E. P. N1kolaeva, N. S. Kl1mova, Vestnik Moskov. Univ., Ser. Mat., Mekhan., Astron, F1z. 1 Khim. 13, No. 3, 217 (1958); Chem. Abstr. 53, 9906 (1959).

526. R. I. Lacoste, M. H. Earing, S. E. Wiberly, Anal. Chem. 23, $871(1951)$.

527. J. S. Fritz, E. C. Bradford, Anal. Chem. 30, 1021 (1958).

528. J. K. Foreman, S. J. R1ley, T. D. Smith, Analyst 82, 89 (1957).

529. D. Dryssen, Svensk. Kem. T1dskr. 68, 212 (1956).

530. D. Dryssen, Acta Chem. Scand. 2, 1567 (1955).

531. D. Dryssen, J. Inorg. Nuclear Chem. 8,291 (1958). 
532. G. R. Choppin, J. Chem. Educ. $\underline{36}, 462$ (1959).

533. J. W. Clegg, D. D. Foley, General Review reference 13.

534. E. V. Spivey, E. I. Leysohn, F. J. Hurst, D. J. Crouse, C. F. Coleman, y-8í (1951).

535. C. F. Tr1visonno, GAT-I-421 (1957).

536. K. A. Kraus, F. Nelson, P/837, Proceed. Internat. Conf. Peacerul Uses Atomic Energy, Geneva, 1955, I, 113 (1956).

537. Y. Marcus, PUB/4P/R-20 (1959).

538. I. Wish, Anal. Chem. 31, 326 (1959).

539. M. Ward, G. A. Welch, Unpublished data quoted by C. J. Hardy, Progress in Nuclear Energy, Ser1es III, Process Chem1stry, 2, $357(1958)$.

540. I. Prevot, J. Corpel, P. Regnaut, P/1271, Proceed. Internat. Conf. Peaceful Uses Átom1c Energy, Geneva, 1958, 17, 96 (1958).

541. J. Korkisch, P. Antal, F. Hecht, J. Inorg. Nuclear Chem. 14, 247 (1960).

542. P. Antal, J. Korkisch, F. Hecht, J. Inorg. Nuclear Chem. 14, 251 (1960).

543. I. R. Bunney, N. E. Ballou, J. Pascual, S. Fot1, Anal. Chem. 31, 324 (1959); USNRDI-TR-228 (1958).

544. G. W. C. Milner, J. W. Edwards, Anal. Chim. Acta 17, 259 (1957).

545. G. W. C. M1iner, J. H. Nunn, Anal. Ch1m. Acta 17, 494 (1957).

546. K. A. Kraus, G. E. Moore, ORNL-330 (1949).

547. D. G. Boase, J. K. Foreman, Talanta 8, 187 (1961).

548. J. Kork1sch, A. Farag, F. Hecht, Z. anal. Chem. 161, 92 (1958).

549. E. Pluchet, R. Muxart, Bull. Soc. ch1m. France 1961, 372.

550. L. W1sh, M. Rowel1, USNRDL-TR-117 (1956).

551. J. Kork1sch, P. Antal, F. Hecht, Z. anal. Chem. 172, 401 (1960).

552. J. P. Far1s, Anal. Chem. 32, 520 (1960).

553. T. R. Bhat, Y. W. Gokhale, J. Sc1. and Ind. Research (Ind1a) 18B, 522 (1959); Chem. Abstr. 54, 23601 (1960).

554. K. A. Kraus, G. E. Moore, ORNL-759.

555. K. A. Kraus, F. Nelson, G. E. Moore, J. Am. Chem. Soc. I7, $3972(1955)$.

556. K. A. Kraus, G. E. Moore, F. Nelson, J. Am. Chem. Soc. I8, $2692(1956)$.

557. K. A. Kraus, F. Nelson, ASTM Spec. Tech. Publ. No. 195, 1958, p. 27 .

558. F. Nelson, R. M. Rush, K. A. Kraus, J. Am. Chem. Soc. 82, 339 (1960). 
559. J. P. Faris, J. K. Brody, Paper 34, P1ttsburgh Conference on Analyt1cal Chemistry and Applied Spectroscopy, February, 1961.

560. D. Carswell, J. Inorg. Nuclear Chem. 3, 384 (1957).

561. D. Naumann, R. Ross, Kernenergle 3, 425 (1960).

562. R. F. Buchanan, J. P. Faris, International Atomic Energy Agency, Copenhagen Conference on the Use of Radiolsotopes in the Physical Sciences and Industry, September 6-17, 1960.

563. J. K. Foreman, I. R. MeGowan, T. D. Smith, J. Chem. Soc. 1959, 738 .

564. F. Tera, J. Kork1sch, F. Hecht, J. Inorg. Nuclear Chem. 16, $345(1961)$.

565. J. L. Ryan, HW-59193 Rev. (1959).

566. T. O'Connor, ACCO-6I (1954).

567. S. H. Jury, J. B. Adams, CF-59-5-127 (1959).

568. T. Ishimor1, H. Okuno, Bull. Chem. Soc. Japan 29, 78 (1956).

569. A. Arnfelt, Acta Chem. Scand. 2, 1484 (1955).

570. S. Fisher, R. Kunin, Anal. Chem. 29, 400 (1957).

571. M. Sus1c, Bul1. Inst. Nuclear Sc1., "Bor1s K1dr1ch," (Belgrade) I, 35 (1957).

572. S. M. Khopkar, A. K. De, Anal. Ch1m. Acta 23, 147 (1960).

573. a. Banerjee, A. H. A. Heyn, Anal. Chem. 30, 1795 (1958).

574. C. V. Banks, J. A. Thompson, W. O. McLaughlin, Anal. Chem. 30, 1792 (1958).

575. S. Misumi, T. Taketatsu, Bull. Chem. Soc. Japan 32, 876 (1959).

576. T. K. S. Murthy, Anal. Chim. Acta 16, 25 (1957).

577. H. J. Se1m, R. J. Morr1s, D. W. Frew, Anal. Chem. 29, 443 (1957).

578. H. J. Seim, R. J. Morris, R. G. Pastorino, Anal. Chem. 31, 957 (2959).

579. E. C. Fre1ling, J. Pascual, A. A. Delucch1, Anal. Chem. 31, 330 (1959).

580. L. W1sh, USNRDI-TR-312 (1959).

581. F. Hecht, J. Korkisch, R. Patzak, A. Thiard, Mikrochim. Acta 1956, 1283.

582. J. Korkisch, A. Th1ard, F. Hecht, Mikrochim. Acta 1956, 1422.

583. J. Korkisch, A. Farag, F. Hecht, M1krochim. Acta 1958, 415.

584. J. Kork1sch, P. Antal, F. Hecht, Mikroch1m. Acta 1959, 693.

585. R. T. Oliver, J. S. Fritz, ISC-1056 (1958). 
586. M. Z1egler, Naturw1ssenschaften 46, 629 (1959).

587. C. J. Hardy, Progress Nuclear Energy, Serles III, 2, 357 (1958).

588. S. Ionescu, O. Constantinescu, D. Topar, E. Gard, P/1424, Proceed. Internat. Conf. Peacerul Uses Atomic Energy, Geneva, $1958,28,58$ (1958).

589. S. M. Khopkar, A. K. De, Anal. Ch1m. Acta 22, 153 (1960).

590. J. C. Sullivan, D. Cohen, J. C. Hindman, J. Am. Chem. Soc. 77, 6203 (1955).

591. R. M. Dlamond, K. Street, Jr., G. T. Seaborg, J. Am. Chem. Soc. 76,1461 (1954).

592. S. V. Suryanarayana, Bh. S. V. Raghava Rao, J. Sc1. Ind. Research (Ind1a) 178, 310 (1958); Chem. Abstr. 53, 11939 (1959).

593. R. Bane, U. S. Patent No. 2,902,338; N. S. A. 14, 6364 (1960).

594. D. Dyrssen, Svensk. Kem. Tidskr. 62, 153 (1950).

595. I. Kuzin, V. Taushkanov, Izvest. Vyssh1kh Ucheb. Zaveden11, Kh1m. 1 Kh1m. Tekinol, No. 2, 70, (1958); Chem. Abstr. 52, 20930 (1958).

596. G. E. Boyd, E. R. Russell, J. Schubert, U. S. Patent No. $2,898,185 ;$ N.S. A. 14,2503 (1960).

597. G. Johansson, Svensk. Kem. T1dskr. 65, 79 (1953).

598. I. J. Gal, O. S. Gal, P/468, Proceed. Internat. Conf. Peaceful Uses Atomic Energy, Geneva, 1958, 28, 17 (1958).

599. G. E. Boyd, U. S. Patent No. 2,849,282; N. S. A. 13, 4308 (1959).

600. J. Kennedy, R. V. Davies, B. K. Rob1nson, AERE-C/R-1896 (1956).

601. H. A. Braler, Rev. fac. clenc. quim., Univ. nacl. La Plata 31, i5l (1959); Chem. Abstr. 24, 22159 (1960).

602. H. A. Braler, P/1568, Proceed. Internat. Conf. Peaceful Uses Atomic Energy, Geneva, 1958, 28, 55 (1958).

603. D. Dolar, 2. Draganic, Rec. trav. 1nst. recherches structure Mat1ere (Belgrade) 2, 77 (1952); Chem. Abstr. 47, 6816 (1953).

604. I. Krawczyk, Nukleonika 2, 549 (1960); N. S. A. 15, 8903 $(1961)$.

605. J. A. Carter, J. A. Dean, Appl. Spectroscopy 14, 50 (1960).

606. I. G. Dragan1c, Z. D. Dragan1c, Z. I. Dizdar, Bull. Inst. Nuclear Sc1., "Borls Kidr1ch," (Belgrade) 出, 37 (1954).

607. R. Klement, 2. anal. Chem. 145, 9 (1955).

608. F. W. E. Strelow, Anal. Chem. 32, 363 (1960).

609. K. A. Kapatsinskaya, N. G. Syromyatnikov, Vestn1k Akad. Nauk Kazakh. S.S.R. 14, No. 4, 60 (1958); Chem. Abstr. 52, 19523 (1958). 
610. M. Fodor, Magyar Tudományos Akad. Konzpont1 Fiz. Kutató Intézetének Kôzlemenye1 5, 445 (1957); Chem. Abstr. 53, 17771 (1959).

611. D. I. Ryabchikov, P. N. Pale1, Z. K. Mikha1lova, Zhur. Anal. Khim. 15, 88 (1960); J. Anal. Chem. USSR 15, 91 (1960).

612. M. M. Senyav1n, Zhur. Anal. Kh1m. 12, 637 (1957); J. Anal. Chem. USSR 12, 655 (1957).

613. F. H. Pollard, J. F. W. McOmle, "Chromatographle Methods of Inorganic Analys is," Academ1c Press, New York, 1953.

614. E. Blasius, "Chromatographische Methoden in der analytischen und praparativen anorganischen Chemie," F. Enke, Stuttgart, 1958 .

615. H. P. Raaen, P. F. Thomason, Anal. Chem. 27, 936 (1955).

616. F. H. Burstall, R. A. Wells, Analyst 76, 396 (1951).

617. W. Ryan, A. F. Williams, Analyst 77, 293 (1952).

618. E. Haeffner, A. Hultgren, Nuclear Sc1. \& Eng. 3, 471 (1958).

619. A. Hultgren, E.Haeffner, $\mathrm{P} / 144$, Proceed. Internat. Conf. Peaceful Uses Atomic Energy, Geneva, 1958, 17,324 (1958).

620. J. Kennedy, F. A. Buford, P. G. Sammes, J. Inorg. Nuclear Chem. 14, 114 (1960).

621. H. Small, J. Inorg. Nuclear Chem. 18, 232 (1961).

622. H. H. Hyman, R. C. Vogel, J. J. Katz, Progress in Nuclear Enerby, Series III, I, 261 (1956).

623. C. C. Casto, "Analyt1cal Chemistry of the Manhattan Project," NNES, DIVIsion VIII, Volume 1, Chapter 23.

624. E. F. Smith, Chem. Ber. 13, 751 (1880).

625. E. F. Smith, D. I. Wallace, J. Am. Chein. Soc. 20, 279 (1898).

626. I. G. Kollock, E. F. Smith, J. Am. Chem. Soc. 23, 607 (1901).

627. R. Coomans, Ing. Chim. 10, 213 (1926).

628. B. Cohen, D. E. HuIl, MDDC-387 (1946).

629. O. A. Cook, TID-5290 (1958), Paper 18, p. 147.

630. A. Brodsky, I. W. Flagg, T. D. Hanscome, NRI-4746 (1956).

631. P. I. Chalov, Trudy Inst. Geol. Akad. Nauk Kirgiz. SSR, No. 9, 231 (1957); N. S. A. I3, 10991 (1959).

632. R. W. Dodson, A. C. Graves, L. Helmholz, D. L. Hufford, R. M. Potter, J. G. Povelites, "Miscellaneous Physical \& Chemical Techniques of the Los Alamos Project," NNES(1952), Division $V$, volume 3 , Chapter 1 .

633. L. Koch, J. Nuclear Energy 2, 110 (1955).

634. C. Rulfs, A. K. De, P. J. Elving, Electrochem. Soc. 104,80 (1957). 
635. C. McAuliffe, A-3626 (1946).

636. G. I. Khlebnikov, E. P. Dergunov, Atomnaya Energ. 4, 376 (I958); AEC-tr-3497.

637. T. Whitson, T. Kwasnosk1, K-1201 (2954).

638. C. R. W1lson, A. Langer, Nucleonics 11, No. 8, 48 (1953).

639. R. Ko, Nucleonics 15, No. 1, 72 (1957).

640. I. Alter, E. Foa, Y. Marcus, J. Trocker, A. Gmenstein, J. Lav1, I. Prulov, J. Tulipman, A. Waldman, P/1609, Proceed. Internat. Conf. Peaceful Uses Atomic Energy, Geneva, 1958, 28, 268 (1958).

641. M. Kahn, MDDC-1605 (1943).

642. R. F. M1tchell, Anal. Chem. 32, 326 (1960).

643. R. Kunin, Progress in Nuclear Energy, Series III, 2, 35 (1958).

644. H. H. Willard, J. J. Finley, K-1219 (1956).

645. "Nouveau Tralte de Chimle Minerale," General Review reference 9, Chapter $X$.

646. E. P. Ste1nberg, ANL-6361 (1961).

647. G. C. Hanna, "Experimental Nuclear Phys1cs," Volume III, Part IX, John W1ley \& Sons, New York, 1959.

648. M. Deutsch, 0. Kofoed-Hansen, "Experimental Nuclear Physics," Volume III, Parts X and XI, John W1ley \& Sons, New York, 1959.

649. C. E. Crouthamel, "Applled Gamma-Ray Spectrometry," Pergamon Press, New York, 1960.

650. A. H. Jaffey, "The Actinide Elements," NNES, D1V1sion IV, Volume 14A, Chapter 16 (1954).

651. D. Strominger, J. M. Hollander, G. T. Seaborg, Revs. Modern Phys. 30, 585 (1958).

652. W. Me1nke, Anal. Chem. 28, 736 (1956); 30, 686 (1958); 32, 104R (1960).

653. D. I. Hufford, B. F. Scott, "The Transuranium Elements," NNES, Division IV, Volume 14B, Paper 16.1, p. 1149 (1949).

654. H. A. C. McKay, J. Milsted, Progress in Nuclear Phys1cs 4 , 287 (1955).

655. B. B. Ross1, H. H. Staub, "Ionization Chambers and Counters," NNES, Division V, Volume 2, p. 210 (1949).

656. K. M. Glover, P. Borrell, J. Nuclear Energy 1, 214 (1955).

657. F. Asaro, I. Perlman, Phys. Rev. 107, 318 (1957).

658. J. R. Hu1zenga, C. I. Rao, D. W. Engelkemeir, Phys. Rev. 107, 319 (1957).

659. D. J. Carswell, J. Milsted, J. Nuclear Energy 44, 51 (1957).

660. D. J. Hughes, R. B. Schwartz, BNL-325, Second Edition (1958). 
661. J. D. Knight, R. K. Smith, B. Warren, Phys. Rev. 112, 259 (1958).

662. W. H. Wade, J. Gonzalez-V1dal, R. A. Glass, G. T. Seaborg, Phys. Rev. 107, 1311 (1957).

663. W. W. T. Crane, G. M. Iddings, MTA-48 (1953).

664. J. Wing, W. J. Ramler, A. L. Harkness, J. R. HuLzenga, Phys. Rev. 114,163 (1959).

665. I. M. Slater, UCRI-244I (1954).

666. R. M. Iessler, UCRI-3710 (1957), p. 87.

667. B. M. Foreman, Jr., W. M. Glbson, R. A. Glass, G. T. Seaborg, Phys. Rev. I16, 382 (1959).

668. T. D. Thomas, B. G. Harvey, G. T. Seaborg, P/2429, Proceed. Internat. Conf. Peaceful Uses Atomic Energy, Geneva, 1958, 15, 295 (1958).

669. R. Vandenbosch, T. D. Thomas, S. E. Vandenbosch, R. A. Glass, G. T. Seaborg, Phys. Rev. 121, 1358 (1958).

670. R. Vandenbosch, G. T. Seaborg, Phys. Rev. 110, 507 (1958).

671. A. Ghiorso, T. Sikkeland, P/2440, Proceed. Internat. Conf. Peaceful Uses Atomic Energy, Geneva, 1958, 14, 158 (1958).

672. R. B. Durfield, J. R. Hu1zenga, Phys. Rev. 89, 1042 (1953).

673. J. E. Gindler, J. R. Hulzenga, R. A. Schmitt, Phys. Rev. 104, 425 (1956).

674. I. Katz, K. G. Mltchell, M. Le Blanc, F. Brown, Can. J. Phys. 35, 470 (1957).

675. J. R. Hulzenga, X. M. Clarke, J. E. Gindler, R. Vandenbosch, Unpublished data.

676. R. C. Koch, "Activation Analysis Handbook," Academic Press, New York, I960.

677. J. C. Warf, General Rev1ew reference 16, Paper 2, p. 29.

678. G. I. Miles, AERE-C/R-1804 (1949); NSA 10, 5577 (1956).

679. B. Ell10tt, ed., MCW-1407 (1957); NSA 14, 15669 (1960).

680. W. W. Schulz, U. S. Patent 2,897,047 (1959); NSA 14, 2501 (1960).

681. I. A. Slot1n, U. S. Patent 2,823,977 (1958); NSA 12, 10243 (1958).

682. R. P. Larsen, Anal. Chem. 31, 545 (1959).

683. J. C. Warf, C. V. Banks, CC-2942 (1945).

684. R. F1sher, CC-1057 (1943).

685. I. Safransk1, CC-1047 (1943).

686. R. FryxeII, CC-1448 (1944). 
687. I. Warf, CC-1194 (1943).

688. H. M. Feder, R. P. Larsen, M. Beederman, H. E. Evans, ANL5103 (1953).

689. BNL-583 (1959); NSA 14, 17642 (1960).

690. W. Sborg1, 2. Elektrochem. 19, 115 (1913).

691. J. A. McLaren, D. W. Cline, H. S. Clinton, J. J. Finley,

J. H. Goode, J. A. Westbrook, K-587 (1950).

692. M. Kolodney, U. S. Patent 2,872,387 (1959); NSA 13, 13320 (1959).

693. Br1t1sh Patent 829,090 (1960); NSA 14, 9444 (1960).

694. C. D. Calkins, R. B. Fllbert, Jr., A. E. Bearse, J. W. Clegg, BMI-243A (1950).

695. E. W. Christopherson, H. R. Grady, R. W. Woodard, C. E. Larson, AECD-4181 (1946); NSA 10, 10740 (1956).

696. L. Steadman, "The Pharmacology and Tox1cology of Uranium Compounds," C. Voegtiln, H. C. Hodge, editors, NNES, D1vision VI, Volume 1, Chapter 19, Section 4, MeGraw-Hill Book Co., New York, 1953.

697. F. S. Grimald1, I. May, M. H. Pletcher, J. T1tcomb, Geol. Survey Bull. 1006 (1954).

698. "Handbook of Chemlcal Methods for the Determination of Uranium in Minerals and Ores," His Majesty's Stationery Office, Iondon, 1950 . 


\title{
NUCLEAR SCIENCE SERIES: MONOGRAPHS ON RADIOCHEMISTRY, RADIOCHEMICAL TECHNIQUES, AND NUCLEAR MEDICINE
}

\author{
Avallable from the National Technical Information Service, \\ U. S Department of Commerce, Sprıngfield, Vırgınıa 22161
}

\section{ELEMENTS}

Aluminum and Gallıum, NAS-NS-3032 [1961]. $\$ 9.25$

Americium and Curium, NAS-NS-3006 [1960]. $\$ 9.75$

Antımony, NAS-NS-3033 [1961], $\$ 9.50$

Arsenuc, NAS-NS-3002 (Rev.) [1965], $\$ 900$

Astatine, NAS-NS-3012 [1960], \$8.75

Barıum, Calcium, and Strontium, NAS-NS3010 [1960], $\$ 11.00$

Beryllum, NAS-NS-3013 [1960], $\$ 9.50$

Bismuth, NAS-NS-3061 [1977], $\$ 11.75$

Cadmium, NAS-NS-3001 [1960], $\$ 9.50$

Carbon, Nitrogen, and Oxygen, NAS-NS3019 [1960], $\$ 8.50$

Cesium, NAS-NS-3035 [1961], $\$ 9.75$

Chromium, NAS-NS-3007 (Rev) [1963], $\$ 9.50$

Cobalt, NAS-NS-3041 [1961], \$10 25

Copper, NAS-NS-3027 [1961], $\$ 9.50$

Fluorine, Chlorine, Bromine, and lodine, NAS-NS-3005 [1960], $\$ 9.25$

Francium, NAS-NS-3003 [1960], $\$ 900$

Germanium, NAS-NS-3043 [1961], $\$ 9.25$

Gold, NAS-NS-3036 [ 1961 ] $\$ 900$

Indium, NAS-NS-3014 [1960], \$950

lodine, NAS-NS-3062 [1977], $\$ 11.00$

Iridium, NAS-NS-3045 [1961], \$8 75

Iron, NAS-NS-3017 [1960], $\$ 9.25$

Lead, NAS-NS-3040 [1961], $\$ 12.00$

Magnesium, NAS-NS-3024 [1961], \$8.75

Manganese, NAS-NS-3018 (Rev) [1971]. $\$ 975$

Mercury, NAS-NS-3026 (Rev.) [1970], $\$ 13.00$

Molybdenum, NAS-NS-3009 [1960], $\$ 9.00$

Neptunium, NAS-NS-3060 [1974], \$1375

Nickel, NAS-NS-3051 [1961], \$11.25

Niobium and Tantalum, NAS-NS-3039 [1961]. $\$ 9.50$

Osmuum, NAS-NS-3046 [1961], $\$ 850$

Palladium, NAS-NS-3052 [1961], $\$ 1100$

Phosphorus, NAS-NS-3056 [1962], $\$ 900$

Platinum, NAS-NS-3044 [1961], \$8 75

Plutonum, NAS-NS-3058 [1965], \$12 75

Polonium, NAS-NS-3037 [1961], $\$ 9.75$

Potassium, NAS-NS-3048 [1961], \$9.25

Protactınıum, NAS-NS-3016 [1959], $\$ 1000$

Radium, NAS-NS-3057 [1964], \$13.25

Rare Earths-Scandium, Yttrum, and Actinium, NAS-NS-3020 [1961], $\$ 1500$

Rare Gases, NAS-NS-3025 [1960], $\$ 9.50$

Recent Radiochemical Separation Procedures

for As, At, Be, Mg, Ni, Ru, and Se, NAS-NS3059 [1974], \$10 25

Rhenuum, NAS-NS-3028 [1961] \$9 25

Rhodium, NAS-NS-3008 (Rev) [ 1965], $\$ 1000$

Rubidium, NAS-NS-3053 [1962], \$1025

Ruthenium, NAS-NS-3029 [1961], $\$ 10.00$

Selenium, NAS-NS-3030 (Rev) [1965], $\$ 950$

Silicon, NAS-NS-3049 (Rev) [1968], $\$ 1000$

Silver, NAS-NS-3047 [1961], \$950
Sodium, NAS-NS-3055 [1962], \$9.25

Sulfur, NAS-NS-3054 [1961], $\$ 9.50$

Technetium, NAS-NS-3021 [1960], $\$ 9.50$

Tellurium, NAS-NS-3038 [1960], \$9.25

Thorium, NAS-NS-3004 [1960], $\$ 9.75$

TIn, NAS-NS-3023 [1960], $\$ 975$

Titanium, NAS-NS-3034 (Rev) [1971], \$10.25

Transcurium Elements, NAS-NS-3031 [1960], $\$ 9.00$

Tungsten, NAS-NS-3042 [1961], $\$ 9.25$

Uranum, NAS-NS-3050 [1961], $\$ 1700$

Vanadium, NAS-NS-3022 [1960], $\$ 10.00$

Zinc, NAS-NS-3015 [1960], \$9.50

Zirconuum and Hatnıum, NAS-NS-3011 [1960], $\$ 9.50$

\section{TECHNIQUES}

Absolute Measurement of Alpha Emission and Spontaneous Fission, NAS-NS-3112 [1968], \$975

Activation Analysis with Charged Particles, NAS-NS-3110 [1966], $\$ 925$

Application of Distillation Techniques to Radiochemical Separations, NAS-NS-3108 [1962], $\$ 9.00$

Applications of Computers to Nuclear and Radiochemistry, NAS-NS-3107 [1962], \$16.00

Cation-Exchange Techniques in Radiochemistry, NAS-NS-3113 [1971], \$13.00

Chemical Yield Determinations in Radiochemistry, NAS-NS-3111 [1967], \$10.50

Detection and Measurement of Nuclear Radiation, NAS-NS-3105 [1961], \$11.50

Liquid-Liquid Extraction with HighMolecular-Weight Amınes, NAS-NS-3101 [1960], \$1025

Low-Level Radiochemical Separations, NAS-NS-3103 [1961], $\$ 9.00$

Neutron Activation Techniques for the Measurement of Trace Metals in Environmental Samples, NAS-NS-3114 [1974], \$10.25

Paper Chromatographic and Electromigration Techniques in Radiochemistry. NAS-NS. 3106 [1962], \$9 25

Processing of Counting Data, NAS-NS-3109 [1965] \$12.25

Rapid Radiochemical Separations, NAS-NS3104 [1961], \$1125

Separations by Solvent Extraction with Trı-n-octylphosphıne Oxıde, NAS-NS-3 102 [1961], \$9.50

Users' Guides for Radioactivity Standards, NAS-NS-3115 [1974], \$10.25

\section{NUCLEAR MEDICINE}

The Synthesis of Carbon-11, Fluorine-18. and Nitrogen-13 Labeled Radiotracers for Biomedical Applications, NASNS-3201 [1982]. \$1125 